Luciana Nicolau Ferrara

\title{
Urbanização da natureza: \\ da autoprovisão de infraestruturas aos projetos de recuperação ambiental nos mananciais do sul da metrópole paulistana
}

Tese apresentada à Faculdade de Arquitetura e Urbanismo da Universidade de São Paulo, para obtenção de grau do título de Doutor em Arquitetura e Urbanismo.

Área de concentração: Tecnologia da Arquitetura

Orientadora: Profa. Titular Maria Lucia Refinetti R. Martins

São Paulo | 2013 
AUTORIZO A REPRODUÇÃO E DIVULGAÇÃO TOTAL OU PARCIAL DESTE TRABALHO, POR QUALQUER MEIO CONVENCIONAL OU ELETRÔNICO, PARA FINS DE ESTUDO E PESQUISA, DESDE QUE CITADA A FONTE.

E-MAIL AUTORA: lucianaferrara@usp.br | luferrara01@hotmail.com

Exemplar revisado e alterado em relação à versão original, sob responsabilidade do autor e anuência do orientador.

O original encontra-se disponível na sede do Programa.

São Paulo, 05 de setembro de 2013

Ferrara, Luciana Nicolau

F374u Urbanização da natureza: da autoprovisão de infraestruturas aos projetos de recuperação ambiental nos mananciais do sul da metrópole paulistana / Luciana Nicolau Ferrara. -- São Paulo, 2013. 384 p. : il.

Tese (Doutorado - Área de Concentração: Tecnologia da Arquitetura) - FAUUSP.

Orientadora: Maria Lucia Refinetti Rodrigues Martins

1.Mananciais 2.Infra-estrutura urbana 3.Urbanização 4.Meio ambiente 5.Justiça ambiental 6.Questão ambiental urbana I.Título 
Luciana Nicolau Ferrara

\title{
Urbanização da natureza: da autoprovisão de infraestruturas aos projetos de recuperação ambiental nos mananciais do sul da metrópole paulistana
}

\author{
Tese apresentada à Faculdade de \\ Arquitetura e Urbanismo da Universidade de \\ São Paulo, para obtenção de grau do Título \\ de Doutor em Arquitetura e Urbanismo.
}

Aprovado em:

Banca Examinadora

Prof. Dr.

Instituição:

Assinatura:

Prof. Dr.

Instituição:

Assinatura:

Prof. Dr.

Instituição:

Assinatura:

Prof. Dr.

Instituição:

Assinatura:

Prof. Dr.

Instituição:

Assinatura: 

A Jorge Hajime Oseki que está sempre em minha memória 



\section{AGRADECIMENTOS}

Seria impossível transcorrer e concluir esse percurso se, durante os seis anos de pesquisa, uma verdadeira rede não tivesse se constituído. Essa rede conectou muitas pessoas que, de formas diferentes, mas todas fundamentais, contribuíram para a realização deste trabalho. Agradeço:

Ao apoio da Fapesp, que financiou a pesquisa do mestrado ao doutorado direto.

À professora-orientadora Malu Refinetti Martins, pela generosidade, amizade e confiança com que me acompanhou durante tantos anos, pelo apoio e pela troca.

Às professoras que compuseram as bancas de qualificação e de passagem ao doutorado, cujas colaborações e questionamentos me fizeram repensar o trabalho até o último momento: Maria Antonieta da Costa Vieira, Odette Seabra, Amélia Damiani, Ângela Rocha, Laura Bueno e Cibele Risek. Um agradecimento especial para Maria Antonieta da Costa Vieira, a querida Eta, que muito me orientou e estimulou na pesquisa de campo.

Aos moradores do baixo Alvarenga, representados por: Neide, Darci, Raimundo, Gustavo, Filismino, Marlene e Ermi. Ao Xiquinho (in memorian) e à equipe da Holos21.

A todos os entrevistados, por terem compartilhado comigo um pouco de sua experiência profissional e de vida. À Sonia Lima, pelos diálogos estimulantes e à Rosangela Staurenghi, por ter me emprestado pilhas de documentos.

Da Secretaria de Habitação da Prefeitura de São Bernardo do Campo, agradeço imensamente: Tássia Regino, Paulo Massoca, Ricardo Couto, Karla Sanches e Aramis. E à Patrícia Lorenz da Secretaria de Gestão Ambiental. Todos me receberam com muita atenção e disposição ao diálogo.

Da Peabiru Trabalhos Comunitários, agradeço: Alexandre Hodapp, Rafael Pereira, Andrea Castro, Andre Drummond, arquitetos engajados na luta pela construção de espaços melhores.

Aos companheiros do Programa Mananciais do Instituto Socioambiental, com quem tive o prazer de trabalhar convivendo numa verdadeira equipe interdisciplinar: Marussia Whately, Paula Santoro, Marcelo Cardoso, Pilar Cunha, Cesinha, Léo Malagoli, Fernanda Blauth, Barbara Gonçalvez, Lilia Diniz.

À Carolina Laiate, Paula de Oliveira, Mariana Guimarães, Ana Akaishi, que com serenidade e competência me auxiliaram em diferentes momentos da pesquisa. Um agradecimento especial para Carolina Frignani e Juliana Petrarolli, que me ajudaram na montagem final da tese. 
À Marília Risi pela revisão cuidadosa do texto final. À Paula Pollini pela amizade, por responder sempre aos pedidos de esclarecimentos apressados. À Paula Prates pelas traduções. À Paula Gabbai pela arte da capa e encadernação.

Um agradecimento especial à leitura atenta e às contribuições fundamentais de: Guilherme Petrella, Edison Kioshi, Paula Santoro, Taís Tsukumo, Luis Mauricio Borges e da Profa. Yvonne Mautner. Seguiremos dialogando. À Karina Leitão, pela amizade e incentivo que eu nunca esquecerei, pela colaboração em todos os momentos da pesquisa, pelas leituras e sugestões, por tudo e mais um pouco. À Carolina Heldt pelas contribuições e compartilhamento de "aflições acadêmicas".

Aos amigos dos grupos de estudos de O Capital e de A produção do espaço, que foram conduzidos por Jorge Oseki e Ângela Rocha. E também aos amigos do grupo de estudos autogerido da Maranhão. Fica aqui meu registro de que esses grupos foram fundamentais na minha formação.

Ao apoio e diálogo prazeroso com Renata Moreira, Beatriz Tone, Ângela Pilotto, Roberta Menezes, José Baravelli, José Paulo, Simone Polli, Pedro Arantes e essa lista poderia continuar com muitos nomes. À Juliana Braga, pela presença em momentos de decisões difíceis e felizes. Ao João Sodré pelo socorro final.

Ao Laboratório de Habitação e Assentamentos Humanos da FAUUSP por ser um espaço aberto e de debate permanente, comprometido com a transformação acadêmica, social e urbana. Agradeço toda a equipe e pelo convívio estimulante com Letícia Sígolo, Daniela Zilio, Márcia Hirata, Patrícia Samora, Luciana Royer, Mariana Fix e tantos outros pesquisadores. Agradeço às colaborações da Profa. Erminia Maricato e os demais pesquisadores do grupo de estudos da Produção do Espaço Urbano. E também à equipe de pesquisa Manejo de Águas Pluviais em Meio Urbano: Profa. Maria de Lurdes Zuquim, Bruno Fukasawa, Francisco Barros, Fernando Nogueira. Ao Prof. João Whitaker, pela força e incentivo e por ter dividido comigo a oportunidade de discutir a "sustentabilidade" nas cidades em plena Rio+20.

Ao professor Carlos Vainer, por ter me colocado em mais uma rede, Métropoles, Inégalités et Planification Démocratique - MIPD, e proporcionado o estágio em Montreal, Canadá. Ao Programme des Futurs Leaders dans les Amériques, que me concedeu a bolsa de estudos por meio do Bureau Canadien de l'Education Internacionale (BCEI) e do Ministère des Affaires Étrangères et du Commerce International (MAECI), para cursar um semestre na Université du Québec à Montreal (UQÀM).

De Montreal agradeço ao Prof. Juan Luis Klein, por ter me recebido, acompanhado e me inserido no contexto acadêmico da UQÀM. À Profa. Anne Latendresse, pela amizade e atenção, e também à Profa. Catherine Trudelle por ter aberto as portas do seu curso para mim. Aos amigos: Catherine Gingras - a quem devo um agradecimento muito especial pelo acolhimento e amizade, Marianne Carlsan, Patricia Leduc, Pierre Mathieu, Mathieu à l'Abri. Ao Diogo e Joana, pelo abrigo amigo em Montreal. Merci à tous! Aos brasileiros, cuja amizade floresceu durante o rigoroso inverso canadense: Nelma, Rodrigo, Glauci, Renata e a todo o grupo. 
Aos meus amigos que compreenderam minhas ausências.

Ao meu pai, José Ferrara, por todo apoio de sempre, pela confiança. E minha mãe, Miriam Ferrara, que além de tudo despertou a pesquisadora adormecida e me ajudou pondo a mão da massa. Aos meus irmãos, pelo apoio incondicional. Estamos sempre juntos.

Ao Luis, meu companheiro de todas as horas, a quem agradeço com muito amor. 

Se eu fosse captar um pouco daquela água em um copo, expor as redes que a trouxeram até ali e seguir o fio de Ariadne através da água, "passaria continuamente do local para o global, do humano ao não humano" (LATOUR, 1993 apud SWYNGEDOW, 2001). Esses fluxos poderiam narrar muitas histórias interrelacionadas da cidade: a estória do seu povo e dos processos socioecológicos que produzem o urbano e seus espaços de privilégio e exclusão, participação e marginalidade, de ratos e banqueiros, de doença de veiculação hídrica e especulação acerca do futuro e das opções da indústria da água, de reações e transformações químicas, físicas e biológicas, do ciclo hidrológico e do aquecimento global, do capital, das maquinações e estratégias dos construtores de barragens, de incorporadores do solo urbano, dos conhecimentos dos engenheiros, da passagem do rio para os reservatórios urbanos. Em suma, meu copo d'água incorpora múltiplas estórias da "cidade como um híbrido". O rizoma (caule) dos fluxos da água, subterrâneos e superficiais, de córregos, tubulações e veios que contribuem para que a água urbana jorre do hidrante é uma poderosa metáfora dos processos socioecológicos corporificados na vida urbana. (SWYNGEDOW, 2001, p.85) 


\section{RESUMO}

\section{Urbanização da natureza: da autoprovisão de infraestruturas aos projetos de recuperação ambiental nos mananciais do sul da metrópole paulistana}

A presente tese focaliza o processo de ocupação dos mananciais do sul da metrópole de São Paulo, abordando um quadro de relações que se estabeleceu na formação e consolidação de loteamentos precários. Os loteamentos irregulares estudados foram construídos durante os anos 1990, em São Bernardo do Campo, na bacia da Billings - área ambientalmente protegida por lei desde os anos 1970. A análise abrange desde a autoprovisão de infraestruturas, passando pela reivindicação de redes públicas pelos moradores, até a realização de projetos de urbanização. Abordam-se as articulações entre agentes públicos e privados, suas práticas espaciais, bem como as leis e as políticas de mananciais que, perpassadas pela especificidade da propriedade privada, engendraram, direta ou indiretamente, a forma urbana dos loteamentos irregulares. Esse quadro de agentes, num outro contexto, também construiu a necessidade da recuperação ambiental, na qual se associou à implementação de infraestruturas públicas a regularização fundiária e urbanística de interesse social. Os conflitos socioambientais que emergem nesse processo colocam em questão as concepções e a forma de expansão das redes de infraestrutura, o que extrapola a escala local, e evidenciam os descompassos que se estabelecem na realização da política habitacional e de saneamento. Nesse quadro, a fragmentação do espaço articula diferentes escalas de análise, explicitando os limites e as possibilidades, ainda que residuais, de uma apropriação socialmente justa do ambiente urbano. As transformações em curso na paisagem dos mananciais, engendradas pelo capitalismo periférico, nos permitem problematizar concepções hegemônicas acerca do novo paradigma ambiental, à luz da reflexão crítica da relação sociedade-natureza. A pesquisa visa, então, contribuir para o debate da "questão ambiental urbana".

Palavras-Chave: mananciais urbanos, infraestrutura, urbanização, meio ambiente, recuperação ambiental, regularização de interesse social, justiça ambiental, questão ambiental urbana. 


\section{Urbanizing nature: from the self-provision of infrastructure to the environmental recovery projects in the water source region in the south of the metropolitan area of Sao Paulo}

The present work focuses on the process of occupation of water source areas in the south of the metropolitan area of Sao Paulo, addressing the conflicts related to the production of infrastructure during the constitution and consolidation of precarious settlements that expanded in the 1990's, in São Bernardo do Campo, in the Billings Basin - an area that has been protected by environmental laws since the 1970's. From the self-provision of infrastructure, passing through the demand of public networks on behalf of the dwellers, reaching the implementation of urbanization projects, we address the articulations between public and private agents, their spatial practices, as well as the laws and policies regarding water source areas, whose relations mediated by the specificity of the private property, engendered, directly or indirectly, the urban shape of irregular settlements. And, secondly, also created the need for environmental recovery, associating the implementation of public infrastructure with land and urban regulation of social interests. The socio-environmental conflicts that emerged during this process challenged the conceptions and the way infrastructure networks expanded, which extrapolates the local scale, and pointed out the unsteadiness that was established when executing housing and sanitation policies. In this panorama, the fragmentation of the space articulates in the different scales of analysis, making explicit the limits and possibilities, although residual, of a collective and socially fair appropriation of the urban environment. The changes that are taking place in the landscape of water source areas enable us to problematize hegemonic conceptions concerning the new environmental paradigm, based on a critical reflection between society and nature. This study aims at contributing to the debate about the urban "environmental issue".

Key-words: urban water sources, infrastructure, urbanization, environment, environmental recovery, regulation of social interest, environmental justice, "environmental issue". 



\section{SUMÁRIO}

INTRODUÇÃO

A trajetória da pesquisa

Perspectivas de análise

26

0 texto resultante

\section{PARTE I. Produção do espaço e apropriação da água no processo de metropolização desigual de São Paulo}

CAPÍTULO 1. Notas sobre o povoamento dos núcleos coloniais: antecedentes dos problemas de habitação e saneamento

1.1 A água na ocupação de São Paulo de Piratininga e Santo André da Borda do Campo

1.20 início do abastecimento coletivo de água com os primeiros chafarizes

1.3 A transformação urbano-industrial na passagem do século XIX para o XX (até 1930)

1.4 A primeira iniciativa privada no saneamento: Companhia Cantareira de Água e Esgoto

1.5 Saneamento como questão do Estado: A Repartição de Serviços Técnicos de Águas e Esgoto

1.6 A atuação múltipla da Light e o surgimento dos múltiplos usos das represas

CAPÍTULO 2. As redes de infraestrutura "correm atrás" da metropolização

2.1 Indústria, metrópole e 0 acirramento dos problemas urbanos (de 1930 a 1949)

2.2 A crise da moradia e sua solução com ou sem Estado

2.4 Descompassos entre a expansão de infraestruturas e o crescimento urbano em São Paulo: as propostas do Plano Geral da RAE

2.5 A supremacia da geração de hidroeletricidade sobre 0 abastecimento de água e drenagem

2.6 Um debate incipiente sobre a proteção de mananciais

2.7 Modernização desigual e centralismo estatal nas políticas públicas de saneamento e habitação (de 1950 ao início dos anos 1980)

2.8 A reorganização da gestão centralizada do saneamento nas escalas federal, estadual e metropolitana 
CAPÍTUL0 3. Mudanças e permanências no ambiente urbano pós-1980

$\begin{array}{ll}3.1 \text { Habitação e saneamento pós-BNH } & 121\end{array}$

$\begin{array}{ll}3.20 \text { setor do saneamento a partir dos anos } 1990 & 125\end{array}$

3.3 Sabesp: abastecimento de água metropolitano desigual e o objetivo da 128 universalização

3.4 Da metrópole à macrometrópole 132

3.50 sistema de tratamento de esgotos e seu impacto na bacia da Billings 139

PARTE II. A construção social do ambiente urbano precário a partir do processo de consolidação de loteamentos irregulares em área de proteção aos mananciais: da autoprovisão de infraestruturas aos planos de urbanização

CAPÍTULO 4. A emergência do loteamento irregular nas áreas de proteção aos mananciais como solução habitacional em São Bernardo do Campo (1950 - 1990)

4.1. Crescimento urbano e ocupação dos mananciais em São Bernardo do Campo

4.2. 0 processo de formação dos loteamentos do baixo Alvarenga: vende-se um terreno e isso é tudo

4.3. Reconstruindo a autoconstrução

CAPÍTUL0 5. Discursos e práticas dos agentes envolvidos na CPI dos Loteamentos Irregulares em São Bernardo do Campo

5.10 s posicionamentos dos vereadores durante a CPI dos Loteamentos Irregulares

5.2 A participação do movimento de moradia durante a CPI dos Loteamentos Irregulares

5.30 movimento ambientalista do $\mathrm{ABCD}$ e a CPI dos Loteamentos Irregulares

5.4 A atuação da prefeitura (de 1989 a 1993) e a CPI dos Loteamentos Irregulares

206

CAPÍTULO 6. Urbanização contraditória nos mananciais e os sentidos da recuperação ambiental

6.1 Plano Emergencial, TAC e Bairro Ecológico: novas práticas nas APMs? 217

6.2 Em busca do TAC: um estudo urbano ambiental e as cartografias comunitárias no 225 baixo Alvarenga

6.3 Potencialidades e Desdobramentos controversos das cartografias comunitárias 244

6.4 Do TAC ao "Plano Estratégico Geral do Alvarenguinha" 249 
PARTE III. Paradoxos da infraestrutura como recuperação ambiental, a partir da ação do Estado

CAPÍTULO 7. Da Lei Estadual de Proteção aos Mananciais (1976) à Lei Específica da Billings (2009)

7.10 conflituoso processo de revisão da LPM e a promulgação da Lei Estadual 256 no9866/1997

7.2 A elaboração da Lei Específica da APRM-Guarapiranga: a instituição de um modelo

7.3 Da metrópole à bacia: a Lei Específica da APRM Billings

7.4 Lei Específica da APRM Billings: um instrumento de planejamento urbano e ambiental

CAPÍTUL0 8. Do Programa Guarapiranga ao Programa Mananciais

8.1 0 Programa de Saneamento Ambiental da Bacia do Guarapiranga - Programa Guarapiranga

8.2 A ampliação do Programa Guarapiranga para a bacia da Billings, a partir de 2000

8.3 Programa de Saneamento Ambiental dos Mananciais do Alto Tietê

CAPÍTUL0 9. Os Programas de Recuperação de Interesse Social em São Bernardo: reflexões sobre a prática recente

9.1 Os PRIS: infraestrutura e regularização

9.2 0 PRIS do PAC Alvarenga

\section{CONSIDERAÇÕES FINAIS}

LISTAS

Lista de Figuras

Lista de Mapas

Lista de Tabelas

Lista de Quadros

Lista de Siglas 

INTRODUÇÃO 



\section{INTRODUÇÃOO}

\section{A trajetória da pesquisa}

A motivação para a pesquisa, que resultou na presente tese, foi meu contato com os loteamentos e favelas à beira da represa Billings em alguns municípios do sul da Região Metropolitana de São Paulo como Diadema, São Bernardo do Campo, Santo André e São Paulo. A proximidade com a realidade desses assentamentos explicitou situações de ocupação urbana que se diferenciavam das demais situações de precariedade que conhecia até então, pois acumulavam passivos ambientais por estarem em área ambientalmente protegida. Também, representavam diversos conflitos resultantes da expansão periférica e a necessidade de proteção ambiental dos mananciais que abastecem a Região Metropolitana de São Paulo e expressavam a luta organizada de movimentos de moradia, ou de associações de moradores, por melhorias urbanas e a insuficiente resposta do poder público às suas demandas.

Essa aproximação se deu quando, como pesquisadora do Laboratório de Habitação e Assentamentos Humanos da FAUUSP, participava da pesquisa em políticas públicas chamada Reparação de Danos e Ajustamento de Conduta em Matéria Urbanística ${ }^{1}$, que foi formulada em conjunto com o Ministério Público e municípios da bacia da Billings, dentre eles São Bernardo do Campo, desenvolvida entre 2002 e 2005.

Nessa pesquisa, aprofundou-se o tema da irregularidade urbana e ambiental, relacionando os campos do Urbanismo e do Direito. Do ponto de vista do tratamento jurídico, se as ações civis públicas contra os loteamentos irregulares fossem cumpridas à risca - o que, no entanto, não havia se confirmado na prática - provocariam remoção em massa, num quadro em que a legislação de proteção aos mananciais se apresentava como um limite para a regularização e para a intervenção do poder público nesses assentamentos. Mesmo com as premissas do Plano Emergencial ${ }^{2}$, uma situação de exceção às restrições ambientais para a implementação de infraestruturas nos casos de maior precariedade e risco físico, o grande conjunto de situações irregulares não se resolveria. Frente a essa situação, o Ministério Público buscava alternativas

\footnotetext{
${ }^{1}$ A pesquisa foi desenvolvida com apoio da Fapesp - Políticas Públicas, sob coordenação da Profa. Maria Lucia Refinetti Rodrigues Martins.

${ }^{2}$ Conforme a Lei Estadual no 9.866/1997, art. 47, definiu-se que: nas áreas de proteção de mananciais de que tratam as Leis no 898, de 18 de dezembro de 1975 e no 1.172, de 17 de novembro de 1976, até que sejam promulgadas as leis específicas para as APRMs - Áreas de Proteção e Recuperação de Mananciais, poderão ser executadas obras emergenciais nas hipóteses em que as condições ambientais e sanitárias apresentem riscos de vida e à saúde pública ou comprometam a utilização dos mananciais para fins de abastecimento.
} 
para encaminhar ações julgadas, mas que não tinham sido cumpridas, persistindo o problema da chamada degradação dos mananciais. Dentre elas, a elaboração do Termo de Ajustamento de Conduta se apresentou como um instrumento que viabilizaria a recuperação urbana ambiental compartilhada entre os diversos agentes envolvidos nas situações de irregularidade, visando futura regularização e reconhecendo o direito à moradia. Do ponto de vista urbanístico, foram elaboradas diretrizes de intervenção para a recuperação ambiental no contexto dos assentamentos precários em área protegida, buscando alternativas de moradia adequada, desenho urbano e infraestrutura (MARTINS, 2006).

Nas visitas de campo realizadas nesse período, outras situações e questões se apresentaram. Na paisagem do Sítio Joaninha, em Diadema, despontavam variadas estruturas de madeira para sustentar tinas de plástico azul e caixas d'água, que eram preenchidas por caminhão-pipa duas vezes por semana para suprir a ausência de rede pública de abastecimento. Quando o caminhão falhava, os moradores ficavam sem água, o que demandava uma grande capacidade de organização e racionamento no uso da água. Em algumas ruas dos loteamentos do baixo Alvarenga, em São Bernardo do Campo, diferentes alternativas de "drenagem superficial" protegiam os passantes do contato com o esgoto a céu aberto.

Assim como no Sítio Joaninha, nos loteamentos do baixo Alvarenga, os poços construídos pelos moradores foram contaminados pelas fossas e seu uso teve de ser interrompido. No baixo Alvarenga, o problema do abastecimento foi parcialmente resolvido após reivindicação dos moradores pela construção de uma caixa d'água coletiva, operada inicialmente pelo antigo Departamento de Águas e Esgotos e atualmente pela Sabesp. Mas houve problemas de distribuição da água entre as partes altas e baixas dos loteamentos.

Em Cidade Ademar, em São Paulo, a ocupação densa e precária de moradias sobre córregos poluídos, fazia dos dias de chuva e das consequentes inundações, o terror dos moradores. Em Santo André, a contaminação de córregos afluentes à represa Billings pelos esgotos provenientes das casas - situação também presente nas demais áreas - já estava sendo remediada com projeto de urbanização com a participação de moradores, no qual se previa a construção de uma estação localizada de tratamento de esgotos, o aumento de área permeável para infiltração da água, e a construção de espaços de lazer.

Em todas essas situações o trabalho dos moradores na construção de soluções para superar a ausência de infraestruturas públicas era explícito. Ou seja, as infraestruturas tinham uma história, que estava relacionada ao problema da moradia. E apesar da questão fundiária e do acesso à terra serem o fundamento da disputa por localização pelas diferentes classes sociais no espaço urbano, transformando o sítio onde se assentam, as infraestruturas se apresentavam como um objeto privilegiado para a pesquisa urbana e ambiental, extrapolando para o espaço público as questões relativas ao uso dos "recursos" naturais no contexto urbano. A repisada noção da ausência de infraestruturas nos assentamentos irregulares e favelas parecia ser insuficiente para entender o contexto de precariedade, que envolvia diversos agentes, práticas, 
momentos e regulamentações. O tema da autoprovisão de infraestruturas deu origem ao projeto de mestrado ${ }^{3}$.

Assim, o tema da relação entre cidade e ambiente foi se desdobrando a partir da autoprovisão das infraestruturas como elemento de debate sobre a urbanização precária - não apenas do ponto de vista técnico, mas também como questão política. Uma abordagem crítica sobre a construção social de espaços urbanos, para além do espaço da moradia, parecia indicar caminhos nesse sentido. Se a pesquisa "Reparação de Danos" privilegiou a discussão das ocupações irregulares na interface com o Direito Urbanístico, o que emergia como interesse de pesquisa era abordar as questões observadas em relação ao tema mais amplo da relação sociedade e natureza.

Ainda como parte das atividades de pesquisa no projeto do LabHab, frequentei reuniões do Subcomitê Billings-Tamanduateí em que, além de acompanhar as discussões de elaboração da Lei Específica da Billings, tive a oportunidade de conhecer diversos profissionais, organizações e militantes na questão ambiental e urbana. Em 2007, o LabHab foi convidado a participar de um projeto em desenvolvimento por uma organização não governamental de São Bernardo do Campo, a Holos21, que havíamos conhecido nas reuniões do Subcomitê. A Holos 21 estava trabalhando com os loteamentos do baixo Alvarenga, a mesma região que havia sido estudada na pesquisa "Reparação de Danos".

Já no mestrado, e após a finalização da pesquisa do LabHab, passei a acompanhar as atividades dessa ONG junto a seis loteamentos em São Bernardo do Campo: Parque Ideal I, Parque Ideal II, Novo Horizonte, Ouro Verde, Nova América e Parque dos Químicos. Todos eles foram construídos irregularmente perante a legislação ambiental e urbanística, a partir do final dos anos 1980, e tinham Ações Civis Públicas em diferentes estágios de andamento. A atuação da Holos21 objetivava assessorar os moradores na discussão e elaboração de um Termo de Ajustamento de Conduta, que estava sendo negociado com o Ministério Público.

Para realizar esse trabalho, em 2007, a ONG submeteu o projeto "Levantamento Socioambiental da Região do Baixo Alvarenga e Curso de Capacitação de gestores socioambientais" (aqui chamado de Projeto GSA) à aprovação para obtenção de recursos do Fundo Estadual de Recursos Hídricos (Fehidro) 4 . O projeto aprovado foi desenvolvido por uma equipe multidisciplinar sob coordenação do engenheiro Francisco da Silva ${ }^{5}$. A proposta de trabalho se estruturava em 17 ações de "caráter corretivo" (conforme conceituado na Lei Estadual de

\footnotetext{
${ }^{3}$ Da elaboração do projeto aos dois primeiros anos do mestrado, de 2007 a 2009, o Prof. Jorge Hajime Oseki orientou a pesquisa. De 2009 em diante ela foi orientada pela Profa. Maria Lucia Refinetti Martins.

${ }^{4}$ Os projetos que pleiteiam recursos do Fundo Estadual de Recursos Hídricos são selecionados anualmente pelo Comitê de Bacia ou respectiva Agência de Bacia. O projeto da ONG Holos21 foi aprovado em 2007 pelo Subcomitê Billings, com o orçamento de R\$150.000,00 mais 30\% de contrapartida. Somente uma parte desse recurso foi executado pois algumas ações previstas no projeto não chegaram a ser implementadas.

${ }^{5}$ Francisco da Silva, engenheiro, trabalhava na Secretaria de Habitação e Meio Ambiente de São Bernardo do Campo e militava na área ambiental há muitos anos, com atuação local em São Bernardo por meio da ONG Holos21. Faleceu em 2009, sem finalizar o projeto. A ausência de sua liderança na condução das atividades gerou grande desmobilização entre os participantes.
} 
Proteção e Recuperação dos Mananciais no 9866/1997) visando o fortalecimento das associações de moradores locais, a realização de diversos diagnósticos participativos e a elaboração de estudo de adequação urbana e ambiental, que dariam subsídios para a formulação de um Termo de Ajustamento de Conduta para o conjunto dos seis loteamentos.

A Holos21 propôs ao LabHab a realização de duas atividades: o levantamento das edificações (diagnóstico da avaliação física e condição de salubridade das moradias) e o estudo de recuperação urbana ambiental (síntese dos diagnósticos realizados, que embasariam a elaboração do TAC). Nesse contexto, passei a acompanhar o projeto e as reuniões que aconteciam aos finais de semana, com a participação de moradores e lideranças das seis associações. Consultei o grupo sobre a possibilidade de, além de participar do projeto, desenvolver ali a pesquisa de mestrado, que tinha como objetivo compreender os processos envolvidos na autoprovisão de infraestruturas e sua relação com o conflito urbano e ambiental nas áreas de proteção aos mananciais. Com o aceite do grupo, iniciou-se a observação participante.

Para os objetivos da pesquisa de mestrado, que enfatizava o processo de construção de infraestruturas pelos moradores, seguido da organização coletiva para reivindicar as redes públicas, bem como o acompanhamento do debate para a formulação do TAC, foi necessário me aproximar das referências da antropologia. Assim, a observação participante foi empregada como método na medida em que pressupôs o engajamento da pesquisadora com seus informantes como pessoas, não como objetos (GEERTZ, 1989, p.14). Apesar do trabalho de pesquisa não se propor etnográfico, como uma "descrição densa" no sentido de Geertz, buscouse na antropologia referências que pudessem colaborar na vivência da pesquisa empírica e na sua interpretação, considerando-as práticas de pesquisa pouco usuais na arquitetura e urbanismo, mas que abrem possibilidades para enriquecê-la.

A pesquisa empírica se constituiu pela utilização de diferentes ferramentas que viabilizaram o diálogo com os moradores. Foram realizadas entrevistas individuais, entrevistas coletivas e registros de reuniões dos moradores, além de acompanhamento das atividades do Projeto GSA, registro fotográfico, anotações de campo, acompanhamento dos moradores em reuniões externas (com prefeitura e Ministério Público) e a realização das cartografias comunitárias. Num certo sentido, a pesquisa empírica foi mais experimental do que objetiva e se construiu no percurso do trabalho, conforme as questões de interesse foram ganhando novos delineamentos.

Com a passagem para o doutorado direto em 2010, a pesquisa se estendeu no tempo e adquiriu novas formulações, mantendo o objeto das infraestruturas como ênfase. $O$ interesse de pesquisar o processo de autoprovisão de infraestruturas, que denunciava o descompasso da construção das redes públicas nessas áreas, uma ação do Estado "às avessas", implicava buscar relações com a forma de construção e distribuição dessas redes no espaço urbano metropolitano, bem como compreender a concepção de macro sistemas de abastecimento de água e coleta e tratamento de esgotos, e suas consequências nas áreas de proteção aos mananciais. 
Apesar do acúmulo de investimentos públicos em saneamento na metrópole paulistana, segundo dados do Sistema Nacional de Informações sobre Saneamento - SNIS, em 2006, 25,4\% do volume de esgoto (em $\mathrm{m}^{3} / \mathrm{s}$ ) da RMSP era coletado. Desse volume, 46,5\% era tratado (WHATELY; DINIZ, 2009, p.35). Já segundo dados da Sabesp, em 2008, as cinco maiores estações de tratamento situadas na Região Metropolitana de São Paulo eram capazes de tratar aproximadamente $18 \mathrm{~m}^{3} / \mathrm{s}$ de esgoto, e respondiam pelo tratamento de aproximadamente 69\% do esgoto coletado na região. Essa disparidade de dados, por um lado, pode ser explicada pela forma como os mesmos são construídos. Mas por outro, revelam a dimensão metropolitana do problema do tratamento de esgotos. De toda forma, o atual sistema se expande, sem que seja questionado, apesar de seus problemas.

O abastecimento de água na Região Metropolitana de São Paulo já aponta o esgotamento do aproveitamento dos mananciais que a suportam, sendo que grande parte da água provém de bacias vizinhas à do Alto Tietế. Os conflitos de uso nos mananciais inseridos nessa bacia, contudo, persistem, particularmente as frequentes tentativas de se ampliar a geração de hidroeletricidade em Henri Bordem, sem que se solucione o problema do esgotos não tratados que circulam nos corpos d'água ${ }^{7}$. Mas o Sistema Billings continua sendo estratégico para os municípios ao sul da RMSP. Além dos problemas relativos à conservação desse manancial, somam-se os demais usos e intervenções públicas ou privadas que comprometem essa função. A resposta tem sido então transpor água de outras bacias, gerenciando os conflitos que isso implica com outros territórios e cidades.

O histórico das políticas para as áreas de proteção aos mananciais, por sua vez, mostra que a infraestrutura passou de elemento a ser restringido, para que se evitasse estimular ocupações (conforme a Lei Estadual de Proteção aos Mananciais de 1975), para condição necessária de recuperação ambiental dos assentamentos precários e da própria represa Billings. As intervenções recentes têm sido pautadas pela noção de recuperação ambiental associada ao saneamento. Diante desse panorama, no qual frequentemente cada problema tem sido tratado dentro do seu escopo setorial, passei então a problematizar o significado prático que a recuperação ambiental da bacia da Billings tem assumido, analisando as leis, os programas e sua realização por meio de projetos de urbanização e o modo de reprodução dos modelos instituídos de infraestrutura.

Além disso, cabia considerar que a diversidade das ocupações presentes nas áreas de proteção aos mananciais, desde áreas densamente ocupadas, até assentamentos distantes da mancha urbana, passou a ser tratada de forma homogênea, ou seja, os loteamentos foram incorporados aos planos de expansão das redes de água e esgoto, independentemente de sua condição e localização.

\footnotetext{
${ }^{6} \mathrm{~A}$ área da bacia do Alto Tietê abrange quase que integralmente a área da Região Metropolitana de São Paulo.

${ }^{7}$ Os conflitos pelo uso da água por esses sistemas serão tratados ao longo da presente tese.
} 
Daí decorre a questão que se explora na presente tese: a realização da política de recuperação e proteção dos mananciais reitera a reprodução de um modelo de saneamento e de intervenção habitacional (promovida pelo Estado), construídos historicamente e que tendem a ampliar a degradação do ambiente urbano e sua fragmentação, ao invés de proporcionar a apropriação ${ }^{8}$ do espaço, do ambiente (e da água) no sentido de seu uso e não via sua mercantilização.

O sentido de apropriação enquanto valor de uso, em dialética com o sentido de propriedade, porta as possibilidades políticas de superação da predominância da troca sobre o uso na produção do espaço. O conceito de fragmentação do espaço também se relaciona com a propriedade e resulta de sua determinação econômica: a natureza vendida em parcelas, em lotes (LEFEBVRE, 2006). A noção de fragmento está presente em todas as escalas socioespaciais que a pesquisa pretendeu analisar, no que tange as relações sociais na produção do espaço. Essas noções, formuladas por Henri Lefebvre e aqui brevemente anunciadas, indicam a perspectiva de análise adotada na tese.

A pesquisa, ao enfatizar o processo de ocupação e consolidação da área de proteção aos mananciais, desde meados dos anos 70, aprofundou-se na formação de loteamentos irregulares que se multiplicaram nos anos 1990, transformando o espaço e as concepções sobre a proteção ambiental. Buscou-se explicitar as relações entre os agentes e suas práticas, bem como a relação de cada um com as normas e poderes instituídos na produção de loteamentos irregulares e precários. Foi então sobre a população pobre que recaiu, ideologicamente, a responsabilização da degradação da represa. Essas articulações de agentes, normas e políticas, que apresentam continuidades e mudanças ao longo do tempo, foram fundamentais para explicitar o contexto em que o conflito sobre a ocupação de área protegida foi transmutado em recuperação ambiental, quando os mesmos loteamentos irregulares, anos depois, são então providos de infraestruturas. A construção de uma reflexão crítica sobre a recuperação ambiental embasouse na noção de fragmentação do espaço, como se buscará desenvolver ao longo da tese.

\section{Perspectivas de análise}

A questão de fundo que se coloca a partir do problema da pesquisa são as possibilidades de se repensar a relação entre cidade e natureza num contexto em que a "questão ambiental urbana" emerge em meio a múltiplos discursos, posicionamentos e práticas ${ }^{9}$ em relação à proteção do meio ambiente, sendo que a qualidade de vida nas cidades é ruim no seu conjunto, mas os efeitos nocivos do processo de urbanização atingem desigualmente diferentes classes sociais, e mais drasticamente os pobres.

\footnotetext{
${ }^{8} \mathrm{O}$ sentido de apropriação, segundo Lefebvre, é entendido em relação ao conceito de propriedade. Seabra, em seu ensaio "A insurreição do uso" ilumina esse par dialético: "A crítica radical implicada no conceito de apropriação esclarece a propriedade, no limite, como não-apropriação, como paródia, como caricatura, como restrição à apropriação concreta. Isso se dá porque a apropriação está referenciada a qualidades, atributos, ao passo que a propriedade está referenciada a quantidades, a comparações quantitativas, igualações formais, ao dinheiro (que delimitando o uso tende a restringi-lo)" (SEABRA, 1996, p.71).

${ }^{9}$ Sobre os "discursos da sustentabilidade" no urbano ver Acselrad (1999) e Costa (1999).
} 
A água, as infraestruturas e a habitação, bem como espaços púbicos e verdes, elementos fundamentais e concretos da vida urbana, não se distribuem equitativamente no espaço. Desvelar os processos que engendram a "precariedade" revela contradições da sociedade de acumulação capitalista na qual a crise atual explicita o fosso que há entre a racionalidade financeira e de investimentos e as necessidades de reprodução material, cujos resultados sociais, espaciais e ambientais têm se mostrado desastrosos.

As paisagens são reveladoras das relações que se estabelecem entre sociedade e natureza (OSEKI, 2000). Ao mesmo tempo, o exame crítico da relação entre sociedade e natureza é simultaneamente um exame crítico da sociedade (HARVEY, 1996).

Na cidade capitalista a natureza (interna e externa ao homem) ${ }^{10}$ está totalmente transformada pela sociedade de acumulação, na qual impera a lógica da mercadoria, tornando-a assim cada vez mais destituída de seu valor de uso (LEFEBVRE, 2006). Nesse aspecto, há uma dificuldade em qualificar o uso e a apropriação social de "espaços naturais", como por exemplo, reconhecer qual seria o estatuto da natureza primeira dentro de uma teoria social do espaço. Esse questionamento elaborado por Oseki (2006, p.77), envolve a reflexão sobre os projetos urbanísticos atuais nos quais tudo é produzido, transformado, e a natureza desaparece, permanecendo como símbolo: é reproduzida (Ibidem).

Atualmente, é raro encontrar alguém que não defenda o meio ambiente, com o qual todos se preocupam, das pessoas às empresas, dos governos locais e nacionais às instituições internacionais. Mas a questão ambiental tem significados distintos para cada um e, como afirmou Harvey (1996, p.117), esse não é um tema alheio às classes sociais, como às vezes aparenta quando, por exemplo, é sustentado por paradigmas hegemônicos, como o da sustentabilidade $^{11}$. Apesar de nos últimos anos a questão ambiental ter se inclinado para interpretações biocêntricas ou recortadas sob a ótica da proteção de ecossistemas, problemas de poluição, ou de recursos exauríveis, "há um crescimento da aceitação pública da ideia de que o que muitos chamamos de 'natural', pelo menos tanto quanto a superfície ecológica do globo e sua atmosfera está em causa, tem sido significativamente alterado pela ação humana" (Ibidem, p. 119$)^{12}$.

Harvey (1996) busca dar sentido ao que genericamente é chamado de questão ambiental, ao colocar a transformação social e ambiental num quadro de pensamento dialético e históricogeográfico, mostrando que todas as preocupações que se referem "ao ambiente" são necessariamente e simultaneamente propostas para a transformação social. Segundo ele, é necessário realizar a crítica sobre as diversas formulações de "ambiente", "sustentabilidade urbana" e "natureza", pois são discursos que escondem uma agenda política concreta,

\footnotetext{
${ }^{10} \mathrm{O}$ homem, ao agir sobre a natureza externa, a transforma, transformando-o a si mesmo por meio do processo de trabalho (MARX, 2004).

${ }^{11}$ O conceito de sustentabilidade consiste em uma noção vaga, cujo discurso está em disputa por diferentes setores da sociedade, conforme Acselrad (1999).

${ }^{12}$ Tradução livre.
} 
frequentemente mais voltada ao controle hegemônico e do poder. Essa crítica politiza a questão, possibilitando pensar qual a potencialidade de transformação social que o paradigma ambiental contém, nos termos de uma abordagem marxista da questão ambiental, da qual essa pesquisa busca se aproximar.

Segundo Foladori (2001, p.105), dentre os autores que escrevem sobre o tema da "questão ambiental" é comum a referência ao marxismo como uma teoria e uma filosofia que não contribui para essa discussão, pois é considerada produtivista, antropocêntrica e desinteressada do valor que a natureza possa apresentar ${ }^{13}$. Em contraposição, dentre os autores que recuperam Marx, estão os que argumentam ser impossível compreender a degradação ambiental sem vê-la como parte necessária do processo de produção capitalista (HARVEY, 1996; SMITH, 1998; SWINGEDOW, 2001). Não se trata somente da crítica ao crescimento e ao produtivismo, e da constatação da finitude dos recursos naturais, mas das constradições entre modo de produção e relações sociais de produção, inerentes à lógica da obtenção desmesurada do lucro sobre a exploração do trabalho e da natureza. Para Lowy (2010, p.36), se essa perspectiva não for considerada, a crítica está destinada ao fracasso ou pior, à sua recuperação pelo sistema.

A abordagem materialista da natureza como parte integral do "metabolismo" entre homem e ambiente, na vida social, é considerada um dos legados da obra de Marx. Foster (2010) recupera o conceito de metabolismo em Marx visando demonstrar que há uma abordagem ecológica nesse autor, para quem o processo de trabalho é em si um processo metabólico que possui duas facetas. "Ele [Marx] capta tanto o caráter social do trabalho, associado à sua reprodução sociometabólica quanto seu caráter ecológico, demandando uma relação dialética contínua com a natureza" (FOSTER, 2010, p.21). Baseado no conceito de troca metabólica, que se origina da química e da biologia, Marx incorporou um sentido mais amplo que o permitiu articular, na análise metabólica, a relação dialética entre homem e sociedade (Ibidem, p.22).

Esse conceito também permitiu que Marx elaborasse a ideia de "falha metabólica" quando identificou o esgotamento de nutrientes do solo agrícola decorrente do avanço do modo de produção capitalista sobre o campo, gerando novas relações antagônicas entre campo e cidade, esta última, local de poluição e despejo de esgotos (FOSTER, 2005, p.201). Mais do que isso, o conceito de metabolismo forneceu a Marx um modo concreto de expressar a alienação da natureza (e da sua relação com a alienação do trabalho) que desde os seus primeiros escritos foi central na sua obra (Ibidem, p.223).

Diferentemente de Foster, Schmidt afirma que na obra de Marx raramente encontram-se escritos sobre a natureza "em si". Mas para ele, a originalidade de Marx está na concepção sócio-histórica da natureza enquanto primeira fonte de todos os meios e objetos do trabalho, ou

\footnotetext{
${ }^{13}$ Foladori descrimina um grupo de autores que representam essa abordagem: "José M. Naredo. La economía en evolución. Historia y perspectivas de las categorías básicas del pensamiento económico. México D.F., Siglo XXI. 1987; Juan Martínez Alier e K. Schlüpmann. La ecología y la economía. México D.F., FCE. 1993; Nicholas Georgescu-Roegen. La ley de la entropia y el proceso económico. Madrid. Fundación Argentaria/Visor. 1996; T. Benton. "Marxism and natural limits: an ecological critique and reconstruction". In: Benton (org.) The greening of marxism. New York, Guilford Press. 1996".
} 
seja, é o início das atividades humanas, pois pressupõe a totalidade dos modos técnicos e econômicos de apropriação dos homens. A partir daí, todos os demais enunciados sobre a natureza já pressupõem a práxis social. Assim, Schmidt desenvolve a análise sobre a natureza em Marx a partir do valor de uso das mercadorias. Valor de uso que só se realiza por meio da troca, pois caso contrário volta ao estado de natureza.

Em relação ao conceito de intercâmbio orgânico, Schmidt considera que Marx introduz uma concepção inovadora sobre a relação homem-natureza na medida em que a apropriação da natureza se dá por meio do trabalho. Nesse sentido, supera o lluminismo, para o qual a natureza se apresenta como algo imediatamente dado e fixo. Porém, a existência natural do homem é preexistente às formas burguesas de produção. Essa relação imediata entre o homem e sua relação orgânica com a natureza se transforma com "o surgimento das condições burguesas de produção, em seu oposto igualmente abstrato: a divisão radical entre o trabalho e suas condições naturais objetivas", tornando-se totalmente exterior ao homem. Com o crescente domínio técnico-econômico e científico sobre a natureza, transformando-a num mundo de máquinas, a natureza se solidifica em um em-si abstrato, exterior aos homens (SCHIMIDT, 1976, p.90).

Contudo, a ação sobre a natureza supre as necessidades do homem, que constrói relações sociais, concepções, ideias. Ao mesmo tempo em que o homem transforma a natureza produz a sociedade e sua própria humanidade. A contradição apontada por Marx é que o crescimento econômico se dá em descompasso com o desenvolvimento social.

A interpretação de Lefebvre avança na teoria sobre o espaço, com o conceito de produção do espaço $^{14}$. Segundo ele o espaço (social) e o tempo (social) não são fatos da "natureza", mas produtos. A produção do espaço é a ação das sociedades sobre a natureza primeira ${ }^{15}$, criando a natureza segunda, por meio de um conjunto de relações sociais. Assim, o espaço não pode mais ser concebido como passivo e vazio. Enquanto produto, o espaço intervém na própria produção por interação ou retroação: organização do trabalho produtivo, transportes, fluxos de matériaprima e energia, redes de repartição de produtos. Enquanto produtivo e produtor ele participa das relações de produção e das forças produtivas; e ainda, da reprodução, ou seja, na reprodução ampliada do capital. O conceito se dialetiza, espaço como produto-produtor, suporte de relações econômicas e sociais (LEFEBVRE, 2006, p.5).

No século XX, o espaço se "mundializou" junto com o capitalismo, transformando tudo sob a lógica da mercadoria. O espaço capitalista moderno, que nos termos de Lefebvre é o espaço abstrato, serve de instrumento à dominação (Ibidem, p.121), ao poder estatal, planejado. O

\footnotetext{
${ }^{14}$ Para formular o conceito de produção do espaço, Lefebvre retoma os conceitos de Marx e Engels de produção, produto e trabalho, que fundam a economia política e permitem analisar as relações de produção. Segundo Lefebvre, em Marx e Engels há duas acepções de "produção". Uma acepção ampla, ou seja, os seres sociais produzem a vida, sua história, seu conhecimento. E uma acepção restrita, trata-se de produzir as coisas, os produtos, por meio do trabalho. Mas sem perguntar: Quem produz? O quê? E como? O conceito permanece uma abstração (LEFEBVRE, 2006, p. 28).

${ }^{15}$ A natureza é o fundamento do espaço. Enquanto natureza primeira, é geradora "gratuita" de valores de uso.
} 
Estado atua reduzindo as diferenças à repetições, destruindo a natureza e os tempos naturais, por meio da força e da violência. Assim, o espaço abstrato se caracteriza por ser ao mesmo tempo homogêneo, fragmentado e hierarquizado. O homogêneo deriva da tecnologia, da padronização dos processos produtivos, mas também do controle técnico-burocrático sobre os usuários, uniformizando a vida urbana. O fragmento deriva da troca, da relação econômica, das fraturas das exigências da divisão do trabalho. A hierarquia dos espaços serve ao poder político e à produção material (Ibidem, p. 8).

No espaço moderno onde tudo é produzido, a natureza se distancia. Essa natureza original não passa de mito, ficção, pois ela é "apenas matéria prima sobre a qual operam as forças produtivas das sociedades diversas para a produção do espaço" (Ibidem, p.15). Contraditoriamente, com "o avanço das forças produtivas, a capacidade técnica e científica de transformar o espaço natural são tão radicais quanto a capacidade de ameaçar a própria natureza" (Ibidem, p.27).

Na produção do espaço, a natureza primeira (o espaço-natureza, "original") é transformada pelo homem, criando a natureza segunda, ou seja, a natureza produzida. A cidade é natureza segunda, como igualmente podem ser consideradas as infraestruturas, que na construção de paisagens urbanas revelam as relações que a sociedade engendra com o meio "natural". Dessa perspectiva se desdobram questões amplas da relação sociedade e natureza, sobre as quais a presente tese visa contribuir.

Nesse sentido, as paisagens urbanas revelam o espaço funcionalizado, que quanto mais manipulado menos se presta a apropriação, porque fica fora do tempo vivido, dos usuários, tempo diverso e complexo. O cotidiano, o tempo vivido, não pode ser compreendido sem a contradição "uso-troca", mas é sobretudo o uso político do espaço que restitui ao máximo o valor de uso: recursos, situações espaciais, estratégias (LEFEBVRE, 1971, p.117). É nesse direção que se abrem as possibilidades do direito à diferença:

O direito à diferença designa formalmente o que pode resultar dos atos e ações práticas, das lutas efetivas: as diferenças concretas. O direito à diferença não dá algum direito que não tenha sido conquistado em grande luta. Este "direito" só vale por seu conteúdo, inversamente ao direito de propriedade que vale por sua forma lógica e jurídica, princípio do código de relações normais no modo de produção capitalista (Idem).

Considerando a perspectiva lefebvriana, não se pode entender a natureza em parcelas - como ocorre atualmente, reforçando visões deterministas parciais, ou ainda idealizadas - como a defesa da preservação de uma natureza "primitiva" e intocada, portanto inalcançável (um mito). No capitalismo, a alienação homem-natureza chegou ao extremo, sendo a natureza transformada em mercadoria, destituída de seu valor de uso. Perdeu-se a noção de natureza enquanto totalidade, a noção de ambiente e da ocorrência de interferências recíprocas entre o que é natural e construído. Lefebvre realiza a crítica radical do processo de alienação, ou das múltiplas alienações, que para ele encontra-se em uma:

situação intolerável porque a realidade humana está mais profundamente dissociada que nunca. Parece que todas as modalidades possíveis de cisão, de dispersão e de contradição se descobrem hoje e convergem em um imenso infortúnio do homem. O 
dinheiro tornou-se a principal necessidade do homem, e assim se torna pouco a pouco a única "qualidade essencial do homem (LEFEBVRE, 1971, p.172).

Esta alienação engendra, por sua vez, "apetites refinados e artificiais, e a simplificação bestial das necessidades; e isso às vezes inclui os próprios seres" (Ibidem).

A superação da alienação estaria na construção de uma nova prática social, não dominada pelo econômico. "O homem total é o sujeito-objeto vivente antes de tudo desgarrado, e dissociado e encadeado à necessidade e à abstração. Através desse desgarramento vai até a liberdade; se torna natureza, mas dominando-a. O homem total é o homem desalienado" (Idem, p.179). A restituição da relação homem natureza, num novo patamar, passaria necessariamente por uma desalienação do próprio homem, seu corpo e suas relações concretas e simbólicas, consigo, com os outros e com o espaço.

É sob essa perspectiva crítica sobre a produção do espaço que se buscou realizar essa pesquisa. Mas, como alerta Swingedown (2001), é recente a aproximação entre o pensamento ecológico, a economia política, os estudos urbanos e teoria crítica social e cultural, o que pode alimentar uma rica ecologia política urbana. Há um campo e uma agenda de pesquisa em construção, que é interdisciplinar, dos quais a pesquisa buscou se aproximar e dialogar.

Desse modo, privilegiou-se a análise do processo de ocupação e consolidação das áreas de mananciais, consideradas as especificidades da metrópole paulistana, a partir dos conflitos e contradições engendrados na produção de infraestruturas, que envolvem uma trama de agentes, práticas, políticas, leis, investimentos que transformam o espaço urbano, urbanizando a natureza.

\section{0 texto resultante}

O texto se organiza em três partes, num percurso que tem como objetivo construir o argumento da tese e debater as questões que dela se desdobram. A Parte I, intitulada "Produção do espaço e apropriação da água no processo de metropolização desigual de São Paulo", é composta de três capítulos com os quais se busca explicitar como as redes de infraestrutura se constituíram historicamente e configuraram o espaço metropolitano, pautadas ou não por projetos e políticas. A partir desse processo, revela-se, em diferentes períodos e contextos, o tratamento do ambiente e das águas. As áreas de proteção aos mananciais e os atuais conflitos em disputa nesse território, são situados nesse contexto histórico, que abrange também os descompassos entre a reprodução do espaço urbano e as políticas de saneamento e habitação.

No capítulo 1, o histórico remonta ao período colonial, com notas sucintas, para pontuar a importância da água no processo de ocupação do território, mas principalmente para recuperar a constituição do problema do abastecimento de água como questão pública, e do saneamento como atribuição do Estado. É a partir do final do século XIX, na transição para o século XX segundo período tratado nesse capítulo - que a água é mercantilizada a partir da necessidade de generalização do saneamento, ou seja, de infraestruturas que suportariam a expansão urbana. 
O segundo capítulo aborda o período do processo de industrialização em duas fases. A primeira, de 1930 a 1949, que antecede o processo de metropolização, enfoca as incipientes ações estatais na política de habitação e a ampliação das infraestruturas que deram suporte ao processo de urbanização. E a segunda fase, de 1950 ao início dos anos 1980, caracteriza-se pelo centralismo da política pública pelo Banco Nacional de Habitação (BNH), pela intensificação da industrialização e pelo aumento da precariedade e da pobreza na metrópole, ou seja, quando essa política muda de padrão.

O capítulo 3, que aborda as transformações a partir dos anos 1980 até nossos dias, enfatiza a transição para o Estado neoliberal e sua implicação nas políticas públicas de habitação e saneamento, bem como a configuração atual dessas políticas. Com esse vasto panorama, é possível evidenciar a constituição dos atuais "modelos" (ou seja, concepções das políticas e sua forma de realização) das políticas de saneamento e habitação em questão na tese, que interferem na política para os mananciais.

A Parte II, intitulada "A construção social do ambiente urbano precário a partir do processo de consolidação de loteamentos irregulares em APM: da autoprovisão de infraestruturas aos planos de urbanização", focaliza a especificidade da ocupação irregular na bacia da Billings, por meio dos loteamentos precários. Nessa parte, composta por três capítulos, a análise articula o contexto dos loteamentos do baixo Alvarenga, onde se desenvolveu a pesquisa empírica, com o contexto da política pública municipal, desde os anos 1990 aos nossos dias.

O capítulo 4 parte de um breve contexto histórico da política habitacional em São Bernardo do Campo para situar o momento em que os loteamentos irregulares surgem de forma mais expressiva, o final dos anos 1980. Com esse panorama, na segunda parte desse capítulo, volta-se o foco para a situação particular de seis loteamentos populares que aqui denominamos "loteamentos do baixo Alvarenga", situados na porção que corresponde à sub-bacia do Alvarenga, construídos nesse período. A pesquisa realizada desde 2007 junto aos loteamentos Parque dos Químicos, Parque Ideal I, Parque Ideal II, Ouro Verde, Novo Horizonte e Nova América permitiu reconstituir seu processo de formação, a partir da narrativa e experiência dos moradores, destacando as estratégias de compra e venda de lotes, os agentes envolvidos, os grandes desafios enfrentados para autoconstruir a moradia e as demais infraestruturas não construídas pelo loteador.

Se a autoconstrução da moradia tem se reproduzido como forma predominante de constituição e consolidação da periferia, conforme já foi identificado em pesquisas anteriores (LEMOS; SAMPAIO, 1977; MAUTNER, 1991; MARICATO, 1982 e 1995); a autoprovisão da infraestrutura revelou novos elementos para a reflexão do impacto social e ambiental gerados pela ausência das redes públicas, que dependem de investimentos, técnicas, projetos e materiais que não podem ser providos pelos próprios moradores. Sendo assim, a autoconstrução de infraestruturas e a conquista de "melhorias" parciais também explicitam o aspecto privatista e fragmentado da construção do ambiente urbano precário, bem como o papel contraditório do Estado nesse processo. 
O capítulo 5, retoma o foco para o contexto mais amplo municipal, ainda no início dos anos 1990, destacando o momento em que o loteamento irregular precário passa a ser denunciado por diversos agentes como um dos grandes responsáveis pela degradação dos mananciais e da represa Billings. Em 1991, é instaurada a Comissão Parlamentar de Inquérito - CPI do Loteamento Irregular na Câmara Municipal de São Bernardo do Campo para apurar os responsáveis pelos empreendimentos. A análise do processo da $\mathrm{CPI}^{16}$, composto por 11 volumes que reúnem diferentes documentos ${ }^{17}$, explicitou o posicionamento de diversos agentes em relação ao conflito: vereadores, representantes do poder público, movimento ambientalista, movimento de moradia, loteadores e imobiliárias irregulares. Assim, configura-se um quadro mais abrangente sobre a "questão dos mananciais" nesse período. Além disso, explicitou-se o tratamento jurídico do problema por parte do poder público, com a proposição de diversas Ações Civis Públicas ${ }^{18}$ - ACPs contra os loteadores irregulares e também a tentativa de coibir a sua ação por meio da repressão policial.

O capítulo 6 aborda um momento, em 1997, em que a tentativa de reprimir o parcelamento irregular do solo atinge seu ápice, culminando numa ação de demolição de um assentamento. Em seguida, mudanças no contexto institucional, legal e no Ministério Público engendram uma inflexão no tratamento desse conflito, no sentido da busca por alternativas jurídicas e urbanísticas para reparar danos causados. A partir de então começam a ser formulados Termos de Ajustamento de Conduta que se articularam a um programa de intervenções chamado Bairro Ecológico, da PMSBC, colocando em relevo a necessidade de se conceber alternativas para a carência de infraestrutura considerando as especificidades da área ambientalmente protegida. As urbanizações de áreas mais críticas foram autorizadas pelo Plano Emergencial, conforme a lei estadual no 9866/1997 que estabeleceu uma nova política para mananciais.

Apesar de terem sido indicados no Plano Emergencial, os loteamentos do baixo Alvarenga não chegaram a firmar TACs e não passaram por intervenções de infraestrutura. Na segunda parte do capítulo 6, voltamos a abordar a situação desses loteamentos, quando, por meio da observação participante pudemos acompanhar de perto novas formas de organização dos moradores. A realização de cartografias comunitárias insere-se como parte de um conjunto de

\footnotetext{
${ }^{16}$ Foram analisados os documentos do processo da CPI cuja cópia está arquivada no Ministério Público. O acesso foi gentilmente cedido pela promotora pública Rosangela Staurenghi.

17 Dentre eles: atas de reunião, denúncias, depoimentos, matérias de jornais, legislação, documentação relativa aos loteamentos, ações civis públicas, registros de manifestos e de manifestações.

${ }^{18}$ Segundo Nogara (2008), a criação da Ação Civil Pública representa um dos esforços na superação das limitações das regras clássicas, voltadas apenas à reparação de danos sofridos individualmente. É uma ação desenvolvida para a defesa de direitos difusos e coletivos, que incluem a qualidade de vida, a saúde, a qualidade do ar, o consumidor (coletivamente), bens de valor histórico, paisagístico etc. A formulação da Lei no 7.347, de 24 de julho de 1985, referente à ACP, foi inspirada em alguns dispositivos da ação popular e da Política Nacional de Meio Ambiente e sofreu alterações introduzidas pelo Código de Defesa do Consumidor. A Lei proporciona a tutela preventiva, para evitar o acontecimento do dano, por meio de ações cautelares e de pedidos de medida liminar antecipadas em ações de conhecimento. E a tutela reparatória, para reparação dos danos já acontecidos, por meio de pedidos de fazer e de não fazer, com ou sem imposição de reparação pecuniária. As indenizações, multas e condenações em dinheiro devem ser encaminhadas a um fundo (gerido por um Conselho Federal e, no nível dos Estados, por Conselhos Estaduais), que tem como objetivo a reconstituição dos bens lesados (NOGARA, 2008, p.119).
} 
atividades coordenadas pela ONG Holos21, que assessorava os moradores na elaboração de um estudo que subsidiaria a elaboração de um TAC para o conjunto de loteamentos. Buscamos destacar nesse processo o embate de concepções sobre as possibilidades de recuperação ambiental quando formuladas a partir da experiência cotidiana.

Com a mudança da gestão municipal em 2009, o novo governo adota o Orçamento Participativo como forma de gerir as demandas da população e organizar a atuação governamental, e deixa de priorizar o TAC como instrumento para a recuperação ambiental. Nesse mesmo ano, é aprovada a lei específica da Billings, permitindo a regularização de assentamentos precários e de interesse social, se vinculada a um Plano de Urbanização Integrada. Nesse contexto, novas contradições entre o ambiente urbano, o cotidiano e a ação do Estado emergem.

Na Parte III, busca-se evidenciar a ação prática do Estado no manejo dos conflitos existentes nas áreas de proteção aos mananciais (APMs), a partir de dois instrumentos: a elaboração de legislação e a execução de programas de financiamento para projetos de intervenção, destacando aqueles destinados à urbanização de assentamentos precários (favelas e loteamentos irregulares populares) e às obras de saneamento (particularmente redes e sistemas de água e esgotos). O objetivo é mostrar como a atual política de mananciais prioriza a urbanização de assentamentos precários como principal componente da recuperação ambiental, reproduzindo os padrões vigentes de intervenção habitacional e de infraestrutura de saneamento, sem que se comprovem melhorias efetivas na qualidade ambiental da bacia e da água. Nesse sentido, a implementação desigual de infraestruturas não aparece como um problema, desde que seja garantida a expansão da rede.

O capítulo 7 recupera brevemente os principais momentos de revisão da Lei Estadual de Proteção aos Mananciais (LPM no 898/1975 e no 1.172/1976), passando pela chamada Nova Política de Mananciais - a Lei Estadual no 9866/1997, até chegar à promulgação das leis específicas de bacias hidrográficas - primeiro da Guarapiranga (2006) e em seguida da Billings (2009). Essa trajetória contribui para a compreensão da atual legislação incidente em APM, que buscou se adequar à realidade da ocupação existente.

A elaboração e a revisão da Lei Estadual de Proteção aos Mananciais (LPM) ocupou por mais de trinta anos uma parcela significativa do trabalho do corpo técnico e político do Estado, em muitos momentos tecnicizando de maneira extremada problemas sociais e reforçando o caráter ideológico da legislação ambiental. O debate sobre essa lei protelou a tomada de decisão do governo do Estado diante do problema dos assentamentos precários, enquanto que a cidade se fazia no embate por diferentes usos desse território e da água como recurso econômico. Em contraponto, a sociedade civil polarizada, principalmente entre movimento ambientalista e movimento de moradia, exerceu importante papel no processo de alteração dessa lei. Cabe pontuar que um dos principais fatores que contribuíram para sua revisão foi a própria prática do poder público municipal em lidar com os assentamentos precários.

No capítulo 8 são apresentados os conteúdos principais dos programas de financiamento para as intervenções públicas em APM, em diálogo com as mudanças normativas. O ponto de partida é 
o primeiro programa de saneamento ambiental da Bacia do Guarapiranga, o Programa Guarapiranga. O estudo desse programa e dos subsequentes identificou de que forma ele se constituiu num modelo que se reproduziu e se ampliou para a escala da Bacia do Alto Tietê, consolidando um modo de intervenção de urbanização de assentamentos precários que é pautado majoritariamente pela execução de obras de urbanização e saneamento. Contudo, esse quadro de projetos e programas não configura, em seu conjunto, uma ação integrada nas áreas de proteção aos mananciais.

No âmbito da política recente de proteção e recuperação dos mananciais a Lei Específica da Área de Proteção e Recuperação dos Mananciais - APRM-Billings (LE-Billings) desempenha um papel relevante na medida em que elege a infraestrutura como elemento fundamental para a recuperação ambiental e para a regularização de interesse social, diferentemente da legislação anterior. A interface dessa lei com situações concretas é o tema do capítulo 9, que apresenta dois diferentes Programas de Recuperação de Interesse social - PRIS, em desenvolvimento no município de São Bernardo do Campo, a partir dos quais tecemos algumas considerações críticas acerca das práticas e da lei.

Com esse percurso, que parte da abordagem histórica da constituição das redes de infraestruturas relativas à água para se chegar a uma discussão sobre ambiente urbano, se problematiza, nas considerações finais, a noção de recuperação ambiental tal como ela tem sido implementada por meio da atual política de mananciais. 
PARTE I 



\section{PARTE I}

\section{Produção do espaço e apropriação da água no processo de metropolização desigual de São Paulo}

A origem da relação cidade e água nos conduz às civilizações antigas, que criaram formas engenhosas de intervenção no meio físico para se estabelecerem e desempenharem diversas atividades, pois a água é condição básica de sobrevivência e suporte de inúmeras relações sociais, urbanas, econômicas, culturais e simbólicas. Nosso interesse particular, nesse vasto espectro de possibilidades que a relação cidade e água pode suscitar é localizar, temporal e espacialmente, as formas de apropriação da água ao longo do processo de urbanização da cidade de São Paulo e de sua região metropolitana no contexto do capitalismo periférico, considerando momentos relevantes de transformação desse processo, até nossos dias. É, portanto, com essa perspectiva que os presentes capítulos 1, 2 e 3 estão construídos na primeira parte dessa tese.

O estudo sobre as formas de apropriação da água - um processo social, entendido a partir do processo de urbanização desigual e contraditório da Região Metropolitana de São Paulo (RMSP), implica em abordar a relação entre as opções políticas, as concepções tecnológicas e os interesses econômicos que, juntos, passam a utilizar a água como um recurso a ser explorado para múltiplos fins. A construção de infraestruturas permite a generalização de seu consumo, ao mesmo tempo em que serve para promover atividades econômicas e acúmulo de capital, engendrando a "urbanização da natureza" (SWYNGEDOW; HEYNEN, 2003). Simultaneamente, a complexidade dos sistemas nos planos técnico, operacional e financeiro, passa a requerer o desenvolvimento de políticas públicas, regulamentações, instituições, para promover a expansão dos serviços. Essa expansão ocorre paulatinamente, mas não garante as melhores condições ambientais e sociais, tornando flagrante um descompasso entre a velocidade de produção de construções e o acompanhamento da implementação das redes de infraestrutura.

Ao mesmo tempo, usos possíveis da água que escapariam à racionalidade da mercadoria (usos residuais, que sobreviveriam ao domínio econômico sobre o espaço e seus recursos naturais), de fruição, vão sendo suprimidos ou pela sua mercantilização ou por sua degradação, apesar desta última não inviabilizar usos econômicos, como a geração de energia, por exemplo. A degradação dos corpos d'água é a face evidente de que a poluição não comprometeu interesses econômicos hegemônicos, produtivos, apesar de significar um desastre ambiental e social, tanto no nível coletivo mais amplo, quanto particularmente para as camadas da população que não acessam as redes formais de infraestrutura, e assim ficam mais expostas a riscos de contaminação por doenças de veiculação hídrica. 
Como se verá, as ações planejadas para o tratamento de esgotos como um sistema só tem início, de fato, em meados da década de 1970. Assim, a relação da sociedade com os corpos d'água, rios e represas poluídos, com esse ambiente urbano transformado - natureza segunda, nos termos de Lefebvre (2000), é frequentemente de anulação ou rejeição. E a defesa da proteção da natureza aparece como algo exterior a esse processo e a nós mesmos, como um mito, apesar de algo incontestável, ao menos no discurso.

Em países do capitalismo avançado, a degradação ambiental chegou a tal ponto que implicou em novas posturas e práticas frente às questões relativas ao ambiente urbano, como demonstram as renaturações de rios $^{1}$ que buscaram reestabelecer, por meio da técnica, suas funções naturais, correspondendo ao que seria uma terceira natureza. Essas preocupações ainda são recentes no Brasil, onde projetos urbanos pouco articulam soluções de infraestrutura com melhorias ambientais de acordo com essa perspectiva. Conforme formulou Oseki (2000), tais questões contribuem para uma reflexão crítica sobre as relações entre sociedade e natureza, e colocam uma dificuldade no que tange ao lugar que a natureza ocupa na produção social do espaço, para além da ideologia "verde".

Nessa primeira parte da tese, busca-se explicitar como as redes de infraestrutura, pautadas ou não por projetos e políticas, configuraram o espaço metropolitano. E a partir desse processo, revela-se em diferentes períodos e contextos, o tratamento do ambiente e das águas. Para isso, cada item do capítulo pontua inicialmente questões de contexto, para abordar em seguida as interfaces e especificidades do espaço da moradia e das redes de infraestrutura, em diálogo com suas respectivas políticas públicas.

Outro pressuposto dessa retrospectiva é que muitos dos conflitos atualmente presentes nas áreas de proteção aos mananciais metropolitanos, áreas "produtoras" de água, em particular na bacia da Billings - enfoque dessa pesquisa - podem ser mais bem compreendidos se situados historicamente, explicitando os interesses econômicos e políticos em jogo em cada momento. São conflitos que envolvem a utilização da água para diferentes fins além do abastecimento público, como a geração de energia, o controle de cheias e o saneamento. E os interesses econômicos que se constituíram como forças capazes de orientar as decisões técnicas e políticas sobre esses sistemas, frequentemente não corresponderam aos interesses públicos, ou até mesmo aos objetivos declarados das políticas governamentais, apesar do contraponto exercido pela população, que sistematicamente reivindicou melhorias de condição de vida urbana, apesar da desigualdade política de sua posição. A universidade também desempenhou seu papel na formulação de concepções, conceitos e planos, no caso em tela, relativos ao saneamento.

\footnotetext{
${ }^{1}$ Essa reflexão foi desenvolvida pelo Prof. Jorge Hajime Oseki em 1997, na pesquisa de Pós-doutorado sobre as experiências de renaturação de rios no Japão, idealizados nos anos 1970 e desenvolvidos posteriormente. Uma síntese pode ser encontrada no texto A Fluvialidade no Rio Pinheiros: um projeto de estudo, publicado na Pós - Revista do Programa de Pós-Graduação em Arquitetura e Urbanismo da FAUUSP, no 8, 2000. Também consideramos as anotações em aulas ministradas pelo professor, no curso de Pós-Graduação da FAUUSP, em 2007 e 2008, nos quais o tema era tratado; e o texto La fluvialité urbaine des fleuves/La fluvialité social des fleuves/paysages fluviaux, do mesmo autor (mimeo).
} 
Se a relação entre crescimento urbano e desigualdade de acesso à habitação e as infraestruturas (nesse caso, particularmente as redes de água e esgotos) é parte constitutiva do processo de urbanização de São Paulo desde o século XIX, no caso das áreas de proteção aos mananciais, o descompasso é ainda maior, devido às restrições impostas pela especificidade legal de proteção ambiental da região. A fragmentação que caracterizou a produção de redes de infraestrutura na escala metropolitana dos sistemas de água e esgotos, como também na implementação de redes locais (OSEKI, 1991), soma-se a esse descompasso. Nesse sentido, os eixos que organizam esse histórico visam contribuir para uma reflexão crítica de como se constituíram convergências, rupturas, realizações e inações, entre as políticas públicas de saneamento e habitação, bem como das respectivas regulamentações e as concepções de infraestruturas físicas, que engendraram transformações desse espaço urbano, considerando, portanto, as ações do Estado nesses campos.

Além disso, questões que se apresentam como relativamente novas, em parte devido à influência que o paradigma ambiental tem exercido sobre as políticas públicas atuais, não são tão recentes assim. Um exemplo é o debate acerca da defesa técnica sobre formas de proteção ambiental de bacias hidrográficas, que se travou já nas primeiras décadas do século XX, entre os sanitaristas, que polarizavam posições entre a adução de água pura em áreas não urbanizadas versus as alternativas de tratamento de água e desinfecção nos rios já contaminados. O que nos interessa destacar é que a opção por uma determinada alternativa correspondeu não só ao conhecimento disponível naquele momento, mas também se articulava a interesses econômicos, com consequências concretas para o espaço.

Considerando esse conjunto de questões, entendemos que os conflitos presentes nas áreas de proteção aos mananciais (APM), se inserem no contexto do desenvolvimento das políticas públicas de modo setorial, cada qual dentro de sua própria lógica, ignorando as demais. Mas se as políticas setoriais não foram (e não são) concebidas de forma articulada em termos de planejamento urbano, elas "se encontram" no espaço, ainda que esse encontro se manifeste pelo descompasso entre redes de infraestrutura e moradias.

Esta parte se organiza em três capítulos que apresentam uma estrutura comum: se iniciam com um breve contexto geral, socioeconômico e urbano, de âmbito nacional, e em seguida abordam os temas relativos ao período nas escalas estadual e municipal. Adotamos como ponto de partida dessa narrativa, construída a partir de pesquisa bibliográfica, a cidade de São Paulo, buscando pontuar as transformações que simultaneamente ocorreram na região metropolitana e em particular no ABC paulista, com enfoque em São Bernardo do Campo - onde a pesquisa empírica desta tese foi realizada. O fio condutor a partir do município de São Paulo não se justifica apenas como contexto, mas principalmente porque aí se deram inicialmente as formulações de concepções urbanísticas que precisam ser pontuadas, porque reaparecem tanto na escala local do caso estudado, como têm repercussão em escala metropolitana, tendo por vezes repercussões no âmbito nacional.

Dessa forma, os capítulos estruturam-se em três períodos representativos de mudança no padrão de urbanização. No capítulo 1 , o histórico se inicia antes mesmo do período mais 
relevante para nosso estudo, ou seja, o final do século XIX. Recuamos ao período colonial, com notas sucintas, para pontuar a importância da água no processo de ocupação do território, mas principalmente para recuperar a constituição do problema do abastecimento de água como questão pública, e do saneamento como atribuição do Estado. É a partir do final do século XIX, na transição para o século XX - segundo período tratado nesse capítulo - que a água é mercantilizada a partir da necessidade de generalização do saneamento, ou seja, de infraestruturas que suportariam a expansão urbana.

O segundo capítulo aborda o período do processo de industrialização em duas fases. A primeira, de 1930 a 1949, que antecede o processo de metropolização, e enfoca as primeiras ações estatais na política de habitação, e a ampliação das infraestruturas que deram suporte ao processo de urbanização. Nesse período o abastecimento de água já contava com a represa de Guarapiranga. E a segunda fase, de 1950 ao início dos anos 1980, caracterizada pelo centralismo da política pública pelo Banco Nacional de Habitação (BNH), pela intensificação da industrialização e pelo aumento da precariedade e pobreza na metrópole.

O capítulo 3, que aborda as transformações a partir dos anos 1980 aos nossos dias, enfatizando a transição para o Estado neoliberal e sua implicação nas políticas públicas de habitação e saneamento, bem como a configuração atual dessas políticas.

Assim, sob a perspectiva de analisar a produção do ambiente metropolitano, à luz do conceito lefebvriano da produção do espaço, o capítulo visa iluminar a articulação entre a forma de ocupação do território e apropriação da água, as concepções de saneamento e a expansão espacial das infraestruturas, e a relação da produção dessas redes com o espaço da moradia, engendrados em diferentes momentos do processo de acumulação capitalista na RMSP. 


\section{CAPÍTUL0 1}

\section{Notas sobre o povoamento dos núcleos coloniais: antecedentes dos problemas de habitação e saneamento}

No período colonial, considerando o contexto de expatriação de recursos naturais, de exploração do trabalho, a concentração fundiária para a monocultura e a submissão da colônia aos interesses da metrópole portuguesa, nos interessa discutir algumas características particulares que resultam da produção social do espaço nesse período, enfocando as soluções relativas à água como condição necessária ao incipiente povoamento. Esse recorte temporal, apesar de remoto, contribui para a compreensão dos antecedentes do processo de urbanização desigual. Esse movimento nos permite identificar inclusive que algumas dessas heranças mais arcaicas se reapresentam atualmente, transformadas, e permanecem como traços característicos de nossa formação socioespacial, como se verificará ao longo da tese.

Como consequência da economia eminentemente voltada ao mercado externo, não havia políticas específicas que conduzissem a ações visando melhorias nas condições de vida dos moradores locais. Sendo assim, nesse período, se destaca o caráter individual das soluções sanitárias e de saúde (HELLER; REZENDE, 2008, p.84). Ao mesmo tempo, a abundância de recursos hídricos na maior parte do território brasileiro fez com que sistemas de saneamento não fossem implantados durante os três primeiros séculos da colonização², o que mudará em meados do século XVIII, quando a população aumenta significativamente, durante a exploração do ouro. Portanto, por muito tempo, apesar das áreas ocupadas serem dispersas, onde havia pequenos aglomerados a condição sanitária e de vida eram extremamente precárias.

O trabalho compulsório dos negros os submetia a todo o tipo de atividade, dentre elas, grande parte dos "serviços de saneamento". Havia os escravos que transportavam potes d'água nas costas para o abastecimento, retirados dos mananciais próximos, e também os chamados "tigres" que esvaziavam nos cursos d'água os potes de dejetos das casas-grandes ou sobrados, que ao escorrer marcavam suas costas, os diferenciando dos demais - o que reforçava sua condição de vida desumana, desconfortável e insalubre (Ibidem, p.90).

Em relação à moradia, grande parte da população vivia em casas bastante simples, pequenas e pobres, feitas de taipa ou adobe, cobertas com folha de palmeira. Do lado externo praticava-se a higiene pessoal, a lavagem dos utensílios e das roupas. Já as casas-grandes, sobrados e vivendas

\footnotetext{
2 As obras mais antigas de saneamento no Brasil foram realizadas durante a permanência de Mauricio de Nassau (1637-1644), no período da ocupação holandesa no nordeste. Ele trouxe técnicos de hidráulica para a construção de canais, diques e aterros na cidade do Recife. Havia também a preocupação com a transmissão de doenças, sob a crença da Teoria dos Miasmas (HELLER; REZENDE, 2008, p.90).
} 
foram sendo construídos conforme se diversificavam a economia e o crescimento urbano, dentro dos padrões de conforto e intimidade mínimos. Essas casas possuíam vários cômodos, entre os quais a secreta "edificação com fins de higiene existente em algumas casas, mas que consistia muitas vezes apenas num buraco, embaixo do qual podiam se instalar os chiqueiros", ou o "quarto das bilhas", onde eram depositadas as excretas em bilhas ou potes, esvaziados nas praias e lotes distantes. Entretanto, a maioria da população dispunha os dejetos em áreas próximas às residências, ficando assim mais exposta às doenças (Ibidem, p.89). Somente nos engenhos de açúcar, unidade produtiva, havia soluções hidráulicas como as "rodas d'água", que davam suporte ao desenvolvimento das agromanufaturas.

Os engenhos e os núcleos de extração mineral passaram por importantes surtos epidêmicos, principalmente de varíola. A falta de cuidados e de assistência com a saúde também era suprida pelos escravos negros, as mucamas e os curandeiros, cujas práticas medicinais que envolviam o uso de ervas e rituais de magia na busca da cura foram, posteriormente, perseguidas e punidas

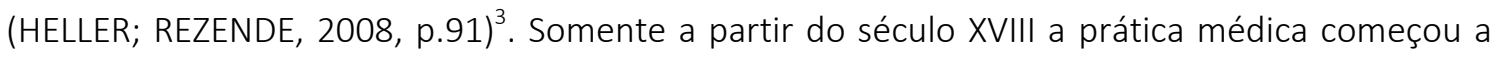
ser exercida no Brasil e possuía um caráter fiscalizador por parte do Estado.

Lentamente a questão sanitária passou a ser tratada no plano coletivo. Uma mudança qualitativa nesse sentido ocorreu quando o fornecimento de água à população passou a ser feito por chafarizes, poços, cisternas e aquedutos, a partir do século XVIII, mesmo a demanda não sendo satisfatoriamente atendida. A administração dos chafarizes era realizada pelas câmaras municipais tuteladas pelos intendentes municipais.

E a partir do último quartel deste mesmo século, a administração colonial portuguesa passou a se ocupar da execução de sistemas de drenagem e aterros em algumas cidades brasileiras, realizados principalmente para a eliminação de áreas alagadas, visando à expansão urbana e à "eliminação dos miasmas". As principais intervenções desse tipo deram-se no Rio de Janeiro. Alguns cuidados relacionados à saúde eram impostos aos moradores das cidades, como a retirada dos dejetos das ruas e dos espaços públicos. No Recife e no Rio de Janeiro chegou a ser aprovada pelas câmaras de vereadores uma lei que tornava obrigatório o uso da expressão "Água vai!" antes do lançamento de dejetos pelas janelas, para avisar os transeuntes (Ibidem, p.105).

A transferência da Corte portuguesa para o Brasil, e a abertura dos portos (1808) às "nações amigas", ou seja, à Inglaterra pôs fim a trezentos anos de sistema colonial. Dentre outras consequências, isso implicou na demanda por melhorias no saneamento dos portos. Em 1829, foram organizados os serviços de Inspeção dos Portos, ficando o município responsável pelo exame de todos os navios que ancorassem em seu território antes do desembarque. Esse setor

\footnotetext{
3 Heller e Rezende (2008) destacam como origem da "identidade sanitária brasileira" a miscigenação étnica entre índios, brancos e negros, sendo as condutas relativas ao saneamento resultantes da integração dessas culturas.

${ }^{4}$ A Teoria dos Miasmas predominou até o século XIX, e explicava que as doenças seriam transmitidas por emanações gasosas provenientes da matéria orgânica em decomposição, frequentemente encontrada em regiões pantanosas. Mas a associação entre meio físico e transmissão de doenças tem origem nas civilizações greco-romanas (Ibidem, p.54).
} 
passou por sucessivas reformulações e, em 1849, foram criadas a Comissão Central de Saúde Pública, a Comissão Central de Engenharia e, em 1850, a Junta da Saúde Pública, que passaram a levantar os problemas sanitários restringindo-se à capital do Império (Ibidem, p.105). Portanto, o tratamento das questões sanitárias ainda estava voltado à garantia das relações comerciais, mas dava os primeiros passos em direção ao seu tratamento no plano coletivo.

\subsection{A água na ocupação de São Paulo de Piratininga e Santo André da Borda do Campo}

O primeiro núcleo colonial formado no interior do planalto que se tem notícia foi Santo André da Borda do Campo, elevado à condição de vila em 1533, pelo primeiro governador-geral, Tomé de Souza. O segundo núcleo, Colégio de São Paulo de Piratininga, foi empreendido pela missão jesuíta com vários missionários da Companhia de Jesus, em 1554, na confluência dos rios Anhangabaú e Tamanduateí.

Em 1560, Mem de Sá - terceiro governador-geral, passou São Paulo à qualidade de vila mandando transferir para lá Santo André da Borda do Campo, que enfrentava diversos problemas, pois não tinha condições favoráveis à sobrevivência nem à segurança contra os índios, assim desaparecendo sem deixar qualquer vestígio (FARIA, 2004, p.37).

Ainda nesse período, a região que hoje corresponde ao atual $A B C D$ paulista era uma grande sesmaria ${ }^{5}$ localizada na Borda do Campo, e pertencia a Amador de Medeiros (que tomou posse em 1574), ouvidor da Capitania de São Vicente. As sesmarias foram herdadas por Miguel Aires Maldonado, que as doou à Ordem de São Bento, em 1637. Apesar de Maldonado ter aí residido, as primeiras benfeitorias foram realizadas somente no século XVIII, quando os monges beneditinos construíram uma capela dedicada a São Bernardo (1717-1720), iniciando a ocupação efetiva das terras. Por isso, passaram a chamar a região nos arredores da capela de bairro de São Bernardo. Em 1812, o território que até então fazia parte da Freguesia da Sé, foi formalmente desmembrado, a pedido da população em demanda ao pároco. Ao longo da segunda metade do século XVI e no decorrer do século XVII, outras concessões de terras foram observadas nessa região (CARVALHO, 2005, p.32-35).

A implantação desses dois núcleos coloniais estabelecia diferentes relações com o ambiente natural, especialmente com as águas. Isso foi observado por Caio Prado Junior (2004) que chama atenção para o fato de, curiosamente, Santo André da Borda do Campo ter se constituído “distante de correntes d'águas, ficando predominantemente situado na orla de uma floresta e sem poder se socorrer de peixes ou água para lavoura ou rebanho, enquanto procedimentos contrários tomaram os jesuítas na escolha de seu estabelecimento" - e a razão dessa escolha é

\footnotetext{
${ }^{5}$ A divisão do território em capitanias hereditárias, doadas pela Coroa, faziam dos donatários possuidores de terras, não proprietários. Os direitos sobre a terra e sua exploração ficavam sob controle da Coroa portuguesa. Os donatários tinham poderes administrativos, o monopólio da justiça e a autorização para fundar vilas, doar sesmarias, alistar colonos para fins militares e formar milícias sob seu comando. A sesmaria era uma extensão de terra virgem, cuja propriedade era doada a um sesmeiro, com obrigação - raramente cumprida - de cultivá-la no prazo de cinco anos e de pagar um tributo à Coroa (FAUSTO, 2011, p.19).
} 
desconhecida. Já para o núcleo jesuíta, a proximidade com a água foi fundamental para seu estabelecimento e a localização sobre a colina viabilizava o acesso à água para sobrevivência, à segurança - pois os rios serviam de barreira natural a possíveis ataques, e também como canal de comunicação e transporte ${ }^{6}$.

Durante os séculos XVI e XVII, enquanto a colônia portuguesa concentrava as atividades de extração de pau-brasil e o cultivo de tabaco e cana-de-açúcar no norte e nordeste da colônia; no mesmo século XVI, as atividades econômicas de São Paulo embasavam-se primordialmente no apresamento e escravização do gentio, e no século seguinte nas bandeiras do ouro. Com isso voltava-se para o interior do território, contrariando os marcos do modelo urbano português de ocupação litorânea (SANTOS, 2011, p.30).

Ao longo do século XVIII o território brasileiro ainda era basicamente rural, e a mineração realizada na região das Minas Gerais representava a principal fonte de riqueza da metrópole européia. Em São Paulo, somente a partir de fins de século XVIII, com a retomada da produção da cana-de-açúcar, se tornou possível sua inserção paulatina na economia internacional enquanto produtora de bens exportáveis ${ }^{7}$, respondendo aos interesses da metrópole. Contudo, somente no final do século XIX é que São Paulo passaria por maiores transformações.

\subsection{0 início do abastecimento coletivo de água com os primeiros chafarizes}

Os primeiros chafarizes da cidade de São Paulo datam de 1744, pois nesse ano a Câmara entrou em entendimento com os padres franciscanos, para que eles fizessem o "encaminhamento das sobras para uso público, por meio de uma fonte de pedra", das águas do Anhangabaú. O suprimento de água manteve-se dessa forma por aproximadamente meio século, sendo transformado em utilidade pública em 1828. O abastecimento era complementado com as "pipas a porta, importando, em média cada barril de 20 litros em 60 réis", enchendo as caixas (MOTTA, 1937, p.203); ou ainda por poços escavados nas residências. Em 1812, a Câmara de São Paulo determinou a captação das águas superficiais do Anhangabaú e outros córregos para alimentar novos chafarizes (AZEVEDO NETTO, 1984, p.107).

Em 1791 o governador Bernardo José de Lorena (1788-1797) mandou fazer a análise da qualidade das águas das diversas nascentes de uso público da cidade de São Paulo, a primeira tentativa racional de controlar o abastecimento público de água na cidade (FARIA, 2004, p.39).

\footnotetext{
${ }^{6}$ O posicionamento da ocupação jesuíta no centro de um sistema hidrográfico fez com que o rio Tietê se tornasse um importante meio para a expansão territorial do país já que curso natural no sentido do interior desembocando no Rio Paraná o tornava um caminho natural para a interiorização do planalto (SANTOS, 2011, p.27).

${ }^{7}$ As medidas adotadas pelo governo de Bernardo José de Lorena (1788-1797) também explicam a alavancagem da acumulação de capital em São Paulo, alterando sua importância no contexto do capitalismo comercial, tais como: a obrigatoriedade do embarque da produção açucareira através do porto de Santos, em detrimento do Rio de Janeiro, proporcionando uma nova dinâmica à cidade portuária e, por extensão, à cidade de São Paulo; e a construção da Estrada do Lorena (1972) que ligava São Paulo a Santos pela Serra do Mar, facilitando o escoamento da produção canavieira das fazendas localizadas no interior até o porto de Santos (SANTOS, 2011, p.32).
} 
Durante o século XVIII, diversos chafarizes foram construídos. Inicialmente, não possuíam encanamento, ou seja, as águas que recebiam e forneciam à população eram conduzidas até eles por meio de valetas abertas que seguiam os declives naturais da topografia. Anos mais tarde, estas valetas seriam canalizadas, a partir das obras realizadas por Tebas, o escravo liberto que se tornou pedreiro, e também empreendeu a solução para o abastecimento regular do Largo da Misericórdia (a mando de Lorena), entre 1792-1793, utilizando-se de pedra de cantaria na construção de canalização das águas do Anhangabaú (FARIA, 2004, p.39; SANTOS, 2010, p.41).

Por volta de 1814, foram construídos os chafarizes da Ladeira da Memória e do Piques, este último alimentado com as águas do tanque do Reúno (AZEVEDO NETTO, 1976, p.24). A obra foi resultado da canalização a céu aberto das águas do Reúno (ou Bexiga), na nascente do Saracura, com o objetivo de abastecer o Jardim Botânico (Jardim da Luz) e o Convento da Luz. Trata-se do primeiro aqueduto público construído. Em seguida foram construídos outros chafarizes, por volta de 14 existiam em operação, mas não eram suficientes para o abastecimento de todos os habitantes (SANTOS, 2010, p.42).

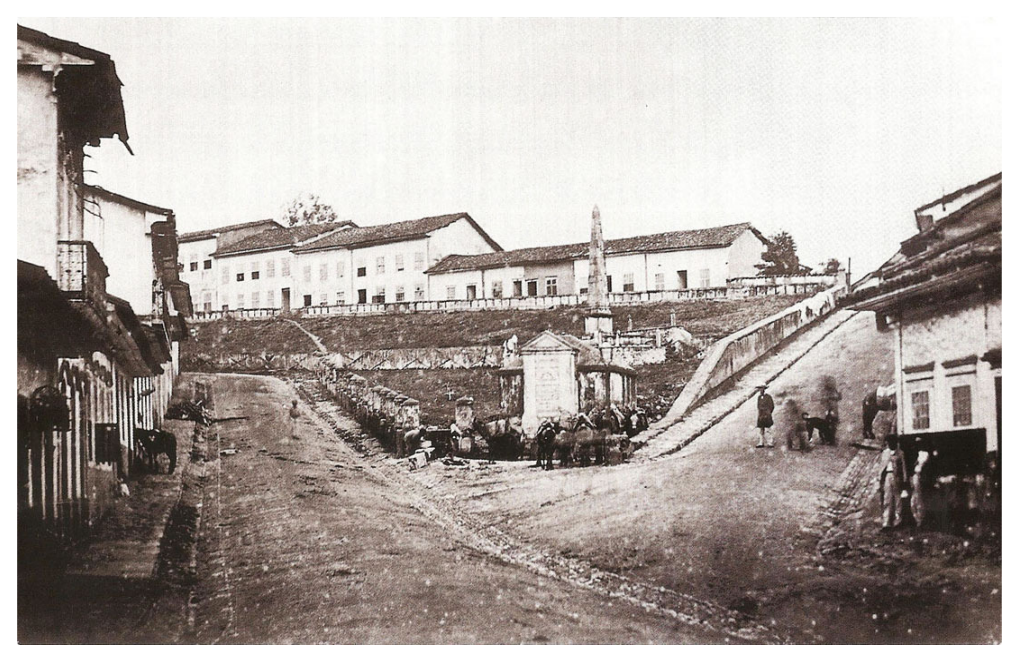

Figura 1 - Largo da Memória e Chafariz dos Piques, 1862. Foto de Militão Augusto de Azevedo.

Fonte: TOLEDO, 2007, p.51.

O entorno dos chafarizes era um espaço de sociabilidade, pois além dos escravos e empregados que buscavam água para seus patrões, o restante da população também o fazia para consumo próprio. Esse contexto ensejou o aparecimento de novas profissões, como o aguadeiro, que vendia água de porta em porta. Por isso, conflitos e desentendimentos aconteciam nesses espaços, entre os que buscavam água para consumo e para a venda como forma de subsistência, o que implicava até em policiamento para manter a "ordem". Também existiam as casas de banho ${ }^{8}$, que ofereciam serviços de higiene para os que não tinham água em casa, mas estas tenderam ao desaparecimento com o advento do abastecimento domiciliar (Ibidem, p.43).

Além dos chafarizes, os próprios rios eram locais de encontro de lavadeiras que trabalhavam nos vários afluentes do Tamanduateí. Nas épocas de estiagem, a disputa pela água crescia, e resultava em legítimas "brigas de lavadeiras" (SÃO PAULO, 1999, p.46). Havia também outras

\footnotetext{
${ }^{8}$ Havia casas de banho no Largo de São Bento, na Rua Boa Vista e na Rua Direita, e se mantiveram como um hábito e uma necessidade enquanto perdurou o problema do abastecimento (FARIA, 2004, p.43).
} 
atividades econômicas como os pescadores e os chacareiros, que navegavam trazendo verduras e frutas para o Mercado Velho (hoje 25 de Março). Por esse rio também se chegava à borda do Campo, o que facilitava o transporte de tijolos e telhas produzidos nas olarias de São Bernardo, sobretudo por imigrantes italianos (Ibidem, p.51).

O primeiro projeto oficial de adução e distribuição de água foi apresentado ao Governo da Província em 1842, pelo tenente de engenharia José Joaquim da Costa Henriques, o qual, entretanto, não foi realizado (MOTTA, 1937, p.203).

Nesse período, aconteceu a primeira intervenção sobre um rio, o Tamanduateí, porque era caudaloso e em qualquer chuva gerava cheias, cujos impactos se agravavam com o crescimento da cidade. Em 1848, durante a administração do Presidente da Província Conselheiro Pires da Motta, com direção do engenheiro Carlos Abraão Bresser, a intervenção se baseou na abertura de um canal reto paralelo ao rio, com maior profundidade. Com isso, afastou-se a margem do rio da zona central, empurrando o problema - já que não o resolveu - para leste da colina histórica ${ }^{9}$. Como consequência, houve alteração nas funções que antes se desempenhavam no seu leito e, associado às cheias, havia o problema dos despejos de águas residuais, que se concentravam nas áreas alagadiças, como a várzea do Carmo. Acreditava-se que esses dejetos acumulados eram responsáveis pela geração de emanações pútridas (SANTOS, 2011, p.58). Apesar disso, devido à péssima qualidade e insuficiente quantidade de água dos chafarizes, por volta de 1858, a população recorria às águas impuras do Tamanduateí.

Com o aumento da população, os problemas urbanos se acirraram. Em relação à água potável, os mananciais próximos já não eram mais suficientes. Em segundo lugar, em razão da precariedade dos sistemas de adução, ou seja, o entupimento dos encanamentos e o desmoronamento dos terrenos que os sustentavam, perdia-se sempre uma porção considerável de água. E, por fim, como lembra Ernani Silva Bruno, uma das causas mais graves que contribuíam para que houvesse pouca água nos chafarizes era a derrubada das matas nas cabeceiras dos mananciais que abasteciam a cidade (FARIA, 2004, p.41).

A relação entre moradia e água, até esse momento, pelas dificuldades de acesso e inexistência de redes, era bastante simplificada. Apesar dos chafarizes representarem a primeira solução coletiva ao problema da provisão de água, era uma fonte pontual, fazendo com que o abastecimento das residências fosse desempenhado por indivíduos - fossem eles escravos, aguadeiros (em geral eram portugueses) ou moradores simples. A água vinha do exterior da casa, do espaço público, e internamente à moradia servia principalmente para a função básica de cozinhar. A higiene pessoal, a lavagem de roupas e o despejo dos dejetos eram feitos fora da unidade, voltando aos espaços coletivos e aos cursos d'água. A maioria dos usos relativos à água, não só os serviços como o lazer e a sociabilidade, portanto, se dava no espaço comum, no entorno dos chafarizes ou nos rios.

\footnotetext{
${ }^{9}$ Essa intervenção extinguiu as Sete Voltas, uma série de sete curvas do rio na altura da colina histórica. Nesta mesma área se localiza hoje a rua 25 de Março (SANTOS, 2011, p.58).
} 
A mudança no contexto econômico, político e social na passagem do século XIX para o XX implicou em uma transformação profunda na sociedade, com os acúmulos de riquezas proporcionados pela exportação do café, que gestou o espaço urbano industrial e, portanto, alterou o modo de construir e organizar a cidade, sob uma racionalidade econômica muito distinta do período anterior. A relação com as águas também se transformaram.

\subsection{A transformação urbano-industrial na passagem do século XIX para o XX (até 1930)}

A produção do café no sudeste foi economicamente importante para o comércio exterior do Brasil e requereu a diversificação de atividades como o aparelhamento de portos, a criação de novos mecanismos de crédito e novos sistemas de transporte, proporcionando um acúmulo de riquezas. Com seu declínio a partir da crise de 1929, o capital foi investido numa série de atividades urbanas que acompanhavam a divisão do trabalho impulsionado pelo processo de industrialização, que por sua vez acelerou o processo de urbanização.

Um dos aspectos centrais da passagem de uma economia a outra, foi a transformação da terra em mercadoria, simultânea ao fim do trabalho escravo e ao processo de imigração de trabalhadores europeus. O marco da mudança foi a promulgação da Lei de Terras no 601 de 1850, que legitimou a prática da aquisição de terras apenas por título de compra, pelos que já detinham "cartas de sesmaria" ou provas de ocupação "pacífica e sem contestação", e da própria Coroa (oficialmente proprietária de todo o território ainda não ocupado), e que a partir de então passava a realizar leilões para sua venda ${ }^{10}$. Com isso impedia-se que os escravos, que seriam juridicamente libertos apenas em 1888, e os imigrantes, presos às dívidas com seus patrões ou simplesmente ignorantes de todos os procedimentos necessários para obter o título de propriedade, comprassem propriedades. Isso, segundo Martins (1981, p.28) "recriava as condições de sujeição do trabalho que desapareceriam com o fim do cativeiro". A terra passa a ser a nova medida da riqueza e já se definia um claro limite entre proprietários e não proprietários de terras ${ }^{11}$.

Segundo Murillo Marx (1991, p.119), a Lei de Terras demorou a se impor no meio urbano, pois a compra e venda conviveu por muito tempo com formas precedentes de aquisição de terras

\footnotetext{
${ }^{10}$ Anteriormente a esta lei, a ocupação da terra podia ocorrer de duas formas: a ocupação de áreas presumivelmente devolutas pelo pequeno lavrador; ou o grande fazendeiro que, por via legal, obtinha cartas de sesmarias, mesmo em áreas onde já existiam posseiros. A carta de sesmaria tinha precedência sobre a mera posse, razão por que em geral o cesteiro ou comprava a roça do ocupante, ou o expulsava ou o incorporava como agregado de sua propriedade (MARTINS, 1981, p.24-25).

${ }^{11}$ Segundo José de Souza Martins os ocupantes de terras e os possuidores de títulos de sesmarias ficaram sujeitos à legitimação de seus direitos, o que foi feito em 1854 através do que ficou conhecido como "registro paroquial". Tal registro validava ou revalidava a ocupação da terra até essa data. No entanto, o mecanismo não impediu uma "verdadeira indústria de falsificação de títulos de propriedades" para validar a posse em cartórios oficiais, geralmente mediante suborno aos escrivães e notários. Grandes conflitos de terra nas frentes pioneiras de São Paulo tinham como base esses documentos (MARTINS, 1981, p.28).
} 
como a concessão de datas, ou partilhadas do rossio; mas foi decisiva. De acordo com Maricato (1995), o mercado de terras efetivamente avançou em São Paulo na Primeira República.

A paisagem urbana passou por transformações com a mercantilização da terra, pois com ela surge, além da necessidade da documentação, a necessidade de precisar a localização, o tamanho do parcelamento e suas frações, configurando o desenho urbano geométrico e racional. A área do lote e sua forma retangular "refletirá a tensão entre a necessidade de atender ao comprador e a de obter o maior lucro possível" (MARX, 1991, p.112). Conforme Murillo Marx, o termo loteamento desponta no final do século XIX e se torna a partir daí corriqueiro (Ibidem, p.108). Nesse momento também passa a existir regulamentações a seu respeito.

Enquanto São Paulo se "modernizava", e atraia investimentos dos países centrais, particularmente no setor de infraestruturas urbanas, os municípios do entorno continuaram a desempenhar atividade rural, fornecendo alimentos, como é o caso de São Bernardo do Campo. De acordo com Martins, quando a vila de São Bernardo foi desmembrada de São Paulo em 1889, era basicamente um núcleo rural e assim se conservou durante muito tempo, produzindo batata, uva e vinho, lenha e carvão para a cidade. Na região que hoje é o ABC, "um esboço da indústria se dissemina com as olarias para fabricação de tijolos, que serviriam para as grandes construções e a grande revolução arquitetônica da cidade de São Paulo, decorrente do desenvolvimento econômico propiciado pelo café" (MARTINS, 2008, p.47). O fato de estarem numa condição intermediária entre cidade e campo, e desempenharem atividades econômicas relacionadas à São Paulo, diferenciava a situação urbana desses núcleos, chamados de subúrbios $^{12}$.

Com a mudança no padrão de acumulação, ocorreu simultaneamente uma transformação nas relações sociais, condutas e costumes. O elemento que abalou a lentidão do século XVIII foi a ferrovia, que chega em 1860, com sua velocidade, nova espacialidade e temporalidade, "o tempo regulado pelo custo e pelo lucro" (MARTINS, 2008, p.16). Além de agilizar o transporte do café para exportação, as ferrovias tiveram um efeito considerável sobre a cidade de São Paulo, que passou a sediar residências de fazendeiros.

Entretanto, em meados do século XIX, as cidades brasileiras estavam em estado de calamidade em função da insalubridade e, consequentemente, de uma série de epidemias ${ }^{13}$, o que se agravava com o aumento do contingente populacional com a imigração. Segundo Costa (1994), a implantação de sistemas de esgotamento sanitário nas grandes cidades em todo o mundo, em

\footnotetext{
12 Essa designação foi primeiramente encontrada por Martins (2008, p.43), num levantamento oficial da população realizado ainda na segunda metade do século XVIII e referia-se à atual região do ABC, antigos bairros de São Caetano, de São Bernardo, da Borda do Campo e do Caaguaçu, que era povoada por moradores de algumas grandes fazendas e de alguns bairros rurais a elas vinculados, muito ligados à dinâmica cotidiana da cidade de São Paulo. O subúrbio era habitado por poucos brancos, por escravos, por índios administrados e por numerosa população de caipiras, então denominados bastardos, filhos da mestiçagem de índias e brancos (Ibidem, p.47). Depois recebera também a chegada de imigrantes estrangeiros, italianos e alemães.

13 Por volta de 1850, epidemias como a febre amarela atingiu o Rio de Janeiro, o Ceará, o Recife, que também teve surtos de cólera e varíola.
} 
geral, só aconteceu após o aparecimento de epidemias de cólera. Em cidades como Paris, Londres, Memphis, Hamburgo e São Paulo, acometidas pela epidemia em 1832, 1854, 1873, 1892 e 1893, respectivamente, tiveram, na sequência, a execução e ampliação de redes de esgotamento (COSTA apud HELLER; REZENDE, 2008, p.67).

O quadro de epidemias, do ponto de vista econômico, ameaçava o desenvolvimento da indústria e do comércio. Isto, aliado à crescente necessidade de adequação das condições sanitárias existentes aos padrões internacionais de comércio, impulsionou a intervenção do Estado nas políticas sanitárias, pois estas se tornavam também imprescindíveis ao avanço da economia ${ }^{14}$. Assim o saneamento já era visualizado como intrinsecamente associado à viabilização das relações de produção, e essencial à prevenção de doenças. No Brasil, a realização de melhorias de infraestrutura urbana e dos meios de produção ocorreu inicialmente por meio da concessão dos serviços à iniciativa privada, particularmente de capital inglês, que foi iniciada em várias cidades $^{15}$. O caso de São Paulo é abordado no item a seguir.

Portanto, a transformação urbano-industrial muda não só a escala e a diversidade das organizações com finalidade econômica, como a vida das pessoas, impulsionando a atuação do Estado sobre aspectos da vida urbana que até então não o ocupava significativamente.

\subsubsection{A urbanização em São Paulo: questões sanitárias e segregação socioambiental}

Considerando brevemente o contexto de transição do modelo agroexportador para o urbanoindustrial abordado acima, passamos a enfocar, no mesmo período, a produção do espaço urbano na cidade de São Paulo, núcleo econômico e geográfico da região metropolitana, que se formará nos períodos subsequentes. Para as temáticas dessa tese, a fase de transição e "explosão" da cidade de São Paulo (para no item seguinte tratar do caso de São Bernardo), reúne uma pluralidade de acontecimentos relevantes, particularmente as mudanças que ocorrem com a infraestruturação da cidade, condição necessária a sua expansão, e por isso mesmo o saneamento passa a ser tratado como problema coletivo, sobre o qual o Estado terá que encontrar soluções. Em paralelo, a questão habitacional passará a ser um problema a ser enfrentado, também do ponto de vista sanitário.

\footnotetext{
${ }^{14}$ As reformas sanitárias para modernizar a cidade no Rio de Janeiro empreendidas pelo médico Oswaldo Cruz e o engenheiro Pereira Passos são emblemáticas desse período.

15 Heller e Rezende (2008) pontuam as primeiras experiências da presença de empresas inglesas no setor de infraestrutura e serviços urbanos em diversas cidades do período. Em 1855, o Rio de Janeiro foi a primeira cidade a ter sistema de coleta de esgotos, na penitenciária pública. Depois a concessão foi dada para a The Rio de Janeiro City Improvements Company Limited, em 1862, sendo as primeiras obras inauguradas em 1864 (adoção de sistema unitário). Recife, em 1873, contou com o sistema de esgotamento sanitário por meio da concessão à companhia inglesa Recife Drainage Company (até 1908). Em Porto Alegre, a concessão à Companhia Hydráulica Porto Alegrense, de capital inglês, ocorreu em 1861, mas o sistema só foi inaugurado em 1866. Em Belém, o abastecimento de água foi implantado pela Companhia das Águas do Grão-Pará, também de capital inglês, a partir de 1881. Em São Luis, os serviços de água, esgotos, tração, luz e prensa de algodão eram controlados por companhias inglesas. Em Fortaleza, o abastecimento de água foi feito pela concessão à Ceará Water Works Company Limited, a partir de 1867 (HELLER; REZENDE, 2008, p. 128-129).
} 
A historiografia demarca a década de 1870 como um momento de inflexão na cidade de São Paulo, quando passou de burgo de estudantes à metrópole do café, também considerada sua "segunda fundação" (DE PAULA, 1954). As transformações urbanas decorrentes do investimento do capital cafeeiro instauraram nova dinâmica na vida urbana, rompendo com inatividade e a pouca importância que a cidade tinha durante o século XVIII. Do ponto de vista quantitativo, de 1872 a 1890, em duas décadas portanto, a população da cidade dobra, passando de 31.385 habitantes para 64.934 habitantes, respectivamente; quadruplicando entre esta data e 1900, chegando a aproximadamente 240 mil habitantes. "Qualitativamente a cidade explode (e implode), sai dos limites do triângulo central e se espalha com o loteamento de antigas chácaras vizinhas" (OSEKI, 1991, p.12).

O poder público local, durante a administração de João Teodoro Xavier (1872-1875), passa a atuar no embelezamento do espaço urbano, realizando diversas obras e melhoramentos, como abertura de ruas, jardins e passeios ${ }^{16}$, pois era necessário estruturar os serviços e equipamentos públicos e coletivos.

A abertura de loteamentos passa a ser objeto de investimentos lucrativos, atraindo o interesse de empreendedores nacionais e estrangeiros. Os chamados bairros aristocráticos começavam a ser construídos e ocupados pelas elites econômicas. O bairro de Campos Elíseos (1879), de Higienópolis (1890), a Avenida Paulista (1891) e em seguida os bairros jardins construídos pela Companhia City em 1915 (Jardim-América, Jardim Europa, Pacaembu, Alto da Lapa, e além do Tietê o alto de Santana) são exemplos do padrão "exclusivo" e higiênico" de ocupação do espaço urbano.

O ramo imobiliário, portanto, foi um dos setores que recebeu investimentos oriundos do excedente econômico do café, além da indústria, comércio de importação, exportação e varejista, sistema bancário e serviços urbanos, todos produtos do capital mercantil urbano (FIX, 2011, p.51). Como argumenta Fix, "a criação de um mercado de trabalho e a mercantilização da terra, aliadas ao crescimento das atividades urbanas, criaram as condições para que o complexo da construção civil começasse a se configurar", o que ocorreu como consequência do mercado de residências de luxo, pois ele abriu oportunidades para a organização da atividade construtora em bases empresariais, com a divisão de trabalho entre escritórios de arquitetura e engenharia, construtoras, comércio de importação de materiais de construção, indústria e comércio locais de materiais de construção (Ibidem, p.67).

\footnotetext{
${ }^{16}$ As intervenções foram: a construção da Ilha dos Amores (1875), formando passeio público na Várzea do Carmo (sem resolver o problema de enchente); a reforma do Jardim da Luz frente à nova estação de ferro; regularização do largo dos Curros (hoje Praça da República); abertura das ruas Conde d’Eu (atual rua do Glicério), ruas João Teodoro e Palha (hoje 27 de abril); alargamento das ruas do Gasômetro, do Pari, do Hospício (hoje Frederico Alvarenga) e Municipal (hoje ladeira General Carneiro); reformulação do Palácio do Governo (SANTOS, 2011, p. 57). Em 1872 a Companhia dos Carris implanta bondes por tração animal e inicia-se a substituição de lampiões a querosene por gás (BUENO, 1994, p. 54).

17 Para esses bairros havia leis que definiam o modo "exclusivo" de construir da elite que, além de determinar um padrão de ocupação, serviam como garantia de proteção de seu espaço. A casa unifamiliar isolada em grande terreno e separada da rua e dos vizinhos ficou conhecida como modelo higiênico (ROLNIK, 2003, p. 46).
} 


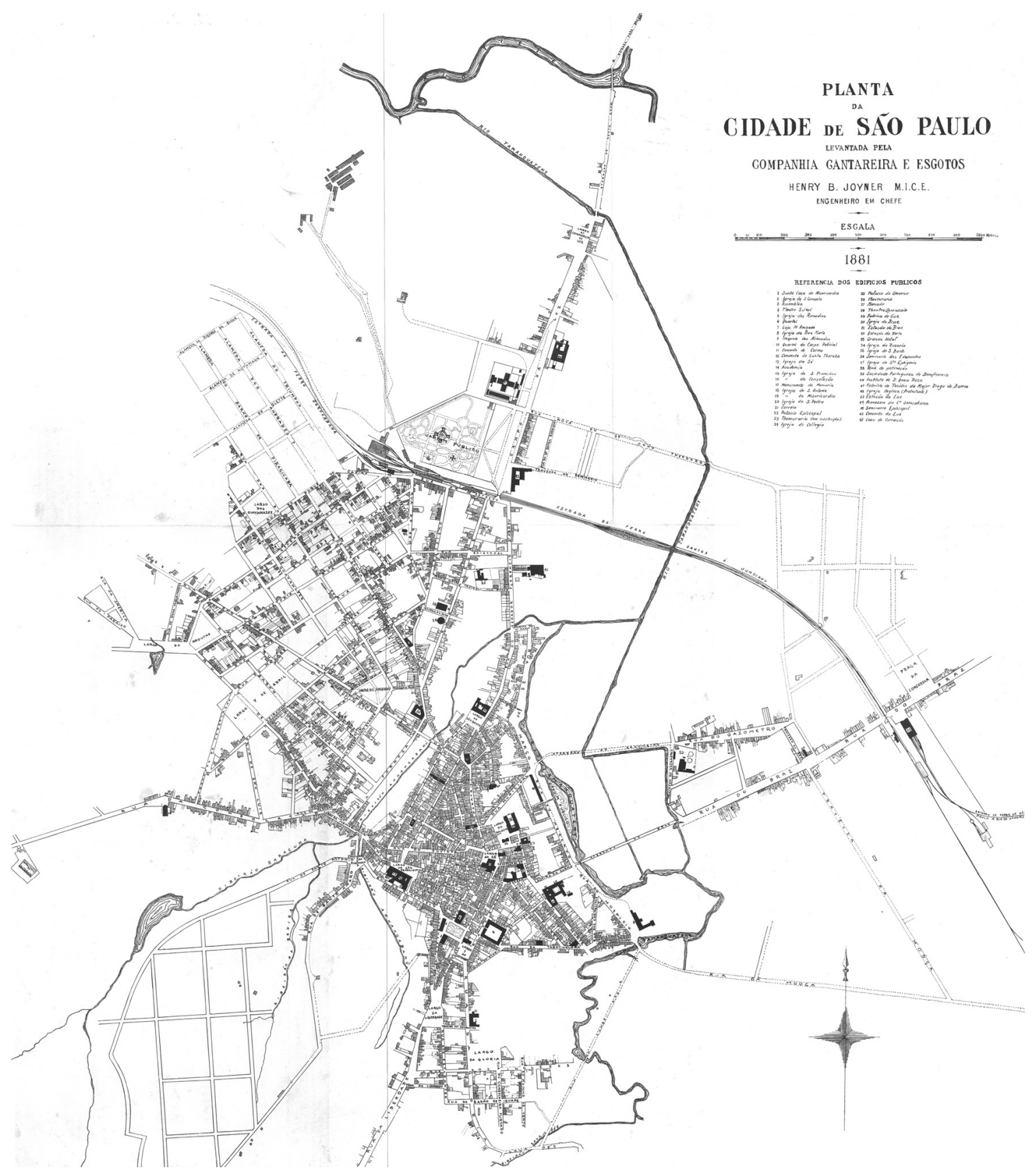

Mapa 1 - Planta da Cidade de São Paulo em 1881. Repartição de Águas e Esgotos de São Paulo.

Fonte: Arquivo Público do Estado de São Paulo, disponível em http://www.arquivoestado.sp.gov.br/upload/ Cartografico/mapas/TemplateWebPage.php?imagem=BR_APESP_IGC_IGG_CAR_I_S_0203_001_002, acessado em: 18/02/2013.

Ao mesmo tempo, pouca atenção se voltava aos bairros populares, onde a população vivia nas piores condições higiênicas e sanitárias, submetida a uma precariedade que aumentava com a crescente aglomeração de trabalhadores mal-alojados.

No início do século XX, a ocupação da cidade apresentava-se dividia em dois blocos separados pela várzea do Tamanduateí. No velho centro, onde está o Pátio do Colégio, já haviam se adensado os bairros da Liberdade, Bela Vista, Consolação, Campos Elíseos, Bom Retiro, Santa Ifigênia; do outro lado, atravessando a várzea do Carmo (atual parque Dom Pedro II), 
concentravam-se os núcleos do Brás, Mooca, Pari e Santana. Os terrenos situados nas áreas altas tinham preferência sobre as áreas baixas e as várzeas inundáveis, que por sua vez tinham menor preço e onde se instalaram diversos cortiços.

Nesse período, até a década de 1930, variadas modalidades de moradia para as camadas sociais de baixa e média renda foram construídas pela iniciativa privada, tais como cortiço-corredor, cortiço casa de cômodos, vários tipos de vilas e corredores de casas geminadas. A vila operária era considerada o modelo ideal de habitação higiênica, mas nem todos os trabalhadores conseguiam pagar os aluguéis, indo morar nos cortiços, onde as condições eram muito mais precárias, deixando os moradores mais suscetíveis aos problemas sanitários. Essa situação estava presente nos bairros de Santa Ifigênia, Bom Retiro, Bexiga e no Brás.

As moradias para classes de renda média também eram em grande parte acessadas por meio do mercado de aluguéis, outra forma de obter grandes lucros com os empreendimentos imobiliários, o que Bonduki (2011) denominou de produção rentista ${ }^{18}$. O investimento tinha retorno garantido e não havia controle estatal sobre os aluguéis, fixados em contrato pela lei da oferta e da procura; o direito de propriedade, garantido pela Constituição Civil, permitia o despejo, favorecendo assim os proprietários (BONDUKI, 2011, p.44).

Mas enquanto a moradia era produzida sem a participação do Estado, no âmbito do empreendimento privado, a infraestrutura insuficiente combinada ao aumento populacional favorecia a propagação de epidemias, constituindo o chamado problema sanitário. É justamente esse problema que forçará a ação estatal sobre habitação popular durante a Primeira República (1889-1930).

Segundo Bonduki, para se compreender o significado da intervenção estatal no espaço urbano nesse período, é preciso considerar que o Estado liberal relutava ao máximo em interferir na esfera privada e nas regulamentações trabalhistas, e tratava a questão social por meio de um aparato policial para controlar os trabalhadores e defender instituições. Na habitação, porém, o Estado foi levado a atuar de forma mais rigorosa (BONDUKI, 2011, p.27).

No final do século XIX, uma importante pressão sobre o Estado foi exercida pelo grupo dos higienistas, médicos e engenheiros que, apesar de liberais, demandavam medidas e uma legislação especial que os possibilitassem intervir nas residências. Tinham como exemplo as leis sanitárias inglesas, francesas e alemãs ${ }^{19}$. A legislação urbanística brasileira nesse período foi influenciada especialmente pela teoria dos fluidos, que dominava o pensamento médico na

\footnotetext{
$18 \mathrm{Na}$ produção rentista predominava a produção por encomenda (construção em etapas), o que viabilizava a participação de diferentes portes de investidores, inclusive pequenos, que construíam conforme a disponibilidade de dinheiro. Em menor número havia trabalhadores que economizavam, compravam lote afastado e barato, e construíam por conta própria, como fizeram alguns imigrantes italianos.

${ }^{19}$ A situação nas cidades européias, que já haviam se industrializado e concentrado população, era muito pior se comparada à das cidades brasileiras. A clássica descrição de Londres, feita por Engels em Situação da Classe Trabalhadora na Inglaterra, ilustrava o contexto alarmante em que viviam os trabalhadores. A Lei Sanitária inglesa foi promulgada em 1848, em meio a muita polêmica e resistência dos liberais, mesmo tendo sido aprovada após cinquenta anos de processo de urbanização e industrialização, e após vinte anos de epidemia de cólera (BONDUKI, 2011, p.28).
} 
França desde o século XVIII e segundo a qual o ar e a água eram considerados veículos mórbidos, portadores de emanações fétidas e pútridas, os miasmas, transmissores de doenças.

Por isso, a legislação orientava a construção de moradias e intervenções no meio físico. Mas, "rapidamente, a observação médica e a teoria do contágio desloca-se do meio físico para o meio social, do espaço público para o espaço privado", responsabilizando os miseráveis urbanos pela propagação de doenças (ROLNIK, 2003, p. 40). Cabe apontar que na década de 1870, a teoria dos micróbios formulada por Pasteur já mostrava que as doenças contagiosas não se transmitiam pelo ar contaminado, conforme acreditava a teoria dos miasmas, mas por germes infecciosos propagados por meio do contato indireto entre pessoas e objetos. No entanto, não foi essa justificativa que embasou a referida legislação (Ibidem, p.42).

Em São Paulo, o conjunto de medidas sanitárias governamentais adotado para enfrentar a propagação de epidemias teve três componentes principais, conforme resume Bonduki (2011, p.30): a criação da Diretoria de Higiene, com poderes de polícia e inspeção sanitária, isto é, podia entrar nos domicílios para controlar a vida, as regras de asseio, higiene e saúde de seus habitantes; a promulgação de vasta legislação de controle sanitário e de produção de habitações, com destaque para o Código Sanitário de 1894; a participação do Estado na gestão de obras de saneamento e de abastecimento de água e de coleta de esgotos, sobretudo pela encampação da Companhia Cantareira de Águas e Esgotos e pela criação da Comissão de Saneamento das Várzeas.

As epidemias causavam pânico na população, o que dava suporte a qualquer medida que a Diretoria de Higiene e polícia sanitária propusessem. Além das violentas ações de desinfecção de edifícios e demolição de cortiços, havia um componente de controle moralizante, que procurava interferir inclusive nos comportamentos e hábitos de vida e asseio doméstico da população pobre, considerada ignorante, sem moral e higiene. Conforme Rolnik (2003, p.41), a associação entre doença, imoralidade e pobreza enredou-se de tal modo que demarcou um território rejeitado na cultura urbanística da cidade de São Paulo. Apesar de grande parte das intervenções da polícia sanitária buscar eliminar focos nas casas pobres, de fato, a falta de saneamento era um dos principais motivos da propagação de doenças.

Outra forma de atuação do Estado foi por meio da regulamentação de controle do uso do solo, fortemente defendida e influenciada pelos higienistas. Em 1886, o Código de Posturas regulamentava a construção de cortiços e das casas operárias, estipulando o tamanho de cômodos, a existência de poço com água e tanque a cada seis habitações e uma latrina com água a cada duas habitações ${ }^{20}$. Nesse sentido, o Código tolerava a presença de cortiços. Ele continha disposições gerais sobre os melhoramentos relacionados com o saneamento urbano, mas não a garantia de meios para sua implantação (ANCONA, 2002, p.118).

\footnotetext{
${ }^{20}$ Sobre o detalhamento das definições dos códigos de posturas ver Rolnik (2003, p.35-42).
} 
No nível estadual, em 1892 é criado o Serviço Sanitário, órgão responsável pelo controle das epidemias $^{21}$. A legislação subsequente, o Código Sanitário de 1894, implantado por decreto, era mais rigorosa e completa, refletindo a ascendência dos higienistas. No que tange à habitação, proibia a construção de cortiços (nos bairros centrais) e atribuía à municipalidade a responsabilidade de fechar os existentes, bem como determinava que as habitações insalubres deveriam ser saneadas ou demolidas. Por outro lado, permitia a construção de vilas operárias higiênicas fora da aglomeração urbana (ROLNIK, 2003, p.47). Em relação aos serviços de saneamento, centralizava a nível estadual o controle da gestão não só dos serviços de águas, esgotos e lixo, mas definia também algumas regras para ocupação do solo urbano e para a gestão municipal como: o dessecamento e drenagem de terrenos urbanos úmidos e pantanosos, o calçamento de ruas e praças, a arborização da cidade, a proibição de cocheiras e estábulos dentro da cidade, o disciplinamento da localização dos edifícios coletivos e cemitérios, relação entre altura e volumetria dos prédios e largura das ruas (BUENO, 1994, p.45).

Exigências semelhantes foram adotadas nas legislações do município de São Paulo no mesmo período. De fato, se essas leis fossem aplicadas com a rigorosidade que preconizavam, teriam desabrigado grande parte dos trabalhadores urbanos. Por outro lado, o não cumprimento de suas normas mantinha o cortiço como fonte de rendimentos de aluguel, garantida pela construção precária e pela demanda habitacional. Segundo Bonduki, "ao se chocar com as condições econômicas estruturais, baseadas nos baixos salários e em regras mercantis de produção de moradias de aluguel, o higienismo perde sua arrogância"; mas a legislação urbana não virou totalmente letra morta, e a polícia sanitária atuou até a década de 1920 (BONDUKI, 1998, p.39).

Diante da demolição de cortiços, a solução liberal do governo foi o incentivo fiscal aos particulares, para que esses construíssem vilas operárias. Nesse contexto foram propostas várias leis de estímulo à construção (Ibidem, p.40). Sendo assim, não se buscava enfrentar, ou ao menos questionar, em nenhum momento, as causas do problema.

Em 1911, o Serviço Sanitário foi reorganizado (Decreto Estadual no 2.141/1911), definindo a competência do Estado para a fiscalização das obras de saneamento e de outros serviços sanitários dos municípios. O decreto, no artigo 3o, atribuía ao município a realização dos "...melhoramentos higiênicos essenciais à localidade como - esgotos, drenagem das águas pluviais, abastecimento de água potável, enxugo do solo, calçamento, e providência quanto à irrigação e asseio das vias públicas, praças, lugares e logradouros públicos, remoção e destino final do lixo." Além disso, o decreto exigia melhoramentos na rede de água e esgotos nos prédios existentes, e que os prédios construídos em áreas providas de redes não poderiam ser habitadas senão depois de dotados desses melhoramentos; permitia a abertura de poços apenas para fins industriais e de horticultura, somente em caráter excepcional para abastecimento público onde não houvesse alternativa; e definia exigências especiais para disposição de

\footnotetext{
${ }^{21}$ Após a proclamação da República, foi promulgada uma nova Constituição para a República Federativa do Brasil, em 1891. No que se refere às questões de saúde, a Constituição reafirmou a autonomia dos Estados para prestarem serviços, incluindo a vigilância sanitária.
} 
efluentes provenientes de indústrias, sendo que os resíduos sólidos deveriam ser removidos para fora do perímetro urbano e os líquidos encaminhados para a rede de esgoto; e por fim, proibia o despejo de matérias residuais nos cursos d'água, dentro ou fora de povoações, salvo em rios de grande porte, ou depois de feita a depuração dos resíduos (BUENO, 1994, p. 46; ANCONA, 2002, p.119-120).

No caso da cidade de São Paulo, apesar da autonomia para a realização de obras e serviços urbanos, essa competência foi partilhada com o Governo do Estado, principalmente por falta de recursos. A separação mais clara de atribuições entre governo do estado e municípios ocorreu em 1925, com a reforma sanitária Paula Souza (BUENO, 1994, p.47).

A combinação de uma legislação urbanística higienista com o interesse crescente das elites por áreas altas e que se valorizavam, em contraposição às áreas baixas e precárias onde viviam os trabalhadores perseguidos pela polícia sanitária, engendrava um processo de urbanização cuja face evidente era a segregação espacial.

No entanto, naquele momento, a falta de condições sanitárias nas moradias e na cidade decorria principalmente da ausência de infraestruturas. Como já comentado, se durante o século XVIII as fontes de água estavam próximas e o abastecimento era suprido por chafarizes (progressivamente tornando-se insatisfatório), em meados do século XIX, com o aumento populacional, estes não eram mais suficientes e estavam poluídos.

Uma primeira ação planejada sobre o problema ocorreu em 1863, quando a província encomendou um estudo ao engenheiro James Brunless, de Londres, para realizar um plano geral de abastecimento e também de esgotos. Brunless levantou a planta topográfica da cidade, traçou um plano e em 1864 apresentou um relatório no qual concluía pela utilização das águas da Serra da Cantareira para o abastecimento urbano. No mesmo ano, o engenheiro Charles Romieu também realizou estudos sobre o problema do abastecimento de água de São Paulo, chegando aos mesmos resultados (FARIA, 2004, p.44). Estes planos, no entanto, demandavam grandes somas de recursos, e foram protelados pela província.

A ausência de soluções para o problema gerou forte reação da população. Conforme Oseki (1991, p.14), a falta d'água nos chafarizes públicos gerou revoltas violentas da população que também reclamava da ausência de um sistema de esgotos. O debate veio a público também por meio do Diário de São Paulo, que registrou o descontentamento e chamou a atenção para o problema em sua edição de 1865, alertou para o problema de saúde que implicava o uso das águas do Tamanduateí, em 1866, e voltou a tratar do assunto sobre a falta d'água exigindo resposta dos governantes em 1867, não obtendo porém, resposta imediata por parte do executivo (VICTORINO, 2002, p.52).

Esse contexto de descontentamentos e revoltas motivou a proposta de concessão dos serviços de água e esgotos para o capital privado, a Companhia Cantareira, como se verá adiante.

Antes de abordar a atuação da companhia, buscaremos tratar brevemente da situação relativa às infraestruturas incipientes na região do atual $A B C$, nesse período. 


\subsubsection{As restritas infraestruturas na freguesia de São Bernardo}

A freguesia de São Bernardo, até o final do século XIX era povoada, principalmente, por negros e descendentes de portugueses e índios, que somavam menos de mil habitantes. Entre 1877 e os primeiros anos do século XX, recebeu intenso fluxo migratório, constituído, sobretudo, de italianos que vinham para ocupar núcleos coloniais recém-criados pelo governo imperial. A Comissão Estadual de Colonização distribuía lotes aos colonos, que tinham um prazo de seis meses para roçar e plantar uma área mínima de mil braças quadradas, com a respectiva construção de uma casa. Os colonos somente teriam direito à obtenção do título definitivo da propriedade após seu pagamento integral e desde que totalmente saldados quaisquer outros débitos junto à Fazenda Nacional. Contudo, eles enfrentavam enormes dificuldades, que iam desde a necessidade da derrubada da mata nativa, às grandes distâncias que separavam suas terras dos centros comerciais, além da ausência de uma infraestrutura urbana mínima (SÃO BERNARDO, 2010, p.27).

Após reivindicação da população local, o pedido de criação do município foi atendido pela Assembléia Legislativa Provincial em $1889^{22}$. Nesse período, São Bernardo englobava em seus limites toda a região do atual ABC paulista. As cidades de São Caetano, Santo André, Mauá e Ribeirão Pires eram bairros ou distritos de São Bernardo.

Como se sabe, a região passou por transformações importantes após a implantação da estrada de ferro São Paulo Railway - SPR, em 1867, que ligava Jundiaí ao Porto de Santos. A atual cidade de Santo André se desenvolveu a partir de uma das estações construídas pela companhia na várzea do Tamanduateí, a "Estação São Bernardo" (atual Estação Celso Daniel). Por isso Santo André era conhecida como bairro Estação, e foi elevado à categoria de distrito em 1910 (SANTO ANDRÉ, 2008, p.39).

Além da estrada de ferro ter atraído fábricas e indústrias interessadas em se instalarem próximas à ferrovia e ao rio Tamanduateí; exigiu a implantação de uma adutora para abastecimento de água das locomotivas. Uma caixa d’água foi erguida e devido ao seu grande volume logo passou a abastecer também os moradores do núcleo. Com a autorização da São Paulo Railway, um chafariz foi implantado utilizando as águas da adutora (Ibidem, p.39).

Portanto, até a primeira década do século XX, quando a população de todo $A B C$ girava em torno de 10 mil habitantes, não havia rede de água instalada nessa região. O sistema de abastecimento era feito por meio de poços rasos, nascentes e córregos urbanos (SÃO BERNARDO, 2010). As primeiras redes de abastecimento foram feitas a partir de 1910, no recém-criado Distrito de Santo André, sendo as águas captadas in natura no Córrego Guarará. Isso se explica em parte porquê as primeiras autoridades, detentoras do poder local, moravam

\footnotetext{
${ }^{22}$ Um grupo formado por políticos locais, o padre Lustosa, antigos sitiantes e também os imigrantes europeus requereram a criação do município por meio de abaixo-assinado enviado para a Câmara Municipal de São Paulo. Em 12 de março de 1889, a lei no 38 foi sancionada pelo presidente da província, Pedro Vicente de Azevedo, oficializando a criação do município de São Bernardo. A instalação da Câmara dos Vereadores de São Bernardo aconteceu no dia 29 de setembro de 1892 (SÃO BERNARDO, 2010, p. 28).
} 
naquele distrito, que era a área mais urbanizada devido à presença crescente de fábricas, indústrias e comércio (SANTO ANDRÉ, 2008, p.39).

Em 1912, a importância da prestação de serviços de saneamento levou à criação de uma seção de água e esgoto na prefeitura de São Bernardo, mas as autoridades se queixavam da falta de recursos para obras. Em 1927, uma comissão de engenheiros chegou a ser formada para elaborar um plano para todo o município, contudo, faltou verba para implementá-lo. Na década seguinte, chegou-se a cogitar a privatização dos serviços, como ocorrera anteriormente em São Paulo. Apesar da atividade econômica e urbana crescente, com a presença de 150 indústrias, dos 54 trens diários, das quatro linhas de ônibus e dos cinco distritos em que se dividia, o município não tinha água encanada, rede de esgoto, serviço de limpeza urbana, ruas e calçadas, jardim ou logradouro público.

As carências eram alvo das disputas políticas locais, que se travavam particularmente com Santo André, devido ao seu rápido crescimento industrial ${ }^{23}$. Os distritos de Santo André e de São Caetano, por onde passava a estrada de ferro, eram os mais poderosos economicamente. Mesmo assim, até 1934, São Caetano não possuía rede de água encanada. O distrito era servido diariamente por um vagão-tanque da SPR. O crescimento urbano aumentou a demanda por água e a prefeitura de Santo André construiu em 1943 uma Estação de Tratamento de água, pois as águas do córrego Guarará já não podiam mais ser distribuídas in natura como antes (SANTO ANDRÉ, 2008, p.40-42).

Até o fim do Estado Novo (1937-1945), praticamente não houve mudanças na área de saneamento nessa região, e as redes de água e esgoto estavam restritas à Santo André (Ibidem, p.40). Isso somente mudará após a construção da represa Billings e a substituição da Repartição de Águas e Esgotos (RAE) pelo Departamento de Águas e Esgotos (DAE estadual), como se verá adiante.

\subsection{A primeira iniciativa privada no saneamento: Companhia Cantareira de Água e Esgotos}

Em São Paulo, diante do contexto da crise no abastecimento e o do descontentamento da população, a entrada da iniciativa privada foi a solução encontrada diante do fracasso dos governos Provincial e Municipal em resolver a falta de saneamento. Em 1875, a lei provincial no 45 de 20 de abril dispõe sobre a instalação obrigatória de um sistema completo de "despejos e esgotos" nos prédios da capital. Entretanto, a obrigatoriedade de instalação de água não foi aprovada. Em outubro, o governo provincial contrata o Coronel Antonio Proost Rodovaldo, o

\footnotetext{
${ }^{23}$ No início do século XX São Bernardo concentrava a parte administrativa e também tinha maior desenvolvimento econômico que Santo André, devido à fabricação de carvão e à então florescente indústria de móveis e serrarias. A partir de uma lei de 1911, contudo, muitas novas empresas preferiram se instalar em locais próximos à estação ferroviária, favorecendo o distrito de Santo André, que passou a se desenvolver num ritmo muito mais acelerado que São Bernardo (SÃO BERNARDO, 2010, p.20).
} 
engenheiro Daniel M. Fox e o Major Benedito Antonio da Silva para o sistema de abastecimento de água da capital (REIS FILHO, 1989).

Em 1877, durante a presidência da província de Sebastião José Pereira (1975-1878), o governo firma concessão com a empresa Companhia Cantareira e Esgotos, montada por alguns capitalistas locais ${ }^{24}$ que contrataram os serviços de engenheiros ingleses. A empresa teria $\mathrm{O}$ monopólio da venda de água e coleta de esgotos por 70 anos, conforme regia o contrato com a província.

A Companhia iniciou a captação do ribeirão Pedra Branca, na Serra da Cantareira. Para a adução de água, executou uma tubulação de 14,5km que ligava o ponto de captação ao norte da cidade ao reservatório da Consolação ${ }^{25}$, construído em cimento Portland. Este reservatório começou a operar em 1881, distribuindo água de boa qualidade da Serra da Cantareira ${ }^{26}$ (SANTOS, 2011, p.58). Ainda em 1878, por força de contrato, a Cantareira inicia a construção dos chafarizes públicos dos Largos de São Bento, do Pelourinho (hoje 7 de setembro), do Brás, dos Guaianases (atual Praça Princesa Isabel), e 7 de Abril (atual Praça da República). Esses chafarizes foram entregues para uso público em 1ำ de janeiro de 1882 (FARIA, 2004, p.46).

Em 1878, quando se inicia o serviço de abastecimento de água domiciliar, o Decreto Imperial no 6833 regula pela primeira vez o preço da água em São Paulo, autorizando as empresas que exploravam o serviço a cobrar $1 \$ 500$ por quilolitro (MOTTA, 1938).

Os prédios e casas ligados à rede foram abastecidos a título gratuito até março de 1882, quando a Companhia começou a cobrar as taxas de consumo. Segundo Santos (2011), esse imposto servia para cobrir gastos com a implantação do serviço, e seria pago pelos "favorecidos da fortuna" e do qual a "população indigente" estaria isenta (SANTOS, 2011, p.58). Em março havia 133 prédios ligados à rede; em dezembro, 150. Em 1883 já estavam ligados à rede 745 prédios; em 1885, 2.776 e em 1888, 5.008 (FARIA, 2004, p.46). Além da adução da Serra da Cantareira, havia também a adução do rio Ipiranga ${ }^{27}$.

Entretanto, sob o argumento de melhorar e ampliar o serviço de saneamento, a Companhia passou a desativar diversos chafarizes como forma de obrigar a população a promover a

\footnotetext{
${ }^{24}$ A primeira diretoria da empresa foi composta pelo Barão de Três Rios, Clemente Falcão de Souza Filho e Raphael Aguiar Paes de Barros (SANTOS, 2011, p.57).

${ }^{25}$ As obras do reservatório da Consolação, que captava as águas dos ribeirões Toucinho e Iguatemi e também do córrego do Barro Branco foram conduzidas pelo engenheiro inglês Henri Batson Joyner. Foi desdobrada também a rede de distribuição de água pela zona urbana da cidade, abrangendo a área que se estende desde a Ponte Grande, atual Ponte das Bandeiras, até o Largo da Liberdade e desde a meia encosta da Rua da Consolação até a Igreja do Brás, numa extensão de encanamentos de 35.660 metros, de diâmetros diversos, variando entre 3 a 15 polegadas (FARIA, 2004, p.45).

${ }^{26}$ Por volta de 1883, os primeiros beneficiários do serviço foram 71 prédios do bairro da Luz. (SAVELLI, 1964, p.84).

${ }^{27}$ Esta adução fornecia aproximadamente 3 milhões de litros de água por dia de uma represa na Água Funda, onde hoje se localiza o Jardim Zoológico da Capital, servindo as zonas de além-Tamanduateí, ou seja, Brás, Mooca e Ipiranga (Faria, 2004, p.46)
} 
instalação da infraestrutura para receber água encanada no interior dos imóveis, o que gerou conflitos e tensões, especialmente com a população pobre.

Por certo, uma série de fatores implicava em relações conflituosas entre a Companhia e o Estado, bem como entre a Companhia, o Estado e a população. No primeiro caso, um dos conflitos referia-se ao próprio entendimento de atribuições entre empresa, Estado e municipalidade. Apesar de reguladas em contrato, as responsabilidades eram frequentemente contestadas por cada parte (MOREIRA, 2008, p.64).

Além disso, Moreira (2008) identificou que de 1881 até a entrega do primeiro distrito de esgotos no bairro da Luz, em $1883^{28}$, há registros de cobranças da Companhia ao governo provincial para que fossem pagas as despesas da instalação da rede de esgotos; e de negativas de pagamentos, alegando má execução da rede, só aceita em 1893. Sendo assim ela conclui que "a sustentação econômico-financeira da atividade e a regulação e controle de seus resultados revelava dificuldades que o padrão de investimento de empresa privada não conseguia suprir." (Ibidem, p.64).

A Companhia precisava expandir o mercado de água, e dependia do retorno de seus investimentos por parte da Província, na forma de tarifas. Para que isso funcionasse, no entanto, a ligação das residências à rede era fundamental, viabilizando a generalização do consumo. Assim, o domicílio que até então não se conectava aos serviços urbanos, passa a ser elemento fundamental para o funcionamento do sistema, especialmente do ponto de vista econômico. Conforme Mautner e Oseki "A implantação das redes de infraestrutura viabilizariam a produção de um espaço virtualmente homogêneo e reprodutível que será sua condição de troca e mercantilização." (MAUTNER; OSEKI, 1993, p.14).

O fato de a Companhia destruir os chafarizes, que até então distribuíam água gratuitamente, fazia com que a água passasse a ser mercadoria, visto que o acesso estava condicionado à conexão da residência à rede urbana da cidade e, principalmente, ao pagamento do serviço. Compartilhamos dessa observação feita por Santos (2011, p.59), mas salientamos que o simples fato da concessão ser repassada a uma empresa privada, já implicaria na generalização de sua mercantilização, o que anteriormente era muito incipiente e pontual com a ação individual dos aguadeiros. Por outro lado, os chafarizes já eram alvo de reclamações, tanto pela quantidade como pela qualidade de suas águas, bastante contaminadas, tornado sua manutenção praticamente inviável.

A destruição dos chafarizes já na década de 1870 também tem como hipótese defendida por alguns autores os interesses especulativos e de cunho moralizante, com o sentido de restabelecer uma civilidade adequada à valorização dos imóveis das imediações, em oposição à barbárie ou incivilidade das aglomerações comuns nos chafarizes. Havia também a tentativa de

\footnotetext{
${ }^{28}$ A rede de esgotos teria ficado pronta em 1883 (TELLES, 1984 apud OSEKI, 1992, p.19), sendo o primeiro distrito de esgotos o da Luz. Oseki (1991) detalha as características e traçado dessa rede, que separava o esgoto da drenagem.
} 
fazer da região central um espaço aburguesado, que não admitia os habituais frequentadores dos chafarizes, em particular os negros (SANT'ANNA, 2004; JORGE, 2006).

A Companhia Cantareira passa a enfrentar sérios problemas porque não tinha capital suficiente para realizar obras que se tornavam de porte cada vez maior, pois a demanda aumentava ininterruptamente com o aumento da população. A empresa entra em crise econômica e é obrigada a recorrer a repetidos empréstimos, pela necessidade de complementar o estabelecimento da rede distribuidora, agravada pela urgência de novas captações (FARIA, 2004, p.47). Isso deixava claro que a construção de condições para posterior prestação de serviços de saneamento não se constituía como atividade lucrativa nesse momento.

Ao final da década de 1880 e início da década de 1890, a demanda populacional de São Paulo superava as expectativas, com cerca de 120.000 habitantes, impulsionada, sobretudo, pela transformação por que passava o trabalho, refletida na vinda dos imigrantes. O sistema projetado para o abastecimento de água era insuficiente para o crescimento da cidade, carecendo de maior volume de água aduzida.

Na busca por soluções para ampliar o abastecimento, a Companhia acabou por adquirir um dos mananciais do Cassununga, também na Serra da Cantareira, quando o Governo intervém em seu auxílio, tomando a seu cargo as obras de adução (FARIA, 2004, p.47). Era o primeiro passo para a encampação, que se deu em novembro de 1892.
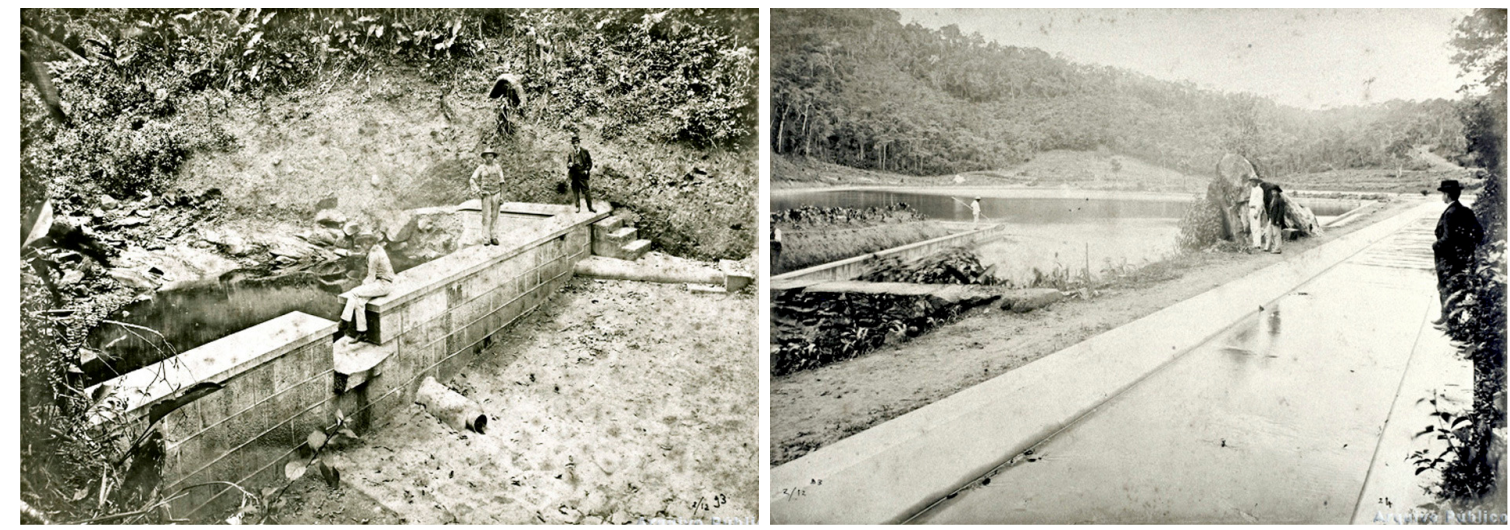

Figuras 2 e 3 - Represa do Cassununga no2 e reservatório de acumulação, respectivamente.

Fonte: Foto Arquivo Público do Estado de São Paulo. Álbum da Secretaria de Agricultura, Comércio e Obras Públicas. Fotos de P. Doumet para a Repartição de Água e Esgotos da cidade de São Paulo, 1893. Disponível em http://www.arquivoestado.sp.gov.br/aguas.php, acesso em 09/04/2013.

Em relação ao tratamento de esgotos, não havia a mesma preocupação tanto por parte da população como do Estado, pois a reivindicação maior era por água. Conforme explica Oseki (1991) a obrigatoriedade da ligação dos prédios no sistema de "despejos e esgotos" servia mais a São Paulo dos ricos, enquanto que a pobreza continuou à margem da rede. Ainda conforme este autor, a concepção e distribuição da rede privilegiava a drenagem da colina e das elevações fronteiras. "A rede coletora de esgotos trabalhando por gravidade e sendo colocada no fundo dos vales drenava as partes altas, havendo apenas uma canalização simbólica em direção ao Brás, que permaneceu muito tempo sem ser utilizada" (Ibidem, p.40). 
Esse descompasso, que se origina desde o início da implementação das redes, só piorou com o tempo, como se verá, chegando a se reproduzir atualmente, como demonstram os índices de coleta e tratamento.

\subsection{Saneamento como questão do Estado: A Repartição de Serviços Técnicos de Águas e Esgoto}

O primeiro serviço público constituído no Estado de São Paulo foi a Repartição de Serviços Técnicos de Águas e Esgoto - RAE ${ }^{29}$, no ano de 1892 (MOTTA, 1937) ${ }^{30}$. A RAE ficou sob responsabilidade do governo estadual, subordinada à Secretaria da Agricultura, pois o município não dispunha de recursos para assumi-la. Após a encampação, o Estado (por meio da RAE) em dois anos estendeu a rede à metade do número total de prédios servidos anteriormente pela Companhia Cantareira, que levou 10 anos para ser construída ${ }^{31}$ (OSEKI, 1991, p.29).

Nessa época, o abastecimento de água contava com duas adutoras, Ipiranga e Cantareira. A primeira fornecia três milhões de litros/dia de uma pequena represa na Água Funda e servia as zonas baixas, além do Tamanduateí, isto é, Brás, Mooca e Ipiranga. A segunda provinha da serra da Cantareira e fornecia a mesma quantidade ao reservatório da Consolação e abastecia o centro da cidade (WHITAKER, 1946, p.5).

Depois de encampados os serviços, a RAE concentrou suas ações na ampliação do abastecimento de água e fez um plano de obras novas. Em 1898, completou o aproveitamento das águas da Cantareira, elevando-se o volume de água que ela fornecia de 3.500.000 de litros/dia para 25 milhões de litros/dia; reforçou a captação do Ipiranga com a adução dos córregos Simão e Borba; incorporou novas fontes de suprimentos, como a captação das águas do rio Tietê ${ }^{32}$, na altura do Belenzinho, que passavam por galeria filtrante sem desinfecção para o abastecimento do Brás, chegando essa captação a fornecer 6 milhões de litros/dia; fez ainda uma tentativa de aproveitamento de águas do subsolo, por meio de poços profundos perfurados

\footnotetext{
${ }^{29}$ Criada pela Lei № 62 de 17 de agosto de 1892 e decreto 1524 de 31 de janeiro de 1893.

${ }^{30}$ A organização da RAE no seu período inicial era a seguinte: uma seção geral, que compreendia a fiscalização geral, contabilidade, organização de projetos e direção de obras da Capital; uma divisão central, a qual incumbia o abastecimento de água e o serviço de esgoto no perímetro da cidade, e o almoxarifado; seis divisões auxiliares, para novas obras de água e esgoto. A RAE era dirigida por um engenheiro-chefe, e após sua reformulação em 1898 foi criado o cargo de diretor.

31 Pela Companhia Cantareira, entre 1883 e 1889, foram ligados à rede 5.702 edifícios; e entre 1890 e 1892, 542 edifícios. Pelo Estado, entre 1893 e 1894 foram ligados 3.410 edifícios à rede de esgoto. (OSEKI, 1991, p.29) Em 1894 foram construídos os coletores de Santa Ifigênia, da Luz, da rua das Palmeiras, da rua Sólon, do Anhangabaú, da Liberdade. E ainda 500m do coletor principal do Brás e da Mooca. Os coletores totalizaram 9,5km construídos (Ibidem, p.30).

32 O rio Tietê, apesar do péssimo estado de suas águas, passa a ser cogitado como alternativa e em 1898 começa a ser captada água na altura do Belenzinho. Em 1903 foram executadas as obras para aumento da captação. Contudo, a captação nas partes baixas do rio implicava em aduzir águas poluídas e essa alternativa não era consensual (VICTORINO, 2002, p.53). Os médicos eram contrários a utilização dessas águas e atribuíam à sua contaminação o grande número de doenças que estavam ocorrendo no Brás, ligadas ao aparelho digestivo: gastroenterite, enterite e diarreia (RIBEIRO, 1993, p.146).
} 
na margem do rio Tamanduateí (atual Parque D. Pedro II), procedimento mais tarde abandonado na medida em que não se obteve a quantidade de água esperada.

Contudo, em 1899 as providências tomadas já eram insuficientes devido à formação de bairros populosos como Perdizes, Água Branca, Lapa, Vila Cerqueira César e Vila Mariana. Já se observava o espraiamento da cidade por diversos núcleos esparsos e separados por vales e espigões, o que traria dificuldades às novas redes de água por seu alto custo de execução (WHITAKER, 1946, p.6).

Além da necessidade de instalação de redes em áreas novas e a insuficiência das antigas, a situação de contaminação do rio Tietê e a condição de saúde da população eram bastante graves. Em 1903, José Joaquim de Freitas, o fiscal de rios da cidade, apresentou para o prefeito o seu relatório alertando sobre a preocupante situação de poluição do rio Tietê. Ele descreveu as "grandes ilhas de lodo" que ficavam acumuladas nas margens do rio, em estado de fermentação; o lançamento de esgotos na porção central da cidade, onde não havia correnteza e possibilidade de diluição; o mal cheiro e os focos de infecção; e nas épocas de chuva as águas se avolumavam e transbordavam em sua várzea, espalhando esse material que ficava a fermentar (JORGE, 2006, p.27-28).

Além dos pontos de despejo de esgotos, a montante da capital, nos núcleos de Mogi das Cruzes, São Miguel e Guarulhos, havia as atividades de criação de gado e suína, que também contaminavam as águas pouco volumosas e de baixa densidade desse rio (BUENO, 1994, p.67).

Outro fator que agravou as condições de suprimento de água foram as condições climáticas de uma forte estiagem em 1903, gerando uma crise. Nesse ano, foi criada a Comissão de Obras Novas de Abastecimento de Água da Capital $^{33}$, pelo governo Estadual, que realizou diversas intervenções em diferentes pontos da cidade.

Em 1907 foram iniciadas as obras de aproveitamento dos mananciais do Cabuçu e do Barrocada, também na região da Cantareira, com a capacidade de 43,2 milhões de litros/dia, tendo por objetivo abastecer a parte baixa da cidade - Santana, Luz, Bom Retiro e Brás - sendo que as sobras eram dirigidas para o reservatório da Rua Taquari, na zona baixa da Mooca. Foi também possível abastecer com água do Cabuçu o reservatório da Consolação, mediante o recalque das Palmeiras, instalado no bairro de Santa Cecília, abastecendo Santana, Luz, Bom Retiro e Brás (FARIA, 2004, p.48).

Esse Plano de Abastecimento desenvolveu-se de acordo com um "lema" estabelecido pelo Dr. Carlos Botelho: "... as águas altas para as zonas altas; as águas baixas, especialmente as do rio, para a zona baixa" (Relatório de 1904, p.229 apud WHITAKER, 1946, p.9). Assim, a zona baixa (entre as cotas 720 e $730 \mathrm{~m}$ de altitude) era tributária do ribeirão Cabuçu, do rio Tietê e mananciais do Ipiranga; a zona média (735 a 770m) era abastecida pelo lado direito do manancial da Serra da Cantareira; e a zona alta (770 a 800m) era abastecida pela ala esquerda do manancial da Serra da Cantareira, por intermédio do reservatório da Liberdade.

\footnotetext{
${ }^{33}$ Chefiada pelo engenheiro Luiz Betim Paes Leme, conforme Whitaker (1946, p.8).
} 
Saturnino de Brito chamou a atenção para o fato que o cumprimento desse lema implicaria em garantir as condições in natura e pós-tratamento das águas do Tietê, o que não aconteceu (BRITO, 1943, p.57) ${ }^{34}$.

Até este momento, a cidade contava com apenas quatro reservatórios de distribuição: Consolação, antigo e novo, Liberdade e da rua Taquari. A utilização de mananciais próximos estava chegando ao seu limite, ampliando a escala do problema e das formas de seu tratamento, implicando na busca de novos mananciais, mais distantes ${ }^{35}$.

Com a realização do conjunto de intervenções da RAE, durante os anos de 1907 a 1910 houve uma trégua no problema do abastecimento da cidade. No entanto, a melhora foi temporária, pois em 1911 o problema voltou à tona. Nesse ano estimava-se que o déficit de adução era de 39 milhões de litros por dia (WHITAKER, 1946, p.9).

Passa-se então aos estudos de novos mananciais, com várias alternativas, sendo que foi escolhida a adução do rio Cotia (para abastecer as zonas altas e altíssimas da cidade). Em 1914 iniciou-se a execução das obras de adução das águas do ribeirão Cotia, sendo que a construção do sistema foi realizada em duas etapas ${ }^{36}$, a segunda iniciada em $1920^{37}$. Mas somente em 1933, com a conclusão da barragem Pedro Beicht, esse manancial foi regularizado, passando a contribuir com 90 milhões de litros/dia para a cidade de São Paulo. Em 1915 também foi construído o reservatório Água Branca.

Em 1925, em consequência de uma das maiores estiagens verificadas no Estado, que reduziu o volume de água aduzido de 156 milhões de litros/dia para apenas 70 milhões de litros, o Governo do Estado, por meio da Comissão de Obras Novas de Abastecimento ${ }^{38}$, resolveu dar

\footnotetext{
34 Saturnino de Brito expõe em seu relatório de 1946, os estudos realizados em 1905 sobre os problemas do abastecimento de água e tratamento de esgotos em São Paulo e entregues ao governador. Ele formulou nesse ano o Plano geral para o abastecimento de água, considerando a topografia, de forma a garantir a distribuição da rede sobre toda área ocupada, buscando evitar soluções parciais. Este "estudo geral" figurou um primeiro plano com visão de todo para a cidade. Contudo, esta alternativa não foi implementada (BRITO, 1943).

${ }^{35}$ Ver em Moreira (2008) a topologia das redes de abastecimento de água, mostrando sua evolução temporal e espacial.

${ }^{36}$ A primeira etapa do sistema permitiu a adução de 39 milhões de litros/dia, reforçando o abastecimento dos bairros situados na cota mais alta da cidade, ao longo do espigão da Avenida Paulista, por meio do reservatório do Araçá. Deste reservatório, construído em 1907 e alimentado pela Cantareira, a água do Cotia passou a ser encaminhada ao reservatório da Liberdade (depois denominado Avenida) e também, a partir de 1914, as sobras ao reservatório da Vila Mariana, concluído na ocasião. As águas do sistema Cotia passaram a alimentar também o novo reservatório da Água Branca, atendendo um outro setor da cidade. A capital passou a ter 120 milhões de litros/dia, ou seja, menos de 1,4 $\mathrm{m}^{3} / \mathrm{s}$ (QUEIROZ, 1964).

${ }^{37}$ Em 1920 houve uma nova crise de abastecimento. Segundo Victorino (2002), um dos motivos foi técnico na avaliação do volume aduzível do rio: supunha-se que o Cotia daria 80 milhões de litros diários para o abastecimento; porém seriam apenas 50 milhões de litros em períodos normais e 36 milhões de litros por dia em épocas de estiagem. Diante do déficit de abastecimento de água que em 1925 era de 130 milhões de litros diários, mesmo na sua melhor condição com atendimento de 80 milhões de litros, ainda faltavam 50 milhões de litros por dia a serem atendidos.

${ }^{38}$ Nesse momento a Comissão de Obras Novas de Abastecimento era chefiada pelo engenheiro Henrique de Novaes.
} 
início às obras do Sistema Rio Claro ${ }^{39}$, afluente formador do Tietê, manancial situado na Serra do Mar, a $80 \mathrm{~km}$ de distância da Capital, o que encarecia sobremaneira as suas obras de adução. O projeto consistia na construção de barragens, estações elevatórias, uma adutora de $80 \mathrm{~km}, 3$ subadutoras que cortavam a cidade e de 4 reservatórios, sendo o da Mooca o principal, e os outros 3 na Lapa, Penha e Pompéia.

Para a execução do Sistema Rio Claro foi utilizado o instrumento de desapropriação da bacia e não somente das áreas inundáveis para garantir a proteção do manancial. O governo estadual desapropriou, até 1927, 2.830 alqueires de terra rural e 15,8 hectares de terra urbana, onde hoje se localiza o Parque Estadual de Salesópolis. E para viabilizar a obra foram abertas cerca de $194 \mathrm{~km}$ de estradas na bacia do rio Claro (BUENO, 1994, p.69-70).

Entretanto, tratava-se de uma obra de grandes proporções e investimento, sobre a qual não havia consenso. Quando a Comissão foi extinta, em $1927^{40}$, a obra ficou parada por quatro anos quando seguiu-se um período de reexame do projeto, até toda a tarefa ser transferida para a RAE. O Sistema Rio Claro passou a aduzir $1 \mathrm{~m}^{3} / \mathrm{s}$ de água à cidade somente a partir de 1939, ampliando a capacidade posteriormente (THOMPSON, 1940, p.34).

Segundo Victorino (2002, p.60), "a primeira e mais fundamental crítica feita ao projeto rio Claro foi relativa às próprias intenções descritas no artigo 1 을 do Decreto de criação da Comissão de Obras Novas, que previa o abastecimento para o triplo da população, ou seja 2 milhões de habitantes ou $6 \mathrm{~m}^{3} / \mathrm{s}^{\prime \prime}$. Segundo Henrique Novaes, o rio Claro atenderia 1.588 .000 habitantes, o que seria atingido em 1942, após esse período seria necessário recorrer às águas do Paraibuna, projeto de extensão que foi apenas esboçado. Ou seja, era mais uma obra custosa e provisória, sempre criticada pela opinião pública e pelos especialistas, por diversos aspectos. Outro motivo central era de ordem econômica, isto é, a distância do manancial implicava na necessidade de mais recursos, enquanto que estudos apontavam maior viabilidade econômica no aproveitamento das águas do Tietê e Pinheiros, ainda que fosse necessária a desinfecção das mesmas.

Durante esse período, portanto, se intensificou o debate sobre as formas mais adequadas de abastecimento da futura metrópole, que dividia opiniões. De um lado, estavam os defensores do ideal de captar águas "de cabeceiras, em bacias vestidas de florestas", conforme o que mandava o Código Sanitário da primeira década do século, defendendo portanto a utilização de águas puras e captação por gravidade. O outro grupo era formado por partidários do aproveitamento em grande escala das águas baixas e já poluídas do rio Tietê, com o emprego de técnicas de purificação de água (VICTORINO, 2002, p.53).

\footnotetext{
39 O primeiro estudo data de 1904 quando o Secretário da Agricultura determina a realização de estudos hidrológicos sobre este rio. Em 1905 o sanitarista Saturnino de Brito indicou o rio Claro como uma das soluções a se examinar na organização de um plano geral de abastecimento. Em 1906 o jornalista e engenheiro Euclydes da Cunha mediu, pela primeira vez a vazão do rio Claro, mas não desenvolveu estudos mais detalhados (VICTORINO, 2002, p.60).

40 A Comissão de Obras Novas de Abastecimento foi substituída pelo governador Julio Prestes pela Comissão de Saneamento da Capital, sob direção de Theodoro Augusto Ramos (WHITAKER, 1946, p.11).
} 
Dentro dos parâmetros definidos pelo Código Sanitário, os únicos mananciais que estavam em um raio de 100 quilômetros da cidade eram os rios Cotia e Claro, mas já se previa também seus limites no prazo de 30 ou 35 anos, conforme Saturnino de Brito.

Os professores da Escola Polytechnica argumentavam que nascentes isoladas eram raras e que a simples filtração natural através da terra não ofereceria proteção, sendo as zonas de captação muito suscetíveis à infecção por vetores, que poderiam originar uma epidemia de febre tifóide, por exemplo. A exemplo de outras cidades do mundo que haviam passado por epidemias de veiculação hídrica, os sanitaristas defendiam que somente o tratamento químico asseguraria a potabilidade da água. Por outro lado, as águas fornecidas em São Paulo eram de boa qualidade, porque vinham de áreas ainda pouco povoadas e cobertas de vegetação. No entanto, ninguém podia garantir que isso se mantivesse no tempo e que estariam livres do risco de contaminação. Os sanitaristas, dentre eles Saturnino de Brito, também ponderavam sobre o relativismo quanto à definição de fontes protegidas, diante do aumento provável da expansão urbana (VICTORINO, 2002, p.53).

Esses argumentos tinham como objetivo final desmistificar a idéia de que a água deveria vir de fontes puras, para viabilizar a ideia da captação no rio Tietê. Para Saturnino de Brito (1944), parecia não haver outra alternativa senão a captação no rio Tietê. Segundo ele, no caso de ser "provado que em São Paulo se terá de recorrer forçosamente, no futuro, às águas baixas, exclusivamente para a zona baixa ou também como complemento do suprimento da zona média (...) iniciar o mais cedo possível este processo de suprimento e o garantir com a lei de proteção dos cursos".

No entanto, Arthur Motta, o principal responsável pelo abastecimento de águas entre 1906 e 1936, era contrário ao tratamento das águas do Tietê, neste momento, por considerá-lo extremamente dispendioso e dependente de progressos técnicos. Essa postura, entretanto, se baseava mais em preconceitos do que em argumentos científicos fundamentados. Além de defender a captação de água em mananciais distantes, ele também acreditava nos mecanismos de desapropriação de toda a bacia, a montante do ponto de captação, como instrumento para garantir a segurança absoluta, no que se refere a epidemias (VICTORINO, 2002, p.55). Para a primeira etapa da adução do rio Cotia, em 1914, foram desapropriado cerca de 10.000 hectares.

A posição de Saturnino de Brito, por sua vez, não era a mesma dos professores engenheiros que acreditavam tecnicamente na desinfecção das águas, pois, além de propor o aproveitamento das águas do Tietê, considerava imprescindível proteger seu curso já em 1905:

O único meio de manter a integridade higiênica do rio é a lei de proteção e a prática do abastecimento: então velarão por ele os interessados pela pureza das suas águas, e o povo e os governos quaisquer, hoje e para sempre. Mesmo que os estudos definitivos provem a vantagem de ainda se recorrer às águas de cursos menos expostos à contaminação (como sejam os dois Cabussus, o Cotia etc.), é preciso proteger as águas do Tietê, a grande reserva para S. Paulo (BRITO, 1943). 
Assim, Saturnino de Brito lançava a ideia da conservação dos rios por meio de legislação, e a necessidade de sua proteção não só por questões sanitárias, mas como um importante elemento da paisagem da cidade, salientando a importância de seu uso nesse sentido.

Contudo, a opção pela realização das obras do Sistema Rio Claro não fora puramente técnica, mesmo porque nesse sentido já havia sido criticada na época. Tampouco era o interesse de retorno da oferta de água na forma de tarifas ou mesmo na forma de benefício social. Havia um oportunismo econômico no interesse da realização de obras e de valorização de terras indenizáveis, e Henrique de Novaes estava diretamente implicado com tais interesses, assessorando proprietários que possuíam terras por onde passava o rio, ou a estrada projetada ${ }^{41}$ (VICTORINO, 2002). As condições foram criadas em 1925, quando Novaes foi chefe da Comissão de Obras Novas de Abastecimento de Água da Capital, e os intermináveis debates entre as opções técnicas de captar águas distantes e puras ou águas próximas com tratamento foram superados, permitindo o início das obras do Sistema do Rio Claro (MOREIRA, 2008, p.93).

O debate sobre a utilização de águas dos rios, por sua vez, não se findou. Em 1924 a Comissão de Melhoramentos do rio Tietê foi restabelecida, sob encargo de Saturnino de Brito. Seu principal objetivo era sanear e promover o combate às inundações da várzea do rio Tietê, possibilitando assim que a área fosse edificada, promovesse a navegação, e o afastamento para jusante das descargas dos esgotos que eram lançados sem depuração. Em 1926, o Relatório da Comissão de Melhoramentos do rio Tietê foi publicado e apresentado ao prefeito Firminiano Pinto. Esse relatório continha um diagnóstico da situação dos esgotos paulistas e sugeria uma solução integrada ao problema.

Nesse Relatório, dentre os principais problemas encontrados, Saturnino de Brito destacou a obsolescência do antigo sistema misto ${ }^{42}$ de coleta de esgotos. Apesar do sistema separador absoluto ser adotado a partir de 1912, em 1926, em boa parte da cidade ainda existiam coletores mistos, inclusive na zona baixa, o que era um contrassenso, porque o esgoto aí era elevado através de bombas (porque não podia ser escoado por gravidade, dada a pouca altura), na usina elevatória da Ponte Pequena (OSEKI, 1991, p.31).

Nos bairros servidos pela antiga rede de esgoto como Cambuci, Liberdade, Sé, Bela Vista, Luz, Santa Efigênia, Brás, Belenzinho e Mooca, Bom Retiro, Santa Cecília, Consolação e Pacaembú, os coletores de alvenaria estavam em péssimo estado de conservação e não suportavam a carga durante as chuvas. Além disso, o coletor do Vale do Anhangabaú estava sobrecarregado,

\footnotetext{
${ }^{41}$ Em 1912 o senador e engenheiro José Mattoso Sampaio Corrêa (assessorado pelo engenheiro Henrique Novaes) propôs aduzir $60.000 \mathrm{~m}^{3}$ deste rio - cujas nascentes localizavam-se em sua propriedade - executando todas as obras e conservando-as durante 20 anos, revertendo ao governo as obras e terras no fim deste prazo. $O$ governo lhe pagaria o volume fornecido à razão de 75 réis por $\mathrm{m}^{3}$ (BRITO, 1944). De acordo com Saturnino de Brito os proponentes "adquiriram direitos (por compra ou por escritura condicional) sobre os terrenos das cabeceiras, como falam na concessão de uma estrada que seguiria grande extensão da projetada linha adutora. Terão adquirido estes direitos no intuito de garantirem o negócio com as águas?" (VICTORINO, 2002, p.60).

${ }^{42}$ No sistema separador absoluto as águas pluviais são drenadas em tubulações separadas dos efluentes dos esgotos, enquanto que no sistema misto essas águas se misturam numa mesma tubulação, o que exige tubulações de maior volume.
} 
malconservado, e com as chuvas extravasavam diretamente para o rio. As previsões de descarga direta no rio Tietê, com o adensamento populacional e de construções, tornaria a situação intolerável (Ibidem, p.32-33). Além disso, quando as tubulações extravasavam com as chuvas, a população entrava em contato direto com as águas contaminadas, conjugando o problema da salubridade e da água como meio disseminador de doenças (SANTOS, 2011, p.221).

Outro documento, o Relatório de Obras do Saneamento de 1927 expressava preocupações semelhantes em relação aos despejos dos esgotos no rio Tamanduateí, os quais já tinham sido objeto de intervenções entre 1892 e 1893 (antes da retificação do rio), e considerava-se urgente a realização de serviços de construção de galerias de drenagem e escoamento de águas pluviais da região do Brás, assim como a construção de interceptores nas margens do Tamanduateí (SANTOS, 2011, p.218). A construção de novas galerias de drenagem estaria baseada no sistema separador absoluto em detrimento do sistema misto.

Diante do diagnóstico da situação, Saturnino propõe um Plano Conjunto que contemplasse o controle público de toda a bacia hidrográfica a montante do Parnaíba de forma a coordenar os diversos interesses sobre o rio e o uso múltiplo de suas águas; propunha obras de retificação, ampliação da calha do rio, barragens, reservatórios, aterros. Previa a construção de avenidas laterais e pontes e recomendava um plano de arruamento feito em parceria entre município e estado. Propunha ainda a preservação de trechos de várzea como reguladores naturais de vazão do rio e o replantio de mata ciliar a montante da cidade; dois grandes lagos na altura da Ponte Grande, para fornecer material para aterros e para uso recreativo; além de parques e jardins ao longo do rio, como um na confluência entre Tietê e Pinheiros (JORGE, 2006, p.63).

Em relação aos esgotos apresentou especial preocupação e propunha: a) um projeto de emissário junto ao Tietê, que eliminasse o despejo em frente à cidade; b) uma opção técnica pela descarga in natura ou pelo tratamento dos despejos, e estipulando o grau de tratamento. Nesse aspecto "a discussão se tornava mais complexa, pois não havia ainda um sistema de depuração barato e a questão era grave e urgente." (OSEKI, 1991, p.33). No entanto, diferentemente da posição anterior, quando defendeu a utilização das águas do Tietê para o abastecimento, Saturnino de Brito argumentava que a depuração não precisaria ser total, pois as águas do rio não serviriam ao abastecimento, e caso fosse utilizá-las melhor seria purificá-las. No caso de São Paulo era indicada a depuração completa, mais onerosa.

Uma solução seria o tratamento artificial por tanques de lodo ativado sem, no entanto, resolver o problema do tratamento do lodo. E a outra seria o poder depurador de águas tranquilas, indicando a represa de Parnaíba para desempenhar tal função. Saturnino seguia o exemplo de Estrasburgo, que conseguira implementar a depuração biológica em águas calmas de lagos com a cultura de peixes.

Apesar dos benefícios que essa solução pudesse gerar, havia o conflito do funcionamento da barragem de Parnaíba em relação ao controle das cheias e a geração de energia pela Light. "Para a Light interessava ter a barragem cheia, em qualquer época. Para se evitar inundações era necessário a barragem vazia, durante as cheias." (OSEKI, 1991, p.35). 
Cabe também destacar, que Saturnino de Brito apontava explicitamente o descaso dos poderes públicos em relação ao problema dos esgotos, bem como a falta de planejamento urbano de conjunto, ou seja, que articulasse os problemas relacionados à água. Nesse sentido, responsabilizava explicitamente a RAE em seus pareceres (SANTOS, 2011, p.228).

Mas após a apresentação dos estudos a Comissão foi extinta. No ano seguinte foi restabelecida, porém, a cargo de Ulhôa Cintra, que reformulou o projeto, retirando a ideia de parques e reservatórios naturais; assumindo um partido de projeto que atrelava a retificação às obras viárias da cidade (o Plano de Avenidas, que elaborou com Prestes Maia em 1930) (SANTOS, 2011, p.230).

Nesse momento a Light implementa planos para ampliação de sua capacidade de geração de energia elétrica, mudando, literalmente, o rumo dos rios e a destinação de suas várzeas.

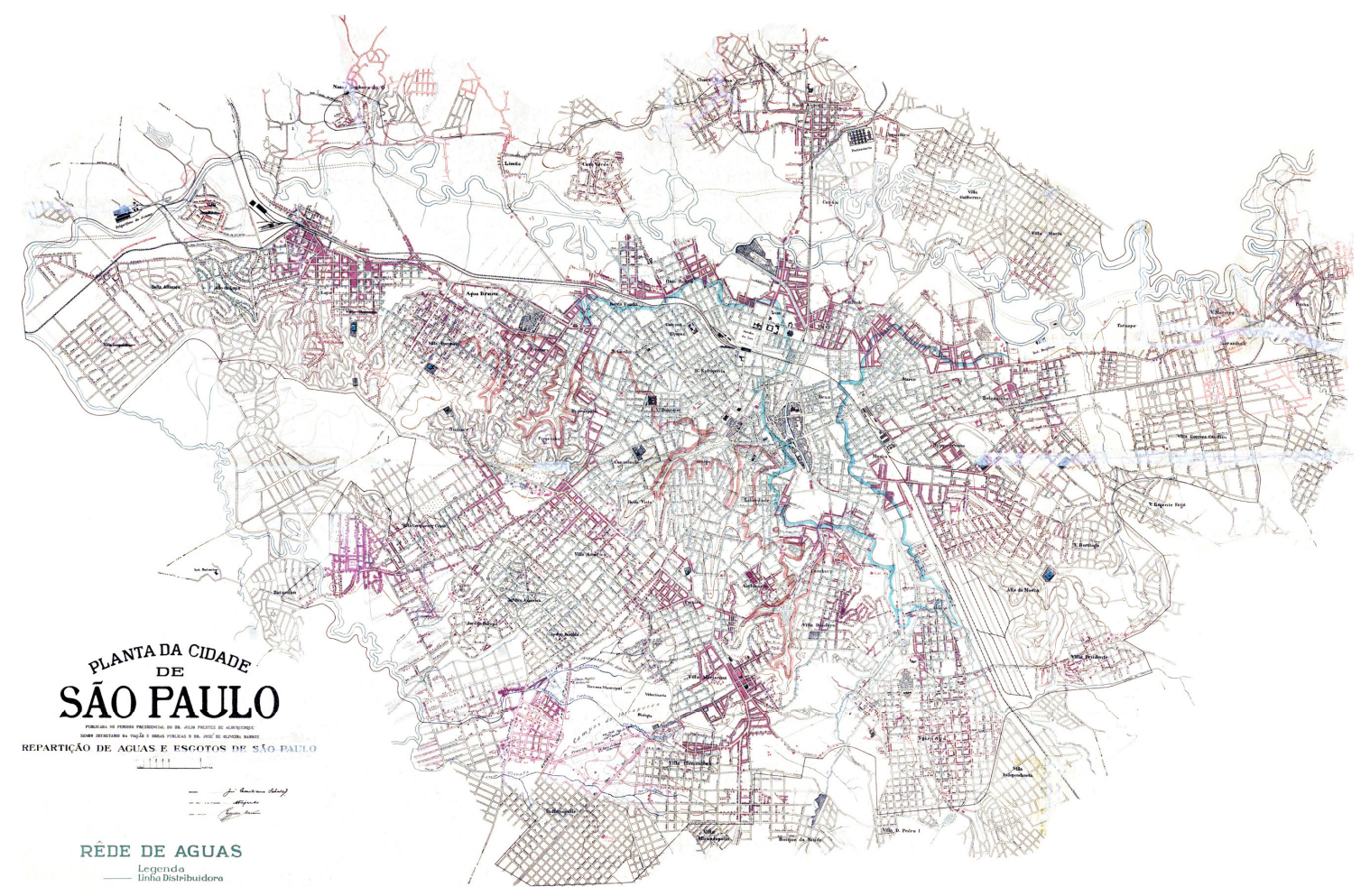

Mapa 2 - Rede de água da cidade de São Paulo, 1929. 


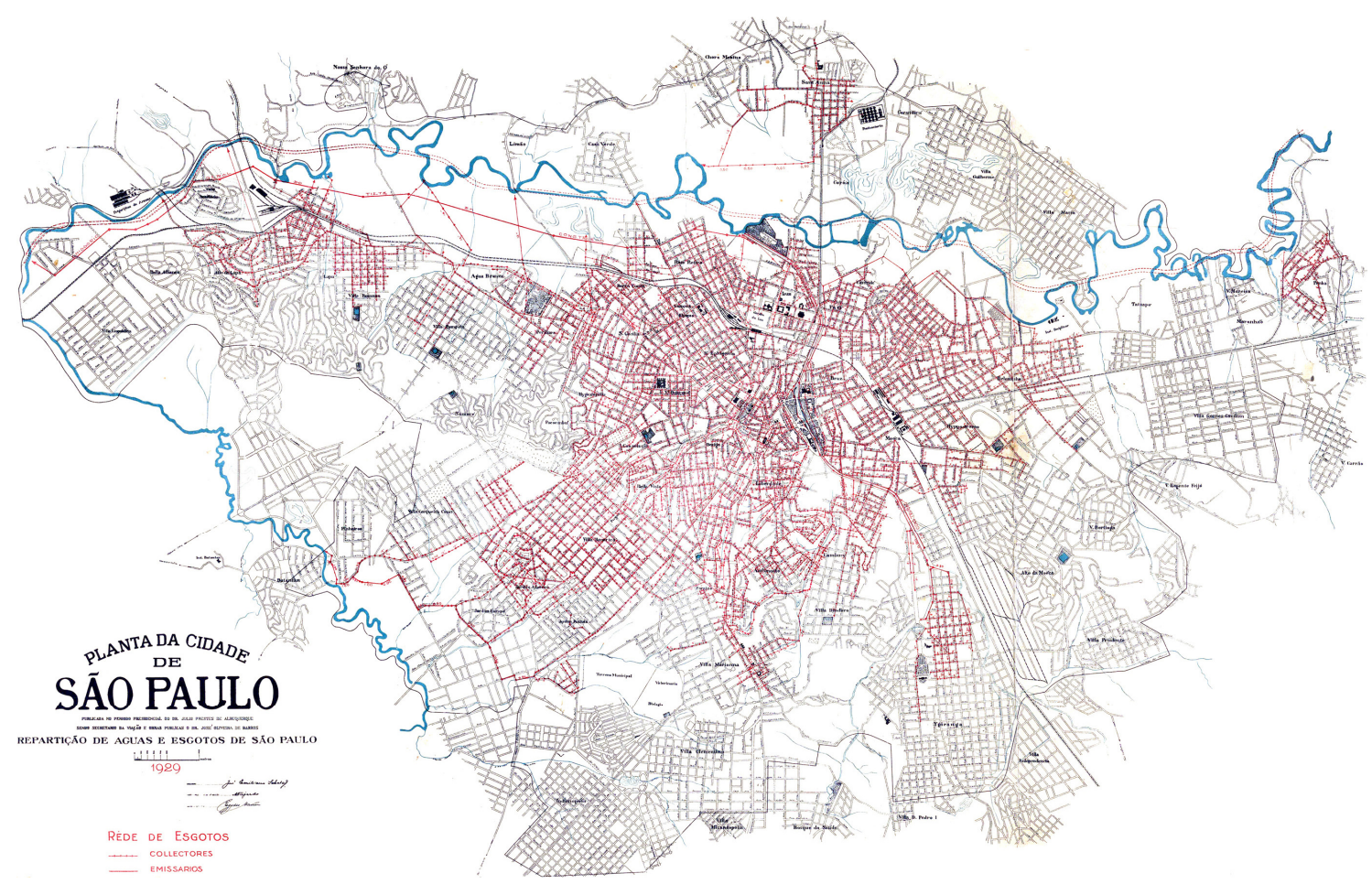

Mapa 3 - Rede de esgotos da cidade de São Paulo, 1929.

Fonte: Arquivo Público do Estado de São Paulo, disponível em http://www.arquivoestado.sp.gov.br/mapas.php, acesso: 18/02/2013.

\subsection{A atuação múltipla da Light e o surgimento dos múltiplos usos das represas}

Enquanto as obras do Sistema Rio Claro não terminavam e a polêmica sobre a utilização das águas do rio Tietê não se concluía, o abastecimento de água mantinha-se uma demanda permanente, quadro que piorou após as fortes estiagens de 1924 e 1925. Em 1929, iniciou-se o aproveitamento das águas da represa do Guarapiranga para abastecimento, localizada na zona sul da cidade, na região de Santo Amaro, construída inicialmente para a produção de energia elétrica.

Com a represa de Guarapiranga o abastecimento de água não seria mais realizado por "águas protegidas" de mananciais distantes. A adução da Guarapiranga foi parte de um plano de emergência e no prazo de 11 meses foi concluído um conjunto completo de obras, compreendendo captação, recalque da água bruta para a estação de tratamento do Alto da Boa Vista, adução até a estação elevatória da Rua França Pinto, no sopé do espigão da Paulista, de onde a água era recalcada para o reservatório da Vila Mariana, sendo que as obras executadas possibilitaram a retirada e distribuição de $1 \mathrm{~m}^{3} / \mathrm{seg}$. Em seguida, de acordo com termo celebrado com a empresa em julho de 1930, o Governo do Estado foi autorizado pela Light a retirar 4 $\mathrm{m}^{3} / \mathrm{seg}$. para abastecimento público. A adução desse volume de água, no entanto, só se completaria em 1958 (QUEIROZ, 1964, p.30).

Nesse período, além das obras destinadas à distribuição das águas retiradas do Guarapiranga, foi programada e concluída a construção de uma bateria de poços profundos, na várzea do Tietê, 
próximo ao Belenzinho, para a obtenção de um volume de 30 milhões de litros/dia, bem como obras complementares para a adução dessas águas aos reservatórios da Penha e Belenzinho. Concluídos e postos em funcionamento os poços não produziram o volume de água que se esperava. Adicionalmente ao plano de emergência de 1929, para manter a vazão da adutora do Cabuçu, que se reduzia na estiagem, foi construída uma estação com aproveitamento das sobras do ribeirão Cabuçu e seus afluentes a jusante da captação, injetando na adutora um volume suplementar de 10 milhões de litros por dia (Ibidem, p.30).

Cabe destacar que além de ampliar a distribuição de água na cidade, a utilização da Guarapiranga para abastecimento de água marca o início de um conflito decorrente do uso múltiplo das represas, somado ao não tratamento de esgotos, que até hoje se faz presente, ainda que de forma mais direta em relação à Billings. O futuro das águas, e do saneamento, seria a partir de então mais determinado pelo interesse na hidroeletricidade. Nesse sentido, consideramos relevante recuperar alguns aspectos da múltipla atuação da Light e seus interesses, retomando suas atividades iniciais.

A The São Paulo Tramway Light and Power Company Limited - Light, empresa criada no Canadá com um conglomerado de capital canadense-anglo-americano, começa a atuar em São Paulo em 1899 por um decreto do presidente Campos Sales. Esse grupo liderava empreendimentos em várias cidades do mundo, funcionando como um conglomerado de capitais. No Brasil ${ }^{43}$, atuava em São Paulo, Rio de Janeiro e Salvador.

A Light atuou desde o princípio com uma estratégia monopolista, e do ponto de vista técnico e organizacional era uma empresa eficaz, que gerava muitos lucros. E para que pudesse operar sem restrições, mantinha relações próximas com a elite política e social, procurando sempre integrá-la aos seus negócios. A empresa mantinha um jornal de circulação diária para se contrapor aos seus numerosos críticos, e chegava a atuar eleitoralmente, alistando seus operários e obrigando-os a votarem na chapa indicada pela empresa (JORGE, 2006, p.74-75).

Conforme Seabra (2012), a Companhia Light estava associada em holding ${ }^{44}$ e tinha como objetivo afastar concorrentes. Em 1901 ela constrói a usina hidrelétrica de Parnaíba, na Cachoeira do Inferno, rio Tietê, na altura de Santana do Parnaíba; e em 1909 obtém ampliação de sua concessão do bonde (sobre o qual tinha exclusividade) para a distribuição de força e luz, liquidando as empresas concorrentes como a Viação Paulista e a Companhia de Força e Luz (BUENO, 1994, p.64). A britânica San Paulo Gás \& Co. resistiu durante algum tempo, e disputou o mercado da iluminação pública, mas acabou sendo incorporada pela Light.

\footnotetext{
43 Em 1904, em meio a certas resistências, o Grupo Light conseguiu instalar-se na cidade do Rio de Janeiro, tendo fundado a The Rio Tramway Light and Power Co. Ltd. e, em 1912, é registrada em Toronto a empresa holding de eletricidade, a Brazilian Traction, Light and Power Co. Ltd. para articular as subsidiárias: The São Paulo Tramway, Light and Power Co. Ltd; a São Paulo Electric Company Limited, formada também em Toronto e autorizada a funcionar no Brasil em 1911, e a já mencionada, The Rio Tramway, Light and Power Co. Ltd.

${ }^{44}$ No começo do século XX, a holding foi um sistema monopolístico de organização de empresas que se configurou no Brasil, e em outros países (Canadá e Estados Unidos) como forma de conjugar capital financeiro e a indústria de equipamentos elétricos (SEABRA, 2012).
} 
Na década de 1920, a Light cresceu para o interior do Estado de São Paulo, por meio do controle acionário de pequenas empresas de energia elétrica do Vale do Paraíba, e também Jundiaí, Itu, Porto Feliz. Expandindo seus negócios em diversas regiões e setores de atuação, ficou conhecida como "polvo canadense" (SANTOS, 1987, p.111).

\subsubsection{A construção da represa de Guarapiranga e a concepção do Projeto Serra}

Em 1912, a usina hidrelétrica de Parnaíba (Edgard de Souza), que inicialmente tinha duas unidades que produziam mil kW em cada uma, atingiu a geração máxima de dezesseis mil kW. Para a ampliação da capacidade de geração de energia da usina, foram instaladas sucessivas turbinas, o que impôs a necessidade de regularização da vazão da água do Rio Tietê, principalmente em épocas de estiagem. Para isso, a empresa construíra um grande reservatório de regularização ${ }^{45}$, em 1908, represando o rio Guarapiranga, afluente do rio Pinheiros, e formando a represa Velha de Santo Amaro, ou Guarapiranga.

Como observou Seabra, "a instalação dessas usinas geradoras, os processos técnicos de transmissão de corrente, significavam atualização tecnológica, pois eram contemporâneas à difusão de hidroeletricidade em escala industrial nos países já industrializados." (SEABRA, 1987, p.157).

A represa de Guarapiranga, e também a de Parnaíba, eram bem vistas pela população, pois representavam obras grandiosas e inéditas e, no caso da Guarapiranga, criava um espaço bonito e aprazível, representavam assim o "progresso". Mas a atuação posterior da Light deixava bem claro seus métodos. Um deles refere-se à obtenção de terras a serem inundadas. A construção do reservatório prejudicou diversos sitiantes e chacareiros que desempenhavam atividade agropastoril e abasteciam São Paulo com seus produtos porque tiveram que se mudar forçosamente recebendo quantidades irrisórias por suas propriedades, e acusavam os empregados das empresas por negociações abusivas (JORGE, 2006, p.77). A forma de obtenção de propriedades e o interesse imobiliário da Light assumirão grandes dimensões posteriormente, com a retificação do rio Pinheiros.

As ampliações de capacidade da usina de Parnaíba possibilitaram, além do uso para prover os serviços de bondes elétricos e iluminação pública, a venda de excedente de energia, viabilizando a expansão industrial e o uso em residências. Apesar das máquinas a vapor serem utilizadas como importantes forças motrizes nas fábricas, os motores elétricos eram cada vez mais requisitados ${ }^{46}$. A partir dos anos 20 , a geração de energia seria a principal fonte de ganhos da

\footnotetext{
45 Na época das chuvas a água era acumulada na represa e nos meses de seca era despejada no rio Pinheiros, chegando por meio deste ao rio Tietê, ajudando a aumentar a geração de energia em Parnaíba.

${ }^{46}$ Segundo o Censo de 1907, do total de 109.676cv (cavalo-vapor) de potência instalada nas indústrias do país, 73\% provinham de energia a vapor, $22 \%$ de energia hidráulica, quase $5 \%$ de eletricidade e o restante distribuído em outras formas de energia. Já o censo de 1920 demonstrou que do total da capacidade energética, 47,2\% advinham da eletricidade, 36,2\% do vapor, 10,4\% da energia hidráulica e o restante de outras fontes (SÃO PAULO, 1999, p.84-85).
} 
Light. A pressão sobre o aumento da produção de energia elevou-se após o fim da Primeira Guerra Mundial.

Nesse momento, contudo, o sistema hidroelétrico montado pela Light já não era capaz de garantir o fornecimento em São Paulo. Apesar disso, a empresa tentava impedir a quebra de seu monopólio, valendo-se de seus recursos financeiros e de influências, conseguindo leis e contratos privilegiados (JORGE, 2006, p.78).

Assim, em 1922, as obras de expansão de geração de energia elétrica serão conduzidas por um engenheiro hidrelétrico americano chamado Asa White Kenney Billings. Após seus estudos, concluiu que era necessário construir uma alternativa de baixo custo, pois a seca do período estava afetando até mesmo o serviço de bondes. Como medida emergencial, a Light inaugurou, em 1925, depois da sua construção às pressas em apenas onze meses, a Usina de Rasgão, perto da cidade de Itu, interior do Estado.

Já estava em elaboração o "Projeto Serra", apresentado em 1923 pela Light. O projeto foi concebido pelo engenheiro Billings, ainda em 1911-1912, e visava, por meio de uma grande operação de engenharia, utilizar as águas da Bacia do Alto Tietê para gerar energia elétrica na Usina Hidrelétrica de Henry Borden (UHB), em Cubatão, aproveitando-se do desnível da Serra do Mar. O Projeto Serra foi aprovado pelo governo federal em 1925, e autorizado pelo Decreto Federal no 16.844, de 27 de março de 1925.

Nesse contexto a represa de Guarapiranga passa a servir ao abastecimento público em 1929.

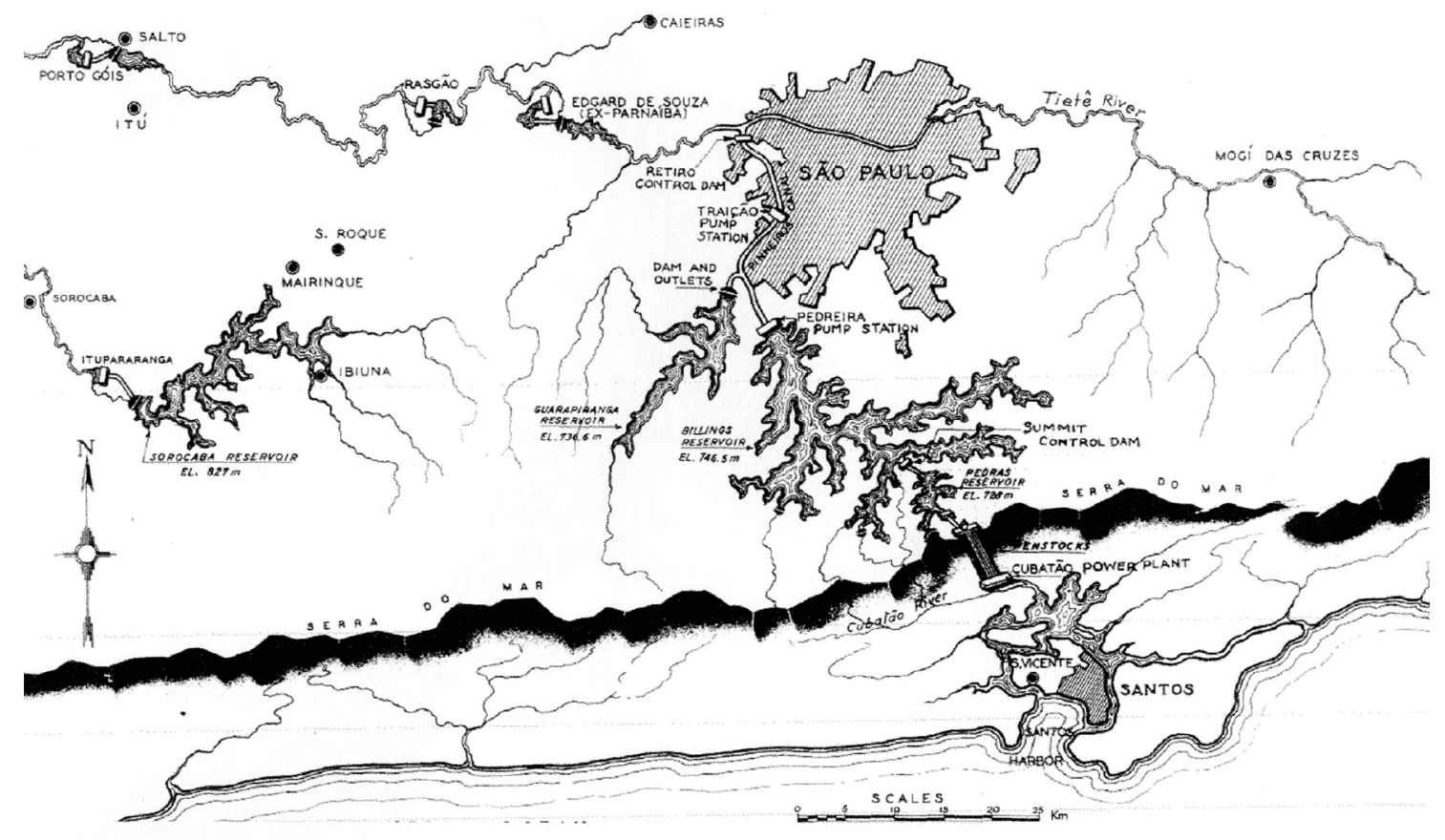

Figura 4 - Réplica do mapa da segunda Concessão do Projeto Serra como construído entre 1928-1944.

Fonte: "Billing and water Power in Brazil" Adolph J. Ackerma ASCE, 1953. Extraído de: Consórcio Intermunicipal do ABC; FUNDUNESP, 2001, p.24. 
Primeiramente, foi construído o reservatório Rio das Pedras, formado por uma barragem e por diques, junto à vertente marítima da Serra do Mar, na cota 733 metros. Também contribuiu para o reservatório um pequeno afluente da margem esquerda do Rio Grande, que foi escavado e dragado para permitir que parte de sua vazão fluísse para o reservatório (SOUZA, 1982, p.105): Em 1926 já entrava em operação o primeiro grupo gerador de Cubatão, com uma potência considerável para a época, 44.347kW (SEABRA, 1987, p.158).

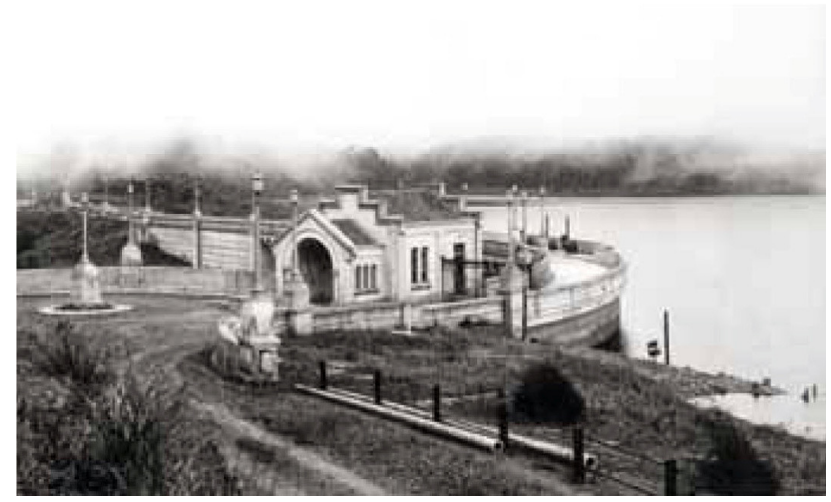

Figura 5 - Barragem rio das Pedras, 1932.

Fonte: Fundação de Saneamento e Energia.

Além da construção de uma usina hidrelétrica ao pé da Serra de Cubatão, o Projeto Serra previa a construção de quatorze reservatórios em São Paulo, que seriam interligados por túneis e canais à represa do rio Grande. Esta concepção retomava propostas de Saturnino de Brito, que planejara o conjunto de represas a montante de São Paulo, como forma de combater as enchentes, ao mesmo tempo, formar mananciais e incrementar a navegação, já que elas poderiam regularizar o regime do Tietê (JORGE, 2006, p.81).

A Light, no entanto, alterou o projeto inicial, pois após aprimoramentos dos estudos de Billings, o engenheiro concluiu que seria menos custoso e mais rentável para a empresa construir o reservatório do rio Grande (ou Jurubatuba), mais tarde chamado de represa Billings. A construção do reservatório contemplou duas grandes barragens: a do Rio Grande, junto ao final do futuro Canal Pinheiros, e o chamado Summit Control, barragem reguladora junto ao canal que controlaria a vazão das águas do Reservatório Rio Grande, no nível 748 metros, até o Reservatório do Rio das Pedras, na altitude de 728 metros. Em seguida foram feitas sucessivas adições de unidades de geração, até que em 1938 chegou-se a capacidade de 65.000kW.

Posteriormente, os anos 1940 são marcados por crises no fornecimento de energia e, o plano de obras no rio Pinheiros é redefinido, conforme se verá adiante.

\subsubsection{Obras de geração de energia entrelaçadas ao interesse imobiliário da Light}

No início do século XX, as concessões de produção e distribuição de energia não eram reguladas ou fiscalizadas, o que gerava problemas sérios para o Estado, pois as empresas utilizavam estratégicos recursos hídricos nacionais. O Código das águas, por sua vez, encaminhado à Câmara federal em 1907, valeria no território nacional apenas em 1934. Odette Seabra explica como a Light influenciou sua elaboração em seu favor, no que se refere ao dispositivo que 
garantia a propriedade sobre o leito do rio alterado por obra humana a quem realizasse a despesa (SEABRA, 1987, p.160).

Em 1927, sob a presidência de Júlio Prestes, a lei no $2249 / 1927^{47}$ concedia à Light os direitos de canalizar, alargar, retificar e aprofundar leitos dos rios Pinheiros e seus afluentes, Grande e Guarapiranga, a jusante das respectivas barragens, nos municípios de Santo Amaro e Capital, drenando, saneando e beneficiando assim os terrenos situados nas respectivas zonas inundáveis. A lei declarava como de utilidade pública os terrenos e outros bens indispensáveis à construção das obras, e de necessidade pública as áreas atualmente alagadiças, ou sujeitas a inundações, saneadas ou beneficiadas (artigo 3ํ). Também concedia o direito de desapropriação dos bens e terrenos objetos de intervenções, tendo que para isso submeter as plantas das obras a executar bem como suas modificações à prévia aprovação do poder executivo (artigo 4으) (Ibidem, p.161).

Para continuar a exploração do potencial de geração do sistema de Cubatão, a Light planejava concretizar o aproveitamento das águas do Tietê através do rio Pinheiros, realizando um conjunto de obras para inverter o curso original desse rio, aumentando a vazão de água que chegava à represa Billings.

Mas Seabra demonstra que a estratégia da Light foi além desse objetivo, e detalha as implicações das indefinições dessa lei no que se refere à propriedade da terra, explicitando a estratégia da empresa em adquiri-las. Apesar da Light ter iniciado a compra de propriedades antes de 1928, amparada pela lei de concessão, se aproveitou de uma situação de desastre, a enchente de 1929, quando, após um período chuvoso "as águas existentes nas várzeas foram acrescidas dos volumes das represas da Light após terem sido abertas as comportas para acrescer o volume retido por processos naturais e assim seria superestimada, como de fato foi, a superfície admitida como planície aluvial do Rio Pinheiros". Uma vistoria ad perpetuam demarcou no terreno o território de domínio da Companhia. Assim foi delimitada a zona inundável, identificada também nos mapas da Companhia, como linha de máxima enchente (SEABRA, 1987, p.12) . $^{48}$.

\footnotetext{
${ }^{47}$ O Decreto estadual no 4487 de 9 de setembro de 1928 aprovou as cláusulas, em execução desta Lei, conforme Seabra (1987).

${ }^{48}$ A autora Odette Seabra explica em detalhe o procedimento de abertura das comportas entre as páginas 173 e 193 de sua tese de doutorado.
} 

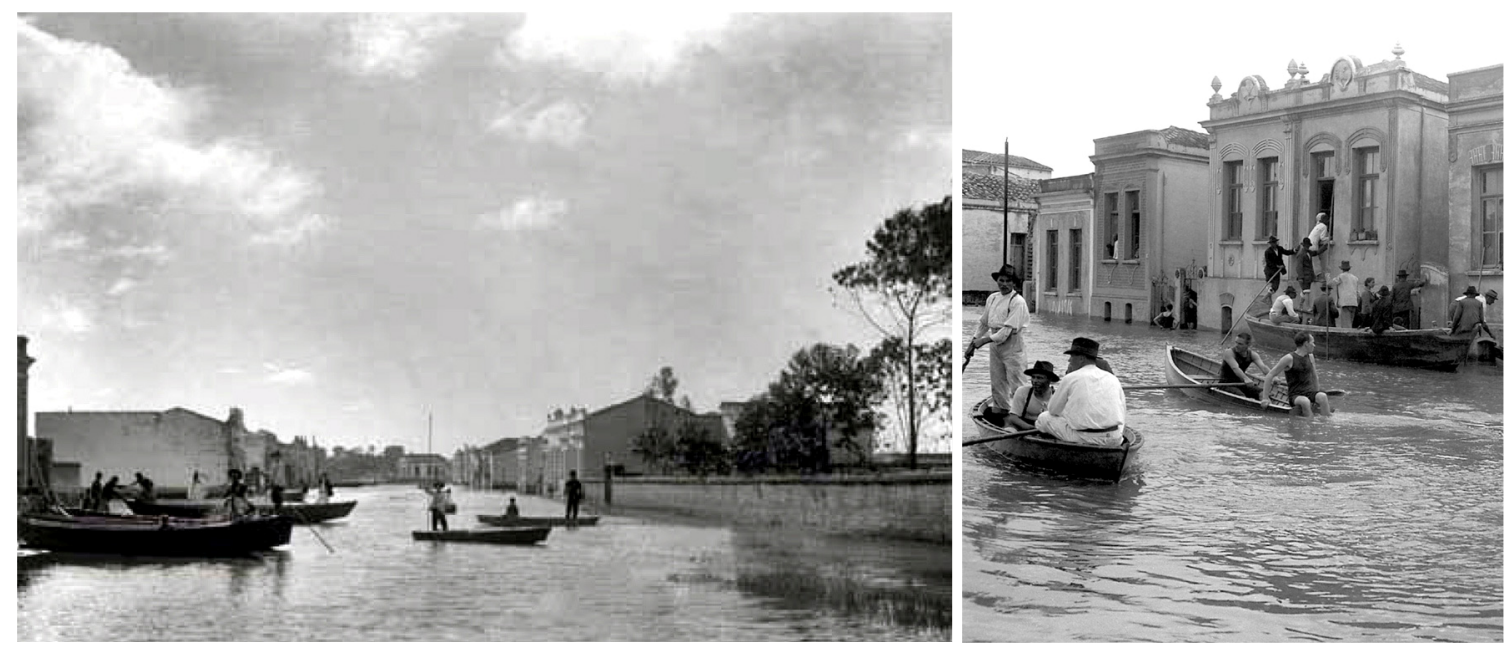

Figuras 6 e 7 - Enchente de 1929 em São Paulo. Autor desconhecido.

Fonte: Catálogo da exposição Inundações em São Paulo, Galeria Olido, São Paulo, 2010.

A partir de então a Light buscou assegurar as propriedades entrando em acordos amigáveis ou litigiosos, desapropriações judiciais, compra etc. (Ibidem, p.201). Conforme o "porte" do proprietário, se grande, pequeno ou público, a negociação tomava diferentes encaminhamentos. As desapropriações judiciais prevaleceram sobre os proprietários menores, e acordos de doação em pagamento eram feitos com os grandes proprietários (Ibidem, p. 244) ${ }^{49}$. E apesar das resistências pontuais, o monopólio sobre as terras da várzea do rio Pinheiros era cada vez maior.

Em resumo, a valorização das terras nas várzeas do rio Pinheiros passou a se constituir como um interesse central da Light. Para sua realização havia uma gestão, presidida sob a lógica financeira, da valorização dos terrenos, que valiam mais ou menos, dependendo da localização e conforme os projetos se realizavam, o que Seabra chamou de "valorização diferencial" que era incrementada pelo próprio crescimento da cidade. A companhia atribuía índices de valorização por metro quadrado conforme um zoneamento pré-definido em 18 partes. As estratégias adotadas pela Light serviam para ela se apropriar da renda da terra, e assim, o que o grupo da empresa recebia nos seus bolsos "não era remuneração de capital investido nos negócios da energia, era formação de capital, por expropriação", uma "acumulação primitiva". (Idem, 1987; 2012). Esse estudo sobre a atuação da Light também elucidou as fragilidades do Estado frente a grandes organizações capitalistas, que dominavam também a tecnologia e o conhecimento técnico, e influenciavam as decisões de governo, alterando inclusive a formulação de legislação.

Portanto, para essa autora, não se tratava somente da construção de um canal para fins de geração de energia, mas da transformação capitalista da cidade, que além de alterar a relação de propriedade das terras nas várzeas, transformou seu uso. A expropriação de terras se deu nos moldes que correspondem historicamente à própria formação de capital, aqui no contexto do processo de urbanização de São Paulo.

\footnotetext{
49 Dentre os grandes proprietários figuravam a Companhia City que promovia loteamentos residenciais; a empresa Dumont Villares que planejava a criação do Distrito industrial do Jaguaré; a Companhia Votorantim que se transformou em grande proprietária no Brooklim; e a Companhia Cidade Jardim.
} 
A transformação do curso do rio em infraestrutura combinou de modo singular, na Light, o setor de hidroeletricidade com o interesse imobiliário. Assim, a péssima qualidade da água que circulava por esses rios não impedia que esses interesses econômicos se realizassem. Ao mesmo tempo, a confluência entre a degradação dos rios, o não tratamento dos esgotos, o aumento da demanda por água para abastecimento e questões de macrodrenagem, que implicam em conflitos pelo uso da água, inicia-se nesse momento e terá implicações futuras com o sistema de saneamento, como se verá adiante. O descompasso entre a distribuição das redes e a expansão da metrópole já era uma realidade. 


\section{CAPÍTUL0 2}

\section{As redes de infraestrutura "correm atrás" da metropolização}

Esse segundo capítulo aborda as transformações no espaço urbano e no sistema de infraestrutura decorrentes do processo de industrialização e urbanização, em dois momentos. A primeira etapa (de 1930 a 1949) é tratada nos itens 2.1 a 2.6. E a segunda etapa de 1950 a 1980, é tratada nos itens 2.7 ao 2.12 .

\subsection{Indústria, metrópole e 0 acirramento dos problemas urbanos (de 1930 a 1949)}

O crescimento urbano que impulsionava a expansão das infraestruturas, e vice-versa, se intensifica com a expansão da produção industrial a partir dos anos 1930. Após a crise financeira mundial de 1929 - que repercutiu no país afetando a exportação do café - o Estado brasileiro assumiu novos contornos, distinguindo-se do anterior não apenas pela centralização política e econômica, como também voltava-se para os objetivos da industrialização, que passará a ser o setor-chave para a dinâmica do sistema (Oliveira, 2006, p.29). Por isso, era necessário destruir as regras do jogo da economia agrárioexportadora, criar as condições institucionais para a expansão das atividades ligadas ao mercado interno e a um novo modo de acumulação.

Uma mudança substancial nesse período foi a regulamentação, por parte do Estado brasileiro, dos fatores de produção da economia, em especial a legislação para regular a relação entre trabalho e capital, o que compunha, junto a outros aspectos, uma nova relação entre o Estado e o urbano. Por um lado, essa legislação estabelecia o salário mínimo apenas como salário de subsistência, o que não garantia as necessidades de reprodução social da classe trabalhadora. E por outro lado, entre 1930 e 1945, a política trabalhista também teve como um de seus efeitos políticos a repressão dos esforços de organização da classe trabalhadora urbana fora do controle do Estado.

Em 1934, o governo Getúlio Vargas, instituiu uma primeira legislação ambiental federal, o Código Florestal, juntamente com os códigos de Água, Minas, Caça e Pesca. O Decreto no 23.793/34 já cria uma reserva legal indiscriminada quando determina que nenhum proprietário pode desmatar ou cortar mais de $3 / 4$ da vegetação existente em seu imóvel (art. 23). Este decreto dará base para a reformulação que culminou no Código Florestal (SANTORO, 2012, p.62). 
A industrialização caracterizava-se como um processo de "modernização conservadora" ${ }^{50}$, numa matriz econômica concentradora de riquezas, que gerava fortes desequilíbrios regionais e desigualdade social.

O problema do acesso à moradia ganhou relevância, pois a habitação era vista como condição básica de reprodução da força de trabalho, como um fator econômico que afetaria a estratégia da industrialização. A questão sanitária deixou de ser a tônica predominante das intervenções no espaço urbano, mas as questões relativas ao abastecimento de água, tratamento de esgotos e das inundações se mantêm como problemas e se acirram do ponto de vista urbano e ambiental. Por outro lado, a crise econômica impactou alguns investimentos que estavam em andamento, como as obras de saneamento. Enquanto que a industrialização demandava o aumento da produção de energia.

Outro aspecto importante do processo de industrialização foi o concomitante processo de metropolização. De 1930 até o final da Segunda Guerra a região sudeste da RMSP - o ABCD paulista, desenvolveu-se com a concentração de indústrias ao longo da estrada de ferro SantosJundiaí. São Bernardo do Campo, apesar de se distanciar do eixo ferroviário em cerca de oito quilômetros, obtinha um nível baixo de industrialização com a atividade moveleira, perfazendo, em 1938, um total de 37 estabelecimentos industriais onde trabalhavam 1551 operários. Já em Santo André existiam indústrias de maior porte como a Rhodia e a Pirelli ${ }^{51}$.

A partir de 1940, a construção de rodovias, somada à valorização imobiliária e ao esgotamento da oferta de grandes terrenos para a instalação das plantas industriais, fizeram com que as indústrias saíssem dos limites administrativos do Município de São Paulo, se deslocando para os municípios vizinhos como: Guarulhos, Santo André, São Caetano, São Bernardo e Osasco. Com isso, se inicia uma nova fase do crescimento da Grande São Paulo (LANGENBUCH, 1971) e consequentemente desses municípios.

No caso do município de São Bernardo do Campo, a implantação da rodovia Anchieta entre 1947 e 1953, ligando São Paulo a Santos promove novas ocupações ${ }^{52}$ e constitui-se em um novo polo de desenvolvimento da região. No entanto, essa expansão urbana não foi acompanhada de investimentos em infraestrutura. Na década seguinte, como se verá adiante, a indústria automobilística promoverá uma grande transformação no município.

\footnotetext{
${ }^{50}$ Termo utilizado por intérpretes da formação brasileira, como Tavares (1993) e outros.

${ }^{51}$ Em 1938, sob a ditadura Vargas e após articulação de um grupo de Santo André, o interventor estadual Adhemar de Barros assinou um decreto transferindo a sede do município de São Bernardo para Santo André, sendo a antiga Vila de São Bernardo rebaixada a distrito. Como reação, em 1943, sob a liderança do banqueiro Wallace C. Simonsen, a Sociedade dos Amigos de São Bernardo solicitou a emancipação do município. Nesse momento, o governo estadual planejava uma reforma administrativa e, sob pressão desse grupo, São Bernardo foi elevado à categoria de município, em 1945, com o nome de São Bernardo do Campo. Wallace C. Simonsen foi nomeado prefeito e governou a cidade até 1947. Posteriormente, ocorrerá a divisão do território em outros municípios autônomos (SÃO BERNARDO, 2010 p.22).

52 Uma delas decorreu da própria construção da via Anchieta, que foi a construção de uma vila com moradias para os trabalhadores do Departamento de Estradas e Rodagem (DER). Muitos trabalhadores eram do Estado de Minas Gerais.
} 


\subsection{A crise da moradia e sua solução com ou sem Estado}

No início da década de 1930, o problema da habitação operária precária já se apresentava como uma crise da moradia. Diversos setores da sociedade ${ }^{53}$ passaram a debater o problema habitacional e a demandar repostas do Estado, pois a opinião generalizada era que a iniciativa privada era incapaz de enfrentá-lo. Em oposição à conduta liberal do período anterior, e com uma nova postura intervencionista, o Estado passa a produzir ou financiar habitações, por meio de órgãos governamentais como as Carteiras Prediais dos Institutos de Aposentadoria e Pensões (IAPs, criados em 1930) e a Fundação da Casa Popular (criada em 1946). Essas instituições são consideradas os primeiros passos da política habitacional estatal no Brasil. Contudo, após os anos 1940, os IAPs atenderam a demanda habitacional de uma classe média crescente.

Outra intervenção do Estado na questão habitacional foi a aprovação da Lei do Inquilinato, em 1942, com a qual o governo congelou os aluguéis e restringiu os despejos injustificados. Até 1940, as moradias alugadas representavam 70\% dos domicílios em São Paulo (BONDUKI, 2011, p.218). Essa lei foi sendo renovada até 1964 , e se por um lado garantiu a estabilidade de antigos locatários, por outro dificultou o acesso ao aluguel pela nova demanda, pelos imigrantes e despejados. Os seus efeitos contraditórios geraram escassez e uma espécie de "câmbio negro nas poucas moradias desocupadas", o que criou dificuldade aos não proprietários, além de afetar a rentabilidade dos próprios rentistas (Ibidem, p.226).

Simultaneamente, foi socialmente construída a ideologia da casa própria individual, amparada na ideia de que a ascensão social e a dignidade eram conquistadas por meio do trabalho. Isso era defendido amplamente e se contrapunha aos argumentos de setores progressistas que identificavam a habitação social como um serviço público e não uma conquista individual, pois reconheciam a dificuldade financeira do trabalhador para conseguir adquirir uma moradia por meio da compra.

No contexto de industrialização e rápida urbanização, a população da cidade de São Paulo passou de 1,3 milhões de habitantes em 1940 para 2,2 milhões em 1950 (IBGE, 1940; 1950). Diante do quadro de poucas unidades novas produzidas (120 mil unidades), se comparado ao déficit habitacional que se avolumava (de mais de 200 mil moradias), a população sem acesso às formas tradicionais de moradia passou a intensificar, sob aceitação do Estado, formas de ocupação precárias, como as favelas e a autoconstrução da casa própria em loteamentos clandestinos desprovidos de infraestrutura (BONDUKI, 2011, p.248).

As favelas significavam não só uma solução habitacional como também uma forma de resistência das famílias em deixar áreas mais centrais e mudar-se para a periferia. Já o processo de abertura de loteamentos, se diferenciava do que ocorrera até os anos de 1920, quando o

\footnotetext{
53 Bonduki (2011, p.75) argumenta que nesse período o problema da moradia tornou-se um tema de reflexão multidisciplinar, envolvendo profissionais e instituições de várias áreas, não somente engenheiros sanitaristas. Os arquitetos, entre 1930 e 1940 passam a atuar organizados em espaços próprios, como o Instituto de Arquitetos do Brasil. Os Congressos Brasileiros de Arquitetos se tornaram uma referência importante no debate sobre habitação, nos quais se consolidaram posições que influenciaram várias gerações de profissionais.
} 
retalhamento do cinturão de chácaras era um tipo de aplicação de capital que visava a valorização futura e não exigia investimentos imediatos em infraestrutura porque não havia demanda para os lotes que permaneciam, na sua grande maioria, desocupados (GROSTEIN, 1987). A partir dos anos 1940, esse processo se altera. Os trabalhadores começam a adquirir lotes mediante pagamento em prestações, localizados em áreas sem infraestrutura e serviços urbanos, distantes do local de trabalho e, por meio da autoconstrução ou de contratação precária de serviços de terceiros, constroem a própria moradia. São os loteamentos populares na periferia.

Como argumenta Pasternak (2010), até 1937 a compra e venda de lotes em São Paulo era feita sem regulação, gerando situações de insegurança nas transações. Nesse ano o decreto federal no 58/1937 regulamentou relações contratuais ${ }^{54}$ e, assim como o decreto 3.079/1938, passa a exigir dos loteadores alguns requisitos urbanísticos mínimos ${ }^{55}$. Mas antes desse decreto federal, já em 1932, a Lei Municipal no 2.611 de São Paulo definia regras para a abertura de loteamentos. Para se proceder a um arruamento, era necessário apresentar o plano de arruamento com curvas de nível de metro em metro, definindo o traçado das ruas e o seu nivelamento, os espaços livres e os sistemas de drenagem. Exigia-se, como doação de área para o poder público, $20 \%$ para vias e $10 \%$ para espaços livres. O lote mínimo deveria ter $300 \mathrm{~m}^{2}$, com frente mínima de $10 \mathrm{~m}$. Os loteamentos populares, no entanto, eram vendidos sem seguir todas essas exigências legais.

Em 1939, o Decreto-Lei oo 4.857 trata da lei dos registros públicos, e contém alguma regulamentação sobre loteamentos. Tal decreto prevê, ainda, a obrigatoriedade de inscrição do memorial para imóveis urbanos ou rurais e a averbação dos contratos de compra e venda dos terrenos loteados. Começam a surgir mecanismos de proteção ao comprador, que passa a ter direito de mover ação contra o loteador nos casos em que se efetuou o pagamento integral das prestações, se o loteador se recusa a fornecer o título definitivo de propriedade. Mas somente em 1949 é que o compromisso de compra e venda passa a ter direito real (PASTERNAK, 2010, p.405).

A legislação relativa a loteamentos continuará sendo modificada nas décadas seguintes sendo, na prática, sistematicamente pouco seguida. Nesse sentido, cabe destacar que a anistia tornouse expediente de regularização frequentemente adotado pelo poder municipal, particularmente após a década de 1950 em diante ${ }^{56}$. As anistias beneficiavam primeiro os loteamentos localizados no centro, ou seja, atendiam antes as classes mais altas depois as mais baixas (SANTORO, 2012).

\footnotetext{
54 As leis federais se concentravam na regulamentação de relações contratuais até a promulgação da lei Federal de parcelamento do solo, № 6766/1979, de cunho primordialmente urbanístico.

55 Área do lote de $250 \mathrm{~m}^{2}$, serviços de água e esgoto, guias nas calçadas, sarjetas, arruamento e arborização e áreas livres.

${ }^{56}$ Como explica Santoro (2012, p.100), o município de São Paulo teve uma sequencia de leis oficializando vias abertas sem registros, nas décadas seguintes, em 1953, 1955 e 1962; e uma anistia aos loteamentos e edificações clandestinas em 1968.
} 
Nesse período, outra face do processo de transformação urbana era a renovação dos centros e uma febre imobiliária de caráter especulativo que consolidou um novo modelo de incorporações para classes de renda média e alta. As camadas de mais alta renda, conforme explicou Villaça (1998), haviam se deslocado dos bairros centrais que já não correspondiam mais ao seu padrão de qualidade urbana. Esse movimento se deu em sentido radial, de forma a mantê-los concentrados num mesmo setor de círculo - o sudoeste, garantindo assim as condições de acesso ao centro e os benefícios dos investimentos públicos, especialmente as obras viárias, concentradas em porções da cidade "rica".

O aperfeiçoamento da legislação urbanística também foi um dos instrumentos que serviu aos privilégios urbanos que a burguesia pretendia manter (VILLAÇA, 1999), a exemplo do primeiro Código de Obras de São Paulo, o Código Arthur Saboya (lei municipal no 3427/1929) que estabeleceu uma série de restrições para garantir a qualidade de ruas com uso exclusivamente residencial. Outro exemplo foi a lei específica aprovada por Anhaia Mello em 1931 (Ato Municipal no 127), que introduziu o conceito de zoning ${ }^{57}$ abrangendo somente a área dos loteamentos da Companhia City, no Jardim América e Jardim Europa. A sua aplicação tinha o objetivo declarado de estabelecer direitos de vizinhança, proteger o valor de mercado da propriedade imobiliária, compatibilizar infraestrutura viária e uso do solo, e controlar a especulação imobiliária (ANCONA, 2002, p.147-148).

As grandes obras de infraestrutura passam a ser priorizadas para prover condições gerais de circulação, produção e reprodução do capital. "Passa-se assim da 'cidade bela' para a 'cidade eficiente', da cidade do consumo para a cidade da produção", sendo que em ambas o interesse imobiliário se fez sempre presente (VILLAÇA, 1999, p.199). Então, a intervenção na cidade deixa de acontecer com base no melhoramento e embelezamento urbano para ser conduzida por "planos gerais" 58 , quando surge um elaborado discurso técnico sobre o planejamento urbano representado pelo Plano Diretor ${ }^{59}$.

\subsection{O saneamento "básico"}

Em relação ao saneamento, sucessivas reformas institucionais foram dirigidas pelo governo federal. Incluídas no conjunto das reformas varguistas ${ }^{60}$, as ações sanitárias e de educação passaram a compartilhar o Ministério da Educação e Saúde Pública - MESP, criado em 1930 e regulamentado em 1934. Em 1937 o setor da saúde foi novamente reformulado e criou-se o Departamento Nacional de Saúde - DNS em substituição ao Departamento Nacional de Saúde

\footnotetext{
57 O conceito de zoning que vinha sendo aplicado na legislação americana há alguns anos que significava "regulamento diferencial de especialização".

58 O plano de Agache para o Rio de Janeiro e de Prestes Maia para São Paulo.

${ }^{59}$ Segundo Villaça, o período do plano intelectual, formulado por técnicos, com base científica, o que ele denominou de "plano-discurso" - pois não se preocupava com a operacionalidade, vai até a década de 1990 (Villaça, 1999, p.204).

${ }^{60}$ Getúlio Vargas suspendeu a Constituição de 1981 e passou a governar por decretos até 1934, quando promulgou nova Constituição.
} 
Pública - DNSP. Interventores de saúde foram nomeados nos Estados, com o objetivo de criar ou reorganizar os Departamentos Estaduais de Saneamento - DES, nos quais foram instaladas Seções de Engenharia Sanitária. Os próprios governadores eram nomeados interventores de saúde pelo presidente da República e na maioria dos Estados essa proposta foi aceita, devido à capacidade de administrar problemas sanitários (HELLER; REZENDE, 2008, p.201).

A partir de 1941, o DNS passou a ter um caráter menos executivo, concentrando-se na coordenação e fiscalização das ações realizadas nos Estados e municípios. Foi criada a Divisão de Organização Sanitária - DOS, à qual era subordinada a Seção de Engenharia Sanitária, responsável pela elaboração de projetos para unidades sanitárias padrão, realização de estudos relacionados à coleta e tratamento de resíduos sólidos, fiscalização e higiene das habitações e locais de trabalho, atuação no saneamento rural e controle da poluição atmosférica (Ibidem, p.202).

Sendo assim, entre os anos de 1930 e 1940, foram organizados órgãos e entidades municipais por todo o país. Os recursos para a implantação das obras públicas passaram a vir predominantemente do orçamento público, investidos a fundo perdido, e de empréstimos de bancos internacionais. O Estado de São Paulo foi o primeiro a assumir a forma de administração na qual o Departamento das Municipalidades, responsável pelo saneamento das cidades do interior, executava obras de saneamento, repassando-os à administração municipal, que se responsabilizava pela gestão dos serviços (Ibidem, 2008, p.203). Isso se coadunava com a Constituição de 1934, que atribuía ao município a organização dos serviços de caráter local, porém, a maioria deles não estava preparada para executar e muitas vezes não tinha recursos para manter as obras que recebia.

No período seguinte, entre 1940 e 1950, os setores de saúde e saneamento constituíram instâncias institucionais e de atuação diferenciadas e para Heller e Rezende (2008), "ampliou-se a dicotomia entre a saúde e o saneamento, caminhando a saúde rumo à privatização e o saneamento em direção a uma maior autonomia, pela via de novos modelos de gestão, como as autarquias e as empresas de economia mista" (HELLER; REZENDE, 2008, p.209).

Além disso, conforme as atividades do saneamento e da saúde foram se dissociando, altera-se a própria concepção de saneamento. Segundo Britto (2006), no campo da engenharia, a concepção de saneamento como preparação de áreas para ocupação urbana, associada ao urbanismo, vai desaparecendo. Estas ações passam a ser objeto de planejamento urbano, que envolve outros saberes e linguagens, como dos arquitetos-urbanistas, dos sociólogos, dos economistas e gestores urbanos. O saneamento, por sua vez, passa por uma especialização, incorporando uma racionalidade técnica e econômica, criando o campo disciplinar da engenharia sanitária. Os engenheiros passam a se dedicar mais diretamente ao planejamento e projeto das redes de infraestrutura e dos equipamentos relativos ao abastecimento de água e esgotamento sanitário e se constrói no âmbito da engenharia uma nova concepção de saneamento que seria designada como "saneamento básico". 
O saneamento básico se referia aos serviços de abastecimento de água e esgotamento sanitário, geridos de forma autônoma dentro da administração pública, dentro de uma perspectiva de planejamento integrado e complementar dos dois sistemas, recorrendo à técnicas modernas de engenharia e orientado por um modelo de gestão empresarial, onde a manutenção e a extensão dos sistemas deve ser financiada pelas tarifas pagas pelos usuários em função do consumo. (BRITTO, 2006)

Essa noção de saneamento básico orientará o setor do saneamento até o final dos anos 1980/90. Isto diferenciava fundamentalmente o saneamento básico de outros serviços como coleta e disposição de lixo, drenagem e controle de inundações, financiados através de taxas ou de outras formas de dotação orçamentária.

O primeiro plano conjunto de água e esgotos feito em São Paulo, conforme abordado no próximo item, fora pautado pela lógica de retorno de investimentos, que marcará os períodos subsequentes das intervenções de saneamento.

Considerando essa reflexão, o que nos interessa discutir é de que modo essa concepção de saneamento básico, que orientou a noção do serviço público com visão empresarial, pautou a construção dos espaços das redes de infraestrutura, estruturando o espaço metropolitano. Do ponto de vista do resultado no espaço construído, aparentemente, seu alto grau de especialização parecia poder ser autônomo do planejamento do conjunto da cidade. Mas os atuais problemas ambientais relacionados à má gestão das águas nos espaços urbanos demonstram as heranças problemáticas desse modo de intervir. O problema é que se antes já havia um descompasso entre a velocidade de reprodução do espaço urbano e o acompanhamento das redes de infraestrutura, o que se observa é que a infraestrutura como política setorial reforça, porém em escalas ampliadas, sua fragmentação.

\subsection{Descompassos entre a expansão de infraestruturas e 0 crescimento urbano em São Paulo: as propostas do Plano Geral da RAE}

Até o início da década de 1950, a RAE era responsável pelos serviços de saneamento relativos à água e esgoto em São Paulo. Durante a década de 1930, após fortes estiagens e crises sucessivas no abastecimento de água, foram realizadas diversas obras emergenciais, até que se decidiu pela utilização da represa de Guarapiranga. Apesar da ampliação das aduções, os estudos realizados entre 1933 e 1939 para o Plano Geral de Whitaker - sobre o período 1929 e 1939 -, demonstravam que os serviços de abastecimento de água estavam sempre em atraso (WHITAKER, 1946). Alguns dados desse diagnóstico fornecem uma ideia quantitativa do problema no período e como foram tratados pelo engenheiro no Plano Geral de 1942.

Com relação ao abastecimento de água, considerando os sistemas ${ }^{61}$ em fins de 1929, a cidade contava com o volume garantido em qualquer época de $174.805 .000 \mathrm{I} / \mathrm{dia}$. A população da Capital era de 851.838 habitantes, existindo 111.116 prédios, dos quais 78.980 abastecidos antes da ampliação das redes distribuidoras, por ocasião da inauguração da adutora (Cabuçu), e

\footnotetext{
${ }^{61}$ Cantareira, Cotia, Poços Profundos, e Santo Amaro.
} 
32.136 sem o serviço de água canalizada. No fim do ano já havia 83.452 prédios abastecidos. Contudo, considerando o volume necessário de água por dia em 250/I por habitante/dia, para abastecer toda a população seria preciso 212.959 .500 litros/dia (851.838 X 250). Mesmo esse volume era insuficiente para estender as redes distribuidoras para todos os prédios da cidade, apresentando um déficit de 38.154.500 I/dia (WHITAKER, 1946, p.14).

Apesar do aumento da adução entre 1929 e 1933, obtida por meio da realização de diversas obras, Whitaker apresentava a situação dos déficits permanentes, tanto em relação ao aumento de volume de água necessário, como em relação aos edifícios atendidos. A quantidade de edifícios crescia e o déficit de prédios não abastecidos acompanhou o crescimento, como ilustra a tabela a seguir:

Tabela 1 - Situação dos prédios existentes e abastecidos na cidade de São Paulo, 1929-1942:

\begin{tabular}{cccccc}
\hline Anos & Prédios existentes & $\begin{array}{c}\text { Prédios } \\
\text { abastecidos }\end{array}$ & $\begin{array}{c}\text { \% prédios } \\
\text { abastecidos / total }\end{array}$ & $\begin{array}{c}\text { Prédios não } \\
\text { abastecidos }\end{array}$ & $\begin{array}{c}\text { \% prédios não } \\
\text { abastecidos / total }\end{array}$ \\
\hline 1929 & 111.116 & 83.452 & $75 \%$ & 27.664 & $25 \%$ \\
1930 & 113.442 & 87.606 & $77 \%$ & 25.836 & $23 \%$ \\
1939 & 164.687 & 128.321 & $78 \%$ & 36.366 & $22 \%$ \\
1940 & 176.415 & 135.242 & $77 \%$ & 41.173 & $23 \%$ \\
1941 & 188.532 & 143.019 & $76 \%$ & 45.513 & $24 \%$ \\
1942 & 196.389 & 148.780 & $76 \%$ & 47.609 & $24 \%$ \\
\hline
\end{tabular}

Fonte: Extraído de Whitaker, 1946, p.19 e 34. Reorganizado pela autora.

Esses déficits eram consequência da adução insuficiente dos sistemas produtores disponíveis Cantareira, Cotia, Santo Amaro, Cabuçu - frente ao crescimento da cidade. Mesmo após a conclusão do primeiro trecho da adutora Rio Claro, que levou quinze anos para ser construído, o problema do abastecimento não estava resolvido. Whitaker atribuía uma grande parte da responsabilidade desse problema à própria opção pela retomada e prosseguimento das obras dessa adutora, em 1932, pondo de lado a possibilidade de construção de novas adutoras provenientes da represa de Guarapiranga em Santo Amaro (WHITAKER, 1946, p.21).

Em 1941 foram concluídas as obras da adutora Rio Claro passando São Paulo a receber desse manancial 225 milhões de I/dia ou cerca de $2,6 \mathrm{~m}^{3} / \mathrm{seg}$, vazão que, por falta de regularização, se reduzia significativamente nas estiagens, podendo chegar a $1,4 \mathrm{~m}^{3} / \mathrm{seg}$. Essa variação de vazão foi controlada com a adoção de novas aduções e estação elevatória entre 1939 e 1942, e finalmente com a construção da barragem do ribeirão do Campo em 1962 (FARIA, 2004, p.50). Entre 1939 e 1942, apesar de seus problemas, o abastecimento com Sistema Rio Claro servia também os municípios de Santo André e São Bernardo do Campo, que não contavam com abastecimento de água. Com a inauguração do sistema Billings, em 1958, foi cortada aquela derivação. Também foi feita uma derivação para o município de Mauá (QUEIROZ, 1964, p.33). 
Em 1942, a população não abastecida na cidade de São Paulo somava 362.819 habitantes, e a abastecida 1.135.191 habitantes. Nesse ano, o déficit em volume de água era de 146.308.890 I/dia (o volume aduzido era 286.616.000 I/dia e o volume necessário 432.924 .890 l/dia) (WHITAKER, 1946, p.34).

Os reservatórios reguladores de distribuição de água ${ }^{62}$ que atendiam bairros centrais e o noroeste da cidade, já estavam com mais de 30 anos, e na avaliação de Whitaker tinham sido construídos com base no atendimento de uma população e de um consumo menor, por isso não estariam adequados ao crescimento da cidade (Ibidem, p.36).

Com base nesse diagnóstico, em 1942 a RAE elaborou, sob coordenação do engenheiro Plínio Penteado Whitaker, um Plano Geral de Distribuição de Água (e um plano de obras de emergência) e um Plano Geral de Coleta e Tratamento Depurador de Esgotos para a Capital.

Nota-se que esses planos incidiriam sobre uma área delimitada de expansão urbana, que fora definida em 1936, através do Ato Municipal no 1057. Em 1941, esses limites foram estabelecidos como área de atuação da $\operatorname{RAE}^{63}$. Segundo Moreira (2008, p.103), essa foi a condição essencial para que a rede de distribuição do volume de água então disponível - com a finalização das obras do Rio Claro e com as ampliações previstas na Guarapiranga - fosse passível de ser planejada no Plano de Whitaker, pois visava atender toda a cidade.

Essa postura de planejamento se diferenciava da adotada anteriormente, quando a expansão da rede se dava conforme a demanda aumentava, com muitas situações emergenciais, ou ainda a partir de previsões sobre o aumento da população quase sempre equivocadas, apesar da dificuldade em prognosticar tais dados na época.

Interessante notar que dez anos antes, em 1931, quando a cidade passou a marca de um milhão, o prefeito Anhaia Mello64, provido de mapas e estatísticas, declarou que a cidade clandestina era muito maior que a cidade oficial (ROLNIK, 2003, p.149). A cidade clandestina era a que crescia por meio dos loteamentos populares, que não eram servidos de infraestrutura. Whitaker detalha em seu estudo diversos locais onde não havia abastecimento e que se localizavam dentro do perímetro considerado pelos planos, ao mesmo tempo em que reconhece a existência de arrabaldes mais distantes, situados fora do limite abastecível.

Para garantir o abastecimento e a distribuição abrangendo a cidade, buscando uma homogeneidade, o plano dividiu-a em setores de abastecimento escolhendo a procedência das

\footnotetext{
62 O centro da cidade, de acordo com o Plano de Emergência de 1929/30, continuava sendo abastecido pela adutora Cotia, com os reservatório de distribuição: Consolação (1897), Araçá (1907), Água Branca (1915), reservatório Praça Amadeu Amaral (1896) e Vila Mariana (1914).

${ }^{63}$ Ato no 1368, Art. 1: "Os prolongamentos de redes de água e esgotos serão executados somente em ruas ou arruamentos situados dentro do perímetro que circunscreve a área considerada abastecível ou esgotável, de acordo com respectivos projetos organizados pela RAE." (Revista DAE - Boletim da RAE, ano 5, № 13, 1941, São Paulo apud, BUENO, 1994, p.82).

${ }^{64}$ Essa declaração foi feita no Primeiro Congresso de Habitação de São Paulo, do Instituto de Engenharia e publicado nos Annaes do Primeiro Congresso de Habitação em 1931 (ROLNIK, 2003).
} 
águas tributárias de cada zona, aproveitando as instalações existentes, sendo que um setor de socorro poderia aduzir água de um para outro.

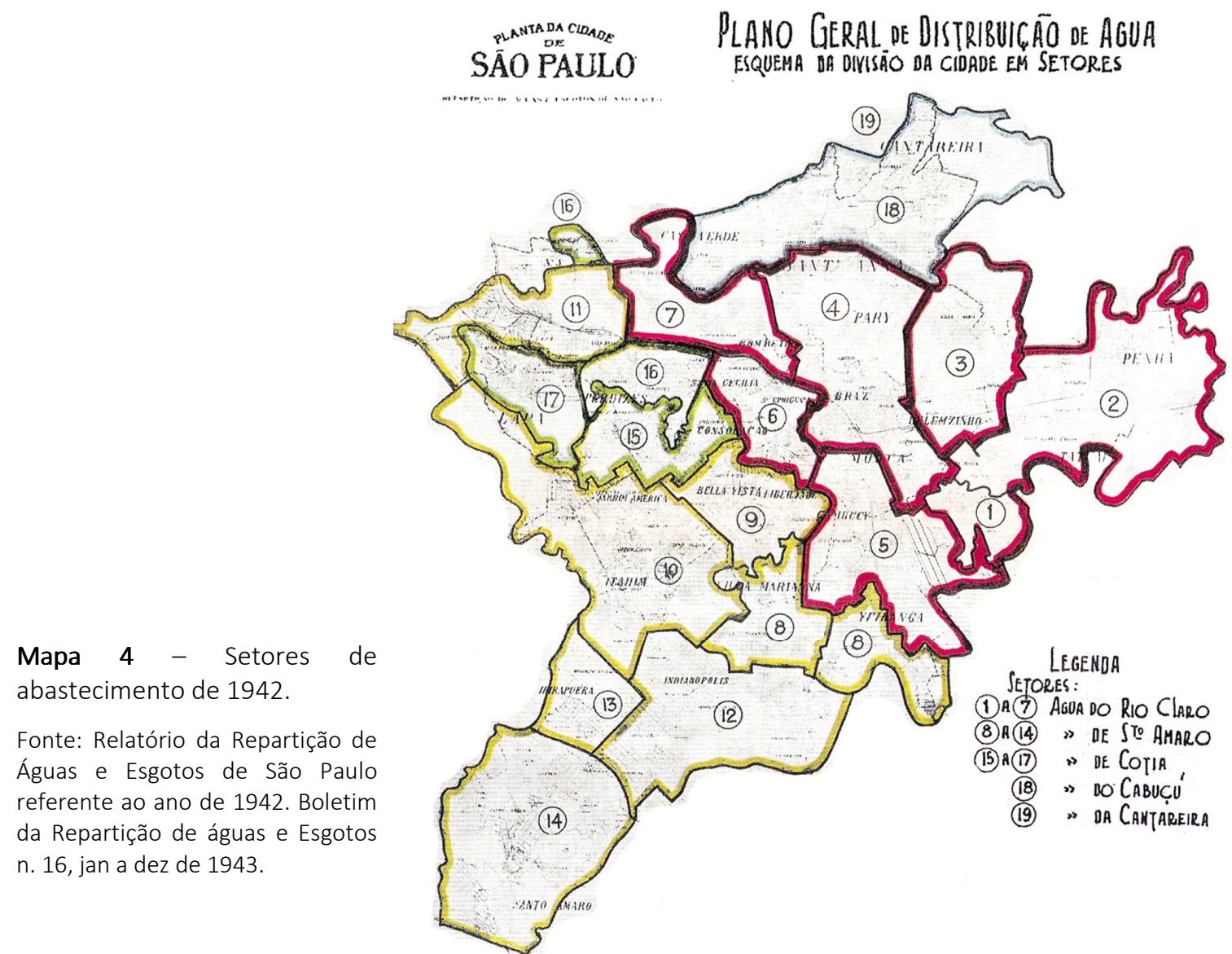

Com a realização do Plano de Abastecimento, em 1942, o engenheiro Whitaker traçou um plano de obras de "reforço do abastecimento e de reforma e ampliação das instalações de distribuição dentro da cidade". O aproveitamento da bacia do Guarapiranga, como já comentado, foi a solução considerada mais rápida e econômica. No detalhamento desse plano foram projetadas instalações para a retirada, recalque, tratamento, adução e distribuição de $11 \mathrm{~m}^{3} / \mathrm{s}$, vazão instantânea da qual se poderia lançar mão em caso de necessidade; em 1948 tinham início as obras novas do sistema Guarapiranga.

Em 1958, novo convênio foi celebrado entre o Governo do Estado e a Light, ratificando entendimentos anteriores, pelo qual ficou o DAE autorizado a derivar daquela represa $9,5 \mathrm{~m}^{3} / \mathrm{s}$, volume que representa a vazão média anual regularizada do manancial. Dentre as obras previstas, estavam elevatórias, linhas de recalque, novos reservatórios e a construção da primeira etapa da estação de tratamento do Alto da Boa Vista, que só entrou em funcionamento em 1957 (QUEIROZ, 1964, p.31).

A assinatura de um "termo de acordo" estabelecia que o DAE se comprometia a compensar a Light pelo volume de água, ou por fornecimento à Light de energia bruta produzida pelo sistema público ou em dinheiro (BUENO, 1994, p.110). Um dos motivos que explica que as obras de ampliação da Guarapiranga tiveram mais sucesso foi o fato dessa represa perder importância no sistema produtor de energia, fazendo com que a Light refizesse seu acordo para ampliação da 
captação. A Light voltava seus esforços para a canalização e reversão do rio Pinheiros, para ampliar a geração de energia, como se verá a seguir. E a Light era responsável pelas boas condições de saneamento desse reservatório.

Em relação aos esgotos, o plano de Whitaker identificava como um dos problemas centrais o crescimento da cidade sobre áreas de topografia acidentada, com o crescimento de núcleos esparsos, o que dificultava a extensão da rede e portanto demandava a abertura de vielas, ruas e avenidas para a passagem de tubulações. Propunha também o tratamento de esgotos, por meio da construção de emissários e estações de tratamento, e era enfático na necessidade de controle das emissões industriais, destacando que o governo deveria exigir tratamento prévio de efluentes (BUENO, 1994, p.85-86).

Das obras previstas no Plano Geral - tanto as de água como as de esgotos - grande parte ficou comprometida durante a Segunda Guerra, pois os investimentos foram interrompidos, assim como o recebimento de materiais. E depois da guerra, os materiais e equipamentos utilizados nas obras dependiam de fornecedores internacionais, que estavam voltados à sua própria demanda. Além disso, a abertura de concorrências internacionais não obteve resposta, pois as empresas não estavam aptas a atuar naquele momento que se voltavam à reconstrução em seus países. Assim, grande parte das obras do Plano de Whitaker para o abastecimento de água será realizada após a criação do Departamento de Águas e Esgotos (DAE), na década de 50 (Ibidem, p.90).

\subsection{A supremacia da geração de hidroeletricidade sobre 0 abastecimento de água $e$ drenagem}

Durante a depressão do início da década de 1930, as obras do Projeto Serra ficaram paralisadas praticamente por três anos, e foram retomadas após o período de recessão econômica, em 1934. Os diques e as barragens foram concluídos em 1937, possibilitando o preenchimento completo do Reservatório do Rio Grande. Em Cubatão, entre 1936 e 1938 são instaladas mais três unidades geradoras, com potência total de 195 megawatts (SOUZA, 1982, p.161).

A partir de 1940, o Projeto Serra se torna mais complexo com a retificação e reversão do rio Pinheiros (que passa a correr em sentido contrário, do Tietê à Serra do Mar), a construção de duas estações elevatórias no canal do Pinheiros (Pedreira em Santo Amaro e Traição na altura da ponte da Av. Bandeirantes) e a estrutura do Retiro (intersecção do Pinheiros com o Tietê). Com isso passa-se a captar também parte das águas do rio Tietê para a represa Billings, e depois para Cubatão. 


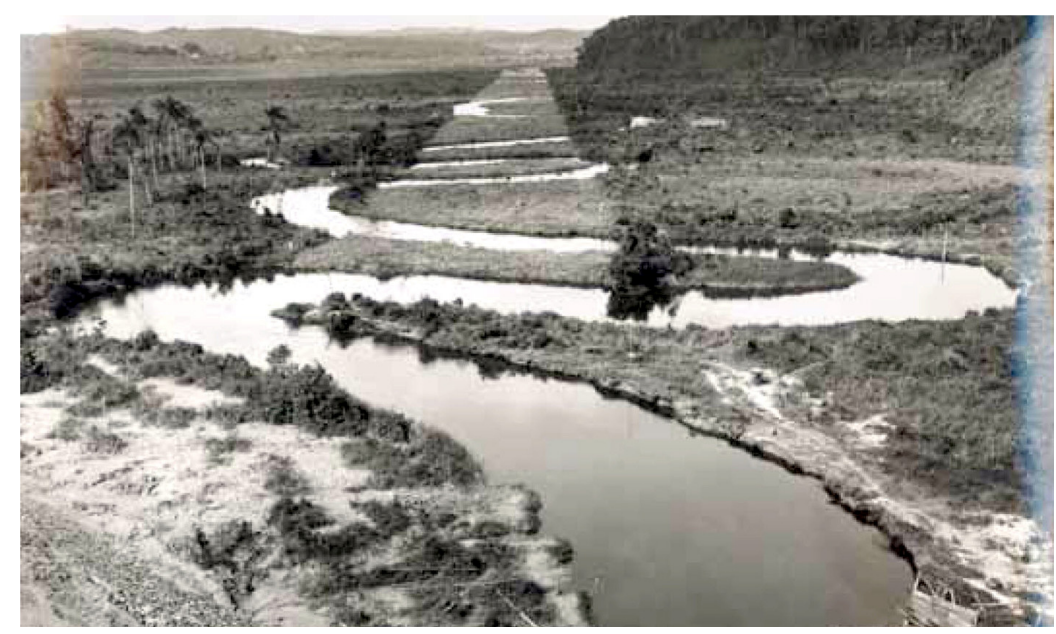

Figura 8 - Rio Pinheiros, anos 1930.

Fonte: Fundação de Saneamento e Energia.

Para ampliar esta vazão ainda mais, elevou-se o nível da barragem de Edgar de Souza (em Santana do Parnaíba) em $6 \mathrm{~m}$ - ao invés de abaixar $1 \mathrm{~m}$ como aconselhava Saturnino de Brito -, e foi construída a barragem de Pirapora do Bom Jesus sobre o rio Juqueri, para bombear mais água para Edgar de Souza. Com isso, o sistema potenciou-se enormemente (OSEKI, 1991, p.37). Entre 1948 e 1951, novas unidades geradoras foram instaladas no sopé da serra, completou-se a potência em superfície com o fornecimento de 474.000kW (SEABRA, 1987, p.250).

Para essa solução que priorizava totalmente a geração de energia, interessava a vazão de água, e não sua qualidade. Dessa forma, deixou-se de lado o saneamento, principalmente a questão do tratamento de esgotos, do abastecimento de água e da drenagem. Em relação à drenagem, segundo Bueno: "Apesar dos estudos da Light e da Escola Politécnica da Universidade de São Paulo negarem que o remanso provocado pelo alteamento chega até Guarulhos, a partir de 1955 começam as grandes inundações dos rios Tietê e Pinheiros, cujas várzeas já se encontram em processo de ocupação" (BUENO, 1994, p.91).

Importante salientar que o sistema de geração de hidroeletricidade promovia a integração de bacias, ou seja, toda a bacia do Alto Tietê passava a contribuir para Cubatão, o que, por sua vez, gerou problemas relevantes, até hoje mal equacionados, nessa mesma bacia. Conforme Seabra:

\footnotetext{
Pode-se dizer que desde a construção da represa do Guarapiranga, no começo do século, se desencadeara um processo que integrava de modo mais ou menos definitivo a Bacia do Alto Tietê à do Pinheiros. Mas a reversão do curso do Pinheiros, com as usinas de recalque, e depois o alteamento da Barragem de Parnaíba, inverteram também o sentido dessa integração. Consumou-se o complexo hidrelétrico de Cubatão e definiu-se uma série de problemas do escoamento superficial do Tietê na cidade de São Paulo. Em 1961 foi completada a capacidade total de Cubatão, então denominada Henry Borden, gerando 2.350.000kW. (SEABRA, 1987, p.251)
}

Segundo essa autora, as terras das várzeas também passariam por novo momento de transformação, com a construção das avenidas previstas inicialmente no Plano de Avenidas (publicado ainda em 1930 por Prestes Maia). A Light, grande proprietária particular dessas terras, no entanto, não liberava a área de $40 \mathrm{~m}$ solicitada pelo prefeito Prestes Maia para a construção da avenida, porque as utilizava como bota fora, local de deposição de material extraído da retificação, aterrando alguns trechos e meandros (Ibidem, p.252). 
O canal foi transferido à administração pública, em 1957, e a Light fazia apenas sua manutenção, mas mantinha a propriedade de toda a várzea. Nos anos 1960, o poder público intensificou a pressão para viabilizar a construção do sistema viário. "A História começa a se inverter. Terras da Companhia nas várzeas foram sendo desapropriadas, para a construção de trevos, passagens, alças, viadutos, conexões de todo tipo e para as vias marginais expressas. Projetos que ironicamente começavam a ser executados com recursos do Banco Mundial". A estratégia da companhia foi a de propor permutas de terras ao poder público e de vender rapidamente suas propriedades. Conforme Seabra, um dos motivos que provocou a rápida resposta da Light, foi a "ascensão econômica e política de empresas construtoras as quais impuseram sua lógica ao processo" (Ibidem, p.252-253).

A construção das avenidas marginais, como se sabe, seria mais um componente que agravaria a situação de inundações. E o bombeamento das águas poluídas dos rios Tietê e Pinheiros serão as principais fontes de poluição da represa Billings até a década de 1990 - tema que será retomado adiante e nos próximos capítulos dessa tese.

\subsection{Um debate incipiente sobre a proteção de mananciais}

A utilização da Guarapiranga para abastecimento público de água em 1929, apesar de representar uma mudança em relação a busca de mananciais distantes e protegidos por meio do instrumento da desapropriação, implicou em novas preocupações dos engenheiros sanitaristas em relação ao saneamento da represa e mecanismos normativos necessários à sua proteção e controle. De certa forma, esse debate já havia sido inaugurado pelos engenheiros sanitaristas, em particular Saturnino de Brito, quando da formulação de propostas para captação de água do poluído rio Tietê, em 1926.

Mas a partir de um artigo publicado em 1936, no Boletim de Águas e Esgotos no2, foi possível identificar preocupações concernentes à proteção do lago de Santo Amaro - a represa de Guarapiranga -, tanto por meio de proposição de medidas legais, como infraestruturais. Esse tema, que é pouco considerado nos trabalhos que tratam de infraestrutura e saneamento nesse período, é relevante para a presente tese e tem desdobramentos até a atualidade, quando se discute alternativas para a proteção de mananciais urbanos. Por isso, recupera-se brevemente a discussão da referida publicação.

Por um lado, a própria localização da represa e formas de uso de seu entorno, e por outro a defesa do controle por meio de legislação com sanções, orientavam as sugestões, ainda no nível propositivo, sobre o que seria uma legislação especifica de proteção aos mananciais. O engenheiro Haroldo Paranhos, autor do artigo, apresenta o seguinte diagnóstico:

Observações feitas pela Secção de Tratamento dessa Repartição, têm constatado o augmento de poluição das águas do lago, com o crescente número de focos de contaminação, resultantes do povoamento que se vem fazendo em todas as suas margens, hoje divididas em villas e pequenas estâncias de repouso. É de prever que, em futuro não remoto, a represa do Guarapiranga, tenha um grande numero de 
habitações, o que certamente constituirá um sério perigo para a relativa pureza de suas águas [grafia original] (PARANHOS, 1936, p.177).

A preocupação da RAE com "a defesa do nosso mais importante manancial" - a represa de Guarapiranga, incentivou o estudo de projetos para a solução sanitária e a reflexão sobre a necessidade de outras formas de proteção. Em termos de solução sanitária, a análise das margens direita e esquerda da represa Guarapiranga levou à indicação de dois tipos de solução pois apresentavam situações distintas.

Na margem esquerda, próxima à barragem do rio Guarapiranga, a um trecho de declividade acidentada seguiam-se praias e enseadas, onde foram construídas residências de repouso e lazer, tais como Praia da Lagoa, Enseada dos Húngaros, Yatch Club Paulista e a Riviera. Esses núcleos eram pouco povoados e afastados um dos outros, e o engenheiro considerava pouco provável o desenvolvimento futuro de zonas intermediárias devido às difíceis condições topográficas. Ao todo, somavam-se 200 casas, o que não justificava a construção de um emissário, túneis e demais obras custosas. A ideia mais rápida e econômica encontrada foi a proposição de uma pequena estação de tratamento de esgotos, com poços Imhoff-Emscher ${ }^{65}$ localizados na Praia da Lagoa, Enseada dos Húngaros e Riviera. Essa solução apresentava ainda como vantagens a possibilidade de aumentar unidades com o crescimento dos núcleos, aproveitamento das condições naturais das correntes do lago e da direção dos ventos dominantes, facilitando a eliminação de patogênicos, condições de autodepuração, a ausência de deposição de resíduos sólidos nas margens, devido ao método do poço Imhoff-Emscher.

Para a margem direita o projeto optava pela solução dinâmica, ou seja, a construção de um emissário, pois desse lado já se previa "a possibilidade de um grande desenvolvimento das vilas ali localizadas". O emissário foi projetado no eixo de uma avenida, margeando o lago, a ser construída pela Prefeitura, desenvolvendo-se depois pela margem até a barra do rio Grande com o Guarapiranga. O local de despejo era a barra desses dois rios, onde seria construída uma estação de tratamento, ou seja, "no futuro canal do Rio Pinheiros" que ainda não tinha sido construído pela Light.

Além dessas duas soluções técnicas, esse artigo expressava a preocupação com a legislação de proteção aos mananciais, argumentado que um dos maiores entraves à ação de saneamento era o direito de propriedade e o conflito entre o interesse público das obras de saneamento e esse direito individual:

Toda legislação sanitária tem por objectivo defender a saúde publica, na lucta entre os interesses privados e o interesse coletivo. A jurisprudência formada em torno do direito de propriedade, é o mais serio embaraço que se apresenta a quem queira emprehender uma obra de saneamento. Dahi as innumeras difficuldades de ordem jurídica que entravam os trabalhos de hygiene publica, impedindo muitas vezes a sua realização. Entre nós, nada existe feito neste sentido, particularmente no sector de proteção aos mananciaes, que mais de perto toca o objectivo deste relatório [grafia original] (PARANHOS, 1936, p.179).

\footnotetext{
${ }^{65}$ Com câmaras de secagem dos lodos digeridos, filtração biológica e cloração prévia do efluente dos poços, antes do lançamento nas águas do lago.
} 
Portanto, já se colocava com clareza no início da década de 1930, os conflitos centrais que implicavam na proteção aos mananciais, dentre eles, os relativos à propriedade privada e interesses particulares em contraposição ao interesse coletivo do saneamento. Nota-se a atualidade dessa observação, ainda que a questão da propriedade da terra tenha se tornado muito mais complexa nas décadas posteriores, implicando em conflitos que vão além da questão sanitária, mas não a exclui, como nos casos estudados nessa tese.

Até o momento, a legislação existente de proteção sanitária consistia no Código das Águas, que no artigo 109 declarava: "A ninguém é licito conspurcar ou contaminar as águas que não consome, com prejuízo de terceiro". E aos atos da prefeitura de São Paulo, o Ato no 7 de 10 de agosto de 1932 e o Ato no 14 de 2 de janeiro de 1934 que, respectivamente, proibia a criação industrial de gado suíno dentro de um perímetro de 3 quilômetros a partir de quaisquer margens, e instituía a obrigatoriedade do uso de fossas sépticas nos terrenos marginais do lago. Estas porém, não eram consideradas suficientes, mesmo porque os engenheiros observavam um aumento considerável de matéria orgânica na represa no período de 1930 e 1934.

Em relação ao modelo de desapropriação, debatia-se ainda que as custosas desapropriações de bacias próximas ao ponto de captação não eram suficientes para a defesa do manancial, e quando se tratava de grandes bacias, era inexequível por falta de recursos. Além disso, apontava a inexistência de medidas legais capazes de garantir "a ação enérgica dos zeladores das matas" dentro do limite das bacias, onde frequentemente "pessoas e animais infringiam as proibições". Diante desse quadro conclui-se ser "preciso uma legislação especial capaz de defender o rio ou o lago das polluições quer oriundas de despejos sanitários, quer de despejos de águas industriaes [grafia original]." (PARANHOS, 1936, p.180).

Quanto aos despejos industriais, defende a proibição da localização de indústrias nas proximidades do lago, e que os efluentes fossem lançados na rede de esgoto sem prévia depuração, como estavam fazendo outras cidades do mundo, por exemplo na França, Inglaterra, Alemanha e EUA.

Por fim, esse projeto de saneamento do lago Santo Amaro delimitou um perímetro (conforme Figura 9) cuja finalidade era demarcar a

zona saneada para defesa do lago de Santo Amaro e dentro da qual, as construções civis, habitações, industrias, chácaras, etc, deverão obedecer as leis municipaes referentes ao perímetro urbano e sub-urbano da Capital e Santo Amaro, as leis que promulgarem relativamente a policia sanitária dos mananciaes, aos tratamento das águas industriaes, às instalações domiciliares e ligações de esgotos estabelecidos pelo decreto no 5799 de 22 de dezembro de 1932 e aos demais atos administrativos que tratam da defesa da saúde publica nas zonas urbanas e suburbanas da Capital [grafia original] (Ibidem, p.182). 


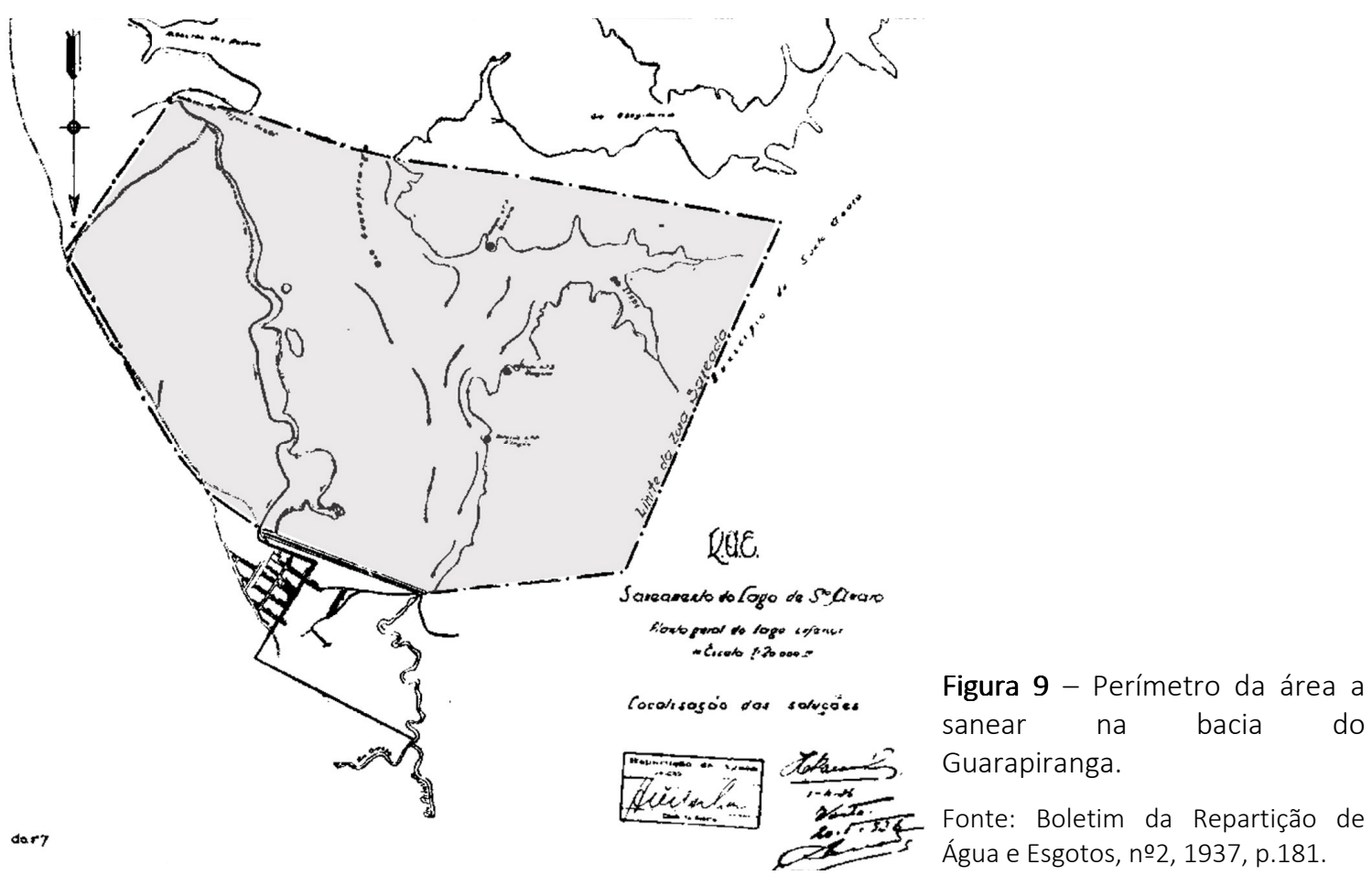

A visão defendida era que o controle amparado por um instrumento legal era a única forma de garantir que o trabalho de saneamento que fosse realizado teria efetividade. "São demasiadamente conhecidas as tendências de nosso povo para infringir os regulamentos, e só pesadas sanç̧ões serão capazes de cohibir os abusos e as complacências [grafia original]." (Ibidem, p.182)

Interessante notar que a visão sanitarista associava a legislação a dois problemas específicos, considerados centrais naquele momento, ou seja, a garantia de manutenção das obras de saneamento do lado que seriam realizadas e o controle dos despejos industriais. A delimitação de um perímetro deixa clara essa intenção. A proposta explicita que a legislação criando a proteção sanitária e a polícia sanitária "não só da zona saneada do lago inferior como das vertentes do lago superior", deveria ser estadual, "estipulando sanções severas que garantam a defesa do manancial" (Ibidem, p.193). É possível que esse tenha sido um dos primeiros artigos que expressam publicamente a necessidade de formulação de uma legislação específica para a proteção de mananciais, que desde sua proposição já acreditava que a rigidez de sanções seria a medida de controle, por meio da polícia sanitária.

Essa preocupação será retomada décadas depois, em 1960, quando outro artigo publicado pelo DAE sugere medidas de saneamento da Guarapiranga como a construção do interceptor de esgotos Interlagos ${ }^{66}$, a proposição de uma portaria para instituir um zoneamento da bacia (em áreas loteáveis para fins urbanos, áreas agrícolas e área de proteção declarada "reserva florestal") e a proposição de um levantamento sanitário da bacia, cujas conclusões apontariam sobre a possibilidade do uso recreativo do reservatório. O zoneamento teria finalidade

\footnotetext{
${ }^{66}$ Um estudo prévio foi formulado pela empresa americana Greeley and Hansen, em 1953 (PEDROSO, 1960).
} 
preventiva, enquanto que o levantamento sanitário forneceria elementos para resolução dos problemas existentes (PEDROSO, 1960).

\subsection{Modernização desigual e centralismo estatal nas políticas públicas de saneamento e habitação (de 1950 ao início dos anos 1980)}

Diferentemente do que aconteceu nos países centrais, onde, durante a expansão que sucedeu o pós-guerra, a produção moderna fordista se combinou a um Estado-providência (1945-1973) e pleno emprego, no Brasil o "fordismo periférico" que se inicia se desenvolve com segregação social. Trata-se da "modernização com exclusão", processo que combina modernização com atraso (MARICATO, 1995, p.5).

Após os anos do retorno de Getúlio ao poder e das medidas nacionalistas, os "anos JK" seguiram a política econômica definida pelo Plano de Metas. Com ele o governo promoveu ampla atividade do Estado nos setores de infraestrutura, energia, transporte, comunicação e no incentivo direto à industrialização. Juscelino atraiu também capitais estrangeiros, concedendoIhes facilidades e desmobilizando, assim, o crescimento da indústria nacional que vinha sendo beneficiada no período anterior.

Um dos setores que se ampliou consideravelmente nesse período, até a década de 1960, foi a indústria automobilística. Empresas multinacionais implantaram-se no $A B C$ paulista, onde havia grandes terrenos disponíveis, localizados próximos às novas rodovias. A chegada dessas indústrias transformou brutalmente esses municípios, que cresceram rapidamente ao atrair mão-de-obra ${ }^{67}$.

As indústrias de bens duráveis também se implantaram, tornando-os acessíveis pela difusão de crédito ao consumidor (MAUTNER, 1999, p.248). Já para a indústria da construção civil, o Plano de Metas fora decisivo, principalmente para o futuro da indústria de construção pesada. Enquanto vários ramos da indústria de transformação se internacionalizaram, na atividade construtora aumentou a dominação do capital privado nacional, com a ampliação dos projetos de grande infraestrutura que contavam, antes, com a presença de empresas estrangeiras (FIX, 2011, p.85). As grandes empreiteiras de obras públicas se fortaleceram no período, especialmente as ligadas à construção de rodovias. Segundo Fix, o setor de edificações não recebeu atenção do Plano de Metas e não se desenvolveu tanto quanto o setor de obras públicas, exceto no episódio da construção de Brasília (Ibidem, p.86).

Na década de 1960, com o avanço da indústria pesada, que provocou também a modernização rural, teve como consequência o aumento dos fluxos migratórios tornando São Paulo o principal centro receptor, ampliando ainda mais sua expansão urbana. Apesar do crescimento industrial, o reequipamento de setores tradicionais diminuiu a quantidade de postos de trabalho. A partir

67 Durante as décadas de 1950, 1960 e 1970 São Bernardo do Campo recebeu o maior fluxo migratório de sua história, o que fez com que sua população saltasse de 29.295 habitantes em 1950 para 425.611 em 1980, sendo que, destes últimos, 292.816 eram migrantes, segundo o censo de 1980 do IBGE (SÃO BERNARDO, 2010, p.37). 
daí a chamada economia "informal" de serviços (de baixa produtividade) acentua sua presença (CANO, 1989, p.72-73).

Entre 1962 e 1967, a crise econômica ${ }^{68}$ somada à postura autoritária do Estado ditatorial relegou a segundo plano os problemas sociais. O "milagre brasileiro" acelerou a modernização da agricultura sem realizar a reforma agrária, o que acentuou os problemas sociais no campo, gerando o êxodo rural em direção às grandes cidades. Nesse contexto, as condições de vida urbana se agravaram sobremaneira.

Entre 1967 e 1974, para enfrentar o período de crise econômica, o governo realiza mudanças institucionais de amplo impacto, aumentando as condições fiscais e financeiras do Estado, com o surgimento do Sistema Financeiro Habitacional e o fortalecimento das empresas estatais. Em 1973, no contexto da crise internacional do petróleo, o governo Geisel (1974) formula o II Plano Nacional de Desenvolvimento (PND), cujo objetivo era completar o processo de substituição de importações, não mais de bens de consumo, mas avançando no caminho da autonomia dos insumos básicos (petróleo, aço, alumínio, fertilizantes etc.) e da indústria de bens de capital.

Nesse período, entre 1950 e o final de 1970, o investimento público promoveu uma importante expansão de infraestruturas de transportes, comunicações e insumos industriais básicos. A estrutura industrial avançou em vários sentidos, se modernizou, mas não se completou enquanto centro nacional de decisões de investimento capitalista, pela manutenção da dependência tecnológica e financeira internacional. Os limites do processo de industrialização brasileiro, bem como, de direção da política pública do Estado, na medida em que se enreda na crise da dívida, aprofunda a desigualdade de renda, os problemas sociais e a perda da qualidade de vida nas cidades. Essa condição é contestada pela emergência de movimentos sociais organizados, como o movimento sindical no campo (luta pela posse da terra) e na cidade (movimento sindical).

Entre 1979 e 1982, a crise externa agravara sobremodo o serviço da dívida externa, o déficit público, o balanço de pagamentos e a inflação - num cenário de aumento de taxa de juros resultado da política norte-americana. Em 1982, o governo autoritário batia à porta do Fundo, Monetário Internacional - FMI. A crise econômica do período 1981-1984 provocaria o maior desemprego aberto, fazendo proliferar nova inchação do terciário. A partir de 1984 o Brasil passa a exportar para os EUA, o que começou a gerar superávits comerciais e a recuperação do crescimento da produção (CANO, 1989). A insolubilidade da crise da dívida, leva à deterioração das contas públicas, das empresas estatais e do financiamento da política pública, notadamente, da de habitação, que anos mais tarde implicaria no encerramento do BNH.

\footnotetext{
${ }^{68}$ Cano caracteriza como de grande complexidade para a sociedade brasileira o período 1961-1964. Na economia, representa o agravamento inflacionário, a crise fiscal e financeira do Estado, a desaceleração do crescimento industrial e o esgotamento do manejo instrumental da política econômica. No plano social, é a tomada de consciência por amplas camadas da sociedade da gravidade dos problemas maiores do país. No plano político, a ruptura com o passado, sem contudo conduzir à modernidade institucional democratizante; antes, abre o cenário futuro para vinte e um anos de autoritarismo, a partir do golpe militar de 1964 (Ibidem, p.81).
} 
Os impactos socioambientais do modelo-urbano industrial se mostraram nefastos, tanto nos países centrais como nos países "subdesenvolvidos". Na década de 1970, as questões ambientais já eram tratadas nas conferências internacionais, como a Conferência de Estocolmo. No Brasil, em meio ao processo intenso de industrialização e urbanização, surgem, em 1973, com a criação da Secretaria Especial do Meio Ambiente - SEMA, as primeiras políticas públicas especificas de meio ambiente, no âmbito federal.

As linhas básicas dessa política eram a proteção dos recursos naturais e o controle da poluição, sendo que esta última recebeu mais ênfase no que tange a regulação e novas exigências para as indústrias poluentes ${ }^{69}$. Para as áreas urbanas o plano compreendia também o zoneamento do uso do solo e controle da localização industrial, e o fornecimento de saneamento básico, de coleta de lixo e de áreas de recreação (ANCONA, 2002, p.30-31).

O discurso ambiental era sustentado pelas elites, extratos superiores da classe média e do próprio governo que passavam a entender os problemas urbanos como problemas ambientais, contudo, não os associavam com o contexto de desigualdade social. Devido ao caráter extremamente técnico ou muito elitizado do tratamento das questões, não foram estabelecidas pontes entre o movimento urbano e o movimento ambientalista durante os anos 1970 (Ibidem, 2002, p.34).

Portanto, a incorporação do "meio ambiente" como política pública se dá nos anos 1970, mediada pelo discurso internacional, mas evidentemente não correspondia à crítica ao desenvolvimento econômico predador que já começava a ser pautada pelo movimento ambientalista. Assim, esse discurso é internamente acomodado aos interesses de desenvolvimento econômico do período, por meio do tratamento técnico do planejamento, e mais focado no controle de poluição. A abordagem ambiental dos problemas urbanos refere-se mais estritamente ao saneamento básico, pouco dialogando com questões estruturais mais amplas, como a crítica do modelo de desenvolvimento e as desigualdades sociais.

\subsubsection{Urbanização com baixos salários e a autoconstrução da moradia}

As transformações que se processaram com a intensificação da industrialização e urbanização, aprofundaram simultaneamente as desigualdades socioeconômicas, com reflexo nas dificuldades de acesso à moradia e infraestrutura pela população, em escala metropolitana. Houve uma mudança no padrão de crescimento urbano se comparado ao período que compreende o início do século XX até 1949.

A partir de meados dos anos 1950 até 1960, a presença de cortiços e favelas em áreas centrais era expressiva, ainda que os loteamentos populares com autoconstrução também se constituíssem como alternativa habitacional. Após os anos 1960 a ocupação urbana extrapolou os limites físicos e geomorfológicos da bacia sedimentar de São Paulo onde antes se concentrava

\footnotetext{
${ }^{69}$ Após o II PND foram aprovados: o Decreto-lei no 1.413/75 e o Decreto Federal no 76.389/75 destinados a disciplinar o controle da poluição industrial, este ultimo considerou as regiões metropolitanas como áreas criticas (Ibidem, p.32).
} 
a ocupação (MARCONDES, 1999, p.119). Ou seja, a construção de moradias se deu em áreas mais distantes dos bairros centrais, sobre áreas de maior declividade, vulneráveis à erosão, ou suscetíveis a inundações de corpos d'água, baseada na autoconstrução e viabilizada pelo transporte público que aos poucos alcançava as áreas periféricas.

Nas décadas de 1970 e 1980, uma relevante produção intelectual crítica marxista e de inspiração na sociologia francesa ${ }^{70}$ refletiu sobre a realidade urbana brasileira das décadas imediatamente anteriores buscando avaliar como o subdesenvolvimento gerava uma condição peculiar de reprodução da força de trabalho, em oposição à que ocorria nos Estados de Bem-Estar Social, engendrando assim características próprias do nosso processo de urbanização. De modo geral, buscavam não reproduzir explicações dualistas, apesar de em alguns casos não conseguirem superar esse esquema de interpretação da realidade (ARANTES, 2009, p.104) ${ }^{71}$.

Os autores que enfocaram a produção do espaço urbano identificaram na relação entre loteamento irregular - autoconstrução - transporte coletivo uma importante característica da expansão periférica metropolitana ${ }^{72}$ que estava em curso e que, do ponto de vista da acumulação capitalista, levava ao rebaixamento do custo de reprodução do trabalhador, configurando a "urbanização com baixos salários".

Para Lúcio Kowarick (1979), tal processo sujeitava a classe trabalhadora a uma dupla dilapidação, pela exploração direta de seu trabalho na produção fabril e pela espoliação urbana no cotidiano, morando nas áreas mais precárias - como favelas, cortiços e loteamentos clandestinos distantes, gastando longo período no transporte. A espoliação urbana estava intimamente ligada à acumulação do capital e ao grau de pauperismo dela decorrente, ou seja, significava a expulsão dos pobres para a periferia, inviabilizando ao mesmo tempo o acesso dessa população ao consumo coletivo.

Em relação ao processo de produção da periferia até a década de 1980, Mautner (1999) o descreve como uma "sequência de três camadas, as duas primeiras consistindo em trabalho,

\footnotetext{
${ }^{70}$ Primeiro com Manuel Castells - a cidade é o espaço do consumo coletivo - e depois com seus críticos.

71 No texto "Em busca do Urbano", Pedro Arantes (2009) realiza uma revisão crítica dessa produção intelectual e identifica dois grupos a partir dos quais uma teoria da urbanização foi ensaiada. O primeiro, ligado ao Cebrap, era composto por Paul Singer, Francisco de Oliveira, Lucio Kowarick, Vinícius Caldeira Brant e Cândido Procópio de Camargo. O outro grupo, que tinha ligações com o primeiro, era composto por professores e pesquisadores da FAUUSP, cuja produção foi reunida no livro organizado por Erminia Maricato "A produção capitalista da casa e da cidade no Brasil industrial" (1982).

72 A primeira pesquisa-piloto "Habitação popular paulistana" realizada por Lemos e Sampaio (1964), objetivou conhecer tanto a origem e as condições de vida do trabalhador quanto caracterizar os processos e estratégias construtivas desenvolvidas para a autoconstrução de moradias em loteamentos da periferia. Entre 1970 e 1972 , fizeram outra pesquisa sobre o tema abrangendo dois campos distintos: tanto o interesse técnico-construtivo como o socioeconômico (LEMOS; SAMPAIO, 1993). Sérgio Ferro no texto "A casa popular" (1972) analisou a construção da casa a partir da teoria crítica marxista abordando seu processo de produção enquanto mercadoria, sua representação e fetiche. Maricato (1982), no texto "Arquitetura possível", e o documentário "Fim de semana", dirigido por Renato Tapajós (1975), retratam a autoconstrução da casa nos horários de folga do trabalhador. Bonduki e Rolnik (1982), na pesquisa realizada em Osasco, enfocaram o processo de formação de loteamentos nas áreas periféricas, percebendo a sua importância para a acumulação do capital e para a reprodução da força de trabalho na etapa recente de expansão do capitalismo no Brasil. Em pesquisa de caráter semelhante, a autora Chinelli (1981) trabalhou em loteamentos no Rio de Janeiro. Ver também VALADARES, (1981).
} 
cobrindo e preparando a terra para a terceira, o capital" (Mautner, 1999, p.256). Nesse processo o Estado não está presente a priori. Ao contrário, o Estado vê o crescimento periférico como um "fenômeno residual" do processo de industrialização e urbanização, sem jamais considerá-lo como parte do processo de produção de espaço, isentando-se assim de apresentar propostas de intervenção para incorporar a "cidade real" na "cidade legal". Já para a população, a percepção é que o Estado é uma instituição que "paira acima das relações sociais". Mesmo que seus benefícios sejam apropriados ou suas normas burladas, a referência é mantida (Ibidem, p.253).

Recuperando sucintamente a descrição dessa sucessão, tem-se na primeira a camada de trabalho, a terra transformada em propriedade, vendida na forma do loteamento irregular. As casas são construídas pelos moradores (conhecido também como autoconstrução, trabalho nãoremunerado), ao todo ou em partes, podendo contar com construção por encomenda. A segunda camada de trabalho, agora remunerada, corresponde à resposta do governo local às pressões dos moradores pela extensão da infraestrutura aos loteamentos. Para isso é desejável a "legalização" dessas áreas, sendo dificilmente possível o cumprimento da legislação urbana vigente e mais comum as anistias.

A extensão de infraestrutura na periferia abre o caminho para a entrada do capital - a terceira camada - em um processo que pode levar vários anos, dependendo da posição do bairro na estrutura urbana, para que essas áreas se transformem propriamente em "espaço urbano"73. Lotes retidos anteriormente são vendidos a preços mais altos, fazendo com que os moradores de menor renda se desloquem para áreas ainda mais distantes, gerando novas frentes de expansão ou então adensando áreas periféricas consolidadas. O aumento da mancha urbana não é um processo de ocupação contínuo, geralmente vem acompanhado da existência de vazios nas áreas mais valorizadas, ou seja, esse processo não significa um ótimo aproveitamento do território já infraestruturado.

Para Maricato (1982) a autoconstrução foi a única alternativa possível de sobrevivência do trabalhador na cidade, pois os baixos salários não cobriam o custo da habitação. A demanda habitacional também não foi suprida pelo Estado que ignorou essa classe enquanto investia em setores mais dinâmicos. Assim, os bens de consumo coletivo também foram autoconstruídos, na medida do possível e precariamente, se estendendo para o espaço urbano (Ibidem, p.79). Como expõe Oliveira (1982), a crítica da autoconstrução como mecanismo de rebaixamento do custo de reprodução da força de trabalho pode ser ampliado para a compreensão da autoconstrução de partes da cidade como rebaixamento dos custos de urbanização.

(...) partindo do ângulo da produção de um bem - a casa ou obras públicas, ou a igreja - que não é uma mercadoria mas que, por sua vez, serve como suporte da reprodução da mercadoria força de trabalho. Trata-se também, neste caso, como se dá a produção de uma riqueza social que não é valor, que não é capital, mas é posta a serviço do capital, na medida em que contribua para rebaixar seja o custo da reprodução da força de trabalho, no caso da residência, seja o custo da urbanização,

\footnotetext{
${ }^{73}$ Um elemento que influencia fortemente o direcionamento dessa expansão é a construção de estradas ou rodovias (pelo Estado) e as vias vicinais (pelo município).
} 
no caso de pequenas obras públicas feitas por moradores em seus bairros, em suas ruas (Ibidem, p.15).

A pesquisa de Bonduki e Rolnik em Osasco mostrou que dificilmente a infraestrutura é prolongada especificamente para atender um único novo bairro e que quando acontece abrange uma grande área de uma só vez. "E isto porque os investimentos feitos pelo poder público em bairros de população de baixa renda dependem muito mais de conjunturas políticas do que de um processo de planejamento" (BONDUKI; ROLNIK, 1982, p.124). Essa interpretação se diferenciava da que entendia que o processo especulativo de produção de periferia se dava com a infraestrutura alcançando pontos mais distantes, fazendo com que os vazios intermediários se valorizassem, e fossem vendidos a preços mais altos.

O processo de valorização fundiária, por sua vez, que se potencializa com a existência de infraestrutura, em loteamentos irregulares chega a independer da sua implantação, podendo ocorrer internamente devido somente às diferenças de melhores localizações dos lotes e aumenta conforme as outras casas são construídas.

Na década de 1970, a legislação do município de São Paulo relativa a loteamentos, a Lei no $7.805 / 1972$ (a chamada Lei de Zoneamento) exigia toda a implementação de infraestrutura e procedimentos complexos de licenciamento para aprovação prévia de loteamentos. No entanto, tais exigências não eram cumpridas. Diante do quadro de irregularidade, até o final da década de 1970, o poder municipal utilizou o instrumento de oficialização das vias, o que Ihe permitia tributar os imóveis aí localizados e os anistiar, pois ainda não havia política de regularização ${ }^{74}$.

A lei federal de parcelamento do solo no 6766/1979, além de estabelecer novas exigências e parâmetros urbanísticos e definir o parcelamento, desdobramento e desdobro de lotes; estabeleceu atribuições de responsabilidades ao loteador e ao poder público; e tornava o parcelamento irregular ou clandestino do solo crime contra a Administração Pública. Como consequência, de fato houve uma diminuição do ritmo de abertura de loteamentos irregulares (MARICATO, 1987; MAUTNER, 1991). Contudo, isso acarretou na restrição de oferta de lotes e, portanto, de moradias para a população de baixa renda. Maricato observa a correlação entre a diminuição de lotes ilegais no município de São Paulo e a explosão no crescimento de favelas durante a década de 1980. Grande parte das favelas que surgiram dos anos 1970 aos anos 1990, foram ocupações de áreas públicas frequentemente as doadas à prefeitura no processo de parcelamento formal do solo, situadas em áreas impróprias para a construção ou áreas de construção interdita pela legislação como as margens dos córregos e de maior declividade.

No município de São Paulo o crescimento da população favelada foi de $446 \%$, enquanto que a população total cresceu 44\%, de acordo com censo IBGE 1980 (podendo-se considerar esse número subestimado) (MARICATO, 1987, p.65). Mas essa mudança não se manteve na década

\footnotetext{
74 Após a Lei no 6.766/1979, foi organizado um serviço para regularização maciça no município de São Paulo, ligado diretamente ao gabinete do prefeito - Superintendência Estadual de Rios e Lagoas (Serla) -, objetivando o registro dos loteamentos e a concessão de títulos individuais aos compradores. A base para as exigências técnicas feitas ao loteador era dada pelo Decreto-Lei no 5.764 ou pela legislação municipal de 1981, segundo a data de abertura dos loteamentos (IPEA/CGPUR; FAUUSP; IE-NESUR/UNICAMP, 2002, p. 64 apud PASTERNAK, 2010).
} 
seguinte, como se verá na parte II, quando os loteamentos irregulares e clandestinos voltam a ser produzidos em grande quantidade, particularmente em área de proteção aos mananciais.

Favelas, loteamentos, cortiços, conjuntos habitacionais estatais, são partes integradas de um mesmo processo de produção do espaço. O não atendimento da grande maioria da população pobre via política estatal, como se verá, foi decorrência de uma concepção empresarial e financista da política habitacional adotada. Essa lógica também conduziu os investimentos em saneamento, que, como veremos, instituiu um modelo de gestão centralizada do setor.

A seguir, abordamos um período de reestruturação do setor de saneamento, para posteriormente tratar da política nacional de desenvolvimento urbano promovida pelo BNH, e seus efeitos contraditórios.

\subsection{A reorganização da gestão centralizada do saneamento nas escalas federal, estadual e metropolitana}

Desde meados da década de 1940, como já comentado, o saneamento se desvinculou do setor da saúde, devido a uma série de fatores que the imprimiram uma feição mais dinâmica, com desenho de novos modelos de gestão que questionavam a administração direta. Segundo Heller e Rezende (2008, p.219), entre as décadas de 1950 e 1960 houve a transição entre o modelo de gestão centralizado para os serviços de natureza autônoma e a implementação do conceito de sustentação tarifária, cuja prática contribuiu para adicionar recursos ao setor. Entretanto, as ações de saneamento associadas à viabilidade econômico-financeira comprometeram a expansão universal do atendimento e favoreceram o atendimento às áreas urbanas, sobretudo nas regiões de maior poder aquisitivo (Ibidem, p.221).

De acordo com esse novo modelo, em 1953, o governo lançou o primeiro Plano Nacional de Financiamento para Abastecimento de Água que, com forte influência dos organismos internacionais, promoveu a descentralização das ações pela União e estimulou a municipalização dos serviços por meio de autarquias e empresas de economia mista, através da adoção da nova lógica financeira do setor: a do retorno do capital investido (MONTENEGRO, 2006, p.36).

O estado de São Paulo, que passava pelo avanço da industrialização e urbanização, começa a se reorganizar. Em 1951 é criado o Departamento de Águas e Energia Elétrica, o DAEE, que tinha a incumbência, entre outras, de formular a política de utilização dos recursos hídricos no estado, planejar as funções de controle de cheias e de geração de energia. Em 1954, ligado à Secretaria da Viação e Obras Públicas, cria-se o Departamento de Águas e Esgotos de São Paulo, o DAE, sob a forma autárquica, que substitui a RAE. (SÃO PAULO, 1999, p.122).

O principal objetivo de constituir o DAE como autarquia era a autossustentabilidade financeira dos serviços de saneamento, através da cobrança de tarifas, e a sua desvinculação da dependência e recursos orçamentários (ANCONA, p.160). Instituía-se a política pautada no conceito do saneamento básico, tratado no item 2.3 anteriormente. 
A atuação do DAE foi fundamental para a ampliação do abastecimento de água na região do $A B C$ paulista, que na década de 1950 já contava como atividade principal a indústria, mas até então apresentava uma grande deficiência no abastecimento de água e no tratamento de esgotos. Segundo diagnóstico do DAE, feito pelo engenheiro-chefe do serviço de obras Walter E. de Oliveira $(1958)^{75}$, a situação sanitária do $A B C$ era uma "calamidade pública", tanto porque afetava a população, como a produção industrial. A população atendida por redes era muito reduzida, e o alto custo das obras necessárias tornava inviável sua realização pelos municípios. Nas áreas de habitação operária, a ausência de redes era suprida por água de poço, quase sempre contaminada pelas fossas negras existentes, construídas pelos próprios moradores. Por isso, havia alto grau de mortalidade infantil, decorrente de moléstias intestinais veiculadas pela água. Ao mesmo tempo, a falta d'água chegava a ameaçar a transferência ou instalação de indústrias que dela dependiam no processo produtivo.

Em 1944, o governo Federal autorizou a retirada da água da Represa Billings para o abastecimento de Santo André (decreto no 15.969 de 1944), derivando até o máximo de $2 \mathrm{~m}^{3} / \mathrm{s}$. Até 1946, os serviços de água eram responsabilidade exclusivamente municipal. Nesse ano, o decreto-lei no 15.739 de 8 de abril de 1946, regulamenta a avocação pelo Estado dos serviços de água e esgoto de Santo André (do qual fazia parte São Caetano) e São Bernardo do Campo.

O fornecimento oficial de água ao ABC pelo Estado teve início em 23 de dezembro de 1949, pelo engenheiro Plínio Penteado Whitaker, diretor-geral da RAE, autorizado pelo governador Ademar de Barros e pelo secretário da Secretaria da Viação e Obras Públicas Lucas Nogueira Garcez. O termo de acordo com os municípios de Santo André, São Caetano e São Bernardo do Campo, autorizou o governo do estado a ceder 5 milhões de I/dia da adutora rio Claro, por 18 meses. Em seguida, esse termo foi sendo renovado, com acordos suplementares, estendendo sucessivamente o prazo do fornecimento de água, até seu encerramento em 1958.

Em 1954, quando o DAE foi instituído como autarquia (pela lei no 2627) junto com ele foi criado o Serviço de Obras de Águas e Esgotos nos Municípios de Guarulhos, São Caetano do Sul, Santo André e São Bernardo do Campo. Nesse mesmo ano, foi entregue aos prefeitos o projeto do novo sistema de abastecimento de água do $A B C$, prevendo o aproveitamento de água da represa Billings, única alternativa de manancial capaz de ampliar o abastecimento na região.

Os municípios celebraram convênio com governo do Estado e DAE, e foi criada a Comissão de Obras Novas de Abastecimento de Água dos Municípios do ABC, encarregada de orientar e fiscalizar as obras do novo sistema, aproveitando $2 \mathrm{~m}^{3} / \mathrm{s}$ das águas da Billings, estabelecendo também os princípios básicos para cálculo de taxa de água e outras medidas ${ }^{76}$.

\footnotetext{
75 As informações abordadas nesse item foram extraídas do relatório publicado pelo engenheiro na Revista do Departamento de Águas e Esgotos, № 32, ano 19, dezembro de 1958, p.41-75.

76 Segundo Oliveira (1958, p.45), os princípios básicos do convênio foram: 1) a construção das obras de captação, adução e tratamento de água; 2) as obras depois de concluídas passam ao patrimônio do DAE; 3) o DAE ficará encarregado da manutenção, conservação e operação das obras executadas, entregando água tratada aos reservatórios municipais, mediante pagamento mensal baseado em uma taxa por metro cúbico de água, revista anualmente e calculada tendo em vista praticamente o preço de custo; 4) a distribuição da água a partir dos
} 
O déficit total de adução para os diversos usos era de 48 milhões de litros diários e a execução da primeira etapa viabilizava a adução de 50 milhões de litros diários. As obras foram projetadas para o consumo até 1975, sendo a execução dividida em etapas, conforme a capacidade financeira do DAE e das prefeituras em realizar a distribuição de água. Como se observa, a utilização da Billings para o abastecimento público do $A B C$ paulista não se inseriu num planejamento maior de adução de água, mas se apresentava como único manancial disponível.

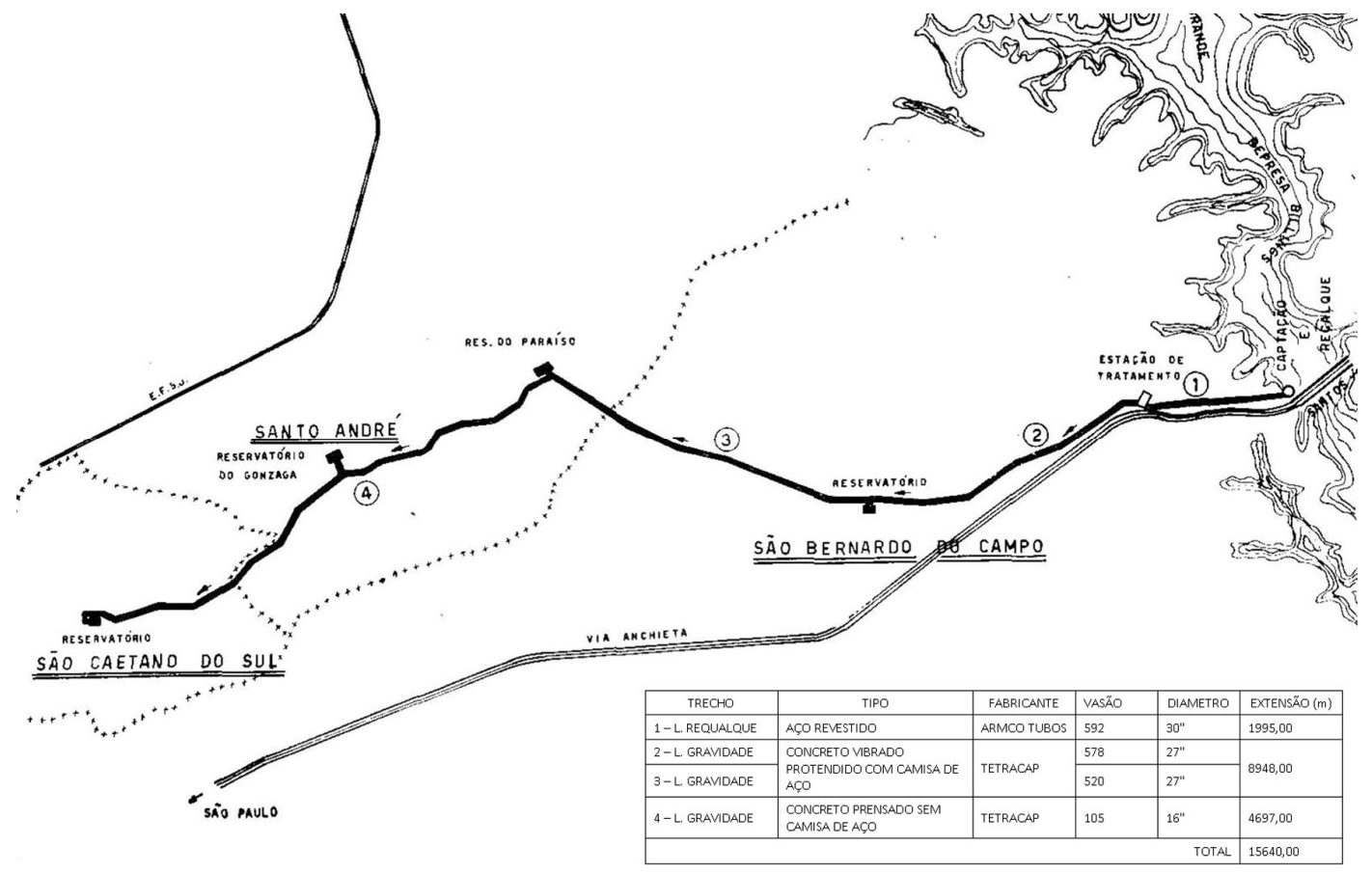

Figura 10 - Planta das linhas adutoras do abastecimento do ABC.

Fonte: Revista do Departamento de Águas e Esgotos, nํ32, 1958, p.56.

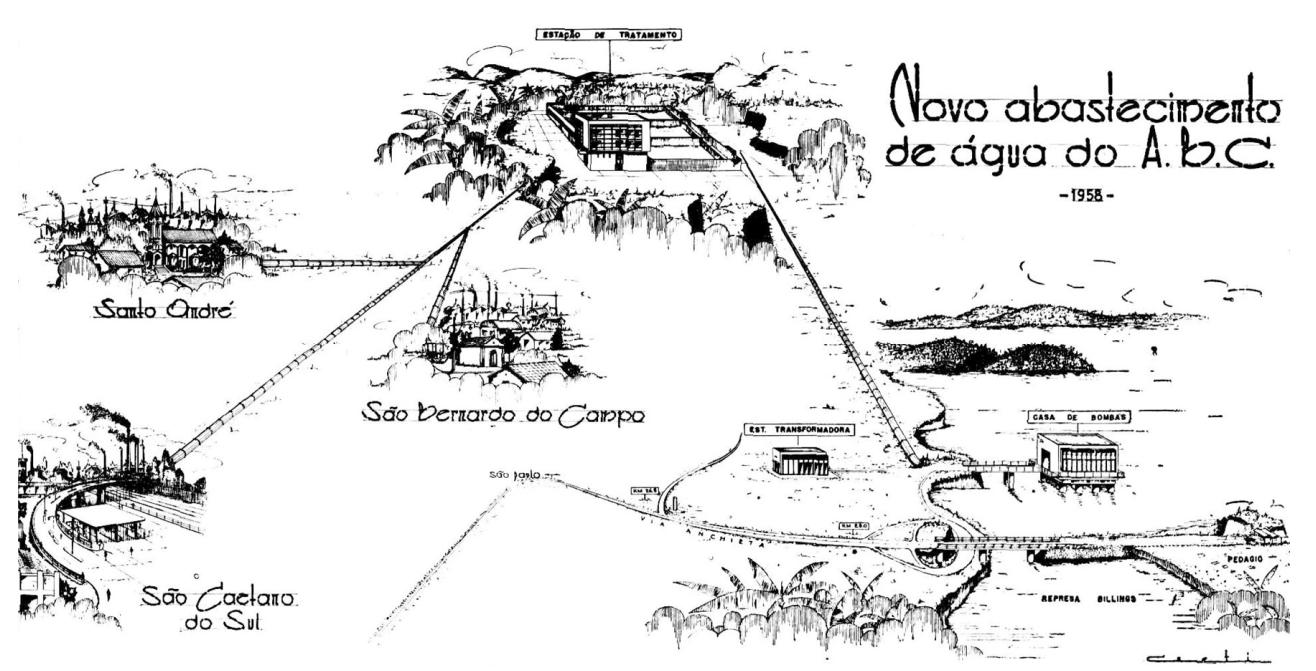

Figura 11 - Ilustração do esquema geral das instalações do sistema de abastecimento do ABC. Fonte: Revista do Departamento de Águas e Esgotos, no32, 1958, p.74.

reservatórios e inclusive estes ficará a cargo dos municípios; 5) os municípios inicialmente terão a seu crédito as importâncias empregadas na execução das obras, não havendo portanto nenhum pagamento até esgotar o crédito mencionado. 


\subsubsection{A esfera estadual da gestão e dos sistemas de saneamento básico}

Apesar da utilização da represa Billings ter sido uma obra estratégica para o abastecimento de água do $A B C$, pode-se dizer que o setor do saneamento não foi priorizado no período, desempenhando um papel secundário em termos de investimentos estatais, que estavam orientados à construção de rodovias e ao setor energético. Por isso, o DAE $\mathrm{D}^{77}$ teve fraca atuação, apesar de ter passado por uma fase de modernização administrativa e técnica (BUENO, 1994, p.110).

O abastecimento de água em São Paulo continuava sendo um problema relevante, e tornava-se mais complexo pois o crescimento em escala metropolitana demandava novos sistemas. Em 1958, frente aos crescentes problemas de água da capital e da região metropolitana, e pensando-se na proteção do Alto Tietê, foram elaborados estudos que apontavam a necessidade de limitar o estabelecimento de indústrias em sua bacia e proibir a implantação das mais poluentes (SÃO PAULO, 1999, p.123).

Desde 1962, frente às expectativas de crise no abastecimento, o DAE cria a Comissão Especial para o Planejamento de Obras de Abastecimento e Distribuição de águas da Capital (CEPA), que passou a estudar o aproveitamento das águas de outras bacias hidrográficas para além da região metropolitana, por meio do plano Hibrace. Como resultado, foi concebido o atual Sistema Cantareira $^{78}$, sendo também planejadas outras reversões, como a do rio Capivari-Monos para o reservatório Guarapiranga, situados na vertente da Serra do Mar; e ainda esboçadas as reversões do Alto Tietê e Juquiá (afluente da margem direita do rio Tietê, que com o barramento atingiria o sopé da Serra da Cantareira, passando pelo maciço montanhoso através de aquedutos e tuneis até atingir a represa do Guaraú) (BUENO, 1994, p.114).

Os estudos de captação das águas ainda puras do Alto Tietê, com a elaboração de projetos e obras, ficaram a cargo de grandes empresas nacionais como a Hidroservice, Promon e Cetenco. Iniciou-se a construção da barragem Ponte Nova e, na década de 1970, a da barragem de Taiçupeba sobre o rio Taiçupeba-Açu, próximo a Mogi das Cruzes. Essas duas barragens, já em funcionamento depois de 1976, objetivavam a regularização do rio Tietê, fazendo parte do que se denomina Sistema Alto Tietê. Em 1968 o DAEE desenvolve o Plano de Desenvolvimento Global dos Recursos Hídricos das bacias do Alto Tietê. Mas a utilização do potencial de água potável dessa bacia foi postergada pelo início das obras do Sistema Cantareira (SÃO PAULO, 1999, p.126). Tais obras, iniciadas pelo DAE, foram transferidas para a COMASP quando da sua criação em 1968.

Segundo Bueno, já na década de 1960 a população de Campinas e Piracicaba se contrapunha à implantação do sistema Cantareira, prevendo uma futura falta d'água na própria região, onde o

\footnotetext{
77 O DAE dependia financeiramente dos recursos do Tesouro Estadual, porque sua fonte de receita, a tarifa pela cobrança dos serviços, era frágil.

78 O sistema Cantareira passou a receber água da bacia do Piracicaba, levando-a, via sistema de recalque, para a Estação de Tratamento da Serra da Cantareira.
} 
aumento da demanda crescia, o que de fato aconteceu. Quando o saneamento passou a ser gerido pela Sabesp, as obras não só se aceleraram, como houve uma mudança de escala tanto das obras como das construtoras, agora nas mãos das grandes empresas de obras públicas (BUENO, 1994, p.129).

As obras do Sistema Cantareira ficaram prontas em 1981 e o Sistema Alto Tietê entraria em operação apenas em 1992 (SÃO PAULO, 1999, p.127).

Após o golpe de 1964, o Governo Federal procede a reformas institucionais que resultam no estabelecimento de empresas de economia mista ligadas a serviços de água e esgotos, com capacidade de captar recursos no exterior, as chamadas Companhias estaduais de saneamento CEBs $^{79}$. Segundo Heller e Rezende (2008), o BID também estimulou a formação de empresas de economia mista por meio de imposições contratuais de financiamento, exigindo a descrição das responsabilidades, autonomia administrativa, autoridade para impor tarifação, arrecadação e legislação por parte das contratantes. A concessão dos serviços à CEBs era condição para acessar os recursos do BNH. Os municípios contaram com financiamento do BID, via Banco Nacional de Habitação (HELLER; REZENDE, 2008, p.238). O BNH, como se verá adiante, operou uma transformação significativa na gestão do setor do saneamento.

O Programa Estratégico de Desenvolvimento, do Governo Costa e Silva (1967 a 1969), estabeleceu diretrizes para a criação de um fundo nacional para o saneamento, que originou o FISANE (Fundo Nacional para Saneamento), que em seguida passou a ser gerido pelo BNH.

No estado de São Paulo, as CEBs se constituíram a partir da FESB - Fomento Estadual de Saneamento Básico, criado em 1966 e transformado em autarquia no mesmo ano. A partir de então foram criadas várias companhias tais como: a COMASP - Companhia Metropolitana de Águas $^{80}$ (1968), a SANESP - Companhia Metropolitana de Saneamento de São Paulo ${ }^{81}$ (1970), a SAEC - Superintendência de Água e Esgotos da Capital de São Paulo ${ }^{82}$ (1970), além de outras no estado de São Paulo ${ }^{83}$. Em 1973, foi criada a SABESP, que incorporou a COMASP e a SANESP e absorveu o patrimônio das demais companhias do estado (HELLER; REZENDE, 2008, p.239-240), coroando assim, a centralização na esfera estadual o controle do setor do saneamento, que seria o modelo adotado pelo Planasa durante a vigência do BNH.

\footnotetext{
79 Depois de constituídas, as CEBs deveriam desempenhar as seguintes funções: obter junto aos municípios a concessão de serviços, estabelecida através de contrato, elaborar um programa de saneamento para o estado, elaborar planos anuais de investimento, que seriam submetidos a avaliação técnica e financeira do COSAN (BRITTO, 2006).

${ }^{80}$ Responsável pela captação, tratamento e fornecimento de água no atacado para os 38 municípios da RMSP.

${ }^{81}$ Responsável pela interceptação, tratamento e disposição final de esgotos dos 38 municípios da RMSP.

${ }^{82}$ Substituiu o DAE na operação dos serviços de água e esgoto.

${ }^{83}$ Tais como: SBS - Companhia de Saneamento da Baixada Santista (1970), e SANEVALE - Companhia Regional de Água e Esgotos do Vale do Ribeira (1972).
} 


\subsection{Saneamento e Habitação pós-golpe de 1964: a atuação do BNH}

Após o golpe de 1964, se estrutura pela primeira vez no país uma política de desenvolvimento urbano de âmbito nacional, com a criação do Banco Nacional de Habitação (BNH), do Sistema Financeiro de Habitação (SFH) ${ }^{84}$ e do Serviço Federal de Habitação e Urbanismo (SERFHAU), vinculados ao Ministério do Interior. O BNH era o órgão central, normativo e financiador do SFH e do Sistema Financeiro de Saneamento (SFS) ${ }^{85}$. Como parte desse sistema, os recursos do Fundo de Garantia do Tempo de Serviço (FGTS - poupança compulsória) e da caderneta de poupança ${ }^{86}$ se tornaram um dos dois principais instrumentos de financiamento para o crédito imobiliário e habitacional no Brasil (ROYER, 2009).

Muitos trabalhos acadêmicos detalharam a fundo os vários aspectos concernentes ao $\mathrm{BNH}^{87}$. $\mathrm{O}$ que cabe retomar, ainda que brevemente, é o modelo centralizado de gestão que a experiência do BNH e do Planasa consolidam, corroborando para a monopolização do setor do saneamento e a formação de um fundo público do setor; bem como os momentos em que o setor de desenvolvimento urbano e saneamento foram priorizados em relação à habitação, devido à lógica financista que prevalecia sobre o interesse social. Isso repercutiu nos resultados alcançados em termos de provisão habitacional e expansão das redes de água e esgotos.

Se por um lado os objetivos iniciais que criaram o BNH pautavam-se na proposta da erradicação de favelas e na construção de grandes conjuntos habitacionais nas periferias das cidades; por outro lado, havia interesses voltados ao fomento da construção civil e para implementação do modelo americano de crédito imobiliário. Essa posição financista, contudo, prevaleceu (ROYER, 2009, p.48). Além disso, a política de provisão habitacional propriamente dita estava plenamente voltada à difusão da casa própria, distinguindo dois mercados: o de renda baixa e o de renda média e alta; ambos regidos pela lógica empresarial privada de operação (ARRETCHE, 1990, p.25).

Do ponto de vista da política de habitação, O BNH se revelou um "verdadeiro fracasso" (MARICATO, 1987, p.38) ${ }^{88}$. Esse fracasso, do ponto de vista do próprio BNH, era financeiro, pois havia muita inadimplência. Mas diversas análises sobre a produção habitacional durante o BNH apontam como crítica do sistema o resultado limitado de provisão e o não atendimento justamente das faixas de renda que tinham mais dificuldade no acesso ao mercado formal de

\footnotetext{
${ }^{84}$ O BNH e o SFH foram criados pela lei federal № 4.380 de 21 de agosto de 1964.

${ }^{85}$ Foi também instituído o Financiamento do Saneamento (FINASA) com subprogramas voltados para implantação ou melhoria de sistemas de abastecimento de água, rede de esgotos ou drenagem e poluição hídrica. Em 1969 o BNH é autorizado a aplicar recursos do FGTS nos sistemas de água e esgotos.

${ }^{86}$ Em 1966 foi criado o Fundo de Garantia do Tempo de Serviço (FGTS), por meio da lei no 5.107 e, em 1968, houve a regulamentação da caderneta de poupança, por meio de Resolução do Conselho Diretor do BNH (ROYER, 2009, p.46).

87 Dentre eles: BOLAFFI (1977; 1982), MARICATO (1987), FARAH (1996), ROYER (2009).

88 Sobre a produção do BNH voltada ao saneamento e sobre o Planasa ver Maricato (1987), especialmente o Capítulo 5 - O sistema Financeiro da Habitação - SFH 1970/80 (p.33 a 58).
} 
habitação, ou seja, a camada mais pobre da população com renda de 0 a 3 salários-mínimos, o que questionava o próprio sistema de financiamento.

Do ponto de vista urbano e social, o fracasso tinha expressão quantitativa e qualitativa. A construção de conjuntos habitacionais afastados de bairros infraestruturados e com serviços, a má qualidade construtiva dos edifícios, os projetos "carimbo", sem variação tipológica e de implantação, a ausência de espaços livres e coletivos, promoviam um modelo urbano de habitação popular cuja qualidade urbana e ambiental eram, no geral, muito ruins. Ao não atender as faixas de mais baixa renda o BNH também não logrou atenuar o processo de favelização e de queda na qualidade habitacional nas cidades brasileiras.

No entanto, para as empresas construtoras, o sistema de crédito atingiu outros objetivos, como o fortalecimento da indústria da construção no setor habitacional e também na geração de emprego (este último, estratégia explícita do BNH) (MARICATO, 1987; MAUTNER, 1999).

Além disso, a partir da década de 1970, os investimentos em habitação diminuíram, ao passo que houve, entre 1971 e 1976, um aumento significativo da orientação dos investimentos do BNH para as obras de saneamento e desenvolvimento urbano, por meio do SFS (criado em 1968), em estados e municípios, e com a elaboração do Planasa (Plano Nacional de Saneamento), em 1971 (MARICATO, 1987, p.33).

O saneamento básico foi a porta pela qual o BNH começou a aplicar recursos no desenvolvimento urbano. A falta de infraestrutura nos conjuntos habitacionais foi outro motivo. Mas como salienta Maricato (1987), as boas intenções do BNH evidentemente não explicam totalmente sua estratégia. A diferença entre a priorização dos investimentos em desenvolvimento urbano correspondiam aos interesses da indústria da construção pesada, que além de oligopolizadas estavam em expansão no período; enquanto que o setor de construção de edificações nem sempre tinha interesses coincidentes, além de serem de menor porte (Ibidem, p.36). Havia também o interesse de empresas internacionais fornecedoras de equipamentos para transportes, energia, saneamento, entre outros.

O Planasa, criado em 1971, tinha como principais objetivos: aumentar cobertura dos serviços de abastecimento urbano de água e coleta de esgotos em curto espaço de tempo, instituir uma política tarifária com valores reais para o setor de saneamento e concentrar a pressão dos serviços à coordenação das Companhias Estaduais de Saneamento Básico (CESBs).

Nesse momento, a estratégia do BNH volta-se aos municípios e estados sendo que os municípios dependiam de financiamento do governo federal para realizar obras públicas. Essa situação reforçou a coação dos municípios à adesão ao Planasa e à política centralizadora, baseada na disseminação da empresa estadual, fortalecendo o caráter de mercadoria do serviço público ${ }^{89}$. No entanto, houve uma adesão paulatina dos municípios ao Planasa, frustrando a expectativa inicial de adesão maciça, o que garantiria a viabilização do fundo rotativo. Para os municípios, a

\footnotetext{
${ }^{89}$ Maricato (1987) complementa que apesar da mortalidade infantil ter decrescido, a eficácia do sistema centralizado deixou muito a desejar em termos de custo. As tarifas eram mais baixas quando se tratavam de empresas municipais.
} 
adesão ao Planasa representava a perda de autonomia municipal, evasão de renda quando os serviços entrassem em operação e a perda de prestígio (BUENO, 1994, p.136). Em 1979 em São Paulo, o acesso aos recursos do BNH ficava condicionado à concessão do serviço municipal à SABESP, e quase metade dos municípios do Estado já se vinculavam à empresa.

Esse modelo consolidou uma prática de planejamento das redes sanitárias pelo governo estadual, ou seja, fora da competência municipal, portanto desvinculada de outras redes e serviços urbanos. O resultado no ambiente construído e sobre os corpos d'água foi extremamente negativo, decorrente da fragmentação de infraestruturas que deveriam ser concebidas e executadas de forma inter-relacionada. Um exemplo da desconexão é a evidente desvinculação entre infraestruturas de abastecimento água, esgotos e sistemas de drenagem. Essa gestão autoritária do saneamento, segundo Britto (2006), recebeu poucas críticas por parte dos municípios, que ao mesmo tempo se desresponsabilizaram da gestão do abastecimento de água e esgotos.

Se por um lado a gestão das diferentes redes pode ser realizada por instâncias e níveis diferentes, como de fato ocorre, seu planejamento integrado principalmente a partir de atores locais, seria imprescindível. Essa possibilidade foi bloqueada pela lógica centralista e autoritária do período, pois dificilmente as companhias estaduais, que detinham mais poder, se submeteriam aos planos locais, o mais provável era que o inverso ocorresse (BRITTO, 2006).

Nesse período, foram realizados três tipos de empreendimentos: apoio aos conjuntos habitacionais (infraestrutura e equipamento complementar); obras urbanas propriamente desligadas de conjuntos habitacionais e até mesmo do uso residencial; obras de apoio a grandes projetos de abrangência inter-regional ou nacional.

O montante de investimentos representou grande crescimento dos índices de abastecimento de água e, em menor grau, da coleta de esgotos do país. Entre 1970 e 1980, o número de pessoas beneficiadas com o abastecimento de água passou de 11,9 milhões para 49,6 milhões. Já o esgotamento sanitário foi menos expressivo: passou de 6,1 milhões para 17,4 milhões de pessoas atendidas (FARIA, S.; FARIA, R., 2004).

Apesar dos benefícios incontestáveis da ampliação do abastecimento de água, outra face dessa política contribuiu para a ampliação do quadro de desigualdades sociais no país. Segundo Heller e Resende, quando se propôs a sanear as zonas urbanas, segundo a lógica da autossustentação tarifária, e nestas, preferencialmente as áreas onde o retorno dos investimentos mostrara-se garantido, o Planasa excluiu grande parte da população carente das ações implementadas (HELLER; REZENDE, 2008). Outra consequência foi a distribuição desigual do atendimento, priorizando a região sul e sudeste, além de não atingir também as periferias urbanas.

O acelerado crescimento urbano e populacional na década de 1970 deve ser também considerado, pois aumentou significativamente a demanda por água. Esse segmento foi priorizado, inclusive devido a seu impacto na saúde pública da população. Já a meta estabelecida para a coleta e tratamento de esgoto ficou longe de ser alcançada. A disposição final de resíduos sólidos e a execução de obras de drenagem urbana, visando controle de cheias e de vetores 
continuaram a ser desenvolvidos pelos municípios e em alguns casos pela União, na maioria das vezes de forma desarticulada das ações das CESBs. Outra deficiência foi a não integração da política de saneamento com outras políticas públicas, o que determinou um atendimento no qual os princípios da integralidade, equidade e universalidade não foram satisfeitos, caracterizando quadro de desigualdades socioambientais.

\subsection{Os planos de abastecimento de água pós-1970: notas sobre o Sistema Adutor Metropolitano em São Paulo}

Voltamos novamente o foco para a situação dos planos de redes em São Paulo. Cabe ressaltar que a partir de meados de 1970, os planos de abastecimento de água começam a ser elaborados tendo como base territorial a região metropolitana. Em relação ao abastecimento de água, foi concebido o Sistema Adutor Metropolitano (SAM), revisado em edições de planos posteriores em função dos novos volumes de água produzidos que deveriam distribuir (SAM-30 de 1973, SAM-53 de 1982, SAM-75 de 1995, SAM-100).

A concepção de um sistema metropolitano se baseou num esquema de áreas de influência dos mananciais, regionalizados, e interligações de adução apenas quando necessárias; e também previu intervenções pontuais sobre a rede existente, resolvendo problemas e viabilizando ampliações. Assim, segundo Moreira (2008), o desenho da rede começava a se desenvolver de forma mais enxuta e organizava-se por setores, se diferenciando da proposta, elaborada pela COMASP no ano anterior, de fornecimento de água em massa por meio dos anéis de adução.

A autora identifica, a partir da leitura desses planos, uma passagem gradual entre uma postura mais intervencionista no território para a construção do sistema de abastecimento - como as obras do SAM-30 (1973), particularmente os reservatórios (nós do sistema adutor metropolitano), que despontavam na paisagem e teriam potencial de integração com espaços públicos - para uma presença menos intervencionista em termos espaciais, como o SAM-53 (1982). Nesse plano, já sob controle da Sabesp, a ampliação da rede se dará, sobretudo, através da implantação de equipamentos de aumento da pressão de água na rede - os boosters. A rede de abastecimento de água vai se tornando mais dispersa, compartimentada e pontual (MOREIRA, 2008, p.130).

Já na década de 1990, com crise de água e rodízios, o SAM-75 volta o enfoque para controles operacionais e o diagnóstico dos problemas de rede foi se tornando mais detalhado e aprofundado. Dessa forma, o controle das perdas de água passou a assumir maior importância.

Entretanto, a rede não se estendeu de forma homogênea no território, e as áreas de assentamentos precários não se integravam a ela. Como se verá adiante, a Sabesp passará a intervir em favelas, com momentos de descontinuidade, somente no final da década de 1970. 


\subsubsection{A Lei Estadual de Proteção aos Mananciais}

Ainda no contexto da década de 1970, mais um elemento importante que compõe o quadro das ações relativas à água no espaço metropolitano foi a promulgação da Lei Estadual de Proteção aos Mananciais, elaborada como parte do Plano Metropolitano do Desenvolvimento Integrado PMDI.

No que se refere ao planejamento no âmbito estadual, em 1970 foi criado o Grupo Executivo da Grande São Paulo - Gegran, com o objetivo de planejar o desenvolvimento metropolitano e coordenar ações governamentais nessa escala de abrangência. No mesmo ano foi contratado um consórcio de empresas (consultores nacionais), com equipe multidisciplinar, para o desenvolvimento de Plano Metropolitano do Desenvolvimento Integrado - PMDI. Esse Plano não foi formalmente aprovado, mas passou a ser uma referência para a definição de políticas da RMSP e, em especial, para a contratação de financiamentos, projetos e obras (ANCONA, 2002, p.177).

Em 1974, foi criada a Emplasa - Empresa Paulista de Planejamento Metropolitano, que assumiu as funções de órgão técnico do Sistema de Planejamento e incorporou o patrimônio do Gegran; e em 1975 foi criada a Secretaria de Estado de Negócios Metropolitanos, subordinada à primeira. Essas instituições tinham como atribuição implementar as diretrizes do I PND e II PND. No que tange as questões ambientais, e de acordo com as diretrizes dos planos nacionais, a tônica era o controle de poluição ${ }^{90}$ dos recursos hídricos. Isso implicava em desconcentrar a atividade industrial de São Paulo, orientando-a para outras regiões.

Nesse contexto, foi elaborado o zoneamento industrial metropolitano ${ }^{91}$ (Lei Estadual $\mathrm{n}$ 으 1.817/1978) e foi elaborada e promulgada a Lei Estadual de Proteção aos Mananciais - LPM (Leis Estaduais no 898/1975 e 1.172/1976; e Decreto Estadual no 9714/1977), que definiu as bacias hidrográficas de proteção para a produção de água e controle do uso do solo por meio de parâmetros urbanísticos e de densidade, incidindo sobre oito municípios total ou parcialmente. As implicações dessa lei no território da Bacia da Billings serão abordadas em maior detalhe ao longo dessa tese. Por ora, cabe ressaltar que seu caráter preservacionista ${ }^{92}$ não condizia com o ritmo de expansão metropolitana em curso, pois já no período anterior à lei apresentavam-se grandes taxas de crescimento da área urbanizada.

Em meio a uma febre industrial desenvolvimentista, a LPM criou limites absolutos para o crescimento demográfico em 50\% da RMSP e representou um "congelamento" de diversos municípios, para garantir a qualidade e quantidade de água para abastecimento, no entanto,

\footnotetext{
90 Seguindo a diretriz de que o controle da poluição industrial deveria ser exercido também no nível estadual, em 1975, é criada a Cetesb - Companhia de Tecnologia de Saneamento Básico e de Defesa do Meio Ambiente do Estado de São Paulo - visando o controle de poluição no ambiente.

${ }^{91}$ Os municípios polemizaram com a lei, pelo seu caráter intervencionista no território municipal.

92 Ainda segundo Ancona, a LPM refletia o discurso do ambientalismo mais radical internacional, "importado" sem filtro crítico pelos urbanistas e tecnocratas paulistas, o que evidenciava sua suscetibilidade a ideologias externas e consideradas de vanguarda (ANCONA, 2002, p.179).
} 
sem considerar os sistemas de tratamento de esgotos. Segundo Ancona (2002, p.178), havia uma divergência de posições quanto à destinação da região sul da RMSP:

Enquanto o PUB [Plano Urbanístico Básico], na esteira do pensamento de Prestes Maia, não continha restrições à expansão urbana em todas as direções e chegava a recomendar a instalação de um novo polo industrial no bairro de Parelheiros, localizado na Bacia do Reservatório Guarapiranga, o PMDI [Plano Metropolitano de Desenvolvimento Integrado] recomendava o controle da expansão do vetor norte-sul e o crescimento preferencial na direção leste-oeste, visando preservar os mananciais de água.

O que se verificou anos depois é que o controle da expansão de indústrias nas áreas protegidas foi mais efetivo do que a expansão de moradias irregulares, sem deixar de considerar também que as indústrias buscaram novas localizações em outras áreas do estado, num quadro de reorganização da atividade industrial nas décadas seguintes.

\subsection{Os planos tardios de esgotamento sanitário}

Se em relação às grandes obras do período o saneamento foi preterido pela ampliação do sistema energético e pela construção de rodovias, no que tange ao próprio setor do saneamento, o tratamento de esgotos historicamente recebeu menos atenção, investimentos e planos se comparado ao abastecimento de água. Isso pode ser aferido pela sequência de planos de esgotos não implementados ou implementados parcialmente desde a década de 1950 (OSEKI, 1991). De qualquer forma, cabe destacar que o tratamento de esgotos somente receberá maiores investimentos em meados dos anos 1970, mas permanece como um problema até hoje, quando ainda se reproduz o modelo adotado a partir do Sanegran (1976).

As primeiras tentativas de tratamento pela Repartição de Águas e Esgotos, em meados dos anos 1940, foi a montagem de uma estação experimental de pequeno porte - Ponte Pequena e a construção da estação experimental no bairro do Ipiranga, onde se estudaram diversos tipos de tratamento.

Após o plano geral de esgotos elaborado por Whitaker (1942), cuja execução ficou comprometida com a Segunda Guerra Mundial, duas estações experimentais de tratamento de esgotos em pequena escala foram construídas.

Em 1946, foram publicados os resultados de um estudo ${ }^{93}$ sobre a situação de poluição do rio Tietê, que recebia o volume de 3,3 $\mathrm{m}^{3}$ de esgotos por segundo, em regime seco, o que correspondia a uma população de 750.000 habitantes, ou seja, 50\% da população da cidade (NETTO, 1946, p.100). Como o rio Tietê era de baixa vazão, os esgotos não se diluíam e a poluição era bastante concentrada. Como resultado, identificaram-se, no curso do rio a jusante da cidade: I) uma zona de degradação, dentro do perímetro da cidade ao longo de $17 \mathrm{~km}$

\footnotetext{
93 O estudo coletou amostras em 9 pontos no curso do rio Tietê, a jusante da cidade, para verificar as depressões de oxigênio dissolvido. O oxigênio dissolvido resulta da decomposição dos esgotos e provoca a desoxigenação de suas águas, comprometendo também a vida aquática. Também verificaram temperatura, presença de germes e bactérias, e a presença de poluentes químicos lançados pelas indústrias. (NETTO, 1946).
} 
extensão), II) uma zona ativa de decomposição, situada a jusante do ponto de descarga dos esgotos em $47 \mathrm{~km}$ de extensão, III) zona de recuperação, caracterizada pela progressiva ascendência da curva do oxigênio dissolvido, um trecho de $15 \mathrm{~km}$. Essas zonas foram representadas no seguinte esquema:

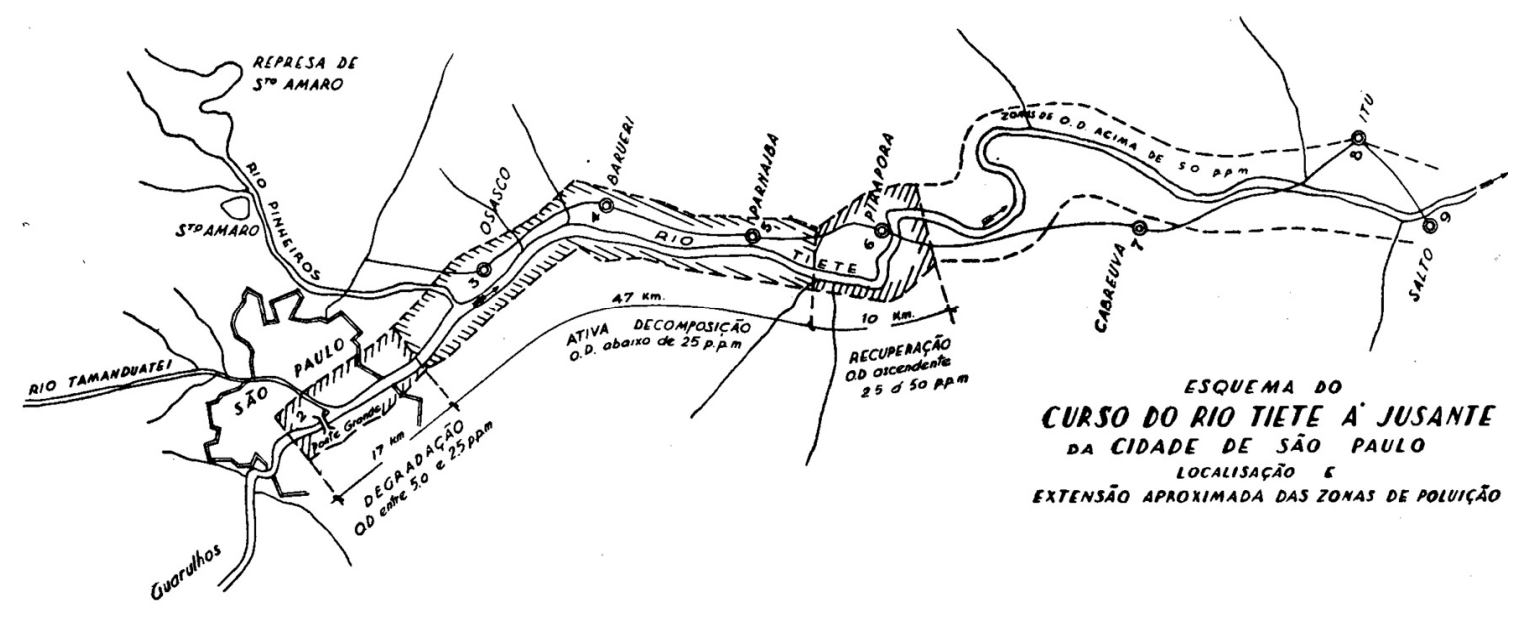

Figura 12 - Esquema do curso do rio Tietê e zonas de poluição, 1946.

Fonte: Boletim da Repartição de Águas e Esgotos, nำ17, 1946, p. 102.

Em relação aos padrões bacteriológicos, o estudo afirmava que o rio Tietê, $92 \mathrm{~km}$ abaixo das descargas dos esgotos, não possuía as qualidades exigidas para as águas potáveis. Portanto, o tratamento dos esgotos era algo que deveria ser implementado e, segundo o engenheiro autor do estudo, a variedade de tipos de tratamento para diferentes graus de desinfecção, era algo que deveria ser objeto de experimentações, para que se chegasse ao tratamento adequado.

Nesse sentido foi construída a estação experimental da Ponte Pequena ${ }^{94}$, que ensaiava o tratamento de esgotos desse rio, numa pequena escala. E a partir dessa experiência foi projetada e construída a estação experimental do Ipiranga, para atender 34.000 habitantes do distrito do bairro do Ipiranga, com rede de esgotos separadora, lançando os efluentes tratados no rio Tamanduateí. Essas foram as duas experiências concretas de tratamento de esgotos em São Paulo, nos anos 1940, e destaca-se seu caráter experimental, a busca de diversas formas de tratamento, e a utilização do gás resultante do tratamento de esgotos na produção de energia para a própria estação.

Em 1953, o Departamento de Águas e Esgotos (DAE) contratou uma empresa americana chamada Greeley \& Hansen, de Chicago, que elaborou um projeto inspirado no Tennessee Valley Authority, experiência americana de uso múltiplo de recursos hídricos. Havia uma preocupação especial em relação ao lançamento de resíduos industriais. E estudo resultou num plano geral para a grande São Paulo, com a indicação de três alternativas possíveis ${ }^{95}$, e no projeto da Estação de Tratamento de esgotos de Vila Leopoldina. O projeto Greeley Hansen, foi

\footnotetext{
94 Nesta estação da Ponte Pequena a RAE coletou as primeiras informações sobre os esgotos mistos e ensaiou a utilização do gás dos esgotos para geração de energia elétrica, por meio de motor de combustão interna, utilizado pela primeira vez nessa estação.

95 A descrição detalhada do projeto pode ser vista em Meiches (1954).
} 
parcialmente implantado. O projeto selecionado previa estações de tratamento de esgoto em pontos estratégicos da cidade (6 pontos) distribuídas nas várzeas dos rios Pinheiros e Tietê, com a utilização de filtros biológicos. Só foi construída a estação Vila Leopoldina e iniciada a estação em Pinheiros (OSEKI, 1991; BUENO, 1994).

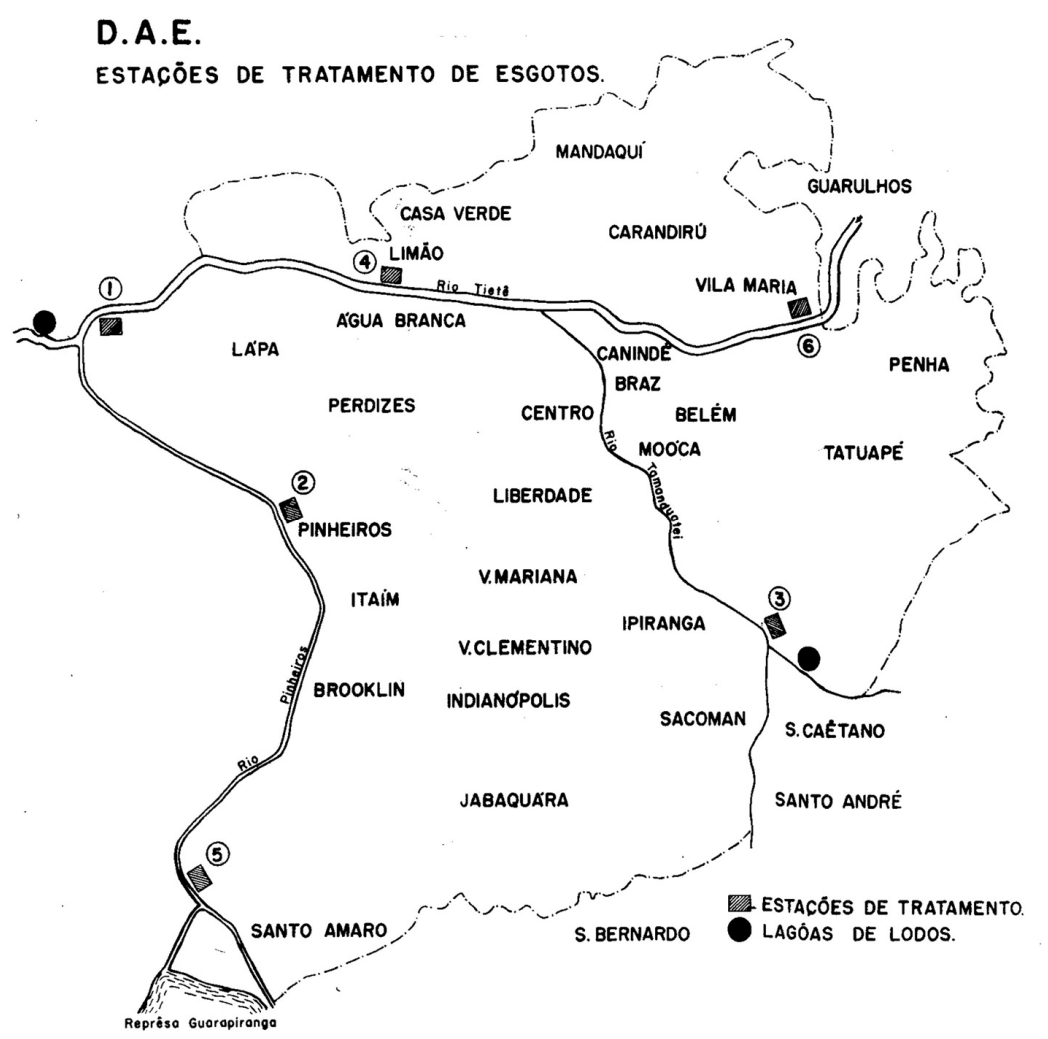

Figura 13 - Estações de tratamento de esgotos DAE.

Fonte: Boletim do Departamento de Águas e Esgotos, nำ25, 1954.

Em 1953, tentou-se ampliar o projeto Hazen Sawyer executado também por uma firma americana que transformava as estações de tratamento em estações elevatórias que bombeariam os esgotos brutos até a Billings onde seriam decantados numa lagoa de estabilização (no Guacuri). O projeto não foi executado (OSEKI, 1991, p.38). Em 1964-67 foi elaborado o projeto Hibrace ${ }^{96}$, que retoma o bombeamento previsto no projeto anterior, ou seja, o esgoto bruto seria tratado na Billings cujos braços seriam transformados em lagoas de estabilização, o corpo central permanecendo sujo, pois recebia esgotos brutos do Tietê. Era ainda o primado energético de gerar energia em Cubatão (BUENO, 1994, p.121).

Em 1970 é formulada a Solução Integrada (projeto da equipe na qual Rodolfo Costa e Silva participa) que propõe a reversão do rio Pinheiros (ao curso normal), drenagem dos esgotos por gravidade, ao longo dos rios Tietê e Pinheiros, e depois, por túnel, a partir da estação de Vila Leopoldina, sob a Cantareira, até a represa de Pirapora onde seriam tratados (por estabilização anaeróbica), para depois serem despejados no Tietê. Assim, era contrária ao bombeamento dos esgotos sem tratamento em direção à Billings.

\footnotetext{
96 O Plano HIBRACE foi desenvolvido por um consórcio de três empresas nacionais, a Hidroservice, Brasconsult e CESA, contratadas pelo DAEE. Tais empresas participaram ativamente dos grandes planos e projetos de saneamento em São Paulo (BUENO, 1994, p.121).
} 
Quando esta solução estava sendo implantada, surge o Plano Diretor Sanegran - Saneamento da Grande São Paulo, aprovado em 1976, já no contexto do Planasa. Conhecido como Projeto Sanegran, desenvolvido pela Hidroservice, visava ampliar os investimentos no tratamento de esgotos, dado o descompasso em relação aos investimentos em abastecimento de água, uma situação que vinha se repetindo há muitos anos. Em 1975, a Região Metropolitana de São Paulo tinha a população urbana de 9.454 .486 habitantes, sendo $67 \%$ desta atendida por água tratada e $36 \%$ atendida por redes de esgotos. A população atendida por tratamento primário de esgotos era de $4,7 \%$. O plano tinha como prazo final o ano 2000 e sua meta era chegar ao atendimento de $88 \%$ da população (cerca de 21 milhões de habitantes) com coleta e tratamento de esgotos (GRUPO..., 1982).

A concepção original do Plano Greeley \& Hansen foi abandonada em definitivo e abriu-se mão da implantação de tratamento secundário nas ETEs Pinheiros e Vila Leopoldina, em função da não disponibilidade de áreas para a ampliação das respectivas unidades, consequência da intensa urbanização registrada no em torno das mesmas (SABESP, 2010).

O Projeto Sanegran previa a construção de três estações de tratamento de esgotos: na cota do Tietê em Barueri, em São Caetano no $A B C^{97}$, e em Suzano (cuja localização seguia a proposta da Solução Integrada) ${ }^{98}$, esta última foi a primeira unidade a entrar em operação, em 1982. O Projeto manteve o complexo Billings-Cubatão, apesar da nacionalização da Light (pela Eletropaulo) e da pouca importância deste sistema na época para a geração da energia elétrica na grande São Paulo.

Inúmeras críticas de técnicos renomados, imprensa e população, recaíram sobre o Sanegran devido ao seu gigantismo e alto custo. No entanto, o plano teve prosseguimento, ainda que as obras tenham sido implementadas lentamente, por motivos econômico-financeiro e técnico como justifica a Sabesp. Os projetos de coletores-tronco e redes coletoras foram contratados em parte pelos meios convencionais da Sabesp. Quanto às obras, foram executadas por pequenas e médias empreiteiras, contratadas diretamente pela Sabesp, sem interferência do gerenciamento privado (BUENO, 1994, p.177).

A construção de um sistema de esgotos baseado em estações elevatórias, coletores-tronco e grandes estações de tratamento consolidou um modelo que se mantém até hoje. Os esgotos "são tratados da forma mais natural possível - só que com sacrifício da metrópole" paulista (OSEKI, 1991, p.38); pois para que eles alcancem tais estações, o percurso é longo e depende da realização de obras complexas, pois são executadas no tecido urbano consolidado. Porém, nem todo esgoto coletado é tratado, voltando a contaminar os mesmos corpos d'água com os lançamentos diretos de efluentes provenientes das áreas não servidas por redes, mantendo assim uma espécie de ciclo da poluição da água.

\footnotetext{
97 A estação do ABC seguia a diretriz proposta pelos projetos HIBRACE e Hanzen \& Sawyer, de concentração de esgotos da região sudeste da metrópole uma estação de grandes dimensões em São Caetano. (BUENO, 1994, p.169)

98 Os recursos que viabilizaram a construção da ETE eram do BNH, do Banco Mundial e do Governo do Estado de São Paulo, totalizando Cr\$ 7.483 bilhões (GRUPO..., 1982, p.49).
} 
De fato há dificuldades técnicas e financeiras para a execução de um sistema como esse, que depende de planejamento, disponibilidade de recursos, negociação com prefeituras, proprietários de imóveis e população que mora em locais onde se prevê a passagem de redes. Quando construídas, decorrem as dificuldades de ligação de redes domiciliares à rede local, particularmente quando se trata de famílias de baixa renda que passam a pagar tarifas quando conectadas às redes. Mas isso explica somente parte do atraso acumulado no tratamento de esgotos, que por se configurar como solução única e centralizada, depende de planos de longo prazo que estão historicamente aquém da velocidade de reprodução do espaço urbano. Não se trata somente de uma opção técnica, mas também de uma estratégia de investimentos da empresa. O argumento que sustenta essa opção, além da realização de grandes obras com grandes empreiteiras que prestam serviço nesse setor, é a relação custo-benefício defendida pela Sabesp, que opta por realizar investimento de porte para otimizar as estruturas existentes $^{99}$.

Sendo assim, há pouca articulação da ação de saneamento com a política de desenvolvimento urbano e o plano de esgotamento sanitário segue como se pudesse ser independente das dinâmicas que conformam os espaços e o ambiente urbano.

Para além do impacto ambiental na metrópole, o que queremos por enquanto pontuar, é que a adoção desse modelo teve (e tem) implicações importantes no que se refere ao saneamento da bacia do Alto Tietê e em particular da bacia da Billings.

Primeiro é preciso esclarecer que em relação aos sistemas públicos de infraestrutura de água e esgoto, a Lei Estadual de Proteção aos Mananciais - LPM (no 898/1975 e no 1.172/1976) não proibiu totalmente sua instalação. Ao contrário, permitiu a implantação nas áreas mais distantes do corpo d'água da represa (classes A e B) ${ }^{100}$ e restringiu nas demais, onde aceitava alternativas, exceto em área de primeira categoria (nas quais deveriam ser instaladas fossas sépticas, seguindo a norma vigente). A diretriz para os efluentes dos sistemas públicos é que eles deveriam ser afastados da área de proteção ${ }^{101}$. Isto porque a lei considerou apenas a capacidade de autodepuração dos reservatórios sem incorporar os sistemas de tratamento de efluentes

\footnotetext{
99 Essa estratégia está presente atualmente, conforme defendem os técnicos da Sabesp, de acordo com as entrevistas realizadas pela autora.

100 Trata-se do artigo 22 da Lei de Proteção aos Mananciais no 1.172/1976. Artigo 24 - Os sistemas particulares de esgotos não ligados ao sistema público deverão ser providos, pelo menos, de fossas sépticas, construídas segundo normas técnicas em vigor, com seus efluentes infiltrados no terreno através de poços absorventes ou irrigação subsuperficial, assegurando-se a proteção do lençol freático.

${ }^{101}$ Conforme artigo 23 da mesma lei, os efluentes dos sistemas públicos de esgotos sanitários deverão ser afastados das áreas de proteção: 1) Quando na bacia receptora não houver sistema de esgotos adequado, os efluentes deverão ser previamente tratados, de acordo com as exigências da Cetesb; 2) Nos casos em que o afastamento e o tratamento forem inviáveis, somente será permitida a disposição de efluentes de sistemas públicos de esgotos nas áreas de 2 a categoria e desde que recebam o tratamento mais conveniente (1. tratamento biológico e desinfecção do efluente; 2. tratamento a nível primário, no mínimo, seguido de infiltração ou irrigação subsuperficial, assegurada a proteção do lençol freático); 3) A Cetesb poderá estabelecer limites à concentração de nutrientes nos efluentes, nos casos em que o manancial manifeste tendências à eutrofização acelerada; 4) Na eventualidade de o órgão responsável deixar de atender ao disposto neste artigo, poderá o Estado assumir os sistemas de saneamento básico para adequá-los às normas desta lei.
} 
(ANCONA, 2002, p.179). Ou seja, todo o esgoto deveria ser exportado e tratado fora das bacias protegidas. Portanto, em termos de concepção do sistema de esgotamento, a LPM era compatível com a diretriz do Sanegran. Mas o próprio modelo do Sanegran, baseado em grandes obras de coletores e grandes estações não se completou, tornou o reservatório Billings o receptor desses esgotos.

A ETE ABC que atende os municípios inseridos na bacia da Billings, projetada no Plano Sanegran, somente começou a operar em 5 de Junho de $1998^{102}$, ou seja, antes dessa data não havia alternativa de tratamento de esgotos para Diadema, São Bernardo do Campo, Santo André, Ribeirão Pires e Rio Grande da Serra, São Caetano do Sul e parte de São Paulo, hoje atendidos por essa estação. Além da ausência da estação de tratamento até essa data, não houve a elaboração de estudos alternativos que pudessem melhorar a qualidade ambiental da bacia, que após os anos de 1980 apresentava uma ocupação acelerada. Tampouco houve convergência entre a política de saneamento com as demais políticas setoriais urbanas, especialmente de habitação e meio ambiente, apesar da legislação de proteção aos mananciais.

Essa situação acarretou em graves índices de poluição da represa, durante os anos 1980, como se verá na parte III dessa tese. Os municípios de Diadema e Santo André, que têm empresas municipais de saneamento, passam a seguir a diretriz de exportar o esgoto da bacia a partir dos anos 2000, quando passam a ter mais recursos para execução de obras.

Considerando o período abordado nesse capítulo, de 1930 a 1980, cabe destacar as principais mudanças no setor do saneamento e sua interface com o espaço da moradia, tanto como elemento de constituição de espaço metropolitano como do ponto de vista da política pública, em dois grandes momentos, de 1930 a 1949 e 1950 a 1980.

A partir de 1930, o Estado brasileiro passa a regular fatores de produção da economia e a intervir em setores que anteriormente delegava à iniciativa privada, visando a industrialização, em um processo que combinou modernização e atraso, crescimento econômico e desigualdade social. O problema habitacional que começou a ser tratado como questão de Estado, articulado às necessidades de desenvolvimento econômico e industrial do país, entretanto, sem se generalizar como solução promovendo o acesso à moradia pela população de baixa renda. Houve uma tímida produção de unidades (com os IAPs) e o preço dos aluguéis foram controlados (com a Lei do Inquilinato), ao mesmo tempo em que cresceram os loteamentos na periferia, que passaram a exigir a extensão de infraestruturas.

O setor do saneamento, que já era atribuição do Estado, passou por uma reformulação institucional com a criação, por orientação do governo federal, de órgãos e entidades municipais em todo o país, para que recebessem recursos a fundo perdido e empréstimos internacionais para a realização de obras de saneamento. O saneamento se dissocia da saúde, e o sanitarismo

102 Conforme Sabesp, informação disponível em http://site.sabesp.com.br/site/interna/Default.aspx? secaold=55, acesso em: 13/12/2012. 
deixa de ser a tônica das intervenções urbanas. A noção de saneamento básico é construída, pautada pela engenharia de obras de água e esgoto, e por uma visão empresarial do serviço público.

O município de São Paulo formula, em 1942, sob coordenação de Plínio Whitaker, um Plano Geral de abastecimento de água e esgotos que visava planejar a ação do poder público, até então predominantemente reativa às situações de emergência. O Plano não foi executado devido a eclosão da Segunda Guerra Mundial. Ao mesmo tempo, o Projeto Serra é implementado, e os interesses do setor energético prevaleceram sobre o saneamento.

No período de 1950 a 1980, o aumento do crescimento urbano e da industrialização acelera o processo de urbanização desigual, resultando no aumento significativo de assentamentos precários autoconstruídos em escala metropolitana. Após o golpe de estado de 1964, a instituição do BNH altera o quadro dos financiamentos habitacionais, ainda sem atender as faixas de mais baixa renda. Mas a partir de 1971, os financiamentos em saneamento superam os habitacionais, e o Planasa estrutura o desenho centralizado de gestão por meio de companhias mistas estaduais. Apesar do impacto dos investimentos terem significado um aumento do atendimento de água, em menor grau de coleta de esgotos em todo o país, os serviços de saneamento continuaram não atendendo a população pobre. A sua principal herança foi, portanto, a centralização da gestão dos serviços de saneamento.

Além disso, o projeto Sanegran, concebido durante a vigência do Planasa, definiu o sistema de coleta e tratamento de esgotos baseado em grandes estações de tratamento, que dependem de investimento de monta, e intervenções de longo prazo. A primazia desse modelo não equacionou os impactos da poluição dos corpos d'água metropolitanos, que continuaram alcançando a represa Billings, até a paralisação do bombeamento dos rios Pinheiros e Tietê, na década de 1980.

Ao mesmo tempo, a distribuição desigual das redes manteve as favelas e loteamentos populares, que apresentaram altas taxas de crescimento nos anos 1970, à sua margem, sendo que as primeiras intervenções nesse sentido foram realizadas em São Paulo na década de 1980, como se verá no capítulo a seguir.

Nesse contexto, evidencia-se que o tratamento tecnicista do saneamento construído desde os anos 1950 e reforçado pelos investimentos em obras durante o BNH, distanciou-o da possibilidade de sua constituição enquanto política ambiental e como elemento fundamental do desenvolvimento urbano. 


\section{CAPÍTUL0 3}

\section{Mudanças e permanências no ambiente urbano pós-1980}

A metrópole dos anos 1980 herdou a herança cruel do binômio "crescimento e pobreza" com o fim do desenvolvimentismo e o novo arranjo internacional (MARICATO, 1995). Os primeiros anos dessa década foram marcados por forte crise econômica, elevada inflação e dívida externa e interna. No que tange a política urbana, a falência do BNH terá consequências importantes em termos de recuo na gestão e nos investimentos, como se verá adiante.

A falta de condições de refinanciamento da dívida nacional, em meio à elevação do nível de taxa de juros internacional, impediu a retomada das condições de realização da política pública ao longo dos anos 1980. A falência do Estado nessa década manifesta-se pelo recuo da ação pública, em vários setores como habitação, saneamento, saúde pública, justiça, segurança.

Contudo, no contexto de abertura política, a sociedade organizada, a partir de diferentes grupos e origens comprometidos com a redemocratização ${ }^{103}$, por sua vez, estava mobilizada no debate do processo Constituinte, levantando temas importantes relativos aos problemas urbanos, explicitando a dimensão do conflito de classes presente nas cidades. Dessa articulação resultou um projeto de lei de iniciativa popular - Emenda Popular da Reforma Urbana, que logrou a inserção na Constituição de um capítulo sobre política urbana com dois artigos que tratam de temas como o cumprimento da função da propriedade e da cidade e da obrigatoriedade de se fazer planos diretores para municípios com mais de vinte mil habitantes (Art. 182 e 183 da Constituição Federal de 1988). Contudo, a regulamentação desses artigos ocorreria apenas treze anos depois, com a aprovação do Estatuto das Cidades.

O movimento de âmbito nacional teve continuidade e originou uma rede chamada "Fórum Nacional pela Reforma Urbana". O movimento ambientalista, assim como o da Reforma Urbana, tinha a percepção de que parte dos desequilíbrios ambientais das cidades era decorrente da lógica privatista e excludente que presidia a produção do espaço urbano, e por isso, ambos trabalhavam para um projeto de cidades socialmente justas e ecologicamente equilibradas. Mas as diferenças se expressavam ao nível programático e nas matrizes discursivas e políticas que conformavam cada um deles. De qualquer modo, a defesa de instrumentos de democracia direta, da participação popular na gestão das cidades e da descentralização do poder para o

\footnotetext{
103 Havia um movimento composto principalmente pelos sindicatos, universidades, Partido dos Trabalhadores (PT) e Igreja Católica - através da Comissão Pastoral da Terra e das Comunidades Eclesiais de Base, que já trabalhavam nas comunidades - organizando a população para lutas específicas (por creches, transporte, entre outras).
} 
âmbito dos municípios constituíam importantes pontos de convergência entre esses dois movimentos (ANCONA, 2002, p.43).

Outro aspecto relevante da Constituição de 1988 é o reconhecimento do município como ente da federação, que passa a ter autonomia financeira, institucional e de poder decisório na escala local, ou seja, atribuição para a execução da política urbana. Nos anos seguintes, diversas gestões municipais passam a realizar experiências de planejamento e projetos habitacionais com gestão democrática, ou seja, promovendo a participação social de cidadãos e moradores e buscando implementar instrumentos da reforma urbana (RODRIGUES, 2008).

No âmbito estadual, também foi importante a mudança instituída na gestão dos recursos hídricos. A Constituição do Estado de São Paulo, promulgada em outubro de 1989, tratou dos recursos hídricos na Seção II, do Título VI - Da Ordem Econômica. No artigo 205, estabelece a criação do Sistema Integrado de Gerenciamento de Recursos Hídricos. A Lei n 7663 , de 30 de dezembro de 1991, regulamenta a Constituição e institui a Política Estadual de Recursos Hídricos e o Sistema Integrado de Gerenciamento de Recursos Hídricos. Essa legislação adota as bacias hidrográficas como Unidades de Gerenciamento dos Recursos Hídricos, estabelece um sistema de gestão descentralizado e participativo com a criação de comitês de bacias e a obrigatoriedade de realização de Planos de Bacias, visando a articulação das ações e a maximização de recursos financeiros no setor hídrico. Dois aspectos dessa legislação merecem destaque: a prioridade do uso da água para abastecimento público e o uso múltiplo dos recursos hídricos.

Entretanto, os direitos garantidos pela constituição federal de 1988 colidem frontalmente com a reorganização neoliberal do Estado, que passa a tomar forma a partir dos anos 1990. Em 1992, durante o governo Itamar Franco, o então Ministro da Fazenda Fernando Henrique Cardoso realiza o Plano Real, logrando controlar o nível de preços da economia. Após eleito presidente, este plano teve continuidade para além da medida de controle monetário. Uma nova agenda passa a pautar a ação do Estado, seguindo o ideário neoliberal, como a realização de privatizações, a supressão de direitos sociais e trabalhistas, e o estímulo ao mercado financeiro, cujas consequências foram drásticas para as cidades.

Propostas neoliberais que acompanharam a reestruturação produtiva não se restringiram às relações econômicas e políticas. O modelo de planejamento também se transformou, influenciado pelas agências multilaterais (BID, Habitat) e consultores internacionais. O planejamento estratégico difundiu a ideia de que as cidades deveriam estar preparadas para uma concorrência internacional, à semelhança dos desafios enfrentados pelas empresas (VAINER, 2000, p.76). Nessa perspectiva, as cidades devem elaborar estratégias de city marketing para atrair investimentos, associando sua boa imagem à projetos culturais, turísticos, segurança urbana e, por que não, à noção de cidade justa e democrática. Vainer busca evidenciar a face perversa do modelo, ou seja, a apropriação da cidade por interesses empresariais globalizados depende, em grande medida, do banimento da política e da eliminação do conflito e das condições do exercício da cidadania (Ibidem, p.78). 
No bojo desse discurso, grandes projetos são defendidos como motores de transformação de áreas urbanas consideradas "degradadas", sobrepondo-se frequentemente a um contexto social de extrema vulnerabilidade. A transformação é defendida sob a ótica do desenvolvimento econômico, sendo a cidade não somente o local da realização dos negócios, como ela em si se torna um negócio ${ }^{104}$.

Esse conjunto de mudanças também afetou uma parte menos visível do ambiente construído, que são as infraestruturas subterrâneas, as redes, e a gestão do saneamento de um modo geral. A lógica financeira foi incorporada até mesmo pelas companhias prestadoras de serviços públicos vitais, como a Sabesp, que abriu capital na bolsa em 2000. A racionalidade neoliberal acabou, por um lado, reforçando a pressão sobre a privatização do setor, mas, por outro lado, verifica-se que seus desdobramentos ainda que não foram analisados de forma profunda. Cabe apontar que as mudanças ocasionadas pelo chamado modelo neoliberal alterou a ação estatal em vários campos, evidenciando o descompasso entre o discurso homogeneizador e universalizador das políticas públicas, com a prática conflituosa concreta. A análise das políticas públicas de saneamento e habitação, em simultaneidade com a aproximação dessa realidade, explicita algumas importantes contradições do urbano. É sob essa perspectiva que se constrói o presente capítulo.

\subsection{Habitação e saneamento pós BNH}

No plano federal, as políticas de habitação e saneamento passam por uma reorganização com o fim do BNH. A crise econômica associada à rolagem da dívida pública, a falta de transparência e a corrupção nos órgãos governamentais enfraqueceram o Planasa e levaram ao colapso do BNH em $1986^{105}$. O governo federal deixou de realizar repasses a fundo perdido para as CESBs e passou a depender cada vez mais de empréstimos internacionais, principalmente do Banco Mundial. Nas companhias, a crise econômica resultou em uma grande defasagem de tarifas (em relação ao elevado índice da inflação) e no não pagamento dos empréstimos, o que acabou por comprometer a capacidade de financiamento do FGTS (ABICALIL, 2000).

Após a abertura política, observada a redução das taxas de investimento no setor do saneamento por anos a fio ${ }^{106}$, o crédito às autarquias municipais foi reaberto ${ }^{107}$, em 1985, uma vez que neste período foram instituídas as leis orgânicas municipais e estaduais, foram descentralizadas inúmeras políticas setoriais e foram elaborados planos diretores municipais.

\footnotetext{
${ }^{104}$ Sobre esse tema ver FERREIRA (2007), e FIX (2007).

${ }^{105}$ As atribuições do BNH, de gestão da política de saneamento, foram parcialmente passadas para a Caixa Econômica Federal, operadora dos recursos do FGTS até os dias atuais.

${ }^{106}$ A taxa de investimento no setor, que foi de $0,34 \%$ do PIB durante a década de 1970 , caiu para 0,28\% na década de 1980 e para 0,13\% na de 1990. Além disso, o saneamento foi o setor mais afetado pela queda nas taxas de investimentos ocorrida no período 90-94, com decréscimo maior do que os ocorridos em energia elétrica e transportes (ABICALIL, 2000).

107 É neste contexto que foi criada a Associação Nacional dos Serviços Municipais de Água e Esgoto (incluindo mais de mil municípios que não tinham aderido ao Planasa), em 1984.
} 
O período entre 1990 e 1994 é caracterizado pelas novas diretrizes econômicas do país e o Planasa é extinto em 1992 (Resolução no 076 do Conselho Curador do FGTS). Nesse período ocorreram várias reformas administrativas e institucionais, mas sem que tivessem produzido melhoras significativas no sistema. Com a ausência do órgão central - BNH, suas funções foram distribuídas entre diferentes órgãos e, até o final da década de 1990, não se conseguiu a rearticulação de uma política nacional para o setor do saneamento.

O governo federal criou programas tais como: Planos de Ação Imediata de Saneamento coordenado pela Secretaria Nacional de Saneamento da Ação Social, tendo como suporte financeiro os recursos da Caixa Econômica Federal. O Plano era formado por três programas: Programa de Saneamento para Núcleos Urbanos - Pronurb, o Programa de Saneamento para População de Baixa Renda - Prosanear e o Programa Social de Emergência e Geração de Empregos - Prosege. Ainda que dotados de diretrizes diferentes do Planasa, mais abrangentes por incluir ações de esgotamento sanitário e direcionadas às populações de baixa renda, esses programas não lograram moldar outro ordenamento institucional para o setor (ABICALIL, 2000, p.36).

Além disso, após o fim do BNH, os serviços passaram a ser prestados sem planejamento ou regulação, cujo "vazio" abriu espaço para que as instituições financeiras internacionais se fizessem presentes, implementando as novas diretrizes neoliberais. No início da década de 1990 o Programa de Modernização do Setor do Saneamento, financiado pelo Banco Mundial, inicia os estudos que vão dar suporte técnico à política de entrada do capital privado no controle das operadoras do setor.

Ao mesmo tempo, os recursos disponibilizados pelas CEBs diminuíram e a concessão dos serviços a essas companhias não aparecia mais como a melhor solução para a gestão do saneamento. Sem o BNH, a política de subsídios cruzados, que estava na origem da constituição das CEBs e justificava concessões, deixou de ter qualquer transparência ou controle (BRITTO, 2006).

No campo da política habitacional e de desenvolvimento urbano, algo semelhante aconteceu com o fim do BNH, quando do desmonte de um sistema que estruturava a política de financiamentos. Do ponto de vista institucional, seguiu-se um período de indefinições e uma sucessão de trocas dos responsáveis pelo direcionamento e implementação das ações da política urbana como um todo ${ }^{108}$ (MARTINS, 2007, p.27).

Diante desse quadro, e devido à autonomia atribuída aos municípios pela Constituição, a política habitacional foi realizada de forma mais direta pelas gestões municipais e estaduais. Se durante

\footnotetext{
108 Em 1985, foi criado o Ministério de Desenvolvimento Urbano e Meio Ambiente; em 1987, esse ministério se converteu em Ministério da Habitação, Urbanismo e Meio Ambiente, ao qual estava subordinada a Caixa Econômica Federal; em 1988, foi criado o Ministério de Habitação e do Bem Estar Social. Em 1990, criou-se o Ministério da Ação Social, vinculando a política de habitação às políticas de ação social. Em 1995, foi criada a Secretaria de Política Urbana, subordinada ao Ministério do Planejamento e Orçamento, que no mesmo governo foi transformada em Secretaria Especial de Desenvolvimento Urbano - SEDU, vinculada à Presidência da República até 2002. Em 2003 foi criado o Ministério das Cidades (Ibidem, p.28).
} 
a década de 1980 as instituições respondiam aos programas e financiamentos formulados no nível federal, depois do BNH passam por uma reorganização institucional e a desenvolver programas próprios.

No estado de São Paulo, a Companhia de Habitação e Desenvolvimento Urbano - CDHU inicialmente dedicava-se à construção de novas unidades em conjuntos habitacionais. No município de São Paulo, além da Companhia Metropolitana de Habitação - COHAB, a atuação direta em habitação era direcionada ao tratamento de casos de risco e emergência, vinculada à área de assistência social. Em 1979, foi somada à essa orientação a contratação das primeiras obras de urbanização em favelas, devido à criação do Fundo de Atendimento à População Moradora em Habitação Subnormal - Funaps, vinculado à Secretaria Municipal de Habitação SEHAB ${ }^{109}$ (ROSSETO, 2003).

A partir dos anos 1990, além da provisão habitacional, passa-se a diversificar o atendimento habitacional, com o programa de mutirões autogeridos, provisão de moradias, urbanização de favelas, regularização de loteamentos e assentamentos informais, atuação em cortiços (melhorias), reforma de edifícios para habitação social, locação social, recuperação de créditos e reabilitação de empreendimentos habitacionais.

A retomada do planejamento e dos investimentos federais em políticas urbanas, dentre elas habitação e saneamento, volta a ocorrer após a criação do Ministério das Cidades - MCidades ${ }^{110}$ a partir de 2003. O Ministério assumiu a função de gestor da aplicação e distribuição dos recursos do FGTS (Ministério das Cidades, 2004a). A política urbana passou a ser discutida nacionalmente, por meio da realização das Conferências das Cidades (em 2003, 2005 e 2007) e da criação e composição do Conselho das Cidades (a partir de 2004).

Em 2005, a Lei Federal № 11.124/2005 previu a elaboração do Plano Nacional de Habitação PlanHab, instituiu o Sistema Nacional de Habitação de Interesse Social ${ }^{111}$ e o Fundo Nacional de Habitação. Para que os municípios possam aderir ao Sistema Nacional de Habitação de Interesse Social, precisam aprovar um Plano Municipal de Habitação, assim como criar um Fundo e um Conselho Municipal de Desenvolvimento Urbano. A estruturação desse sistema buscou reverter a ausência de direcionamento da política habitacional federal dos períodos anteriores e, ao mesmo tempo, fornecer instrumentos para fortalecer a sua execução nos níveis estaduais e municipais, inclusive com novos aportes significativos de financiamento, estabelecendo com mais clareza os procedimentos e organização dos mesmos para a execução da política habitacional.

\footnotetext{
${ }^{109}$ Criada em 1977 pelo Decreto Municipal no 14.451.

${ }^{110}$ A concepção do Ministério buscou integrar diferentes políticas setoriais, estruturando-se em quatro Secretarias Nacionais: Habitação, Programas Urbanos, Saneamento Ambiental e, também, Transporte e Mobilidade Urbana.

${ }^{111}$ O Sistema Nacional de Habitação (SNH) é o instrumento que organiza os agentes que atuam na área de habitação. Ele se divide em dois subsistemas: o Sistema Nacional de Habitação de Interesse Social (SNHIS), direcionado à população de baixa renda, e o Sistema Nacional de Habitação de Mercado (SNHM), voltado para famílias de maior renda e que podem ser atendidas pelo mercado.
} 
Contudo, enquanto o Plano Nacional de Habitação ainda estava em elaboração, e independentemente dele, o Governo Federal anunciou, em 2009, o programa Minha Casa Minha Vida - MCMV. O MCMV foi lançado com duplo objetivo: medida contra a crise econômica internacional e também como política social. A primeira meta prevista pelo governo foi a construção de 1 milhão de moradias para famílias com renda mensal de até dez saláriosmínimos, visando reduzir o déficit de moradias em 17\%. O montante dos investimentos totalizava 34 milhões de reais.

Logo em seguida ao seu lançamento, já estavam claros alguns aspectos contraditórios do programa. Por um lado, apresentou importante avanço ao viabilizar subsídio às famílias que ganham de zero a dez salários-mínimos, segmento social até então alijado dos programas habitacionais federais. Para as faixas de renda de zero a três salários-mínimos o subsídio é grande, enquanto que para faixas acima de 6 salários-mínimos o atendimento dá-se via financiamento ao mercado privado que constrói unidades acessíveis e econômicas. Além da habitação, a infraestrutura tem linha especial de financiamento. Como resultado da negociação com os movimentos de moradia, no mesmo ano o governo lançou o MCMV Entidades, voltado para atendimento de necessidades habitacionais de famílias de baixa renda, organizadas em cooperativas habitacionais ou mistas, associações e demais entidades provadas sem fins lucrativos.

No entanto, a opção por ampliar a participação do mercado privado na produção de habitação social consolidou-se como a principal estratégia do governo. Por isso, no desenho inicial do programa, 97\% do subsídio público disponibilizado pelo pacote habitacional, com recursos da União e do FGTS, seriam destinados à oferta e produção direta por construtoras privadas e apenas $3 \%$ a entidades sem fins lucrativos, cooperativas e movimentos sociais para produção de habitação urbana e rural por autogestão.

Além disso, a forma como o financiamento é realizado, faz com que construtoras e empreiteiras tenham bastante autonomia na escolha de terrenos e na realização de projetos. Para terem ganho de escala, tais empresas rapidamente compraram grandes terrenos, frequentemente em cidades médias ou pequenas, ou em áreas periféricas, para a construção de grandes conjuntos, monofuncionais, reproduzindo um padrão de ocupação criticado desde o período do BNH. Além disso, a produção de habitação para baixas faixas de renda é também atividade inédita para essas empresas, que não apresentam preocupação quanto ao projeto habitacional nem urbanístico e frequentemente desconsideram experiências anteriores que buscaram melhorar a unidade e a implantação do conjunto habitacional ${ }^{112}$. A baixa qualidade se mantém em favor da lucratividade e ganho na produção em escala.

Outro importante aporte de recursos para os municípios passa a ocorrer em 2007 com a criação do Programa de Aceleração do Crescimento - PAC, cujo objetivo era a retomada do

\footnotetext{
${ }^{112}$ Uma análise dos projetos realizados pelo chamado segmento econômico, que produz habitação no mercado para faixas de renda acima de seis salários mínimo pode ser vista em FERREIRA (2012). Para a atuação das empresas na produção de HIS ver SHIMBO (2012), e sobre o setor imobiliário ver FIX (2011).
} 
planejamento e execução de grandes obras de infraestrutura social, urbana, logística e energética no país. Assim como o MCMV, o PAC foi entendido pelo governo como uma medida para garantir empregos e renda aos trabalhadores durante a crise mundial, garantindo ao mesmo tempo a continuidade do consumo de bens e serviços, mantendo ativa a economia nacional.

O PAC abrange investimentos em todas essas áreas e, no que tange os projetos urbanos e habitacionais se organiza em: Urbanização de assentamentos precários e Financiamento Habitacional via Sistema Brasileiro de Poupança e Empréstimo - SBPE, além do MCMV. Os investimentos também podem ser destinados ao subprograma Cidade Melhor, que contempla saneamento, prevenção de risco (obras de drenagem), pavimentação e mobilidade urbana; ao programa Comunidade Cidadã, para construção de equipamentos públicos e ao programa Água e Luz para todos. A partir de 2011 o PAC entrou na segunda etapa.

Para além de compor o quadro mais amplo da política urbana que é em grande medida "desenhado" por essas linhas de financiamento de projetos habitacionais e de urbanização (infraestruturas), é relevante situá-las na presente pesquisa na medida em que, particularmente o PAC urbanização, tem se constituído a principal fonte de recursos para os projetos de urbanização nas áreas de mananciais realizados (e em projeto), particularmente no município de São Bernardo. Esse tema será tratado no contexto de discussão de dois projetos nesse município, tratados no capítulo 9. A importância do PAC também se fez presente a partir de 2008, como uma importante fonte de recursos do Programa Mananciais coordenado pela Secretaria de Saneamento e Energia do estado de São Paulo, tema do capítulo 8.

\subsection{O setor do saneamento a partir dos anos 1990}

Enfocando as mudanças no setor do saneamento, outro importante aspecto da crise que o afetou nos anos 1990 foi relativo ao tema da municipalização da gestão dos serviços (BRITTO, 2006). Os municípios que não tinham aderido ao Planasa se reuniram na criação da Associação de Serviços Municipais de Água e Esgotos - Assemae e defendiam a municipalização, considerando que essa escala tornava possível a integração das intervenções públicas, dada a proximidade com diversos setores da sociedade, viabilizando o controle comunitário. Tratava-se de postura que se contrapunha à centralização das CEBs.

Essa problemática, segundo Britto (2006) foi debatida em dois âmbitos: no governo federal de Collor, que idealizou o Programa de Modernização do Setor do Saneamento - PMSS; e no debate liderado pela Associação Brasileira de Engenharia Sanitária e Ambiental - Abes e Assemae, entidades da sociedade civil. Essas entidades conduziram uma revisão da noção de saneamento básico para a formulação de uma nova noção de saneamento ambiental, mais ampla e integradora dos serviços de água, esgotos, drenagem urbana, controle de vetores de doenças, resíduos sólidos. 
O esforço para a superação do "vazio institucional" - desde a falência do Planasa até a extinção do BNH - foi iniciado em 1991, com a tramitação na Câmara Federal do Projeto de Lei no 53, que em 1993, passou a ser denominado Projeto de Lei da Câmara 199 (PLC 199), o qual dispunha sobre a política nacional de saneamento e seus instrumentos, e que incorporava a noção de saneamento ambiental. Esse projeto foi discutido em diversos fóruns por aproximadamente quatro anos, tendo sido aprovado pelas duas casas legislativas (Câmara e Senado) no ano de 1994. O PLC 199 fazia claro contraponto às iniciativas do Governo Federal, que a essa altura procurava organizar o setor à luz das orientações dos organismos internacionais de financiamento, que já vislumbravam o interesse da iniciativa privada por alguns setores controlados por empresas estatais, a exemplo das CESBs (MCidades, 2004, p.36).

Ao tomar posse em 1995, o Presidente Fernando Henrique Cardoso assume como uma das suas primeiras medidas de governo o veto, na íntegra, do PLC 199, criando as condições para se dar continuidade à política de reestruturação do setor com ênfase no incentivo governamental e financeiro à participação privada no saneamento brasileiro, desconsiderando a proposta das entidades representativas do setor. Assim, ocorreram diversas manifestações de repúdio ao veto do PLC 199. Ainda em 1995, o Presidente Fernando Henrique sanciona a chamada Lei das Concessões (Lei o 8.987), que regulamentava o regime de concessões da prestação dos serviços públicos para a iniciativa privada. Iniciava-se, assim, a pavimentação das condições necessárias para a entrada da iniciativa privada tratando o saneamento como negócio (MCidades, 2004, p.36).

Como explicam Heller e Rezende (2008), é a partir do segundo semestre de 1998, com a desvalorização do real e o pedido de socorro ao FMI, que a privatização do saneamento é colocada com maior ênfase na pauta do governo federal. A área econômica do governo assume claramente o comando do setor. Aprofunda-se o ajuste fiscal e, ainda em julho de 1998, o Conselho Monetário Nacional suspende os financiamentos com recursos do FGTS para órgãos públicos, incluindo as operadoras de água e esgoto estaduais e municipais, as companhias habitacionais sob controle público, os Estados e municípios. Um dos componentes da estratégia fica claro: sufocar a capacidade de investimento dos operadores públicos.

Neste mesmo ano, buscando avançar na formulação de uma proposta para viabilizar as concessões privadas (fosse via privatização das companhias estaduais, fosse via entrada de capital privado) e compatibilizar as expectativas do Banco Mundial, o BNDES formula um programa orientado a financiar o processo de desestatização do setor de saneamento, ao mesmo tempo em que sugere adaptações ao PL 266/96 ${ }^{113}$, no sentido de adequar o marco jurídico-institucional às diretrizes do programa de desestatização do BNDES (MCidades, 2004, p.37).

Em janeiro de 2001, o Governo Fernando Henrique envia o PL 4147 à Câmara dos Deputados, com pedido para tramitar em regime de urgência. Este projeto instituía diretrizes nacionais para

113 O PL 266/96 transferia a titularidade dos serviços de saneamento dos Municípios que integram regiões metropolitanas, aglomerados urbanos e microrregiões, para os Estados. 
o saneamento básico e contemplava grande parte das ações propostas pelo Banco Internacional para Reconstrução e Desenvolvimento - BIRD, decorrentes de uma missão do banco e sistematizadas no documento intitulado "Regulação do Setor de Saneamento no Brasil: prioridades imediatas". Com isso, travou-se um forte embate entre os governistas e uma frente formada por diversas entidades do setor - a recém-criada Frente Nacional pelo Saneamento Ambiental - FNSA. A total impossibilidade de se construir algum nível de consenso em torno do projeto pode ser comprovada tanto no âmbito do legislativo, quanto na esfera pública ampliada, em que a sociedade organizada chegou a apresentar ao Congresso Nacional um abaixo-assinado com 720 mil assinaturas pela não aprovação do PL 4147 (Ibidem, p.38). Como resultado desse processo, o projeto ficou paralisado no Congresso.

A partir de 2003, é dada outra orientação para o setor, no sentido do resgate e do fortalecimento da gestão pública e a retomada dos investimentos visando à universalização com eficácia na aplicação dos recursos e qualidade na prestação dos serviços. Constitui-se um Grupo de Trabalho Interministerial de Saneamento, que contribuiu para o redesenho da atuação do governo federal no setor. Dentre os principais legados desse grupo está a conquista da aprovação do projeto de lei elaborado para instituir o novo marco regulatório do saneamento, a aprovação da Lei Federal no $11.445 / 2007^{114}$, que significou um avanço ao reestruturar a regulação do saneamento ambiental no país, contrariando a perspectiva de privatização do setor que estava em disputa havia pelo menos 13 anos.

Segundo prefácio de Montenegro (HELLER; REZENDE, 2008), o resultado a que se chegou com essa lei expressa tanto o compromisso com a visão de que o saneamento é um negócio, como com aquela que o encara como política pública de relevância social; deixando assim espaço para que a disputa continue no plano local ou regional.

A lei amplia o conceito de saneamento básico incluindo os serviços de abastecimento de água, esgotamento sanitário, manejo de resíduos sólidos e manejo das águas pluviais e determina que eles sejam prestados observando planejamento, regulação e fiscalização definidos pelo titular do serviço. Essa definição aparentemente simples vai exigir enorme esforço para ser implementada pelos municípios (Ibidem, p.25). A lei também fixou diretrizes e objetivos para a Política Federal de Saneamento Básico, bem como condicionantes aos financiamentos e recursos públicos. No bojo do novo marco regulatório do setor, o Ministério das Cidades elaborou o Plano Nacional de Saneamento Básico - Plansab ${ }^{115}$, que tem metas de curto, médio e longo prazos, com horizonte em 2030, ainda não aprovado.

\footnotetext{
114 Outro marco legal relevante, aprovado em 2005, foi a chamada lei de consórcios públicos no 11.107, que estabeleceu regra de contratação da prestação do serviço no âmbito da cooperação interfederativa (HELLER; REZENDE, 2008, p.23).

115 O texto com a proposta do Plansab foi concluído em abril de 2011, passou por seminários regionais, consulta pública e passará por avaliação do documento pelos Conselhos Nacionais de Saúde, de Meio Ambiente, de Recursos Hídricos e das Cidades, sendo que, posteriormente o mesmo será apreciado e deliberado pelo Ministro das Cidades e pela Presidência da República. Fonte: http://www.cidades.gov.br/index.php?option=com_content\&view=article\& id=302: plansab\&catid=84\&ltemid=113, acesso: 12/2012.
} 
As disputas continuam presentes nos debates sobre a aprovação do Plansab pois há empresas do setor contra a sua aprovação, cujos interesses estão voltados para a privatização da água. Enquanto o Plansab não é aprovado, os planos municipais de saneamento, obrigatórios para que os municípios acedam aos recursos federais, estão sendo elaborados sem uma diretiva nacional. A esse problema se somam as diferenças de capacidade técnica e institucional das prefeituras de todo o país em gerir os recursos obtidos.

Além disso, há a dificuldade de passar do discurso e da proposição da integração dos serviços à prática operacional, o que tem sido defendido por vários especialistas da área. Os serviços de saneamento tem uma estrutura fragmentada. Segundo Britto (2006), a lógica de oferta de serviços de drenagem urbana é incompatível com aquela dos serviços de abastecimento de água e esgotamento sanitário, passíveis de tarifação individualizada, e menos compatível ainda com a lógica operacional dos serviços de coleta e disposição de resíduos sólidos. Estes serviços demandam diferentes estratégias de investimentos e funcionam segundo perspectivas muito diferentes de amortização. A solução para a integração estaria justamente dependendo de uma estratégia mais ampla de planejamento.

A ausência de planejamento abrangente também não foi um empecilho para o aumento dos investimentos em obras de infraestrutura. Os municípios receberam grande aporte de recursos do PAC I e II, com resultados bastante díspares em todo o país.

Por outro lado, logo após o lançamento do "PAC Saneamento", foram retirados do programa dois componentes importantes, que objetivavam o apoio à reestruturação da prestação de serviços de abastecimento de água e de esgotamento sanitário nos estados e municípios cujas companhias estavam fragilizadas, e o apoio ao desenvolvimento e implementação de serviços regionais de manejo de resíduos sólidos em 12 regiões metropolitanas (HELLER; REZENDE, 2008). Isso ressalta o fato do PAC setorial ter se tornado um programa de obras com ênfase na velocidade de produção.

\subsection{Sabesp: abastecimento de água metropolitano desigual e 0 objetivo da universalização}

Em relação ao abastecimento de água, como tratado nos itens anteriores, desde a década de 1970, a Sabesp passa a concentrar as obras de captação ${ }^{116}$ da maioria dos municípios da metrópole e, em 1980, a cobertura dos serviços de água da capital e da área conurbada era quase total. Em 1975 a empresa passa a implementar um programa de ligações gratuitas (já obrigatoriamente com hidrômetro), que elevou sobremaneira o número de residências ligadas à rede, fazendo com que ela se legitimasse diante da sociedade, reforçando opinião pública favorável ao modelo institucional imposto pelo Planasa (BUENO, 1994, p.160).

\footnotetext{
${ }^{116}$ Em 1975 a empresa conclui a duplicação da adutora rio Claro.
} 
Apesar disso, a distribuição dos serviços de saneamento não era homogênea, particularmente nos assentamentos precários pois a Sabesp não considerava a população pobre em condições de atendimento, ou melhor, como consumidora; além de considerar um risco, para o investimento na construção de redes, a precariedade da posse dos terrenos ocupados, passíveis de desapropriação. Contudo, a partir de 1979, a Sabesp passa a executar o abastecimento de água em favelas, iniciando pela capital e depois atuando na região metropolitana.

Em São Paulo, o prefeito de São Paulo Reynaldo de Barros, que havia sido presidente da Sabesp, firmou convênio com a mesma criando o programa Pró-água. As primeiras ligações de água foram executadas em situações em que não era preciso alterar seus padrões técnicos, como em barracos lindeiros às vias ou em vielas de no mínimo $4 m$ de largura (BUENO, 1991, p.161). A empresa tinha muita resistência em atuar no Pró-água e, apesar de pouca extensão da rede executada, houve redução da mortalidade infantil nas áreas atendidas.

Em seguida, em 1982, a empresa manteve esse atendimento por meio do Programa de Abastecimento de Água à População de Baixa Renda, com recursos do BNDES. A mudança na prática da empresa foi estimulada em grande medida por crescentes pressões políticas da população ${ }^{117}$. A partir de 1983, a Sabesp passa a propor inovações técnicas de adequação e adaptação à realidade de ocupação das favelas, empregando a utilização de novo material para as redes e ramais de distribuição (o PEAD - polietileno de alta densidade), que por ser flexível viabilizava o assentamento em vielas mais estreitas. Para a coleta de esgotos, previa a instalação de sistema de coleta interno às favelas, seguido de fossas sépticas, com encaminhamento do efluente destas fossas para o córrego mais próximo, ou para a rede de drenagem, ou por meio de infiltração do efluente no solo. Estas inovações técnicas foram normatizadas e transformadas em procedimentos rotineiros da companhia (MOREIRA, 2008, p.136).

No entanto, o posicionamento da Sabesp diante da questão social da atuação em favelas teve momentos de retrocesso e a companhia se recusou a ampliar a extensão da rede de água nos loteamentos irregulares, particularmente em área de proteção aos mananciais (onde havia inúmeros casos de hepatite), em diversas obras de urbanização de favelas executadas pela SEHAB, sob argumentação de que o loteamento estava ilegal. Contudo, esse posicionamento não era uniforme e algumas sedes regionais concordavam e até colaboravam na extensão de água aos favelados e outras se negavam, sempre com argumentação legal ou regulatória. Aparentemente os técnicos da empresa tinham opiniões diferentes sobre o assunto e influíam nas decisões regionais, mas existia também o fato da companhia estar em dificuldades financeiras (endividamento) e cortar investimentos não atraentes (MARICATO, 1995, p.31-32).

Como se verá adiante e em maior detalhe no capítulo 8, a elaboração de um projeto específico para as áreas de proteção aos mananciais e obtenção de financiamento internacional

\footnotetext{
117 Além das mudanças citadas, em 1984, após uma passeata que reuniu 4.000 pessoas, o governador Franco Montoro instituiu a Tarifa social da água, que definiu que as famílias que morassem em favelas pagariam o equivalente a um consumo mensal de $10 \mathrm{~m}^{3}$ de água, independentemente do consumo real (BUENO, 1994, p.163).
} 
viabilizaram a realização do Programa Guarapiranga, a partir do qual a atuação em urbanizações de favelas em APM se tornará uma prática constante.

Em relação ao abastecimento metropolitano de água, o sistema o apresentou sérios problemas para o atendimento da demanda e passou por crises severas de recursos. Por isso, foi implementado o sistema de rodízios ${ }^{118}$ e racionamento, que eram mais intensos anteriormente à execução do sistema Alto Tietê, que entrou em operação em 1992. Em 1982 fora entregue na zona Leste a adutora Cantareira, que cruza São Paulo de norte a sudeste, atravessando o rio Tietê por uma estrutura aérea, e para garantir a manutenção do rio Grande aos municípios do $A B C$, a Sabesp executou a barragem de compartimentação do braço do rio Grande, para protegê-lo da contaminação presente no restante da represa Billings.

A partir da metade da década de 1990, mudanças significativas passam a ocorrer na Sabesp, tanto do ponto de vista institucional quanto operacional e técnico, diante do quadro de endividamento da empresa e da orientação do governo federal para a privatização do setor. Se até então a empresa se caracterizava mais como uma empresa de engenharia, que realizava obras, a partir de 1995 o enfoque será justamente a gestão dos sistemas de controle de perda de água para viabilizar a manutenção do atendimento da escala metropolitana. Essa será a base da universalização dos serviços. Em termos territoriais, a empresa passa a se organizar em Unidades de Negócios ${ }^{119}$ regionalizadas que, segundo Moreira (2008) correspondem a um critério de equilíbrio financeiro garantindo o retorno de ativos mais ou menos na mesma quantidade de ligações, além do equilíbrio de quantidade de população e da compatibilização geográfica das sub-bacias (2008, p.159).

No que se refere à extensão física das redes de abastecimento de água perante a complexidade da ocupação metropolitana e da própria rede existente, a Sabesp diagnosticou que os problemas de perdas precisavam ser controlados e que isso era mais eficiente do que realizar grandes obras de ampliação e adução. Novas tecnologias foram estudadas e gradativamente adaptadas à realidade metropolitana, passando a ser empregada a instalação de válvulas de pressão (VRPs) para efetuar esse controle, que são acompanhadas por um sistema de informações computadorizado (MOREIRA, 2008, p.160).

\footnotetext{
118 O sistema de rodízio causava muitos prejuízos na tubulação e era evitado ao máximo pela Sabesp.

${ }^{119}$ Cada Unidade de Negócio desenvolve projetos experimentais próprios buscando melhorar a eficiência da rede, segundo as especificidades locais.
} 


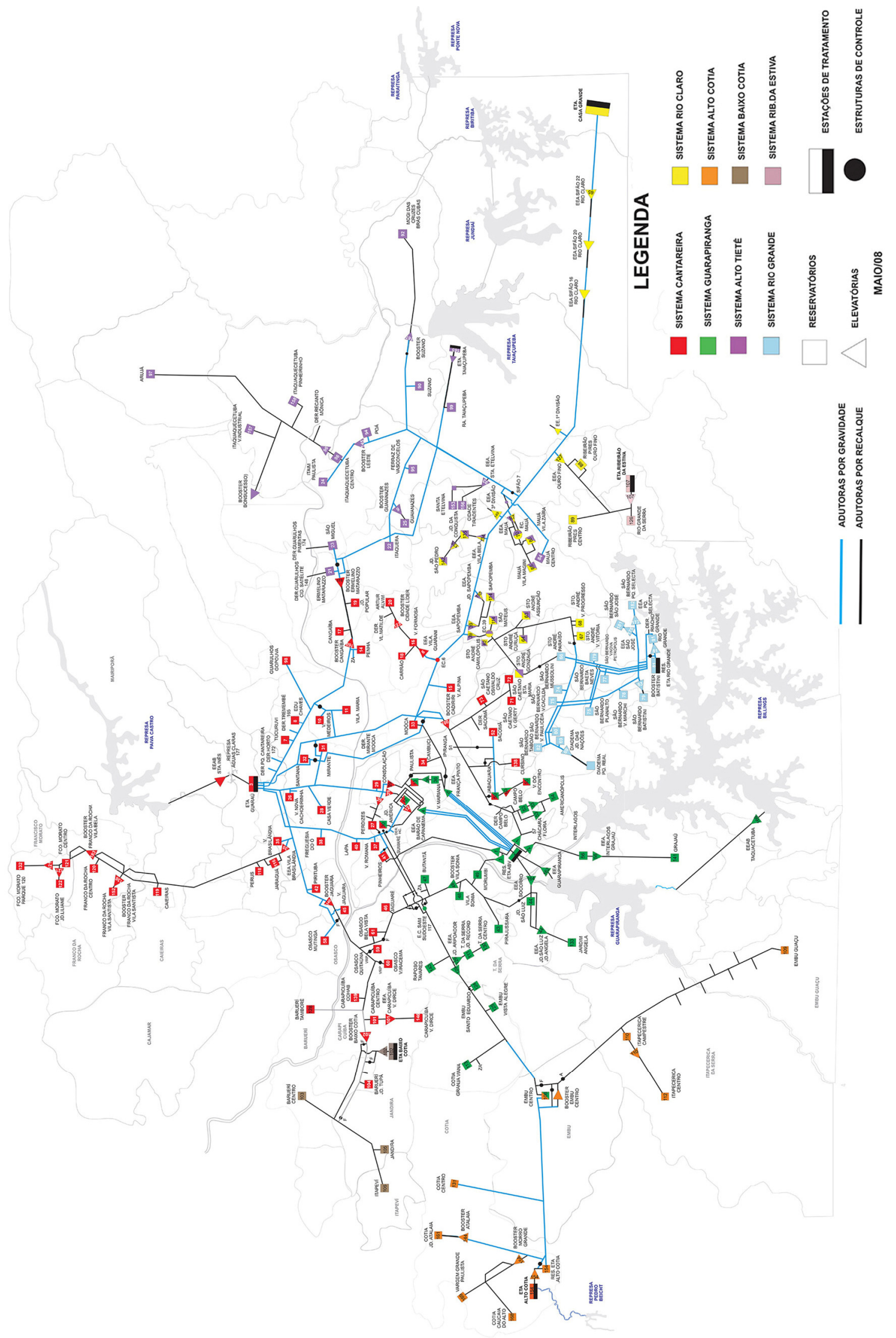

Mapa 5 - Sistema adutor metropolitano.

Fonte: Cobrape; Sabesp. Disponível em http://www.cobrape.com.br/home/biblioteca/mapas/mapa\%20SAM\%20\%20RMSP.pdf, acesso em 12/03/2012. 
Além disso, a Sabesp não foi privatizada, diferentemente de outros setores de infraestrutura, mas a lógica da rentabilidade a levou à abertura de parte de seu capital na Bolsa de valores de São Paulo e Nova lorque a partir de $2002^{120}$, passando a integrar o sistema financeiro. Segundo Moreira (2008), a abertura para o mercado foi inevitável com a crise de desvalorização cambial de 1998-99, porque a empresa dependia de muitos empréstimos internacionais em moeda estrangeira. A partir de então, o controle refinado e abstrato da rede metropolitana serve ao planejamento e controle de operações; mas também converge com a necessidade de demonstrar resultados financeiros da empresa, que são cobrados pelos seus acionistas.

A Sabesp foi homenageada na Bolsa de Valores de Nova lorque pela excelente valorização de suas ações: 601\% em 10 anos, superando a performance do índice Dow Jones que subiu 29\% no período, além de destacada posição de maior empresa de saneamento das Américas e quarta do mundo em número de clientes, atendendo cerca de 27,6 milhões de pessoas ${ }^{121}$. Em novembro de 2012, o capital social da empresa se dividia entre Governo do Estado de São Paulo ${ }^{122}$ (50,3\%), BM\&F Bovespa $(24,8 \%)$ e NYSE $(24,9 \%)^{123}$.

Nessa perspectiva, a busca pela universalização é condizente com as metas de sucessivas ampliações da rede, ainda que ela se dê de forma desigual no território. Apesar das dificuldades que a empresa possa enfrentar no mercado financeiro, ela detém o monopólio de um recurso natural, vital, e um mercado cativo. A empresa anuncia como meta ampliar atendimento de municípios, estados e atuar internacionalmente. Parte dessa estratégia converge com as atuais políticas de busca de novos mananciais, como aponta o Plano Diretor de Aproveitamento de Recursos Hídricos da Macrometrópole, tratado a seguir.

\subsection{Da metrópole à macrometrópole}

Os planos recentes sobre abastecimento de água têm se baseado na noção da escassez. De fato, há uma situação posta que define em grande medida esse problema. Localizada nas cabeceiras da bacia do rio Tietê, a RMSP encontra-se numa região de baixa disponibilidade hídrica que é suprida pela importação de $32,2 \mathrm{~m}^{3} / \mathrm{s}$ de água de bacias hidrográficas adjacentes, e suporta um processo de urbanização que ignorou (e ignora) suas condições naturais. Por outro lado, a escassez é socialmente construída, numa sociedade em que crise ambiental, nesse caso a crise

\footnotetext{
${ }^{120}$ A partir de 2002, a Sabesp passa a negociar ações nas Bolsas de Valores de São Paulo, sob o código SBSP3, e Nova Iorque, sob o código SBS. Fonte: http://www.sabesp.com.br/CalandraWeb/ CalandraRedirect/?temp=4\&proj= investidoresnovo\&pub=T\&db=\&docid=B8E8FCF437413CBA83257723004C2D2F\&docidPai=1698C08F24239E5A83257 68C00517EF8, acesso: 10/06/2012.

121 Fonte: http://site.sabesp.com.br/site/imprensa/noticias-detalhe.aspx?secaold=65\&id=4038, acesso: 10/06/2012.

122 De acordo com a Lei Estadual no 119/73, que autorizou a criação da Sabesp, a Fazenda do Estado de São Paulo deve manter, direta ou indiretamente, participação mínima correspondente a mais da metade das ações com direito a voto do capital social.

123 Fonte: http://www.sabesp.com.br/CalandraWeb/CalandraRedirect/?temp=4\&proj=investidoresnovo\&pub=T\&db= \&docid=1C3C5C495E396CD0832570DF006A4017\&docidPai=1698C08F24239E5A8325768C00517EF8\&pai=filho3, acesso: 11/2012.
} 
da água, é decorrente do consumo crescente de materiais e matérias-primas necessários ao aumento incessante da produção de valor e lucro (acumulação de valor e acumulação como processo material que depende de condições naturais) (BURKET, 1999, p.112). Esse aspecto da tendência antiecológica da acumulação do capital, e da produção do espaço capitalista, tem sido pouco considerado na elaboração de planos e políticas públicas.

Atualmente, na RMSP, quase a totalidade das demandas de abastecimento de água é atendida pelo Sistema Integrado da Sabesp (oito sistemas produtores de água), que possui capacidade nominal de $68,2 \mathrm{~m}^{3} / \mathrm{s}$. Na avaliação desses sistemas produtores realizada pela Agência Nacional de Águas, à exceção do Ribeirão da Estiva, todos requerem ampliações ou melhorias que assegurem o abastecimento de água para a Grande São Paulo (ANA, 2010).

Além disso, grande parte da água que supre a RMSP já vem de outras bacias. Para produzir 30 $\mathrm{m}^{3} / \mathrm{s}$ o Sistema Cantareira ${ }^{124}$, que é um dos principais que abastece a RMSP, faz a transposição entre duas bacias hidrográficas, importando água da bacia do Piracicaba para a bacia do Alto Tietê.

Quadro 1 - Sistemas produtores de água na RMSP.

\begin{tabular}{|c|c|c|c|}
\hline Sistema & $\begin{array}{l}\text { Disponibilidade } \\
\text { hídrica }\left(\mathrm{m}^{3} / \mathrm{s}\right)^{(1)}\end{array}$ & Principais Mananciais & Sedes Urbanas Atendidas \\
\hline Cantareira & 30,00 & $\begin{array}{l}\text { Represas Jaguari, Jacareí, } \\
\text { Atibainha, Cachoeira e Paiva } \\
\text { Castro }\end{array}$ & $\begin{array}{l}\text { Barueri; Caieiras; Cajamar; Carapicuíba; } \\
\text { Francisco Morato; Franco da Rocha; } \\
\text { Guarulhos; Osasco; São Caetano do Sul; } \\
\text { São Paulo }\end{array}$ \\
\hline Guarapiranga & $16,00^{(2)}$ & $\begin{array}{l}\text { Represas Guarapiranga e } \\
\text { Billings (Taquacetuba) e Rio } \\
\text { Capivari }\end{array}$ & $\begin{array}{l}\text { Cotia; Embu; Itapecerica da Serra; São } \\
\text { Paulo; Taboão da Serra }\end{array}$ \\
\hline Alto Tietê & $12,30^{(3)}$ & $\begin{array}{l}\text { Represas Paraitinga, Ponte } \\
\text { Nova, Jundiaí, Biritiba-Mirim } \\
\text { e Taiaçupeba }\end{array}$ & $\begin{array}{l}\text { Arujá; Ferraz de Vasconcelos; } \\
\text { Itaquaquecetuba; Guarulhos; Mauá; } \\
\text { Mogi da Cruzes; Poá; Suzano; São Paulo }\end{array}$ \\
\hline Rio Claro & 4,00 & $\begin{array}{l}\text { Rio Claro - Represa Ribeirão } \\
\text { do Campo }\end{array}$ & $\begin{array}{l}\text { Mauá; Ribeirão Pires; Santo André; São } \\
\text { Paulo }\end{array}$ \\
\hline Rio Grande & $4,84^{(4)}$ & $\begin{array}{l}\text { Represa Billings - Braço do } \\
\text { Rio Grande }\end{array}$ & $\begin{array}{l}\text { Diadema; Santo André; São Bernardo do } \\
\text { Campo }\end{array}$ \\
\hline Alto Cotia & 1,20 & $\begin{array}{l}\text { Represas Pedro Beicht e } \\
\text { Cachoeira da Graça }\end{array}$ & $\begin{array}{l}\text { Cotia; Embu; Embu-Guaçu; Itapecerica } \\
\text { da Serra; Vargem Grande Paulista }\end{array}$ \\
\hline Baixo Cotia & 0,90 & Rio Cotia - Isolinas & Barueri; Itapevi; Jandira \\
\hline Ribeirão da Estiva & 0,10 & Ribeirão da Estiva & Rio Grande da Serra \\
\hline Sistemas Isolados & $\mathrm{SI}$ & $\begin{array}{l}\text { Mananciais Superficiais / } \\
\text { Mistos }\end{array}$ & $\begin{array}{l}\text { Biritiba-Mirim; Juquitiba; Mairiporã; } \\
\text { Pirapora do Bom Jesus; Salesópolis; } \\
\text { Santana de Parnaíba; São Lourenço da } \\
\text { Serra }\end{array}$ \\
\hline total & 70,34 & & \\
\hline
\end{tabular}

${ }^{124}$ O Sistema Cantareira é formado por cinco bacias e $45 \%$ da área de sua área está inserida no estado de Minas Gerais, abrangendo total ou parcialmente quatro municípios. E 12,4\% da área do sistema está inserida na área de proteção aos mananciais da RMSP, que corresponde à parte da bacia do rio Juquehy, abrangendo total ou parcialmente 12 municípios do estado de São Paulo (WHATELY; CUNHA, 2007, p. 13). 
(1) Dado extraído de Relatório Síntese RI/1, Cobrape, DAEE, 2009, p.74. ${ }^{(2)}$ Considerada a transferência de $4 \mathrm{~m}^{3} / \mathrm{s}$ do braço do Taquacetuba (represa Billings) para Guarapiranga, no pico. A média anual deverá ser de $2,2 \mathrm{~m}^{3} / \mathrm{s}^{\text {; }}{ }^{(3)}$ Consideradas as represas Paraitinga e Biritiba-Mirim $\left(+2,5 \mathrm{~m}^{3} / \mathrm{s}\right) ;{ }^{(4)}$ Considerada disponibilidade de $+0,6 \mathrm{~m}^{3} / \mathrm{s}$, ainda sem outorga.

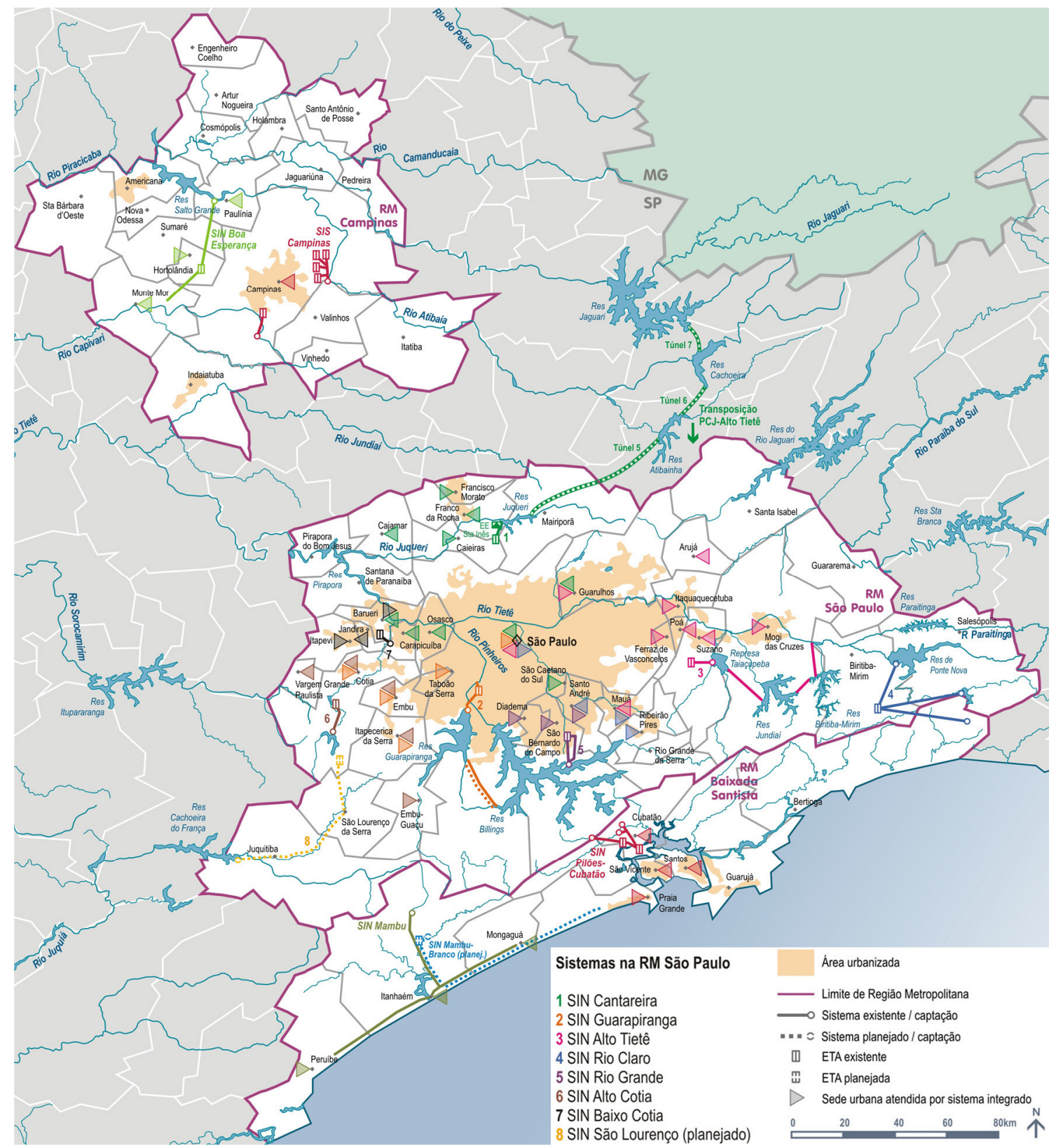

Mapa 6 - Sistemas produtores na Região Metropolitana de São Paulo.

Fonte: Agência Nacional de Águas. Atlas Brasil: abastecimento urbano de água: resultados por estado, 2010, p.76.

O Plano de bacia do Alto Tietê (PBAT) demonstra ainda de forma mais clara o problema, ou seja, os mananciais disponíveis ao abastecimento metropolitano nessa bacia estão no limite ou acima do limite do que pode ser explorado. 
Tabela 2 - Análise da Situação dos sistemas Produtores de água na bacia do Alto Tietê, 2009.

\begin{tabular}{lccc}
\hline Sistemas produtores & $\begin{array}{c}\text { Vazão garantida c/ } \\
95 \% \mathrm{~m}^{3} / \mathrm{s}^{(1)}\end{array}$ & $\begin{array}{c}\text { Produção da Sabesp } \\
\mathrm{m}^{3} / \mathrm{s}^{(2)}\end{array}$ & $\begin{array}{c}\text { Percentual de } \\
\text { utilização (\%) }\end{array}$ \\
\hline Alto Cotia & 1,5 & 1,0 & $67 \%$ \\
\hline Baixo Cotia & 1,0 & 0,9 & $90 \%$ \\
\hline Guarapiranga & 13 & 14 & $108 \%$ \\
\hline Rio Grande & 4,0 & 4,8 & $122 \%$ \\
\hline Totais & 19,4 & 20,7 & $122 \%$ \\
\hline
\end{tabular}

Fonte: Comitê de Bacia do Alto Tietê; Fundação de Apoio à Universidade de São Paulo - FUSP. Plano de Bacia do Alto Tietê, dezembro de 2009, p.156.

Segundo o PBAT, apenas o Sistema Alto Cotia apresenta uma possibilidade de expansão da produção para o atendimento da demanda. A produção atual do Sistema Baixo Cotia de 900l/s está muito próxima da vazão garantida com 95\%. A produção atual do Sistema GuarapirangaBillings de 14,0 m³ $/ \mathrm{s}$ já expõe as regiões Sudoeste e Sul da RMSP a riscos de racionamento de $9 \%$. Por sua vez, a produção atual do Sistema do Rio Grande de $4,8 \mathrm{~m}^{3} / \mathrm{s}$ expõe a população de Diadema, São Bernardo do Campo e Santo André a riscos de racionamento superiores a $20 \%$ (COMITÊ..., v.1, 2009, p.156).

No que se refere ao sistema Guarapiranga/Billings/Rio Grande:

a transposição das águas do braço do Taquacetuba (da represa Billings) ${ }^{125}$ para a represa Guarapiranga alcança, em condições de estiagem (segundo a outorga), 4,0 $\mathrm{m}^{3} / \mathrm{s}$. Uma vez que a contribuição específica do rio Taquacetuba é de $1,75 \mathrm{~m}^{3} / \mathrm{s}$, isto equivale aproveitar $2,3 \mathrm{~m}^{3} / \mathrm{s}$ de outros braços. $O$ aproveitamento futuro do braço do rio Pequeno (com barramento para isolá-lo do corpo central do reservatório e transferi-lo para o braço do Rio Grande), com vazão prevista de $2,2 \mathrm{~m}^{3} / \mathrm{s}$, esgota as disponibilidades hídricas de aproveitamento dos vários braços da Billings cogitados para abastecimento (além do Taquacetuba e Pequeno, também o Capivari e Pedra Branca). Como observado, porém, a Sabesp está procedendo aos estudos para a transposição das águas do rio Juquiá até um ponto na bacia do Guarapiranga, na vazão de 4,7 m³ $/ \mathrm{s}$, prevista para operação em 2013 (Extraído de Relatório Síntese $\mathrm{RI} / 1$, Coprabe, DAEE, 2009, p.76 - grifo nosso).

Diante do quadro diagnosticado de escassez não só na bacia do Alto Tietê como também na região metropolitana de Campinas e Baixada Santista, o governo do Estado de São Paulo Secretaria de Saneamento e Energia (SSE) tem estudado, desde 2008, as possibilidades de ampliar a busca por novos mananciais por meio do Plano Diretor de Aproveitamento de Recursos Hídricos da Macrometrópole ${ }^{126}$. Os estudos que constam nos poucos documentos

\footnotetext{
${ }^{125}$ Conforme o Plano de Desenvolvimento Ambiental da bacia da Billings, a primeira iniciativa para a ampliação do uso da represa Billings para o abastecimento público, utilizando outras áreas da represa além do braço do Rio Grande, foi a sua interligação com a represa Guarapiranga, através do braço Taquacetuba, cuja operação de bombeamento é de até $4 \mathrm{~m}^{3} / \mathrm{s}$, teve início em agosto de 2000 (SÃO PAULO, 2011).

${ }^{126}$ A macrometrópole abrange as regiões metropolitanas de São Paulo, Campinas e Baixada Santista, mais as áreas vizinhas e as macrorregiões do Vale do Paraíba e de Sorocaba. Totaliza 180 municípios e $75 \%$ da população do estado de São Paulo.
} 
disponíveis ao público que foram consultados, apontam claramente a estratégia de ampliar transposições de outras bacias:

(...) a observação das áreas vizinhas à Macrometrópole revela que existe água disponível, em quantidade e qualidade superiores àquele excesso de demanda que ultrapassará a capacidade de suporte do território macrometropolitano. Neste sentido, pode-se colocar em foco, por exemplo, os mananciais das bacias hidrográficas do Paraíba do Sul e do Ribeira de Iguape, do Alto Paranapanema e o Aquífero Guarani. Cálculos técnicos indicam que estas vazões agregadas e excedentes são mais que suficientes ao atendimento das demandas futuras e, portanto, um fator de superação das restrições ao desenvolvimento que se aproximam. Assim, se a perspectiva de abordagem dos problemas de recursos hídricos for devidamente alterada, da atual disputa em meio à escassez intrarregional, para a visão muito mais abrangente da Macrometrópole, é menos relevante a limitação física, e são muito mais essenciais as questões econômicas e aquelas de ordem político-institucional. (Relatório Síntese RI/1, Coprabe, DAEE, 2009, p.6)

A apresentação desses estudos levantou discussões no Comitê de Bacia Hidrográfica do Paraíba do Sul - CEIVAP, prefeituras da região e sociedade civil atuante, que contestaram dados do relatório, cobraram esclarecimentos quanto aos impactos locais e encaminharam sugestões a $\mathrm{SSE}^{127}$. A bacia do Paraíba do Sul já abastece parte do Rio de Janeiro, gerando um cenário de conflitos regionais. O plano até o momento não foi concluído, o que não nos permite maiores aferições.

A discussão sobre o planejamento na escala macrometropolitana certamente levanta uma série de questões. Uma delas se refere à capacidade de gerenciar os recursos hídricos e sistemas de infraestrutura sob uma perspectiva de integração nessa escala, o que tem sido defendido por diversos profissionais atuantes no setor do saneamento, desde a formulação do Plano de Bacia do Alto Tietê (COSTA; NUCCl; SILVA, 2012) $)^{128}$.

A defesa dessa escala de planejamento parte da premissa que os atuais problemas relacionados, direta ou indiretamente, com os recursos hídricos precisam de tratamento integrado de políticas setoriais e maior aderência a políticas territoriais, pois as atuais infraestruturas apresentam uma grande complexidade (sistema de abastecimento de água, coleta e tratamento de esgotos, estruturas de macrodrenagem, além da impermeabilização e uso e ocupação do solo) e não podem mais ser tratadas de forma dissociada. Além disso, a bacia do Alto Tietê já se relaciona

\footnotetext{
127 Ver artigo "Projeto desperta preocupação nos Comitês de bacias". Revista CEIVAP - Pelas águas do Paraíba, 2010, p.11-12.

128 Os autores argumentam que a visão de integração dos recursos hídricos com políticas urbanas territoriais começou com o Programa Mananciais em continuidade à experiência pioneira do Projeto Guarapiranga, que pela primeira vez estabeleceu objetivos correlacionados de melhoria urbana e recuperação da qualidade da água em operações multissetoriais e intergovernamentais. Em seguida a proposta de integração é aplicada também ao Plano de Bacia do Alto Tietê, ao Plano Diretor de Aproveitamento de Recursos Hídricos para a Macrometrópole Paulista e o Terceiro Plano Diretor de Macro Drenagem da Bacia do Alto Tietê - PDMAT 3 (Ibidem).
} 
intensamente com as bacias vizinhas, tanto na transposição para o abastecimento, como no controle de inundações ${ }^{129}$.

Contudo, apesar dos planos setoriais buscarem em suas propostas avanços na integração, na prática o que se percebe são melhorias ainda restritas a cada sistema, como por exemplo o aumento paulatino de índice de cobertura de rede de água e principalmente de esgotos; mas não em seu conjunto, como projetos integrados. Os impactos negativos dessa fragmentação, por sua vez, acirram os problemas urbanos como enchentes e a poluição dos recursos hídricos, como já comentado anteriormente.

Ainda não foi divulgado de que forma o governo estadual pretende implementar não só um plano mas uma gestão macrometropolitana, apesar dessa ideia já estar em desenvolvimento. Para Costa, Nucci e Silva (2012), a macrometrópole implica em novos desafios tecnológicos, gerenciais e institucionais, pois os atuais mecanismos e instrumentos estão postos em xeque. “Não se trata de uma simples expansão territorial da metrópole, mas de um novo patamar de complexidade territorial e funcional de interconexões, que exige ampla revisão de paradigmas de planejamento, operação, gestão e regulação."

Cabe ponderar que propostas semelhantes em termos de definição de escala de planejamento metropolitano que têm sido elaboradas desde o PBAT (PORTO; SILVA, 2003) não foram totalmente implementadas. Assim, ainda vale a crítica da falta de implementação de mecanismos básicos de decisão integrada e de caráter metropolitano (Ibidem, 2003).

Mas mesmo que aqui o tema seja tratado brevemente e de forma simplificada, buscamos evidenciar que a questão dos "mega planos" de abastecimento metropolitano não tem se articulado às políticas de desenvolvimento urbano, ficando pouco claro seu impacto nos territórios afetados, ao menos até o presente momento.

A decisão sobre a utilização dos reservatórios Billings e Guarapiranga para o abastecimento ou outros fins continua em pauta, pois ainda que a legislação específica recentemente promulgada defina a prioridade do abastecimento, a defesa dos múltiplos usos sem que se equacionem os problemas atuais entre as infraestruturas que impactam o recurso hídrico, acaba por abrir possibilidades de uso e ocupação que não são compatíveis com essa função. O resultado é a manutenção da disputa e dos usos concorrentes da água por diferentes setores econômicos, como o energético e o de saneamento.

\footnotetext{
${ }^{129}$ A Bacia do Alto Tietê relaciona-se a oeste com a Bacia do Médio Tietê/Sorocaba, para onde se dirige o fluxo natural do Rio Tietê. (...) Ao sul estabelece-se uma relação de descarga por meio do Reservatório Billings, que recebe o curso revertido do Rio Pinheiros. Em que pese a proibição legal de bombeamento de águas poluídas do Tietê para o Rio Pinheiros, as vazões de cheia bombeadas na estação úmida são significativas. (...) No sentido das nascentes do Tietê, a leste, para o trecho central da Bacia, na altura da foz do Rio Tamanduateí, o primeiro grande complexo de estruturas hidráulicas é formado pelos reservatórios do Sistema Produtor do Alto Tietê (SPAT), que desempenha também importante função de controle de inundações. Do ponto de vista da macrodrenagem, a sub-bacia de Cabeceiras, entre as nascentes do Rio Tietê em Salesópolis e a Barragem da Penha, é a área onde a detenção das ondas de cheia é mais vital para a integridade de toda a metrópole (COSTA; NUCCI; SILVA, 2012, p.106).
} 
No que se refere à bacia da Billings especificamente, sua ligação com o rio Pinheiros e o complexo de geração de energia em Henri Borden, faz com que os múltiplos usos desse manancial continuem tendo um papel estratégico na Bacia do Alto Tietê. Esse funcionamento e os consequentes conflitos de usos são descritos por Costa, Nucci e Silva (2012), que argumentam pela defesa de grandes infraestruturas como solução e uma visão conciliadora desses múltiplos usos, cujo trecho transcrevemos a seguir:

O fato de a mancha urbana da RMSP desenvolver-se integralmente ao longo da Bacia do Alto Tietê e de esta ter como única descarga natural o Médio Tietê - com grandes restrições trazidas pela própria dinâmica urbana da região - torna absolutamente crítica a operação de controle de cheias pelo Rio Pinheiros, única alternativa de conexão hídrica da Bacia, a jusante, que não o Médio Tietê. A reversão do Rio Pinheiros mediante bombeamento é conhecida mais por seu papel na geração hidrelétrica em Henry Borden do que pelos demais benefícios que gera. Hoje, no entanto, diante da escassez hídrica e da delicada situação da macrodrenagem metropolitana, não se pode desconsiderar os benefícios da ampliação da disponibilidade no Reservatório Billings, para abastecimento urbano, e o papel de alternativa à descarga natural do Alto Tietê a oeste, diante da situação crítica do Médio Tietê (Ibidem, p.102).

Em relação ao próprio aproveitamento energético em Henry Borden, uma visão estratégica macrometropolitana tenderá a revalorizar o papel daquela usina como elemento vital de segurança energética da região, como demonstrado no episódio do "apagão" de 10 de novembro de 2009, ao promover a imediata energização dos circuitos prioritários, entre eles, as principais bombas para controle de cheias na RMSP.

Além disso, não há uma política estruturada de proteção desses mananciais, visando garantir a água em quantidade e qualidade das nascentes e cursos d'água existentes, especialmente nas propriedades particulares onde estão preservadas pela vegetação remanescente; apesar de existirem alternativas técnicas e projetos nesse sentido, inclusive experiências implementadas em outras metrópoles ${ }^{130}$. Assim, a combinação entre a ausência de políticas de incentivo a proteção ambiental, e o insuficiente tratamento de esgotos implicam no aumento do custo de tratamento da água, piora da sua qualidade, e também no seu acesso (citar o Tuci - ISA). E a necessidade da busca por mananciais mais distantes se coloca como a principal alternativa sem que se pondere e se compare essa solução com outras possibilidades.

Diante desse quadro otimista em relação à capacidade institucional, ao propósito de integração de infraestruturas que raramente foram pensadas em conjunto, à superação dos conflitos existentes entre os usos múltiplos dos recursos hídricos e à necessidade de construção de grandes infraestruturas, algumas questões importantes se colocam, especialmente quando vistas em retrospectiva histórica, como ensaiamos aqui fazer, ou seja, verificar as distâncias entre planos urbanos e práticas concretas, entre a velocidade de reprodução do espaço precário e a insuficiente infraestrutura que o acompanha, e do passivo ambiental que esse modo de urbanizar a natureza, ainda que já seja uma natureza totalmente transformada pela ação humana, resulta.

\footnotetext{
${ }^{130}$ Ver em TAGNIN (2008) algumas dessas experiências.
} 
No caso das infraestruturas, a necessidade de visualizar as diferentes propostas em diferentes escalas, que são desarticuladas na concepção mas se encontram no espaço, é fundamental para que se possa ao menos compreender sua extrema fragmentação, em diversos níveis, o que coloca em contradição sua função básica e sistêmica. Não se trata contudo de uma leitura somente técnica, como este e os demais capítulos da tese buscarão abordar.

\subsection{0 sistema de tratamento de esgotos e seu impacto na bacia da Billings}

Em relação ao sistema de esgotos, com a quebra do fluxo de financiamento das obras pelo BNH, os investimentos em todo o sistema de coleta e tratamento ficaram parados até 1990. Nessa década há dois momentos importantes. Primeiro, a Revisão do Sanegran e depois a criação do Projeto Tietê, também chamado Plano Diretor de Esgotos da Sabesp.

De 1985 a 1987, pelo Consórcio COPLADES, foram realizados estudos para reavaliação do Sanegran e proposição de alternativas, num contexto de redirecionamento da ação da Sabesp, que nesse período teve como presidentes Gastão Bierrenbach, Nelson Nucci e João Luis Araújo (alguns dos idealizadores da Solução Integrada). Essa revisão visava reavaliar as projeções demográficas, de consumo, distribuição espacial dos incrementos populacionais e da atividade industrial e custo de implantação das obras; pois as projeções do Sanegran superestimavam as taxas de crescimento populacional, gerando distorções. Além disso, concluiu-se ser necessário ampliar o número de estações de tratamento de esgotos, evitando que todo o esgoto da porção leste da metrópole tivesse que cruzar a área urbana para alcançar a ETE Barueri. A ETE Barueri ${ }^{131}$ foi redimensionada e foram incluídas as ETEs Novo Mundo e São Miguel. Em relação ao esgoto industrial houve uma mudança de postura, atribuindo às médias e grandes indústrias os ônus do tratamento (BUENO, 1994, p.180-181).

Em 1989, o sistema de tratamento tinha capacidade instalada para tratar 18\% dos esgotos coletados na RMSP, sendo que a coleta abrangia 59\% dos domicílios (ANCONA, 2002, p.223). Havia poucos coletores-tronco e o impacto da poluição atingia a metrópole.

Em 1990, a poluição do rio Tietê mobilizou uma manifestação pública em defesa de sua despoluição, que foi liderada pela rádio Eldorado FM, jornal O Estado de São Paulo e pelo Jornal da Tarde, que organizaram um abaixo-assinado reunindo em um ano 1,2 milhão de assinaturas. A causa foi abraçada por SOS Mata Atlântica (que formou o Núcleo Tietê, com recursos do Unibanco), Fiesp e Secretaria Estadual do Meio Ambiente. A Câmara Municipal também aderiu à iniciativa, aprovando três moções de apoio à campanha que tinha o slogan "O Tietê pede água. Você não pode negar". Nesse momento, a questão ambiental estava em voga devido à Conferência Eco 92.

\footnotetext{
${ }^{131}$ ETE Barueri iniciou as operações em 11 de maio de 1988. Atualmente serve a maior parte da cidade de São Paulo e também atende os municípios de Jandira, Itapevi, Barueri, Carapicuíba, Osasco, Taboão da Serra e partes de Cotia e Embu. Fonte: http://site.sabesp.com.br/site/interna/Default.aspx?secaold=56, acesso: 06/12/2012.
} 
A mobilização teve efeitos práticos. Em 1992, o Governo do Estado passou a empreender, através da Sabesp, a Primeira Etapa do Projeto Tietê. O objetivo era ampliar a infraestrutura de coleta e tratamento de esgotos. Contudo, as obras só se aceleraram após a obtenção da renegociação do financiamento do BID, em 1995. Com isso entraram em operação as ETEs ABC, Parque Novo Mundo e São Miguel, em junho de 1998. Além disso, foram implantados $1.500 \mathrm{~km}$ de redes coletoras, $315 \mathrm{~km}$ de coletores-tronco, $37 \mathrm{~km}$ de interceptores e realizadas $250 \mathrm{mil}$ novas ligações domiciliares de esgotos até 1998, elevando o índice de coleta de 66\%, em 1992, para $78 \%$, em 1998, e o de tratamento de $24 \%$ para $63 \%$ no mesmo período (SABESP, 2010, p. 29). O combate à poluição industrial foi outro foco de ação do projeto ${ }^{132}$. Essa fase recebeu o financiamento de U\$ 1,1 bilhão, sendo U\$ 450 milhões financiados pelo BID, US\$ 450 milhões com recursos próprios da Sabesp e US\$ 200 milhões em financiamentos de outras fontes, como a Caixa Econômica Federal (Ibidem).

À luz da nova modulação proposta pelo Plano COPLADES, em 1999 a ETE Barueri foi reformulada e ampliada para tratar vazões de até $9,5 \mathrm{~m}^{3} / \mathrm{s}$ em um primeiro de três grandes módulos, ao passo que a ETE Pinheiros seria definitivamente desativada. Somados aos $3,0 \mathrm{~m}^{3} / \mathrm{s}$ da ETE ABC, aos 2,5 $\mathrm{m}^{3} / \mathrm{s}$ da ETE Parque Novo Mundo, aos $1,5 \mathrm{~m}^{3} / \mathrm{s}$ da ETE São Miguel e aos 1,5 m³ $/ \mathrm{s}$ da ETE Suzano, a capacidade nominal atual das ETEs do Sistema Principal da RMSP chegou aos atuais $18 \mathrm{~m}^{3} / \mathrm{s}$ (Ibidem).

Entre 1997 e 1999 foi realizada uma nova revisão do Plano Diretor de esgotos da RMSP, denominada PDE-2000. Como principais resultados desse trabalho a própria Sabesp destaca: a consolidação do Sistema Principal, com a manutenção da configuração das cinco ETES existentes, e a reversão de vazões de alguns dos Sistemas Isolados para o Sistema Principal.

\footnotetext{
132 Mais de 1.200 indústrias, correspondente a 90\% da carga poluidora industrial lançada no rio Tietê, aderiram ao Projeto. Site do Projeto Tietê: http://www.arcplan.com.br/rededasaguas/nucleo/projeto_tiete.htm, acesso: 12/2012.
} 


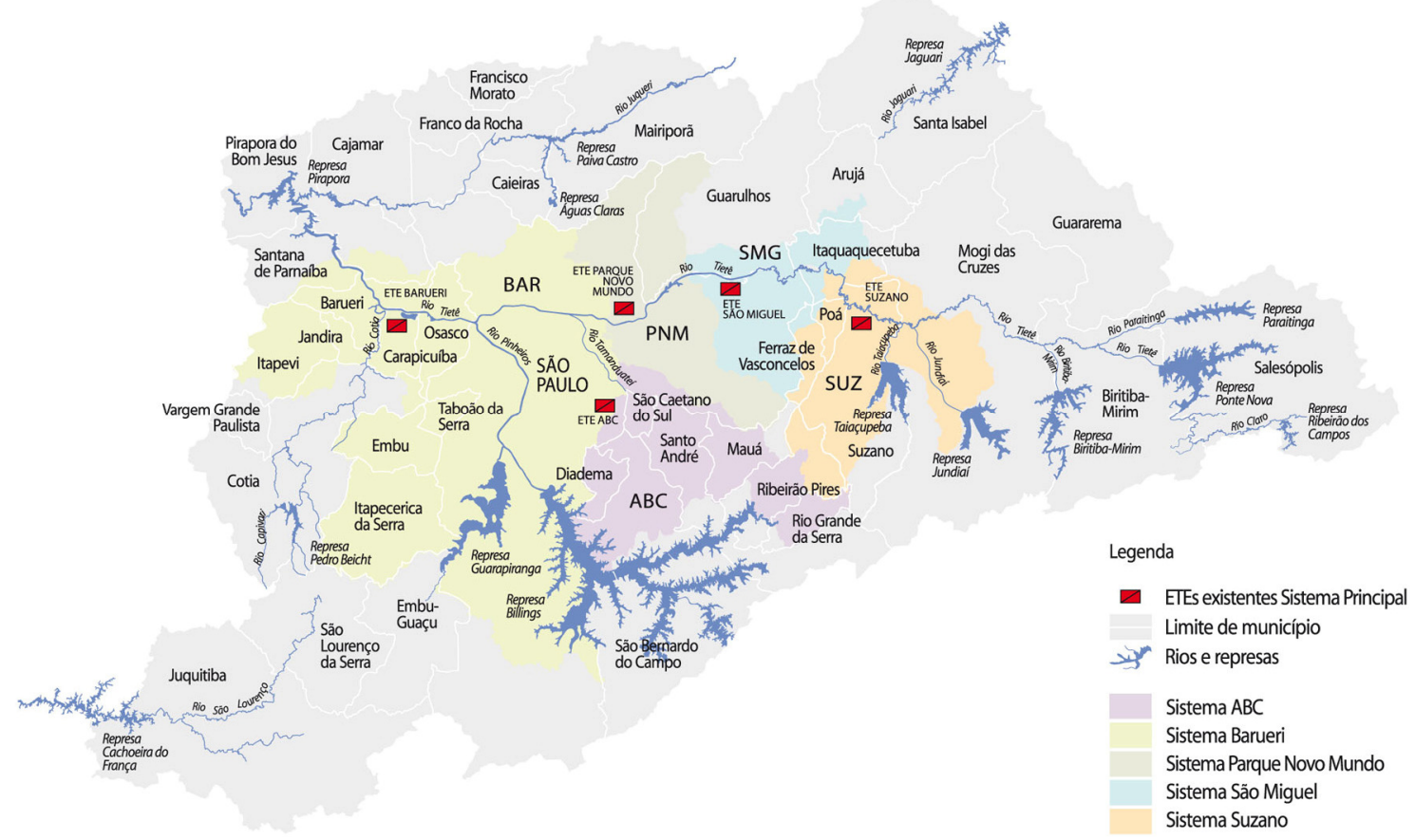

Mapa 7 - ETEs existentes e sistema principal, 2010.

Fonte: Plano Diretor de Esgotos, Sabesp, 2010, p. 40.

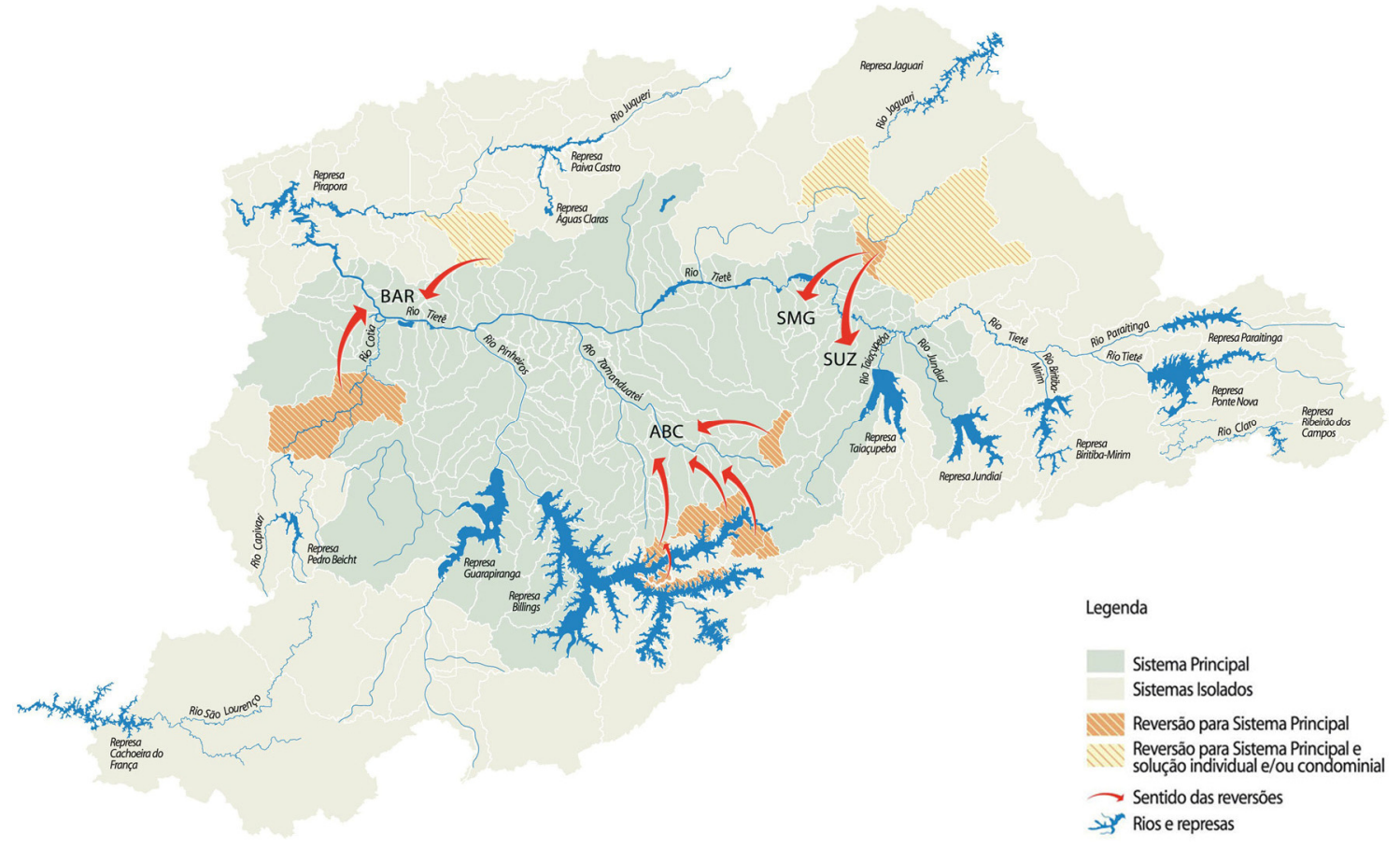

Mapa 8 - Reversão dos sistemas isolados.

Fonte: Plano Diretor de Esgotos, Sabesp, 2010, p. 76. 


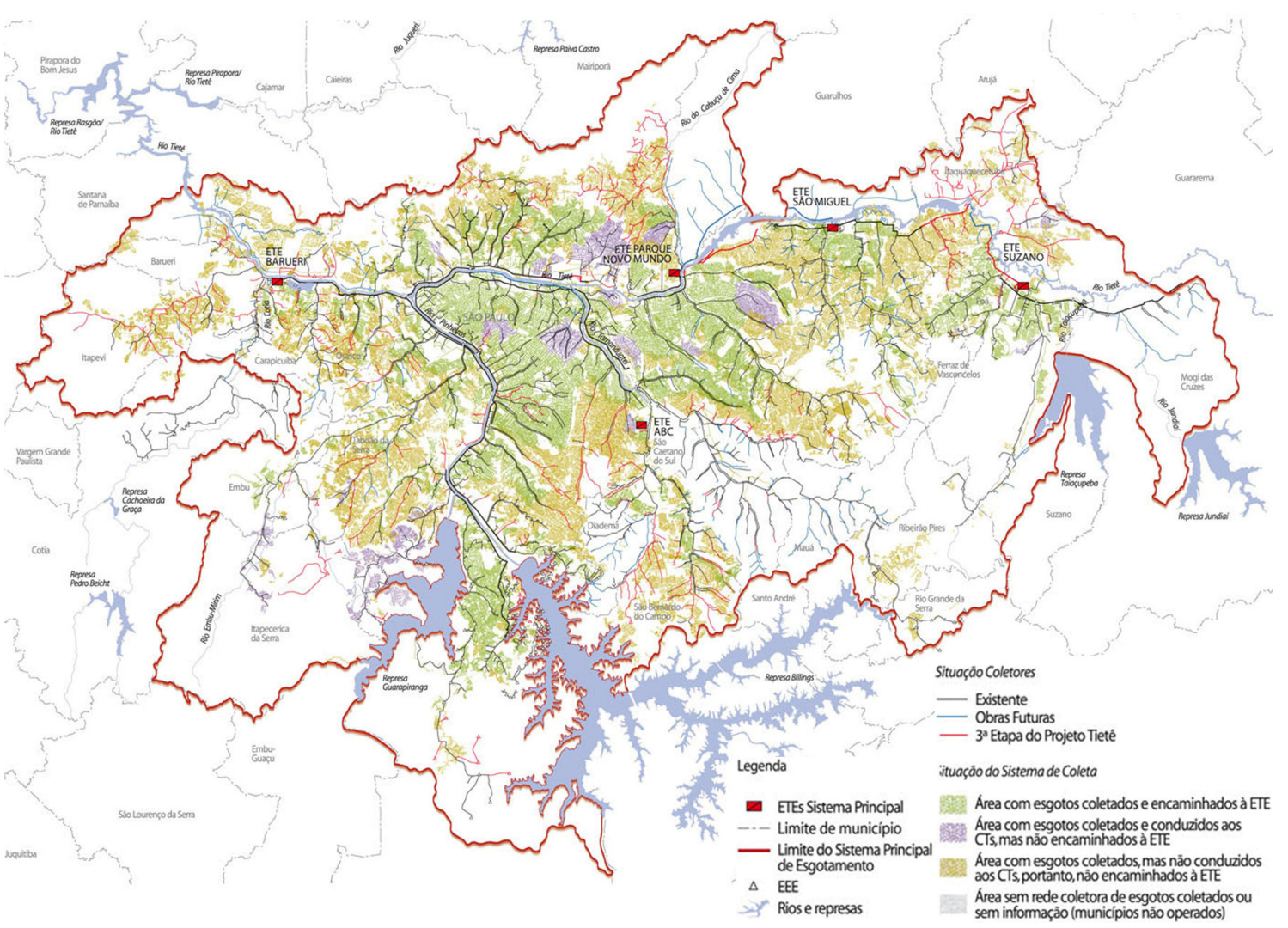

Mapa 9 - Situação atual do sistema de coleta de esgotos e encaminhamento para as ETEs.

Fonte: Plano Diretor de Esgotos, Sabesp, 2010, p. 76.

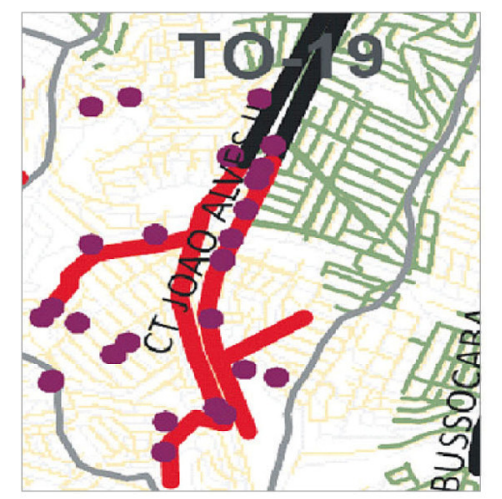

Redes Coletoras não Conectadas aos CTs

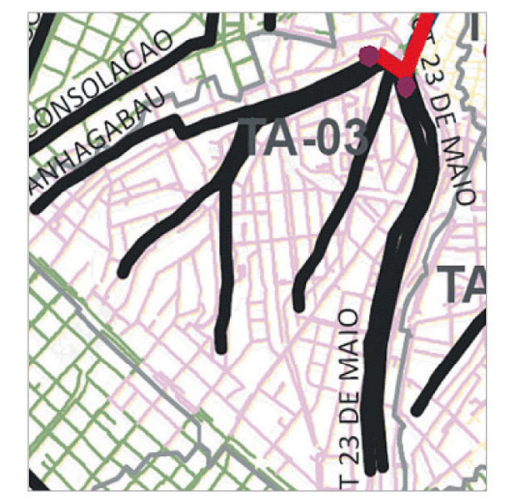

Redes Coletoras Conectadas aos CTs, mas os Esgotos não vão para Tratamento

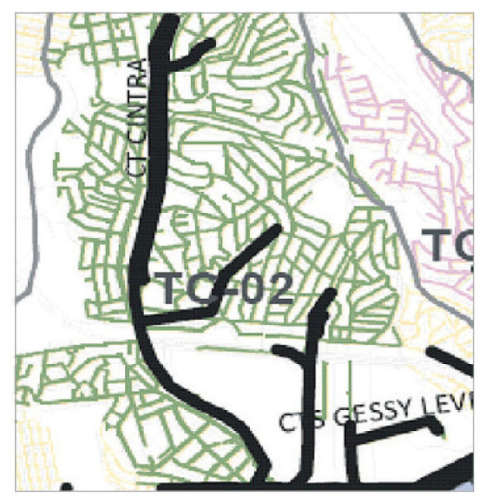

Redes Coletoras cujos Esgotos vão para Tratamento

Figura 14 - Esquemas dos coletores de esgotos.

Fonte: Plano Diretor de Esgotos, Sabesp, 2010, p. 68.

A 2a Etapa do Projeto Tietê teve início em 2000 e desenvolveu-se até 2008, com financiamento de U\$ 500 milhões. A expansão da rede de esgotos teve continuidade, mas o foco principal voltou-se à bacia do rio Pinheiros e entorno da represa Billings. As principais obras foram a Estação Elevatória de Esgotos Pomar (EEE Pomar) e a implantação dos interceptores IPi-6 e IPi-7. 
A 3a etapa do Projeto começou em 2010 e tem previsão de encerramento em 2015, com financiamento de U\$ 800 milhões, sendo U\$ 600 milhões do BID. O objetivo dessa etapa é aumentar a coleta e o tratamento de esgoto em 31 cidades. Faz parte da 3 a etapa do Projeto Tietê a extensão da rede de esgotos na área de proteção aos mananciais no município de São Paulo e também colabora para a extensão da rede coletora em outros municípios da bacia, como São Bernardo do Campo. Nesse município, a Sabesp estenderá a rede coletora de esgotos nas áreas de proteção aos mananciais por meio de financiamento do governo japonês - o Programa Pró-Billings - que pretende exportar os esgotos da bacia para a ETE ABC até 2018. Essa ETE tem previsão de ampliação, segundo Plano diretor de Esgotos da Sabesp.

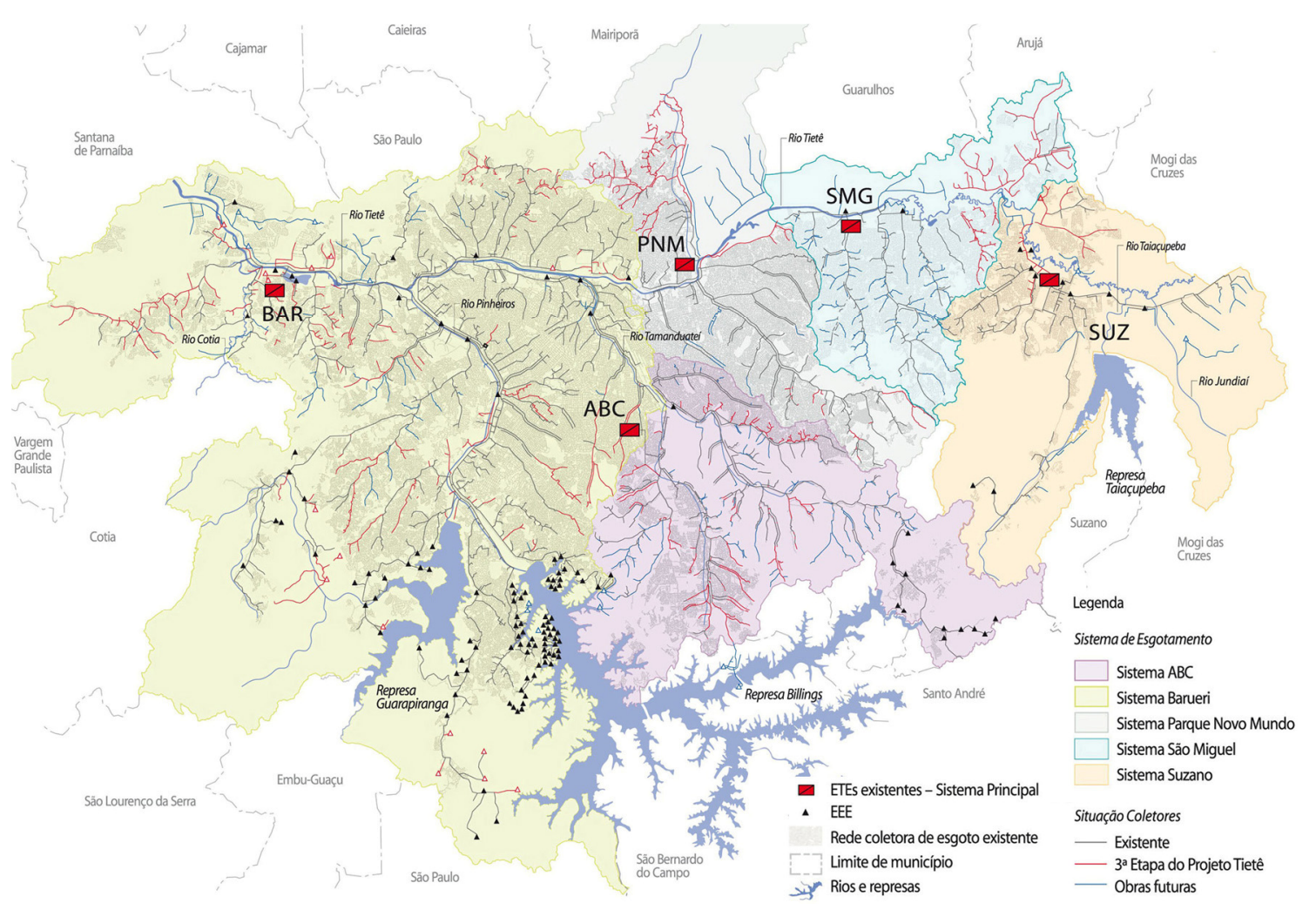

Mapa 10 - Sistema Atual e Projeto Tietê 3ạ etapa.

Fonte: Plano Diretor de Esgotos, Sabesp, 2010, p. 44. 


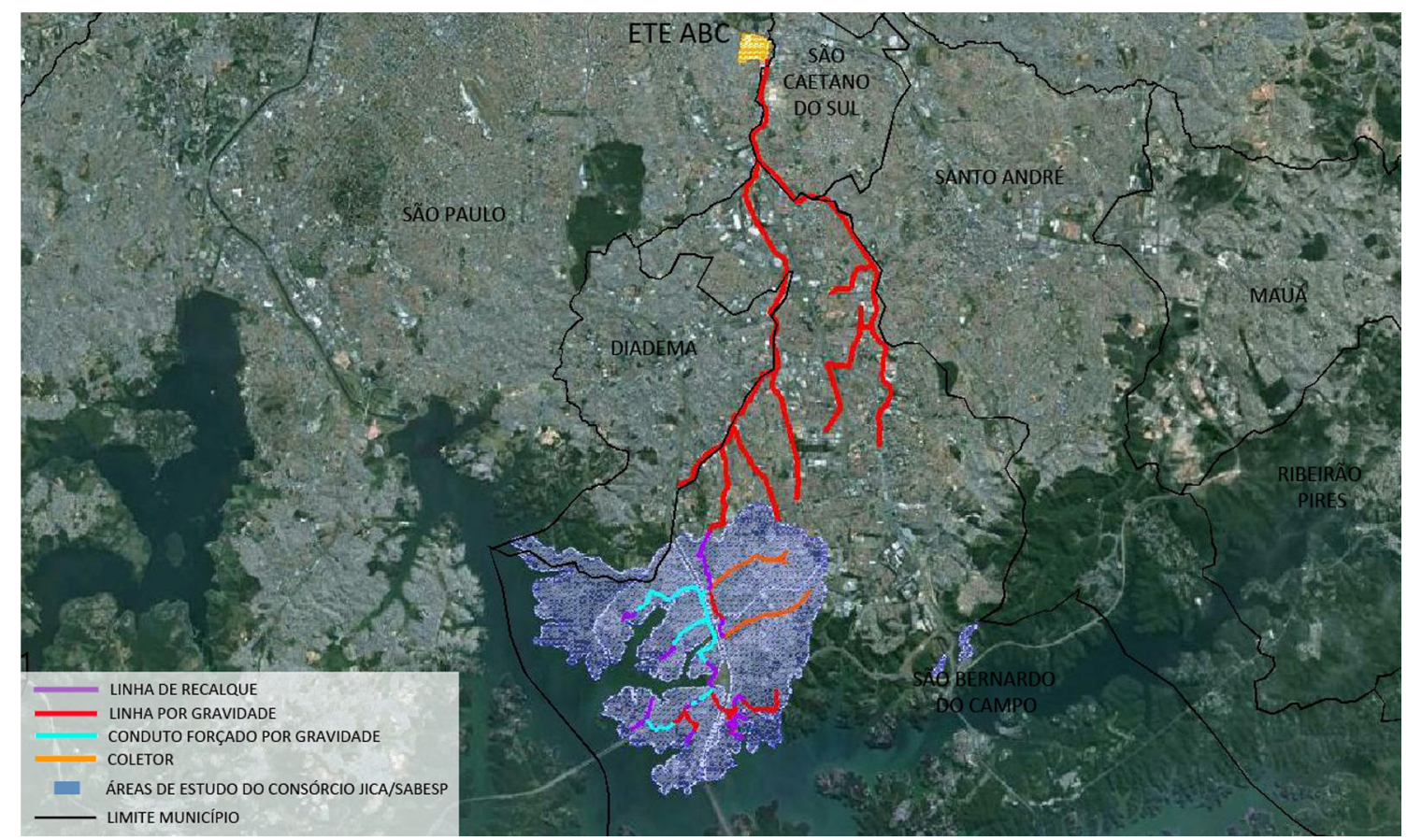

Mapa 11 - Área de atuação do Projeto Pró-Billings/Sabesp.

Fonte: Sabesp, 2012. Elaboração: a autora. Redesenho: Paula Custódio de Oliveira.

Ainda que o uso prioritário das represas nas últimas décadas seja o abastecimento público, o governo estadual buscou (e ainda busca) alternativas para voltar a reversão e aumentar a capacidade de geração de energia na Usina Henri Borden ${ }^{133}$. Para isso desenvolveu o projeto da Flotação ${ }^{134}$, que ficou impedido pela justiça durante 10 anos, e sofreu críticas contundentes de ambientalistas e especialistas do saneamento desde seu lançamento até seu abandono. O projeto foi implantado de 2008 a 2011 e consistia num tratamento dos esgotos no próprio leito do Rio Pinheiros, que tinha como objetivo melhorar a qualidade de água afluente à Billings e viabilizar a retomada de seu bombeamento ao reservatório. No entanto, os testes comprovaram a ineficiência do sistema quanto ao grau de tratamento exigido de despoluição e desinfecção. O projeto custou, em 10 anos e segundo dados divulgados na mídia, $\mathrm{R} \$ 160$ milhões ao governo paulista e à Petrobrás (que custeou R\$ 40 milhões), a perspectiva de adotá-lo em larga escala foi finalmente abandonada em 2011. No entanto, a busca de soluções se mantém, conforme Resolução SMA № 56, de 11 de outubro de 2011, que criou grupo de trabalho para análise e discussão de tecnologias aplicáveis ao tratamento de problemas relacionados ao odor e aos sedimentos do rio Pinheiros ${ }^{135}$.

\footnotetext{
${ }^{133}$ Segundo o Plano de Desenvolvimento e Proteção Ambiental (PDPA) da Billings, atualmente, a Usina Henry Borden tem capacidade de gerar cerca de 889 MW. Porém, devido às restrições no bombeamento, opera com capacidade media de $108 \mathrm{MW}$ e está sendo utilizada principalmente para suprir a falta de energia em horários de pico e situações emergenciais em São Paulo (SÃO PAULO, 2011, p. 12).

134 Programa instituído em 2000, na gestão de Ricardo Trípole na Secretaria de Estado do Meio Ambiente. Até hoje, Trípole defende o sistema, conforme matéria "Flotação foi 'experiência fantástica', diz Tripoli", Folha de São Paulo, Caderno Cotidiano, 01/10/2011.

135 Resolução publicada no Diário Oficial do Estado de 12-10-2011 Seção I p.59. Disponível em http://www.ambiente.sp.gov.br/legislacao/estadual/resolucoes/2011/56_111011.pdf, acesso em: 02/11/11.
} 
A proposta dessa tese é refletir sobre a construção de infraestruturas na bacia da Billings, considerando sua inserção nos demais planos e intervenções de saneamento que buscamos relatar, problematizando então o significado socioambiental, espacial e político que a recuperação das áreas de proteção aos mananciais tem assumido na prática. Um dos desafios é justamente articular a produção de infraestruturas em diferentes escalas e por diferentes atores - dos moradores à Sabesp; dos planos aos projetos de intervenção.

A ocupação do território da bacia da Billings e da Guarapiranga o constituiu em uma área de assentamento da população de baixa renda, resultado do processo de urbanização desigual, e da distribuição desigual dos investimentos das políticas de habitação e saneamento. Desse ponto de vista, a área dos mananciais assemelhasse a outras áreas periféricas da RMSP. Mas a análise da atual configuração espacial das ocupações da bacia, bem como da própria bacia enquanto manancial, não pode se desligar do histórico da configuração e extensão das redes de infraestrutura, o que coloca em evidência um panorama de conflitos que provocam uma reflexão sobre a questão ambiental urbana e como considerá-la para além do discurso ambiental, e dos limites do recorte geográfico da bacia hidrográfica.

Apesar da especificidade normativa e da finalidade prioritária de abastecimento público das áreas de proteção aos mananciais, o histórico dessas áreas quando situado no processo de urbanização e metropolização explicita que a água enquanto recurso está em disputa, ainda que esta disputa não ecloda frente à sociedade com toda a complexidade socioambiental que representa, nem traga à tona claramente os interesses em questão de forma simultânea. 
PARTE II 



\section{PARTE II}

\section{A construção social do ambiente urbano precário a partir do processo de consolidação de loteamentos irregulares em área de proteção aos mananciais: da autoprovisão de infraestruturas aos planos de urbanização}

Essa segunda parte da tese, composta pelos capítulos 4, 5 e 6, trata da construção do ambiente urbano precário a partir das infraestruturas urbanas ${ }^{1}$, analisadas sob o enfoque de sua dimensão socioambiental e política. Para isso, recupera-se o processo de formação dos loteamentos irregulares nas áreas de proteção aos mananciais (APM), na bacia da Billings, no município de São Bernardo do Campo, particularmente a partir do final da década de 1980, quando apresentaram crescimento significativo. Focalizam-se as múltiplas dimensões das relações sociais com o meio físico e o ambiente urbano resultante da apropriação ilegal da terra, os agentes envolvidos nesse processo, bem como as mudanças de concepção e de ação política do poder público municipal sobre o conflito entre ocupação urbana versus proteção ambiental, presentes nesse território.

Além da questão fundiária, que fundamenta o conflito pelo espaço da moradia de interesse social e sua mercantilização, no estudo desse processo destacou-se a importância das redes de infraestruturas como elementos de qualificação do ambiente urbano, tanto na escala local dos loteamentos quanto na escala metropolitana, ou seja, como condição de recuperação ambiental das águas afluentes à represa Billings. Em área de proteção aos mananciais a consolidação e infraestruturação das ocupações irregulares explicitam contradições relevantes do ponto de vista da produção desse espaço, em diferentes escalas. É justamente nesse sentido que a presente tese privilegia o estudo do processo de construção das infraestruturas urbanas em área de manancial.

Os capítulos seguintes tratam das questões relativas às redes de infraestrutura articuladas ao problema da moradia, em diferentes momentos da consolidação dos loteamentos - da autoprovisão pelos moradores à chegada das redes públicas - mostrando como se reproduz, nas décadas recentes, descompassos e desigualdades constituídos historicamente (como tratado na primeira parte da tese), apesar de apresentar contornos específicos.

\footnotetext{
${ }^{1}$ Particularmente as relacionadas diretamente às águas, ou seja, as redes de abastecimento de água, coleta e tratamento de esgotos e drenagem - apesar dessa última ser abordada com menor aprofundamento.
} 
Os capítulos baseiam-se no processo e nos resultados de diferentes momentos da pesquisa empírica, que se estruturou fundamentalmente na observação participante ${ }^{2}$ nos loteamentos do baixo Alvarenga, durante a qual foram utilizados métodos variados, tais como entrevistas individuais e coletivas, levantamento fotográfico, cartografias comunitárias, participação em reuniões de moradores. Também foram utilizadas fontes documentais, como o processo da Comissão Parlamentar de Inquérito sobre os loteamentos irregulares da Câmara de São Bernardo, matérias de jornal, partes das ações civis públicas e Termos de Ajustamento de Conduta - TACs, dos loteamentos estudados.

Complementarmente, objetiva-se mostrar que, do momento de ocupação mais intensa, passando pela consolidação dos loteamentos até a busca de alternativas de projetos visando a recuperação ambiental, a interpretação da legislação e a própria legislação urbana e ambiental alteraram-se, marcando momentos de mudança no tratamento do conflito nas áreas de mananciais. Busca-se demarcar esses momentos, nos quais a relação com a água e a noção de meio ambiente é moldada por posições e práticas heterogêneas e contraditórias do poder público, do mercado imobiliário e da população.

Sendo assim, os capítulos se alternam entre tratar a especificidade dos loteamentos estudados e o contexto urbano e socioambiental municipal, a partir de uma perspectiva mais ampla, mostrando que os casos estudados exemplificam um processo geral e tendências de reprodução do espaço urbano contemporâneo.

Dessa forma, nessa segunda parte da tese busca-se explicitar, a partir da materialidade dos problemas urbanos em áreas de fragilidade ambiental e vulnerabilidade social, o quadro de injustiça espacial e socioambiental e seu contraponto político, ou seja, as possibilidades da justiça ambiental.

\footnotetext{
${ }^{2}$ A observação participante foi empregada como método na medida em que expressa o engajamento da pesquisadora com seus informantes como pessoas ao invés de objetos. Mas como pondera Geertz (1989, p.14), essa noção pode levar o antropólogo "a bloquear da sua visão a natureza muito especial, culturalmente enquadrada, do seu próprio papel e imaginar-se algo mais do que um interessado (nos dois sentidos da palavra) temporário" e assim se transformar em "fonte de má fé". Apesar do trabalho de pesquisa não se propor etnográfico, no sentido de Geertz, buscou-se na antropologia referências que pudessem colaborar na vivência da pesquisa empírica da tese e na sua interpretação.
} 


\section{CAPÍTUL0 4}

\section{A emergência do loteamento irregular nas áreas de proteção aos mananciais como solução habitacional em São Bernardo do Campo (1950 - 1990)}

Esse capítulo se inicia situando um panorama da ocupação habitacional de baixa renda em área de proteção aos mananciais em São Bernardo do Campo no quadro mais amplo da política habitacional municipal, evidenciando como essas áreas se tornaram frente de expansão urbana do município. Nesse percurso, destaca-se o início dos anos 1990, quando os loteamentos irregulares ${ }^{3}$, clandestinos ${ }^{4}$ e ocupações de terra ${ }^{5}$ emergiram como um conflito nas áreas de proteção aos mananciais nesse município.

Do ponto de vista legal, trata-se de um conflito que explicita a inadequação da legislação urbanística e ambiental, vigente no período, diante da realidade de desigualdade social que, combinada ao interesse econômico do mercado informal (ou ilegal) de terras e à condescendência do poder público, tornou-a inaplicável ante o padrão precário dos assentamentos. Além da demanda habitacional não atendida pelo mercado ou pelo Estado, especialmente no contexto de poucos investimentos em políticas urbanas nos anos 1990, a ocupação das APMs corresponde também ao processo de valorização fundiária e imobiliária da RMSP, cuja consequência foi a ocupação irregular de áreas distantes dos centros urbanos onde há maior fragilidade ambiental.

Em seguida, aborda-se em maior detalhe o processo de construção de seis loteamentos irregulares, localizados no baixo Alvarenga, em São Bernardo do Campo, nos quais desenvolvemos a pesquisa empírica dessa tese. Identificamos a articulação dos agentes envolvidos, os processos de obtenção da gleba e suas estratégias de venda, e a forma urbana resultante. Considera-se que recuperar esse processo é ponto de partida para debater as questões propostas nessa tese.

\footnotetext{
3 Considera-se loteamento irregular o empreendimento que recebeu algum tipo de aprovação pelos órgãos competentes, em alguma das fases do processo de licenciamento, mas não o concluiu.

${ }^{4}$ Considera-se loteamento clandestino aquele que foi implantado totalmente sem ser dado o conhecimento aos poderes públicos.

${ }^{5}$ Considera-se ocupação de terra o movimento político e organizado de ocupação de terra pública ou privada, conforme adotado pelos movimentos organizados de luta por moradia. Diferencia-se da invasão por se tratar de uma organização coletiva com caráter reivindicatório de acesso à terra e à habitação.
} 


\subsection{Crescimento urbano e ocupação dos mananciais em São Bernardo do Campo}

Como abordado no capítulo 3, o município de São Bernardo do Campo passa a ter maior crescimento após 1950, com a instalação das indústrias automobilística e química, atraídas pela oferta de áreas disponíveis e pela construção de rodovias, primeiro a Anchieta em 1947 e depois a Imigrantes nos anos 1970. A urbanização se desenvolveu ao longo dessas vias. Entre 1950 e 1960 o município passou por um significativo aumento demográfico ${ }^{6}$ sendo que no quadro econômico as transformações foram ainda mais radicais, com aumento expressivo da produção industrial ${ }^{7}$ (VILLAÇA, 1966).

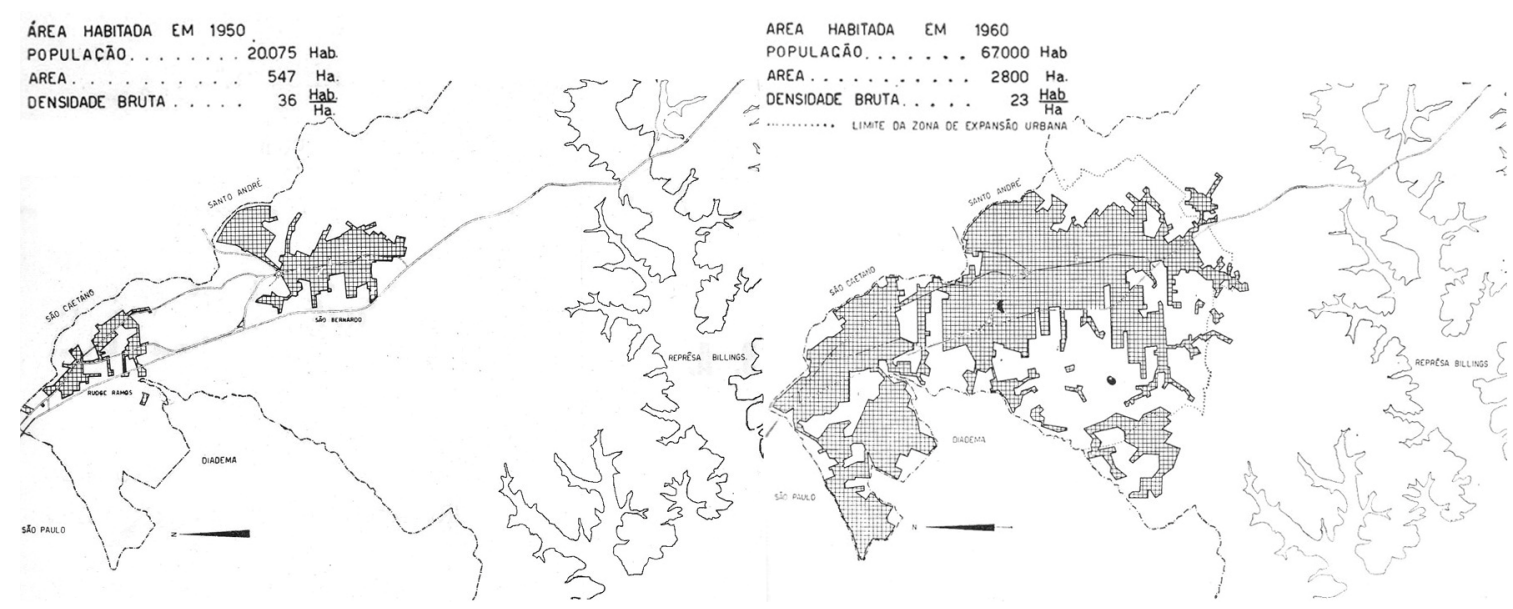

Mapa 12 - Área habitada de SBC em 1950.

Mapa 13 - Área habitada de SBC 1960.

Fonte: Revista Engenharia Municipal, no 26, ano X, São Paulo, p. 21 - 47, 1966.

Até 1955, é justamente a implantação das indústrias que vai dirigir o processo de parcelamento do solo, que se caracterizou pela abertura de grandes loteamentos, cujas dimensões e quantidade ultrapassaram as necessidades de assentamento da população em novas áreas urbanas (BARRETO; SÓCRATES; TANAKA, 1976). Segundo as autoras, isso foi motivado pelas expectativas de demanda potencial e de valorização dessas áreas, o que pode ser visualizado no mapa 14, que evidencia a área loteada maior que a ocupada, nesse período. A ocupação urbana e a localização dos loteamentos nessa fase concentrou-se em Rudge Ramos, no Centro ${ }^{8}$ e a oeste ao longo da rodovia Anchieta, na periferia da zona urbana, cuja característica era a baixa densidade demográfica (ver mapa 15 com a sequência de abertura dos loteamentos).

\footnotetext{
${ }^{6}$ A população total (urbana mais rural) em 1950 era de 26.272 habitantes e em 1960 de 84.411 , sendo o crescimento de 213\% (VILLAÇA, 1966 p.21).

7 O valor da produção industrial do município em 1949 era apenas 8,12\% do valor total da produção do $A B C$ e em 1959 passou a ser 34,10\% (Ibidem, p.23).

8 Já na década de 1920, Rudge Ramos tinha posição privilegiada pois se localizava no entroncamento do Caminho do Mar com a Estrada do Vergueiro, onde foram abertos loteamentos de porte médio. Entre 1920 e 1930 a abertura de loteamentos também ocorreu nas proximidades do Centro. Até 1960 essas serão as duas principais áreas de concentração populacional do município (BARRETO; SÓCRATES; TANAKA, 1976).
} 


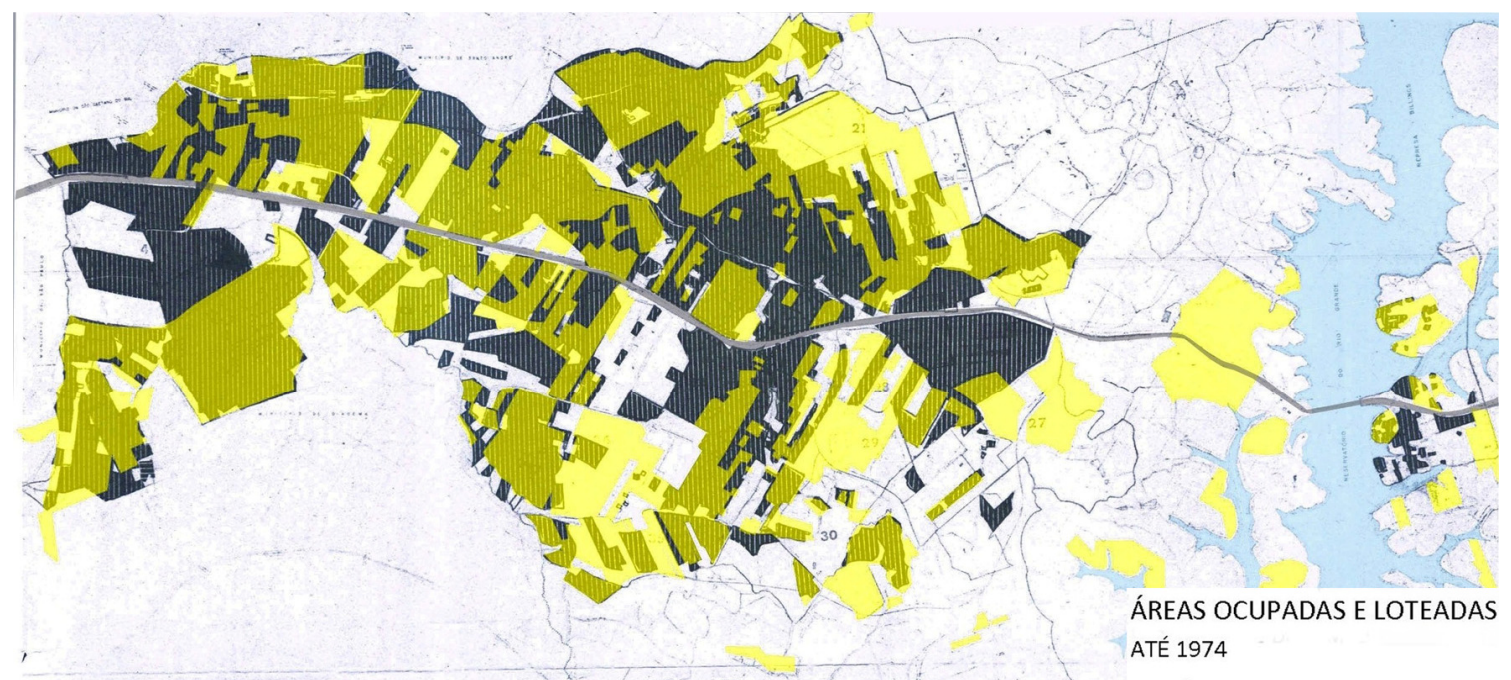

$\square$ Áreas ocupadas Áreas loteadas

Mapa 14 - Áreas ocupadas e loteadas até 1974.

Fonte: Relatório de pesquisa: Loteamentos em São Bernardo do Campo, FAU-USP, 1976. Redesenho: Paula de Oliveira (mapas 14, 15 e 16).

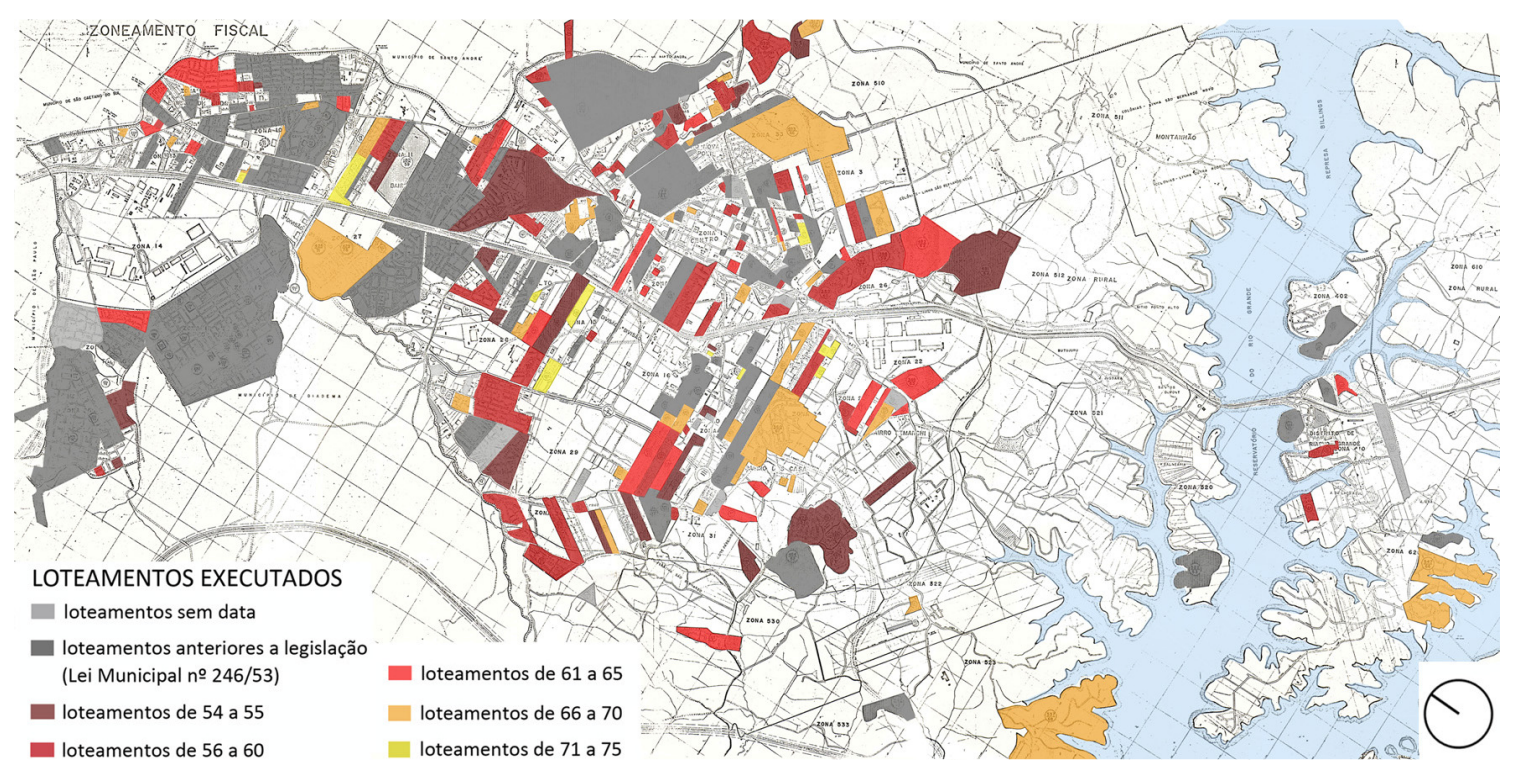

Mapa 15 - Loteamentos urbanos executados, por período.

Fonte: Relatório de pesquisa: Loteamentos em São Bernardo do Campo, FAU-USP, 1976.

No período seguinte, de $1956^{9}$ a 1975 , momento de expansão da indústria e instalação de indústrias de apoio, com aumento significativo da população devido à chegada de trabalhadores de outros estados, o movimento de abertura de loteamentos teve continuidade, abrangendo outros bairros (Ibidem, 1976, p.43), integrando assim uma mancha contínua de ocupação. Contudo, um diagnóstico realizado em 1975 pela Progresso de São Bernardo do Campo S.A. PROSBC para a obtenção de recursos do Projeto Comunidades Urbanas para Recuperação

\footnotetext{
${ }^{9}$ Em 1956 a lei municipal no 533 definiu normas para os loteamentos residenciais da cidade e para sua aprovação (RAKAUSKAS, 2012, p.35).
} 
Acelerada - CURA (BNH), mostra que esse crescimento urbano não foi acompanhado da expansão de redes de infraestrutura (mapa 16).

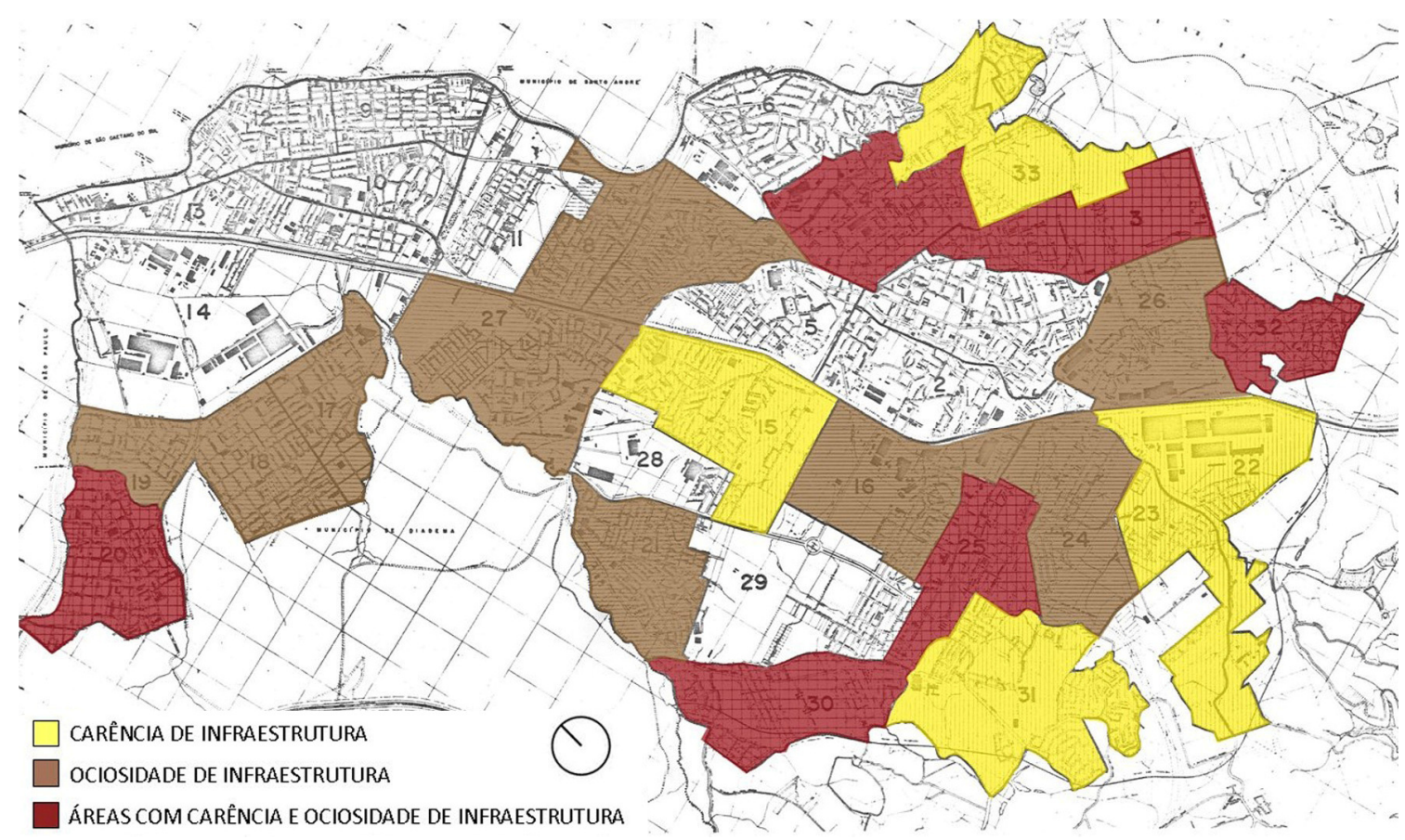

Mapa 16 - Situação de infraestrutura em zonas fiscais de São Bernardo do Campo - Projeto CURA, 1977

Carência de infraestrutura: área que apresentavam satisfatório índice de utilização do solo, não possuindo, porém, uma rede de infraestrutura suficiente. Ociosidade de infraestrutura: caracterizava-se pelo grande número de lotes vazios, servidos por rede de infraestrutura. Áreas com carência e ociosidade de infraestrutura: nessas áreas havia população onde não havia infraestrutura e esta servia principalmente aos lotes vagos.

Fonte: Progresso de São Bernardo do Campo S.A - PROSBC. Projeto CURA - Plano Plurianual, 1977.

Nesse período que antecedeu a promulgação da Lei Estadual de Proteção aos Mananciais (em 1975), as cartografias oficiais do município frequentemente não representavam a porção ao sul da represa Billings, o que mostra que essa área era pouco ocupada e pouco significativa em termos de intervenção do poder público municipal, pois era considerada zona rural ${ }^{10}$ e seu uso estava mais associado às atividades recreativas como clubes de campo e chácaras.

Nessa década, o município tinha um parque industrial de importância, e apresentava desenvolvimento econômico superior ao de outros municípios da RMSP ${ }^{11}$. A prefeitura apresentava um aparelho burocrático e administrativo estruturado, com diversas empresas de economia mista atuando nos serviços públicos. Mas como constatou Maricato (1977), essa

\footnotetext{
${ }^{10}$ Conforme lei municipal no 913/1961, a zona urbana correspondia ao distrito sede e a zona rural correspondia ao distrito de Riacho Grande, exceto a zona suburbana, e abrangia uma área muito mais extensa do que a zona urbana. $\mathrm{O}$ Plano Diretor de 1962 (lei no 1050/1962) considerou a zona urbana como perímetro de aglomeração, ou de expansão, urbana e a zona rural como área externa ao perímetro de aglomeração urbana. Desse plano participaram Flavio Villaça e Héctor J. Arroyo e seu objetivo era reverter o crescimento espraiado da cidade, adensando a área urbana. Já em 1972, um novo zoneamento (lei no 1980/1972) estabeleceu, ao norte da represa Billings, uma zona rural e uma zona de recreio, ambas inseridas na APM, definidas poucos anos depois (RAKAUSCAS, 2011).

${ }^{11}$ Em 1977 o município de São Bernardo do Campo tinha a maior arrecadação municipal no país proporcionalmente a sua população (MARICATO, 1977).
} 
municipalidade "rica" contrastava com a população "pobre", pois todo esse aparato institucional não garantia melhores condições de vida aos trabalhadores. Não é por acaso que um dos mais importantes movimentos sindicais foi organizado no ABC.

No que se refere à habitação, a maioria da população construía sem qualquer esclarecimento acerca da legislação e não recebia assistência técnica sobre condições de insolação, iluminação e salubridade, apesar da existência de técnicos, na Secretaria do Planejamento e na Secretaria de Obras; de a Secretaria de Saúde e Promoção Social ter, em 1974, um organismo dedicado à questão das favelas (CAP) e de haver a empresa mista de habitação (PROCAP - Casas Populares de São Bernardo do Campo S.A.).

Além disso, apesar da quantidade de área disponível, grande parte dos loteamentos não foi adquirida pela população de baixa renda no chamado mercado imobiliário formal. O surgimento de favelas no município, acompanhando o movimento no ABCD, deu-se ao longo nos anos 1960 e cresceu na década seguinte. Segundo Kowarick (1979, p. 38), em São Bernardo do Campo o número de favelados passou de 281 mil em 1974 para 374 mil em 1978, o que representava 9,1\% da população do município. Em Diadema havia cerca de 12.750 favelados, correspondendo a $9 \%$ de sua população. No município de São Paulo, no mesmo ano, havia cerca de 500 mil favelados.

Em 1974, os trabalhadores que conseguiam comprar lotes e apresentavam devida documentação de propriedade, todavia, não tinham recursos para construir uma moradia de qualidade, sendo predominante a presença de barracos precários, assemelhando esses assentamentos às favelas (MARICATO, 1977, p.58).

Além do rápido crescimento populacional por que passaram os municípios do $A B C D$, sem que houvesse uma resposta pública para a questão da moradia, até a Constituição de 1988, a esfera federal concentrava a arrecadação de impostos e as prefeituras não tinham recursos próprios para investir em habitação. Segundo Kfouri (1992), nessas circunstâncias, até 1989, os municípios do $A B C D$ paulista não atuavam diretamente e de forma significativa na política habitacional de interesse social.

Em São Bernardo do Campo, por exemplo, na década de 1980, a política municipal era principalmente a produção de lotes urbanizados (atendimento de 5.046 unidades), viabilizados com recursos próprios, e pouquíssima produção de unidades habitacionais com recursos estaduais (50 unidades habitacionais) (SÃO BERNARDO, 2010b, p.71).

A partir de 1989, porém, ocorre uma distinção entre os municípios do $A B C D$ no que tange a execução da política habitacional. Mauá, São Caetano, Ribeirão Pires e Rio Grande da Serra continuaram a não reconhecer o problema e a não realizar empreendimentos habitacionais ou ações setoriais especificas nesse campo. Já Santo André, São Bernardo do Campo e Diadema, que elegeram prefeitos do Partido dos Trabalhadores - PT, e levantavam a bandeira do direito à habitação, passam a estruturar suas Secretarias de Habitação e a realizar programas habitacionais, com mais recursos próprios do que federais (do Sistema Financeiro Habitacional) (KFOURI, 1992). 
A ênfase da atuação desses municípios era a urbanização de favelas (implantação de infraestrutura urbana e regularização fundiária), a produção de lotes urbanizados e o apoio à construção comunitária ou mutirão. Essas gestões foram consideradas democráticas por seu caráter de abertura à participação popular na formulação e execução de programas e políticas urbanas, particularmente a habitacional.

No município de São Bernardo, uma das primeiras experiências de construção em regime de mutirão foi o projeto da Vila Comunitária, em 1985, realizado após muita reivindicação e mobilização dos moradores de favela, que se organizaram em uma associação para adquirir um terreno em negociação com a Cúria Metropolitana e a prefeitura. Desde a concepção do projeto até a realização da obra a Associação de Construção Comunitária por Mutirão contou com a assessoria técnica voluntária de arquitetos $^{12}$ que já trabalhavam com experiências autogestionárias em habitação. Por se tratar de um caso excepcional no município, e para que o empreendimento fosse realizado, a prefeitura aprovou a lei municipal no 2667 de 27 de março de 1985, autorizando sua construção e definindo diretrizes para o projeto urbanístico e de edificação (PINHATA, 1987).

O projeto da Vila Comunitária foi um dos primeiros no qual a constituição de uma associação de moradores foi a solução encontrada para a aquisição coletiva e organizada de terra, o que foi feito também por outros grupos, posteriormente. Mas apesar das experiências exitosas de organização comunitária como essa, o modelo foi apropriado nos anos seguintes por interesses privados na produção de loteamentos irregulares, particularmente em área de proteção aos mananciais (APM), descaracterizando o papel político e reivindicatório que tais arranjos representavam. Essa questão será retomada adiante, no capítulo 5.

Em relação à atuação pública na habitação, a década de 1990 apresenta maior número de atendimento em relação à década anterior, com a participação de recursos do Governo Federal e da esfera Estadual. Além da produção de lotes urbanizados, aumentam a construção de novas unidades e o atendimento de situações emergenciais com assentamentos provisórios (SÃO BERNARDO, 2010b).

Tabela 3 - Produção Habitacional do município de São Bernardo do Campo, na década de 1990.

\begin{tabular}{lccccc}
\hline & $\begin{array}{c}\text { Lote } \\
\text { urbanizado }\end{array}$ & $\begin{array}{c}\text { Lote urbanizado } \\
\text { + cesta de } \\
\text { material }\end{array}$ & $\begin{array}{c}\text { Unidade } \\
\text { Habitacional } \\
\text { nova }\end{array}$ & $\begin{array}{c}\text { Assentamento } \\
\text { provisório }\end{array}$ & $\begin{array}{c}\text { Total de } \\
\text { atendimento }\end{array}$ \\
\hline Municipal & 10.442 & 117 & 268 & 580 & 11.407 \\
Estadual & - & - & 125 & - & 956 \\
Federal & - & - & 400 & - & 400 \\
\hline
\end{tabular}

Fonte: Secretaria de Habitação de São Bernardo do Campo, 2010³. Diagnóstico do Plano Municipal de Habitação (mimeo).

\footnotetext{
${ }^{12}$ Os arquitetos que assessoram o projeto e obra da Vila Comunitária foram Laila Mourad e Leonardo Pessina.

13 As tabelas-síntese apresentadas, produzidas com dados da SEHAB/PMSBC, correspondem somente aos atendimentos que possuíam data de entrega e número de unidades beneficiadas.
} 
Mas, esse atendimento habitacional continuou não oferecendo solução para o conjunto da demanda do município. Em 1989, São Bernardo do Campo apresentava um déficit de 40 mil moradias e havia 25.628 barracos distribuídos em 100 favelas $^{14}$. Nesse momento, a ocupação sobre as áreas de proteção aos mananciais foi bastante expressiva, como mostram a tabela e o mapa a seguir.

Tabela 4 - População nas áreas de proteção aos mananciais por bairro, São Bernardo do Campo, 1980 a 2009.

\begin{tabular}{|c|c|c|c|c|c|c|}
\hline BAIRRO & 1980 & 1991 & 1996 & 2000 & $2008^{(1)}$ & $2009^{(1)}$ \\
\hline Alves Dias (parte) & 872 & 2.631 & 3.372 & 3.908 & 4.226 & 4.151 \\
\hline Balneária & 441 & 451 & 623 & 606 & 647 & 643 \\
\hline Batistini & 6.742 & 12.089 & 24.581 & 27.655 & 31.893 & 31.117 \\
\hline Botujuru (parte) & 1.500 & 2.278 & 3.022 & 2.970 & 3.610 & 3.790 \\
\hline Cooperativa (parte) & - & 763 & 8.114 & 9.024 & 12.331 & 12.969 \\
\hline Demarchi (parte) & - & 2.807 & 4.636 & 4.711 & 5.203 & 5.295 \\
\hline Dos Alvarenga & 7.781 & 27.974 & 43.569 & 54.585 & 69.025 & 71.391 \\
\hline Dos Casa (parte) & 22.802 & 24.910 & 36.159 & 38.559 & 44.174 & 45.150 \\
\hline Dos Finco & 2.229 & 5.738 & 7.988 & 9.435 & 11.504 & 11.841 \\
\hline Montanhão (parte) & 257 & 3.934 & 7.351 & 9.504 & 13.008 & 14.228 \\
\hline Rio Grande & 4.210 & 4.894 & 5.379 & 6.429 & 7.914 & 8.138 \\
\hline Total Zona Urbana & 46.834 & 88.469 & 144.794 & 167.386 & 203.535 & 208.713 \\
\hline Zona Rural & 3.290 & 5.604 & 10.900 & 12.169 & 13.863 & 13.980 \\
\hline Total geral & 50.124 & 94.073 & 155.694 & 179.555 & 217.398 & 222.693 \\
\hline
\end{tabular}

(1) Estimativa. Fontes: IBGE/Censos Demográficos; PMSBC/Secretaria de Orçamento e Planejamento Participativo (estimativas). Extraído de Sumário de Dados 2010 - São Bernardo do Campo, p.78.

\footnotetext{
${ }^{14}$ Fonte: Folha de São Paulo, SP ABCD, Caderno Cidades, “Ocupações agravam situação em São Bernardo", 10 de janeiro de 1991, p. J-4.
} 


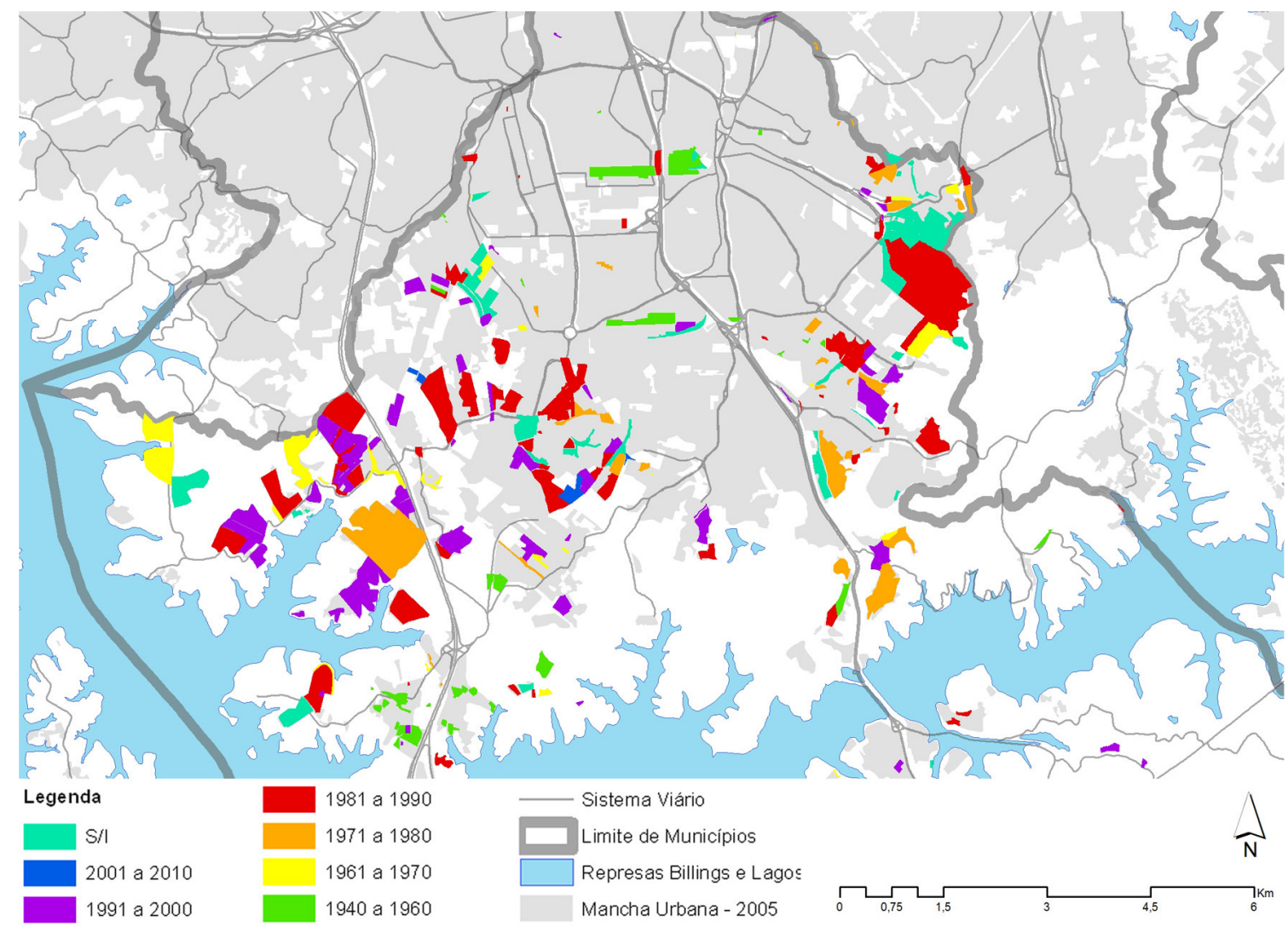

Mapa 17 - Assentamentos precários segundo período de ocupação inicial.

Fonte: Secretaria de Habitação de São Bernardo do Campo. Mapeamento, caracterização e hierarquização dos assentamentos precários e irregulares de São Bernardo do Campo, 2010a. As informações utilizadas foram obtidas em entrevistas com moradores e comparadas com documentação disponível de cada área. Dados reelaborados pela autora. Produção do mapa: Mariana Guimarães.

Tabela 5 - Período inicial da ocupação por tipo do assentamento.

\begin{tabular}{|c|c|c|c|c|c|c|c|c|c|c|}
\hline \multirow{2}{*}{$\begin{array}{l}\text { PERÍODO DA } \\
\text { OCUPAÇÃO }\end{array}$} & \multicolumn{2}{|c|}{ FAVELA } & \multicolumn{2}{|c|}{$\begin{array}{c}\text { FAVELA } \\
\text { URBANIZADA }\end{array}$} & \multicolumn{2}{|c|}{$\begin{array}{c}\text { FAVELA } \\
\text { PARCIALMENTE } \\
\text { URBANIZADA }\end{array}$} & \multicolumn{2}{|c|}{$\begin{array}{l}\text { LOTEAMENTO } \\
\text { IRREGULAR }\end{array}$} & \multicolumn{2}{|c|}{ Total } \\
\hline & $\begin{array}{l}\text { FORA } \\
\text { MANAN- } \\
\text { CIAL }\end{array}$ & $\begin{array}{c}\text { NO } \\
\text { MANAN- } \\
\text { CIAL } \\
\end{array}$ & $\begin{array}{l}\text { FORA } \\
\text { MANAN- } \\
\text { CIAL }\end{array}$ & $\begin{array}{c}\text { NO } \\
\text { MANAN- } \\
\text { CIAL } \\
\end{array}$ & $\begin{array}{l}\text { FORA } \\
\text { MANAN- } \\
\text { CIAL }\end{array}$ & $\begin{array}{c}\text { NO } \\
\text { MANAN- } \\
\text { CIAL } \\
\end{array}$ & $\begin{array}{l}\text { FORA } \\
\text { MANAN- } \\
\text { CIAL } \\
\end{array}$ & $\begin{array}{c}\text { NO } \\
\text { MANAN- } \\
\text { CIAL }\end{array}$ & $\begin{array}{l}\text { FORA } \\
\text { MANAN- } \\
\text { CIAL } \\
\end{array}$ & $\begin{array}{c}\text { NO } \\
\text { MANAN- } \\
\text { CIAL } \\
\end{array}$ \\
\hline 1940 a 1950 & 2 & 8 & 1 & 1 & 1 & 0 & 1 & 4 & 5 & 13 \\
\hline 1951 a 1960 & 1 & 5 & 4 & 0 & 0 & 0 & 2 & 3 & 7 & 8 \\
\hline 1961 a 1970 & 5 & 7 & 3 & 3 & 0 & 0 & 2 & 4 & 10 & 14 \\
\hline 1971 a 1980 & 12 & 7 & 6 & 5 & 1 & 1 & 0 & 5 & 19 & 18 \\
\hline 1981 a 1990 & 7 & 5 & 17 & 8 & 1 & 0 & 6 & 26 & 31 & 39 \\
\hline 1991 a 2000 & 6 & 12 & 7 & 0 & 0 & 0 & 9 & 37 & 22 & 49 \\
\hline 2001 a 2010 & 0 & 1 & 0 & 0 & 0 & 0 & 2 & 1 & 2 & 2 \\
\hline SI & 11 & 8 & 2 & 0 & 0 & 0 & 1 & 2 & 14 & 10 \\
\hline Total & 44 & 53 & 40 & 17 & 3 & 1 & 23 & 82 & 110 & 153 \\
\hline
\end{tabular}

Fonte: Mapeamento e Caracterização dos Assentamentos Precários, SEHAB/SBC, 2010. Elaborado pela autora. Obs: a data da ocupação foi declarada pelos moradores quando do levantamento de campo do Mapeamento. 
As tabelas 4 e 5 acima e o mapa 17 mostram que o período de maior crescimento de ocupações de assentamentos precários deu-se entre as décadas de 1970 e 1990. No período da década de 1980 até 2000, a quantidade de loteamentos irregulares em área de proteção aos mananciais é mais expressiva, o que confirma dados anteriormente apresentados sobre a ocupação recente da região.

Do ponto de vista quantitativo, ou seja, do número de novos assentamentos, a tabela 5 Período inicial da ocupação por tipo do assentamento, mostra que durante a década de 1980 esse crescimento foi de mesma grandeza, tanto dentro quanto fora da área de proteção aos mananciais. Já na década de 1990, foi mais expressivo dentro da área protegida, quando acontece o boom dos loteamentos clandestinos e irregulares.

O mapa 17 ilustra, além disso, que esses loteamentos foram abertos em áreas mais afastadas da mancha urbana, de difícil acesso, próximas ao corpo d'água da represa, e em terrenos de declividade acentuada, onde a precariedade é ainda mais alta não só porque o sítio apresenta maior fragilidade ambiental, o que implica em ocupações em áreas de risco (deslizamentos ou enchentes) ou construções em áreas impróprias; mas também porque a vida cotidiana é mais dura, pois depende de serviços urbanos que nem sempre estão próximos e o transporte público é escasso. Dessa forma são áreas de menor visibilidade, não só pela sua localização geográfica, mas principalmente por sua condição de precariedade urbana e socioambiental.

Sendo assim, os loteamentos irregulares mais recentes se diferenciam em vários aspectos dos loteamentos mais antigos, situados mais próximos da mancha urbanizada e que apresentavam infraestrutura, apesar da irregularidade fundiária de alguns deles ${ }^{15}$.

Portanto, durante os anos de 1980 e 1990, a área de proteção dos mananciais tornou-se uma frente de expansão urbana do município, num contexto em que os problemas das ocupações precárias e irregulares já eram uma realidade conhecida, principalmente em São Paulo e nos municípios de maior crescimento urbano do $A B C D$, como São Bernardo do Campo.

Ao mesmo tempo, o aumento da poluição da represa Billings, que recebia toda a carga de poluição proveniente dos rios Pinheiros e Tietê, somada à ausência de tratamento de esgotos nos municípios do $A B C$, foi mais um elemento que estimulou a venda de terras da região, que perdia o seu atrativo recreativo e de lazer preconizado pela lei estadual de proteção aos mananciais. O padrão de ocupação elitista dessa lei, baseado em grandes lotes e ocupação de baixa densidade, não se manteve.

A forma física e urbana dos loteamentos precários será abordada em maior detalhe nos itens a seguir. Mas cabe destacar que o processo que prevaleceu como solução habitacional foi a

\footnotetext{
${ }^{15}$ Segundo o Plano Municipal de Habitação de São Bernardo do Campo, em 2010 havia 53 assentamentos precários que dependiam somente de regularização fundiária (e não realização de obras) em todo o município, totalizando 12.675 unidades (SÃO BERNARDO, 2012, p.55). Desse total, 28 assentamentos estão situados em área de proteção aos mananciais e somente três são anteriores à LPM, conforme dados do Mapeamento de Assentamentos Precários (SÃO BERNARDO, 2010a). Esse levantamento não considerou loteamentos de média e alta renda que também podem apresentar situação irregular.
} 
aquisição do lote individual e a autoconstrução da moradia em parcelas. Desse modo, a reprodução da força de trabalho se deu baseada na propriedade privada da terra, ainda que em condição irregular, e na produção doméstica da casa. Um processo que se caracteriza pela dimensão privada e particular (familiar) da produção da moradia, inserido num contexto em que as políticas públicas e sociais eram insuficientes.

As redes de infraestrutura não acompanharam o crescimento dos loteamentos em APM, seja pelas interdições ambientais legais, seja pelo próprio modo como são planejadas as suas extensões, em outras palavras, pela priorização econômica e política de determinadas partes da cidade dada pelas políticas estatais, como se busca descrever e problematizar ao longo da tese. Diferentemente da moradia, as redes de infraestruturas têm um caráter sistêmico, público e social. Ao mesmo tempo em que são meios de consumo coletivo (HARVEY, 1982; PRETECEILLE, 1986; JARAMILLO, 1986) ${ }^{16}$, ou serviços urbanos, funcionam quando estão ligadas às moradias, ou seja, são complementares a elas. Mas a distribuição desigual dos meios de consumo coletivos no espaço é inerente à produção do espaço capitalista e implica em especificidades quanto às necessidades de reprodução da força de trabalho e da segregação socioespacial.

No caso em estudo, para exemplificar do ponto de vista quantitativo que a distribuição das redes de infraestrutura no espaço não ocorre de forma contínua e equitativa, consideramos duas situações. A primeira compara os dados de atendimento dos serviços de água e esgotos em assentamentos precários situados dentro e fora da área de manancial. Quando comparadas as duas situações, a precariedade de infraestrutura é maior nas APMs (tabelas 6 e 7) ${ }^{17}$, mas não há uma diferença expressiva. Já quando se compara a situação de infraestrutura dos assentamentos precários de forma geral com os índices de atendimento de abastecimento de água e esgotos do conjunto da cidade, essa desigualdade fica mais clara (tabelas 8 e 9).

Em relação às APMs, enquanto o índice de atendimento de água da Sabesp no município, em 2009, era de 89\%; nas áreas de mananciais, aproximadamente 55\% dos assentamentos precários (ou $71 \%$ dos domicílios nesses assentamentos) apresentavam rede de abastecimento em sua totalidade (consideramos a soma de $A$ mais A/E na tabela 6 a seguir). Outra parcela significativa, $30 \%$ dos assentamentos (ou $22,5 \%$ dos domicílios) tinha redes parciais de abastecimento de água.

Já a situação do esgotamento sanitário é mais crítica. O índice de coleta de esgotos no município em 2009 era de 77\%, ou seja, 23\% da população não era atendida. Considerando os assentamentos sem redes coletoras, somando aos que apresentavam somente rede de água, total ou parcial, conclui-se que $45 \%$ dos assentamentos precários (ou 22,4\% dos domicílios em

\footnotetext{
${ }^{16}$ Harvey (1982) e Preteceille (1986) realizam a crítica marxista da socialização estatal do consumo de equipamentos e infraestruturas em sociedades do capitalismo dito avançado e mostram sua crise na década de 1970, enquanto que Jaramillo $(1986$, p.19) trata da realidade latino-americana. Jaramillo destaca a imprecisão do termo "meio de consumo coletivo" e o utiliza enquanto expressão de "uma série de valores de uso, que por algumas de suas características são difíceis de ser providos pelo capital individual, sendo porém indispensáveis para a acumulação do capital em geral".

17 Os dados utilizados do Mapeamento de Assentamentos Precários em São Bernardo do Campo não distinguem favelas e loteamentos irregulares, nesse caso.
} 
assentamentos precários) não apresentam redes coletoras de esgotos. Há que se ponderar ainda que a existência de redes coletoras no assentamento não significa seu afastamento completo, pois o coletor-tronco para o encaminhamento dos esgotos até a estação de tratamento de esgotos do $A B C$ está em construção. Portanto, muitas áreas servidas por redes locais ainda despejam nos corpos d'água mais próximos os esgotos coletados.

Tabela 6 - Assentamentos Precários e situação de infraestrutura em 2010, em APM.

\begin{tabular}{lcccc}
\hline & $\begin{array}{c}\text { No de Assent. } \\
\text { Precários }\end{array}$ & $\%$ & $\begin{array}{c}\text { Unidades } \\
\text { mapeadas }\end{array}$ & $\%$ \\
\hline Sem redes & 23 & $16,0 \%$ & 2.553 & $6,1 \%$ \\
AP e EP & 20 & $13,9 \%$ & 5.859 & $13,9 \%$ \\
AP & 22 & $15,3 \%$ & 3.623 & $8,6 \%$ \\
A & 20 & $13,9 \%$ & 3.253 & $7,7 \%$ \\
A/E & 59 & $41,0 \%$ & 26.826 & $63,7 \%$ \\
Total & 144 & $100 \%$ & $\mathbf{4 2 . 1 1 4}$ & $100,0 \%$ \\
\hline
\end{tabular}

Tabela 7 - Assentamentos Precários e situação de infraestrutura em 2010, fora de APM.

\begin{tabular}{lcccc}
\hline & $\begin{array}{c}\text { № de Assent. } \\
\text { Precários }\end{array}$ & $\%$ & $\begin{array}{c}\text { Unidades } \\
\text { mapeadas }\end{array}$ & $\%$ \\
\hline Sem redes & 10 & $10,2 \%$ & 550 & $1,6 \%$ \\
AP/EP & 12 & $12,2 \%$ & 3.244 & $9,6 \%$ \\
AP & 15 & $15,3 \%$ & 3.825 & $11,3 \%$ \\
A & 8 & $8,2 \%$ & 3.527 & $10,4 \%$ \\
AP/E & 7 & $7,1 \%$ & 1.035 & $3,1 \%$ \\
A/E & 46 & $46,9 \%$ & 22.126 & $65,5 \%$ \\
Total & 98 & $100 \%$ & 33.757 & $100 \%$ \\
\hline
\end{tabular}

A - rede de água; AP - rede parcial de água; E - rede de coleta de esgotos; EP - rede parcial de coleta de esgotos. Foram desconsiderados os assentamentos sem informação quanto à situação de infraestrutura.

Fonte: Levantamento dos Assentamentos Precários de São Bernardo do Campo, cedido à autora em junho de 2011. Elaborado pela autora.

Tabela 8 - Índice de atendimento (percentual da população atendida) pela rede de esgoto e índice de tratamento de esgoto SABESP, São Bernardo do Campo, 2004 e 2009.

\begin{tabular}{lcc}
\hline SISTEMA DE ÁGUA & 2004 & 2009 \\
\hline Índice de atendimento de água - ${ }^{(1)}$ & $85 \%$ & $89 \%$ \\
População com intermitência no abastecimento & 380.000 & 45.000 \\
Índice de perdas de água - \% & $63 \%$ & $35 \%$ \\
\hline
\end{tabular}

(1) Não são considerados os domicílios urbanos em área de proteção aos mananciais e domicílios na área rural. Fonte: SABESP/Companhia de Saneamento Básico do Estado de São Paulo. Extraído de Sumário de Dados PMSBC, 2010, p.383.

Tabela 9 - Índice de atendimento (percentual da população atendida) pela rede de esgoto e índice de tratamento de esgoto SABESP, São Bernardo do Campo, 2004 e 2009.

\begin{tabular}{lcc}
\hline SISTEMA DE ESGOTO & 2004 & 2009 \\
\hline Índice de atendimento de coleta de esgoto - ${ }^{(1)}$ & $73 \%$ & $77 \%$ \\
Índice de atendimento de tratamento de esgoto - $\%$ & 9 & 26 \\
\hline
\end{tabular}


(1) Consideram-se apenas as ligações hidrometradas. Fonte: SABESP/Companhia de Saneamento Básico do Estado de São Paulo. Extraído de Sumário de Dados PMSBC, 2010, p.383.

Como será abordado adiante, a ausência de infraestrutura pública, no momento inicial dos loteamentos, e sua implementação fragmentada ao longo dos anos, implica na sua provisão parcial, também por meio de processos de autoprovisão pelos moradores. Ou seja, acaba, indiretamente, se tornando um custo e mais um elemento do sobretrabalho assumido pelo morador. O caráter eminentemente social e público das redes de infraestrutura aparece então invertido, até que a reivindicação pelas redes oficiais sejam de fato atendidas o que, no entanto, muitas vezes não supera sua fragmentação, como buscaremos problematizar.

\subsection{0 processo de formação dos loteamentos do baixo Alvarenga: vende-se um terreno e isso é tudo.}

Considerando o contexto da política habitacional em São Bernardo do Campo e o surgimento dos loteamentos irregulares como forma predominante de ocupação ${ }^{18}$ dos mananciais no município, passamos nesse item a abordar em maior detalhe a constituição dos loteamentos, o processo de aquisição e parcelamento do solo, a autoconstrução de moradias e a autoprovisão parcial de infraestrutura, salientando como se formou parte significativa do passivo ${ }^{19}$ socioambiental presente atualmente nas APMs.

A metodologia utilizada na pesquisa empírica foi a observação participante, composta também por entrevistas individuais, entrevistas coletivas e a produção de cartografias comunitárias. Inicialmente, as entrevistas individuais ${ }^{20}$, que não objetivaram aferição estatística, mas qualitativa, enfocaram o processo de autoconstrução no lote, tanto da moradia como da infraestrutura, cuja descrição foi complementada por observações de campo e registros fotográficos.

O histórico de formação dos loteamentos estudados, Parque dos Químicos, Nova América, Novo Horizonte, Ouro Verde, Parque Ideal I e II, expressa um processo que, em linhas gerais, repete-se em outros bairros de São Bernardo do Campo, bem como em outros municípios inseridos na área de proteção aos mananciais ao sul da RMSP como São Paulo, Diadema e Santo André.

\footnotetext{
${ }^{18}$ Segundo dados do Mapeamento dos Assentamentos Precários e/ou Irregulares, em São Bernardo do Campo há 68 favelas (17.166 unidades habitacionais) e 83 loteamentos irregulares (25.534 unidades habitacionais) em área de proteção aos mananciais. Fora da área protegida há 87 favelas (35.159 unidades habitacionais) e 23 loteamentos irregulares (4.711 unidades habitacionais) (SÃO BERNARDO, 2010a).

${ }^{19}$ Passivo ambiental é um termo comumente utilizado para expressar os danos ambientais causados por empresas, de forma a estabelecer a responsabilidade e gastos das mesmas para saná-los. Aqui o termo passivo ambiental é utilizado para expressar o conjunto de danos ambientais e sociais causado pela ocupação dos mananciais, que por sua vez foi promovida por diversos agentes, ou seja, refere-se a um processo social. Os impactos negativos dessa ocupação afetam tanto as populações locais como repercutem na escala metropolitana. Os problemas decorrentes das ocupações de favelas fariam parte desse passivo, mas não são objetos dessa análise.

20 Sobre as entrevistas individuais, foram feitas duas atividades distintas. Inicialmente, foi feita a aplicação de questionário para aferição qualitativa sobre aspectos gerais da autoconstrução, realizada em 131 residências entre outubro e dezembro de 2007. Em seguida, foram feitas entrevistas com moradores escolhidos, por serem moradores mais antigos, não necessariamente envolvidos na diretoria das associações de moradores.
} 
No bairro dos Alvarengas, a configuração espacial dos assentamentos existentes apresenta situações diversificadas quanto à localização, consolidação e precariedade. Ao norte desse bairro, há ocupações consolidadas, infraestruturadas (total ou parcialmente) e integradas à malha urbana do município, pois geralmente são assentamentos mais antigos, alguns anteriores à Lei Estadual de Proteção aos Mananciais de 1975. Ao sul, as ocupações são mais recentes, esparsas, e conformam uma paisagem que mistura a existência de favelas e loteamentos populares adensados, com poucos serviços públicos, formando um mosaico de múltiplos usos, entre áreas ocupadas e vegetadas ${ }^{21}$. Muitos desses assentamentos estão próximos à represa Billings, tendo como único caminho de acesso a Estrada dos Alvarengas ${ }^{22}$. O conjunto de loteamentos estudados insere-se nessa região, conforme mapa 18 a seguir, que é chamada de baixo Alvarenga pelos moradores (como adotado ao longo dessa tese), de Alvarenguinha ou ainda de "turma do fundão" - pelos representantes do poder público.

O bairro dos Alvarengas tem população de baixa renda, comparativamente mais pobre em relação ao perfil socioeconômico do município como um todo. Em 2010, houve um aumento dos domicílios com renda de 2 a 5 salários-mínimos, o que representou uma pequena melhora em relação a 2000.

Tabela 10 - Perfil de renda segundo rendimento do responsável pelo domicílio, bairro dos Alvarengas, São Bernardo do Campo, 2000-2010.

\begin{tabular}{l|cc|cc}
\hline \multirow{2}{*}{$\begin{array}{l}\text { Classes de rendimento } \\
\text { nominal mensal da pessoa }\end{array}$} & \multicolumn{2}{|c|}{ Bairro do Alvarenga } & \multicolumn{2}{c}{ Município de SBC } \\
\cline { 2 - 5 } responsável pelo domicílio & 2000 & $\mathbf{2 0 1 0}$ & $\mathbf{2 0 0 0}$ & $\mathbf{2 0 1 0}$ \\
\cline { 2 - 5 } & $\begin{array}{c}\text { \% de } \\
\text { domicílios }\end{array}$ & $\begin{array}{c}\text { \% de } \\
\text { domicílios }\end{array}$ & $\begin{array}{c}\text { \% de } \\
\text { domicílios }\end{array}$ & $\begin{array}{c}\% \text { de } \\
\text { domicílios }\end{array}$ \\
\hline de 0 a 2 SM & $37,30 \%$ & $37,80 \%$ & $14,00 \%$ & $26,00 \%$ \\
de 2 a 5 SM & $37,90 \%$ & $43,50 \%$ & $23,00 \%$ & $36,00 \%$ \\
de 5 a 10 SM & $21,10 \%$ & $16,20 \%$ & $27,20 \%$ & $24,00 \%$ \\
mais de 10 SM & 3,7 & $2,60 \%$ & $36,10 \%$ & $15,00 \%$ \\
\hline
\end{tabular}

Fonte: IBGE - Censo Demográfico. Dados do Universo 2000 e 2010. Elaborado pela autora.

As famílias que habitam os seis loteamentos do baixo Alvarenga acompanham o perfil de renda do bairro, ou seja, são em sua maioria de baixa renda ( $5 \%$ dos domicílios tem renda de até 1 salário-mínimo, 67\% dos domicílios tem renda de 2 a 3 salários-mínimos, seguido de 21\% na faixa de 4 a 5 salários-mínimos e $7 \%$ acima de 6 salários-mínimos). Os 4.250 moradores exercem (ou exerceram) ocupações diferenciadas na indústria (operadores de máquinas, auxiliares, metalúrgicos), no comércio (vendedor, balconista, comerciante), no setor de serviços (em diferentes áreas) e na construção civil, além de atividades domésticas e pequeno comércio

\footnotetext{
${ }^{21}$ A vegetação nessa região, que tem como bioma original a Mata Atlântica, apresenta estágio médio e avançado de regeneração.

22 A Estrada dos Alvarengas existe desde o período da colonização e ligava o "porto dos alvarengas" (nome da embarcação utilizada), situado ao sul da foz do Taquacetuba, ao atual centro de São Bernardo. O transporte fluvial de mercadorias era utilizado para levar as mercadorias dos vales dos rios Bororé, Taquacetuba, Curucutú, Pedra Branca, Capivari, Pequeno, Rio Grande ou Jurubatuba, que eram trazidas rio abaixo. Também havia o transporte de madeira que era utilizada para a produção de móveis.
} 
$\mid$ local ${ }^{23}$. Segundo dados do Mapeamento de Assentamentos Precários no Município de São Bernardo do Campo 2010, SEHAB/SBC, os seis loteamentos somam 1.148 domicílios.

A maioria das famílias é oriunda do mesmo município ou de municípios próximos, ou seja, a ocupação dos mananciais em São Bernardo supriu uma demanda por terrenos para habitação social do próprio município. Já a origem das famílias é diversa, prevalecendo os estados do Nordeste, São Paulo e Minas Gerais. Em 2007, aproximadamente 86\% dos habitantes morava há cerca de 6 a 11 anos, ou mais, nesses loteamentos ${ }^{24}$. O levantamento de campo permitiu aferir que há vários parentes que moram no mesmo loteamento, normalmente convivem duas gerações da mesma família dividindo a mesma moradia ou em outro lote.

\footnotetext{
${ }^{23}$ Informações levantadas por meio de questionário socioeconômico aplicado pela equipe da ONG Holos21 em 2007 e cedidas à autora. Esse levantamento não identificou o número de desempregados.

${ }^{24}$ Idem nota 26.
} 


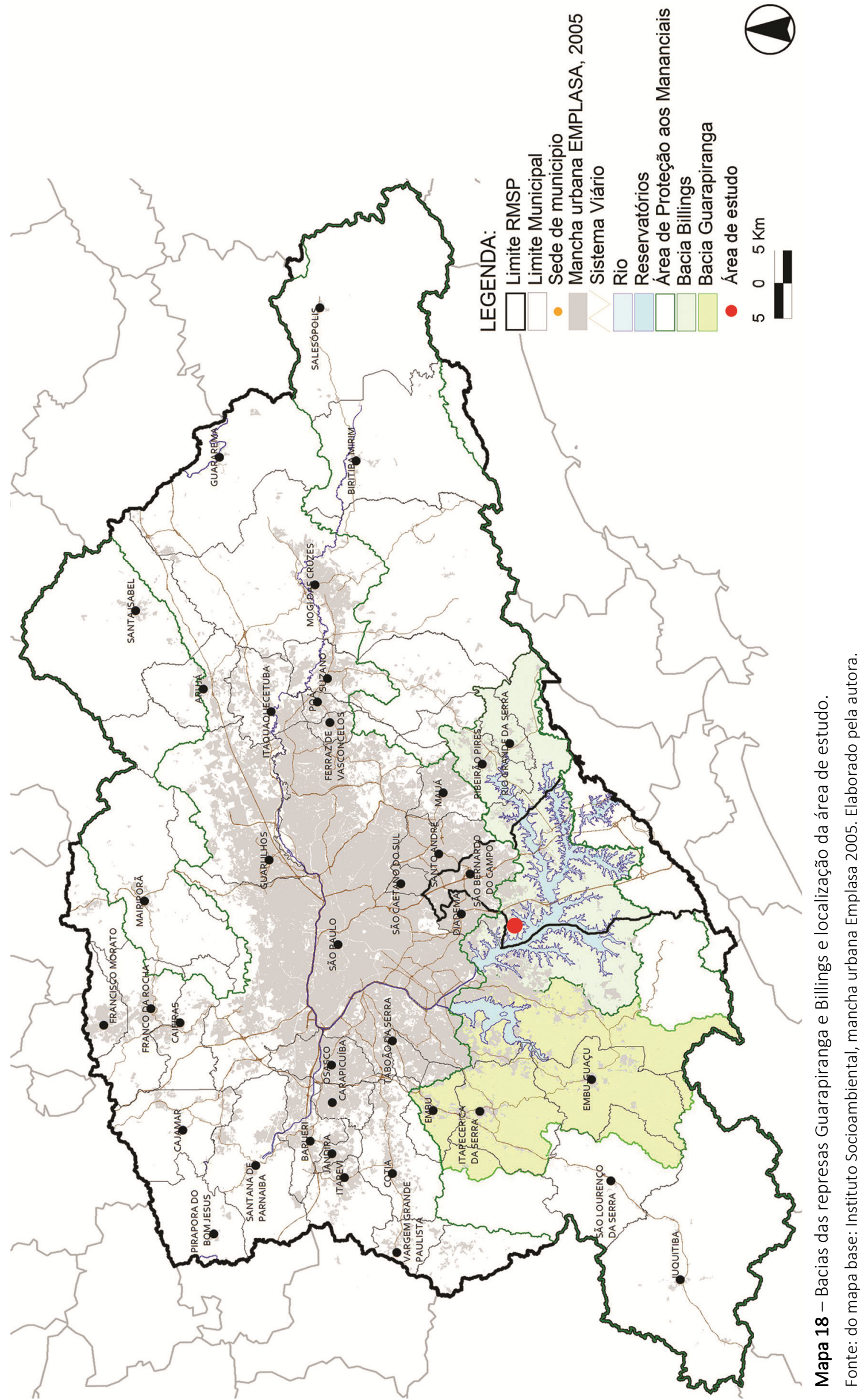




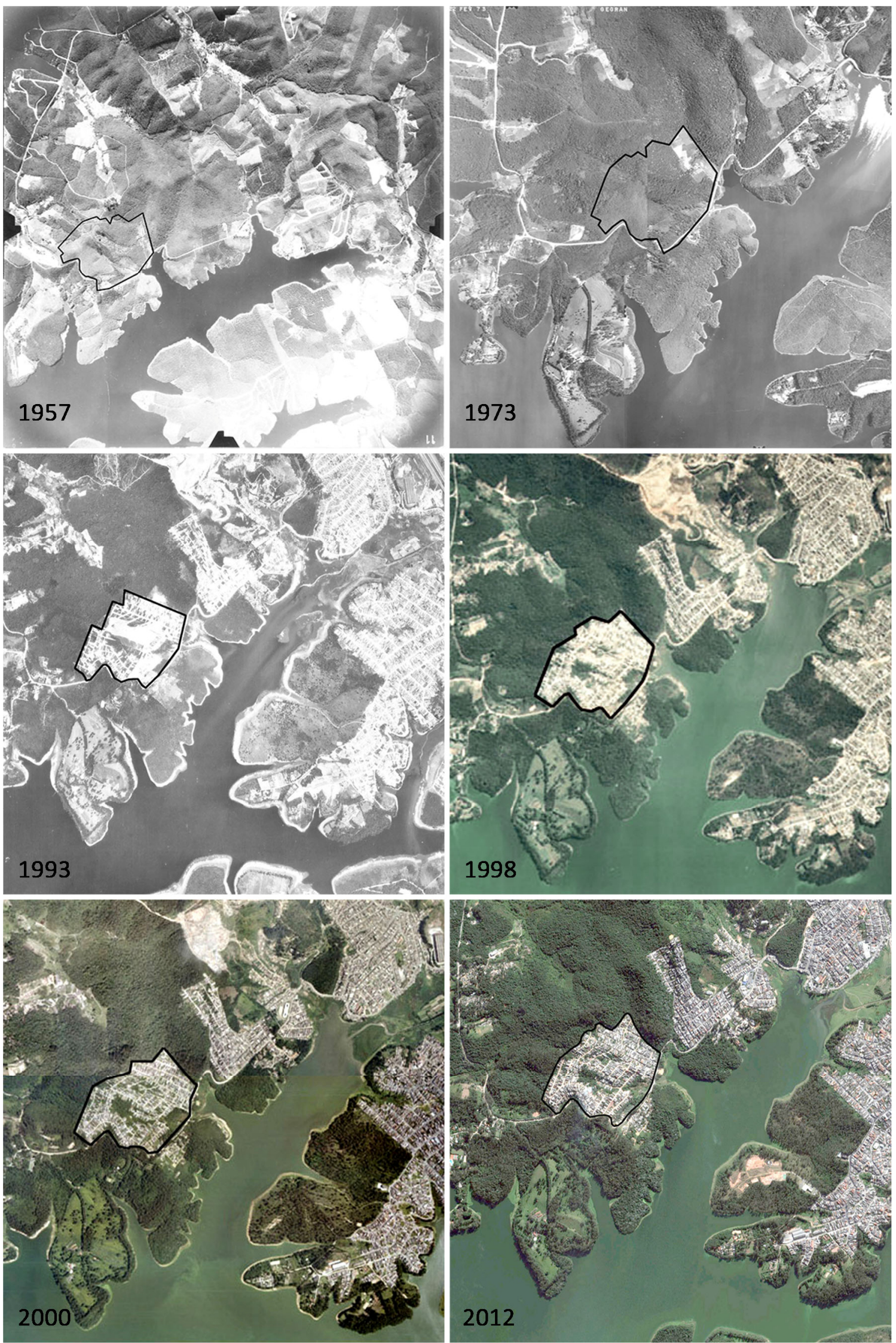

Figuras 15 a 20 - Sequência de fotos aéreas, com destaque para loteamentos do baixo Alvarenga 19572012.

Fonte: Figuras 15 a 19: fotos aéreas cedidas à autora pelo Departamento de Cadastro e Cartografia, Secretaria de Planejamento urbano da prefeitura de São Bernardo do Campo em 2009. Figura 20: Google Earth. 
Aproximadamente a partir de $1985^{25}$, os seis loteamentos estudados foram abertos um após o outro, a partir do parcelamento de glebas maiores, propriedades particulares de diferentes donos. Segundo relatos em entrevistas e informações extraídas de documentação disponível, o primeiro a ser implantado foi o Parque dos Químicos (1987), seguido do Parque Ideal (1988), Novo Horizonte (1992), Nova América (1993) e Ouro Verde (1992)26.

A sequência de fotos aéreas bem ilustra a mudança de uso do solo que a implantação desses loteamentos representou. As glebas parceladas eram sítios, muitos deles não ocupados, que apresentavam cobertura vegetal (em parte com eucaliptos, em parte mesclada à vegetação de mata atlântica em estado de regeneração) e passaram a ser ocupações urbanas, em porções distantes, praticamente "desconectadas" da malha urbanizada. Tratam-se portanto de ocupações de borda, ou de fronteira ${ }^{27}$, onde a situação do sítio apresenta maior fragilidade ambiental (presença de cursos d'água, nascentes e topos de morro).

A pesquisa identificou um processo comum de formação dos loteamentos, não somente dos seis casos estudados em maior detalhe, como de vários outros que se repetiram na área de proteção aos mananciais, como será demonstrado adiante (no capítulo 5). Esses loteamentos se iniciam com a criação pelos loteadores de uma associação de moradores, em nome da qual compravam e registravam a matrícula do imóvel, para depois vender frações ideais de terreno, os lotes. Os loteadores geralmente não eram os proprietários da terra, mas estes compactuavam em muitos casos com a realização do parcelamento irregular. Com a gleba em nome das associações, os empreendedores do loteamento disfarçavam seu envolvimento no comércio ilegal de terras e buscavam proteger-se individualmente por detrás do nome da associação ${ }^{28}$.

A partir da definição estritamente jurídica, todos eles são loteamentos clandestinos, pois se implantaram desrespeitando tanto os parâmetros, quanto os procedimentos de licenciamento da lei estadual de proteção aos mananciais n 898/1975 e n 1172/1976 e os da lei federal de parcelamento do solo urbano $n^{\circ} 6766 / 1979$. Ou seja, foram criados sem aprovação ou autorização do poder público. No entanto, do ponto de vista urbanístico, essa distinção é menos relevante e ambos podem ser objetos de regularização. Nesse sentido a denominação empregada geralmente (e nessa tese) é irregular, de modo que assim também não se reitera a carga pejorativa do termo clandestino.

\footnotetext{
${ }^{25}$ As matrículas das glebas foram registradas no $2^{\circ}$ Cartório de Registro de Imóveis de São Bernardo do Campo.

${ }^{26} \mathrm{O}$ conjunto de informações apresentadas a seguir foi obtido a partir de diferentes fontes, como entrevistas, partes de processos de inquérito de Ações Civis Públicas e dados do município, reelaboradas de forma a permitir compreender o processo e a sequência de abertura de cada loteamento.

${ }^{27}$ A fronteira como categoria de análise da expansão urbana é formulada por diversos autores, dentre eles TORRES (2003), para representar as áreas mais periféricas, onde há crescimento populacional expressivo, e áreas de maior fragilidade ambiental e vulnerabilidade social.

${ }^{28}$ Apesar dessa estratégia, a Lei Federal de Parcelamento do Solo no 6766/1979 não isenta a pessoa física responsável individual ou solidariamente da responsabilidade pela irregularidade quando do envolvimento no parcelamento irregular.
} 
Notam-se outros casos de loteamentos irregulares em que o parcelamento da gleba poderia até mesmo ser aprovado na prefeitura, com lotes de dimensão legal, de 500 ou $750 \mathrm{~m}^{2}$. Mas na prática eram subdivididos em lotes menores, de $125 \mathrm{~m}^{2}$, tornando o desmembramento ${ }^{29}$ irregular, pois não passava pelo processo de aprovação da mesma forma ${ }^{30}$.

No caso do Parque dos Químicos, o Sindicato dos Químicos do ABC criou a Associação Pró-Casa Própria para venda de lotes aos trabalhadores associados. A Associação comprou a gleba de uma imobiliária, que também participou da venda de lotes. Segundo registros em documentos que constam no processo da Ação Civil Pública ${ }^{31}$, a decisão pela compra da gleba ocorreu em assembléia do sindicato, sediado em Santo André, na qual se discutiu a necessidade de solução habitacional dos associados. Um membro da Associação que constava como réu na Ação Civil Pública declarou que chegou a verificar na prefeitura se havia áreas disponíveis para doação e construção de casas populares, mas diante da resposta negativa, resolveram comprar uma área de $113.608,00 \mathrm{~m}^{2}$, alegando não saber que se tratava de área de proteção aos mananciais. Para adquirir o terreno e organizar as vendas foi criada a Associação, que funcionava no próprio sindicato. Os compradores pagavam as parcelas do lote na mesma imobiliária. A área loteada em 1999 era de $16.355,52 \mathrm{~m}^{2}$, dividida em 300 lotes de 100 a $125 \mathrm{~m}^{232}$.

Ou seja, diferentemente dos demais loteamentos, o Parque dos Químicos é o único caso em que o argumento político da luta por moradia aparece sustentado pelos representantes do sindicato envolvidos na promoção do loteamento. No entanto, o procedimento que se deu após a aquisição da gleba e a venda de lotes não o distinguiu dos demais casos em que o interesse financeiro prevaleceu sobre uma possível ocupação organizada da área pelos moradores.

Já o loteamento Nova América, conforme narraram os primeiros moradores, a gleba chamada de chácara Gebara (nome do proprietário), com aproximadamente $30.000 \mathrm{~m}^{2}$ (conforme descrito no instrumento particular de compra e venda), seria destinada a um clube de campo. Contudo, em 1992, após sua venda para a Associação Comunitária Repartição do Espaço a mesma foi desmatada e feita a terraplanagem. Logo em seguida, em 1993, a venda de lotes foi iniciada pela Associação, cujo plano de vendas contemplava 150 partes ideais, cada uma no valor de quinze milhões de cruzeiros, sendo que 130 delas foram vendidas em um ano ${ }^{33}$. O dinheiro decorrente

\footnotetext{
29 Segundo definição de Lei Federal de Parcelamento do Solo no 6766/1979, considera-se desmembramento a subdivisão de glebas em lotes destinados à edificação, com aproveitamento do sistema viário existente, desde que não implique na abertura de novas vias e logradouros públicos, nem no prolongamento, modificação ou ampliação dos já existentes.

${ }^{30}$ Conforme aferido em entrevista com Secretário Adjunto da Secretaria de Habitação de São Bernardo do Campo, concedida à autora em 25/10/2011.

${ }^{31}$ As informações referentes à Ação Civil Pública do loteamento Parque dos Químicos constam do relatório de pesquisa FAPESP/FAUUSP de Mariana Mencio intitulado A presença do tema "assentamentos populares irregulares em área de mananciais" no Judiciário, nas Promotorias de Justiça de Habitação e Urbanismo, nos Registros de Imóveis e Órgãos Licenciadores, 2003.

32 Conforme Laudo do Departamento de Uso do Solo Metropolitano - DUSM de 1999, segundo os parâmetros da Lei de Proteção aos Mananciais (artigo 16 inciso III), os lotes deveriam ter 7.500 m², num total de 13 unidades.

33 Informação extraída da Ação Civil Pública proposta pelo Ministério Público, em 1993. Documento consultado no Ministério Público em São Bernardo do Campo, em 2012.
} 
das vendas, contudo, não foi para um caixa comum da Associação para ser utilizado em obras de infraestrutura, mas beneficiou os indivíduos que compunham sua diretoria ${ }^{34}$.

O loteamento Parque Ideal, foi criado pela Sociedade Amigos do Parque Ideal, em 1988. E a Associação Comunitária Ouro Verde deu origem ao loteamento Novo Horizonte I. Essas duas associações adquiriram uma área com cerca de $50.000 \mathrm{~m}^{2}$ cada uma, pertencentes a um mesmo proprietário. A área maior era conhecida como Sítio Capuava, com área total de $441.554,16 \mathrm{~m}^{2} \mathrm{e}$ que fora desmembrada em oito módulos de propriedades menores, gradualmente vendidas para diferentes associações. Assim, além do Parque Ideal e do Novo Horizonte I, outros loteamentos foram criados a partir da compra de módulos dessa mesma propriedade, como é o caso do Parque das Garças. Por outro lado, a ação conjunta do MP com a polícia interveio neste processo, impedindo que outros loteamentos fossem abertos como mostram as áreas não ocupadas entre os loteamentos, na foto aérea com a divisão das áreas a seguir.

A Associação Comunitária Jardim das Orquídeas, criada em $1991^{35}$, foi responsável pelo loteamento Novo Horizonte II, promovido por Orlando Casadei, que efetuava os contratos de compra e venda ${ }^{36}$. Hoje esse loteamento corresponde à Associação Comunitária Novo Horizonte.

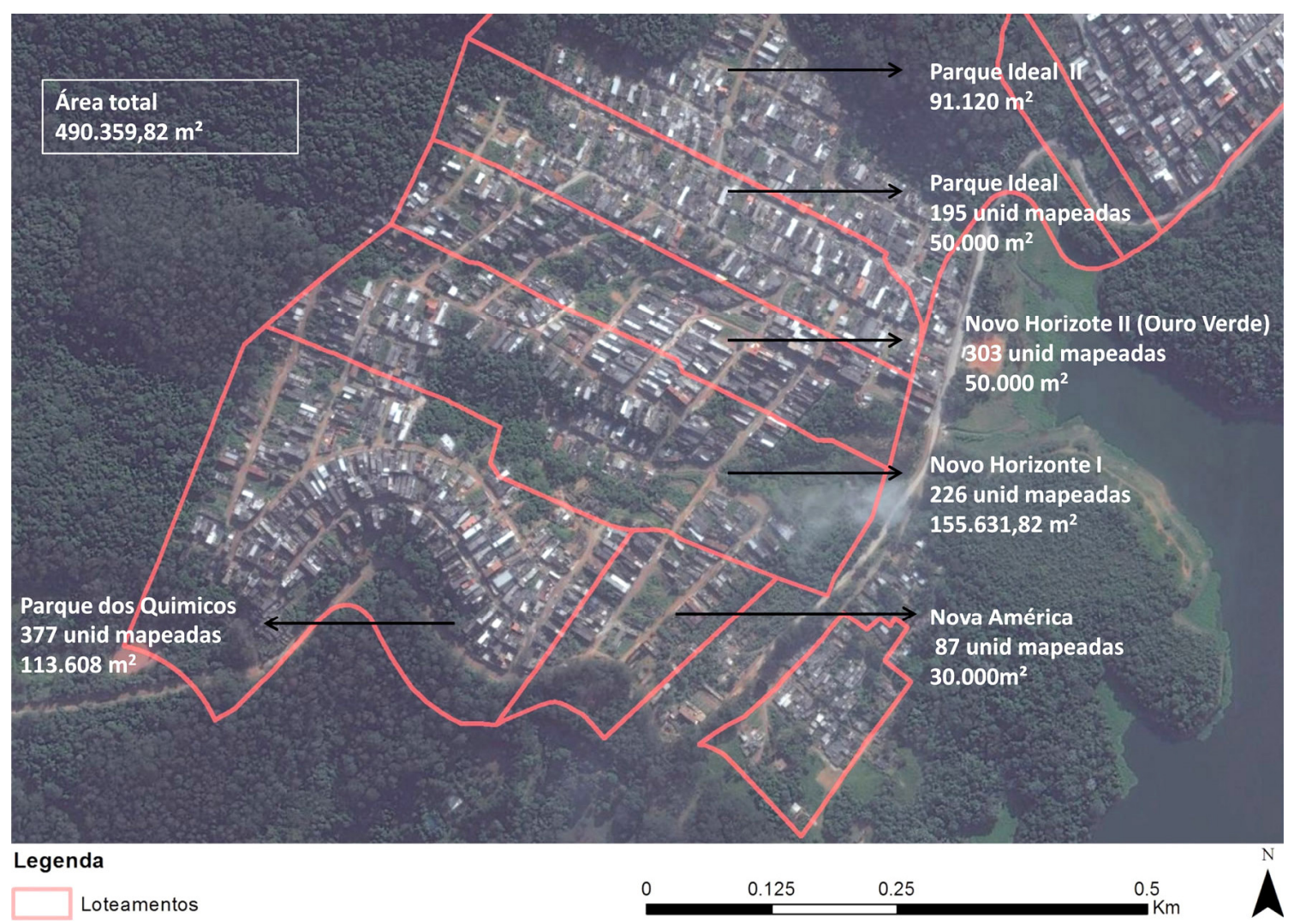

Figura 21 - Delimitação da área dos loteamentos estudados. Fonte: Secretaria de Habitação de São Bernardo do Campo, 2012. Informação cedida à autora em 2012.

\footnotetext{
34 Ibidem. Com esse fato, o MP alegou a má-fé dos envolvidos na Associação.

${ }^{35}$ Segundo Estatuto da Associação Comunitária Jardim das Orquídeas ela foi fundada em 05 de julho de 1991, com sede provisória, localizada na Rua 01 № 151, Jardim das Orquídeas em SBC.

${ }^{36}$ Conforme Acórdão do Poder Judiciário de 28 de setembro de 2000. Documento consultado no Ministério Público em São Bernardo do Campo, em 2012.
} 


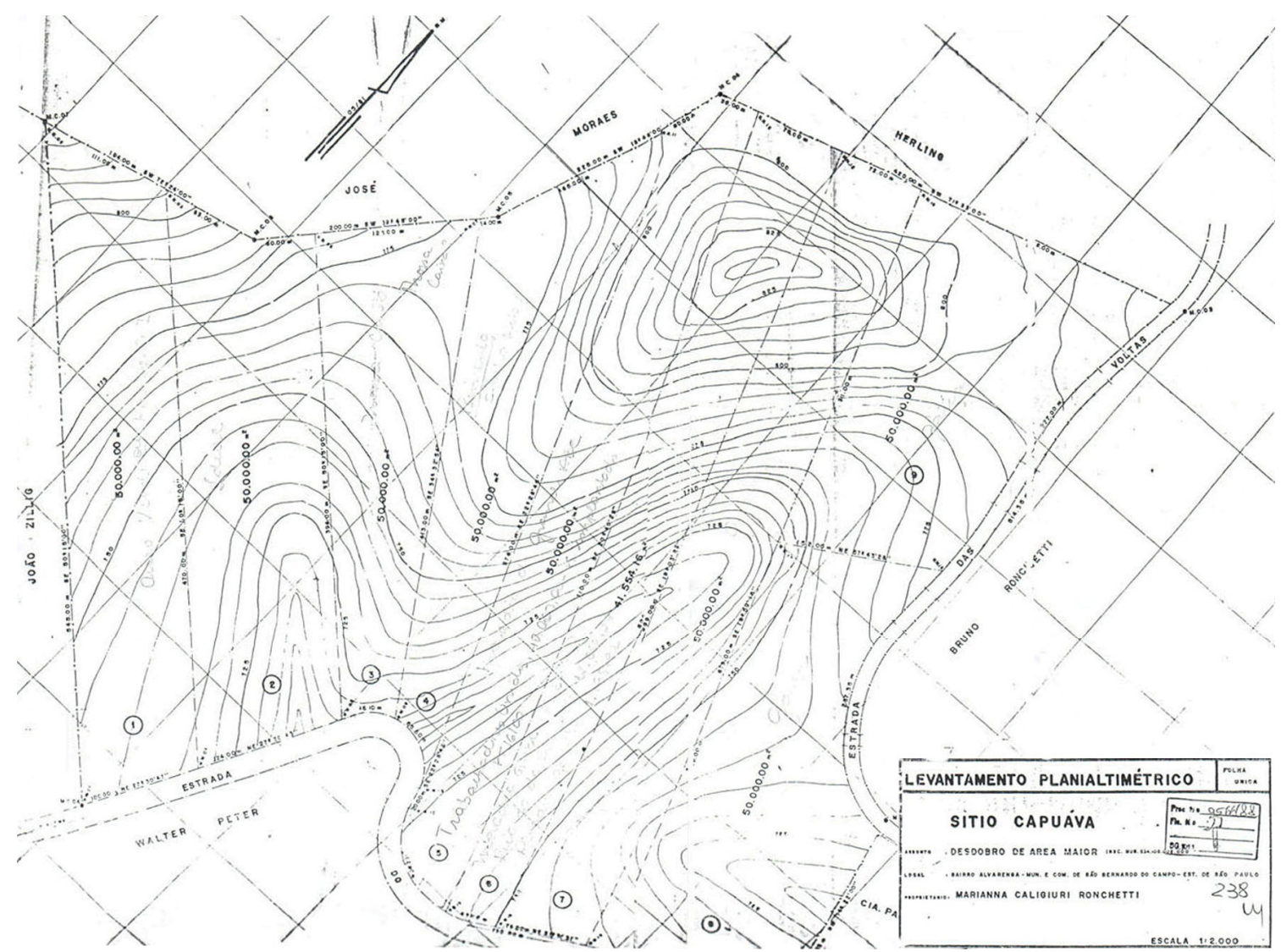

Figura 22 - Levantamento planialtimétrico, Sítio Capuava.

Fonte: Matrícula da gleba cedida para autora pela promotora pública Rosângela Staurenghi.

A divulgação dos lotes à venda era feita por meio de diferentes estratégias. Segundo declaração de moradores, havia um "corretor" que fazia seu automóvel de "imobiliária ambulante" e circulava pelos municípios da região, entre São Bernardo e Diadema, ofertando terrenos. A publicidade também acontecia com a distribuição de panfletos (Figura 23) ou com a organização de visitas de possíveis clientes à área, organizadas pelas próprias Associações. Contudo, conforme relembra um dos moradores do Nova América, o processo de venda por meio da associação de moradores não durou muito tempo:

Eu acho que ela ficou [vendendo] mais ou menos um ano. Depois quem comprou da associação foi revendendo. Vendia para outros e assim foi. Tem terreno aqui que já deve ter tido uns dez, doze donos. (Informação verbal, entrevista concedida à autora, com morador do loteamento Nova América em 27/06/2010.) 


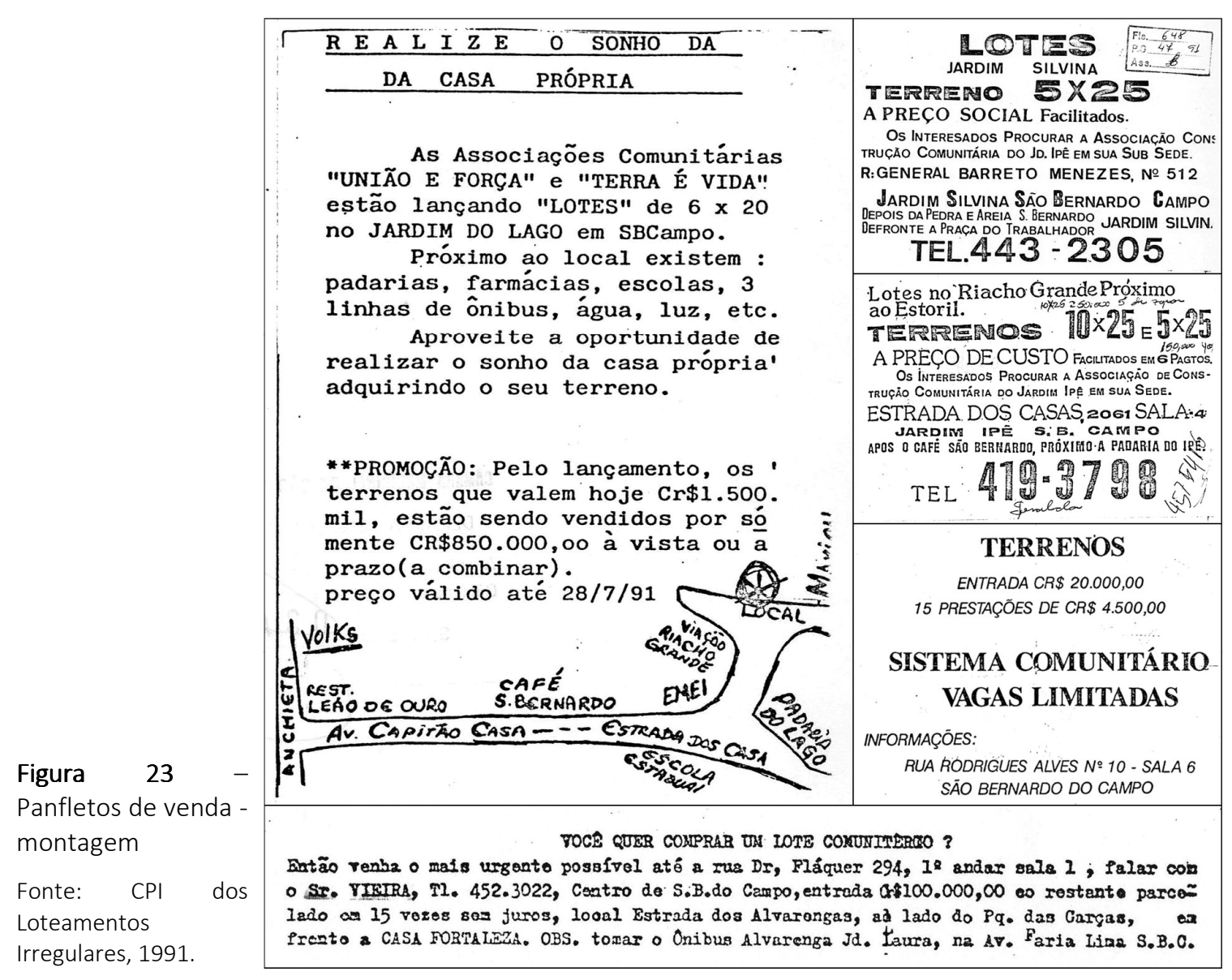

Sem registro individualizado de matrícula ou qualquer outra forma de controle da documentação que não fosse um contrato de compra e venda, os lotes passaram de mão em mão. Assim, os problemas decorrentes da irregularidade foram sendo transferidos de um para o outro, até que os moradores que permaneceram, e em geral dependiam dessa alternativa para resolver seu problema habitacional, assumiram os ônus e as dificuldades impostas por essa condição. Buscou-se aferir com os moradores os preços pagos pelo lote nos primeiros anos da ocupação, mas a informação foi muito variada, inclusive pela instabilidade da moeda na época.

Pode-se dizer que a existência de planta, mesmo que não tenha passado por aprovação, fazia parte da estratégia de venda, pois mostrava a posição dos lotes em relação ao conjunto e aparentava certa seriedade do negócio. Quatro dos seis loteamentos têm desenho do parcelamento, conforme reproduzido a seguir. 

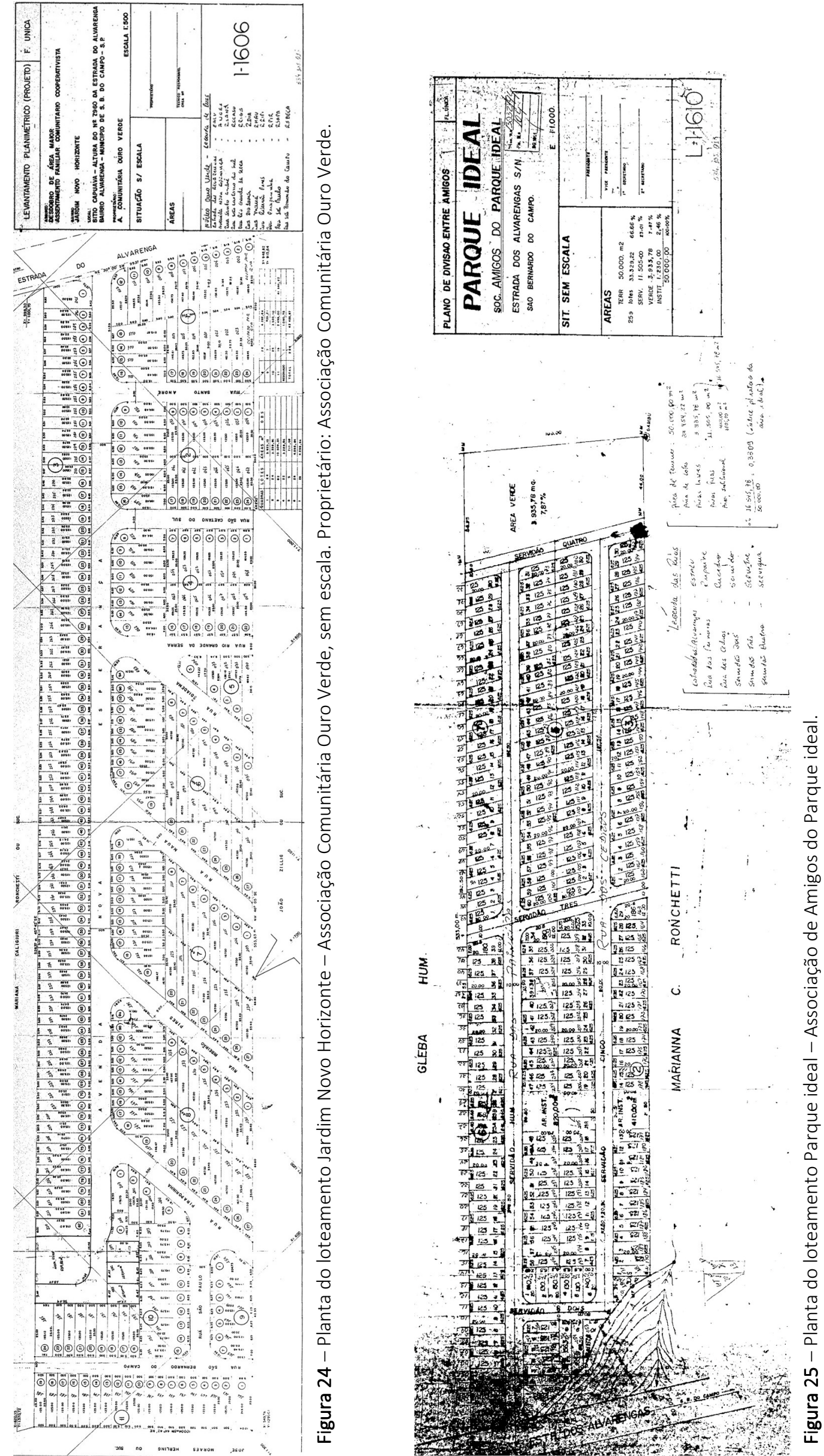


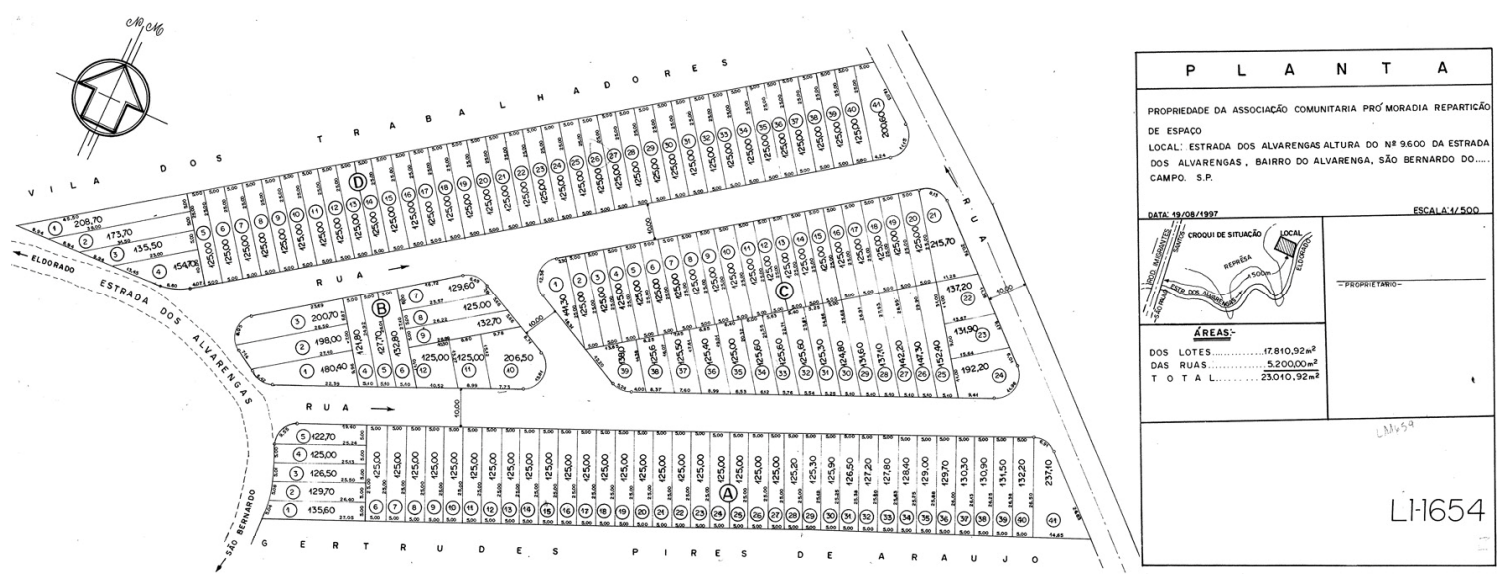

Figura 26 - Planta do loteamento Jardim Nova América. Proprietário: Associação Comunitária Pró-Moradia Repartição do Espaço.

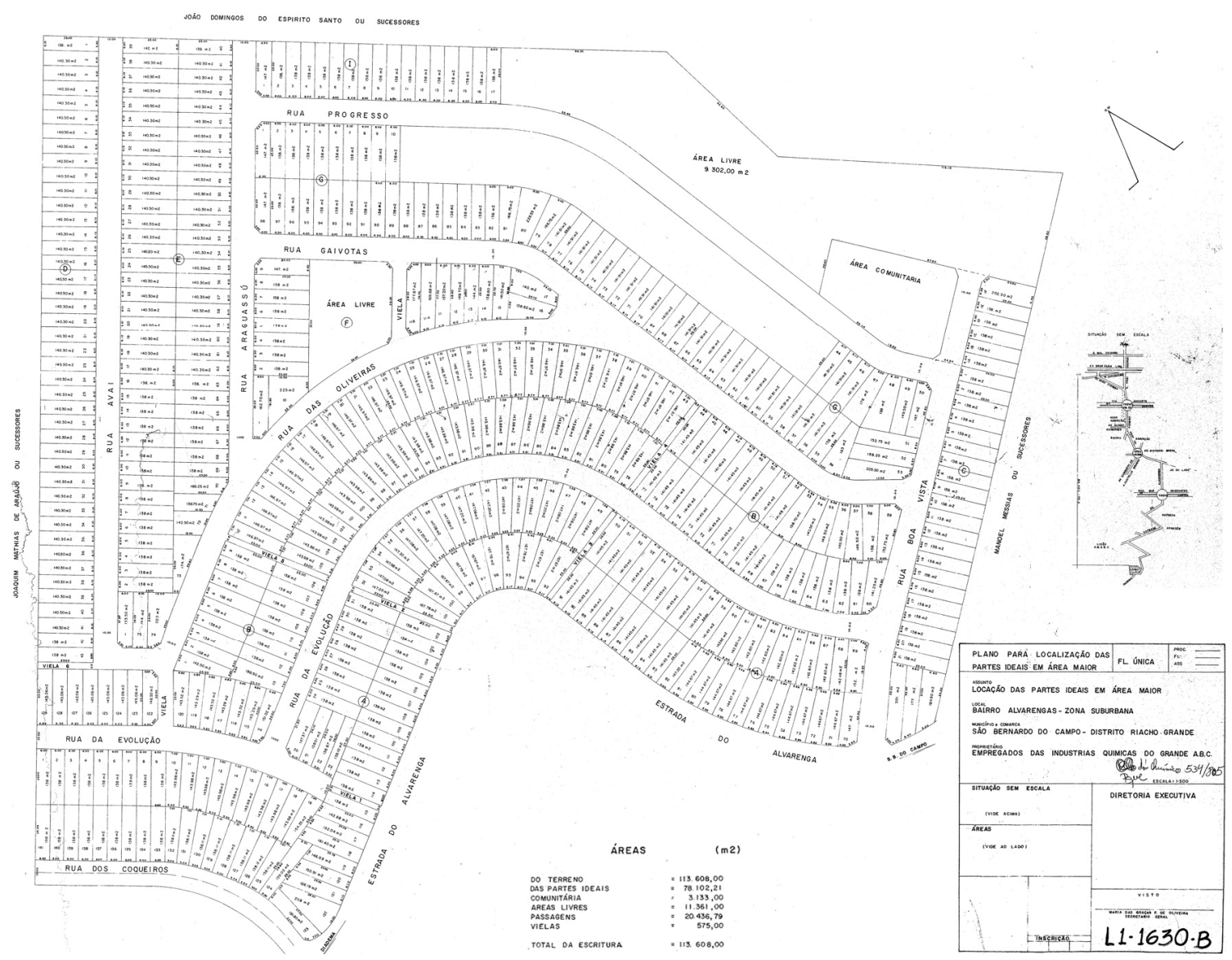

Figura 27 - Planta do loteamento Parque dos Químicos - Associação Parque dos Químicos. Proprietário: Empregados das Indústrias Químicas do ABC.

Fonte: Plantas dos loteamentos cedidas à autora pelo Departamento de Cadastro e Cartografia, Secretaria de Planejamento Urbano da prefeitura de São Bernardo do Campo em 2009.

Segundo as plantas dos loteamentos acima, o Jardim Novo Horizonte apresenta destinação de área livre que se mantém desocupada, enquanto o loteamento Parque Ideal apresenta destinação de área institucional e área verde que se mantém desocupadas, além de faixas de servidão e lotes. Neste, as áreas públicas (exceto lotes), segundo a planta, somam 33,34\% da 
área da gleba e quase se enquadram na determinação da lei no 6766/1979 que define que as áreas públicas não podem ser inferiores a 35\% da gleba. Já a planta do loteamento Nova América não apresenta áreas verdes e institucionais.

A planta do loteamento Parque dos Químicos diferencia-se das demais, pois apresenta um certo cuidado na implantação dos lotes que seguem as curvas de nível da topografia, numa porção do terreno, o que indica a realização de um projeto. Contudo, na outra porção, há problemas de adequação à topografia, o que fez com que a abertura de ruas não seguisse o desenho, gerando uma ocupação que não corresponde a essa planta. Apesar da destinação de uma grande área livre em planta, esta área foi ocupada por lotes e a parte que se manteve desocupada apresenta relevo muito acentuado, onde é praticamente inviável construir com poucos recursos.

As plantas desconsideraram os cursos d'água presentes na gleba e muitos lotes foram demarcados nas margens ou sobre córregos. Os córregos menores foram aterrados, outros desviados. A falta de adequação à topografia gerou (e gera) inúmeros problemas de circulação. O viário existente não corresponde exatamente ao desenho em planta, principalmente porque muitas ruas previstas não foram construídas diante da inviabilidade de transposição de vales e morros, num relevo acidentado. A destinação de áreas institucionais e livres são insuficientes segundo a legislação federal no 6766/79, mas quando existem não foram ocupadas (com exceção do Parque dos Químicos), o que indica que são reconhecidas pelos moradores como áreas das associações, apesar de não apresentarem uso além de passagem de pedestre.

Não foi possível aferir quem executou estes desenhos, mas a partir do relato de casos semelhantes (conforme capítulo 5 a seguir), pode-se dizer, por aproximação e pelas características dos desenhos, que as associações contratavam serviços técnicos de empresas de terraplanagem, topografia ou engenharia, para a realização da implantação de lotes no terreno e definição de abertura de ruas. Em diversas ações civis públicas, empresas de terraplanagem figuraram como réus assim como os proprietários e representantes de associações de moradores por terem participado diretamente da concepção e/ou implantação dos loteamentos.

Em pesquisa realizada em outros loteamentos situados em área de proteção aos mananciais nos municípios do $\mathrm{ABC}^{37}$, como Diadema e Santo André, constatou-se que até mesmo a aprovação parcial da planta poderia ser forjada irregularmente, quando havia envolvimento de funcionários da prefeitura assinando documentos dando "ares" de aprovação sem, contudo, passar pelos demais órgãos e trâmites de licenciamento do estado. O desenho de projetos de parcelamento e de redes de infraestrutura também aconteceu em São Bernardo do Campo, conforme informação verbal da promotora Dra. Rosângela Staurenghi ${ }^{38}$.

\footnotetext{
${ }^{37}$ A referida pesquisa foi desenvolvida em 2005, no Projeto Políticas Públicas (Fapesp), intitulado Reparação de Danos e Ajustamento de Conduta em Matéria Urbanística, coordenado pela professora Maria Lucia Refinetti Martins, de cuja equipe de pesquisadores a autora fez parte.

${ }^{38}$ Informação verbal, conforme entrevista concedida a autora em 30/08/2012.
} 
O imbróglio jurídico das propriedades e a falta de aprovação junto aos órgãos públicos competentes garantiam vantagens ao loteador ou empreendedor do parcelamento já que, dessa forma, não arcavam com custos cartoriais de registro nem de aprovação de projeto e custo de execução de obras de infraestrutura, que eram exigidas pela lei federal no 6766/1979, aumentando assim seu lucro com a venda de um pedaço de terra, e nada mais.

Os moradores assim retrataram essa situação inicial dos loteamentos:

Era só.... o trator tinha passado não tinha mais nada! Tava tudo limpinho aqui ó, nem capim tinha, igual tem hoje. Não tinha mais nada quando eu comprei (informação verbal) $^{39}$.

Outra moradora relembra:

E ai quando ele [marido] me trouxe eu fiquei assim, um tanto assustada, porque já tinham desmatado, mas tava só os tocos, assim, tinha desmatado, feito a queimada, e ainda eles não tinham feito a terraplanagem. E a reunião [da associação] era lá em baixo, no Parque Ideal, na avenida. E ai eu perguntei: mas onde que é o terreno? E ele "é ali". Mas ali não tem terreno. Porque eu olhava, só via tudo desmatado, mas não tinha nada demarcado e vim uma vez só na reunião. E nessa época não tinha ônibus aqui, a gente descia lá na Casa Fortaleza e vinha andando. Enfim, passou, eu não vim mais em nenhuma reunião. Aí começou a construir, quando a casa já tava levantada, já tava os dois cômodos aqui em baixo, foi quando eu vim. Aí, assim, já tava um pouquinho melhor, você tinha uma ideia, já tinha rua, nos terrenos tinha umas três casas só quando a gente construiu aqui e ai eu mudei em 1995 pra cá (informação verbal) ${ }^{40}$.

A prefeitura de São Bernardo do Campo, por sua vez, ao identificar a existência de movimentação de terra nesses loteamentos, notificou e embargou os mesmos logo após a sua abertura. A primeira notificação foi para o Parque dos Químicos, em 1988. As outras notificações e embargos ocorreram em sequência: em 1990 no Parque Ideal, em 1992 no Ouro Verde e Novo Horizonte e em 1993 no Nova América ${ }^{41}$. Houve apreensão de máquinas de terraplanagem e ferramentas de construção e quando a fiscalização se intensificou com a abertura de processo civil por parte da promotoria pública, alguns dos representantes das associações "sumiram", como no caso do Nova América e do Novo Horizonte.

Chegaram aqui no Novo Horizonte, aqui a Polícia Florestal prendia as ferramentas e levava embora porque estavam construindo. Só que o pessoal comprava outra no outro dia e continuava. Foi só na época também, dali pra cá nunca mais eu vi uma pessoa aqui do meio ambiente ou da polícia rodando aqui pra proibir alguma coisa (informação verbal) ${ }^{42}$.

E depois disso os dirigentes da associação:

(...) Saiu tudo fugido rapaz! A doutora promotora caiu de pau em cima, vazaram! Certo? Aí depois de muito tempo que foram aparecer aí... Eles apareciam aí, mas só na escondida! Aí o cara que loteou aqui tentou lotear do outro lado, na chácara

\footnotetext{
${ }^{39}$ Conforme morador do loteamento Nova América, em entrevista concedida a autora em 27/06/2010.

${ }^{40}$ Conforme moradora do Novo Horizonte (Ouro Verde), em entrevista concedida a autora em 23/08/2012.

41 Informações concedidas à autora pela Secretaria de Planejamento Urbano da Prefeitura de São Bernardo do Campo, em 2009.

${ }^{42}$ Conforme entrevista com morador do Nova América concedida à autora, em 27/06/2010.
} 
Damasceno, só que aí ele já tinha vendido bastante terreno lá também e a polícia pegou ele de jeito também e saiu vazado, aí sumiu, saiu fugido aí, não sei nem por onde anda (informação verbal) ${ }^{43}$.

Mas se inicialmente a prefeitura de São Bernardo do Campo não foi totalmente conivente porque interferiu e notificou a situação de construção em situação irregular, também não foi completamente repressora - pois não impediu a construção dos loteamentos. Perdurou por muitos anos esse "meio termo", entre a fiscalização e conivência.

Importante também destacar nesse processo de formação dos loteamentos, a mudança por que passaram as associações de moradores, cuja função inicial era forjar uma imobiliária para a venda de lotes. Essas primeiras associações tinham estratégias para transmitir sua figura jurídica aos moradores do loteamento e, para isso, realizavam sucessivas eleições de diretoria, incorporando aos poucos os moradores do local. Desse modo, as pessoas responsáveis pelas vendas se desligavam formalmente do loteamento, apesar de continuarem exercendo influência política nos bairros, como é o caso de alguns loteadores que se elegeram vereadores nos anos seguintes.

Ocorre que, posteriormente, as associações foram reapropriadas pelos moradores, que se tornaram novas lideranças locais, pois passaram a atuar na reivindicação de infraestrutura e outras melhorias junto à prefeitura. Conforme relatam lideranças que já participaram (ou ainda participantes) das diretorias das associações, o momento mais significativo da atuação conjunta das seis associações foi justamente a reivindicação de infraestrutura, nos anos iniciais da ocupação. Além disso, passaram a acompanhar o andamento das Ações Civis Públicas, junto ao Ministério Público, nas quais as associações figuravam como um dos réus. Por outro lado, como observam essas mesmas lideranças, há pouco envolvimento dos demais moradores no momento de renovar diretorias, seja pela dificuldade de acompanhar reuniões externas e internas, seja por receio de assumir responsabilidades; e nos últimos anos os mesmos moradores acabam revezando-se entre si nas sucessivas diretorias das associações.

Além disso, as atuais associações de moradores apresentam situações diferenciadas quanto à sua atuação. Algumas desempenham funções e atividades essencialmente comunitárias e trabalham voltadas aos objetivos de regularizar e melhorar seu bairro, procurando o diálogo com a prefeitura para apoiar seus projetos; enquanto que outras se limitam às atividades internas da própria associação, sem promover o envolvimento coletivo dos moradores para sustentar uma atuação política autônoma. Há ainda a diferença de posicionamento diante da gestão municipal, que decorre das filiações político-partidárias dos diretores das associações e sua afinidade com o partido do governo municipal.

Apesar do maior ou menor engajamento das associações em reivindicações políticas e questões comunitárias locais, o que há de comum em todas elas é que representam a unidade fundiária do conjunto, ou seja, cada morador proprietário de lote detém uma fração ideal de terreno, à semelhada de um condomínio, e está formalmente atrelado à sua respectiva associação de

\footnotetext{
${ }^{43}$ Idem.
} 
moradores. As lideranças que acompanham a ACP há mais tempo reconhecem que a solução de regularização fundiária e urbanística dependerá de uma solução de conjunto. Esse aspecto, contudo, não é percebido da mesma forma por todos os moradores, o que coloca limites para a atuação das associações ${ }^{44}$.

A compreensão da constituição desses loteamentos, portanto, passa necessariamente por explicitar o aspecto jurídico-fundiário articulado ao papel das associações de moradores, que promoveram tanto um modo particular de apropriação do solo urbano, como engendraram, ainda que de modo contraditório, a organização social presente nesses espaços.

Por isso, recuperamos o momento inicial de formação dos loteamentos irregulares, que foi regido pela viabilização de um negócio imobiliário irregular e envolveu diversas estratégias para sua realização. Nesses casos, fica bastante claro que os loteadores conheciam as restrições ambientais da região, mas ao não segui-las garantiram maior aproveitamento da gleba e portanto maior lucro, decorrente de sua comercialização irregular e do pouco trabalho nela incorporado, ou seja, para que as vendas acontecessem bastou o desmatamento, a movimentação de terra, a abertura de sistema viário e a demarcação de lotes. Soma-se a isso o processo de valorização interna do loteamento, que acontece em grande medida após o surgimento de novas construções, normalmente realizadas pela autoconstrução, e de algumas melhorias urbanas realizadas pelos próprios moradores. Ou seja, parte da apropriação da valorização, pelos empreendedores irregulares, também decorre do investimento do comprador e de seu próprio trabalho investido. A posição do lote e sua situação (topográfica, física, bem como a proximidade de córregos ou de vias principais) também são elementos que contribuíram para a definição do preço dos lotes. Esse processo de valorização é continuo e os terrenos foram sendo vendidos a preços cada vez mais elevados ${ }^{45}$. As intervenções públicas, discutidas adiante, acontecem quando o loteamento está estabelecido.

Em seguida, passamos a detalhar o processo de autoconstrução da moradia e da autoprovisão de infraestrutura nos (e dos) loteamentos do baixo Alvarenga.

\subsection{Reconstruindo a autoconstrução}

Após a compra do lote, a construção da moradia é a próxima camada ${ }^{46}$ de ocupação desse espaço urbano (MAUTNER, 1999), envolvendo o trabalho dos próprios moradores, os novos pequenos proprietários (FERRO, 1972). Assim como em outras áreas da periferia metropolitana, a autoconstrução é o processo predominante nos loteamentos do baixo Alvarenga.

\footnotetext{
${ }^{44}$ Conforme entrevistas com lideranças do Novo Horizonte, Nova América e Parque dos Químicos.

45 Conforme entrevistas coletivas com moradores realizadas durante a produção das cartografias comunitárias, realizadas em março de 2009.

${ }^{46}$ Como tratado no capítulo 2 da Parte I, Mautner (1991) emprega a noção de camadas para explicar o processo de trabalho incorporado à terra no processo de urbanização da periferia, referindo-se até o início dos anos 1980. Utilizamos aqui essa referência pelas semelhanças do processo, apesar de se tratar do contexto socioeconômico e político da década de 1990 em diante ser bastante distinto do momento anterior.
} 
A pesquisa de campo realizada de 2007 a 2012 permitiu identificar diferentes momentos para o que aqui se denomina autoconstrução, indo além do sobretrabalho implicado na construção de moradias e de outros espaços coletivos não supridos pelo Estado nas periferias, conforme já tratado em pesquisas precedentes (MARICATO, 1982 e 1995). Ou seja, a noção de autoconstrução estende-se na presente tese também às infraestruturas, pois a condição de irregularidade, combinada a uma invisibilidade consentida por parte do Estado, fez com que sua ausência fosse resolvida, na medida do possível, pelo morador, numa espécie de "presença às avessas". Há uma funcionalidade nessa "ausência", que num primeiro momento da ocupação foi total, e que ao longo do tempo foi sendo implementada em parcelas pelo morador e também, fragmentariamente, pelo poder público. De um lado, transferindo para o indivíduo os custos de construção do espaço público, que deveriam ter sido arcados, anteriormente, pelo empreendedor, e, posteriormente, pelo poder público - quando as áreas públicas resultantes de um loteamento são doadas à municipalidade; aumentando também, ainda que de forma menos direta, a exploração cotidiana do morador. E de outro lado, servindo ao clientelismo e à troca de favores ou de votos, que se estabelece no momento da negociação das melhorias, aqui e ali. Ou então, a infraestrutura é implementada quando o Estado a assume como ônus do que não foi construído pelo loteador, realizando projetos de urbanização.

Nesse sentido, as infraestruturas assim construídas também expressam uma forma de espoliação urbana, agravada por um contexto de maior fragilidade ambiental e precariedade. Isso não significa dizer que a implementação de infraestruturas, apesar de necessária, seja suficiente para reverter essa condição. Ao contrário, diante da extrema vulnerabilidade social, pode acarretar em valorização da área e consequente processo de expulsão da população aí estabelecida.

Por outro lado, a autoprovisão de infraestruturas representa, ainda que contraditoriamente e de forma residual, uma forma de adaptação ao padrão de ocupação irregular que muitas vezes não é considerada em projetos de urbanização devido, dentre vários motivos, às exigências normativas das infraestruturas públicas e seu modo repetitivo de construção. Isso não significa que a autoprovisão de infraestruturas seja entendida como solução de urbanização, mas ela coloca em questão o próprio padrão de construção de infraestruturas públicas e as possibilidades de sua concepção associadas ao desenho urbano.

Além disso, o diálogo com os moradores mais antigos, que participaram da construção dos loteamentos, evidenciou um conhecimento sobre o terreno e suas características anteriores à ocupação, como por exemplo a localização original de cursos d'água modificados, que muitas vezes não podem ser aferidos nas cartografias oficiais ou mesmo por levantamentos de campo.

O reconhecimento desses aspectos indicaria possibilidades de intervenção no espaço considerando a infraestrutura para além da solução técnica da engenharia, ou seja, articulada ao desenho urbano e ambiental de forma mais ampla.

Considerando esses aspectos e contradições, a reconstrução da autoconstrução, contemplando a autoprovisão de infraestruturas, ilumina característica da produção do espaço periférico 
recente que levanta novas questões e interpretações sobre sua importância em termos urbanos, sociais e ambientais. Nesse sentido, esse item se subdivide em três momentos, que expressam como a autoprovisão de infraestrutura se constituiu no processo de consolidação dos loteamentos.

Primeiramente, a autoprovisão de elementos de infraestrutura articula-se ao processo de autoconstrução da moradia (poço, fossa, despejo de águas servidas) e, num segundo momento, avança sobre os espaços coletivos (canaletas de drenagem, calçadas, escadarias, pequenas praças, concretagem de trechos íngremes etc.).

No decorrer dos anos, o esforço para melhorar as condições de vida do lugar desdobra-se na organização dos moradores para a reivindicação, junto ao poder público, de implantação de pavimentação, redes de água, esgoto, drenagem e eletricidade, quando outras restrições, conflitos ou trocas de favores se manifestam.

Se por um lado algumas reivindicações são atendidas, ainda que parcialmente, desviando-se de restrições da lei estadual de proteção aos mananciais (até sua alteração em 2009), e vão viabilizando-se como troca política; por outro lado, as reivindicações locais dialogam e entram em embate, ainda que indiretamente, com as concepções da política pública, as formas de gestão do território, as prioridades estabelecidas pelos planos de habitação e saneamento, as possibilidades de financiamento para obras de urbanização. Esse aspecto também compõe o quadro dos conflitos presentes nas áreas de mananciais, e será retomado adiante.

Por ora, consideramos as características, conflitos e contradições dos momentos iniciais da autoconstrução como forma de explicitar os processos de constituição desse ambiente, conforme o subitem a seguir.

\subsubsection{A autoconstrução da moradia}

Antes de abordar a autoprovisão de infraestruturas especificamente, recuperamos resumidamente algumas características relativas à autoconstrução da moradia, presente como forma de construção dos seis loteamentos, inclusive porque se relaciona com o momento inicial da autoprovisão das infraestruturas.

No estudo dos loteamentos aqui destacados, do ponto de vista da solução habitacional, para muitos moradores a compra do lote significou deixar para trás a habitação de aluguel, principalmente em favelas da região do $A B C$, e ter acesso à casa própria. Apesar da conquista da propriedade individual, a condição de irregularidade faz com que a segurança da posse seja sempre instável e a regularização algo a ser conquistado por meio de reivindicações junto ao poder público. Contudo, a precariedade ambiental e urbana continua presente.

Conforme dados coletados em visitas de campo e entrevistas qualitativas, a construção inicial das casas passou por muitas dificuldades: como a distância do loteamento das lojas de material de construção, a dificuldade de transportar materiais e a inexistência de redes de eletricidade e de água, necessárias à atividade da construção. 
Assim, a inexistência de redes de infraestrutura, somada à dificuldade de acesso ao isolado loteamento, bem como às características ambientais e topográficas do terreno, impuseram à autoconstrução da moradia dificuldades adicionais, superadas pelo esforço extraordinário dos moradores que empreenderam em parte, ou em sua totalidade, a construção da casa.

A construção das moradias frequentemente iniciou-se com um cômodo ou barraco improvisado, para ser habitado rapidamente, e desenvolveu-se ao longo dos anos numa construção em alvenaria e laje plana, conforme a condição de renda da família. Essa construção em parcelas pode durar até mais de 10 anos, com a realização de melhorias sucessivas e construção de mais um pavimento. Na maioria das entrevistas, percebe-se que a construção do cômodo começou logo após a compra do lote e demorou em torno de três anos para se completar um núcleo inicial, que passou a ser habitado mesmo em estado inacabado. Os acabamentos em geral foram feitos primeiramente na parte interna da moradia, sendo comum a utilização de cerâmica no piso e menos frequente a aplicação de azulejo nas paredes da cozinha e do banheiro. Normalmente as paredes dos ambientes receberam pintura. Evidentemente, os acabamentos foram acrescentados conforme a disponibilidade de recursos financeiros do morador.
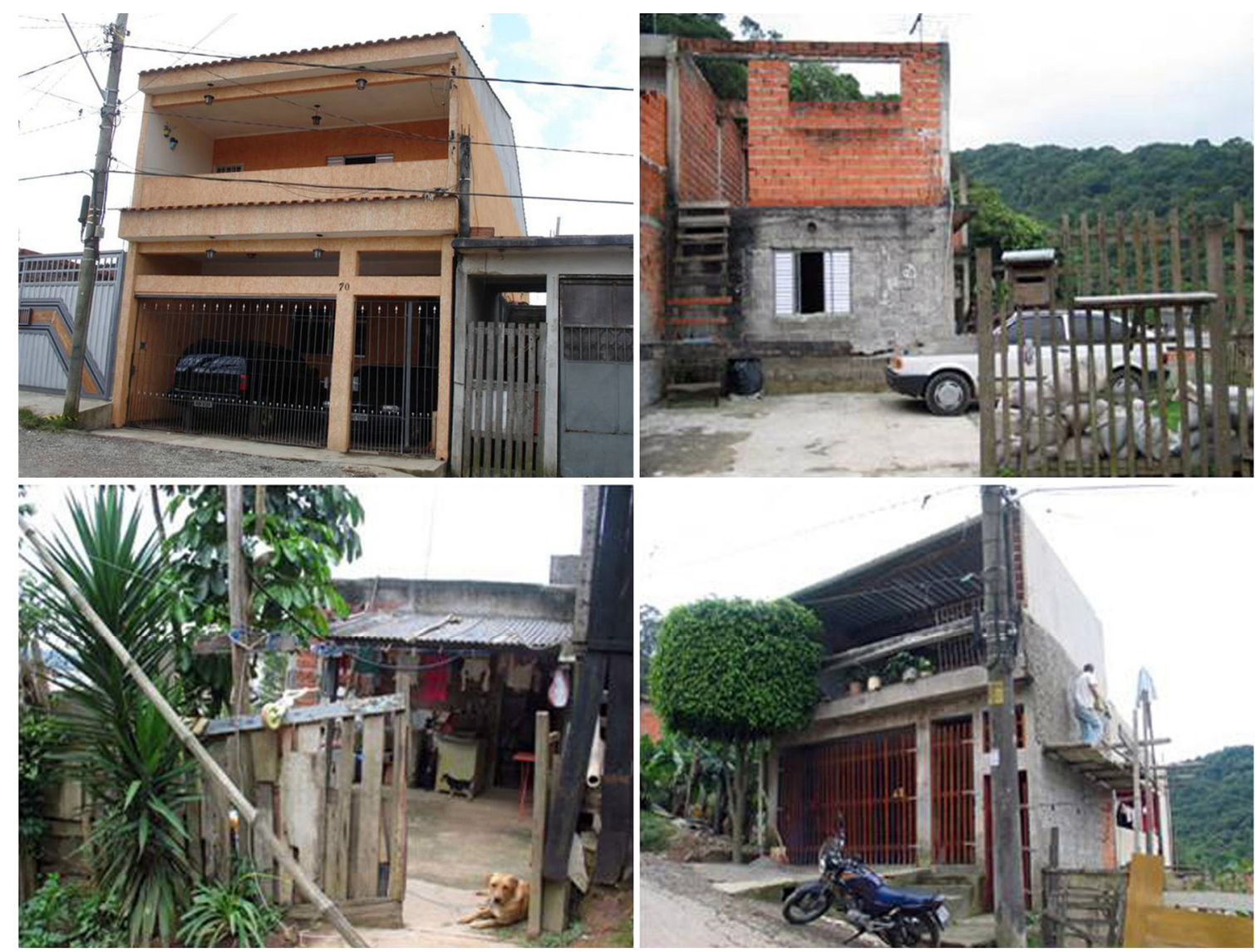

Figura 28 a 31 - Moradias no baixo Alvarenga.

Fotos da autora, 2008-2009.

A mão-de-obra pode ser contratada ou do próprio morador com ajuda da família. As duas situações são consideradas como autoconstrução nesse estudo, porque o empreendimento da construção como um todo é feito do começo ao fim pelo morador, sem contar com a ajuda de 
profissionais especializados na elaboração de projeto, gerenciamento de obra etc. Cabe destacar que a pesquisa revelou que a maioria dessas construções foi feita com mão-de-obra contratada em algum estágio da edificação (das 131 entrevistas em residências, em 55\% delas havia contratação desse serviço), sendo que em alguns casos o proprietário auxilia na construção (7\%). A segunda forma mais frequente foi a construção familiar (31\%). Não se encontrou quantidade expressiva de mutirão de vizinhança (apenas 7\%).

Isso corrobora para a reflexão de pesquisas anteriores (MAUTNER, 1991) que mostraram que a casa de periferia não é feita somente pelo morador ou em sistema de mutirão de vizinhança. Nos loteamentos estudados, a contratação de serviço de pedreiro acontece especialmente quando a faixa de renda das famílias não é extremamente baixa. Mas a contratação de mão-deobra também se explica pela construção em parcelas, feita aos poucos e conforme a condição financeira da família permite e, assim, torna-se viável também para as famílias mais pobres e que trabalham fora de casa na maior parte do tempo.

Quando a construção é feita exclusivamente pelo morador, o sobretrabalho é extraordinário e muito mais intenso do que normalmente já é o trabalho braçal na construção civil, porque as condições de trabalho eram ainda piores nos momentos iniciais de abertura do loteamento. A título de exemplo dessa condição, um morador explica:

(...) Era difícil, eu morava em Diadema e vinha todo o dia, eu saía de casa às três horas da manhã, chegava aqui, aí eu tinha que carregar material de lá até lá em cima, no carrinho, porque o caminhão não encostava. Aí enquanto estava escuro eu tava carregando material, a hora que clareava... Água eu pegava de um poço que tinha aqui ó, nesse terreno do lado aí... Aí eu trabalhava até as 7 horas da noite, porque estava dia ainda. Aí depois que escurecia eu ia tirar água na lata do poço de 14 metros prá carregar pra encher uma caixa d'água lá pra trabalhar no outro dia. Eu sofri. (Informação verbal) ${ }^{47}$

Atualmente veem-se novas construções sendo frequentemente erguidas, apesar de grande parte dos lotes estar construída. Há um mercado de aluguel e de compra de terrenos edificados ativo, mesmo com as advertências de que não se pode construir, indicadas por meio das placas da prefeitura. Apesar dos recentes compradores já adquirirem terrenos com casas construídas, ou incompletas, observa-se que tanto as ampliações e reformas como as construções novas também são autoconstruídas.

A área do lote padrão na região dos mananciais de São Bernardo do Campo é normalmente de $125 m^{2}(5 \times 25 m)^{48}$ e a casa ocupa integralmente sua superfície, não restando área permeável ou livre. A verticalização da construção em dois pavimentos ou mais, permite que novos núcleos familiares coabitem no mesmo lote, garantindo a expansão da família em novas gerações ou a locação como forma de obtenção de renda.

\footnotetext{
${ }^{47}$ Conforme morador do Nova América, entrevista à autora em 27/06/2010.

${ }^{48}$ A metragem dos lotes atendeu à Lei Federal de Parcelamento do Solo no 6766/79, que definiu lote mínimo de $125 \mathrm{~m}^{2}$.
} 
Assim, é rara a presença de jardins e área permeável no fundo ou na frente do lote. Alguns pequenos jardins são plantados em áreas que sobram, como esquinas ou partes de calçada não construídas. Há ainda hortas em alguns poucos lotes desocupados.

Figura 32 - Pequenos jardins.

Foto da autora, 2012.

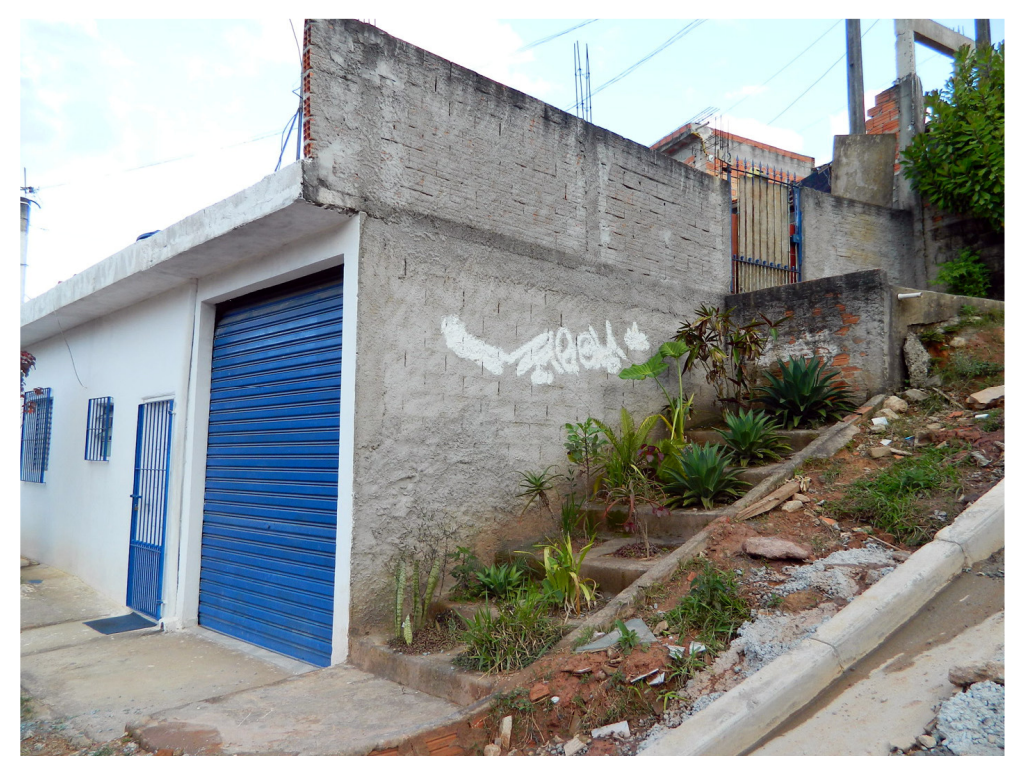

A precariedade da moradia, em termos construtivos, depende do estágio em que ela se encontra, dos materiais utilizados e de sua posição no terreno em relação ao relevo. Num mesmo loteamento popular, encontram-se diferentes portes e qualidades de moradia. Nota-se que nos loteamentos que existem há mais 10 ou 20 anos, há pouca precariedade relativa à estabilidade da construção, mas há sérios problemas de salubridade e conforto ambiental, porque há moradias muito próximas aos taludes desprotegidos e cortes abruptos de terra. Além disso, as casas são mal iluminadas e ventiladas, pois normalmente as esquadrias são um componente caro da construção, sendo poucas e pequenas as janelas e aberturas existentes.

O sistema construtivo das moradias fica aparente devido à inexistência de acabamentos externos em grande parte das casas: predomina a estrutura em concreto (pilares e vigas), fechamento com blocos de concreto no primeiro pavimento e blocos cerâmicos no segundo, com laje plana na cobertura (sistema vigota pré-moldada e preenchimento com lajota cerâmica). A laje não recebe tratamento e impermeabilização, gerando um frequente problema de umidade na parte interna na casa. Após muitos anos, os moradores fazem uma sobre-cobertura de telha ondulada na laje, o que resolve o problema de infiltração e cria um espaço de convivência, onde é comum haver uma churrasqueira, é também a área de secagem de roupas.

Semelhante a outros bairros residenciais da RMSP (independentemente da faixa de renda), praticamente todas as casas têm grandes portões e são bastantes fechadas em relação à rua. Muitos moradores apresentação satisfação quanto à qualidade da casa, manifestando entretanto o descontentamento com a parte externa. A ausência de asfalto nas ruas é apontada como um dos principais problemas, pois dificulta a acessibilidade, especialmente em dias de chuva, e nos dias secos há sempre uma poeira grossa suspensa no ar, o que dificulta até mesmo a respiração, particularmente das crianças. 
Portanto, encontra-se nos loteamentos baixo Alvarenga o padrão da autoconstrução da moradia que se reproduz nas periferias paulistanas.

\subsubsection{A autoprovisão da infraestrutura e mais...}

No processo de consolidação dos loteamentos estudados, além da autoconstrução da moradia, a autoprovisão de infraestrutura, ou seja, a construção de estratégias individuais e coletivas para superar a ausência dessas redes, tornou-se um elemento central de análise porque explicita uma contradição fundamental da construção do ambiente urbano precário: a criação de infraestruturas pelos moradores buscou remediar, por meio da ação particular e pontual, a ausência das redes públicas, que são eminentemente coletivas e deveriam funcionar como um sistema. Assim, o que chamamos de autoprovisão de infraestrutura não se constitui num sistema, numa rede, e também não supera a precariedade do conjunto, compondo mais um aspecto da urbanização desigual e do sobretrabalho do cidadão pobre. Nesse sentido a autoprovisão de infraestrutura revela um problema, ou seja, aponta para a inviabilidade da sua construção individualizada ao mesmo tempo em que coloca em evidência a importância do espaço público coletivo e a dimensão ambiental do espaço urbano, problematizando a ação do Estado na construção das infraestruturas, particularmente nos espaços periféricos. O papel do Estado aparece então invertido, pela sua ausência.

Por outro lado, a autoprovisão de infraestruturas coloca em questão as próprias redes públicas de infraestrutura - sua forma, agentes, tempo de execução, e levanta a possibilidade de se pensar arranjos diferenciados para sua construção, de modo a se buscar desenhos que melhor se adaptem ao padrão da ocupação precária.

As soluções encontradas durante o trabalho de campo, aqui ilustradas por meio de fotografias, explicitaram essas diferentes dimensões e questões relativas às infraestruturas. Alguns exemplos dessas soluções pontuais são: a construção de poços d'água, fossas, canaletas de drenagem, concretagem parcial de leitos de ruas, abertura de caminhos, construção de escadarias, de espaços de lazer e de convívio comunitários. As observações de campo feitas a cada visita, nas quais novos elementos construídos surgiam, foram complementadas com informações e relatos dos próprios moradores. Assim, os exemplos aqui abordados não são considerados soluções em si, mas entendidos como objetos-problema, no sentido de que apontam para possibilidades de concepção e construção de infraestruturas que problematizam as soluções comumente empregadas pelo Estado e construtoras e cujo domínio técnico as tornam aparentemente inquestionáveis e desejáveis por todos.

A autoprovisão de infraestruturas apresenta diferentes momentos no que tange a sua construção. Num primeiro momento estão associadas à construção da moradia e em seguida se estendem aos espaços coletivos.

Como relatam os moradores, foi por meio da negação de seus pedidos de ligação de redes públicas de infraestruturas (como eletricidade, telefone e água), devido as restrições legais, que 
a "questão" ambiental dos mananciais apareceu para eles. Ou seja, naquele momento ela era uma categoria totalmente abstrata, algo distante da realidade do morador, sobre o qual se impõe a necessidade habitacional, porém com implicações cotidianas muito concretas.

No início da ocupação dos lotes, a primeira dificuldade enfrentada em relação à ausência de infraestrutura foi o acesso à água, já no momento de construção da moradia. Por isso, uma das primeiras atividades essenciais é a escavação de um poço, muitas vezes feito pelo próprio morador.

Muita gente ficava [sem água], eu nunca tive [esse problema] porque eu tenho o poço, ele está ali aberto até hoje porque eu não fechei. Mas tá cheio de fossa agora. Aí eu não uso, tem até a bomba, funciona e tudo, mas eu não uso. Eu uso às vezes quando falta água para lavar o quintal, aí eu coloco a mangueira. E era boa a água, nossa! Eu fiz o poço por aqui, ninguém tinha, aí quando o caminhão-pipa não vinha, ficava todo mundo sem água, formava uma fila, que ia até lá embaixo na rua, cada um com um baldinho, dois baldinhos, pegando água desse poço. Em 94, 93 por aí. Aí em 95 por aí é que fizeram a ligação. (informação verbal do morador do Nova América em entrevista concedida à autora, em 27/06/2010)

Com o aumento da construção de casas e fossas, os moradores pararam de utilizar a água de poço devido à contaminação do lençol freático. Além dos poços nos lotes, as moradias situadas nas partes mais altas, próximas à área vegetada, retiravam a água diretamente das nascentes. Aproximadamente em 1993, a água passou a ser fornecida por caminhão-pipa pela prefeitura e assim se manteve por volta de três anos ${ }^{49}$, até a construção de um poço coletivo.

Figura 33 - Caixas da Sabesp para o abastecimento de água.

Foto da autora, 2009.

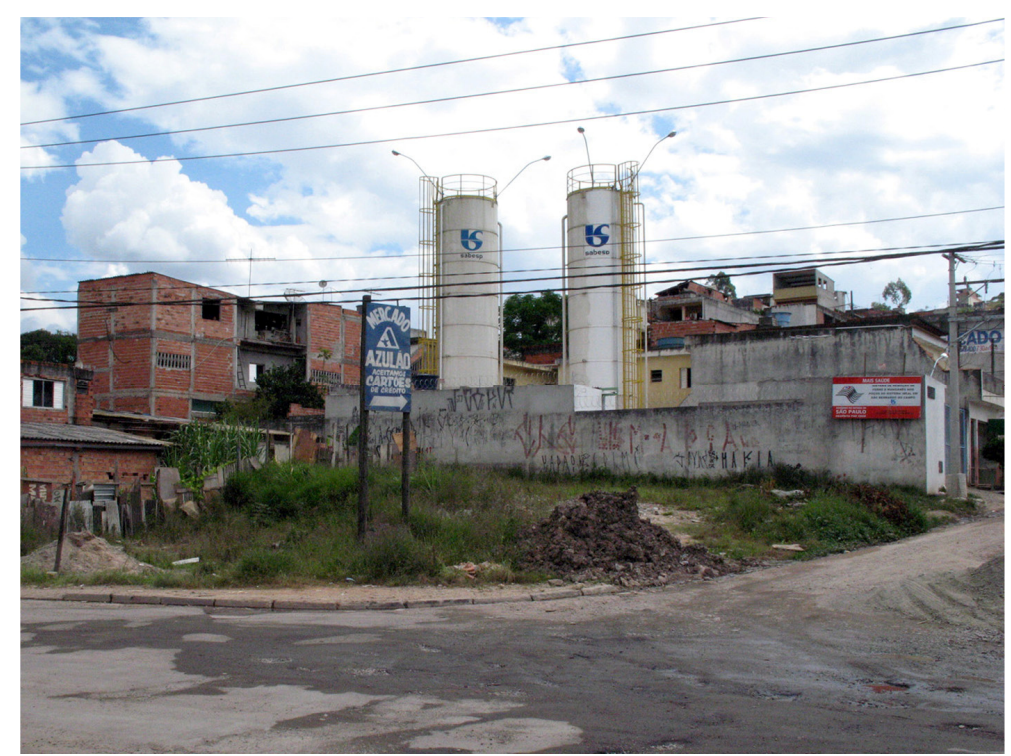

A ausência de rede de coleta de esgoto é um dos principais problemas apontados pelos moradores. A construção de uma fossa negra (escavada diretamente no terreno) ou séptica (construída com anéis, tubo de concreto ou tijolos) são as duas soluções por eles empregadas.

\footnotetext{
49 Em outros assentamentos em área de proteção aos mananciais, a distribuição de água por caminhão-pipa permanece até os dias hoje.
} 
De acordo com relatos, havia alguns moradores que prestavam o serviço de construção das fossas no loteamento. Geralmente as fossas foram posicionadas na frente do lote, no espaço destinado à garagem, ou no recuo lateral.

Ainda segundo as entrevistas, apesar da baixa manutenção necessária, quando não é feito o esvaziamento periódico da fossa (serviço especializado que custa de 200 a 300 reais) acontece o vazamento de seu conteúdo na rua, agravando a situação do contato direto das pessoas com o esgoto. Já as moradias próximas aos córregos, despejam os esgotos diretamente neles. As águas servidas de pia e chuveiro são lançadas a céu aberto, nas ruas, ou são direcionadas para terrenos baldios ou então deságuam em pequenos jardins, que sutilmente disfarçam o impacto negativo disso. Dessa forma, é frequente as águas servidas correrem a céu aberto por todas as ruas.

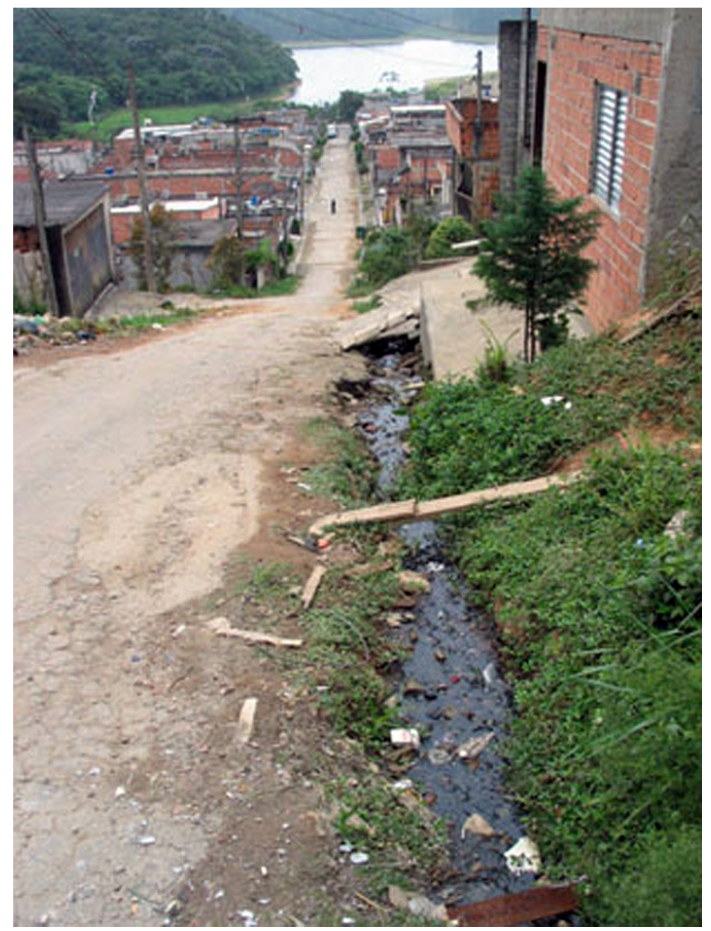

Figura 34 - Ausência de rede de esgoto.

Foto da autora, 2007.

Em algumas ruas, esse problema foi resolvido coletivamente, com soluções simples e diversificadas de tubulações, grelhas, tampões, colocação de manilhas de concreto em alguns trechos, que servem para afastar a água poluída do contato direto com os pedestres e crianças. Mas na maioria das vezes as soluções são individuais, ou seja, feitas somente na frente de lote, como ilustram as figuras 35 a 38. As imagens também demonstram que são utilizados desde materiais muito simples, como madeira, até elementos pré-fabricados, como manilhas de concreto. O que se observa é que funcionam como uma espécie de drenagem superficial, particularmente nas ruas de maior declividade, facilitando o acesso ao lote e à garagem pelo automóvel, o que não seria possível quando a soleira da casa está acima do nível da rua. Já o caminho do pedestre fica comprometido pela declividade, descontinuidade e variedade de alternativas adotadas. 

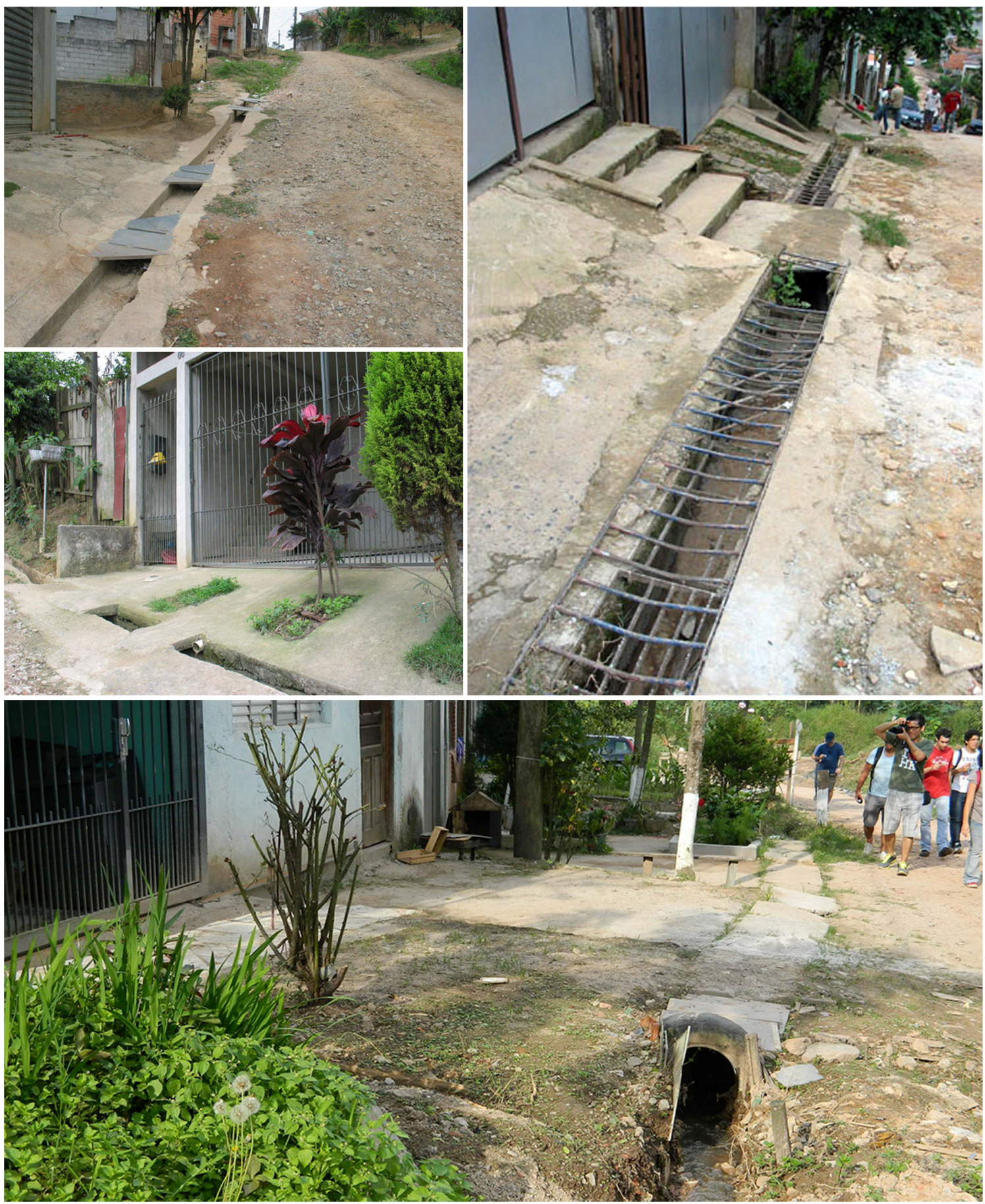

Figuras 35 a 38 - Melhorias pontuais.

Fotos da autora, 2007-2012.

As calçadas, que não existem ao longo de todas as ruas, são interrompidas pelos elementos improvisados de drenagem e também por escadarias de acesso ao lote. Interessante notar que nos últimos anos, em algumas ruas, há uma repetição de padrão de calçadas adotado em outros bairros urbanizados pelo Programa Bairro Ecológico (tratado no capítulo 6, adiante), nos quais a PMSBC incentivou a ampliação de área permeável quebrando partes das calçadas para plantação de grama. Apesar de insuficiente enquanto solução para o conjunto, esse tipo de 
solução bastante simples foi apropriada e demonstra o interesse de cada família em fazer pequenas ações que colaborem para uma futura regularização.

Os problemas de circulação e mobilidade, decorrentes da implantação inadequada sobre topografia acidentada, gerou diversos pontos nos quais a ligação entre ruas em desnível somente é possível por vias de pedestres e escadarias, também feitas pelos moradores, nas quais não se observou cuidados de construção ou manutenção, como ocorre nas soluções individuais encontradas em alguns lotes.
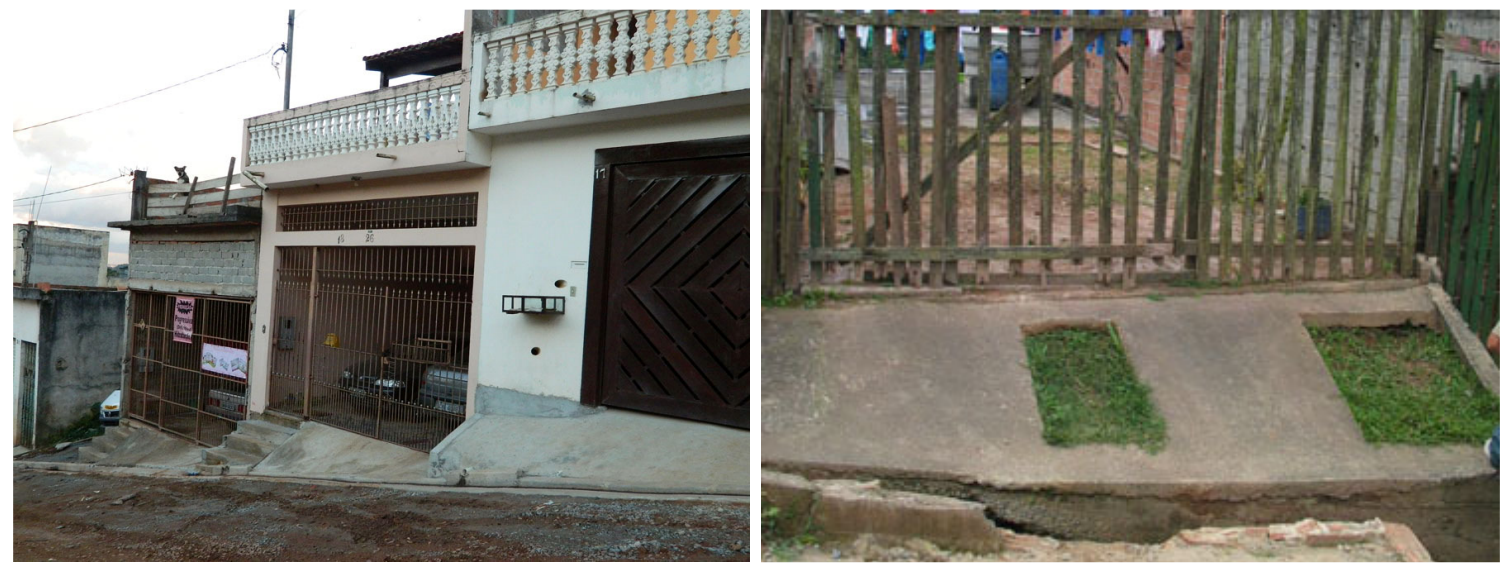

Figuras 39 e 40 - Calçadas e circulação.

Fotos da autora, 2012. 

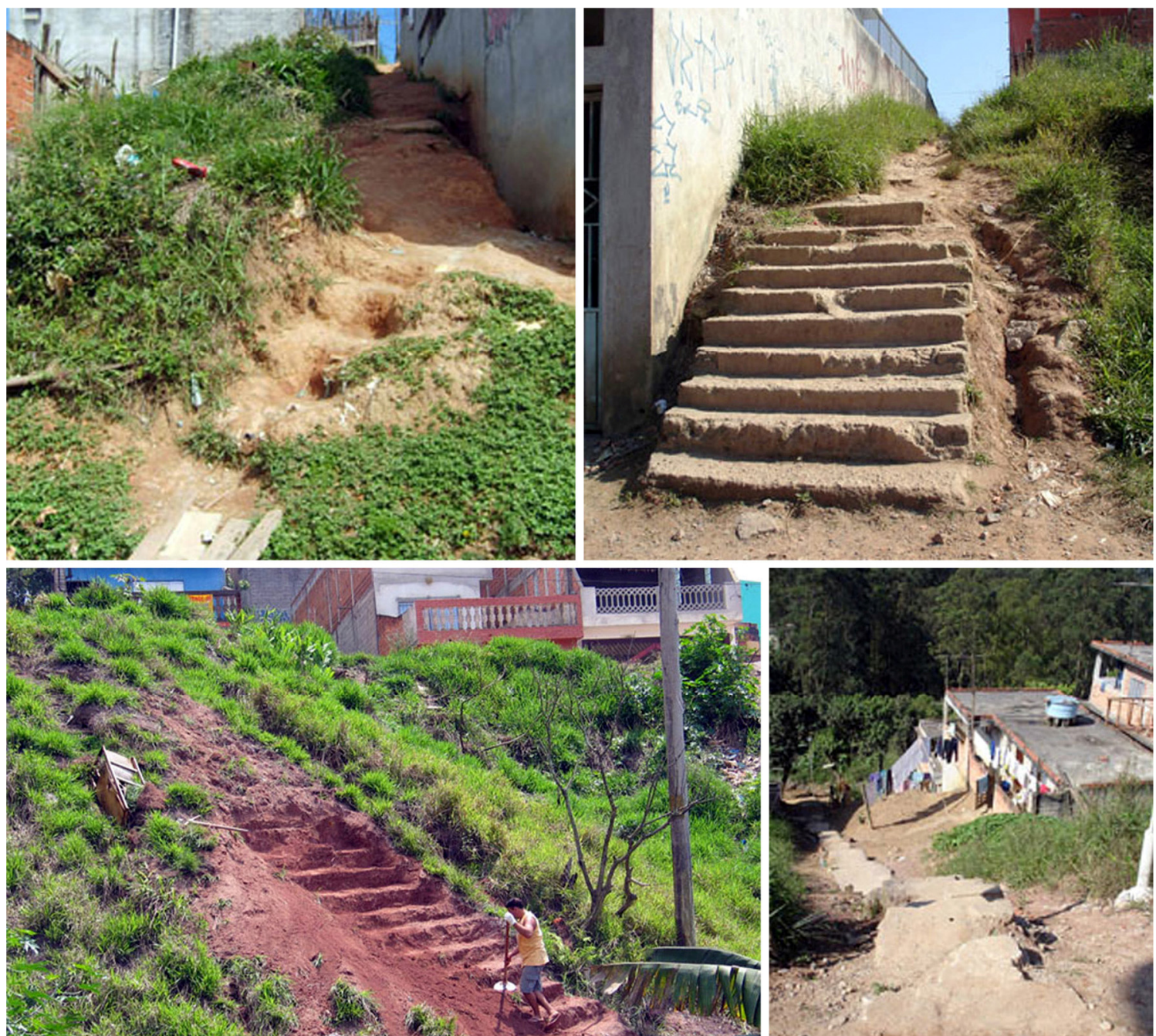

Figura 41 a 44 - Escadarias e passagens.

Fotos da autora, 2007-2019.

Contrariamente às ações que apontam para a tentativa de qualificar o ambiente em que se vive, outras atitudes aumentaram o impacto negativo decorrente da própria construção do lugar, como é o caso da movimentação de terra feita para a construção das casas e o despejo de terra e entulho (bota-fora) em determinadas áreas, aumentando os desníveis e gerando terrenos instáveis e íngremes. 


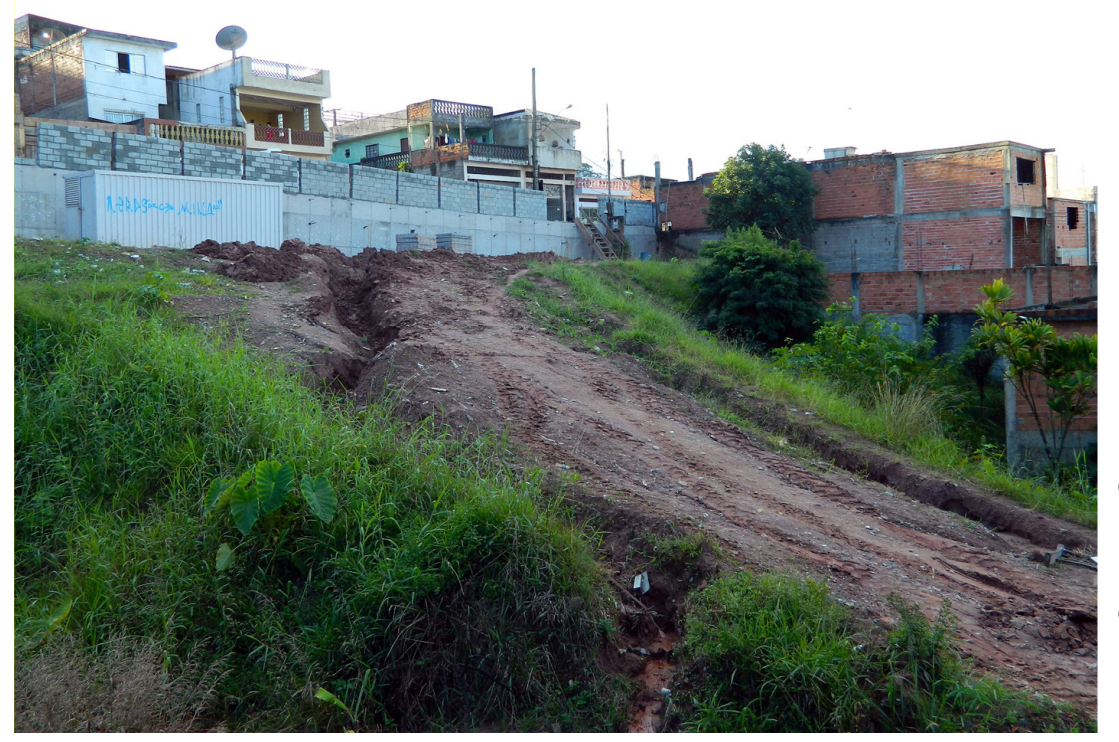

Figura 45 - Área aterrada com ao longo do tempo. Na parte superior da imagem: muro de contenção construído pela PMSBC em 2011-2012.

Foto da autora,2012.

Para a ligação de energia elétrica, durante muitos anos foram feitos os conhecidos "gatos", ligações clandestinas puxadas diretamente da rede existente na estrada principal, formando um emaranhado de fios até chegar às casas. Apesar de a energia elétrica ter sido estendida até o baixo Alvarenga, alguns "gatos" permanecem.

Além da força física despendida em todas essas atividades, cabe destacar o alto risco a que os moradores se submeteram (e ainda se submetem) ao realizá-las. Além disso, na autoconstrução da moradia é patente a cópia e a repetição de elementos e sistemas construtivos aprendidos na construção, assimiláveis com a prática (MAUTNER, 1999). Já as soluções de infraestrutura pública acontecem em grandes canteiros de obras, com procedimentos, conhecimentos práticos e materiais específicos, e nesse sentido não são reproduzíveis na pequena escala, por mais que se busquem melhorias pontuais.

Um dos espaços que de fato se apresenta como uma proposta coletiva é a praça; geralmente pequena em tamanho e número, também autoconstruída e localizada em áreas residuais dos loteamentos. As praças foram feitas a partir de iniciativas individuais, ou de grupos de moradores. Esse exemplo também ilustra a grande abrangência da autoconstrução para além da casa, nos assentamentos precários.

É importante destacar que, apesar de todas as dificuldades que a autoprovisão de infraestruturas impõe ao cotidiano dos moradores, as redes públicas só ganham status de reivindicação coletiva quando o loteamento já está bastante ocupado, como será tratado no item a seguir.

\subsection{3 ... a chegada das "melhorias".}

Diferentemente da casa que é construída por etapas e cujo aprimoramento depende da condição de renda das famílias; as "melhorias" no bairro, como a implementação das redes de 
infraestruturas, a pavimentação das ruas e construção dos demais espaços de uso comum, depende em grande medida da organização coletiva e da pressão dos moradores sobre o poder público municipal para que sejam realizadas. Como comentado no início desse item, a resposta do poder público a essa pressão social usualmente ocorre inicialmente de forma fragmentada, para resolver situações emergenciais, de risco (físico, ambiental e de saúde pública) ou ainda de modo a servir a interesses eleitoreiros. Nos casos estudados, onde os empreendedores dos loteamentos irregulares não construíram as infraestruturas sob sua responsabilidade, o poder público $0^{50}$ assumiu, gradualmente, o ônus de parte do investimento que era de responsabilidade do loteador.

A fim de caracterizar como ocorreu a chegada fragmentada de algumas infraestruturas nos seis loteamentos do baixo Alvarenga, o relato a seguir reúne as informações obtidas por meio de entrevistas individuais e coletivas, além das que surgiram durante a elaboração dos mapas comunitários (tratado em maior detalhe no capítulo 6), enfocando particularmente a chegada das redes de infraestruturas e o contexto em que foram implementadas. Passamos a enfocar de que forma as respostas públicas são dadas nesses casos, a relação com a legislação e a implicação dos diferentes agentes.

Por volta de 1991-1992, a primeira rede pública de energia elétrica residencial é implantada no Parque Ideal I, resultado de uma permissão direta do prefeito.

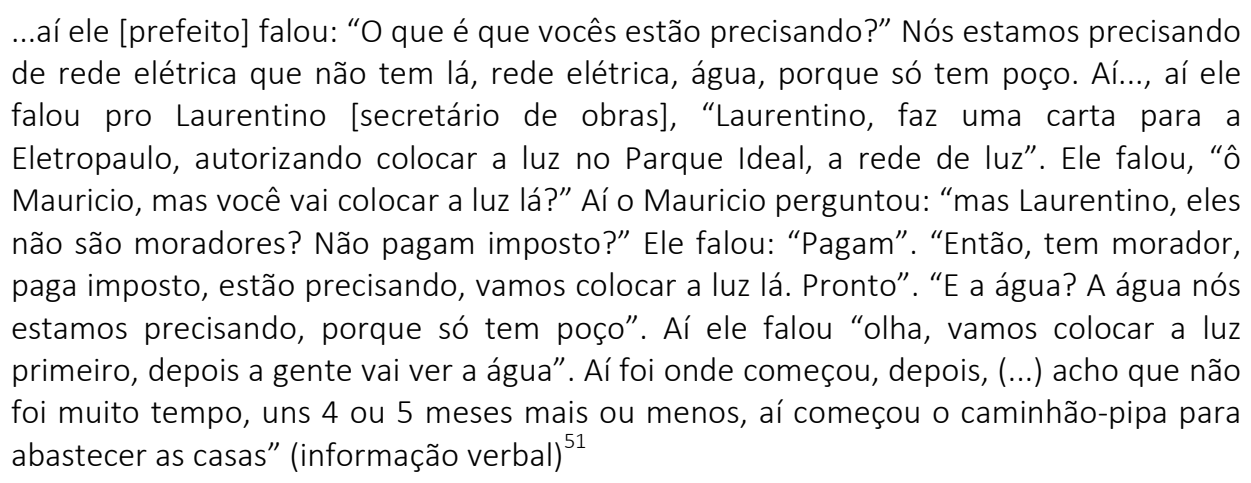

A iluminação das ruas foi implantada no Parque Ideal I e II em 1994, como se vê, por interferência direta do prefeito e do secretário de obras daquele momento. Já nos demais loteamentos a rede elétrica nas casas ocorreu em 1998 e nas ruas foi completada somente em 2007. Como comentado no item anterior, ainda há "gatos" de eletricidade em algumas moradias, segundo relato dos moradores.

A implantação da rede de abastecimento de água também decorreu da negociação dos moradores com a prefeitura e o Departamento de Águas e Esgotos (DAE). O abastecimento de água por caminhão-pipa é uma solução bastante recorrente em áreas periféricas, distantes da

\footnotetext{
${ }^{50}$ Essa situação em que o Estado assume o ônus da infraestrutura urbana que inicialmente era responsabilidade do empreendedor privado não ocorre somente em áreas de baixa renda, mas também em outros contextos e cidades brasileiras, que via de regra são assim produzidas.

${ }^{51}$ Conforme morador do Parque Ideal I, entrevista concedida à autora em 04/04/2009.
} 
rede pública de água e onde não há solução local coletiva. No entanto, o fornecimento por caminhão-pipa gerou uma série de problemas relativos à qualidade da água. Conforme relato de um morador do Parque Ideal, essa solução era muito precária, pois devido à falta de coleta de esgotos, que corria a céu aberto nas ruas, a mangueira do caminhão alcançava as caixas d'água arrastando toda a sujeira proveniente das ruas, deixando a água sempre suja e contaminada. Além do problema de intermitência do abastecimento.

Essa situação se manteve até que as associações de moradores do Novo Horizonte, Ouro Verde e Ideal se reuniram para a aquisição e doação de um terreno destinado à construção de um poço coletivo, que foi negociado na época com o Departamento de Águas e Esgotos (DAE). Em 1994 o poço começou a ser construído nesse terreno, mas logo em seguida ao início da escavação foi embargado pelo Ministério Público durante seis meses. Após a liberação da construção, o abastecimento de água dos seis loteamentos passou a ser feito pelo poço artesiano, de onde a água saía com coloração escura, o que gerava dificuldade para a utilização em alimentos e em lavagem de roupas, apesar do DAE garantir sua boa qualidade para consumo. Em 2003, a Sabesp passou a atuar em São Bernardo do Campo e, após anos de reclamação, em 2007 essa empresa instalou filtros e novas bombas, para melhorar a qualidade e a distribuição de água em todos os assentamentos.

De 1990 até hoje, a coleta e o tratamento dos esgotos continuam sendo lutas prioritárias entre as lideranças das associações, que buscam se reunir periodicamente com a Sabesp para cobrar soluções. Contudo, é recente a definição sobre a extensão da rede coletora de esgotos sobre as áreas de proteção aos mananciais de São Bernardo do Campo. De 2005 a 2006, foi desenvolvido um estudo para a elaboração do Plano Integrado de Melhoria Ambiental da Área de Proteção aos Mananciais da Represa Billings, concluído em 2007, através da JICA (Agência de Cooperação Internacional do Japão). Em seguida, esse plano foi desenvolvido pela Sabesp, que o denominou de Programa Pró-Billings, no qual prevê ampliar a rede de esgotos em São Bernardo do Campo até 2015, em conformidade também com Plano Diretor de Esgotos $2010^{52}$.

Em relação ao tratamento de esgotos, não houve o estudo de soluções alternativas ou localizadas que minimizassem o lançamento de esgotos na Billings durante os mais de vinte anos de existência dos loteamentos.

Quanto à coleta de resíduos sólidos, segundo os moradores, até aproximadamente 2001 o caminhão não entrava nos loteamentos. O lixo era depositado em uma estrutura de madeira, feita pelos moradores, na Estrada dos Alvarengas. Também não havia local para colocar o lixo reciclável, como há atualmente no Parque dos Químicos.

A declividade acentuada das ruas, somada à falta de pavimentação, dificulta a circulação de pedestres, o que piora em dias de chuva. Além disso, o assoreamento decorrente das ruas de terra é outro problema bastante frequente, com grande impacto sobre os corpos d'água e sobre a represa Billings, devido à sua proximidade com os loteamentos. Por isso, o cascalhamento das

\footnotetext{
${ }^{52}$ Esse plano será tratado no capítulo 9, adiante.
} 
ruas passou a ser uma necessidade, muitas vezes realizada pela própria prefeitura. Em uma das ruas, os moradores se cotizaram para concretar o leito carroçável, pois este era intransitável em dias de chuva.

Durante os anos 1990, portanto, a chegada de algumas infraestruturas ocorreu de forma negociada, sem seguir aos trâmites formais estabelecidos pela legislação ambiental, e se resolveu seja por ordem do prefeito, seja por negociação direta com empresas concessionárias de serviços.

O que caracteriza esse processo é a fragmentação, tanto do ponto de vista físico e territorial, pois as "melhorias" não são pensadas para o conjunto, ao contrário, favorecem alguns pontos dos loteamentos; como do ponto de vista político e social, já que as demandas são respondidas de forma desigual diante da pressão exercida por cada associação, quando não corresponderam a trocas de favores, especialmente com vereadores locais. A consolidação do loteamento realizase assim de modo bastante gradual, num embate permanente tanto interno aos bairros, ou seja, na construção instável da organização coletiva dos moradores; quanto externo, no diálogo dos moradores com o poder público.

O embate pelas "melhorias" também se travou no plano jurídico, no acompanhamento das Ações Civis Públicas, cujas sentenças determinavam o desfazimento do loteamento, para a reconstituição do estágio original da vegetação, e por isso interditavam a realização de obras e construções. Apesar de representarem ameaças permanentes de remoção dos moradores, essas sentenças não foram cumpridas. Como se verá adiante, o quadro político e institucional alterase no final dos anos 1990, quando ocorre uma mudança na condução do trabalho do próprio MP, da prefeitura de SBC e consequentemente no tratamento dos loteamentos irregulares. Nesse momento, a legislação de proteção aos mananciais será pautada por uma lei que estabeleceu uma nova política de mananciais, definindo situações de exceção para a realização de obras de urbanização enquadradas no Plano Emergencial (abordado no capítulo 6). Nesse contexto, a utilização do Termo de Ajustamento de Conduta será o instrumento jurídico utilizado pelo MP para viabilizar a "reparação de danos" causados pelos loteamentos irregulares, portanto, se constituirá como alternativa para a realização de obras de infraestrutura e de regularização fundiária dos assentamentos.

Nos loteamentos do baixo Alvarenga, essas mudanças impulsionaram um debate interno das associações e moradores, envolvendo uma ONG local, e a elaboração de um estudo que daria as bases para a formulação de um TAC para o conjunto. Nesse contexto de debate e elaboração se inserem as cartografias comunitárias, sobre as quais realizamos um exame mais detido no capítulo 6, onde também serão abordadas as intervenções públicas mais recentes nos loteamentos Nova América e Parque dos Químicos. 


\section{CAPÍTUL0 5}

\section{Discursos e práticas dos agentes envolvidos na CPI dos Loteamentos Irregulares em São Bernardo do Campo}

Considerando o período do final dos anos 1980 e o início dos anos 1990, passamos da descrição do processo de formação dos loteamentos do baixo Alvarenga para, nesse capítulo, voltar o foco novamente ao contexto geral do município, retratando o momento em que os conflitos inerentes aos loteamentos irregulares em APM ganham amplitude e o tema alcança o debate público, relevando implicações práticas e políticas dos agentes envolvidos.

Em São Bernardo do Campo, o rápido crescimento de loteamentos irregulares foi produzido num contexto em que um emaranhado de relações se estabeleceu, envolvendo a participação de diversos agentes, cada qual visando seu objetivo e sustentando discursos próprios, ora em oposição, ora em articulação e parceria: proprietários de terras, loteadores, empresas imobiliárias, empresas projetistas e de terraplanagem, associações de bairro, movimentos de moradia, políticos locais do poder executivo (prefeitos, secretários, técnicos) e legislativo (vereadores), movimento ambientalista.

Nesse momento, os loteamentos irregulares passaram a ser frequentemente denunciados, tanto pelo movimento ambientalista do $\mathrm{ABCD}$ e pela imprensa, como por alguns compradores de lotes que se sentiram lesados. Essa situação provocou a explicitação de diferentes posicionamentos diante da ocupação irregular para moradia da área de proteção de mananciais, a partir dos quais é possível melhor compreender como a questão foi encaminhada politicamente nessa fase em que grande parte dos loteamentos se estabeleceu.

O presente capítulo busca evidenciar a participação contraditória desses agentes nesse processo. Ao mesmo tempo, explicitamos o tratamento político da questão urbana e ambiental no início dos anos 1990, que passará por mudanças somente no final dessa década - período que será abordado no capítulo subsequente.

O estopim do conflito foi acionado pela imprensa em 1991, a partir da publicação de uma sequência de matérias de jornais que trataram do caso de uma área particular ocupada, chamada Vila Zumbi, no Jardim Tupã. Uma das primeiras notícias denunciava que a invasão teria sido incitada e organizada por "falsas lideranças" ligadas ao vereador estadual Walter José 
Demarchi (PTB). Quando a matéria foi publicada, o pedido de reintegração de posse havia sido expedido e os moradores estavam sob a iminência de remoção ${ }^{53}$.

Em carta aberta à população, os coordenadores da comissão [de ocupantes] dizem ter sido 'manipulados por falsas lideranças (Nina, Osório e Dionísio) que não têm interesse em fortalecer a luta organizada pela habitação' (Folha de São Paulo, 04/01/1991. "Invasores acusam simpatizantes de Demarchi de organizar ocupação").

Nas semanas seguintes, o caso continuou sendo noticiado ${ }^{54}$. As matérias enfocavam, sobretudo, as acusações recíprocas entre vereadores do PTB e do PT sobre quem seriam os possíveis responsáveis pela invasão ${ }^{55}$. Além do jogo político-partidário que o tema suscitava, o impacto ambiental era outro aspecto que também ganhava destaque nos jornais ${ }^{56}$. O desmatamento causado pela ocupação chamou a atenção do movimento ambientalista do ABCD, que passou a exercer pressão sobre a prefeitura para impedir que esta, por meio da assistência jurídica gratuita à população ${ }^{57}$, conseguisse suspender o pedido de liminar da reintegração de posse ${ }^{58} d a$ Vila Tupã.

A partir do caso da Vila Tupã, outras situações de venda irregular de lotes passaram a ser noticiadas. A matéria do Diário do Grande ABC denunciava a existência de um "esquema" de "falsas associações" ou "associações fantasmas" para a venda de lotes, mostrando que o problema era mais amplo:

Empresas imobiliárias e grupos de loteadores clandestinos organizados em associações de sem-teto foram responsáveis nos últimos 18 meses pela destruição de uma área de 123 mil metros quadrados de matas virgens em São Bernardo - o que corresponde a quase $60 \%{ }^{59}$ da área total de mananciais do município, de 211 mil metros quadrados. A denúncia consta de um relatório do Serviço de Assistência Judiciária da Prefeitura, que fez uma radiografia das áreas próximas à represa Billings que estão sendo ocupadas, aumentando o desequilíbrio ecológico da região. $O$ órgão descobriu a existência de uma indústria que movimenta milhões de cruzeiros e que já lesou cerca de 4 mil famílias só no município. (Diário do Grande ABC, de 23/01/91. "São Bernardo já perdeu mais da metade de sua área de manancial").

A notícia trazia à tona tanto o envolvimento de empresas imobiliárias que realizavam a venda de lotes em parcelamentos irregulares, como a formação de associações de bairro (ou de

\footnotetext{
${ }^{53}$ Os moradores propuseram ao proprietário a compra da área. O proprietário negociou um número máximo de famílias que poderiam ficar no local, mas não cumpriu o acordo.

54 “Lideranças trocam acusações sobre ocupação de área na 'Vila Zumbi”" Folha de S. Paulo, 9 de janeiro de 1991.

${ }^{55}$ Folha de S. Paulo 09 de janeiro 1991 "Lideranças trocam acusações sobre ocupação de área na 'Vila Zumbi'”. As pessoas citadas pelos ocupantes na matéria anterior, acusam um vereador do PT (Aldo dos Santos) de ter organizado tal ocupação.

56 “Ocupações agravam situação em São Bernardo" e "Invasão provoca danos ecológicos", Folha de S. Paulo, 10 de janeiro de 1991.

57 O prefeito Maurício Soares instituiu esse serviço com a lei municipal no 3388 de 23 de outubro de 1989, que dispunha sobre a criação de Assistência Jurídica Gratuita na Secretaria de Assuntos Jurídicos, em convênio com a Faculdade de Direito de São Bernardo do Campo.

58 Folha de S. Paulo 10 de janeiro de 1991 “Ocupações agravam situação em São Bernardo".

${ }^{59}$ Consideramos esse dado superestimado, pois o desmatamento atual é inferior a $60 \%$ da área de mananciais do município.
} 
moradores), também conhecidas como associações de construção comunitária, registradas em cartório, que funcionavam como imobiliárias, visando esse mesmo fim. Em alguns casos houve atuação articulada de ambas na promoção de loteamentos. Em outra matéria complementar, "Entidade fantasma vende lote a 350 mil em área de manancial" - Diário do Grande ABC, 31/01/91, o repórter se fez passar por comprador de lote para mostrar como funcionava tal esquema.

Mas, no momento em que o tema ganhou as páginas dos jornais já não se travava de descoberta de um fato inédito, particularmente para a prefeitura, que desde 1989 já propunha Ações Civis Públicas (ACP) contra os loteadores irregulares. Entretanto, por se tratar de ocupação sobre área protegida de mananciais, a pressão da opinião pública acirrava-se, particularmente a do movimento ambientalista.

Diante desse quadro, as denúncias nos jornais motivaram a instauração da Comissão Parlamentar de Inquérito chamada "CPI do Loteamento Irregular", criada pela portaria no 1260 de 13 de maio de 1991 na Câmara Municipal de São Bernardo do Campo, "para apuração sobre responsabilidade de criação de loteamento clandestino em APM", sob coordenação do vereador Ademir Silvestre da Costa (PSB) ${ }^{60}$.

Os documentos reunidos ${ }^{61}$ durante a vigência da CPI revelaram-se materiais importantes para a pesquisa e a partir do seu exame foi possível identificar diferentes posicionamentos diante da questão dos loteamentos irregulares, particularmente da gestão municipal, dos vereadores (envolvidos diretamente ou não na abertura de loteamentos irregulares), do movimento popular de moradia e do movimento ambientalista. Não pretendemos fazer uma análise extensa de seus discursos, mas destacar em linhas gerais seus posicionamentos, que são bastante heterogêneos, por vezes ambíguos e contraditórios, evidenciando interesses divergentes, seja dentro de um mesmo partido, movimento ou na própria gestão municipal (no que se refere à atuação de diferentes secretarias responsáveis por partes do problema). Com isso, ficam claras as diferentes apropriações do discurso ambiental e da defesa da ecologia, bem como do problema social articulado ao da moradia, por esses diferentes sujeitos e suas respectivas práticas (ACSELRAD, 1999).

A partir da leitura dos depoimentos e documentos, foi possível identificar um movimento geral de produção dos loteamentos irregulares, corroborando com as análises apresentadas anteriormente sobre o trabalho de campo nos loteamentos do baixo Alvarenga, ou seja, confirmando a repetição das estratégias criadas para a sua realização. Todavia, há uma diversidade de especificidades dentre as associações de moradores que aparecem nos citados

\footnotetext{
${ }^{60}$ A CPI foi composta pelos vereadores: Sidney Coppini (PTB), José Roberto de Melo (PRB), Ary José de Oliveira (PFL), Oswaldo Alves Pereira (PRN) e José Ramos de Oliveira (PSC).

${ }^{61}$ Durante a pesquisa, consultamos no Ministério Público as cópias dos 11 volumes dos processos que compõem a $\mathrm{CPI}$, já arquivada. O processo contem os seguintes tipos de documentos: atas de reunião da Câmara nas quais constam depoimentos de diversos sujeitos envolvidos; denúncias e cartas dos movimentos ambientalistas; notícias de jornais; cópias das ações civis públicas, autos de infração e embargo; documentos relativos a venda dos loteamentos pelas "falsas associações" (contratos, recibos de pagamento); leis municipais, estaduais e federais pertinentes ao tema.
} 
documentos, que não pretendemos abordar, pois demandariam uma pesquisa mais extensa para além dos registros documentais reunidos na CPI. Por isso, os aspectos aqui abordados buscam destacar os principais pontos do conflito e seus agentes, a partir da documentação analisada, complementada pelas entrevistas realizadas durante a pesquisa.

\subsection{Os posicionamentos dos vereadores durante a CPI dos Loteamentos Irregulares}

Apesar de aprovada pela maioria dos vereadores, desde sua proposição, a CPI dos Loteamentos Irregulares foi criticada por alguns deles, que consideravam o tema caso de polícia e não objeto a ser tratado pela Câmara Municipal ${ }^{62}$. Entretanto, as primeiras denúncias indicavam o envolvimento indireto ou direto de vereadores, tanto no apoio político às ocupações organizadas por movimentos, como participando diretamente dos empreendimentos irregulares; o que também explica parte da resistência às investigações. Nesse sentido, na leitura dos documentos, aparece como uma constante o jogo político-partidário entre vereadores explorando o tema em questão. Se por um lado alguns vereadores expressavam abertamente sua atuação apoiando os movimentos de moradia na luta pela melhoria das condições de habitação, por outro lado, a participação dos vereadores na promoção dos loteamentos irregulares revelava outros interesses econômicos e políticos.

Em seu conjunto, pode-se dizer que a CPI logrou aprofundar o conhecimento sobre a formação dos loteamentos e ao fazê-lo, foi atuante no debate sobre o tema que, no início dos anos 1990, ganhou relevância não só no município de São Bernardo, mas reverberou também nos demais municípios do $A B C D$, principalmente em Diadema e Santo André, onde a questão da moradia para a população de baixa renda e a ocupação das áreas de proteção aos mananciais também era um problema relevante.

As atas das reuniões da CPI nos primeiros meses de sua vigência demonstram que ela se constituiu num espaço de diálogo no qual associações de bairro, movimentos organizados e indivíduos participaram de várias sessões, nas quais expuseram queixas, pediram auxílio de vereadores em alguns casos (como para impedir a reintegração de posse da Vila Zumbi), realizaram denúncias ou deram esclarecimentos sobre envolvimento nos loteamentos.

Todavia, a partir do avanço das investigações, a atuação do vereador coordenador da CPI passou a ser mais incisiva, assumindo um caráter de cumprimento estrito das leis pertinentes ao tema. A postura legalista - num contexto de total descumprimento da lei - foi o modo como a CPI conduziu o conflito, o que resultou no encaminhamento de alguns casos ao Ministério Público e à delegacia de polícia, chegando a instruí-la para realização de prisão em flagrante de loteadores irregulares.

\footnotetext{
${ }^{62}$ Conforme Ata 14ㅇ Sessão Ordinária da Câmara Municipal de São Bernardo do Campo de 08/05/1991.
} 
A primeira prisão em flagrante, de um loteador irregular ${ }^{63}$ no ato da venda de lotes no Riacho Grande, ocorreu numa área de propriedade em nome de sua empresa, localizada distante do centro do município e dos bairros já consolidados em APM. Em seguida, outras duas prisões de

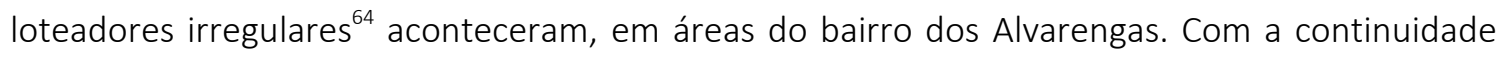
da CPI, em janeiro de 1992, mais dois flagrantes foram realizados pela polícia, em situações semelhantes, em áreas da Associação Comunitária Jardim do Ipê e Associação Comunitária Próhabitar. Contudo os supostos vendedores não confirmaram que estavam vendendo lotes, mas apenas mostrando as áreas ${ }^{65}$.

A motivação dessas prisões amparou-se no argumento da degradação ambiental dos mananciais, comprometendo a produção de água afluente à represa Billings, ao qual se somou a crítica contra a exploração da condição de pobreza da população, considerada como vítima do esquema montado pelos loteadores irregulares e clandestinos. Contudo, o argumento legal que deu suporte à prisão foi a lei federal no 6766/1979 (artigo 50, inciso I) que definiu a atividade de parcelamento irregular do solo como crime contra a administração pública.

Para a Comissão, a aplicação da lei no 6766/1979 tinha como objetivo coibir as organizações consideradas criminosas, que lucravam com o negócio do loteamento irregular, destinado à população de baixa renda, situado em área de manancial. De fato, foi identificada uma atuação de grupos e de loteadores que se comportavam enquanto tal, disfarçando a atividade ilegal a partir de associações de fachada supostamente comprometidas com a luta por moradia. Contudo as prisões recaíram sobre indivíduos, muitos deles pessoas sem grandes posses (uma enfermeira, um comerciante), não alcançando de fato as organizações ou grupos maiores cuja atuação era organizada.

Além disso, a lei federal no $6766 / 1979^{66}$ não vinculava a penalidade do crime contra a administração pública ao ato em flagrante de venda de lotes, já que a irregularidade poderia ser

\footnotetext{
${ }^{63}$ Conforme matéria do Diário do Grande ABC do dia 01/09/1991 “Loteador clandestino acaba preso" e do Diário Popular "Grileiro é preso após enganar 100 pessoas", na mesma data. O loteamento situava-se na Estrada do Rio Acima, no Riacho Grande e estava sendo desmatada para a realização do parcelamento. Conforme ofício no $27 / 91$ de 04 de setembro de 1991, da Câmara Municipal de SBC, o presidente da CPI, Ademir Silvestre, encaminha ao Ministério Público as provas e testemunhos "que evidenciam a absoluta necessidade de prisão [do loteador] que ora é solicitada por esta CPI, como ato de defesa da população" (consta do v. 5, p. 803 do processo arquivado da CPI). O alvará de soltura do loteador foi concedido na mesma semana da prisão em flagrante (em setembro de 1991) "por ausência de justa causa de prosseguimento" (Cf. Alvará de Soltura, v. 7, p. 1294).

${ }^{64}$ Em 06 de setembro de 1991, outra matéria do Diário do Grande ABC intitulada "Polícia prende dois loteadores de área de manancial" publicava a prisão provocada por denúncia de Ademir Silvestre. Um dos loteadores era membro do Conselho Fiscal da Associação Lutar e Viver, responsável pela venda de cem lotes de $5 \times 25$ metros, num terreno de 9,2 mil m². E a outra, enfermeira de profissão, atuava como corretora de venda de lotes na Associação Comunitária Ouro Verde (um dos loteamentos estudados nessa tese), ambos loteamentos situados no Bairro dos Alvarengas em SBC. Os acusados foram defendidos pelo advogado Edinho Montemor, cuja atuação junto às associações para a venda de lotes aparece em mais de um caso nos documentos da CPI.

${ }^{65}$ Conforme matéria "Polícia flagra dois loteadores de mananciais", publicada no Diário do Grande ABC, 10/01/1992, p. 3 A.

${ }^{66}$ Art. 50. Constitui crime contra a Administração Pública. I - dar início, de qualquer modo, ou efetuar loteamento ou desmembramento do solo para fins urbanos, sem autorização do órgão público competente, ou em desacordo com as disposições desta Lei ou das normas pertinentes do Distrito Federal, Estados e Municípios; II - dar início, de qualquer modo, ou efetuar loteamento ou desmembramento do solo para fins urbanos sem observância das determinações
} 
comprovada de outras formas, com define o artigo 50 da lei. Ou seja, se fosse levado a cabo a sua aplicação, as denúncias já apuradas e confirmadas também incorreriam em outras diversas prisões. É importante destacar que a aplicação da lei no 6766/1979 dessa forma não se repetiu sistematicamente fora da área de proteção aos mananciais, em outros casos de loteamentos irregulares. No caso em análise fica claro que o argumento ambiental da proteção dos mananciais reforçou sua utilização.

O tratamento da questão como caso de polícia, diante da denúncia de crime organizado, chegou ao ponto de o vereador coordenador da CPI solicitar proteção policial alegando ter recebido ameaças anônimas.

O movimento de moradia rapidamente posicionou-se contrariamente às prisões efetuadas, que haviam afetado trabalhadores. Por isso, organizou uma passeata seguida de manifestação na Câmara. A manifestação foi recebida pelos vereadores, com a realização de uma sessão ordinária, na qual diversos participantes se expressaram.

Em sua maioria, os vereadores se pronunciaram como favoráveis à CPI, desde que visasse a apuração de fatos, mas eram contrários às prisões, reiterando o argumento de que uma questão social não deveria ser tratada como caso de polícia. Respondendo a essa crítica, o coordenador da CPI - Ademir Silvestre, por sua vez, reafirmava seu papel de seguidor da lei.

Nesse debate, durante a fala de vereadores que se opunham às prisões, o problema da moradia foi colocado em evidência, como uma questão de abrangência nacional, decorrente da falta de políticas e recursos para a solução do problema habitacional, e não como um problema particular de São Bernardo do Campo. Dessa forma, a ocupação das áreas de proteção aos mananciais era considerada como fato consumado, relacionado à falta de políticas habitacionais, e por isso seria necessário buscar alternativas para futura regularização a partir da mudança da legislação de proteção aos mananciais. Assim, os discursos desviavam o foco da questão específica em debate e não criticaram o impacto social e ambiental negativo inerente ao loteamento irregular promovido exclusivamente por interesses de lucro imobiliário de um mercado informal que havia se criado.

constantes do ato administrativo de licença; III - fazer ou veicular em proposta, contrato, prospecto ou comunicação ao público ou a interessados, afirmação falsa sobre a legalidade de loteamento ou desmembramento do solo para fins urbanos, ou ocultar fraudulentamente fato a ele relativo. Pena: Reclusão, de 1(um) a 4 (quatro) anos, e multa de 5 (cinco) a 50 (cinquenta) vezes o maior salário-mínimo vigente no País.

Parágrafo único - O crime definido neste artigo é qualificado, se cometido. I - por meio de venda, promessa de venda, reserva de lote ou quaisquer outros instrumentos que manifestem a intenção de vender lote em loteamento ou desmembramento não registrado no Registro de Imóveis competente. II - com inexistência de título legítimo de propriedade do imóvel loteado ou desmembrado, ressalvado o disposto no art. $18, \S \S 4^{\circ}$ e $5^{\circ}$, desta Lei, ou com omissão fraudulenta de fato a ele relativo, se o fato não constituir crime mais grave. (Redação dada pela Lei no 9.785 de 1999). Pena: Reclusão, de 1 (um) a 5 (cinco) anos, e multa de 10 (dez) a 100 (cem) vezes o maior salário-mínimo vigente no País.

Art. 51. Quem, de qualquer modo, concorra para a prática dos crimes previstos no artigo anterior desta Lei incide nas penas a estes cominadas, considerados em especial os atos praticados na qualidade de mandatário de loteador, diretor ou gerente de sociedade. 
Por outro lado, a defesa da ecologia estava presente em todas as falas como algo incontestável, apesar do conflito que estava sendo discutido. A qualidade ambiental como um direito associado à moradia, ou seja, enquanto perspectiva política de luta pela cidade, não apareceu nas falas. Um dos enfoques sobre a questão ambiental derivou para o problema da poluição da represa Billings pela carga proveniente do rio Pinheiros, cujo bombeamento ainda não tinha sido interrompido naquele momento.

Após essa audiência, a CPI teve continuidade. Já nos últimos meses, encaminhou ao promotor de justiça mais denúncias e levantou provas do envolvimento de políticos, ou candidatos a vereador, na atividade irregular de venda de lotes. Um exemplo, foi a acusação contra o advogado Edinho Montemor, alegando o exercício ilegal da profissão em diversas atividades, dentre elas a de defender associações promotoras de loteamentos ilegais e também por ser proprietário de uma imobiliária que promovia reiteradamente a venda irregular de lotes em $A P M^{67}$. Outra acusação, encaminhada ao Ministério Público, recaiu sobre o engenheiro e proprietário de uma empresa de projeto e terraplanagem, envolvido no parcelamento irregular e na promoção de diversos loteamentos.

A CPI foi concluída em fevereiro de 1992, quando produziu um relatório final. Apesar dos debates promovidos, da junção de diversos depoimentos e documentos e das prisões de pessoas envolvidas com a venda de lotes irregulares, a Comissão chegou a poucos resultados concretos no sentido de propor novos encaminhamentos para lidar com o conflito. Também não conseguiu reverter ou paralisar a abertura de novos loteamentos irregulares e clandestinos, o que fica claro pela falta de conclusões objetivas de seu relatório final. As polêmicas iniciais sobre a postura legalista adotada pela comissão como forma de reprimir a atuação dos loteadores, com forte componente de judicialização do conflito, se manteve até o encerramento da CPI e o relatório final não foi aprovado pelos vereadores.

\subsection{A participação do movimento de moradia durante a CPI dos Loteamentos Irregulares}

Como comentado no item anterior, a reação das associações de moradores contra as prisões foi imediata, com a divulgação de um "Manifesto das Associações de Construção Comunitária de São Bernardo do Campo - Pelo direito à moradia, em defesa da ecologia" (reproduzido abaixo Figura 46) e realização de uma passeata até a Câmara. Os pronunciamentos de representantes das associações de bairro, na sessão da Câmara, no dia do protesto, repudiava que eles fossem considerados "como bandidos", criticando o tratamento policial dado à questão.

${ }^{67}$ Conforme Ofício no 52/91 da Câmara de SBC, v. 7 p. 1207. 

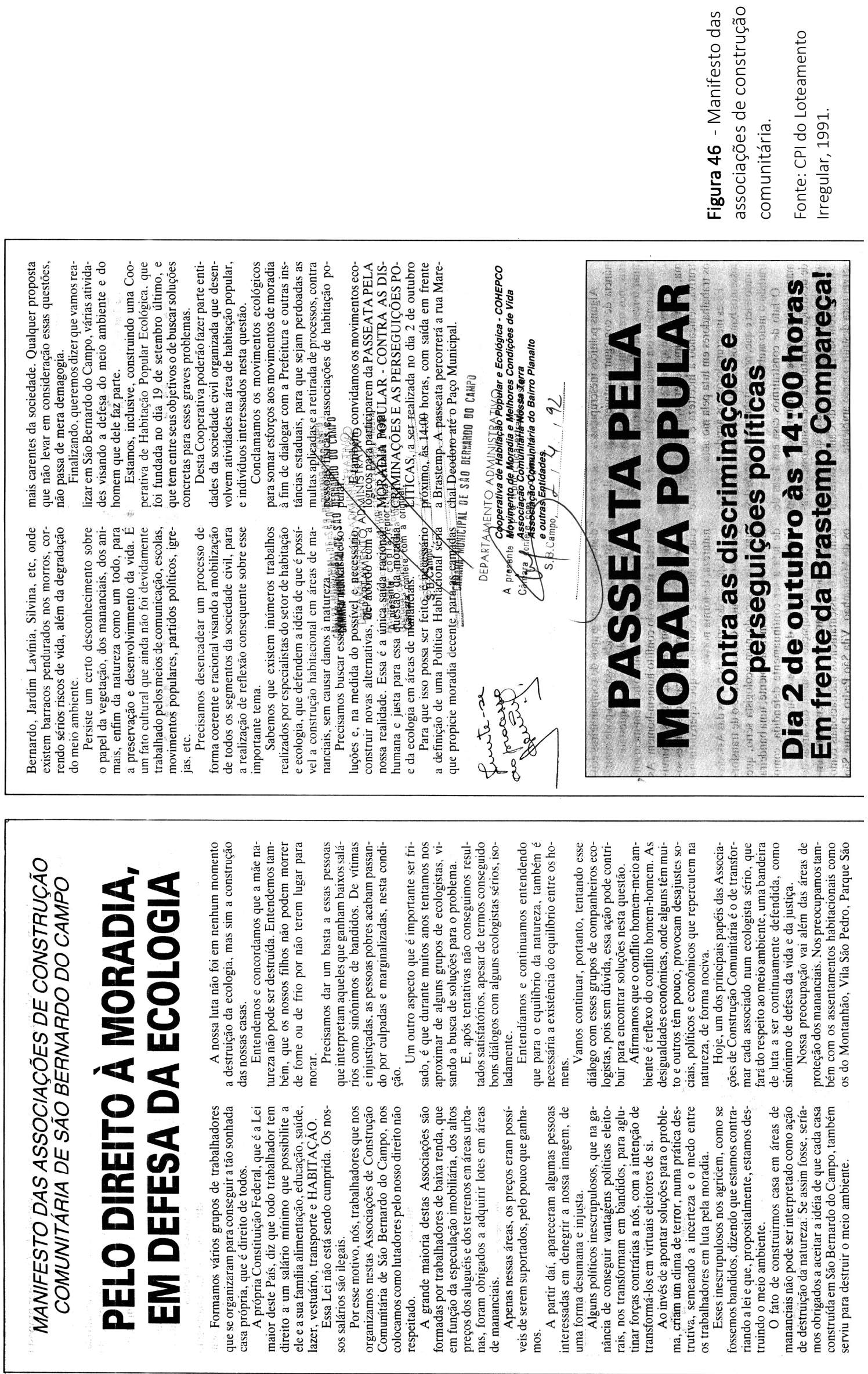
O que os depoimentos deixam claro é que, no momento em que o debate emerge na manifestação, o direito à moradia é colocado acima de qualquer irregularidade. E o que se reivindica é a permanência dos moradores em seus loteamentos e a futura regularização, sem estender a reivindicação de melhorias mais amplas desses assentamentos. A condição de pobreza e o arrocho salarial dos trabalhadores são problematizados como causa principal da falta de acesso à moradia, que por sua vez é entendida dentro de um contexto nacional, com consequências locais. Entretanto, a necessidade de se pensar alternativas e políticas habitacionais locais, fora de áreas protegidas, aparece pontualmente como proposição para superar o impasse da ocupação das áreas de mananciais.

Por outro lado, ainda que o discurso do direito à moradia unificasse as associações de moradores, é difícil afirmar se a manifestação foi organizada por "associações falsas" ou pelo movimento de moradia, ou ainda se naquele momento a reprodução dos loteamentos irregulares já era tão expressiva a ponto dessas duas situações se confundirem. Se por um lado subentende-se que as "falsas associações" se apropriaram do discurso da defesa do direito à moradia para fins imobiliários, por outro lado o movimento organizado não explicitava discordar abertamente desse mercado perverso, ao menos diante dos vereadores e do público em geral.

Apesar desse quadro ambíguo, é patente que as "falsas associações" em muitos aspectos se diferenciavam dos movimentos organizados de luta por moradia, que priorizavam processos políticos de decisão coletiva e não visavam o lucro quando da conquista ou compra de terra, ainda que em muitos casos, nos conjuntos habitacionais e nas ocupações de favela, posteriormente à ocupação, tenha se formado um mercado informal.

Cabe frisar que a luta pela moradia se intensificou nesse período em que a crise econômica e a retirada do Estado dos investimentos urbanos e habitacionais impulsionava o crescimento do déficit habitacional. O movimento organizado de moradia atuava expressivamente no $A B C D$, pautava a mudança de políticas públicas, reivindicava o acesso à terra junto ao poder público municipal, por meio de um processo essencialmente político e coletivo, porém não isento de conflitos no que tange à conquista de terra. A partir de 1988 a organização de grupos em associações comunitárias constituiu-se num caminho possível para a aquisição coletiva de terrenos e se difundiu a partir de experiências exitosas, como no caso da Vila Comunitária, de construção por mutirão, localizada fora da área de proteção aos mananciais (como tratado no capítulo 4). O histórico dos movimentos organizados por moradia mostra que a ocupação de terras e edifícios públicos desocupados é um meio de reivindicação política pelo acesso à habitação, e que, no limite, reivindicam a redistribuição da propriedade privada da terra.

Já as "falsas associações" incorporaram não só o discurso em defesa da moradia, mas também o modo de organização que havia surgido da população organizada. Assim, criaram diversas estratégias para forjar a legalidade dos loteamentos e angariar clientes, potenciais compradores de lotes. A proposta de venda de uma determinada área podia ocorrer para um grupo previamente organizado, ou reunir diferentes interessados em torno de uma nova associação, 
forjando uma nova "comunidade". A promessa da implantação de infraestrutura e futura regularização também fazia parte do discurso de convencimento dos vendedores.

A ação premeditada das associações-imobiliárias também se verifica nos contratos de compra de venda, nos quais frequentemente está explícito o reconhecimento de que o lote é irregular e situado em área de proteção aos mananciais. Tomando como exemplo os contratos firmados

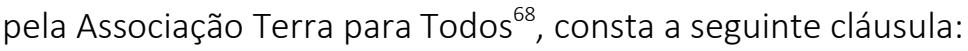

É de conhecimento do ASSOCIADO que a fração ideal que lhe corresponde bem como todas as demais frações da ASSOCIAÇÃO, não faz parte de loteamento aprovado pelos poderes públicos competentes. A área se localiza em região de mananciais, estando regulado seu uso por LEI ESTADUAL (lei de proteção aos mananciais). Tanto Lei estadual como Municipais restringem o uso dessas áreas e o ASSOCIADO declara ter pleno conhecimento dessas restrições.

Outro mecanismo utilizado para forjar um aspecto de seriedade eram as plantas de vendas nas quais a implantação do loteamento, apesar de não cumprir os parâmetros urbanísticos legais e os procedimentos de licenciamento, eram feitas a partir de serviços técnicos contratados, tais como os de topografia, estudo de viabilidade e implantação de lotes, e movimento de terra ${ }^{69}$. Como mostram as plantas dos loteamentos do baixo Alvarenga (no capítulo 4), as glebas eram aproveitadas no seu máximo, sem a destinação de espaços coletivos e públicos. Mas nem sempre os serviços técnicos eram concluídos, muito menos assinados por um profissional, devido à constatação da irregularidade, a interrupção de pagamento ou embargo da prefeitura. Mesmo assim, um estudo prévio já era suficiente para que as associações realizassem o desmatamento e a abertura de ruas seguindo um plano de demarcação de lotes ainda que imprecisamente definido.

Em depoimento à CPI, a presidente da Associação Comunitária Terra para Todos relata como foi realizado o projeto na sua área:

(...) o levantamento da área foi realizado por agrimensor o qual não lembra o nome, posteriormente foi contratada a firma BIM-Banco de Ideias e Negócios São Paulo, que confirmou as dimensões da área mas não foi contratada para execução do projeto do loteamento, por ter apresentado proposta muito alta; e que a BIM foi lhe recomendada pela Associação Pró-Terra. Rejeitada a proposta de urbanização apresentada pela BIM em assembleia da Associação, foi contratado agrimensor cujo nome não se lembra, que elaborou o projeto de urbanização do loteamento mas não assinou o referido projeto porque sabia que não seria aprovado. Após a elaboração do projeto os interessados previamente inscritos e cadastrados foram convocados para formalizar a aquisição de lotes da área que foram vendidos em duas glebas de $45.000 \mathrm{~m}^{2}$ cada uma. ${ }^{70}$

Interessante destacar que, quando consideradas em conjunto, as ações civis públicas reunidas pela CPI permitem identificar que as mesmas empresas muitas vezes prestavam serviço para várias associações, que estavam sob a organização de um mesmo grupo. Nesse sentido, fica clara a articulação entre compradores de glebas a serem loteadas irregularmente e os donos de

\footnotetext{
${ }^{68}$ A cópia desse contrato faz parte dos documentos reunidos pela CPI do Loteamento Irregular.

${ }^{69}$ Conforme depoimento do proprietário da empresa, processo da CPI, v.6, p.1123.

${ }^{70}$ Conforme depoimento que consta na Ata da 16으 reunião da CPI que trata do requerimento no 17/91, P.G. 47/91.
} 
empresas de terraplanagem ou de assistência jurídica, quando não eram as mesmas pessoas também proprietárias de imobiliárias.

A irregularidade como alternativa de acesso à casa própria, forjou um pacto não declarado entre os loteadores irregulares e os moradores. As possibilidades de autogestão, germinadas no movimento de moradia organizado e experimentadas de um modo particular nos mutirões, não alcançaram os mananciais, onde prevaleceu o parcelamento do solo indiscriminado, voltado ao máximo aproveitamento da terra na forma de lotes.

\subsection{0 movimento ambientalista do ABCD e a CPI dos Loteamentos Irregulares}

O movimento ambientalista do ABCD, composto por várias organizações ${ }^{71}$, manifestou seu apoio à realização da CPI dos Loteamentos Irregulares desde seu início. A atuação desse movimento na defesa da proteção dos mananciais, em especial da represa Billings, tinha como foco de preocupação a manutenção da quantidade e qualidade das águas, consideradas em permanente ameaça diante do avanço das ocupações na bacia ${ }^{72}$. Nesse sentido, participaram ativamente de diversas sessões da CPI na Câmara, contribuindo com denúncias, depoimentos, entrevistas em jornais, problematizando o desmatamento e o comprometimento das fontes de água que tais empreendimentos causavam.

Em um dos documentos de denúncia entregues à CPI, intitulado "Mananciais x Habitação", um conjunto de entidades expõe seu posicionamento esperando que o mesmo fosse "considerado pela justiça", defendendo:

I) Luta pela manutenção da Legislação de Proteção aos Mananciais;

II) Utilização de todos os meios necessários para o seu cumprimento, inclusive ações judiciais contra os órgãos públicos omissos em todos os níveis e a cassação de políticos;

III) Fiscalização nas áreas protegidas por legislação;

IV) Congelamento das ocupações e invasões em área de mananciais;

V) Negociação de soluções Ecológicas para os atuais problemas, após assegurado o congelamento das ocupações;

VI) Destinação de impostos e multas para a recuperação e conservação das áreas de mananciais. $^{73}$

A postura conservacionista do movimento ambientalista em relação às áreas de mananciais explicitava-se pela posição conservadora em relação ao processo de revisão da LPM, pois esta

\footnotetext{
${ }^{71}$ Dentre elas: Terra Viva - Movimento de Resistência Ecológica de São Bernardo do Campo, Movimento Brasil Verde, SATS - Serviço Aéreo e Terrestre de Salvamento, Grupo Tucuxi de Proteção ao Boto, Comissão de Defesa do Haras São Bernardo, MDV - Movimento em Defesa da Vida do Grande ABC, SOS Billings, Associação Ecológica de Pescadores profissionais, Amadores e Amigos da Represa Billings.

72 O documento cita as "devastações ocorridas nas localidades Rubeba, Areião, Sabesp", áreas de risco acentuado. Outra importante frente de luta nesse sentido era pela efetiva paralisação do bombeamento do rio Pinheiros para a represa Billings, que aumentava sobremaneira a poluição desse manancial.

73 O documento "Mananciais x Habitação" conta do processo da CPI dos Loteamentos Irregulares, v. 2, p. 364.
} 
era considerada um bom instrumento de controle, cuja falha de aplicação recaía sobre a fiscalização insuficiente, de responsabilidade do governo do Estado e do município. Isso se contrapunha ao movimento de revisão dessa legislação, que naquele momento estava em discussão no governo estadual. O crescimento das ocupações irregulares e sem infraestrutura era justamente um dos motivos que pressionavam a mudança da lei, um desafio a enfrentar.

O posicionamento contrário à propagação dos loteamentos irregulares também é bastante claro, ainda que estivesse presente no discurso dos representantes do movimento o reconhecimento da situação social e da pobreza que originou tais ocupações.

Em outro documento, o "Manifesto dos Ecologistas" 74 divulgado uma semana antes da manifestação das Associações contra as prisões, realizada na Câmara, as entidades ecológicas declaram seu apoio ao movimento de moradia, propondo a ele um acordo, conforme reprodução do panfleto abaixo (Figura 47). O conteúdo desse acordo tinha como proposta central a articulação desses dois movimentos, que juntos poderiam exigir da prefeitura medidas relativas à abertura de canais de participação da sociedade civil em conselhos, projetos e no Plano Diretor do município.

Além disso, o acordo contemplaria um levantamento das áreas já ocupadas e um comprometimento dos moradores na fiscalização dos loteamentos que seriam "congelados", ou seja, novas construções não poderiam ser erguidas nos lotes não ocupados dos assentamentos existentes em APM.

A proposta do congelamento aparecerá também, posteriormente, nas propostas da prefeitura e do Ministério Público. Por mais ideal que essa proposta pudesse parecer do ponto de vista do controle da ocupação, ela reproduzia um desentendimento da dinâmica social que estava em curso, diante de uma demanda crescente por moradias e da ausência de alternativas habitacionais concretas fora das áreas protegidas. Atribuir a fiscalização - uma função do Estado - ao morador, também se constituiu numa proposta difícil de ser realizada, pois por mais engajado que o morador fosse com essa causa, o medo de se indispor com os demais moradores superaria esse comprometimento.

Enfim, as denúncias realizadas pelo movimento ambientalista, que em diversos momentos foi fundamental para avançar na recuperação da represa Billings ${ }^{75}$, encontrou na questão dos loteamentos irregulares maiores dificuldades para a implementação de suas pautas, devido à distância entre suas formulações e propostas ambientais conservacionistas e a complexidade da dinâmica social das ocupações em questão.

\footnotetext{
${ }^{74}$ Consta no v. 5, p. 944 da CPI.

${ }^{75}$ Como, por exemplo, na luta e pressão que exerceu sobre o governo estadual para a paralisação do bombeamento do rio Pinheiros para a represa, ou ainda em outras denúncias de indústrias poluentes.
} 


\section{Manifesto dos Ecologistas}

Objetivando a preservação das áreas de mananciais, que significa a manutenção das nascentes de água que alimentam a represa Billings, fonte de abastecimento de água para a população, as ENTIDADES ECOLÓGICAS que subscrevem este Menifesto vem, a público esclarecer que APOIAMOS 0 MOVIMENTO DE MORADIA por um projeto de habitação sério, que preserve os mananciais entendendo que:

- Não seria possivel a vida sem água potável;

- Que o Projeto Juquiá só favorecerá Empreiteiras;

- Não é justo prejudicar mais de 1000 pessoas que sobrevivem da pesca na Billings;

- Que a maioria da população ribeirinhna de baixa renda sofre hoje de esquistossomose e outras doenças resultantes da poluição das águas;

- E que o lazer dos trabalhadores fique comprometido.

Por diversas vezes apresentamos às lideranças do Movimento de Moradia e à Administração de São Bernardo do Campo, a proposta que agora reafirmamos com objeto de acordo entre o Movimento Ecológico e o Movimento de Moradia, desde que as partes respeitem as seguintes condições necessárias ao equilibrio da natureza e do ser humano.

\section{CONDIÇÕES PARA O ACORDO}

1.) Congelamento das ocupações sob a fiscalização dos próprios moradores dessas áreas e das associações comunitárias;

2.) Levantamento das áreas já ocupadas e do número de habitantes existentes nesses locais;

3.) Exigir em conjunto com o Movimento Ecológico que a Prefeitura oficialize a Coordenadoria do Meio Ambiente, bem como envie o projeto do CONDEMA (Conselho Municipal de Defesa do Meio Ambientè) para a Câmara Municipal pois é o único canal de participação da sociedade civil na Administração para questões ambientais e habitacionais;

4.) Que se forme um grupo composto de Técnicos, Ecologistas e Movimento de Moradia a fim de realizar estudos de cada caso ou seja: de cada ocupação, para que se possa elaborar projeto de saneamento adequado, remoção de áreas de riscos, reflorestamento dos locais degradados;

50) Que a Prefeitura leve a discussão com a população do Plano Diretor, que também significa um plano habitacional para a cidade.

\section{Convite}

Para viabilizar o entendimento, convidamos todos os Associados do Movimento de Moradia e interessados na questão habitacional, para reunião com o Movimento Ecológico.

DATA: 30 de Setembro de 1991 - segunda-feira

HORA: 19:00 horas

LOCAL: CÂMARA MUNICIPAL DE SÃO BERNARDO DO CAMPO

Nota: O MOVIMENTO ECOLÓGICO PRETENDE COM ESTE ACORDO, SOLUCIONAR A PROBLEMATICA HABITACIONAL NAS ÁREAS DE MANANCIAIS, CONTANDO, PARA TANTO, COM A BOA VONTADE DE TODOS QUE COMPREENDEM QUE HOMEM E NATUREZA DEVEM VIVER EM HARMONIA CUIDANDO DA CASA DE TODOS QUE É O PLANETA TERRA.

Assinam: Terra Viva - Movimento de Resistência Ecológica de S. B. Campo Movimento Brasil Verde SATS - Serviço de Salvamento Aéreo e Terrestre Grupo Tucuxi de Proteção ao Boto Comissão em Defesa do Haras São Bernardo MDV - Movimento em Defesa da Vida do Grande ABC

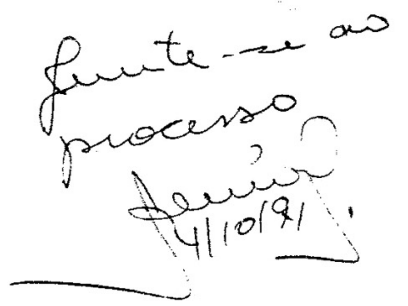
S.O.S. Billings Associação Ecológica, de Pescadores Profissionais, Amadores e Amigos da Represa Billings.

Figura 47 - Manifesto dos ecologistas

Fonte: CPI do Loteamento Irregular, 1991. 


\subsection{A atuação da prefeitura (de 1989 a 1993) e a CPI dos Loteamentos Irregulares}

Diante do aumento das ocupações irregulares no município, a gestão do Prefeito Maurício Soares, a partir de 1989, passou a reconhecer e atuar sobre o problema. Mesmo antes da instauração da CPI, a prefeitura passou a propor diversas Ações Civis Públicas (ACPs) contra os responsáveis pelo loteamento irregular. Após a criação da Coordenadoria da Habitação (futura Secretaria de Habitação), um Grupo de Trabalho de Regularização de Parcelamentos do Solo Urbano foi formado com o objetivo de pensar formas de regularização de loteamentos ilegais e clandestinos, inclusive os situados em área de proteção aos mananciais (KFOURI, 1992, p.35).

Apesar dessa incipiente estruturação da atuação municipal em relação à habitação de interesse social, os encaminhamentos dos conflitos relativos aos loteamentos irregulares em APM variaram segundo os diferentes órgãos da prefeitura, como o Departamento Jurídico e a Secretaria de Obras, sem constituir uma ação integrada e coerente sobre a questão.

As Ações Civis Públicas propostas pelo município, por meio de seu Departamento Jurídico, apresentavam de forma clara o diagnóstico sobre os loteamentos irregulares do ponto de vista da prefeitura ${ }^{76}$ :

Sob a retórica da 'defesa do direito de moradia', observou-se, a partir do último semestre de 1988, a formação de inúmeros grupos de loteadores, ditos integrantes do "Movimento Popular de Moradia", com a finalidade de adquirir imóveis no Município, em zonas de proteção aos mananciais, para subdividi-los em lotes de metragem inferior à permitida nas referidas áreas (nas quais, via de regra, não é permitido parcelamento do solo que resulte em lotes com área inferior a $500 \mathrm{~m}^{2}$ ) sem qualquer anuência ou apreciação de projetos por parte dos órgãos públicos competentes, grupos estes organizados em diversas Associações específicas, algumas possuindo estatutos que foram, inclusive, levados a registro público, no intuito único de dar aparência de legalidade às atividades por elas desenvolvidas.

Com efeito, a ação destes grupos consiste em adquirir glebas de terras em nome das Associações ou mesmo de pessoas físicas a elas ligadas, providenciando o registro do título aquisitivo de algumas áreas junto ao Cartório Imobiliário competente.

Subjacente a estas transações preexistentes, na realidade, um denominado "Plano de Divisão entre Amigos", que corresponde a projeto de loteamento das glebas adquiridas, cujas subdivisões denominam de "frações ideais" e as vias de uso comum abertas atribuem o nome de "servidões".

Desta forma, as mencionadas 'frações ideais' são comercializadas, por vezes com a intermediação de Imobiliárias, as quais, além de efetuar a sua divulgação por meio de anúncios de jornais, providenciam a elaboração de 'propostas de vendas e compras', recebendo parcela do valor da transação. (Extraído do Documento Ação Civil Pública com pedido de Liminar, proposto pela Prefeitura de São Bernardo do Campo Departamento Jurídico, em 03 de maio de 1990) ${ }^{77}$

\footnotetext{
${ }^{76}$ Reproduzimos aqui esse argumento, extraído de uma Ação Civil Pública, cujo conteúdo se repete nas demais peças analisadas que constavam do processo da CPI, que totalizam três ações contra 20 associações de moradores entre 1989 e 1991.

${ }^{77}$ Esta Ação Civil Pública lista como réus: Sociedade Amigos do Parque das Garças, Sociedade Amigos do Parque Ideal; Sociedade Amigos de Vila Vitória, Sociedade Amigos do Jardim Floral, Associação Comunitária Nossa Terra;
} 
Os parcelamentos irregulares infringiam leis municipais ${ }^{78}$ e lei federal de parcelamento do solo no 6766/79, pois não passavam pelos procedimentos de licenciamento do empreendimento nos órgãos responsáveis; o que em área de proteção ambiental não se limitava ao município, mas também aos órgãos ambientais estaduais. Ao mesmo tempo, infringiam a lei estadual de proteção aos mananciais, tanto por não proceder ao licenciamento como pelo descumprimento de parâmetros de uso e ocupação do solo.

Com base nesses argumentos, a prefeitura pedia a liminar, em resumo, para: a) a citação dos réus (pessoas ou empresas responsáveis pelo parcelamento irregular); b) para que os réus cessassem definitivamente a veiculação de qualquer tipo de propaganda acerca dos empreendimentos irregulares bem como alienação de lote em frações ideais; c) para que paralisem quaisquer obras; d) para que se promovesse a regularização dos lotes já compromissados à venda, obedecendo a legislação em vigor, mediante apresentação de projeto; e) aplicação de multa diária no caso do descumprimento dos itens b, c, d. Em geral, nesse momento, figuravam como réus da ação os loteadores, os representantes legais das associações de moradores, empresas de terraplanagem e demais envolvidos diretos no empreendimento.

Com essa interpretação e procedimento, a prefeitura propôs ACPs contra 20 associações de moradores, entre 1989 e 1991. A via jurídica foi o caminho adotado para tentar coibir e interromper a atividade irregular. Mas muitas vezes, conflitos urbanos complexos não resolvidos pelas políticas existentes, não encontram no judiciário sua plena solução.

Cabe ponderar que, nesse momento, regularizar os lotes já compromissados à venda significava adequá-los aos parâmetros da Lei de Proteção aos Mananciais, ou seja, os lotes de $125 \mathrm{~m}^{2}$ deveriam ser de no mínimo $500 m^{2}$ (conforme posição em relação à represa Billings), além das demais exigências de áreas coletivas, infraestruturas etc. Ou seja, o baixo padrão do loteamento, destinado a uma população de baixa renda, se readequado, não atenderia os mesmos moradores. De todo modo, a regularização dessa forma não se concretizou.

Em agosto de 1990, um juiz de São Bernardo concedeu liminar para três Ações Civis Públicas movidas pela prefeitura, determinando a paralisação da venda de imóveis em diversos loteamentos clandestinos sob pena de nulidade da aquisição, e exigiu a publicação de editais na imprensa, alertando a população a não comprar os lotes das "falsas associações".

Apesar dessas decisões judiciais, e da realização da CPI buscando aprofundar as investigações sobre os loteamentos, as atividades de venda não cessaram, como por exemplo, aconteceu com a Associação Comunitária Senhor do Bonfim, conforme notícia de jornal:

Hambiental - Empreendimentos Imobiliários S/C Ltda, Vila Rica S/C Ltda. e cinco pessoas físicas envolvidas nos parcelamentos irregulares.

${ }^{78}$ Lei no 533/1956 que determinava que loteamentos e arruamentos só poderiam ser executados mediante título de propriedade do imóvel e autorização prévia da prefeitura, dentre outras relativas ao encaminhamento de projeto de parcelamento do solo. E lei no 2409/1980 que definia que os interessados em realizar empreendimentos e movimentos de terra no município deveriam solicitar diretrizes com o encaminhamento de uma série de documentos comprobatórios da propriedade e plantas com o projeto pretendido. 
Donizete [secretário da Associação] afirmou que a área de 250 mil metros quadrados foi adquirida do Joquey Clube, por um valor que ele não soube revelar. Ele disse que 'muita gente está fazendo reserva de lotes' e admite que o loteamento é irregular. 'Ainda este mês vamos dar entrada na papelada' - afirmou. ${ }^{79}$

Ou ainda com Associação Comunitária Terra para Todos, situada às margens da represa Billings (estrada dos Imigrantes altura km 27).

Os lotes de $125 \mathrm{~m}^{2}(5 \times 25 \mathrm{~m})$, com exceção dos terrenos de esquina com $400 \mathrm{~m}^{2}$, foram vendidos a Cr\$350mil, com pagamento dividido em parcelas, contrariando a decisão em caráter liminar do juiz Fermino Magnani, da 1a Vara Civil de São Bernardo, que proibiu a venda. ${ }^{80}$

Portanto, as decisões judiciais dessas primeiras Ações Civis Públicas foram ignoradas sistematicamente. Como explica a promotora pública em São Bernardo do Campo, Rosângela Staurenghi, os pedidos das ACPs propostas pela prefeitura ou pelo Ministério Público apresentavam algumas diferenças de conteúdo. Enquanto que as primeiras recaiam somente contras as associações e pediam a paralisação das atividades, além de exigir a regularização; as propostas pelo MP pediam o desfazimento do loteamento e a recomposição da vegetação e do solo ao estágio anterior ao desmatamento. Diante da falta de resultados de ambas, o Ministério Público passou a colocar no polo passivo da ação também o município, acusando-o de ter sido omisso na fiscalização e brigando-o a fazê-la. Entretanto, não houve mudanças. Num terceiro momento, o governo do estado também passou a ser citado, porque de acordo com a Lei de Proteção aos Mananciais ele tinha competência para atuar nas atividades de fiscalização no município. Mas também sem nenhum efeito ${ }^{81}$.

A fiscalização no município, apesar da equipe pequena e de poucos recursos materiais (veículos etc.), identificava que as atividades irregulares aconteciam. Ainda segundo a promotora, os fiscais encaminhavam as situações irregulares aos seus chefes que, por sua vez, não davam andamento aos processos, deixando-os parados por mais de um ano. Em relação à fiscalização estadual, o diagnóstico é semelhante, pois a promotoria recebia os laudos e autos de vistoria que relatavam os danos causados e como proceder, mas também não havia encaminhamento concreto para realizar demolições e demais definições de reparação de danos. O governo estadual interpretava a LPM e argumentava que a atribuição de demolir era do empreendedor, o que jamais ocorreria. A promotora pública "percebia que não havia o problema para identificar a atividade, existia um problema de decisão política de parar a atividade" ${ }^{\prime 2}$.

O diagnóstico sobre a atividade de fiscalização, assim formulado, coloca em questão sua efetividade não por uma falha do Estado em termos genéricos, mas levanta problemas específicos e concretos que envolvem a atuação de um conjunto de agentes e autoridades

\footnotetext{
79 Diário do Grande ABC, 22/02/1991. "Venda de Lotes irregulares não para, apesar de ordem judicial". CPI, v. 4, p.610.

80 Diário do Grande ABC, 10/05/1991 “Entidade desmata área de manancial para lotear”). CPI, v. 4, p.612

${ }^{81}$ Entrevista da promotora pública Dra. Rosângela Staurenghi, concedida à autora em 30/08/2012.

82 Idem.
} 
públicas. Por mais que se possa questionar a fiscalização punitiva no lugar de uma atuação preventiva - como será debatido nos anos seguintes ${ }^{83}$, as relações de poder evidenciavam seu limite naquele momento.

Por outro lado, se as demolições fossem todas realizadas, para o município seria praticamente impossível solucionar toda a demanda habitacional resultante. Tratava-se de um impasse que não se colocava abertamente enquanto tal, e sobre o qual poucas alternativas eram buscadas.

A implementação de infraestruturas parciais nos loteamentos irregulares era outro ponto controverso do posicionamento da prefeitura. Ao mesmo tempo em que denunciava as associações nas Ações Civis Públicas, ela respondia à pressão social das associações para a instalação das infraestruturas básicas como água e luz em assentamentos precários.

Esse aspecto também foi tratado durante a CPI dos Loteamentos Irregulares, quando foram chamados a depor o secretário de obras Laurentino Hilário e o vereador José Ferreira (PT), candidato a prefeito, pois eles haviam participado de uma assembléia no bairro dos Casa que reuniu cinco associações de bairro na qual se comprometeram a levar as infraestruturas. 0 secretário, por sua vez, se posicionava contra o desmatamento, mas defendeu seu ponto de vista: "a questão da moradia tem que ser a principal preocupação de uma administração" ${ }^{84}$.

Como comentado anteriormente (no capítulo 4), foi a partir de uma negociação semelhante com o secretário de obras que a rede de iluminação pública chegou aos loteamentos do baixo Alvarenga, bem como o fornecimento de água por caminhão-pipa. Mais uma situação em que o desvio da regra se impunha, agora como intervenção da própria prefeitura no atendimento de demandas concretas e em muitas situações emergenciais. Em alguns casos apurados pelo Ministério Público, a prefeitura chegou a fornecer projetos de redes de água e material para que os próprios moradores as construíssem ${ }^{85}$.

Ainda nesse período, o envolvimento direto ou indireto de outros políticos na promoção de loteamentos irregulares foi bastante expressiva. Como relembra a promotora pública, o candidato a prefeito de oposição, Walter Demarchi (PTB), cunhou sua candidatura participando diretamente da promoção de loteamentos irregulares, sendo eleito em 1993. Mas pôde-se comprovar seu envolvimento nesses casos, resultando em sua condenação pela atividade irregular, apesar da prescrição do crime. A sua gestão na prefeitura de São Bernardo do Campo foi considerada "ocupacionista", por envolver os departamentos da prefeitura na promoção de loteamentos populares.

Outros casos corroboram para a compreensão do envolvimento direto da prefeitura na promoção de ocupações irregulares, que também realizava a distribuição de lotes e kits de

\footnotetext{
${ }^{83}$ No município de São Paulo, a expansão das ocupações irregulares na bacia da Guarapiranga impulsionaram a elaboração do programa de fiscalização integrada entre prefeitura e governo estadual, chamado SOS Mananciais. Mas a experiência não teve continuidade e não contemplou a bacia da Billings.

${ }^{84}$ Diário do Grande ABC, 30/09/1991 “Promessa da Laurentino fere a lei”. CPI, v. 5 p. 933.

${ }^{85}$ Entrevista da promotora pública Dra. Rosângela Staurenghi, concedida à autora em 30/08/2012.
} 
construção. O assentamento Santa Cruz é um exemplo no qual prefeitura levou famílias removidas para uma área mais afastada do centro, ao sul do município, chamada pós-balsa. 0 assentamento Batistini ${ }^{86}$ é outro caso, pois foi ocupado para relocar pessoas desalojadas pelas chuvas ocorridas por volta de 1995. O prefeito Walter Demarchi (1993-1996) definiu uma área, fez uma terraplanagem, aterrando 3 ou 4 nascentes, e dividiu a gleba em lotes de 50 e $60 \mathrm{~m}^{2}$. Em cada lotes se construía um cômodo e um banheiro, para colocar as pessoas numa espécie de assentamento provisório, que permanece até hoje ${ }^{87}$. A Ação Civil Pública nesse caso foi contra a prefeitura $^{88}$.

Sendo assim, os representantes políticos não desconheciam a produção da irregularidade, ao contrário. Seja por interesse político imediato (ganho eleitoral direto ou indireto) de prefeitos, vice-prefeitos ou vereadores, que autorizaram verbalmente o loteamento ou prometeram posterior regularização; seja por interesse econômico, por exemplo, com o envolvimento de vereadores que influenciavam decisões técnicas internamente às secretarias ou com participação direta de técnicos gerando aprovações parciais do parcelamento; a produção desses loteamentos envolveu toda sorte de relações políticas, negociações e oportunismos, mediadas por relações de mercado entre proprietários de terras, promotores imobiliários, associações de moradores e políticos locais. Isso explicita que a produção da irregularidade urbana não se restringe ao descumprimento de legislação por parte de loteadores e compradores de lotes, mas passa também por relações imbricadas de interesse econômico e de poder, que ocorrem de forma oculta, ainda que tenha se constituído numa prática difundida.

As diferentes atuações e intervenções de setores da prefeitura ante as ocupações irregulares dos mananciais no município indicam, portanto, que a omissão completa não é o aspecto que melhor caracteriza a ação do poder público em relação ao conflito. O que marca essa atuação, no final dos anos 1980, é uma mistura de consentimento da irregularidade combinada aos poucos recursos financeiros para políticas urbanas e aos modos parciais - por vezes precários de atendimento das demandas da população e do cumprimento da legislação urbana e ambiental, o que provocou ações irregulares do próprio poder público.

O quadro apresentado nesse capítulo buscou explicitar o posicionamento dos diversos agentes envolvidos em relação aos conflitos decorrentes da ocupação ilegal das áreas de proteção aos mananciais, enfocando as ambiguidades e as contradições presentes nas suas práticas. Importante notar as diferentes combinações de interesses na promoção das ocupações ilegais, especialmente entre políticos e associações de moradores, o que colabora para desmistificar generalizações acerca do problema ambiental que ocupações das áreas de mananciais representam e que tendem a culpar a população pobre pela degradação ambiental.

\footnotetext{
${ }^{86}$ A área do Batistini é hoje um Perímetro de Recuperação de Interesse Social, segundo a lei específica da Billings, e está com projeto de urbanização em desenvolvimento pela assessoria técnica Peabiru.

${ }^{87}$ Desde 2012 essa área é objeto de plano de recuperação ambiental e regularização fundiária segundo os parâmetros da Lei Específica da Billings.

${ }^{88}$ Conforme entrevista com Paulo Massoca, concedida à autora em 07/11/2011.
} 
O que se destaca nessa fase, do final dos anos 1980 ao início dos anos 1990, em termos de política pública, é uma ausência de alternativas que buscassem alterar a dinâmica da produção do loteamento irregular e precário, por meio do controle do uso do solo e provisão habitacional fora de áreas protegidas. Na gestão municipal o caminho encontrado para reprimir a atividade irregular foi a via judicial, também adotada pelo MP.

A vigência da restritiva Lei Estadual de Proteção aos Mananciais, desde 1975, e sua defesa por diversos setores da sociedade, como parte do movimento ambientalista, também dificultou a formulação de alternativas para lidar com a questão. O governo estadual voltou seu foco para a revisão dessa legislação até o final da década de 1990 (como tratado no capítulo 7). Sendo assim, a LPM desempenhou um papel ideológico quando utilizada como instrumento de defesa da proteção dos mananciais, pois na prática o poder público estadual e municipal não avançaram na proposição de políticas ou programas específicos, de escala metropolitana, para lidar com os conflitos reais (exceto no município de São Paulo, como será tratado na parte III a seguir). Como se viu, o poder público municipal respondia as demandas da população por infraestrutura consolidando, precariamente, os assentamentos.

Destaca-se nesse quadro de agentes o papel das associações de moradores, que protagonizou as ocupações, e a forma como os empreendedores se apropriaram do discurso e de algumas formas de organização dos movimentos de moradia, subvertendo seu papel político pela solução aparentemente fácil da compra do lote. A população, por sua vez, viu nas associações a alternativa para solução de seu problema habitacional, apesar da precariedade urbana e ambiental dos loteamentos.

O processo da CPI revelou a parcialidade do discurso ecológico com viés preservacionista, sustentado pelos vereadores proponentes da comissão e apoiado por parte do movimento ambientalista. Nesse momento a degradação dos mananciais foi utilizada pelos vereadores da CPI como a principal justificativa para coibir ocupações irregulares, o que reiterou a adoção de uma postura legalista diante de um contexto de total descumprimento da LPM e, mais do que isso, de total impossibilidade de seu cumprimento ante a consolidação dos assentamentos. Sendo assim, o encaminhamento da questão não ultrapassou o campo de uma disputa de poder político, com pouca efetividade sobre os problemas concretos dos assentamentos, que envolviam tanto a localização da moradia da população pobre como seu impacto sobre os recursos hídricos dos mananciais. 


\title{
CAPÍTUL0 6
}

\section{Urbanização contraditória nos mananciais e os sentidos da recuperação ambiental}

Na segunda metade da década de 1990, um levantamento realizado pelo município de São Bernardo do Campo contabilizou 140 loteamentos irregulares, sendo que a maioria deles continha mais de 500 lotes, aproximadamente (nem todos ocupados) $)^{89}$. A população do bairro dos Alvarengas ${ }^{90}$ - que concentra grande quantidade de loteamentos irregulares - passou de 27.974 habitantes em 1991, para 43.569 em 1996 (SÃO BERNARDO, 2010, p. 78), ou seja, houve um acréscimo de 15.595 habitantes em seis anos. Além de receber moradores do próprio município, a região continuou a receber migrantes, até a década seguinte ${ }^{91}$. Nas áreas de proteção aos mananciais, a atividade dos loteamentos continuava sem esmorecer, mantendo-se como alternativa habitacional para essa população.

Em meados de 1995, como relata uma promotora pública do município, a situação das ocupações ilegais agravou-se ainda mais:

\begin{abstract}
Mas o que estava acontecendo? Se no começo existia uma certa organização, a partir de 1995-1996 a gente começa a ter um forte trabalho de especulação. Então, é gente querendo ganhar dinheiro a qualquer custo com essa atividade, porque percebe que isso é muito rentável... e aí a gente começa a ter casos muito sérios de grilagem. Gente que aparece com títulos fajutos e todo mundo comprando qualquer coisa. Então, quando o Dr. Maurício Soares foi eleito em $1997^{92}$ a gente já tinha um cenário mais ou menos desenhado de que era necessário parar isso, porque não tinha dinheiro público suficiente para levar tanta infraestrutura, a administração não conseguia acompanhar esse crescimento todo, e estavam se criando situações de regularização muito difíceis no futuro, regularizações fundiárias mesmo, de titularidade da terra, e situações que poderiam provocar problemas sociais muito grandes de reintegração de posse. (Informação verbal) ${ }^{93}$.
\end{abstract}

Diante desse quadro, em 1997, uma conjunção de fatores altera a conduta tanto da prefeitura como do Ministério Público em relação aos loteamentos irregulares e clandestinos.

\footnotetext{
${ }^{89}$ Conforme entrevista de Rosângela Staurenghi, promotora pública em São Bernardo do Campo, concedida à autora em 30/08/2012.

90 Além do bairro dos Alvarengas, os bairros mais populosos em área de proteção aos mananciais são, em ordem decrescente: o bairro do Batistini, Riacho Grande, Montanhão e Cooperativa.

91 Conforme dados da PMSBC, os bairros de maior vulnerabilidade social como dos Alvarengas, Cooperativa e Montanhão, são os que apresentaram maior taxa geométrica de crescimento anual populacional (acima de $3 \%$ ) entre os anos 2000 e 2009 (SÃO BERNARDO, 2010, p. 122).

92 Trata-se do segundo mandato do prefeito, quando saiu do PT e filiou-se ao PSDB.

${ }^{93}$ Conforme entrevista de Rosângela Staurenghi, concedida à autora em 30/08/2012.
} 
No âmbito institucional municipal foi criada a Secretaria de Habitação e Meio Ambiente (SHAMA) que, segundo Paulo Massoca foi um fato importante porque até então não havia um espaço de diálogo e de consertação que tratasse os conflitos das áreas de mananciais de forma integrada do ponto de vista institucional ${ }^{94}$. Além disso, como relata a diretora de meio ambiente que assumiu o departamento em 1997, o setor de meio ambiente não tinha recursos pessoais, materiais e nem mesmo o mapa da Lei Estadual de Proteção aos mananciais para trabalhar ${ }^{95}$. Apesar do conhecimento do problema, até esse momento o envolvimento direto ou indireto da prefeitura nos loteamentos irregulares tendia mais a incentivar do que coibir as ocupações ilegais, como tratado no capítulo anterior.

No Ministério Público os serviços da promotoria foram reorganizados agrupando Meio Ambiente e Urbanismo ${ }^{96}$ justamente para lidar com os diversos processos de loteamentos irregulares em APM. Nesse momento, a meta assumida pela promotora pública era impedir o surgimento de novos loteamentos irregulares:

(...) Em 1997 quando nós redistribuímos o serviço da promotoria para ficar uma só atividade Meio Ambiente e Urbanismo, eu estabeleci uma meta, olha, minha meta é parar os loteamentos novos depois pensar o que eu vou fazer com tudo isso que ficou pra trás que a gente não conseguiu parar e também atuar numa fase anterior a ação judicial que é da fiscalização. Por que tanta gente tem atribuição para fiscalizar, o município tem, o [governo do] estado tem, a polícia tem que investigar o crime, o MP tem que propor ação civil e ninguém consegue nenhum resultado nada, nada, absolutamente nada? O que é que está acontecendo? Então eu comecei a trabalhar uma tese de improbidade administrativa dos administradores públicos. (Informação verball) ${ }^{97}$.

Diante da avaliação da ineficácia das ações anteriores e do agravamento dos casos de grilagem de terras, uma decisão conjunta envolveu o Ministério Público, a prefeitura de São Bernardo do Campo, a polícia florestal e o governo do estado, que passaram a atuar articuladamente com o objetivo de paralisar a atividade irregular.

Enfim, aí em 1997 então decidimos. Trabalhávamos junto com a fiscalização do município, do estado, polícia florestal (na época era polícia florestal), e estava na hora de parar. E nesse momento também o movimento ambientalista estava cobrando muito, passou lá pela Secretaria de Meio Ambiente o [Fábio] Feldmann ${ }^{98}$ que também fez uma campanha para parar essa atividade de ocupação dos mananciais, a imprensa começa a falar de meio ambiente. Então, 1997 parece que era um ano que era um momento propício pra gente dar uma parada. Mas não dava para conversar porque, assim, ações, conversinha, já não resolvia; ordem judicial de paralisação também não

\footnotetext{
${ }^{94}$ Conforme entrevista com Paulo Massoca, engenheiro que trabalhou na SHAMA no período, concedida à autora em 07/11/2011. Desde 2009, ele é secretário adjunto da SEHAB/PMSBC.

95 Informação verbal de Sônia Lima, diretora de Meio Ambiente da PMSBC de 1997 a 2009, em entrevista concedida à autora em 20/07/2012.

${ }^{96}$ A partir dessa reformulação a promotora pública Dra. Rosângela Staurenghi passou a atuar na área de meio ambiente e habitação.

${ }^{97}$ Conforme entrevista de Rosângela Staurenghi, concedida à autora em 30/08/2012.

${ }^{98}$ Secretário estadual de Meio Ambiente na época.
} 
era obedecida, então tinha que ter mesmo uma, uma... medida mais drástica. E aí a gente fez de tudo pra parar com o Falcão. (Informação verbal) ${ }^{99}$.

O Jardim Falcão era um loteamento clandestino, cuja venda de lotes teve início em 1996, e logo em seguida o MP identificou os responsáveis, caracterizando-os como uma organização criminosa pela investigação policial. Em 1997, quando a Polícia Florestal, a Polícia Civil, os fiscais do Município e os fiscais do Estado começaram a agir, muitos lotes já tinham sido vendidos, mas ainda não tinham sido ocupados. Nesse momento eles reprimiram a atividade removendo piquetes de demarcação de terrenos e desfazendo arruamentos. A polícia ficava de tocaia à noite para ver quem voltava os piquetes no lugar, porque os loteadores não interrompiam a construção do loteamento. A promotora chamou os empreendedores para negociar o desfazimento, sem sucesso. Quando os lotes começaram a ser ocupados, o Ministério Público entrou com uma ação pedindo a paralisação ao juiz, o que também não surtiu efeito. Em maio de 1997, ocorre a primeira demolição de três casas, com a área cercada pelo batalhão de choque, numa ação ostensiva, violenta e de grande visibilidade.

No dia do desfazimento, foi uma coisa tão bárbara para mim, inesquecível. Aquela tropa de choque da polícia militar ali, com aqueles cachorros segurando, aqueles cachorros treinados para conter rebeliões. O nível de tensão era tão grande que um cachorro comeu a mão de um policial, nossa, foi uma correria, o cachorro comeu a mão do cara! Então assim, tal a tensão que existiu. E as bombas molotov, aquelas coisas todas. Durante o período que aquilo estava sendo preparado, discutido, analisado, tinha assim, a polícia reservada foi morar dentro do Falcão para mapear tudo, nos mínimos detalhes, havia uma segurança logística para estudar o que estava acontecendo. (Informação verbal) $^{100}$.

Contudo, no mês seguinte, o loteamento continuava a ser ocupado e diversas casas foram construídas. Em 1998 a decisão final foi pela demolição total das 180 casas existentes.

O Jardim Falcão foi o primeiro e único loteamento no qual a sentença judicial de demolição foi executada. Uma decisão que, apesar de pontual, buscava romper com a ideia de que "depois de construído ninguém tira", incentivada pelos loteadores. O MP optou pelo enfrentamento do descumprimento da lei e argumentava que esse caso serviria de exemplo para que novas ocupações irregulares não acontecessem. Foi o ápice da ação repressora nos casos de loteamentos ilegais no município que ocorrera até então. Como lembra Sônia Lima, o município estava "em estado de guerra" e durante um tempo a promotora pública e o secretário de obras chegaram a sofrer ameaças pessoais por estarem à frente das decisões. Houve também um desgaste político do prefeito, que assumiu uma medida como essa.

Mas o maior passivo desse episódio, o social, estende-se até os dias de hoje e a associação de moradores ainda briga por indenização ${ }^{101}$. Na época, as pessoas que compraram os lotes

\footnotetext{
${ }^{99}$ Conforme entrevista de Rosângela Staurenghi, concedida à autora em 30/08/2012.

${ }^{100}$ Conforme entrevista de Sônia Lima, diretora de meio ambiente da Prefeitura de São Bernardo do Campo em 1997, concedida à autora em 20/07/2012.

101 Em 2010, antigos moradores e da Cammesp (Central de Atendimento aos Moradores e Mutuários do Estado de São Paulo) organizaram dois atos públicos, um na Praça da Igreja Matriz e outro na Câmara Municipal, com o objetivo de "fazer alerta sobre a situação das famílias, que perderam seu dinheiro e seu teto e não foram indenizadas" com a desocupação do Jardim Falcão. Diário do Grande ABC, 22 de julho de 2010.
} 
perderam tudo o que tinham. Como relembra Paulo Massoca, a demolição causou um grande impacto social:

E tinha quase 200 casas em construção, foi um prejuízo enorme, mas a primeira vez que ocorreu uma circunstância dessas, e não tinha mais gente porque uma parte estava guardada para ser comercializada depois, está certo? Tanto que eu acho que isso ainda é uma questão, uma dívida social que precisa ser resgatada, quer dizer, foram os mais pobres que eles [os loteadores] puseram na frente, não é? E eles falam, o pessoal do movimento, já tem mais de 10 anos, 1998, são 13 anos, julho de 1998 [que os loteadores] falavam: "vendam tudo, comprem material e construam, porque depois ninguém tira”. Mas foi um impacto muito grande. E traumático. (Informação verbal) ${ }^{102}$.

Sob muitos aspectos - social, ambiental, urbanístico - essa é uma situação mal resolvida até hoje. Por outro lado, segundo a promotora pública relata, a demolição do Jardim Falcão chocou os moradores de outros bairros que também tinham Ações Civis Públicas em andamento e contraditoriamente provocou reações. Eles passaram a procurar o Ministério Público em busca de orientações, dispondo-se a realizar medidas de reparação, pois a segurança de que as sentenças de demolição não seriam cumpridas parecia não ser mais uma plena verdade e temiam a remoção em seus bairros ${ }^{103}$. Por outro lado, não havia a perspectiva do MP em replicar ações demolitórias como aquela novamente.

Ao mesmo tempo, as solicitações dos moradores pela colocação de pavimentação e demais infraestruturas em diversos bairros, continuavam sendo negados pelas sentenças judiciais, mesmo para as ocupações mais antigas. Nesse momento, a SHAMA começa a questionar os encaminhamentos restritivos do MP e busca estabelecer um diálogo. Visitas aos loteamentos, estudos de processos, buscas de alternativas jurídicas para lidar com uma situação que não corresponderia à legislação existente foram realizados no intuito de se pensar alternativas de recuperação urbana e ambiental. Em termos jurídicos, o Termo de Ajustamento de Conduta $(T A C)^{104}$ com as associações é estudado como alternativa possível para encaminhar novas formas de acordos.

Adicionalmente, a revisão da Lei Estadual de Proteção aos Mananciais resultou, em 1997, na chamada nova política para mananciais, a lei estadual no 9866/97, que estabeleceu novas diretrizes de gestão para as bacias hidrográficas. Entretanto, essa lei não substituiu a anterior que continuou vigorando com os mesmos parâmetros restritivos de uso e ocupação do solo e infraestrutura. Sendo assim, foi criada uma situação de exceção para autorizar a implementação de infraestrutura e obras de urbanização realizadas pelo poder público em áreas ocupadas de

\footnotetext{
102 Conforme entrevista de Paulo Massoca, atual secretário adjunto da SEHAB de São Bernardo do Campo, concedida à autora em 07/11/2011.

103 Informação verbal, conforme entrevista da promotora pública Rosângela Staurenghi, concedida à autora em 30/08/2012.

104 Termo ou Compromisso de Ajustamento de Conduta: É um termo de compromisso, responsabilidade e ajustamento de conduta celebrado entre um ente e o Ministério Público, quando houver violação de algum direito da sociedade. Conforme glossário do mestrado de Mônica Nogara (2008, p.245).
} 
maior precariedade. Tratava-se do Plano Emergencial ${ }^{105}$, regulamentado pelo Decreto Estadual no 43.022/98, que classificou as diferentes sub-bacias de mananciais segundo o nível de criticidade da degradação ambiental em função da ocupação urbana, sendo esse o principal critério para autorização das obras emergenciais, portanto, em assentamentos precários e de interesse social.

Nesse momento, pode-se dizer que houve uma inflexão no tratamento jurídico, político, socioambiental e urbanístico das ocupações irregulares em APM em São Bernardo do Campo. A solução para a degradação dos mananciais deixa de ser o caráter estritamente repressor da prática do loteamento ilegal e passa a ser concebida a partir do reconhecimento da questão social inerente às ocupações precárias, mas sem desconsiderar os danos causados sobre os recursos hídricos. A intervenção do poder público pretendeu ser mais "reparadora" do que repressora ou "ocupacionista", como fora nos períodos anteriores.

\subsection{Plano Emergencial, TAC e Bairro Ecológico: novas práticas nas APMs?}

Em São Bernardo do Campo praticamente todas as áreas irregulares que não tinham sentença judicial foram demarcadas no Plano Emergencial| ${ }^{106}$, totalizando 63 assentamentos $^{107}$, ou seja, tratou-se a regra como situação de exceção. Do total de áreas indicadas, 49 situavam-se na subbacia dos Alvarengas/Lavras ${ }^{108}$. As obras previstas para esses assentamentos assim se distribuíam: além de medidas necessárias ao controle de poluição das águas, em 13 áreas (26,53\%) estava prevista a construção de rede de abastecimento de água; em 46 (93,88\%), rede de coleta e tratamento de esgotos; em 45 (91\%), sistemas de drenagem superficial; em 49 (100\%), instalação de rede de energia elétrica, além de arborização e revegetação; em 46 (93\%) havia sérios processos erosivos, com previsão de contenção de taludes e em $6(13,04 \%)$ havia áreas com risco de deslizamento de encostas (ITIKAWA, 2008, p. 127).

Com as premissas do Plano Emergencial, a prefeitura passou a trabalhar articuladamente com o Ministério Público na negociação de Termos de Ajustamento de Conduta (TAC), visando requalificar os assentamentos, envolvendo todos os agentes responsáveis na sua produção. Para que os TACs fossem elaborados e realizados, a aproximação com os moradores e associações tornou-se fundamental. Após as diversas ações civis contra as associações e os loteadores irregulares, a prefeitura passou a dialogar com a população explicando o impacto das ocupações sobre a represa e a qualidade da água, visando compartilhar responsabilidades nas ações de

\footnotetext{
105 O Plano Emergencial foi pautado em grande medida pela experiência precedente do Programa Guarapiranga, em andamento no município de São Paulo desde 1992, e visava a recuperação desse manancial por meio da urbanização dos assentamentos precários. Nessas urbanizações, o padrão definido em leis e códigos de obras era inaplicável à ocupação irregular, o que impunha a necessidade de se buscar alternativas de adaptação e de flexibilização desses parâmetros. O Plano Emergencial será retomado na Parte III dessa tese.

${ }^{106}$ Conforme entrevista de Paulo Massoca concedida à autora em 07/11/2011.

107 Conforme dados do mapeamento da Secretaria de Habitação e Meio Ambiente - SHAMA, cedidos à autora em 2008.

${ }^{108}$ As demais áreas se situavam: 10 no Rio Grande, 3 no Rio Pequeno e 1 no Rio Pedra Branca.
} 
recuperação e urbanização. Nesse contexto e no bojo das discussões que estavam em curso, foi elaborado o programa Bairro Ecológico.

A noção de recuperação ambiental dos assentamentos adotada por esse programa foi construída a partir da reflexão sobre quais seriam os principais danos causados pelas ocupações, particularmente sobre a produção de água: o esgoto chegando sem tratamento à represa, a impermeabilização excessiva do solo, o desmatamento, o aterramento de nascentes, de pequenos fios d'água e de córregos, o assoreamento de ruas de terra sem pavimentação, a poluição difusa e a ausência de infraestruturas de drenagem. Além disso, havia situações de inadequação habitacional, moradias em situação de risco e em áreas de preservação permanente, como margens de córregos, que demandavam intervenções prioritárias.

(...) a gente sentou e começou a conversar com eles ${ }^{109}$, e ai a gente começou a formular o que seriam compensações ambientais em glebas totalmente impermeabilizadas. Nós vamos limpar o fundo do rio, vamos plantar a mata ciliar, vamos fazer com as crianças, vamos explicar, vamos fazer laboratório. A Rosângela "isso não dá"... aí, nesse processo de discussão, saiu um acórdão para o [loteamento] Ipanema que dizia que eles tinham que providenciar uma área de compensação ambiental de 24 mil metros quadrados. Ai eu falava, doutora, eu fui lá, eu medi aqui esse pedacinho, esses lotes vazios, não dá 24 mil metros eu não sei como é que faz. Ela falou "ah, se vira, quebra a calçada". Achei melhor não falar nada, a mulher está uma fera. Ai, eu sai dali batendo na minha cabeça. Eu morava em Perdizes eu vinha naquele congestionamento, pensando "se vira, quebra a calçada". Bom, a gente vai quebrar a calçada, porque se a gente quebrar a calçada, a gente mede e aí você não acredita, nós convencemos as pessoas. Olha, foi um processo emocionante, porque os caras tinham aqueles blocos de concreto nas calçadas, metalúrgico, o cara pegava o maçarico pra cortar, pra fazer, que fazia bolha, sangrava. A gente ia à noite na casa deles. A interação com as pessoas ficou muito familiar, ficou uma grande família. (Informação verbal) ${ }^{110}$.

O desenvolvimento das chamadas "calçadas ecológicas", que tinham como objetivo aumentar a área permeável no loteamento foi sendo aprimorada pela equipe da Secretaria de Obras a partir das considerações dos moradores e passou a ser replicada em diversos assentamentos. As ações de reparação de danos ampliaram-se durante o desenvolvimento do programa Bairro Ecológico, que incluiu outros componentes como, por exemplo, o aproveitamento dos lotes vazios, hortas comunitárias, coleta seletiva de lixo, o reflorestamento com plantio de mudas de árvores nativas e "que eram ações duradouras, permanentes, que iam ficar ali num significado que ia mudar" (informação verbal) ${ }^{111}$. Todas as intervenções eram acompanhadas de um trabalho informativo sistemático da SHAMA para explicar à população a importância da bacia hidrográfica e sua função ambiental, os impactos causados pelas ocupações junto à represa, e os limites impostos pela legislação para a regularização fundiária e urbano-ambiental.

\footnotetext{
109 Sônia Lima refere-se às lideranças dos bairro nos quais moravam muitos metalúrgicos e militantes políticos de movimentos populares.

${ }^{110}$ Conforme entrevista com Sônia Lima concedida à autora em 20/07/2012.

${ }^{111}$ Conforme entrevista com Sônia Lima concedida à autora em 20/07/2012.
} 
Muitas das ações de educação ambiental, determinadas como parte do cumprimento do TAC, foram realizadas por ONGs locais que também passaram por uma mudança de postura diante das ocupações irregulares, realizando um trabalho conjunto.

No que se refere às soluções infraestruturais, havia a premissa de implantar as infraestruturas básicas e em seguida contemplar outras intervenções de recuperação ambiental, como a recuperação de nascentes e margens de córrego envolvendo a participação dos moradores ${ }^{112}$. Iniciou-se uma pesquisa de aplicação de materiais e soluções de infraestrutura que até então não eram utilizados, como a aplicação de asfalto drenante (chamado de asfalto ecológico) ${ }^{113}$, pequenos poços de infiltração ${ }^{114}$ e o aumento de área permeável em calçadas. A solução de pavimentação foi desenvolvida por uma empresa local| ${ }^{115}$, que adaptou o asfalto utilizado em rodovias, de maior porosidade para o escoamento das águas ${ }^{116}$.

As obras de infraestrutura eram pagas com recursos dos moradores, dos proprietários ou da própria prefeitura, variando conforme a negociação realizada para firmar o TAC. Nesse aspecto, era preciso o apoio do ministério público para que a prefeitura investisse em área particular, assumindo os ônus das infraestruturas não construídas pelo loteador.

As soluções de saneamento, particularmente coleta e tratamento de esgotos, eram o ponto mais difícil de ser resolvido, pois dependiam de outro agente, a Sabesp. Como contraponto à implementação de redes convencionais de exportação de esgotos, a solução com estações locais de tratamento de esgotos era considerada uma alternativa adequada, pois tanto possibilitava o tratamento em áreas mais difíceis de serem atendidas pela rede pública, como porque conceitualmente era entendida como uma forma de controlar a ocupação, desde que isso fosse apropriado pelos moradores.

Uma primeira experiência de ETE local foi realizada no loteamento Jardim dos Pinheiros (ou Pinheirinho, Associação Comunitária Terra para Todos). No TAC definiu-se que o custeio da ETE local e o congelamento da ocupação seriam responsabilidades dos moradores. Os antigos

\footnotetext{
112 Sobre esse tipo de intervenção em APM é relevante a experiência do município de Santo André que, em 1998, desenvolveu um projeto para o loteamento irregular Parque Andreense, com o objetivo de criar um modelo de Gestão Participativa em Áreas de Mananciais (GEPAM) que pudesse ser replicado em áreas com problemas semelhantes. O projeto envolveu os moradores e também diversos órgãos da prefeitura local, ONGs, movimentos populares e universidades (Universidade de São Paulo e University of British Columbia de Vancouver). O redesenho do loteamento foi orientado pela implantação de infraestruturas não convencionais, menos impactantes e que melhorassem a qualidade de vida da população local. Destaca-se a solução de drenagem superficial, com canaletas e calçadas de grama, a criação de áreas de praças permeáveis e a arborização. As casas foram mantidas. Além disso, foi implantada uma estação local de tratamento de esgoto. Atividades de geração de renda para a população local também integraram o projeto (SANTO ANDRÉ, 2004).

${ }^{113}$ Os trabalhos de avaliação de projetos consultados apontam que o maior problema em relação ao asfalto ecológico é sua manutenção, feita frequentemente com asfalto comum, que não tem o mesmo desempenho. (BUENO, 2005; ITIKAWA, 2008)

114 Poços de infiltração são elementos do sistema de drenagem que recolhem a água de chuva e promovem sua absorção no solo lentamente.

${ }^{115}$ Construtora Emparsanco.

${ }^{116}$ Essa solução, contudo, apresenta problemas à longo prazo, pois com o tempo a porosidade do asfalto deixa de existir, comprometendo a permeabilidade.
} 
proprietários construíram a rede coletora de esgotos e custearam ações de educação ambiental e o loteador ficou responsável pela arborização. A Prefeitura executou as obras das redes de drenagem pluvial, controle de erosão, guias, sarjetas e pavimento ecológico (BUENO, 2005).

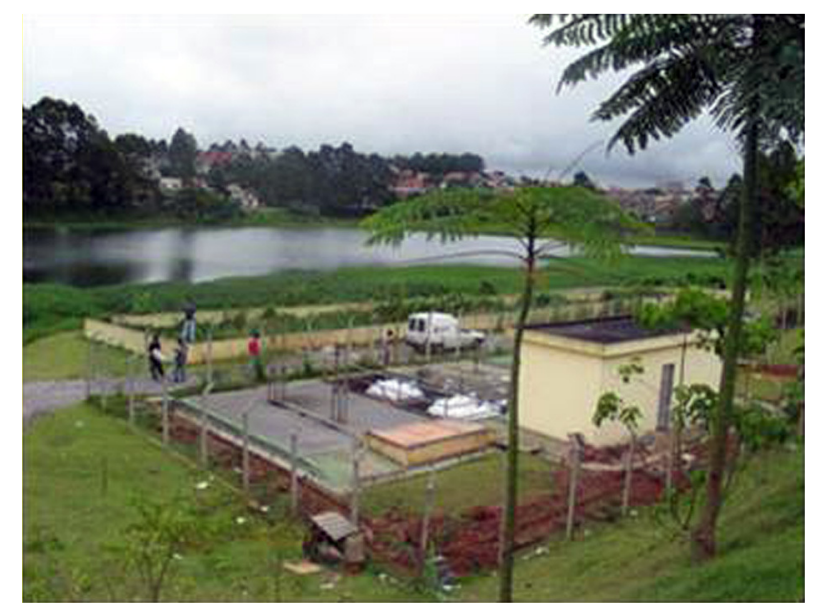

Figura 48 - Estação localizada de tratamento de esgoto no Jardim Pinheirinho

Foto da autora, 2005.

A ETE local do Pinheirinho funcionava a partir de processos biológicos de decomposição dos efluentes, tratando os esgotos no nível terciário. Para o seu pleno funcionamento, os moradores precisavam respeitar algumas regras como não usar detergentes ou outros produtos que comprometessem o desempenho do processo. Além de depender de mudanças de hábitos dos moradores, o que é de difícil controle, houve alguns problemas de gestão e manutenção da estação. Quando a Sabesp assumiu os serviços de saneamento em São Bernardo em 2003, ela manteve a ETE funcionando por um tempo e depois a desativou.

Em outros bairros, a construção da rede de esgotos não se ligou aos coletores (pois ainda não haviam sido construídos), fazendo com que houvesse uma melhoria significativa nos córregos dos assentamentos, mas piorando a qualidade de água afluente à represa. Nesse sentido, a avaliação dos resultados das intervenções dos Bairros Ecológicos é mais positiva no que tange a melhoria da qualidade de vida urbana e ambiental dos moradores do que sobre a qualidade da água do afluente à represa Billings ${ }^{117}$.

A negociação de lotes vazios para relocação de famílias em área de risco também fazia parte dos acordos, nos quais o acompanhamento das associações de moradores garantia que fossem realizados minimizando conflitos.

Este foi um momento em que se abriram possibilidades de intervenção com participação social e que mudou a atuação municipal sobre a região, que deixou de ser pautada pela repressão policial, vinculando a punição - que antes se limitavam à aplicação de multas, a investimentos na reparação de danos causados.

\footnotetext{
${ }^{117}$ Uma avaliação do Projeto do Loteamento Pinheirinho - SBC, em comparação com o Parque Andreense - Santo André foi realizada por Laura Machado Bueno, no artigo "Análise da Recuperação urbana e ambiental de assentamentos de interesse social na área de mananciais do ABC paulista". Disponível em http://www.usp.br/fau/depprojeto/labhab/biblioteca/textos/bueno_urbenvironcongress9_05.pdf, acesso em:
} 23/08/2011. 
Em termos do planejamento das intervenções de urbanização nesse território, o que guiou o andamento dos projetos foi principalmente os acordos do TAC, ou seja, não houve um critério ambiental mais amplo que orientasse a priorização das intervenções, visando avaliar seus resultados na bacia hidrográfica como um todo. Naquele momento o enfoque da SHAMA era pensar alternativas na escala dos loteamentos, porque também era o que conseguia viabilizar com os recursos disponíveis.

Com o desenvolvimento de algumas experiências, contudo, a escala da bacia ou microbacia de drenagem começou a ser discutida, devido à sua importância nos estudos de drenagem bem como para o controle dos resultados da implementação da infraestrutura e de seu impacto na melhoria da qualidade da água. Apesar do avanço conceitual ${ }^{118}$, projetos concebidos nessa escala não foram desenvolvidos.

A proposição de intervenções na escala da microbacia poderia ser um contraponto diante de algumas avaliações críticas sobre a demarcação generalizada de áreas no Plano Emergencial, que acabaram descaracterizando justamente seu caráter emergencial (CARMO; TAGNIN, 2001, p. 437). Na prática isso se agravou com a não execução de obras de saneamento, pois boa parte das obras pelas quais a concessionária estadual se responsabilizou a realizar no curto prazo, com recursos próprios, de acordo com o estipulado no Plano Emergencial previsto em lei, foi incluída posteriormente no pleito do Programa de Recuperação Ambiental da Bacia da Billings, em $1999^{119}$.

Apesar de seus limites, a experiência dos Bairros Ecológicos foi marcada por experimentalismo e inovação, cujo processo provocava a mudança de postura dos envolvidos - da população, técnicos do Meio Ambiente da Prefeitura e Ministério Público - no sentido do reconhecimento dos direitos sociais dos moradores dessas áreas. O seu componente de informação e mobilização da população para as questões ambientais da região de mananciais é o aspecto considerado mais relevante pelos que trabalharam no programa. Segundo o ponto de vista da promotora pública:

Essa capacitação era importante porque nós entendíamos que ela seria útil no caso da gente ter um administrador público que não tivesse consciência da necessidade de preservar ou de manter esse trabalho. Então o que a gente queria era criar uma massa crítica que cobrasse do administrador público sempre um olhar para aquela região. (...) E foi um trabalho que deu muito certo, porque a gente conseguiu lideranças muito atuantes inclusive para fiscalizar o que o município estava fazendo. Por outro lado, nós não tínhamos muito controle sobre como as obras são feitas, como não temos até hoje. O setor de obras públicas do município é muito fechado, quer dizer, eles decidem ali num grupo pequeno, licitam e acabou; eles vão fazer do jeito que eles quiserem e a intervenção do MP em como a obra vai ser feita é muito pequena. (Informação verbal) $^{120}$

\footnotetext{
${ }^{118}$ Esse debate decorreu da pesquisa FAPESP - Políticas Públicas, intitulada "Reparação de Danos e Ajustamento de Conduta em Matéria Urbanística, sob coordenação de Maria Lucia Refinetti Martins, em 2005, da qual participaram municípios da RMSP e Ministério Público.

${ }^{119}$ Esse programa será tratado em maior detalhe no capítulo 8.

${ }^{120}$ Entrevista da promotora pública Dra. Rosângela Staurenghi, concedida à autora em 30/08/2012.
} 
De outro lado, a premissa da participação subentendia o reconhecimento de que o poder público municipal, sozinho, não teria meios para lidar com a situação e desenvolver os projetos de intervenção.

No que se refere à regularização fundiária, não houve avanços significativos. De acordo com Sônia Lima, a regularização era entendida a partir de várias dimensões: a social - que significava inserir a comunidade no processo e informá-la; a urbanística - que tratava do redesenho interno dos loteamentos, remoção de moradias em áreas de risco e em áreas de preservação permanente relocando-as em lotes melhor localizados no interior do assentamento; e a jurídica - ou seja, o registro de documentação sobre a propriedade do terreno. No entanto, para a regularização fundiária havia a dependência da promulgação da nova legislação específica da Billings, em discussão naquele momento. Com essas dimensões ela argumenta que estava "percorrendo o caminho da regularização"121. Portanto, as áreas que passaram por intervenções de urbanização não foram regularizadas do ponto de vista fundiário, naquele momento.

O Bairro Ecológico, entendido como ação conjunta entre prefeitura, promotoria e população, representou um esforço coletivo para superar os entraves legais da intervenção pública em APM, e explicitou a importância da solução de infraestruturas na recuperação urbana e ambiental dos assentamentos precários, com a participação dos envolvidos, gerando contribuições nesse campo. Mas ao se restringir aos loteamentos consolidados e não se articular a uma política habitacional e ambiental mais ampla, não se propôs a interferir na dinâmica de ocupação dos mananciais considerando a demanda e o déficit crescente de moradias do município. Esse foi um de seus limites. Durante sua realização, a sua influência nesse sentido se concentrou na tentativa de desincentivar a compra de lotes em parcelamentos irregulares, na medida em que buscou informar a população sobre as restrições e riscos quanto à regularização da posse da terra nessas áreas. Mas a suspensão desse trabalho comprometeu sua efetividade.

Além disso, o Bairro Ecológico não foi institucionalizado formalmente como um programa e não foi priorizado na destinação de recursos financeiros durante duas gestões municipais. Ou seja, grande parte das ações realizadas deveu-se ao empenho e militância, por um lado, dos técnicos envolvidos e, por outro, dos moradores, além da pressão exercida pelo Ministério Público para o cumprimento dos TACs.

Na mudança de gestão do prefeito Luis Marinho, o programa foi interrompido e o contato com as demandas da população passou a ser realizado por meio do Orçamento Participativo. A realização de TACs deixou de ser uma prioridade, o que também decorreu da aprovação da Lei Específica da Billings em 2009, que permitiu a regularização de assentamentos irregulares desde que realizados os Programas de Recuperação de Interesse social (PRIS), tema que será retomado adiante.

Uma apreciação quantitativa dos resultados alcançados pelo programa Bairro Ecológico pode ser extraída do mapa realizado pela SHAMA em 2009, quando mudou a gestão municipal. De 1997 a

\footnotetext{
${ }^{121}$ Informação verbal em entrevista com Sônia Lima, concedida à autora em 20/07/2012.
} 
2009 a experiência do programa abrangeu 82 assentamentos (entre loteamentos e favelas), com níveis de intervenções ${ }^{122}$ variadas, como mostra o mapa 19 a seguir. Desse total, 20 assentamentos $(24,4 \%)$ encontravam-se no nível I, $28(34,1 \%)$ no nível II, $10(12,2 \%)$ no nível III e $24(29,3 \%)$ não apresentavam qualquer intervenção. Se considerados apenas os assentamentos demarcados no Plano Emergencial, que totalizam 63 assentamentos, a situação era a seguinte: 12 assentamentos $(19,0 \%)$ no nível I, 18 (28,5\%) no nível II e $9(14,3 \%)$ no nível III. Portanto, das 63 áreas demarcadas pelo Plano Emergencial, 27 passaram por intervenções variadas de urbanização por meio do Bairro Ecológico.

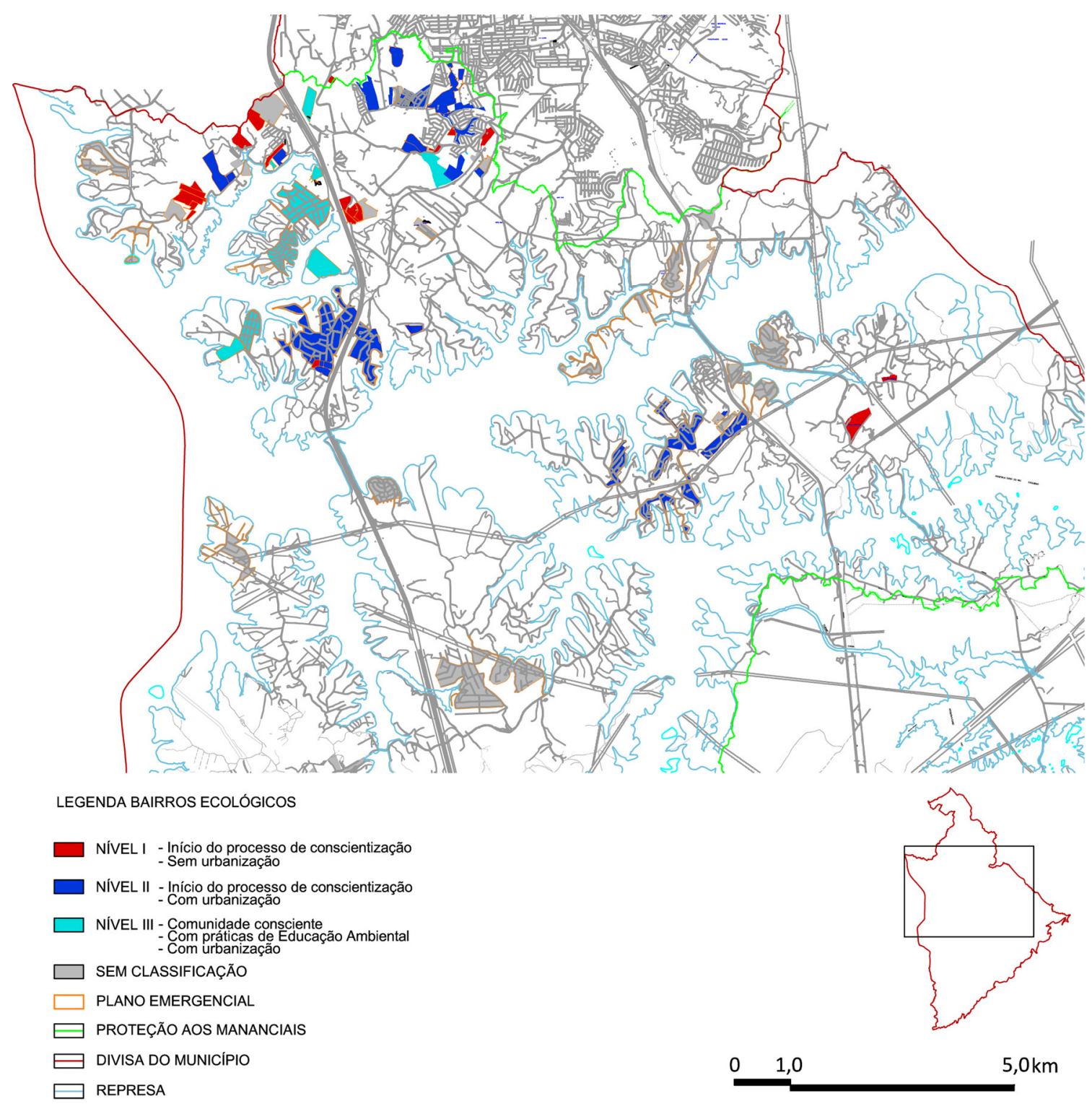

Mapa 19 - Bairros Ecológicos segundo os níveis de intervenção de urbanização.

Fonte: Secretaria de Habitação e Meio Ambiente de São Bernardo do campo. Informação concedida à autora em 2008.

\footnotetext{
${ }^{122}$ Nível I: assentamentos sem urbanização, onde o processo de conscientização foi iniciado. Nível II: assentamentos com urbanização, onde o processo de conscientização foi iniciado. Nível III: assentamentos urbanizados, comunidade consciente e com práticas de educação ambiental implementadas. Conforme dados de SHAMA, 2008.
} 
Há loteamentos, como o Jardim Senhor do Bonfim, considerado de nível III, onde as obras de urbanização foram mantidas e ações de recuperação replicadas pelos moradores, o que demonstra que o aprendizado e a prática foram apropriados por eles. Esse assentamento, que foi considerado um dos exemplos bem sucedidos do programa, apresenta atualmente uma qualidade ambiental superior aos demais. Conforme uma das lideranças locais, essa qualidade é usufruída por moradores da região, que ali vão passear e fazer caminhada. Mas essa situação convive com mecanismos de diferenciação e valorização desse loteamento, o que se explicita, por exemplo, pela presença de uma cancela na sua rua de entrada, à semelhança dos condomínios fechados de alta renda. Novas contradições aparecem. Atualmente, a Associação do Jardim Senhor do Bonfim está iniciando o processo de regularização fundiária do loteamento.

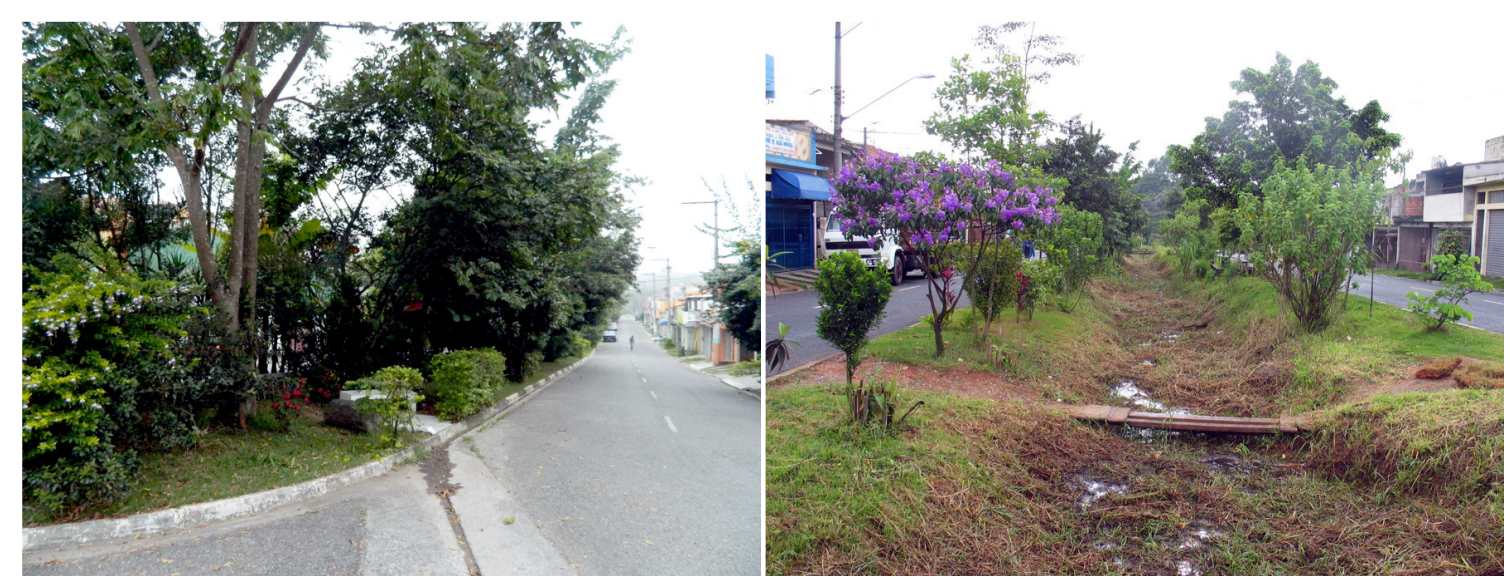

Figuras 49 e 50 - Loteamento Jardim Senhor do Bonfim - recuperação de córrego.

Fotos da autora 2012, 2005.

Em outros casos, a interrupção do programa fez com que algumas práticas e intervenções que dependiam de manutenção e do acompanhamento do poder público fossem abandonadas ${ }^{123}$. Mas como toda ação do poder público, as intervenções não abrangeram o conjunto dos assentamentos indicados pelo Plano Emergencial. No caso dos seis loteamentos do baixo Alvarenga, por exemplo, onde projetos e obras não foram implementados, as reivindicações mantiveram-se, ainda pautadas pelo diálogo com o Ministério Público e prefeitura. O item 6.2, a seguir, aborda justamente as consequências do "não atendimento" das demandas de melhorias de infraestrutura e regularização.

Cabe destacar que a experiência dos Bairros Ecológicos, considerando os limites e conflitos que gerou ao longo de sua realização, levantou uma questão relevante quanto ao tema do tratamento das infraestruturas em área de proteção aos mananciais com sua abordagem social e ambiental, explicitando sua importância para além da fragmentação da propriedade privada do lote e da habitação, apesar de não modificar a estrutura dessa fragmentação. A busca por soluções diferenciadas, de menor impacto, foi impulsionada pela condição de precariedade social, ambiental e urbana dos assentamentos, mas sua implementação dependeu da adesão dos moradores. Ou seja, o objetivo de associar urbanização à recuperação ambiental dos

\footnotetext{
${ }^{123}$ Conforme avaliação de Sônia Lima, em entrevista concedia à autora em 20/07/2012.
} 
mananciais, estimulou a busca de tecnologias e de desenhos de infraestruturas diferentes do padrão urbano normatizado, colocando tanto a gestão municipal, quanto os moradores, em contato com questões até então não tratadas - como a recuperação de corpos d'água, o aumento de área permeável, dentre outros exemplos acima citados - e que dependeram de seu envolvimento para que fossem implementadas. Ainda que o problema principal do tratamento de esgoto não tenha sido resolvido, ou seja, o ganho ambiental em termos de qualidade da água não tenha melhorado significativamente, há que se destacar o aspecto socioambiental dessas desses projetos, até então não considerados como modo de intervir nos assentamentos em APM em São Bernardo do Campo.

Entretanto, os assentamentos que receberam as obras do Bairro Ecológico passaram, em seguida, por uma "inescapável" valorização fundiária resultante desse trabalho social que contraditoriamente promove, paulatinamente, uma mudança no perfil de renda dos moradores. Apesar desse processo não ter sido objeto específico de investigação dessa tese, há de ser considerado como parte inerente ao processo de urbanização desigual, ao qual se soma o elemento da qualidade ambiental, a exemplo dos Bairros Ecológicos.

\subsection{Em busca do TAC: um estudo urbano ambiental e as cartografias comunitárias no baixo Alvarenga}

Nesse item do capítulo, considerando o contexto político e institucional dos anos 1990 e início de 2000, saímos da abordagem geral dos loteamentos em área de proteção aos mananciais (APM), para voltar o foco para a situação específica dos loteamentos do baixo Alvarenga. O objetivo é justamente evidenciar os desdobramentos socioespaciais de uma área que não passou por intervenções do programa Bairro Ecológico, o que foi possível acompanhar durante a pesquisa de campo a partir de 2007.

A experiência dos Bairros Ecológicos durante duas gestões municipais alcançou uma abrangência significativa quanto à mobilização de moradores pela recuperação dos mananciais, mas foi menos expressiva em termos de urbanizar e "infraestruturar" os assentamentos, apesar das soluções diferenciadas de infraestrutura que visou implementar. Como abordado no item anterior, a mobilização social promovida pelo trabalho conjunto entre governo municipal, Ministério Público e população, foi um de seus principais avanços. Essa mobilização estava associada às possibilidades de realização de obras de infraestrutura e futura regularização fundiária e reverberava em outros bairros e loteamentos que visavam, com essa referência, formular seus próprios Termos de Ajustamento de Conduta (TAC).

Dessa forma, a promotora pública Rosângela Staurenghi passou a desempenhar o papel de mediadora na negociação dos TACs e continuou orientando as lideranças das associações de bairro ao longo da tramitação das ações civis públicas nas quais os acordos não haviam sido firmados. Os seis loteamentos do baixo Alvarenga enquadram-se nesse segundo grupo dos assentamentos não contemplados por projetos e obras, apesar de terem sido indicados no Plano Emergencial e com os quais a formulação de um TAC estava em perspectiva. O TAC se mantinha 
como instrumento jurídico para a negociação e urbanização dos loteamentos irregulares, pois ainda não havia sido promulgada a Lei Específica da Billings que posteriormente tratou do tema.

No início de década de 2000, as ações civis públicas, dos seis loteamentos, iniciadas no final dos anos 1980 estavam em etapas diferentes. As sentenças de desfazimento e recomposição da vegetação original a cargo das associações evidentemente não haviam sido cumpridas e, devido à consolidação das construções durante o longo andamento dos processos, foram posteriormente transformadas em perdas e danos (na forma de pagamento de multas ou com definição de obras de reparação). Somente a ação civil pública contra a Associação Comunitária Jardim das Orquídeas (loteamento Novo Horizonte II) ainda apresentava a sentença de demolição. Segundo a promotora, diante do não cumprimento das sentenças era difícil envolver os moradores desses loteamentos, pois eles não acreditavam que seriam cumpridas.

Contudo, em 2002, a Associação Comunitária Jardim Ouro Verde (loteamento Novo Horizonte), em negociação com a promotora, comprometeu-se em contratar a ONG Holos21, com o objetivo de ser instruída e auxiliada na realização de medidas de recuperação ambiental, visando a futura elaboração do TAC. Um contrato foi firmado para "prestação de serviços so cioambientais limitados à qualificação e responsabilidade civil da formação profissional de seus associados, (...) para elaboração de estudo preliminar para projeto de recuperação ambiental, a partir da gestão socioambiental, relativo aos impactos provocados pela ocupação"124. A ONG tinha como premissa a participação dos moradores na construção desse projeto.

Como lembra a moradora do Ouro Verde, que fazia parte da diretoria da Associação na época do acordo com o MP, a mobilização maior dos moradores ocorreu nos primeiros anos do loteamento, para a reivindicação de melhorias, mas não teve continuidade da mesma forma nos anos seguintes. Quando o acordo foi firmado, a mobilização já tinha arrefecido:

Pela busca das melhorias as pessoas tinham um interesse maior. Porque até então, assim, era tudo novo. A ânsia de ter as coisas. Então houve uma participação maior. Com o decorrer dos anos, das coisas acontecendo, as informações que nós tínhamos e passávamos. Eu acho que as pessoas começaram meio que a ficar descrentes e achar que a Prefeitura tem que fazer. Por mais que a gente explicasse, não, não é a Prefeitura. A Prefeitura tem que fazer sim, mas a partir do momento que a gente mobilizar e fazer de acordo com o que o Ministério Público quer e determinar vai ser assim, assim, assim, a Prefeitura entra com a obra. E as pessoas não entendiam muito isso; não aceitavam isso. Então assim, no decorrer dos anos o que aconteceu: muitas pessoas foram embora. Meio que cansaram, desistiram daqui. Então alguns venderam suas casas, outros alugaram, e aí as pessoas que entraram não tem esse entendimento. Eu confesso pra você, assim, que falta mais conscientização, falta informação. Porque eu acho que a partir do momento que a pessoa tem informação, tem entendimento, ela participa mais. Se não tem isso, não tem como você exigir de algum morador ou associado, uma participação se ele não sabe do que se trata. E nesse período no caso

\footnotetext{
${ }^{124}$ Termos do contrato cedido à autora, para consulta, pela associação de moradores Outro Verde, em 2011. Estudos necessários para futura elaboração de projeto de recuperação, que constam na cláusula segunda do contrato: 1) levantamento topográfico altimétrico com base na planta apresentada pela comunidade; 2) levantamento fundiário; 3) estudo da identidade jurídica da Entidade; 4) acompanhamento do processo $n^{\circ} 782 / 93$; 5) levantamento documental; 6) acompanhamento da mobilização social.
} 
que eu fiz parte da diretoria eu e a Eli ${ }^{125}$ a gente passava a informação. Então a gente tinha até um número maior de pessoas mesmo sendo contra. (...) Hoje é difícil pra você fazer uma assembleia, ter um número grande de pessoas, é difícil, é meio complicado assim. Aí depois também as outras duas diretorias que entrou também não teve muita participação nesse sentido de estar dando informação. (Informação verbal) ${ }^{126}$.

O trabalho da ONG com a Associação Comunitária Ouro Verde teve andamento, mesmo com a dificuldade de envolver os moradores. Mas o loteamento (Novo Horizonte) era cercado por mais cinco loteamentos com situações semelhantes e completamente articulados do ponto de vista urbano. Então, visando lidar com esse conjunto, a promotora propôs que o trabalho da Holos21 se ampliasse, incluindo a discussão para a formulação de um TAC para os seis loteamentos. Com isso, um plano abrangeria o conjunto, seguindo a diretriz de intervir na escala de uma microbacia de drenagem, de forma a garantir melhorias ambientais mais efetivas, particularmente do ponto de vista hídrico e de drenagem.

Para dar prosseguimento a essa concepção, em 2007 a ONG submeteu o projeto "Projeto Levantamento Socioambiental da Região do Baixo Alvarenga e Curso de Capacitação de gestores socioambientais" (Projeto GSA) e obteve financiamento do Fundo Estadual de Recursos Hídricos (FEHIDRO) para desenvolvê-lo. O objetivo central do projeto era elaborar coletivamente um estudo urbano-ambiental com a participação dos moradores em todas as etapas do processo, para que eles se formassem enquanto gestores ambientais e pudessem, quando da realização do TAC, acompanhar as intervenções previstas nos seis loteamentos. Os estudos resultantes desse processo subsidiariam a elaboração do TAC.

Devido à experiência acumulada de pesquisa em Políticas Públicas urbanas e ambientais o Laboratório de Habitação e Assentamentos Humanos da FAUUSP (LabHab) foi convidado a participar desse projeto. Dentre as "17 ações de caráter corretivo" que o projeto previa, duas contavam com a participação do LabHab: o levantamento das edificações (diagnóstico da avaliação física e condição de salubridade das moradias) e o estudo de recuperação urbana ambiental (síntese dos diagnósticos realizados que embasariam a elaboração do TAC). Como já tratado na Introdução, no item Trajetória da Pesquisa, é nesse contexto que se inseriu a pesquisa de campo dessa tese, desenvolvida junto aos loteamentos do baixo Alvarenga.

Se, por um lado, havia demandas locais muito concretas a serem trabalhadas coletivamente e sobre as quais havia expectativa quanto à nossa contribuição acadêmica e profissional, por outro, havia também uma grande abertura para propostas. Assim, a participação enquanto pesquisadora nas atividades desse grupo estava associada às atividades desta pesquisa de doutorado, o que deixamos claro desde o princípio para os moradores. Dessa forma, passamos a realizar a observação participante acompanhando as atividades e as oficinas para a formação de gestores, com a aceitação e colaboração do grupo envolvido no Projeto.

\footnotetext{
${ }^{125}$ Nome fictício atribuído à moradora citada pela entrevistada.

${ }^{126}$ Conforme entrevista da moradora do Novo Horizonte, concedida à autora em 23/08/2012.
} 
Cabe esclarecer que o Projeto GSA desenvolveu-se em meio a diversas dificuldades operacionais e contava com uma participação muito variável dos moradores, o que prejudicava a continuidade das atividades. Isso porque muitos deles já estavam desestimulados e descrentes diante da ausência de soluções objetivas, outros simplesmente não podiam ou não estavam dispostos a participar. A falta de envolvimento devia-se em grande parte à desinformação e gerava uma incompreensão da atividade da ONG no local. Isso ficou claro quando um morador do loteamento Nova América explicitou que muitos moradores não frequentavam as reuniões porque temiam perder seus lotes (informação verbal) ${ }^{127}$.

Apesar disso, quando presentes, os moradores eram bastante ativos e críticos, inclusive sobre a função do próprio projeto e suas dificuldades. Alguns deles já atuavam nas associações há muito tempo, ou também em outras instâncias de participação, como o Subcomitê BillingsTamanduateí, discutindo a elaboração da Lei Específica da Billings. Nesse sentido eram interlocutores bastante inteirados não só dos conflitos cotidianos locais como dos conflitos em relação à lei de proteção aos mananciais. Apesar desse potencial evidente, a participação, quando acontecia, era representativa do próprio loteamento, não havendo uma identidade de grupo.

Após a realização de diversos diagnósticos e levantamentos programados no curso de gestores, a atividade conclusiva do Projeto GSA era a execução do "Estudo de recuperação urbana e ambiental". No entanto, a metodologia para fazer esse debate, cujo resultado deveria ser sistematizado num estudo que embasaria a formulação do TAC para os seis loteamentos, não estava previamente definida no projeto da Holos21. Como reunir o conhecimento disperso dos moradores em torno de um debate visando a construção coletiva de diagnósticos e propostas? Como esse debate poderia se diferenciar das cansativas reuniões, que já não contavam com muita participação, e abrir novos debates? Que ferramenta poderia explicitar diferentes interpretações sobre o espaço e sobre o ambiente em que se vive? Nesse sentido, propusemos como método as cartografias comunitárias, que se mostrava apropriada para o tipo de discussão que se pretendia desenvolver. Ao mesmo tempo constituíam um método para a pesquisa em curso.

O método de construção de cartografias comunitárias ou mapeamento comunitário, conhecidos de um modo geral como "mapeamento participativo", não é novo ${ }^{128}$ enquanto campo de reflexão sobre as relações entre espaço, recursos naturais e conhecimentos sociais ou tradicionais. Nas três últimas décadas têm sido mais aplicadas em contextos de demanda de terras indígenas, como também para planificar o manejo dos recursos naturais (ACSELRAD; COLI,

\footnotetext{
${ }^{127}$ Conforme relato de campo sobre reunião realizada em 06/07/2008.

128 Segundo Acselrad e Coli (2008), experiências pioneiras de mapeamento participativo e uso de um Sistema Participativo de Informações Geográficas (SPIG) remontam ao Canadá há três décadas. O primeiro estudo sistemático reconhecido como uma forma de SPIG foi o Inuit Land Use and Occupancy Project (Projeto de Uso e Ocupação de Terras pelos Esquimós). Eles citam o trabalho de Chapin et alli (2005) que afirma que o mapeamento de terras indígenas para a garantia da posse, manejo de recursos naturais e para o fortalecimento de determinadas culturas é um fenômeno recente, iniciado no Canadá e no Alasca nos anos 1960 e, em outras regiões, ao longo da última década e meia. (ACSELRAD; COLI, 2008, p.16).
} 
2008, p. 19). Mas recentemente, a cartografia comunitária tem também sido experimentada para planejar e/ou intervir sobre o território urbano ${ }^{129}$, sendo considerada uma ferramenta adequada para o planejamento participativo em regiões de alta complexidade, o que é facilitado pela utilização de sistemas de informação geográfica (SIG).

No caso específico dos loteamentos do baixo Alvarenga, a proposta da cartografia comunitária não tinha um vínculo institucional e baseou-se em alguns pressupostos. Como construção coletiva de dados a partir da experiência individual ou de um grupo, os conteúdos trabalhados tem origem no diálogo com a população envolvida, ou seja, busca-se atuar sobre a representação do vivido de forma não impositiva, buscando um diálogo entre o conhecimento técnico e o conhecimento cotidiano, no qual os moradores vivenciam as dificuldades diárias e seus conflitos. Além disso, o envolvimento da população no mapeamento participativo pode qualificar, diversificar e politizar o processo de planejamento e constituir "contra-projetos" ou "contra-planos", quando se contrapõe a projetos impositivos. Dessa forma, mapeamento é entendido como um ato eminentemente político e não se restringe a questões técnicas e operacionais, apesar de considerá-las (SYDENSTRICKER-NETO, 2008).

Além disso, por meio das cartografias, buscava-se compreender de que modo os moradores articulavam (ou não) aspectos da ocupação urbana, seus problemas e potencialidades, com as características ambientais da região de mananciais e do sítio por eles transformado. Para isso a cartografia poderia ser mais bem trabalhada partindo de recursos gráficos e visuais de fotos aéreas e plantas do conjunto. Ensaiava-se portanto uma atividade não institucionalizada de planejamento urbano e ambiental a partir da experiência cotidiana de construção do espaço.

Assim, a opção pelo mapeamento participativo possuía múltiplos objetivos. Um deles era fomentar o debate em grupo, num contexto em que somente a elaboração conjunta de diagnósticos e propostas forneceria subsídios consistentes e negociados coletivamente para a futura formulação de um Termo de Ajustamento de Conduta (TAC). Além disso, o próprio "fazer" tinha a potencialidade de implicar os participantes nessa construção e explicitar situações vividas, banalizadas, mas que apresentavam conteúdos que poderiam ser tratados quando da elaboração de uma pauta de reivindicações ou de um projeto, incorporando questões que normalmente permanecem fora de pauta em intervenções de urbanização ${ }^{130}$.

\footnotetext{
${ }^{129}$ Em contextos urbanos a aplicação mais frequente dessa ferramenta visa a elaboração de planos de gerenciamento de bacia hidrográfica ou de ordenamento territorial, como planos diretores e planos de desenvolvimento local (como por exemplo os Planos de Ação Local de Cidade Tiradentes e Jardim Ângela, realizados respectivamente pela USINA e LABHAB, em 2003, para a PMSP). Em 2002, Santo André utilizou o biomapa como metodologia para desenvolvimento do Projeto GEPAM - Gerenciamento Participativo em Área de Mananciais, em parceria com a Canadian Internacional Development Agency (CIDA). Um dos resultados alcançados foi o desenvolvimento do projeto de urbanização do Parque Andreense. Uma aplicação diferenciada ocorreu no "Seminário Billings 2002 - Avaliação e identificação de áreas e ações prioritárias para a conservação, recuperação e uso sustentável da Bacia Hidrográfica da Billings como manancial de abastecimento de água para Região Metropolitana de São Paulo", coordenado pelo Instituto Socioambiental, no qual se utilizaram ferramentas de SIG para reunir e sistematizar as informações produzidas durante o seminário (WHATELY, 2002, p.5).

${ }^{130}$ Nesse sentido, minha contribuição, na qualidade de pesquisadora e participante, era estimular o debate a partir da identificação, nas falas dos moradores, de elementos relevantes, explicitados ou não nas narrativas e representações cartográficas.
} 
Ao mesmo tempo, os mapas são representações, expressam recortes da realidade, ou seja, a seleção ou desconsideração de informações pelos participantes também os compõem. É por isso que nas cartografias realizadas, que congregaram experiências diversas, bem como diferentes posicionamentos sobre determinados temas, as narrativas e debates que ocorreram durante suas elaborações também foram considerados nessa análise, mesmo não tendo sido representados graficamente. Essa abordagem da cartografia já não correspondia aos objetivos específicos de elaboração do TAC, ou seja, foi trabalhada a partir dos objetivos da pesquisa propriamente dita, que visava, nesse processo, explicitar contradições de uso do espaço num lugar onde reivindicações concretas convivem com restrições e condicionantes ambientais abstratos. Mas considerávamos que o processo de discussão poderia levantar questões que colaborariam inclusive com a elaboração do próprio TAC.

A primeira cartografia comunitária ${ }^{131}$ serviu como um diagnóstico urbano e ambiental, explicitando problemas e conflitos de uso do espaço. Constituiu-se num momento particularmente importante para a pesquisa pois, ao longo desse debate, reconstituímos o caminho percorrido pelo grupo na reivindicação por melhorias e a chegada fragmentada de infraestruturas nos loteamentos, conforme abordado anteriormente no capítulo 4. Essa cartografia também demonstrou o conhecimento socioambiental dos moradores sobre aquele espaço urbano, tanto pelos problemas apontados como consequência da ocupação irregular, como pelos destaques relativos à existência de nascentes, córregos, várzeas e espécies vegetais.

A segunda cartografia comunitária ${ }^{132}$ visou formular proposições para o conjunto dos loteamentos e assim avançar no debate da relação entre a ocupação existente e o que seria uma recuperação ambiental possível, levantando inúmeros conflitos que comentaremos adiante.

\subsubsection{Diagnósticos e propostas a partir da construção das cartografias comunitárias}

Durante a elaboração da primeira cartografia comunitária, de caráter diagnóstico, a espacialização da leitura dos problemas decorrentes da ausência de infraestruturas deu-se de forma bastante completa, constituiu-se em meio de expressão, ainda que parcial, da experiência cotidiana dos moradores, suas dificuldades e necessidades, bem como suas estratégias de sobrevivência para superar a ausência das redes públicas de infraestrutura.

Os grupos organizados por loteamento saíram a campo, por sua própria sugestão, com uma planta (contendo a localização de ruas, terrenos, curvas de nível, cursos d'água e áreas de preservação permanente) e uma foto aérea, para levantar pontos problemáticos relativos à infraestrutura, ao sistema viário, aos espaços coletivos e a outros temas que pudessem surgir.

$\mathrm{Na}$ cartografia de diagnóstico foram indicadas as áreas mais suscetíveis a alagamentos durante as chuvas, indicando inclusive suas diferentes intensidades; os locais que apresentavam erosão

\footnotetext{
${ }^{131}$ Esse mapa diagnóstico foi realizado de dezembro a fevereiro de 2009 (com a pausa de final de ano), em reuniões na sede comunitária do Parque dos Químicos.

${ }^{132}$ A elaboração do mapa propositivo e as reuniões de aprofundamento dos temas ocorreram de março a abril de 2009, na sede comunitária do Parque dos Químicos.
} 
nas ruas de terra; os pontos com dificuldade de acesso de pedestres e automóveis, ou onde a declividade excessiva não permitia a passagem de ambulâncias ou caminhões de coleta de resíduos sólidos. Também foram indicadas a ausência de coleta e tratamento de esgotos, bem como de outras infraestruturas, serviços e espaços públicos; a existência de "gatos" de eletricidade; o despejo de entulho e lixo nos lotes desocupados. Alguns moradores demonstraram conhecer as nascentes de água e o curso dos córregos, mesmo os já aterrados. Por serem autoconstrutores de seu espaço de moradia, com conhecimento sobre a ocupação do lugar, os problemas foram facilmente localizados e registrados e depois complementados pelas narrativas na apresentação de cada um desses mapas. As leituras de cada grupo foram reunidas pela autora em uma única cartografia (conforme mapas 20 e 21 a seguir).

Importante destacar que houve muitos pontos negativos levantados sobre a Estrada dos Alvarengas, uma via estreita de mão dupla, único acesso aos loteamentos e com poucas linhas de transporte coletivo, o que implica em dificuldades de mobilidade dos moradores no seu diaa-dia; enquanto que não houve menções negativas sobre a represa Billings, que se faz presente na paisagem, mas não tão presente do ponto de vista das necessidades cotidianas, nem mesmo como potencial área de lazer. O único uso nesse sentido acontece num pequeno campo de futebol às margens da represa, situado na frente dos loteamentos.

O debate sobre os problemas urbano-ambientais dos loteamentos não se dissociou dos motivos que geraram o padrão de ocupação, guiado pelo principal objetivo dos loteadores: vender a maior quantidade de lotes possível. O resultado espacial desse parcelamento voraz do solo implica na ocupação inadequada em relação às condições topográficas e físicas da gleba, o que acarreta inúmeros problemas de circulação (tanto interna como para ambulâncias, caminhões de lixo e ônibus) e drenagem, que se agravam com o adensamento das construções. Além disso, como é comum em loteamentos irregulares, não há cumprimento das exigências normativas quanto à destinação de áreas livres, públicas e de proteção ambiental (como margens de córregos e declividades acima de 30\%). Essa lógica da rentabilidade máxima do empreendimento e seu impacto na qualidade urbana do loteamento foram bem explicitados na fala dos moradores:

Teve um erro grave que ela [a associação] comprou as áreas onde não devia ser comprado e não podia ser loteado. Mas o objetivo das associações, não as que nós tomamos conta hoje, as demais, foi que elas só pensaram em vender, vender, vender, elas não deixaram área para lazer, porque você não só precisa morar, você precisa de lazer, você precisa de passagem, e aqui nos Químicos, por exemplo, você não tem travessa, você só tem as ruas, para você se deslocar de uma rua para outra você tem que dar a maior volta. (Informação verbal) ${ }^{133}$

A dificuldade de circulação interna nos loteamentos foi superada em alguns pontos com a destinação de lotes não ocupados à passagem de pedestres. Em áreas mais íngremes, é frequente a escavação de escadas e trilhas (conforme as figuras do capítulo 4). Para melhorar a

$\overline{133}$ Relato de um morador do Parque dos Químicos. Trecho da reunião realizada em 16/03/2009. 
circulação, há colocação de pedregulho nas ruas e até mesmo a concretagem de alguns trechos, cuja compra do concreto foi cotizada entre os moradores, bem como a construção de calçadas, tornando o viário local bastante descontínuo.

Quanto à presença de áreas de risco ambiental (inundação e deslizamento), a cartografia considerou as conclusões do levantamento feito em 2009, pelo geólogo Fernando Nogueira, que participou do estudo previsto pelo Projeto GSA. As visitas a campo do geólogo foram acompanhadas pelos moradores e pela autora. A primeira conclusão que se destacou foi o fato das próprias construções consolidadas e estáveis servirem de contenção aos cortes de terra feitos sem proteção, o que faz com que não haja risco de deslizamento ou desabamento significativo nos loteamentos, sendo demarcados poucos setores de risco naquele momento.
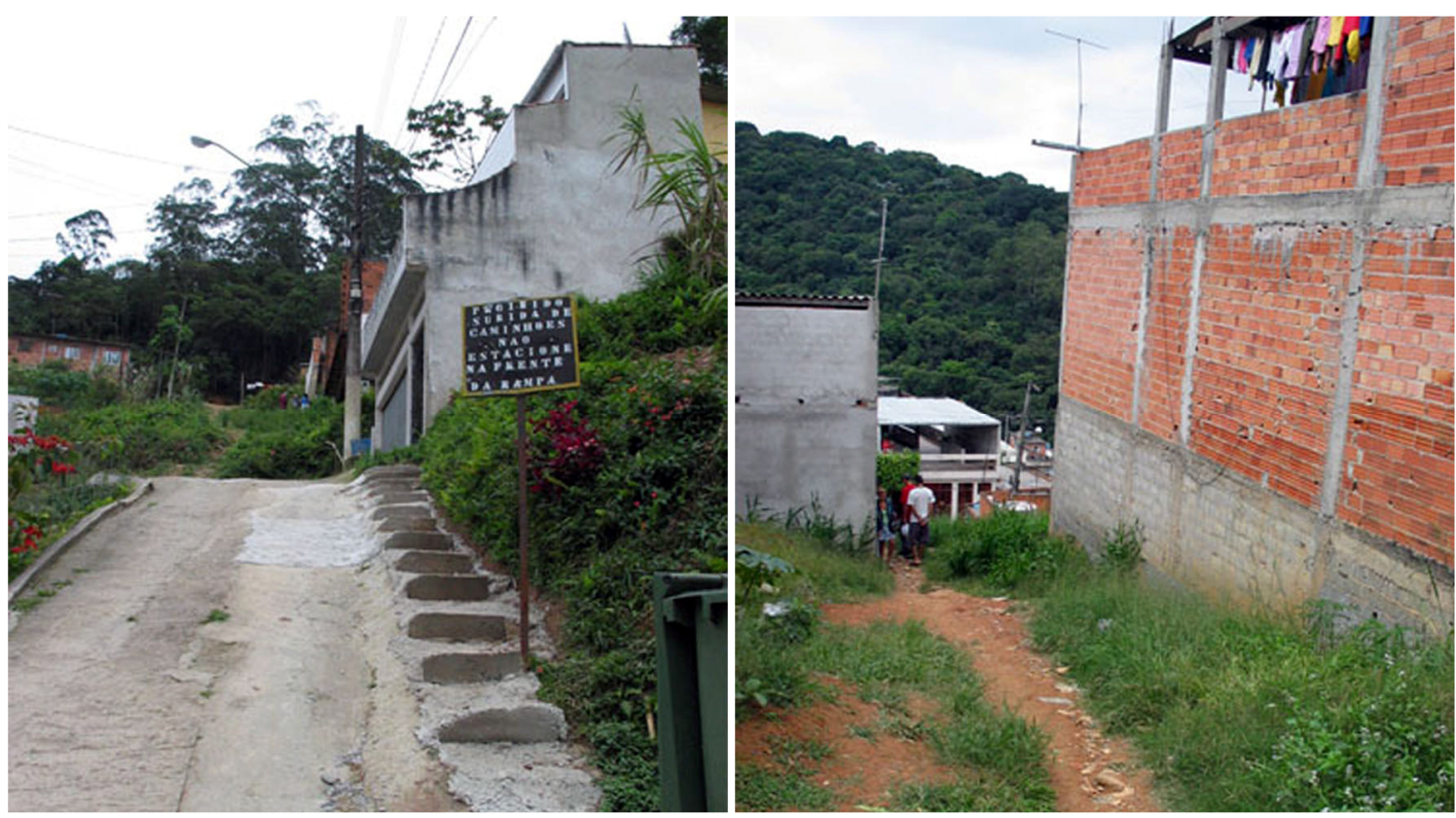

Figuras 51 e 52 - Circulação, escadas e acessos.

Fotos da autora, 2009.
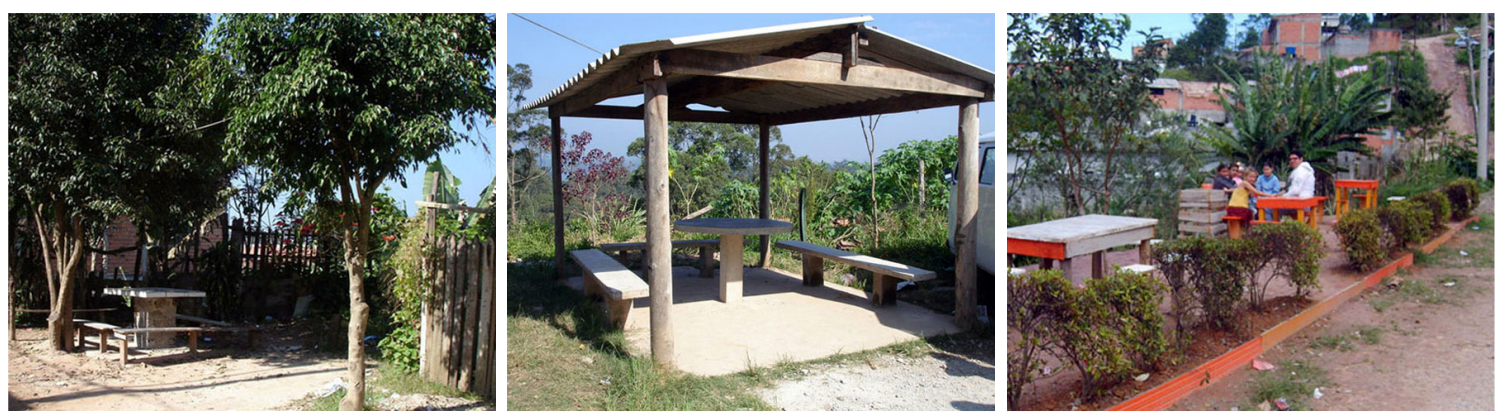

Figuras 53 a 55 - Praças e espaços coletivos.

Fotos da autora, 2009. 

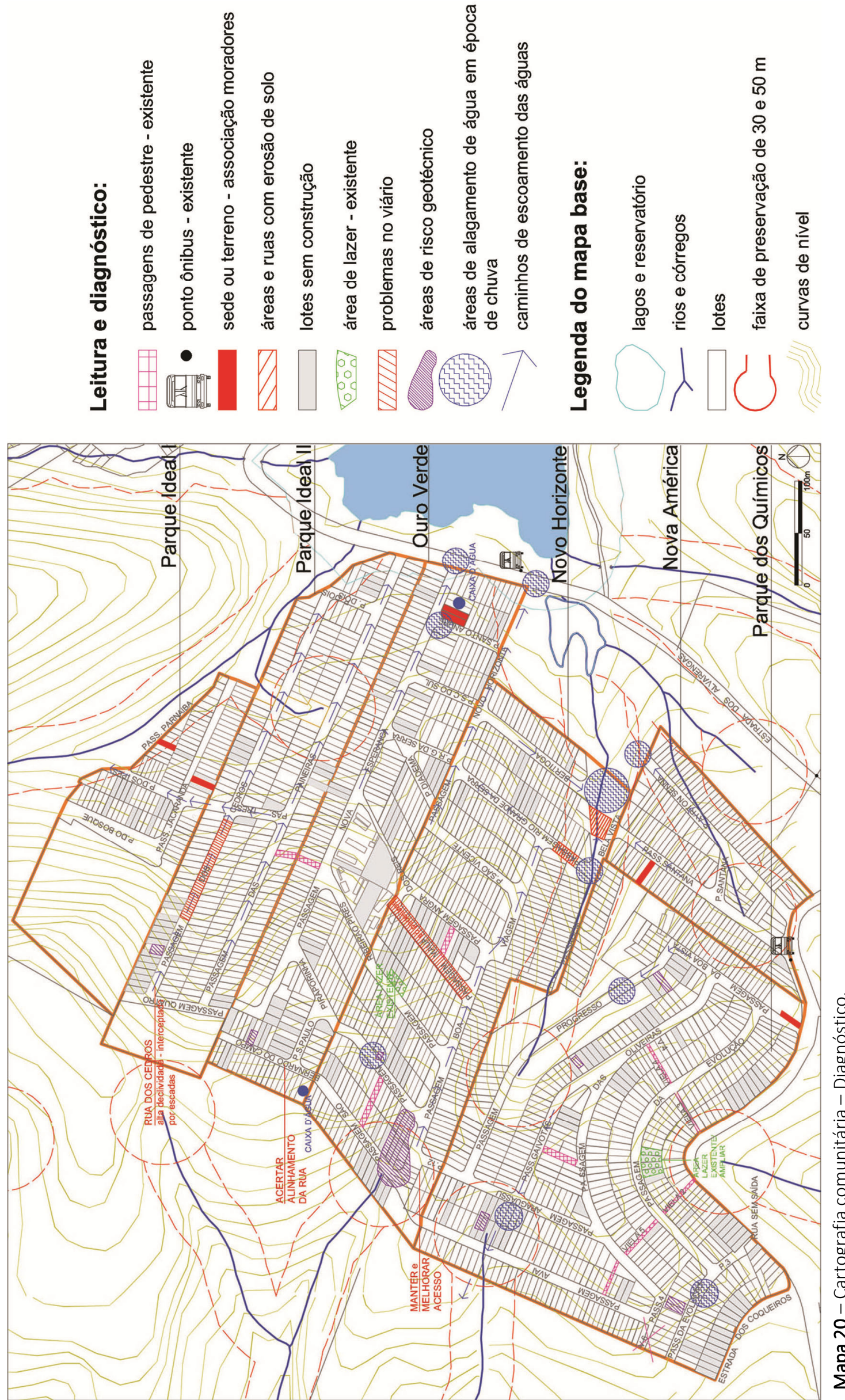

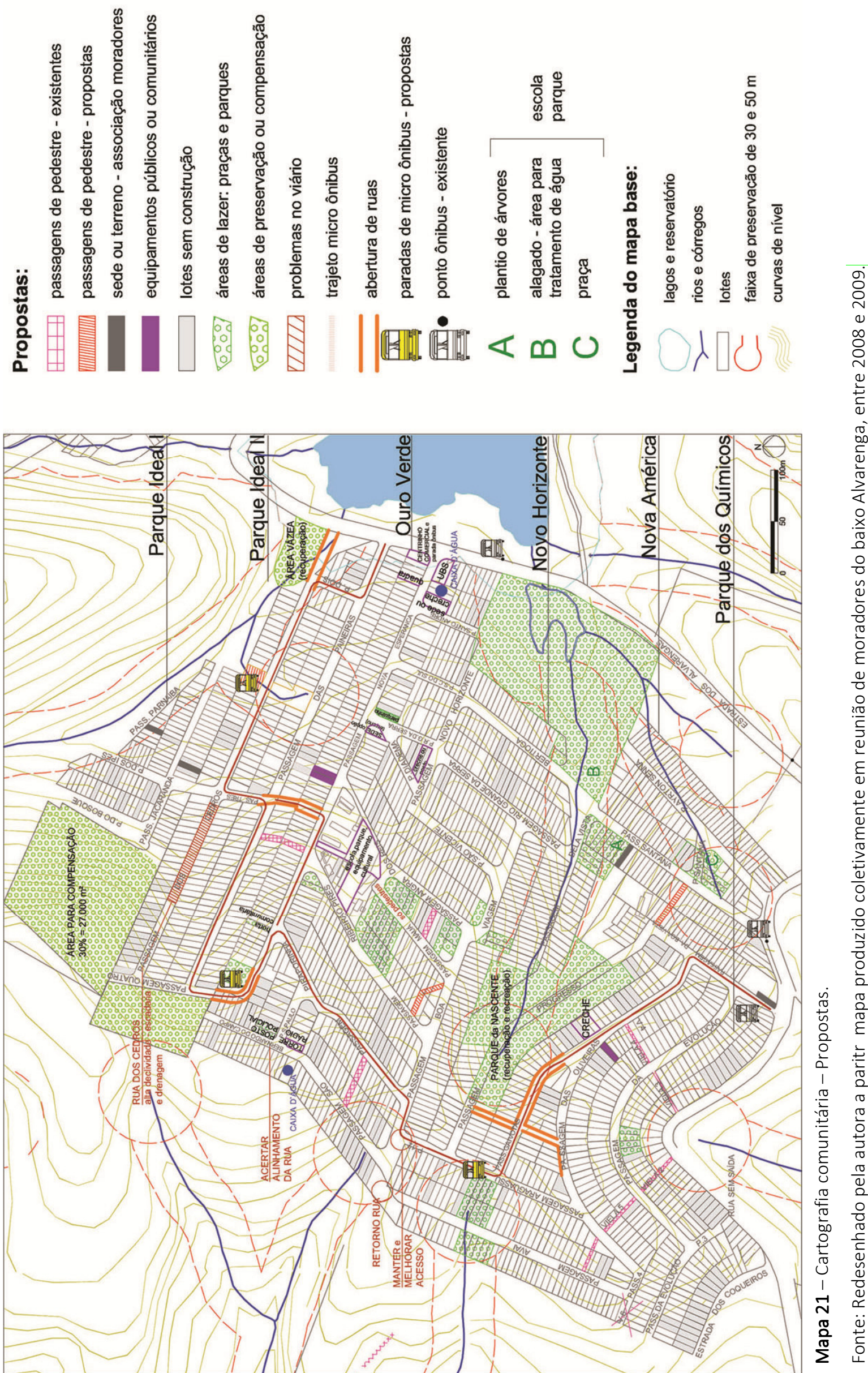
A segunda cartografia comunitária foi construída a partir de propostas, na perspectiva de discussão de uma futura recuperação urbana e ambiental das áreas. Qual seria o entendimento de "recuperação" por parte dos moradores? Naquele momento, com a experiência precedente do programa Bairro Ecológico em áreas semelhantes e devido às orientações da promotora pública, os moradores já haviam assimilado a ideia de que quanto mais ações de recuperação ambiental eles conseguissem viabilizar, mais fácil seria a negociação do TAC. Até que ponto a apropriação da noção de recuperação ambiental teria a potencialidade de gerar transformações? Ou ela reiteraria a ideologia ecológica que serviria mais como um discurso, do que com novas práticas sobre o espaço coletivo?

Inicialmente realizou-se um debate para elencar quais temas seriam tratados, que foram: a) levantamento de lotes desocupados, b) os usos possíveis desses lotes desocupados, c) alternativas para as habitações em áreas de risco, d) alternativas para as áreas de preservação permanente, e) soluções de infraestruturas e os serviços urbanos, f) o transporte e a mobilidade internamente aos loteamentos.

Nesse momento a dinâmica da discussão alterou-se um pouco, porque os moradores decidiram debater previamente suas propostas durante a semana, acreditando que assim o trabalho era mais produtivo; e depois apresentá-las ao grupo completo nas reuniões, quando participavam também a autora e os integrantes da Holos21.

Também por sugestão dos participantes, o trabalho com as cartografias deveria incorporar contribuições dos demais moradores do bairro. Daí a sugestão dos mapas serem debatidos em outros espaços de discussão, como em bares e igrejas, locais de reunião de pessoas que não participavam do projeto, mas cuja participação seria importante naquele contexto. Essa estratégia espontânea, e instigante num primeiro momento, que pretendia ampliar o debate, no entanto, dependia de uma preparação e engajamento do grupo no seu acompanhamento, o que não se deu completamente. Mesmo assim, foi um momento importante durante todo o processo, pois explicitou o reconhecimento do mapa como ferramenta potencialmente aglutinadora no sentido da participação. 


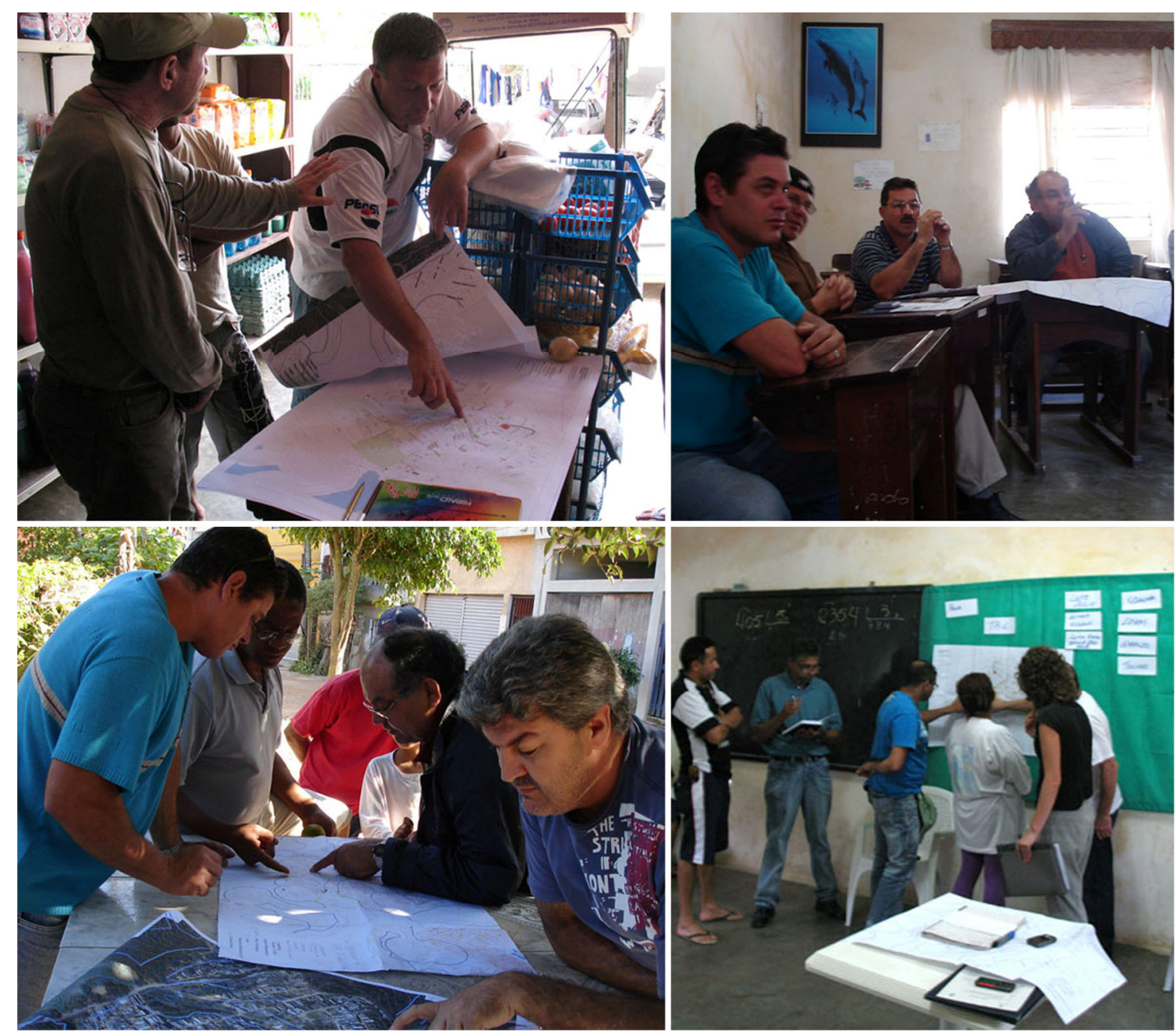

Figura 56 a 59 - Discussão das cartografias comunitárias.

Fotos da autora, 2009.

No que se refere às primeiras propostas mapeadas, as maiores áreas desocupadas, cobertas de vegetação e geralmente com declividades bastante acentuadas, foram rapidamente indicadas como áreas de lazer, de esportes ou praças, revelando a grande demanda por espaços desse tipo. Como tratado no capítulo 4, as pequenas praças e áreas de convívio coletivo existentes localizam-se em espaços residuais dos loteamentos e foram construídas pelos próprios moradores. Por outro lado, as áreas que restaram com vegetação nos loteamentos são impróprias à edificação por causa da grande declividade da topografia e por isso sua transformação em praças e parques seria um uso adequado e possível, compatível com a sua manutenção como área verde, evitando a ocupações de novas áreas potencialmente de risco.

A proposta de uma escola-parque, na área alagadiça da várzea de um córrego (indicada na legenda da cartografia propositiva com as letras A, B e C), incluía a ideia de uma possível estação local de tratamento de esgotos, para o tratamento da poluição difusa, nitidamente associada com uma ideia de recuperação e educação ambiental. Nota-se que essa formulação elaborada da escola-parque, que se diferencia da proposta de um parque convencional por articular lazer, recuperação e educação ambiental, surgiu de moradores que atuaram nos Comitês de bacias e participaram de diversos debates sobre a recuperação dos mananciais, o que indica que esse 
aprendizado fora apropriado e aplicado nas propostas para essa área. Entretanto, atualmente, a ocupação de parte dessa área é o oposto dessa proposta pois, no terreno vizinho à área do alagado foram construídos um pequeno depósito e uma loja de material de construção, sem qualquer cuidado para conter o carreamento de areia e pedras para dentro do córrego.

O consenso da utilização de áreas vegetadas para fins coletivos e de lazer, no entanto, não ocorreu da mesma forma em relação aos demais lotes individuais ainda não ocupados. Esses foram intensamente debatidos, polarizando opiniões quanto às possibilidades de uso coletivo para a construção de equipamentos como creches, posto de saúde, pequenas praças, parquinho infantil, horta comunitária, quadra de esportes - todos indicados como importantes. Essas demandas também expressavam a necessidade desses usos e serviços e simultaneamente abriam a possibilidade de se pensar novas formas de uso e sua transformação. Por outro lado, havia a defesa da propriedade e dos proprietários desses lotes, ou seja, eles não poderiam ser destinados sem negociação.

Esse foi o tema que causou maior embate de posicionamentos entre os moradores, explicitando a tensão entre projetos coletivos e individuais. Alguns participantes questionavam as propostas porque elas estavam sendo elaboradas à revelia do proprietário. Outros moradores ligados às diretorias das Associações mostravam-se preocupados em sofrer ameaças pessoais ao apenas indicar usos possíveis desses lotes. Apesar de ponderarmos que se tratava de elaboração de diretrizes e que, caso o estudo se transformasse em projeto, todas essas propostas teriam que ser rediscutidas, essa questão se apresentou bastante polêmica, explicitando pontos de vista divergentes, mas no geral conservadores em relação à proteção da propriedade privada da terra e suas possibilidades de novos usos e formas de gestão. Os trechos desse debate, reproduzidos a seguir, ilustram as ambiguidades e contradições em relação aos lotes desocupados e à responsabilidade dos diretores das associações de moradores.

O parque ideal tem diversos lotes vazios. Eu não... entendeu, como vice-presidente hoje, não vou responder. A razão é o seguinte, o Parque Ideal ele é uma gleba que tem 50 mil m² e nessa área foi loteado 259 [parcelas]. Mas como tinha os lotes maiores eles foram desmembrados para dois e passaram para 264 lotes, mas nesses lotes ainda tem muitos que não foram construídos. Acontece o seguinte, nessa região muitas pessoas comprou para explorar, muitos comprou e não tem condições de construir, muitos comprou e nem aqui veio morar, foi pro nordeste e tal. O que acontece, quando vir as melhorias, esses caras vão aparecer de uma vez, se esses lotes estiver sendo envolvidos assim, e a diretoria tiver resolvido que vai ser isso ou aquilo outro o cara não vai vir para cima de Xiquinho ${ }^{134}$ não. Vai vir para cima da diretoria, mas vem com tudo. Esse tipo de coisa eu não concordo e não vou responder diretamente na justiça sem que descubra quem são os donos desses lotes, chamar ele junto e falar, qual é a sua posição a partir de agora? É deixar que não construa? Por que você não construiu qual a razão de ter o lote? Esse dono desse lote tem que aparecer. (Informação verbal) ${ }^{135}$.

Outro morador complementa:

\footnotetext{
${ }^{134}$ Xiquinho era o coordenador da ONG Holos21 e coordenador do Projeto GSA que promoveu esse debate.

135 Declaração de diretor da Associação do Parque Ideal. Trecho de reunião coletiva do Projeto GSA, em 16/03/2009 na sede da Associação comunitária do Parque dos Químicos.
} 
O que eu vejo é o seguinte, não é por causa de meia dúzia que compraram aqui para explorar, que estão lá fora, estão ganhando dinheiro, que eu não vou trabalhar para essa gente que mora aqui, eu vou trabalhar sim para essa gente que está aqui, a gente vai trabalhar o máximo que puder, não só pelos Químicos, mas como Novo Horizonte, Ideal e todos que precisar do nosso apoio nós vamos trabalhar em cima disso porque eu não vejo um cara desses.... os Químicos por exemplo tem 20 anos, se um cara ganhando, ele consegue juntar e fazer 2 cômodos em um terreno, então é mentira o cara falar que está na favela "porque eu não posso", ele está na favela porque é sem vergonha e ele quer explorar, ele quer [que] nós paguemos a conta... Se um cara comprou um terreno e em vinte anos ele não conseguiu construir, em duzentos anos ele não vai conseguir, e valoriza para ele ganhar dinheiro em cima disso, é isso que acontece. (Informação verbal) ${ }^{136}$.

Outro tema que ganhou centralidade nas cartografias propositivas foram as propostas que expressaram uma articulação interessante entre espaços de circulação, espaços de lazer ou equipamentos urbanos e a preservação de funções ambientais, como área de várzea, conforme levantado pelos moradores do Parque dos Químicos:

O que é que nós pensamos aqui nos Químicos, nós pensamos que no lote 94 da rua Gaivota e o lote 5 da Rua Progresso, quadra G, seria uma passagem, para se locomover tanto pedestre como carro, porque se quebra um carro na Rua Araguassu, a gente não consegue passar. Essa foi uma das propostas. Descendo na rua Araguassu, tem um fundo de vale lá que a gente fizemos uma proposta para ter uma praça, porque a praça ela não vai ser impermeável e ela pode ser usada para lazer. (...) Nós fizemos uma proposta para essa área livre ser um parque, e ao lado, segundo o Secretário, ele tem recurso e podia estar fazendo uma creche nesse espaço aqui. Colado com o parque. (Informação verbal) $)^{137}$

Outro morador reforça a importância das vias de circulação propostas:

Eu tinha pedido o direito à palavra, ao microfone era justamente para falar daquela passagem da rua Evolução para as Oliveiras e aquela lá de cima que o Zé estava falando porque ali passam caminhões de lixo, passam direto por ali né? Por enquanto nós não tem asfalto, não tem nada, se não fosse aquela passagem o lixeiro não subia lá. Só que aí virou, o Gustavo lembrou também já falou beleza, mas aí, eu só... como eu tinha pedido meu tempo técnico aí eu só queria dizer o seguinte: que nós não abre mão do direito dessas ruas que nós citamos lá, nós não abre mão, se nós vamos ser atendidos não sei, se nós que vamos pagar os terrenos para as pessoas, para os donos, se é nós que vamos pagar, nós não sabe, se a prefeitura vai bancar alguma coisa não sei, se os caras que não paga IPTU vão perder isso é problema da justiça mas nós não abre mão disso aí, porque o cunhado do morador João ${ }^{138}$ outro dia teve um infarte lá, e eu peguei o carro, quando eu fui sair para vir por aqui tinha um caminhão dos alemão ali quebrado, quebrou a ponta de eixo, se não fosse aquela passagenzinha lá eu tinha chegado meia hora a menos e o cara tinha morrido. Ele está vivo para dar despesa pro morador João até hoje (risos). (Informação verbal) ${ }^{139}$

\footnotetext{
${ }^{136}$ Declaração de diretor da Associação do Parque dos Químicos. Trecho de reunião coletiva do Projeto GSA, em 16/03/2009 na sede da Associação comunitária do Parque dos Químicos.

137 Declaração de diretor da Associação do Parque dos Químicos. Trecho de reunião coletiva do Projeto GSA, em 16/03/2009 na sede da Associação comunitária do Parque dos Químicos.

138 Nome fictício.

139 Declaração de morador do Parque dos Químicos. Trecho de reunião coletiva do Projeto GSA, em 16/03/2009 na sede da Associação comunitária do Parque dos Químicos.
} 
Além dessas, mais preocupações em relação aos lotes vazios foram levantadas. Uma delas é que os próprios moradores despejam entulho e lixo nesses lotes, o que gera inúmeros problemas decorrentes do acúmulo de sujeira, como a presença de ratos e outros animais. Como possível solução, a associação do Ouro Verde discutira a possibilidade de compra de lotes vazios vizinhos de casas existentes, desde que o mesmo não fosse estratégico para as intervenções de urbanização e sob a condição de não ser construído, ou seja, o morador teria a sua área total de terreno ampliada, sob a condição de cuidar dela.

A discussão dos lotes vazios foi central ao longo do debate chegando ao ponto de um morador solicitar ficar com um mapa para conferir a quantidade de lotes ainda não ocupados nos loteamentos. Ele chegou à conclusão que pouco havia mudado em relação à foto aérea de 2006, ou seja, em dois anos. Esse debate intensificou-se quando se abordou a sobreposição das áreas de preservação permanente ao desenho existente do loteamento, tornando inevitável a discussão da necessidade de remoções e das alternativas de solução habitacional.

Para a realização da discussão sobre as áreas de preservação permanente (APP) foi elaborado um mapa, no qual se demarcaram aquelas definidas pelo Código Florestal, ou seja, o raio de 50 metros em volta de nascentes e faixa de 15 metros ao longo das margens de córrego (optou-se pela demarcação menos restritiva), além dos lotes ocupados e não ocupados localizados nessas áreas, para que fosse possível visualizarmos a situação deles e servisse de base para o debate a seu respeito ${ }^{140}$.

Para os seis loteamentos, nesta data, havia aproximadamente 479 lotes situados total ou parcialmente em área de preservação permanente. Considerando que o total de lotes existentes nos seis loteamentos é de aproximadamente 1694 unidades, a porcentagem de lotes em APP era de aproximadamente $28 \%$ do total. Além disso, considerando o total de lotes situados em faixas de APP, 51,3\% estavam construídos. Esses dados permitiram concluir que as áreas de preservação permanente estavam menos ocupadas do que o esperado, talvez por se tratarem das áreas mais impróprias à edificação.

\footnotetext{
${ }^{140}$ Este mapa foi elaborado a partir de foto aérea e mapa cadastral de lotes ambos fornecidos pela SHAMA - PMSBC, foto aérea datada de 2006.
} 


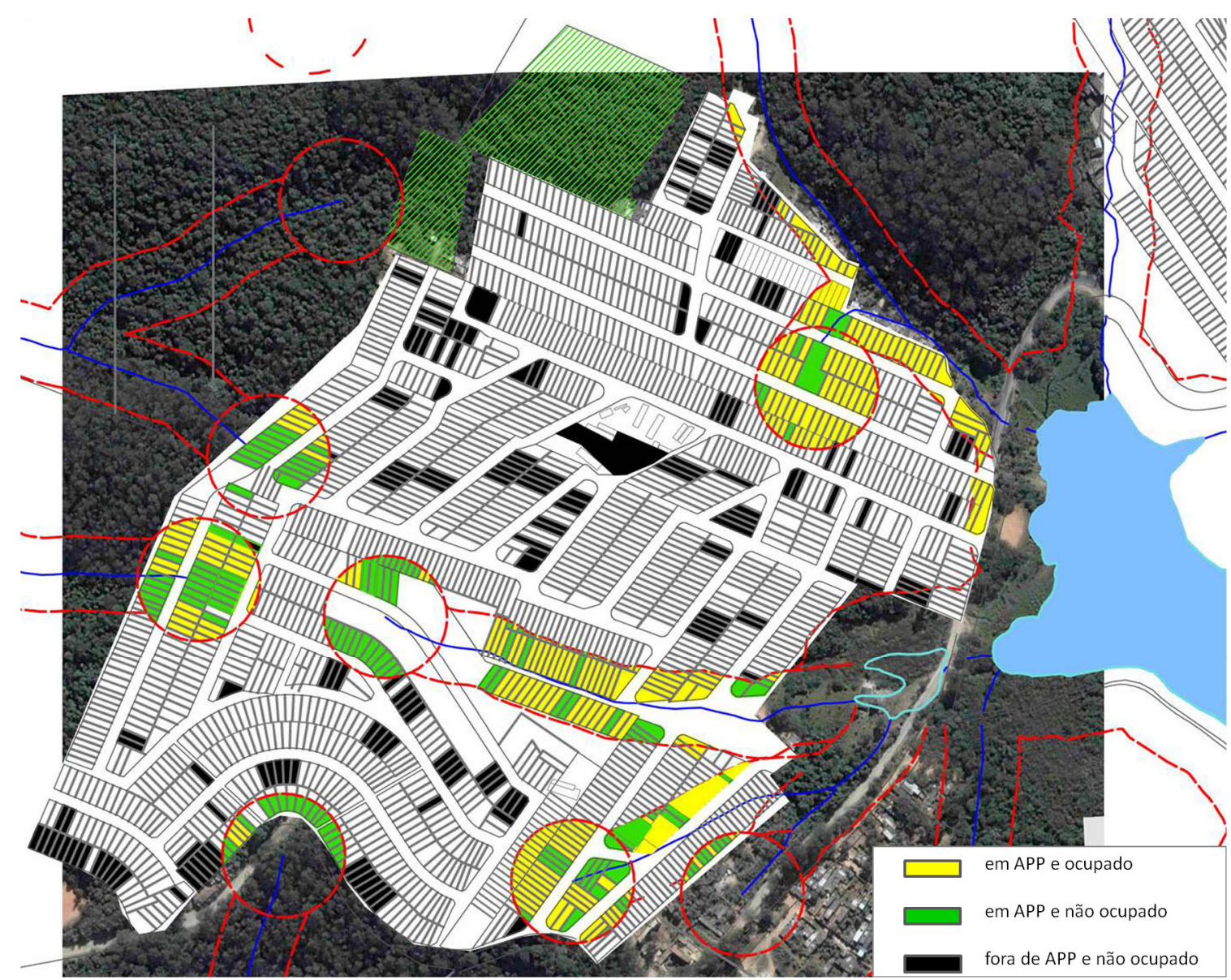

Mapa 22 - Localização das APPs e situação dos lotes - mapa-base utilizado na discussão.

Fonte: Elaborado pela autora a partir de mapa base cedido pela Secretaria de Habitação e Meio Ambiente de São Bernardo do Campo em 2007.

A partir da observação desse mapa um morador fez uma leitura urbanística destacando que a maior parte dos lotes vazios localizava-se fora das áreas de preservação permanente. Isso indicava que os "terrenos bons", desocupados, estavam nos melhores lugares, enquanto que aqueles que primeiro foram vendidos, estavam em áreas "piores". Desse modo, ficava clara a relação entre a forma da ocupação e sua circunstância de produção, o que corroborava com as primeiras observações dos moradores acerca da "voracidade" no parcelamento do solo, sem a previsão de outros espaços que não o lote.

O debate sobre as áreas de preservação permanente (APP), onde havia lotes com construções, desencadeou o debate sobre a moradia em áreas de ocupação proibida por legislação. Entretanto, o tema habitacional não foi discutido em maior profundidade e não foi representado no mapa. Por um lado, porque o grupo não considerava a moradia um problema, pois, de uma forma ou de outra, havia sido solucionada. Além disso, houve muita resistência em se pensar possibilidades de remoção de casas em APPs e realocação, mesmo considerando possibilidades de utilização de outros lotes dentro dos próprios loteamentos.

Assim, se o mapa constituiu-se como bom instrumento para expressar e selecionar informações importantes, o que ficou fora dele também tem de ser considerado na reflexão, ou seja, sobre os elementos que não foram incorporados e por quê. Nesse caso, a habitação como questão de 
conflito ficou fora no mapa justamente porque ela é um ponto sensível da discussão e explicita a insegurança dos moradores de serem afetados individualmente, quando se coloca em discussão um conjunto de necessidades e problemas, principalmente os de caráter coletivo, como a instalação de infraestruturas ou a recuperação de corpos d'água ${ }^{141}$, uma relação dialética entre habitação e infraestruturas.

Outro tema que não foi debatido e que, no entanto, estava muito presente no diálogo dos moradores com a promotora pública foi o controle da ocupação por meio da interdição de construir, o chamado "congelamento". Apesar de fazer parte do acordo com a promotora para paralisar as ações civis públicas, a fiscalização atribuída ao morador ou à liderança local é uma questão delicada, seja porque as denúncias feitas não são atendidas pela fiscalização, seja porque o morador não se sente responsável por essa atribuição, além de não pretender se indispor com os vizinhos, ou ainda, sofrer ameaças.

Apesar de preponderar a defesa da propriedade individual pelos moradores, é interessante destacar as diferentes apropriações possíveis, que não são evidentes nem mesmo para eles, nos quais o uso coletivo se impôs. Por exemplo, os lotes vazios que se tornaram ruas ou caminhos de pedestres e não foram questionados em nenhum momento, devido à sua apropriação coletiva, $\mathrm{e}$ que supriram uma necessidade concreta. Ou ainda, as pequenas praças autoconstruídas em espaços residuais do loteamento. Estes espaços não têm valor comercial e, portanto, são espaços que se associam mais ao uso do que à troca, escapando à lógica do espaço-mercadoria.

Já na discussão sobre as infraestruturas, o mapeamento comunitário propositivo ampliou ainda mais o debate sobre as dificuldades vividas na região devido à ausência de serviços e da distância dos centros de comércio. As propostas chegaram ao ponto de indicar a localização de posto policial, posto de gasolina, banco (para pagamento de contas) e um traçado para a circulação de micro-ônibus com pontos de parada nas ruas mais acessíveis dos loteamentos. 0 que se discutia era uma visão de cidade.

Para além da ausência de algumas redes de infraestrutura, chamou atenção a forma como algumas delas foram executadas. Por exemplo, os problemas relacionados à rede de energia elétrica, demonstram que esta não abrange o conjunto de lotes, seja por dificuldade de adequação ao padrão de ocupação ${ }^{142}$, seja por má prestação de serviço; apesar de ter sido a primeira rede pública instalada.

\footnotetext{
${ }^{141}$ Como o diálogo com os moradores tornou-se mais difícil nesse ponto, buscou-se eliminar falsas expectativas, esclarecendo que o tema estava apenas em discussão, levantando possibilidades a serem consideradas na elaboração de um futuro TAC, e que não se tratava de um projeto de urbanização, que deve ser cuidadoso ao criar critérios de remoção e relocação habitacional.

142 Um exemplo dessa situação foi relatado pelos moradores do Parque Ideal II: na parte mais alta da Rua dos Cedros não chegou a rede de iluminação, pois os moradores aterraram as ruas, criando grandes desníveis. Por isso há muitas casas com ligações clandestinas. Onde a rede alcança há casas sem relógio de medição. Além disso, descreveram que, de modo geral, a rede elétrica é incompleta, faltam postes em algumas ruas e muitos deles apresentam problemas e estão comprometidos por serem muito antigos e de madeira. A localização de alguns postes é muito ruim, acontecendo no meio da rua ou até mesmo dentro de lote (caso da Rua das Paineiras).
} 
A implantação e expansão das redes de infraestrutura (como água e esgoto) segue a priorização de investimentos do Estado e das empresas de saneamento em determinados trechos do tecido urbano, frequentemente em detrimento de áreas periféricas. No caso da rede de água, foi solucionada com poço construído no local, conforme descrito no Capítulo 4. Já a rede de esgotos, no padrão adotado pela Sabesp, implica em planos de longo prazo e investimentos de grande porte, e ainda não foi iniciada.

Assim, a fragmentação da implantação das redes oficiais não ocorre continuamente, mas de forma intermitente, chegando a comprometer o próprio funcionamento em rede, enquanto sistema (OSEKI, 1992). O descompasso entre o tempo do planejamento e da execução de infraestruturas públicas, em atraso em relação à velocidade de reprodução da cidade, é um dos aspectos da produção social da precariedade urbana e ambiental.

Os loteamentos do baixo Alvarenga explicitam que apesar de todo o investimento dos moradores nas pequenas melhorias, por meio da autoconstrução individual ou coletiva - o que coloca em evidência o caráter extremamente privado dessas urbanizações, em descompasso com a ação pública, a expectativa que a infraestrutura seja solucionada pelo poder público, de forma convencional, esteve sempre presente nos debates das cartografias, porque de fato é algo que está fora do alcance dos moradores, como a implantação da rede de esgotos, de drenagem, pavimentação etc. A sua não realização ao longo do tempo, submete os moradores a situações precárias e de risco durante décadas, implicando cada vez mais em iniciativas de autoprovisão sobre o espaço coletivo, quando possíveis. As tentativas dos moradores em suprir funções públicas no contexto de precariedade e vulnerabilidade socioeconômica tem portanto um limite de alcance. Soma-se a isso o fato de que a construção parcial de infraestruturas públicas, como descrita nos capítulos anteriores, também contribui para a manutenção da precariedade do conjunto.

Nesse sentido, o que chamamos aqui de precariedade urbana e ambiental não se restringe aos aspectos físicos e ambientais das ocupações, mas é a expressão da tensão e da relação contraditória entre o público e o privado que engendra a construção do espaço urbano precário ${ }^{143}$.

A esse processo de urbanização precária somam-se mais alguns componentes, a importância ambiental da região produtora de água, sua legislação particular e seus efeitos práticos, sociais e espaciais. Ao remontar o processo de formação dos loteamentos até o acompanhamento das discussões recentes dos moradores foi possível observar como se transformou o seu relacionamento com a legislação e com a noção de recuperação ambiental.

Se no início da ocupação dos loteamentos a Lei Estadual de Proteção aos Mananciais era uma interdição à própria ocupação e à instalação de infraestruturas - uma lei abstrata que se fez presente de forma autoritária no cotidiano e não se sustentou; a mudança de contexto e de

\footnotetext{
143 Isso não significa que o Estado esteja isento de produzir, diretamente, espaços precários, como é o caso de inúmeros conjuntos habitacionais, conforme analisado por Petrella (2012).
} 
tratamento jurídico, legal e urbanístico associou o discurso ambiental da proteção da água com a recuperação urbana e ambiental, a exemplo do programa Bairro Ecológico e dos TACs, garantindo a permanência dos moradores nessas áreas.

Nos loteamentos do baixo Alvarenga, onde não houve projeto de urbanização e regularização, a possibilidade de atender aos requisitos da legislação ambiental passou a ser incentivada pelo poder público e pela promotoria e assim significar uma possibilidade de regularização futura para os moradores. Para os moradores, esse aprendizado assumiu um significado de resistência e proteção do espaço da moradia. Daí a defesa da preservação de áreas de compensação ambiental (como no Caso do Parque Ideal) e a participação dos moradores no Projeto GSA e em outras atividades de plantio de mudas promovidas em parceria com instituições municipais. Entretanto, quando a legislação ambiental afeta a propriedade individual - como no caso da discussão dos lotes em APPs durante a elaboração das cartografias - a defesa ambiental deixa de ser prioritária e é desconsiderada ${ }^{144}$.

Ao mesmo tempo, apesar dessa postura prevalecer entre os moradores, a defesa da qualidade ambiental não se restringiu à estratégia de defesa da propriedade individual. Ou seja, a experiência em discussões, reuniões e oficinas, teve diferentes apropriações por parte de moradores, que reconheceram as possibilidades de qualificar o espaço coletivo por meio de ações de recuperação ambiental. As cartografias expressam uma parcela dos projetos concebidos, como praças e diversos espaços coletivos indicados. Mas observaram-se também iniciativas autônomas, dentre as quais se destaca a tentativa de transformar um terreno particular por onde passa um córrego contíguo aos loteamentos num espaço de lazer, com pista de caminhada ao longo de suas margens, o que implicaria em sua recuperação. Para isso, os moradores já organizaram mutirões de limpeza desse córrego e tentam negociar a área com o proprietário, que tem dívidas de impostos, por intermédio da promotora pública e prefeitura - o que até a finalização desse trabalho não havia sido solucionado.

Apesar das dificuldades, essa iniciativa de transformar uma área não ocupada num pequeno parque linear, recuperando uma área de preservação permanente e atribuindo-lhe um uso, sem entrar em conflito com os moradores de outras APPs, levanta o debate sobre o significado do ambiente urbano possível para além da rigidez da legislação ambiental, ao mesmo tempo em que a considera. O limite para a concretização de um "projeto informal coletivo" são os entraves da negociação de uma propriedade particular, o que não será feito de forma pontual, ou seja, desvinculada de um projeto de intervenção mais abrangente, como discutido a seguir.

\footnotetext{
${ }^{144}$ A defesa da propriedade privada não é considerada aqui como algo negativo atribuído à população de baixa renda, que a reitera num contexto de desigualdade e necessidade, mas como parte necessária da sociedade capitalista. Nesse sentido, a propriedade privada da terra é a fragmentação extrema do ambiente e do espaço como totalidade, ao qual se contrapõe. O objetivo é explicitar essa contradição no contexto estudado.
} 


\subsection{Potencialidades e Desdobramentos controversos das cartografias comunitárias}

Ao final do processo de discussão e elaboração das cartografias comunitárias, somaram-se as demais informações produzidas durante o Projeto GSA, que compuseram um "Estudo de recuperação urbana e ambiental do baixo Alvarenga". Esse Estudo foi entregue à promotora pública numa reunião em que estavam presentes representantes dos seis loteamentos. A intenção era que com esse documento a negociação do TAC prosseguisse, incluindo também a prefeitura como parte indispensável do acordo. Assim, as cartografias e o Estudo como um todo, assumiam um sentido potencialmente reivindicatório. Todavia, esse sentido não se sustentou socialmente no tempo, com a mudança de contexto político, conforme tratado no presente item.

Com a eleição do prefeito Luis Marinho (PT) para o governo municipal em 2009, a gestão da política urbana do município de São Bernardo do Campo passou por reestruturação e o Orçamento Participativo $(\mathrm{OP})^{145}$ foi adotado como principal meio de relacionamento da prefeitura com a população, para o planejamento dos investimentos municipais. Nesse contexto, a perspectiva de elaboração de um TAC com os loteamentos do baixo Alvarenga não era mais uma prioridade para a gestão. Com isso, a expectativa dos moradores de obter um retorno da prefeitura sobre o estudo produzido, se frustrou.

Não é objetivo desse trabalho aprofundar o debate crítico sobre as potencialidades e os limites do Orçamento Participativo, considerado por governos progressistas um instrumento capaz de colaborar para democratização da gestão pública da cidade ao promover a participação cidadã nas decisões sobre os investimentos a serem realizados. Não entraremos no mérito do seu significado político mais amplo, pois essa análise já foi feita com maior propriedade em outras pesquisas que se debruçaram sobre a experiência de diversas cidades brasileiras e latinoamericanas $^{146}$. Mas o que nos interessa destacar é de que maneira a mudança operada pelo Orçamento Participativo (OP) em São Bernardo do Campo repercutiu concretamente nos loteamentos do baixo Alvarenga e nas intervenções em APM, sob dois aspectos.

O primeiro aspecto refere-se à organização dos moradores para participar do primeiro ano das plenárias deliberativas do $\mathrm{OP}$ e às suas reivindicações. Conforme os próprios moradores, as lideranças das associações do baixo Alvarenga não se articularam para levar pautas comuns de reivindicação ao OP, mesmo após a experiência de construção coletiva das cartografias comunitárias e da discussão do TAC coletivo. Uma explicação para essa desarticulação foi

\footnotetext{
145 O chamado ciclo orçamentário foi iniciado em São Bernardo do Campo com o debate do Plano Plurianual Participativo (PPA Participativo) em plenárias realizadas no primeiro ano de mandato em 2009. Depois da aprovação do PPA na Câmara, foram realizadas as 20 plenárias regionais deliberativas do Orçamento Participativo, previstas para acontecerem a cada dois anos (2010 e 2012) e plenárias regionais de prestação de contas (2011). Nas plenárias deliberativas os moradores inscritos elegeram três demandas por região onde acontecem as reuniões, além de uma demanda para todo o município. As demandas foram reavaliadas por um conselho, composto pela prefeitura e conselheiros da sociedade civil, eleitos por região, que definem o que entra na peça orçamentária. Além desses, há representantes eleitos por microrregião cuja função é compor as comissões regionais de acompanhamento da fiscalização das obras e serviços.

${ }^{146}$ Sobre o Orçamento Participativo ver: PONTUAL (2000); CARVALHO et alli (2002); CARVALHO; FELGUEIRAS; (2000).
} 
identificada em diversas entrevistas, nas quais os moradores elencaram as divergências pessoais e político-partidárias como o grande limite para a ação conjunta. A desarticulação acentuou-se ainda mais após falecimento do coordenador do projeto da Holos21, o que interrompeu a sua continuidade.

Do ponto de vista da prefeitura, por outro lado, a organização coletiva dos moradores é premissa para que eles consigam levar as demandas ao $O \mathrm{P}^{147}$ e que essas sejam incluídas entre as elegíveis. Com isso, outros arranjos de organização ou tentativas de diálogo ficam submetidos aos tempos e procedimentos estabelecidos pela via institucional do OP. A organização dos moradores torna-se um critério indireto de seleção para o atendimento da prefeitura.

Sendo assim, apesar da falta de articulação do baixo Alvarenga, os representantes do Parque dos Químicos organizaram-se de forma independente e lograram incluir a demanda do asfaltamento das ruas na votação, que foi eleita em plenária e, em seguida, aprovada pelo Conselho do OP para ser implementada ${ }^{148}$. Como resultado, a Secretaria de Obras comprometeu-se a executar uma primeira etapa, ou seja, a colocação de guias e sarjetas (drenagem superficial e definição do leito carroçável) e a construção de muros de contenção (arrimos) em áreas passíveis de desabamento.

Portanto, o "Estudo de recuperação urbana e ambiental do baixo Alvarenga" não foi levado ao primeiro ciclo do OP como demanda coletiva dos moradores, ou seja, como uma reivindicação pela urbanização integrada dos seis assentamentos. A experiência de construção de cartografias comunitárias não foi suficiente para superar as diferenças e disputas internas entre os moradores e não foi utilizada como ferramenta de reivindicação de propostas do grupo de moradores nesse diferente contexto político. Assim, a potencialidade que a cartografia continha de se tornar um instrumento de diálogo com o poder público foi abandonada, também porque as tentativas anteriores nesse sentido não frutificaram.

Apesar de não aprofundarmos as contradições dessa organização social, no entanto, é preciso considerá-las na medida em que explicitam alguns dos limites de uma atuação coletiva, no caso particular do conjunto dos loteamentos do baixo Alvarenga. Essa situação levanta o debate sobre as formas instituídas de organização popular e as possibilidades de discussão mais ampla e autônoma dos conflitos urbanos e ambientais, quando confrontadas com o processo seletivo de obras, por exemplo, do Orçamento Participativo.

O segundo aspecto refere-se ao resultado alcançado nesse processo, ou seja, à realização da obra de guias, sarjetas e contenções, que apesar de considerada como uma conquista pelos moradores do Parque dos Químicos e do loteamento Nova América (também contemplado pelas obras), pode ser interpretada de outro modo, a partir da observação em campo, em alguns momentos durante a execução das obras.

\footnotetext{
${ }^{147}$ Conforme informação verbal de Tássia Regino, em entrevista concedida à autora em 16/01/2012.

148 Além das guias e sarjetas do Parque dos Químicos, foram aprovados o pedido de continuidade da Estrada dos Alvarenga e sua pavimentação até a divisa com Diadema e o estudo de viabilidade de intervenção para o Jardim Serro Azul.
} 
Do ponto de vista urbanístico, por mais que se trate da primeira etapa de uma obra de pavimentação, ela foi realizada sem alterar estruturalmente pontos problemáticos das vias de circulação e das calçadas dos loteamentos. Além disso, a colocação de guias e sarjetas não foi acompanhada por projeto de drenagem, numa área de topografia acidentada, causando, em alguns pontos, problemas decorrentes da própria obra como, por exemplo, a aceleração das águas nas áreas mais íngremes, afetando as casas situadas nas partes mais baixas, e a formação de áreas de erosão devido à não pavimentação dos leitos carroçáveis.

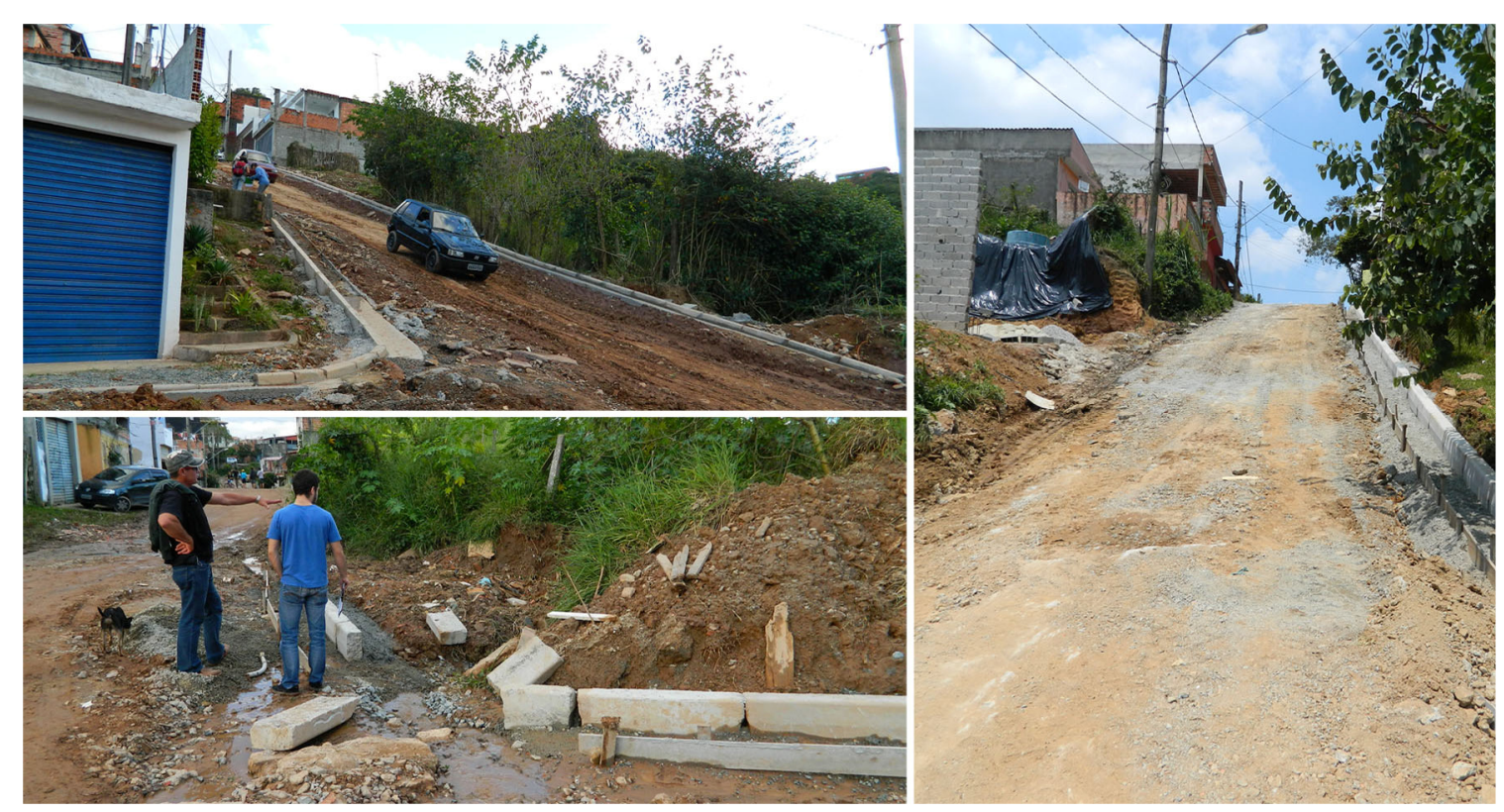

Figuras 60 a 62 - Obras de guias e sarjetas, no loteamento Parque dos Químicos e Nova América.

Fotos da autora, 2012.

Apesar desses problemas, que podem ser corrigidos futuramente, o que chama a atenção é a intervenção parcial de infraestrutura constituir-se na forma sistemática do poder público se fazer presente em algumas áreas não priorizadas pela intervenção integral de urbanização, o que pôde ser observado inclusive em governos que preconizam processos democráticos de gestão urbana.

Mais uma vez, a intervenção realizada explicita a fragmentação social e territorial, agora com a presença direta do poder público como protagonista da intervenção. Fragmentação social porque inviabiliza a construção e realização de um projeto coletivo, e na medida em que reforça a intervenção desigual numa mesma área, contribuindo para romper com um processo de organização comunitária precedente, que já se constituía com fragilidades. E fragmentação territorial porque não decorre somente de uma obra tecnicamente inadequada e parcial, mas principalmente porque corresponde a uma ação que se orienta mais pela disponibilidade de recursos e capacidades de implementá-los, do que se articula a um projeto ou planejamento de conjunto, mais amplo, que se relacione com a previsão de implantação das demais infraestruturas. Dessa forma, a realização de obras parciais interessa ao poder público, em termos eleitoreiros, e às construtoras que executam as obras. 
Cabe ponderar que essa intervenção parcial de colocação de guias e sarjetas no baixo Alvarenga diferencia-se de outras áreas que de fato conseguiram aprovar a demanda pelo projeto integrado, como é o caso, por exemplo, dos assentamentos Capelinha e Cocaia, situados em APM (que serão tratados no capítulo 9). Mas não se pode deixar de notar o caráter clientelista que esse tipo de atendimento pontual reforça, ao mesmo tempo em que conforma a reivindicação popular que, por sua vez, precisa se manter ativa para formular novas demandas, ainda que também parcelares.

Se por um lado o OP é um meio de gerir as demandas da população, há que se considerar de que modo tais demandas articulam-se (ou não) às políticas setoriais, no que se refere aos critérios de priorização e planejamento, no caso particular, à política habitacional municipal e também sua relação com as especificidades das áreas de proteção aos mananciais.

O Plano Municipal de Habitação de São Bernardo do Campo (Plano Local de Habitação de Interesse Social - PLHIS) foi elaborado a partir do Mapeamento de assentamentos precários e/ou irregulares do município, contratado no primeiro ano da gestão, com base em extensos levantamentos das situações de risco e precariedade habitacional no município. A partir desses dados, foram criadas tipologias de assentamentos precários, que os classificam dos mais consolidados aos mais precários. Essas tipologias definiram no PLHIS graus e prioridades de intervenção, desde áreas onde a consolidação da ocupação não é possível, às urbanizações complexas e às regularizações fundiárias em áreas consolidadas e infraestruturadas. A partir dos diagnósticos realizados concluiu-se também que há situações de precariedade mais graves fora da área de proteção aos mananciais, particularmente por causa das favelas que ocuparam os morros de alta declividade. Assim, o PLHIS define que as situações emergenciais e de risco são prioritárias sobre as urbanizações mais simples. Esses critérios, somados às demais diretrizes do PLHIS, apresentam com clareza o posicionamento da política habitacional de interesse social com base na situação concreta existente ${ }^{149}$.

Ao mesmo tempo, o PLHIS consubstanciou as práticas, os projetos e os financiamentos que já estavam em andamento na SEHAB, organizando-os em linhas programáticas, estimando seu impacto na redução do déficit habitacional existente além de calcular a necessidade de áreas e recursos para superar esse déficit nos próximos anos ${ }^{150}$. Portanto, cabe destacar que um dos principais condicionantes para a realização dos projetos de urbanização são os financiamentos que se viabilizam junto ao governo federal, estadual, municipal ou junto a órgãos internacionais como o Banco Mundial. Nesse sentido, nem sempre os critérios de planejamento e de

\footnotetext{
149 Para a elaboração do PLHIS, foram promovidas diversas reuniões com a sociedade civil e com as demais secretarias, principalmente a Secretaria de Planejamento Urbano, que desenvolvia a revisão do Plano Diretor, e também com a Secretaria de Orçamento e Planejamento Participativo, Assuntos Jurídicos e Cidadania, Serviços Urbanos e de Gestão Ambiental.

${ }^{150}$ A elaboração do PLHIS ocorreu num momento importante da política habitacional em São Bernardo do Campo, em que o número de contratações de empreendimentos habitacionais, de projetos de urbanização e de produção habitacional, assim como o de entrega de títulos alcançou patamares significativos, auxiliados pelo impulso da retomada de investimentos habitacionais e urbanos por parte do governo federal a partir de 2003.
} 
priorização de projeto são compatíveis com as exigências e o tempo necessário de obtenção dos financiamentos.

Dessa forma, quando as demandas pela urbanização integrada são aprovadas no OP, são confrontadas ao planejamento e às possibilidades da SEHAB, que passa a fazer estudos de viabilidade técnica e de fontes de financiamento. Assim, a população que entra na "lista de espera" precisa então manter ativa sua participação, acompanhando todas as etapas do OP, desde a aprovação do recurso para o projeto até aprovação da obra. De fato, a intervenção do executivo pouco se altera devido à priorização prévia de projetos, seja ela técnica ou política, mas especialmente em relação aos financiamentos obtidos - o que também implica em negociações com outras esferas de governo.

Diante desse quadro, apesar dos avanços da política habitacional em São Bernardo do Campo, que nas gestões anteriores era pouco expressiva, o tratamento do manancial como área estratégica para a produção de água aparece como algo secundário e tem influenciado pouco as decisões de intervenção no território da bacia. Isso fica claro quando considerados o modo de gestão do território por meio do OP e os limites da política habitacional municipal.

A ação da SEHAB é bem estruturada e ampliou significativamente sua atuação no município, apesar dos limites impostos pelos financiamentos e da dificuldade de sair de padrões homogêneos de projetos habitacionais, replicados indiscriminadamente pelas empresas projetistas e construtoras. Por outro lado, o conflito relativo à recuperação dos mananciais, que foi tratado como uma questão relevante nas gestões anteriores, não avançou para além das soluções circunscritas aos perímetros de projeto, ou seja, tais projetos não se articulam e não são orientados por um plano para a bacia hidrográfica como um todo - o quê, por sua vez, dependeria de uma articulação intersecretarial e não somente da ação da SEHAB. Tampouco o OP se ampara num planejamento socioambiental mais amplo, que inclua, por exemplo, a identificação de áreas prioritárias para intervenção a partir do comprometimento hídrico ou a discussão sobre a destinação das propriedades ainda não ocupadas ou desmatadas da bacia, voltadas ao interesse social e público ${ }^{151}$.

Portanto, a política do Orçamento Participativo e a política habitacional municipal não apresentam articulação em termos de planejamento do território, tanto em relação aos projetos habitacionais, quanto em relação às urbanizações em área de proteção aos mananciais. Um paralelo pode ser estabelecido também em relação ao planejamento das infraestruturas. Essa questão será retomada e complementada nos próximos capítulos.

\footnotetext{
${ }^{151}$ De acordo com entrevista de Paulo Massoca, concedida à autora em 07/11/2011, a Prefeitura de São Bernardo do Campo prevê a elaboração de um Plano de Desenvolvimento e Proteção Ambiental Local (PDPA Local), a ser financiado pelo Programa Mananciais, com recursos do Banco Mundial. O PDPA Local é um desdobramento do PDPA da Bacia da Billings, um instrumento previsto na Lei Estadual no 9866/97, que deveria ter precedido e embasado a elaboração da Lei Específica da Billings. Entretanto foi concluído após a promulgação dessa lei. Esse tema será abordado em maior detalhe na Parte III dessa tese.
} 


\subsection{Do TAC ao “Plano Estratégico Geral do Alvarenguinha”}

Em relação aos seis loteamentos do baixo Alvarenga, em 2011, a sentença de demolição da ação civil pública (no 782/93) contra a Associação Comunitária do Jardim das Orquídeas (loteamento Novo Horizonte II) voltou à tona, colocando em alerta os moradores. Essa sentença foi dada há muitos anos e seu argumento central se amparava num diagnóstico de que o loteamento havia sido construído numa área muito inadequada, de encosta e de risco, somado ao fato de se localizar em área de proteção aos mananciais.

Além da Associação responsável pelo loteamento, eram réus na ação civil pública o loteador Orlando Casadei (que também promoveu o loteamento Nova América) e a empresa Areia e Pedra Ltda., ou terraplenagem Paulicéia S/C Ltda., que foram condenados a promover o desfazimento do loteamento e a recuperação do solo e da vegetação, o que não foi cumprido.

Em 2010, a prefeitura havia realizado um levantamento das áreas de risco e chegou à conclusão de que a situação do Novo Horizonte II não era tão grave e emergencial como a de outras áreas, não implicava em remoções, e o risco poderia ser remediado com a realização de obras de contenção. Como a decisão da demolição já tinha transitado em julgado ${ }^{152}$, propôs um acordo com a promotoria.

Em paralelo, um advogado acompanhado de um técnico da prefeitura foi ao loteamento e informou a população que a sentença continuava a ter validade e que seriam despejados. Os moradores confirmaram a informação junto à SEHAB e à Secretária do OP, o que despertou o medo da remoção, mobilizando a população a procurar a promotoria. A diretora da Associação, que respondia pessoalmente pela ACP, buscou recuperar o "Estudo de recuperação urbana e ambiental do baixo Alvarenga", que serviria como parte do cumprimento do antigo acordo com a promotora, em defesa dos moradores.

Nesse momento, a promotora pública retomou a proposta de se fazer um TAC para o baixo Alvarenga, denominado "Alvarenguinha" no termo do acordo, "a fim de evitar o desfazimento total dos loteamentos Jardim Novo Horizonte II e Jardim nova América e propiciar a regularização fundiária sustentável de todos os parcelamentos que integram o assentamento" ${ }^{153}$.

A Lei Específica da Billings já havia sido promulgada (desde 2009), definindo que a intervenção em assentamentos precários deveria ser realizada por meio de um Programa de Recuperação de Interesse Social - PRIS. Os loteamentos do baixo Alvarenga, demarcados como Zonas Especiais de Interesse Social - ZEIS, no Plano Diretor, e como área de recuperação ambiental segundo a LE-Billings, cumpriam os requisitos necessários à realização de um PRIS. Com essa orientação, no

\footnotetext{
${ }^{152}$ Trânsito em julgado: Expressão usada para uma decisão (sentença ou acórdão) de que não se pode mais recorrer, seja porque já passou por todos os recursos possíveis, seja porque o prazo para recorrer terminou. Nesse caso, dá-se o trânsito em julgado e a decisão pode ser executada. Conforme glossário elaborado por Nogara (2008, p. 245).

${ }^{153}$ Conforme Minuta do Termo de Ajustamento de Conduta consultado pela autora no MP.
} 
TAC firmado, a prefeitura se comprometeu a implementar o "Plano Estratégico Geral do Alvarenguinha".

Além disso, foram incluídas no TAC as obras de contenção e drenagem (guias e sarjetas) no Parque dos Químicos previstas no OP 2009/2011, as quais se somou as intervenções necessárias à circulação de micro-ônibus prevista no estudo elaborado pelas lideranças das associações sob orientação da Holos21 no Projeto GSA, dentre outras providências. Essa proposta havia sido formulada durante as cartografias, que então foram recuperadas parcialmente pela promotora.

No acordo específico do Jardim Novo Horizonte II, o réu Orlando Casei se comprometeu a doar um terreno de 15.631,82 m², contíguo ao loteamento como área de compensação, e a transferir créditos que porventura possua sobre a venda da gleba, ou decorrente da implantação do loteamento, ao Fundo Municipal de Meio Ambiente.

E a Associação Comunitária Jardim das Orquídeas se comprometeu a recuperar o cadastro de todos os adquirentes de lotes, visando conferir pagamentos e eventuais créditos, a serem cedidos ao Fundo Municipal de Meio Ambiente, até o limite dos investimentos do Município (em infraestrutura). Caso haja lotes não vendidos, a Associação comprometeu-se a transferi-los ao município em dação em pagamento pelas obras de infraestrutura e como indenização por áreas institucionais não previstas no plano do loteamento. Além disso, foi estipulada uma multa de hum mil reais a cada adquirente de lote a título de indenização por danos ambientais a serem depositados no Fundo Municipal de Meio Ambiente; a fomentar a arborização de ruas, com observância do projeto de regularização e também a colaborar com as ações da prefeitura, bem como na permanente campanha de educação ambiental.

A co-ré Terraplanagem Pauliceia deverá doar ao município três mil mudas de árvores nativas da Mata Atlântica, a serem preferencialmente usadas no baixo Alvarenga, e 100 horas/máquina, em até 36 meses, para o Município, através das Secretarias de Habitação, Gestão Ambiental ou Vias Públicas, em ações de recuperação ambiental e urbanística.

Por fim, como consequência desse processo de negociação, nas plenárias do OP 2013 foi aprovada a demanda de realização de um Plano Estratégico Global para a região dos bairros Nova América, Parque Ideal, Jardim Novo Horizonte I, Novo Horizonte II, Parque dos Químicos e Jardim Cruzeiro do Sul (outro assentamento precário próximo). Assim como outras áreas aprovadas, o baixo Alvarenga entrou para a programação de projetos a serem realizados pela $\mathrm{SEHAB/PMSBC}$ nos próximos anos.

O acompanhamento desse processo enquanto método de pesquisa para a presente tese chegou até esse ponto. O "Plano Estratégico Global do Alvarenguinha" ainda será formulado, as possibilidades de sua realização ainda estão em aberto, tanto para a prefeitura, como para a população, e pode ter desdobramentos diversos. O que cabe destacar, considerando a reflexão proposta nesse capítulo, é que a aprovação desse plano no OP não significa necessariamente um "final feliz" de uma história conflituosa, mas sim a continuidade de uma disputa pela urbanização dos loteamentos. Ilustra, assim, mais uma etapa do processo de urbanização desigual e contraditório. 
PARTE III 



\section{PARTE III}

\section{Paradoxos da infraestrutura como recuperação ambiental, a partir da ação do Estado}

Nessa terceira parte da tese, composta pelos capítulos 7, 8 e 9, busca-se evidenciar a ação prática do Estado no manejo dos conflitos existentes nas áreas de proteção aos mananciais (APMs), a partir de dois instrumentos: a elaboração de legislação e a execução de programas de financiamento para projetos de intervenção, destacando aqueles destinados à urbanização de assentamentos precários (favelas e loteamentos irregulares populares) e às obras de saneamento (particularmente redes e sistemas de água e esgotos).

Além das contradições relativas ao descompasso histórico entre a abstração da lei e a realidade concreta, engendrando ações contraditórias do Estado e dos demais agentes envolvidos na produção de espaços irregulares e precários em área protegida - tratadas na Parte II - ampliouse a escala de análise para abordar as concepções sobre o tratamento ambiental dos assentamentos precários e sua interface com os sistemas de infraestrutura de água e esgotos, conforme expressos nas leis e programas de abrangência metropolitana. Considerando a multiescalaridade da questão do saneamento dos mananciais e a realização prática dessa política, problematizam-se as noções de recuperação e proteção, que são argumentos de base das leis e programas voltados a essas áreas.

O capítulo 7 recupera brevemente os principais momentos de revisão da Lei Estadual de Proteção aos Mananciais (LPM no 898/1975 e nㅇ 1.172/1976²), passando pela chamada Nova Política de Mananciais - a Lei estadual no 9866/1997, até chegar à promulgação das leis específicas de bacias hidrográficas - primeiro da Guarapiranga (2006) e em seguida da Billings (2009). Essa trajetória contribui para a compreensão da atual legislação incidente em APM, que buscou se adequar à realidade da ocupação existente.

A elaboração e revisão da Lei Estadual de Proteção aos Mananciais (LPM) ocupou por mais de trinta anos uma parcela significativa do trabalho do corpo técnico e político do Estado, em muitos momentos tecnicizando de maneira extremada problemas sociais e reforçando o caráter ideológico da legislação ambiental. O debate sobre essa lei protelou a tomada de decisão do governo do Estado diante do problema dos assentamentos precários, enquanto que a cidade se

\footnotetext{
${ }^{1}$ Disciplina o uso de solo para a proteção dos mananciais, cursos e reservatórios de água e demais recursos hídricos de interesse da Região Metropolitana da Grande São Paulo e dá providências correlatas.

2 Delimita as áreas de proteção relativas aos mananciais, cursos e reservatórios de água, a que se refere o artigo 2 . da $^{\circ}$ Lei n. ${ }^{\circ} 898$, de 18 de dezembro de 1975, estabelece normas de restrição de uso do solo em tais áreas e dá providências correlatas.
} 
fazia no embate por diferentes usos desse território e da água como recurso econômico. Em contraponto, a sociedade civil polarizada principalmente entre movimento ambientalista e movimento de moradia exerceu importante papel no processo de alteração dessa lei. Cabe pontuar que um dos principais fatores que contribuíram para sua revisão foi a própria prática do poder público municipal em lidar com os assentamentos precários, além da pressão da própria população.

No capítulo 8 são apresentados os conteúdos principais dos programas de financiamento para as intervenções públicas em APM, em diálogo com as mudanças normativas. O ponto de partida é o primeiro programa de saneamento ambiental da Bacia do Guarapiranga, o Programa Guarapiranga. O estudo desse programa e dos subsequentes identificou de que forma ele se constituiu num modelo que se reproduziu e se ampliou para a escala da Bacia do Alto Tietê, consolidando um modo de intervenção de urbanização de assentamentos precários que é pautado majoritariamente pela execução de obras de urbanização e saneamento. Contudo, esse quadro de projetos e programas não configura, em seu conjunto, uma ação integrada nas áreas de proteção aos mananciais.

No âmbito da política recente de proteção e recuperação dos mananciais a Lei Específica da APRM Billings (LE-Billings) desempenha um papel relevante na medida em que elege a infraestrutura como elemento fundamental para a recuperação ambiental e regularização de interesse social, diferentemente da legislação anterior. A interface dessa lei com situações concretas é o tema do capítulo 9, que apresenta dois diferentes Programas de Recuperação de Interesse social - PRIS, em desenvolvimento no município de São Bernardo do Campo, a partir dos quais tecemos algumas considerações críticas acerca das práticas e da lei.

Com esses elementos - leis, programas e projetos de intervenção - o objetivo dessa terceira parte é debater como os governos (federal, estadual e municipal) lidam atualmente com conflitos históricos desse espaço, que têm como um de seus aspectos centrais a provisão de infraestruturas, em dois níveis que se relacionam. Um no nível dos assentamentos precários, ou seja, de que modo a lei possibilita sua regularização e urbanização, provendo a expansão das redes sem se articular a um planejamento integrado entre saneamento, desenvolvimento urbano (controle do uso e ocupação do solo) e proteção ambiental. E numa escala mais ampla, da bacia hidrográfica e da metrópole, onde entram em conflitos os usos múltiplos da água e a prioridade do abastecimento público. A análise coloca em destaque as contradições e os impasses dessa prática. 


\section{CAPÍTUL0 7}

\section{Da Lei Estadual de Proteção aos Mananciais (1976) à Lei Específica da Billings (2009)}

Esse capítulo tem como objetivo central discutir, a partir de um panorama da transformação das leis incidentes em área de proteção aos mananciais, a passagem da sua inadequação à dinâmica social e urbana, à progressiva "adaptação" à realidade das ocupações precárias existentes, tendo em vista a permanente tensão entre o duplo objetivo dessas leis que é recuperar e proteger os mananciais.

A lei é uma abstração concreta nos termos de Henri Lefebvre (1974), isto é, possui ao mesmo tempo uma realidade mental e prática. Nesse sentido, toma-se como premissa que essa "inadequação social" da legislação é socialmente construída, representa concepções hegemônicas do espaço urbano e da técnica, e tem consequências espaciais e ambientais concretas. É nessa perspectiva que consideramos tanto os efeitos da legislação de proteção aos mananciais, bem como sua utilização e interpretação por diferentes agentes envolvidos na produção de loteamentos irregulares, como parte do quadro de conflitos existentes nas áreas de proteção aos mananciais.

A Lei Estadual de Proteção aos Mananciais (LPM) no 898/1975 e no 1.172/1976, que delimitou as bacias hidrográficas protegidas para a produção de água, foi promulgada na gestão do governador Paulo Egídio (1975-1979), como um dos instrumentos do Plano Metropolitano de Desenvolvimento Integrado (PMDI), elaborado num momento em que o planejamento tecnocrático e controlador era a tônica da ação do Estado brasileiro. Essa lei foi formulada num contexto em que o crescimento populacional na RMSP aumentava a demanda por água, acompanhado do aumento do aporte de poluição nas represas - devido ao não tratamento integral de esgotos.

Por isso, nos primeiros anos de 1970, a Companhia Ambiental do Estado de São Paulo (Cetesb) foi obrigada a realizar operações de remoção da mancha anaeróbia presente na Represa Billings. O surgimento desta mancha foi consequência da falta de coleta e tratamento de esgotos que havia intensificado a poluição do Rio Tietê e de seus afluentes comprometendo a qualidade da água dessa represa, mas ao mesmo tempo mantinha-se a vazão que garantia a geração de energia na Usina de Henri Borden, Serra do Mar abaixo.

A LPM já foi extensamente debatida e analisada em trabalhos precedentes a essa tese (SÓCRATES; GROSTEIN; TANAKA, 1985; MOREIRA, 1990; MARICATO 1995; TAGNIN, 2000; MARTINS, 2006). Por isso, retomam-se aqui somente os aspectos centrais que corroboram para 
o entendimento dos conflitos acerca do processo de ocupação e urbanização em área de proteção aos mananciais, particularmente aqueles que relacionam padrão de ocupação urbana precária e padrão de expansão das redes de água e esgotos - ambos restringidos pelos parâmetros da LPM. Em seguida, enfoca-se brevemente o processo político de sua revisão que, por um lado, foi pressionado pela crescente demanda popular por infraestrutura e regularização fundiária, seguido da resposta do poder público com as obras de urbanização; e, por outro, sua manutenção era defendida por setores governamentais e pelo movimento ambientalista, de cunho conservacionista ${ }^{3,}$ que resistiam contra a sua flexibilização.

Desse processo, que explicita a dimensão da disputa política sobre as áreas de mananciais, resulta a chamada nova política para mananciais, a Lei Estadual no 9866/1997, que instituiu um sistema de gestão das bacias hidrográficas sem, no entanto, substituir por completo a LPM, o que acontece anos depois com a promulgação das leis específicas de bacias.

As leis específicas de bacias constituem o enfoque principal do capítulo porque definem, atualmente, a regulamentação de uso e ocupação do solo nas bacias da Guarapiranga e da Billings. Por isso, a análise visa identificar de que forma a elaboração, os instrumentos e os parâmetros urbanísticos e ambientais dessas leis traduzem espacialmente seus objetivos centrais que são a recuperação e proteção dos mananciais.

Para corroborar com a reflexão sobre os efeitos práticos dessa lei, apresentamos adiante, no capítulo 9, no final dessa terceira parte, dois projetos elaborados como Programa de Recuperação de Interesse Social - PRIS, em áreas do município de São Bernardo do Campo que seguiram as definições da Lei Específica da Bacia da Billings. A partir desses PRIS tecem-se algumas considerações sobre sua aplicação, destacando algumas contradições da noção de recuperação ambiental.

\subsection{0 conflituoso processo de revisão da LPM e a promulgação da Lei Estadual no9866/1997}

A Lei Estadual de Proteção aos Mananciais (LPM) № 898/1975 e № 1.172/76 visava proteger os mananciais e a água das represas de abastecimento controlando o uso e ocupação do solo nos terrenos localizados nas bacias hidrográficas, por meio do estabelecimento de parâmetros urbanísticos que eram mais restritivos quanto mais se estava próximo ao corpo d'água da Represa ${ }^{4}$. Assim, pretendia-se controlar a densidade populacional de ocupação nas bacias. No

\footnotetext{
${ }^{3}$ O Conservacionismo é uma das correntes mais antigas do Movimento Ecológico e tem como raiz histórica o naturalismo do século XIX, quando se iniciaram movimentos para conter a destruição de áreas naturais. Apesar dos méritos da luta pela conservação do ambiente natural e contra as tendências destrutivas do crescimento da economia industrial, seu foco de ação está mais na crítica do que na busca de alternativas para a transformação da sociedade (PÁDUA, 1984, p. 34-35). O movimento ambientalista se caracteriza por uma pluralidade de posições, mas refere-se aqui aos conservacionistas como aqueles que, ao longo dos anos 1980 e 1990, defenderam a estrita letra da lei, sem considerar os problemas sociais que implicaram a ocupação dos mananciais.

${ }^{4}$ A lei definiu como de 1ạ categoria, não edificáveis, as áreas de preservação permanente, definidas pelo Código Florestal (faixas marginais dos córregos), áreas com declividade superior a 60\%, a faixa de 50 metros ao redor do reservatório e áreas cobertas com vegetação primitiva. As áreas edificáveis, chamadas de 2ạ categoria, subdividiam-se
} 
entanto, esse "congelamento" que abrangia 27 municípios, no caso das bacias das represas Guarapiranga e Billings, incidia justamente sobre as áreas mais ocupadas e dinâmicas, próximas a área industrial - Santo Amaro em São Paulo e a região do ABC.

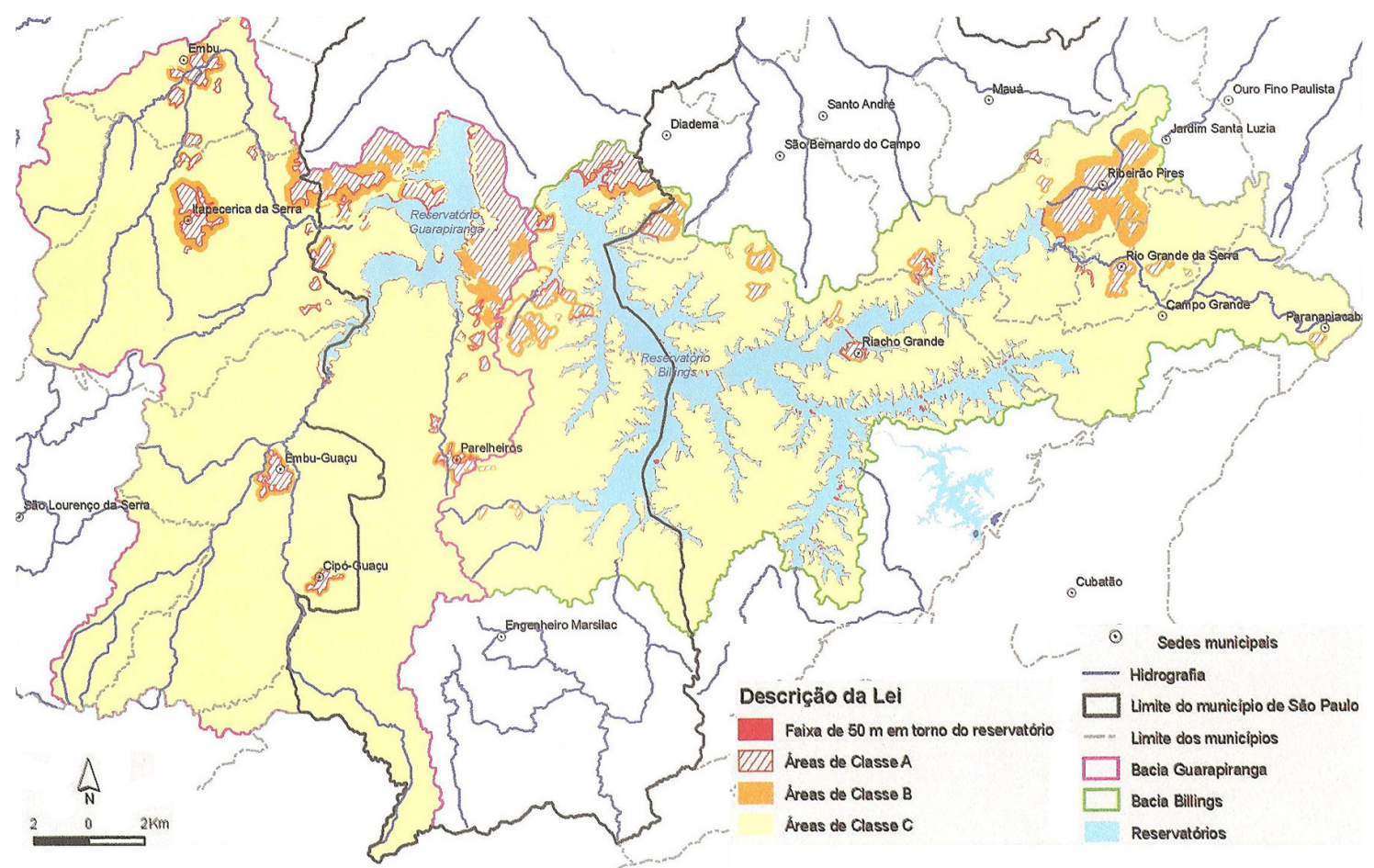

Mapa 23 - Legislação Estadual de Proteção aos Mananciais - LPM no 1.172/1976.

Fonte: WHATELY et.alli, 2008, p. 161.

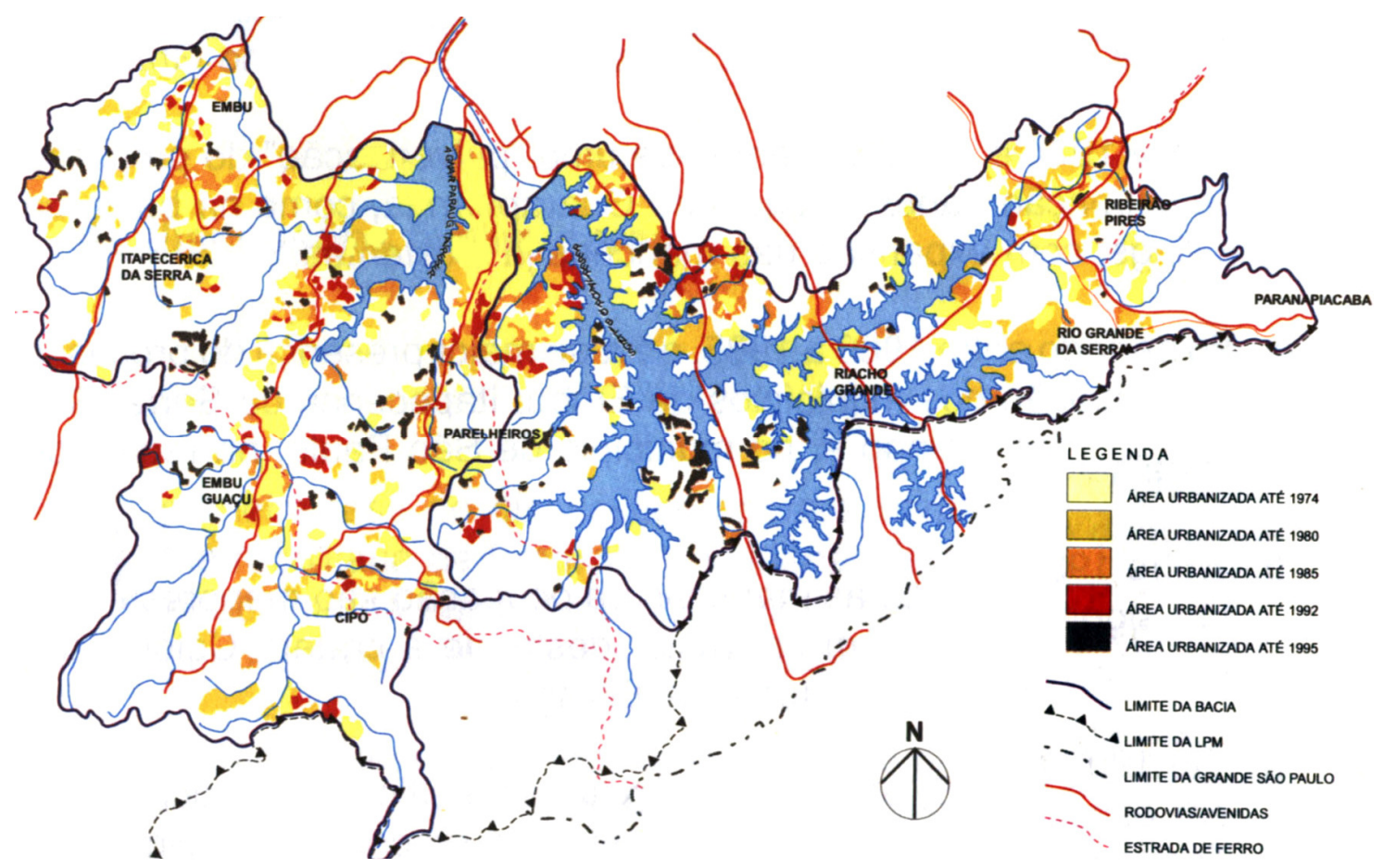

Mapa 24 - Períodos de ocupação da bacia da Billings.

em classes A, B e C. As áreas de classe A são as que já estavam arruadas e ocupadas na data da promulgação da lei e apresentavam densidade superior a 30hab/ha. As áreas de classe B tinham parâmetros definidos a partir de cálculo e planilha constantes na lei. $\mathrm{E}$ as áreas de classe $\mathrm{C}$ eram as que não estavam compreendidas entre as de classe $\mathrm{A}$ e $\mathrm{B}$. 
Fonte: Lei Estadual no 9866/1997, Secretaria de Estado de Meio Ambiente (SMA/CPLA/GTLPM), p.7.

Como já abordado na primeira parte dessa tese, ao mesmo tempo em que se aplica a Lei Estadual de Proteção aos Mananciais executa-se o Projeto de Saneamento para a Grande São Paulo - Sanegran, que trouxe como consequência o comprometimento das águas da Represa Billings, por receber o esgoto da RMSP lançados nos rios Tietê e Pinheiros. O que mostra que, desde o primeiro momento, o objetivo central de proteção integral dos reservatórios já estava comprometido, pois dependeria do tratamento completo dos esgotos, o que até hoje ainda não aconteceu.

No que se refere à implantação de infraestrutura pública, a LPM também restringiu e na maioria das áreas proibiu sua execução, pois a entendia como vetor de estímulo à ocupação (conforme abordado na Parte I, Capítulo 2). Além disso, na definição de parâmetros de ocupação do solo, considerou apenas a capacidade de autodepuração dos reservatórios sem incorporar os sistemas de tratamento de efluentes (ANCONA, 2002). Ou seja, todo o esgoto deveria ser exportado e tratado fora das bacias protegidas, exceto em áreas onde a implantação da rede era inviável como, por exemplo, em situações de áreas isoladas da malha urbana, ou de difícil transposição da topografia ${ }^{5}$.

A proteção de áreas vegetadas, corpos d'água e nascentes, estava relacionada sobretudo ao controle do uso e ocupação do solo. De forma sintética, quanto ao uso residencial, os parâmetros adotados estabeleceram um padrão elitizado de ocupação do solo ao permitir somente a existência de grandes lotes (de no mínimo $500 \mathrm{~m}^{2}$ ) e residências unifamiliares ${ }^{6}$, além de aumentar as restrições de uso das propriedades particulares - o que contrariava a lógica lucrativa de grande parte dos proprietários de terras urbanas nessas áreas. De fato, a LPM atribuiu ao proprietário privado a responsabilidade e os encargos da proteção, pois o Estado já não utilizava mais o instrumento da desapropriação de bacias como medida de proteção de mananciais, como fez no início do século XX (conforme tratado na Parte I, Capítulo 1).

Adicionalmente, os parâmetros urbanísticos não correspondiam à dinâmica predominante de parcelamento do solo que estava em curso, como ilustrado na Parte II, sendo que esse processo de abertura de loteamentos irregulares e ocupações de favelas intensificou-se do final dos anos 1980 aos anos 1990. A insuficiente provisão habitacional por parte do Estado, a crise econômica, o aumento do desemprego, o comprometimento da renda familiar com o aluguel seja em favelas ou cortiços, fez com que o loteamento popular se constituísse como uma alternativa para o acesso à habitação, ainda que em situação irregular (fundiária e/ou urbanística) e precária. Dessa forma, a lei aplicou um modelo abstrato sobre uma dinâmica real de ocupação do solo que ocorria ao contrário dos propósitos de preservação que objetivava.

\footnotetext{
${ }^{5}$ Nessas situações, a lei definia a necessidade de tratamento biológico, e desinfecção do efluente, e tratamento no nível primário, no mínimo, seguido de infiltração ou irrigação subsuperficial, assegurando a proteção do lençol freático (art. 23 da lei no 1.172/1976).

${ }^{6}$ Para uma explicação detalhada sobre os parâmetros de densidade e classificação das áreas definidas pela LPM ver MARCONDES (1999).
} 
Por outro lado, hoje, avalia-se que um aspecto positivo da LPM foi ter contido a expansão das indústrias nas áreas protegidas. Para isso colaborou o zoneamento industrial e o fato da indústria ser um tipo de uso mais difícil de se instalar irregularmente, por ser uma atividade econômica de maior porte e controle público. Já outras atividades, como a mineração, foram menos controladas.

Outro aspecto digno de nota é que a LPM, apesar do seu reconhecimento técnico particularmente por parte dos técnicos do governo estadual que a consideravam uma lei avançada para a época, na prática, seus instrumentos eram de difícil aplicação por parte das prefeituras, devido aos complexos cálculos de parâmetros que se diferenciavam dos zoneamentos homogêneos utilizados até então na legislação urbanística (ANCONA, 2002).

A lei vigorou por muito tempo como um instrumento isolado, ou seja, não havia um sistema de gestão ao qual pudesse se articular. Também não se integrava a uma política pública de desenvolvimento urbano e habitacional mais abrangente. Ao contrário, ela supervalorizou o controle por meio da fiscalização e dos processos de licenciamento de projetos pelos órgãos estaduais responsáveis pelo controle ambiental, que se mostraram falhos e insuficientes. Isso não significa que a criação posterior de um sistema de gestão tenha resolvido plenamente os conflitos, como se verá adiante.

Como identificaram Sócrates, Grostein e Tanaka (1985) num dos primeiros estudos sobre o tema, a LPM expressava um monopólio técnico e político da questão dos mananciais especialmente por parte do poder público estadual, com pouca manifestação por parte dos municípios, que segundo as autoras, poderiam contribuir para novas abordagens dos conflitos a partir de sua experiência de intervenção cotidiana nos territórios protegidos, de forma menos setorializada. Além disso, havia uma polarização de opiniões entre os defensores da lei em sua essência, os defensores de sua revisão, considerando o passivo ambiental existente como um fato consumado, e a população, cuja necessidade de sobrevivência se impunha e o contato com a legislação ocorria somente após terem ocupado áreas interditas legalmente ${ }^{7}$.

Como visto no capítulo 5, mesmo em São Bernardo do Campo - um município onde os órgãos de planejamento constituíam parte importante da gestão municipal, condição que o destacava em relação aos demais municípios do $A B C$, a LPM não só não foi aplicada, como foi subvertida pela própria Prefeitura, quando diversos loteamentos irregulares foram promovidos pelos políticos locais e pelo próprio prefeito, até o final da década de 1980. De fato, olhando retrospectivamente, uma conjunção de fatores e interesses explica a não aplicação dessa legislação tanto nos níveis estadual e municipal sendo que muitos desses fatores escaparam, propositadamente ou não, à esfera de controle do planejamento estatal, prevalecendo interesses relativos ao mercado de terras e clientelismo político.

\footnotetext{
${ }^{7}$ Uma avaliação pormenorizada dos diferentes posicionamentos de técnicos, profissionais, sociedade civil e órgãos públicos sobre a Lei Estadual de Proteção aos Mananciais no período 1975 - 1984 é elaborada em: SÓCRATES; GORSTEIN, Marta Dora; TANAKA, Marta Dora (1985).
} 
Entre 1977 e 1989, a qualidade da água do reservatório piorou, principalmente devido ao despejo de esgotos diretamente nos corpos d'água, ameaçando progressivamente a continuidade do abastecimento público. Os conflitos ambientais, a falta de saneamento, os problemas de saúde pública e de moradia demandavam mudanças nas ações dos governos municipais e estadual, que ainda eram limitadas do ponto de vista legal pelas restrições da Lei Estadual de Proteção aos Mananciais, tornando necessária e desejável sua revisão. Durante a década de 1980, projetos pontuais de alteração da LPM foram elaborados, por iniciativa de deputados e da Emplasa, no sentido da permitir regularizações, mas não foram encaminhados à Assembleia Legislativa para aprovação ${ }^{8}$. Assim, durante a década de 1990, diante dos inúmeros conflitos criados tanto pelas aplicações como pelo não cumprimento da LPM, o processo de discussão da revisão ganha importância ${ }^{9}$.

Nota-se que a Emplasa, na gestão do Secretário Almino Afonso decidiu, com base em parecer jurídico (no 117/84), que não havia impedimentos para a instalação de sistemas de abastecimento de água e coleta de esgotos nos loteamentos, arruamentos e demais situações preexistentes à lei de proteção aos mananciais. Com isso autorizou a implantação dessas redes em extensas áreas urbanizadas e ocupadas previamente (MOREIRA, 1990, p.46). Porém, essa e outras decisões relativas à LPM não eram consensos internamente ao órgão e foram revogadas com a mudança de gestão.

Pode-se dizer que legislação da década de 1970, além de não corresponder ao processo social de expansão metropolitana que estava em curso, serviu para encobrir questões de gestão pública do território e de saneamento muito relevantes para proteção dos mananciais, que acabaram ficando em segundo plano diante da responsabilização da ocupação irregular como a principal causadora da degradação do manancial, nas décadas seguintes.

Já no final dos anos 1980, os conflitos provocados pelas ocupações e loteamentos irregulares também pressionavam em grande medida a revisão da LPM. Na esfera municipal, enquanto em São Bernardo do Campo o reconhecimento do conflito das ocupações por parte da Prefeitura engendrou contradições conforme abordado nos capítulos 4 e 5 precedentes, tendo como consequência a judicialização do conflito; no município de São Paulo, onde a ocupação das bacias era mais extensa, passou por um processo um pouco diferenciado, a partir da gestão da prefeita Luiza Erundina em 1989. A prefeita tinha comprometimento assumido com o movimento de moradia e em particular com os assentamentos precários das áreas de mananciais ao sul do município e, nesse sentido, passa a buscar alternativas para realizar projetos de urbanização e ao mesmo tempo se elabora o Plano de Preservação e Manejo da

\footnotetext{
${ }^{8}$ As iniciativas de alteração da LPM no governo de Paulo Maluf (que propôs reduzir a área protegida) e no governo de Franco Montoro (que retoma a proteção e a defesa da despoluição da represa Billings) são descritas em Moreira (1990).

${ }^{9}$ A continuidade do debate sobre a revisão da LPM durante a década de 1990, enfocando os aspectos políticos, pode ser vista em Ancona (2002).
} 
Área do Município de São Paulo ${ }^{10}$ para área correspondente à APM Guarapiranga e Billings e dos rios Capivari e Monos.

Além disso, foi criado o Grupo Executivo de Urbanização de Favelas (GEUFAVELAS) na Secretaria de Habitação de São Paulo, com recursos do PROFAVELA. Esse grupo de trabalho estabeleceu, em conjunto com a Sabesp, normas especiais para intervenção em áreas de favelas criando critérios para urbanização fora dos padrões habituais da concessionária. E a diretriz de intervenção de $\mathrm{HABI}^{11}$ na Zona Sul era selecionar prioritariamente áreas cuja proximidade de corpos d'água comprometesse a qualidade da água do manancial, particularmente na Bacia da Guarapiranga (UEMURA, 2000, p.62). Nessa gestão (1989-1992) um grande número de famílias foi atendida, conforme dados de Uemura (Idem) ${ }^{12}$.

A fiscalização passa a ter um programa específico com a criação do SOS Mananciais ${ }^{13}$, que integrou a atuação de técnicos e fiscais do Estado, Prefeitura, polícia florestal, representantes da SMA e Sabesp.

Em 1990 ocorre uma floração de algas na Represa de Guarapiranga devido à concentração de fósforo e nitrogênio presentes nos esgotos, aumentando o processo chamado de eutrofização $0^{14}$. O gosto e odor da água tornam-se perceptíveis ao consumidor, que passa a questionar a Sabesp, e o problema chega a ser debatido publicamente na mídia.

Em 1992, a Sabesp (por meio da Secretaria Estadual de Energia e Saneamento) e a PMSP fazem uma parceria buscando alternativas para a recuperação desse manancial e elaboram o Programa de Saneamento Ambiental da Bacia da Guarapiranga (Programa Guarapiranga), que agregou e aprimorou a experiência de urbanização de favelas em áreas protegidas que estava em curso. Diante da ausência de normas que possibilitassem o licenciamento ambiental do Programa Guarapiranga, ele foi objeto de EIA/RIMA ${ }^{15}$ e a autorização para a execução de obras foi

\footnotetext{
${ }^{10}$ Esse plano identificou diferentes formas de ocupação coexistentes na bacia da Guarapiranga e propôs intervenções específicas. No Setor 1 - Norte - constituído por mancha urbana contínua que se desenvolve em direção ao Sul - o estudo propôs a implementação de infraestrutura com reurbanização dos loteamentos precários e favelas, realocando a população moradora em área de risco. No Setor 2 - intermediário, caracterizado por núcleos urbanos dispersos, se propôs o estímulo às atividades agrícolas e de lazer. E no Setor 3 - constituído pela área inserida na bacia dos rios Capivari e Monos, foi proposta a preservação permanente, mediante a desapropriação e incorporação do setor ao perímetro do Parque da Serra do Mar (SILVA, 1997, p.218).

${ }^{11}$ Divisão regional da SEHAB/PMSP.

12 O total das intervenções atendeu 13.191 famílias, sendo 5.627 famílias atendidas por conjuntos habitacionais, 4.996 atendias por urbanização de favelas e 2.568 por melhorias habitacionais, conforme Relatório de Gestão 1989-1992 do Programa de Habitação de Interesse Social.

${ }^{13}$ O SOS Mananciais foi criado pela portaria no 237 de 22/07/91. O grupo mantinha um escritório-piloto na Capela do Socorro - escritório regional da Sabesp, localizado na área de proteção aos mananciais, o que garantia melhor desempenho da fiscalização.

${ }^{14} \mathrm{O}$ esgoto in natura é matéria orgânica que entra em decomposição gerando como produtos finais nitrogênio e fósforo. No processo de eutrofização esses elementos funcionam como fertilizantes e aceleram a produção de algas, que se sedimentam e tornam a água imprópria ao consumo, chegando a alterar o tempo de vida útil de um reservatório.

${ }^{15}$ Estudo de Impacto Ambiental seguido de Relatório de Impacto Ambiental, contratado pela Secretaria de Energia e Saneamento.
} 
acompanhada por um contrato de financiamento que garantia sua efetivação, firmado com o Banco Mundial (ANCONA, 2002, p.308).

Apesar do foco predominante da tese ser a porção da bacia da Billings inserida no município de São Bernardo do Campo, aborda-se a experiência do município de São Paulo devido ao protagonismo do Programa Guarapiranga como intervenção do poder público em assentamentos precários em áreas de mananciais, sua influência sobre a revisão da Lei Estadual de Proteção aos Mananciais e seus desdobramentos em programas que abrangeram, posteriormente, as bacias da Billings e do Alto Tietê. Nesse sentido, a referência ao município de São Paulo é necessária na medida em que é parte fundamental para o entendimento da constituição da política recente dos mananciais situados ao sul da RMSP.

Outras transformações contribuíram para mudar a postura em relação aos recursos hídricos. Paralelamente à elaboração do Programa Guarapiranga, em 1991, no nível estadual, foi criado o Sistema Integrado de Gerenciamento dos Recursos Hídricos $(S I G R H)^{16}$, instituindo uma nova Política Estadual dos Recursos Hídricos. O novo sistema de gestão estruturou-se com a criação do Conselho Estadual de Recursos Hídricos $(\mathrm{CRH})$, de órgãos colegiados - os Comitês e Subcomitês de bacias hidrográficas, e do Fundo Estadual de Recursos Hídricos (FEHIDRO). Dentre seus princípios básicos estavam a descentralização administrativa, a participação tripartite e o entendimento da água enquanto um bem público de valor econômico. A lei também estabeleceu a obrigatoriedade de realização de Planos de Bacias visando a articulação das ações e a maximização de recursos financeiros no setor hídrico; definiu a prioridade do uso da água para abastecimento público e o uso múltiplo dos recursos hídricos (CARMO; TAGNIN, 2001, p.428).

Nesse mesmo ano, na gestão do governador Luiz Antônio Fleury Filho (1991-1995), as competências para aplicação da Lei Estadual de Proteção dos Mananciais passaram para a Secretaria do Meio Ambiente (Decreto Estadual no 33.135/91), mas esta não elaborou proposta de revisão de legislação e continuou investindo em estudos que a amparasse ${ }^{17}$.

Em 1993, com a piora da qualidade da água e sob a pressão de ambientalistas, determina-se a paralisação do bombeamento das águas poluídas do Rio Pinheiros para a Represa Billings ${ }^{18}$, conforme estabelecido na Constituição Estadual de São Paulo de 1989. Mesmo com uma melhora na qualidade da água decorrente da paralisação do bombeamento, o tema da revisão

\footnotetext{
${ }^{16}$ A Constituição do Estado de São Paulo, promulgada em outubro de 1989, tratou dos recursos hídricos na Seção II, do Título VI - Da Ordem Econômica. No artigo 205, estabelece a criação do Sistema Integrado de Gerenciamento de Recursos Hídricos. A lei n 7.663, 30 de dezembro de 1991, regulamenta essa Constituição e institui a Política Estadual de Recursos Hídricos e o Sistema Integrado de Gerenciamento de Recursos Hídricos. Essa legislação adota as bacias hidrográficas como Unidades de Gerenciamento dos Recursos Hídricos, estabelece um sistema de gestão descentralizado e participativo.

${ }^{17}$ Foi contratado o consórcio JNS/UMAH/SRL para elaborar estudos de "Revisão, Atualização e Aperfeiçoamento dos Critérios Técnicos e da Base Institucional da Legislação de Proteção aos Mananciais de Interesse da RMSP" (ANCONA, 2002).

${ }^{18}$ Como tratado na Parte I - Capítulo 2, a reversão do Rio Pinheiros para a Represa Billings se iniciou em 1940, com a execução do Projeto Serra para geração de energia em Henry Borden, na descida de Serra do Mar, em Cubatão.
} 
da LPM continuava em pauta, devido à extrema precariedade social e ambiental das ocupações, o que se reforçou com as dificuldades encontradas na execução do Programa Guarapiranga.

Em 1995 o governador Mário Covas (1995-1999) criou a Comissão Especial de Revisão da Legislação de Proteção aos Mananciais, coordenada pela Secretaria de Estado de Meio Ambiente $^{19}$. A revisão da LPM encontrou resistência dos grupos ambientalistas preservacionistas, de setores da academia e de entidades de classe, como a OAB-SP, que temiam a ocupação de novas áreas caso as restrições fossem flexibilizadas (ANCONA, 2002). Mas, se por um lado existia a resistência de grupos ambientalistas com viés estritamente conservacionista, também se observa a formação de grupos que discutiam a necessidade de compatibilizar a preservação com a ocupação existente (POLLI, 2011).

Ao contrário do período anterior, a década de 1990 é marcada por um intenso debate acerca de políticas e instrumentos, pela formalização do SIGRH, dos subcomitês, com o objetivo de propor alternativas ao conceito de proteção integral, dada a inviabilidade do modelo anteriormente adotado. À iniciativa da Prefeitura de São Paulo com o Programa Guarapiranga somou-se o trabalho de Fábio Feldman, Secretário de Meio Ambiente no governo estadual, que impulsionou a revisão da LPM.

Desse processo resultou a Lei no 9.866/97, chamada de Nova Política de Mananciais, de abrangência estadual, que incorporou a gestão democrática de bacias hidrográficas conforme a Lei no 7.663/91 (os Comitês e Subcomitês de bacias tripartites ${ }^{20}$ ), estabeleceu a obrigatoriedade da formulação de leis específicas por bacia, voltadas à realidade de cada uma delas, e definiu áreas de intervenção, reconhecendo a diversidade de ocupações e usos presentes nas bacias ${ }^{21}$. Além de enfocar a mudança de gestão, não revogou a LPM, mas permitiu situações de exceção para viabilizar a implantação de infraestrutura nas áreas que estivessem comprometendo a qualidade ambiental, por meio do Plano Emergencial ${ }^{22}$.

Como tratado no capítulo 6, o Plano Emergencial foi o que tornou possível muitas prefeituras definirem áreas a serem urbanizadas enquanto não se aprovava a Lei Específica. Esse plano

\footnotetext{
${ }^{19}$ A Comissão Especial de Revisão da LPM era coordenada pela SMA e integrada pela Cetesb, Departamento de Águas e Energia Elétrica (DAEE), Sabesp, Eletropaulo, Emplasa, Companhia de Desenvolvimento Habitacional e Urbano do Estado de São Paulo (CDHU), Secretaria de Economia e Planejamento e Procuradoria-Geral do Estado.

${ }^{20}$ O Subcomitê Cotia-Guarapiranga foi instalado em setembro de 1997 com 33 membros. E o Subcomitê BillingsTamanduateí foi instalado em dezembro de 1997 com 24 membros. Os principais temas tratados eram os conflitos em APM e a destinação dos recursos do FEHIDRO (ANCONA, 2002, p.300).

21 Áreas de Restrição à Ocupação (ARO): além das definidas pela Constituição do Estado e por lei como de preservação permanente, são aquelas de interesse para a proteção dos mananciais e para a preservação, conservação e recuperação dos recursos naturais; Áreas de Ocupação Dirigida (AOD): são as de interesse para a consolidação ou implantação de usos rurais e urbanos, desde que atendidos os requisitos que garantam a manutenção das condições ambientais necessárias para a produção de água em quantidade e qualidade para o abastecimento das populações atuais e futuras; Áreas de Recuperação Ambiental (ARA): são aquelas cujos usos e ocupações estejam comprometendo a fluidez, potabilidade, quantidade e qualidade dos mananciais de abastecimento público e que necessitem de intervenção de caráter corretivo.

22 Lei no 9.866/97, art. 47. Nas áreas de proteção de mananciais de que trata as Leis no 898, de 18 de dezembro de 1975 e № 1.172, de 17 de novembro de 1976, até que sejam promulgadas as leis específicas para as APRMs - Áreas de Proteção e Recuperação de Mananciais, poderão ser executadas obras emergenciais nas hipóteses em que as condições ambientais e sanitárias apresentem riscos de vida e à saúde pública ou comprometam a utilização dos mananciais para fins de abastecimento.
} 
significaria a ampliação de infraestrutura de saneamento nas áreas mais precárias, principalmente para a Bacia da Billings que não recebia investimentos semelhantes aos do Programa Guarapiranga. Assim, o Plano Emergencial incluía a autorização de melhorias em 228 bairros no entorno da Billings (67 no município de São Paulo) e 20 na Guarapiranga, dentre o total de 313 áreas abrangidas (POLLI, 2010). Entretanto, nem todas as áreas indicadas foram contempladas por obras de urbanização e saneamento, como será abordado adiante.

Por não ter revogado a LPM o governo estadual não assumiu integralmente a responsabilidade de alterar a legislação e, com isso, acalmava opiniões que temiam alterações, anistias e flexibilizações maiores (ANCONA, 2002, p.307). Mas viabilizava a realização de obras com o Plano Emergencial, contemplando assim as diferentes demandas sociais conflitantes, particularmente entre as posturas mais preservacionistas (de movimentos e de órgãos ambientais públicos) e a dos municípios, cuja ação sobre os assentamentos precários ficava inviabilizada sem que a LPM fosse revista.

\subsection{A elaboração da Lei Específica da APRM-Guarapiranga: a instituição de um modelo}

O fato da LPM ter vigorado por muitos anos ${ }^{23}$, no contexto descrito, colaborou para gerar inúmeros conflitos sociais, urbanos e ambientais. Ainda que os problemas concretos pusessem em evidência as falhas do modelo de proteção adotado pela LPM, pouco se avançou nos estudos de alternativas econômicas e usos compatíveis para dirigir o uso de áreas não ocupadas e assim garantir a proteção ${ }^{24}$ - o que acontecerá, ao menos na esfera propositiva, nos estudos técnicos para a elaboração das leis específicas da Guarapiranga e da Billings.

Além disso, a LPM foi base de muitos processos judiciais contra os loteamentos irregulares movidos pelo Ministério Público, que em alguns casos tramitam até hoje, a exemplo dos loteamentos em São Bernardo do Campo, como abordado na Parte II, mas também em outros municípios inseridos em APM. Assim, essa situação mantinha a população sob o risco permanente da remoção, ainda que novos instrumentos de defesa do direito à moradia tenham sido regulamentados após o Estatuto das Cidades, em 2001.

O longo e polêmico processo de revisão da LPM que culminou na promulgação da Lei Estadual no 9.866/97, também protelou ao máximo a decisão do poder público sobre o modo como passaria a atuar em relação aos assentamentos precários em APM, mesmo com a experiência do Programa Guarapiranga em andamento.

\footnotetext{
23 De 1975 a 2006 na bacia da Guarapiranga e de 1975 a 2009 na bacia da Billings, quando foram aprovadas as respectivas leis específicas.

${ }^{24}$ A criação de Áreas de Proteção Ambiental (APA) e de parques naturais no município de São Paulo ocorre a partir dos anos 2000. A APA Capivari Monos é criada pela Lei Municipal no 13.136, de 09 de julho de 2001, e localiza-se na Subprefeitura de Parelheiros, e a APA Bororé-Colônia foi criada pela Lei no 14.162, de 24 de maio de 2006, e localizase nas Subprefeituras de Parelheiros e Capela do Socorro. Além dessas, há o Parque Estadual da Serra do Mar, uma Reserva Particular do Patrimônio Natural Federal (RPPN Curucutu) ao Sul do município de São Paulo.
} 
Desde 1992, a urbanização de favelas e loteamentos situados na Bacia da Guarapiranga, por meio do Programa Guarapiranga, tinha como argumento central que a manutenção da população era possível com a melhora da condição de saneamento. A avaliação crítica dos resultados do Programa será abordado neste item 8.2, a seguir. Mas cabe ressaltar que essa diretriz orientou o desenvolvimento de estudos técnicos consubstanciados no Plano de Desenvolvimento e Proteção Ambiental (PDPA) da Guarapiranga (1995), que visavam melhor compreender o impacto da ocupação sobre a qualidade da água do reservatório e, a partir disso, desenvolver instrumentos que pudessem conciliar a qualificação dos assentamentos por meio do saneamento e ao mesmo tempo recuperar a qualidade da água afluente para a represa. Outros aspectos também foram tratados, tais como o mapeamento do uso e ocupação do solo na bacia, a situação de degradação da vegetação nos diferentes municípios e a condição de infraestrutura existente.

Uma das conclusões do PDPA da Guarapiranga era que $88 \%$ das cargas poluidoras afluentes à Represa Guarapiranga eram provenientes de esgotos domésticos (ANCONA, 2002, p.311). Em 1995, considerando os municípios com ocupação irregular inseridos na bacia ${ }^{25}$, havia 117.654 habitantes em favelas e 188.648 habitantes em loteamentos irregulares, totalizando 304.719 habitantes, dos quais $94,41 \%$ se concentravam no Município de São Paulo. Do total da população residente na bacia (622.507 habitantes em 2005), 48,95\% moravam em condições precárias (UEMURA, 2000, p.73).

Diante da extensa e densa ocupação na porção Norte da bacia e da inviabilidade econômica e política da remoção das ocupações, os estudos desenvolvidos voltaram-se para a elaboração de modelagens matemáticas visando relacionar cenários de ocupação e diferentes usos do solo com a geração de carga de fósforo, um poluente que deriva da decomposição de esgotos e compromete a qualidade da água. Considerando também a utilização dos sistemas de tratamento de esgotos, o modelo de qualidade da água denominado MQUAL, definiu uma cargameta máxima, ou seja, a quantidade de fósforo que o reservatório suportaria.

Então, se por um lado o controle de cargas de fósforo reiterava a diretriz da LPM de conservação do reservatório, por outro lado, a consideração dos sistemas de tratamento de esgotos proporcionando a redução das cargas poluentes alterava a quantidade de população admissível na bacia (ANCONA, 2002). E para diminuir a carga poluente a prioridade era o saneamento nos assentamentos precários.

O MQUAL fez parte das análises do PDPA, mas não teve aplicação prática, mesmo em caráter experimental, enquanto instrumento de monitoramento da qualidade da água durante as obras de urbanização do Programa Guarapiranga. Segundo Márcia Nascimento isso se deveu ao fato

\footnotetext{
${ }^{25}$ São Paulo (15,3\% do território inserido na bacia), Embu (58,1\%), Itapecerica da Serra $(96,1 \%)$ e Embu-Guaçu (100\%). Além desses municípios estão inseridos na bacia da Guarapiranga Cotia (6,8\%), São Lourenço da Serra $(17,7 \%)$ e Juquitiba (1,5\%), conforme dados do PDPA Guarapiranga atualizado em 2000 (SMA/CPLA, 2000).
} 
de que esse instrumento ainda não estava regulamentado em $\mid \mathrm{el}^{26}$. Por outro lado, pode-se dizer que a sua concepção foi a base da Lei Específica da Guarapiranga, que definiu a carga máxima total afluente ao reservatório e uma carga-meta de fósforo definidas por sub-bacias e por município, uma referência que deve ser respeitada e monitorada ao longo do tempo, com revisões periódicas, conforme as atualizações do PDPA, conforme períodos estabelecidos por esse plano.

Em linhas gerais, além das cargas-meta resultantes do MQUAL, a LE-Guarapiranga definiu parâmetros urbanísticos que variam conforme as áreas de intervenção, delimitadas em mapa que determina o zoneamento da bacia. A LE-Guarapiranga também criou: um Sistema de Planejamento e Gestão da APRM-G composto por um órgão colegiado ${ }^{27}$, um órgão técnico ${ }^{28} \mathrm{e}$ órgãos e entidades da administração pública estadual e municipal e um Sistema de Monitoramento da Qualidade Ambiental da APRM-G.

Os instrumentos e demais conteúdos da Lei Específica serão abordados adiante, à luz da Lei Especifica da Billings, que seguiu o mesmo modelo da Guarapiranga. O que cabe agora pontuar é que, desde a LE-Guarapiranga, a instalação de infraestrutura de saneamento, particularmente nos assentamentos precários, passa a ser entendida e, mais do que isso, legalmente definida, como condição de recuperação dos mananciais. Entretanto, as críticas quanto ao seu papel indutor de ocupação e, portanto, comprometedor da qualidade do manancial, continuam em voga, porém, sem um equacionamento claro.

Sem entrar nas minúcias do processo de aprovação da LE-Guarapiranga, destaca-se que o longo processo de discussão até sua aprovação tornou explícito o desinteresse político em realizá-la ${ }^{29}$. A primeira minuta foi formulada pela Secretaria de Recursos Hídricos e passou por reelaborações quando discutida pela Secretaria de Estado de Meio Ambiente. Como destaca Ancona, "as duas propostas mantinham possibilidades de regularização dos assentamentos populares no âmbito discricionário das decisões do governo estadual, pois não estabeleciam regras gerais que contemplassem essa regularização" (ANCONA, 2002, p.322). Quando a minuta chegou ao Subcomitê Cotia-Guarapiranga, as suas indefinições geraram diversas críticas e ela foi novamente modificada, dessa vez com a participação da sociedade civil, chegando à sua versão final no ano 2000. A aprovação no Subcomitê e pelo Comitê ocorreu em 2001 e em seguida foi encaminhada à Assembleia Legislativa.

\footnotetext{
${ }^{26}$ Márcia Nascimento é arquiteta e urbanista e atuou como representante da SMA nos Subcomitê BillingsTamanduateí e coordenou o grupo de trabalho da Lei Específica da Billings bem como do decreto regulamentador. Entrevista concedida a autora em 25/10/2012.

${ }^{27}$ O órgão colegiado de caráter consultivo e deliberativo é o Comitê de Bacia Hidrográfica do Alto Tietê - CBH-AT, ou o Subcomitê Cotia-Guarapiranga.

28 O órgão técnico do Sistema de Planejamento e Gestão da APRM-G será a Agência de Bacia Hidrográfica do Alto Tietê através de seu escritório regional.

${ }^{29}$ O desinteresse político pela aprovação de uma nova legislação também aparece nas entrevistas realizadas com profissionais que participaram das discussões de elaboração no Subcomitê.
} 
Em meio a esse processo, o secretário estadual de Meio Ambiente, Ricardo Tripoli, levou outra proposta de revisão da LPM diretamente ao governador, sem submetê-la ao Subcomitê. $O$ conteúdo desse projeto de lei possibilitava a regularização de lotes e edificações em APM mediante compensação das irregularidades com terrenos desocupados não contíguos. Apesar de ter sido apresentada como medida geral de regularização, tinha como objetivo atender as indústrias e grandes estabelecimentos comerciais em APM (ANCONA, 2002, p.327). Entretanto, não seria viável para atender a maior demanda por regularização que era justamente a dos loteamentos irregulares populares, pois para compensar os danos causados, os moradores teriam que arcar com a compra de áreas muito maiores do que seus lotes, em um terreno que ficaria totalmente preservado. Mesmo assim, alguns setores populares contraditoriamente apoiaram a proposta, percebendo posteriormente que ela impediria a regularização fundiária das classes mais pobres.

A proposta foi a debate no Subcomitê onde a pressão por um processo participativo e democrático era maior e, naquele momento, exercido por forças progressistas (ANCONA, 2002, p.329). Como consequência a chamada Lei Tripoli não foi alterada, mas conseguiu-se que a Lei Específica da Guarapiranga fosse encaminhada conjuntamente para a Assembleia Legislativa, garantindo ao menos mais um passo para sua aprovação.

Contudo, a Lei estadual n 12.233, de 16 de janeiro de 2006 - a Lei Específica Guarapiranga, que define a Área de Proteção e Recuperação dos Mananciais da Bacia Hidrográfica do Guarapiranga APRM-G, foi aprovada somente em 2006. O Decreto no 51.686 que a regulamentou, que também gerou inúmeros conflitos, foi promulgado em 22 de março de 2007.

\subsection{Da metrópole à bacia: a Lei Específica da APRM Billings}

Apesar do resultado final da LE-Billings seguir a estrutura da LE-Guarapiranga, o processo de discussão de sua elaboração apresenta premissas diferenciadas das adotadas na LEGuarapiranga. Essa última foi pautada, primordialmente, pela experiência das urbanizações do Programa Guarapiranga como forma de recuperação ambiental. Na Billings, os estudos iniciais consideravam uma leitura regional da questão dos mananciais e não só as questões específicas tratadas no recorte da bacia hidrográfica. Essa orientação foi transformada posteriormente.

Para que o instrumento da Lei Específica possa ser mais bem compreendido e debatido cabe retomar, por um lado, os momentos relevantes de sua construção e que evidenciam de que maneira as disputas sobre o território da bacia hidrográfica foi manejada politicamente ao longo dos anos, destacando os avanços e retrocessos em proposições de políticas públicas que viabilizassem sua função como manancial.

Mas antes de abordar o processo de elaboração da Lei Específica é relevante explicitar algumas características da degradação das águas do reservatório Billings, complementando as informações já tratadas na Parte I dessa tese. Com isso, pretende-se destacar algumas de suas 
especificidades que foram tratadas nos documentos que antecederam a opção pela adoção do modelo de Lei Específica, formulado para a Bacia da Guarapiranga.

Além de apresentar características físicas próprias, a Represa Billings apresenta historicamente uma pior condição de qualidade da água se comparada à Represa Guarapiranga, apesar de conter uma grande disponibilidade hídrica natural ${ }^{30}$ e apresentar um volume útil sete vezes maior que o da Guarapiranga.

Em 1981, devido à grande quantidade de esgoto despejado na Billings, que resultaram em sérios problemas de contaminação por algas cianofíceas (cianobactérias), algumas potencialmente tóxicas, a solução encontrada para proteger parte do reservatório foi a interceptação total do braço do Rio Grande, através da construção da Barragem Anchieta, para garantir o abastecimento de água do $A B C$.

Mas, o principal motivo do comprometimento da qualidade de água na Billings foi o bombeamento das águas dos poluídos rios Tietê e Pinheiros, para a geração de hidroeletricidade, por anos a fio, até a mudança mais significativa da regra operacional, resultante da promulgação da Resolução Conjunta SMA/SES 03/92 ${ }^{31}$. Aos esgotos industriais e domésticos carregados por esses rios até a Represa Billings, somou-se o aporte de esgotos domésticos gerados pelas ocupações na própria bacia - por fontes pontuais ou difusas, além dos poluentes gerados por outras atividades, como de mineração, e a circulação e transporte de cargas perigosas de indústrias e postos de combustíveis, além dos fármacos que não são retirados da água pelo processo de tratamento.

Até a suspensão do bombeamento (exceto em situações emergenciais de enchentes) em 1993, o reservatório refletia a condição das águas dos rios Tietê e Pinheiros. Apresentava eutrofização acelerada e a poluição concentrava-se principalmente próxima à estação elevatória de Pedreira, onde havia a presença de metais pesados, também presentes no fundo do corpo central onde grande quantidade de sedimentos de esgotos ${ }^{32}$ foi depositada, impactando os demais braços. 0 ribeirão Colônia, afluente do Taquacetuba, e os ribeirões Pires Sul e Pires Norte, afluentes do braço do rio Grande, apresentavam concentrações de nutrientes e coliformes fecais elevados. $\mathrm{E}$ os três afluentes que drenam diretamente para o reservatório Billings - Apurás, Guacuri e Alvarenga - localizados na margem direita, na porção próxima à estação elevatória Pedreira, estavam altamente poluídos e, devido às pequenas vazões de contribuição, apresentavam concentrações próximas ao nível de esgoto bruto. Portanto, as águas da Billings eram

\footnotetext{
${ }^{30}$ Esse fato dispensaria a necessidade de construção de grandes infraestruturas para que fosse utilizada para fins de abastecimento de água, segundo especialistas do relatório FUNDUNESP.

${ }^{31}$ Anteriormente a essa resolução, a primeira interrupção no bombeamento dos rios Tietê e Pinheiros para a Represa Billings (exceto em caso de enchentes) aconteceu no governo Montoro, em 1982, e toda a disponibilidade de água foi lançada Tietê abaixo. Com isso a população ribeirinha e de Pirapora recebeu toda carga de poluição e protestou. A decisão seguinte foi repartir a vazão da bacia do Alto Tietê, numa "solução balanceada", que manteve ambas as represas, Billings e Pirapora, poluídas.

32 A grande quantidade de sedimentos de esgoto acumulados no fundo do reservatório, especialmente no corpo central, foi estimada pela CETESB em cerca de 50 milhões de m³ em 1975 (CONSÓRCIO...; 2001).
} 
completamente impróprias ao consumo e seu uso seria adequado apenas para outros fins que não o abastecimento público (FUNDUNESP, 2001, p.38).

É relevante pontuar que os acordos sobre o bombeamento variaram muito ao longo dos anos. A última norma identificada sobre a operação do Sistema Billings é a Resolução SES-SMA-SRH 50-I, de 13/03/1996, na qual o bombeamento dos rios Tietê e Pinheiros ficam autorizados em situações de emergência em caso de cheias, mas também no caso de geração insuficiente de energia em Henry Borden para situações emergenciais. Além disso, as regras operacionais não foram discutidas com a sociedade e ficaram limitadas a uma visão particular do subsistema Billings, não tendo sido avaliados os impactos decorrentes em outras bacias da qual ele faz parte. O subsistema Billings integra o sistema Alto Tietê, que apresenta fortes interações com as bacias do Médio Tietê e dos rios Piracicaba e Cubatão, além do estuário de Santos (CONSÓRCIO...,2001, p.35).

Assim, apesar da melhora da qualidade da água após o controle da reversão, ainda era preciso tomar cuidado na captação e melhorar o saneamento de forma geral, implementando diversas ações para que a água servisse a um abastecimento de qualidade e quantidade.

Mas mesmo diante do quadro de comprometimento da água, a pressão para a retomada de aumento de vazão a fim de gerar energia nunca saiu de pauta. Se por um lado a defesa dos múltiplos usos que passa a conceituar a legislação dos recursos hídricos nos anos 1990 buscava o aproveitamento desse recurso de forma integrada, ao mesmo tempo, e particularmente no caso da Billings, deixava brechas para a retomada do bombeamento, sob o argumento do aproveitamento econômico da infraestrutura existente instalada. Dessa forma, o uso múltiplo dos recursos hídricos expressa mais uma concorrência entre usos econômicos do recurso, do que sua possível integração, já que a qualidade e quantidade da água para abastecimento público não é historicamente priorizada pelos governos.

Nesse contexto, alguns projetos surgiram nos anos 1990, como a proposta do Consórcio HIDROPLAN (em 1995) de segmentar os braços da represa separando-os do corpo central por meio de barragens, viabilizando o múltiplo uso sem melhorar a qualidade de água, o que era muito polêmico e contrário aos projetos de recuperação do manancial. Em seguida, o Projeto Tietê, que previa o tratamento integral das águas desse rio e poderia proporcionar a retomada do bombeamento, o que entretanto não se concluiu até hoje. E entre 1997-1998 a Eletropaulo retomou o bombeamento independentemente das chuvas, mas foi impedida pelo Ministério Público. O motivo era a realização de testes para implementação do sistema de flotação das águas do rio Pinheiros, realizado anos depois, também sem sucesso e com muitos gastos públicos ${ }^{33}$.

\footnotetext{
33 O sistema de flotação foi oficialmente anunciado em 2001. Em 2003 o Ministério Público proibiu sua realização, alegando que a técnica era inadequada. Em 2007 o projeto é retomado pelo governo em negociação com o MP. Finalmente foi interrompido em 2011 após os testes mostrarem a insuficiência do tratamento da água num nível aceitável para bombeá-la novamente para a represa Billings. Nesse período de dez anos, o governo do estado investiu R\$ 160 milhões no projeto. Fonte: http://www1.folha.uol.com.br/cotidiano/1097172-juiz-manda-retirar-lodo-eaparelhos-do-rio-pinheiros-em-sp.shtml, acesso em 24 de março de 2013.
} 
Além dos conflitos dos usos múltiplos incompatíveis com a função de manancial, a Billings apresentava os mesmos desafios da Guarapiranga em relação à grande quantidade de assentamentos precários e irregulares ${ }^{34}$ que, até o Plano Emergencial, não haviam passado por projetos e obras de urbanização e saneamento, como ocorrera nas áreas objeto do Programa Guarapiranga.

Segundo dados do Instituto Socioambiental $(2002)^{35}$, entre os anos de 1989 e 1999, a Bacia Hidrográfica da Billings passou por transformações significativas, perdeu mais de $6 \%$ de sua cobertura vegetal, enquanto a expansão urbana foi da ordem de $48 \%$. Além disso, mais de $37 \%$ da ocupação urbana registrada ocorreu em áreas que possuíam sérias ou severas restrições ambientais, tais como encostas íngremes, regiões de aluvião ou de várzea. Apenas $12 \%$ do crescimento da mancha urbana ocorreu sobre áreas favoráveis. A construção irregular seguida dos movimentos de terra (abertura de estradas, terraplenagem e construções não autorizadas) figuravam no topo das ocorrências irregulares, respondendo por 70\% dos 988 registros efetuados pelo Departamento de Uso do Solo Metropolitano (DUSM), no período de 1978 a 1998. Apesar do avanço da ocupação, a Bacia Hidrográfica da Billings apresentava mais de $53 \%$ de seu território recoberto por vegetação nativa, o que proporcionaria condições ambientais favoráveis à garantia de produção de água (CAPOBIANCO, 2002).

Os primeiros estudos que se debruçaram sobre esse quadro de degradação na Bacia da Billings iniciaram-se após a criação da Unidade de Gerenciamento do Projeto Billings (Decreto Estadual no 41.716/97), integrada pelas Secretarias Estaduais do Meio Ambiente, de Energia e Recursos Hídricos. No sentido de desenvolver um projeto específico, em 1999 foi produzido o documento Termo de Referência para o Programa de Recuperação Ambiental da Bacia da Billings (TRBillings), coordenado pela SMA e financiado pela Sabesp. O TR-Billings resultou num relatório contendo extenso diagnóstico da bacia e sua inserção regional, abrangendo dados de uso e ocupação do solo, dados socioeconômicos, análise institucional, avaliação da carga poluidora gerada na bacia e aplicação de modelo matemático de correlação entre uso do solo e afluência de cargas poluidoras e a avaliação das interfaces entre a Bacia Billings e demais problemas estruturais da RMSP.

Ele indicou também as diretrizes de ação e atividades necessárias para que os objetivos fossem alcançados, bem como apresentava uma estimativa de custo preliminar. E para buscar superar interesses setoriais, ante os inúmeros conflitos de usos coexistentes e visando garantir sua sustentação política, esse documento foi produzido a partir de um amplo processo de consulta e participação dos diversos agentes do setor público municipal, estadual e da sociedade civil intervenientes na bacia, constituindo-se uma ação inovadora no sentido do trabalho integrado de políticas setoriais que atuavam frequentemente de modo fragmentado.

\footnotetext{
${ }^{34}$ Segundo dados da SMA (1999), havia em 1996 na Bacia da Billings 163 núcleos de favelas: 84 em São Paulo, 44 em São Bernardo do Campo, 29 em Diadema e 6 em Ribeirão Pires. A população total residente em favelas era de 121.147 habitantes (16,92\% da população total). E havia 211 loteamentos clandestinos, no mesmo ano.

35 A análise do Instituto Socioambiental baseou-se nos dados relativos à evolução da expansão urbana no período de 1989 a 1999 e no mapa de aptidão física ao assentamento urbano do IPT (1980).
} 
Após a realização do Termo de Referência, o governo do estado instituiu o Projeto Billings, com o objetivo de desenvolver as ações previamente identificadas no Termo de Referência para "tornar plena a utilização da Billings para o abastecimento público, bem como aquelas que estabelecerão os parâmetros e condições para os demais usos, subordinados às exigências desse aproveitamento" (SÃO PAULO, 2002). Estruturado como um abrangente programa, o Projeto Billings organizou suas linhas de ação em sete categorias: Captação de Água na Represa; Recuperação Ambiental da Bacia Billings; Monitoramento e Avaliação da Qualidade e Quantidade das Águas; Melhoria da Qualidade das Águas; Controle de Inundações; Novo Modelo de Gestão Operacional e Articulação Institucional. O horizonte de realização previsto era de 12 anos, sendo que algumas delas teriam continuidade posteriormente, como a manutenção e operação dos sistemas implantados e de seus instrumentos de controle e acompanhamento.

Cada um desses componentes foi detalhado no Projeto, o que não cabe ser integralmente retomado aqui. Porém, é relevante ressaltar o sentido geral da abordagem da questão dos mananciais e a proposta de sua recuperação naquele momento. Um primeiro aspecto é o enfoque multiescalar adotado, ou seja, a importância de tratar as questões estruturais conforme sua abrangência, seja na escala regional, metropolitana, da bacia ou municipal; de modo que responsabilidades específicas seriam atribuídas a cada ente governamental, sendo estratégica a colaborações entre eles.

Nesse sentido, a degradação das águas e a indução à ocupação, entendidos como processos metropolitanos, deveriam ser enfrentados nessa escala de abrangência, sem o quê as ações de saneamento das ocupações existentes na bacia, indispensáveis em qualquer hipótese, teriam apenas uma "eficácia tópica", sem repercussão significativa para o resgate e sustentação das condições de qualidade e produção de água (SÃO PAULO, 2002). A destinação de terra urbanizada para habitação de interesse social em áreas não protegidas ambientalmente, se contrapondo ao processo de valorização imobiliária crescente, seria uma política fundamental para se atingir o objetivo de orientar o crescimento urbano para fora do manancial.

Além disso, dentre as ações de Recuperação Ambiental da Bacia Billings, diversas medidas foram elencadas com o objetivo de resgatar e dar sustentação às condições de qualidade e à produtividade desses mananciais ao longo do tempo, tais como, a necessidade de sustentação econômica da produção de água, o que incluiria a compensação a proprietários e municipalidades pela manutenção das áreas protegidas, como forma de impedir atividades econômicas e industriais poluentes e impactantes, que funcionam também como indutores de novas ocupações. Para isso, instrumentos financeiros de incentivo à proteção foram sugeridos, como a cobrança de uso da água, o pagamento por serviços ambientais e o princípio do poluidor pagador, não se restringido aos disputados e insuficientes recursos do FEHIDRO.

O Projeto Billings também defendia que a sustentação da produção dos recursos hídricos deveria passar pela inserção do habitante no resgate da qualidade desse ambiente, que poderia ser iniciado pela recuperação das condições sanitárias do perímetro imediato de sua unidade habitacional, e também por meio de atividades de recuperação ambiental que se constituíssem 
como alternativas de geração de emprego e renda ${ }^{36}$. A recuperação deveria ser incorporada também ao trabalho dos funcionários públicos, através de programas de formação específica e aperfeiçoamentos para o desenvolvimento de suas práticas.

O controle social do desenvolvimento e implementação do Projeto tinha como objetivo garantir a continuidade das ações independentemente das trocas de governos, por meio da criação de um sistema de gerenciamento e de auditoria ambiental independente e a difusão do estabelecimento de compromissos formais, do tipo utilizado para a regularização ou reparação de danos ambientais. A disponibilidade contínua de informações e de indicadores para a população estariam também acessíveis para a tomada de decisão política.

Esses pontos centrais ilustram que o Projeto Billings fora concebido por uma diversidade de ações com diferentes abrangências, escalas e atribuição de responsabilidades entre as esferas de governo. Mas o cerne de suas proposições era conseguir, por meio de ações combinadas e multiescalares, reorientar o crescimento urbano para fora da Bacia da Billings, pautando ações simultâneas de recuperação e proteção, ou seja, a qualificação da ocupação precária existente tinha o mesmo peso e importância que as alternativas de usos econômicos para a proteção nas áreas não ocupadas intensamente e portanto mais preservadas da bacia. A função de produção de água tinha como premissa a proteção e apresentava uma perspectiva crítica quanto às consequências de implementação de infraestruturas em loteamentos. Mas, também considerava a pesquisa de alternativas para o tratamento de esgotos e da poluição difusa.

Contudo, o que the faltou foram os recursos financeiros para sua implementação, que ficou prejudicada com o andamento de ações desenvolvidas pelo próprio governo estadual, na sua sequência. Entretanto a falta de financiamento não foi a única barreira à implementação do Projeto Billings na sua integridade. Por um lado, Renato Tagnin ${ }^{37}$ - coordenador do estudo à época - pondera que alguns programas elaborados, de fato foram levados adiante, como, por exemplo, a melhoria do sistema de monitoramento da qualidade da água no corpo do reservatório, que passou a abranger mais pontos e uma quantidade maior de componentes, adotado pela Cetesb. Por outro lado, ele explica que apesar do projeto ter sido negociado junto a cada órgão estadual e com Consórcio do $A B C$, a hegemonia dos setores de obras hidráulicas e de energia, que assumiram os planos e projetos subsequentes, como por exemplo, o Plano de Bacia do Alto Tietê, desconsideraram grande parte das premissas e dos conteúdos do Projeto Billings.

Em paralelo, havia também o interesse de consolidar o Programa Guarapiranga como um grande caso de sucesso a ser reconhecido nacional e internacionalmente, tanto por parte da Prefeitura de São Paulo como por parte do Banco Mundial, com isso reforçando a realização de obras de

\footnotetext{
${ }^{36}$ Segundo documento do Projeto Billings, dessa forma seriam criadas alternativas de trabalho para atividades de pequenas oficinas ou indústrias informais de "fundo de quintal" altamente poluentes, que não são sujeitas a controle. Essas últimas foram identificadas como reflexo do desemprego industrial que atingiu a Região do $A B C$, forçando a busca de outras fontes de renda, agora exercida de forma clandestina nas frágeis áreas de mananciais.

37 Informação verbal em entrevista concedida à autora em 29/11/2011.
} 
urbanização, ainda que estas apresentassem problemas quanto à melhoria ambiental devido a sua dispersão no território da bacia, tema que será retomado adiante.

Apesar da importância das obras de urbanização do ponto de vista da melhora da condição urbana e ambiental nos assentamentos precários e na saúde da população - o que também apresentava variações dependendo do projeto realizado e das soluções adotadas - não se pode deixar de considerar que ao mesmo tempo se formou um grande campo de trabalho para consultorias e um vasto campo de obras de infraestrutura a realizar. Com a experiência acumulada do Programa Guarapiranga, nesse momento já havia uma rede de empresas de consultoria técnica e construtoras que prestavam serviços à PMSP, à Sabesp e à SMA e que tinham grande interesse na continuidade e ampliação desse Programa. As empresas de consultoria que aprenderam e desenvolveram acervo técnico nos estudos realizados, ao mesmo tempo passavam a concentrar as informações e o modo de operar os projetos em área de manancial. Um sucinto levantamento dos currículos dessas empresas mostra que, desde a concepção do Programa Guarapiranga, são praticamente as mesmas que atuam nos projetos em APM até hoje ${ }^{38}$.

Portanto, os arranjos políticos construídos até então com o Projeto Billings não foram aproveitados para a elaboração do PDPA da Billings e nem para a minuta de sua lei específica. Adicionalmente, a falta de interesse do governo do estado, na gestão de Mário Covas (19992001), na aprovação das leis específicas ficou clara no começo do ano 2000, quando diminui significativamente sua participação nos órgãos colegiados do Subcomitê.

Em contraponto, os municípios tinham grande interesse em manter os trabalhos e pressionar pela alteração da LPM na Billings. Por isso, o Consórcio do ABC contratou a consultoria da Fundação para o Desenvolvimento da Unesp (FUNDUNESP) que elaborou as “Diretrizes para a Lei Específica e o Plano de Desenvolvimento e Proteção Ambiental (PDPA) da Área de Proteção aos Mananciais (APRM) Billings-Tamanduateí", recuperando conteúdos dos estudos anteriores, com o objetivo de subsidiar os municípios para que eles formulassem uma minuta de lei específica e, em seguida, a colocassem em debate no Sistema de Recursos Hídricos ${ }^{39}$. Mas o PDPA da Billings não chegou a ser sistematizado e concluído naquele momento. Ao mesmo tempo, o Município de São Paulo passa a integrar o grupo de discussão e traz a experiência da

\footnotetext{
${ }^{38}$ Essas informações podem ser aferidas nos sites dessas empresas, a exemplo da JNS e Cobrape, que atuam junto à PMSP e Governo do Estado de São Paulo há muitos anos. A Cobrape foi contratada pela Sabesp para a Elaboração do Pedido de Financiamento e Formulação do Programa de Saneamento Ambiental da Bacia da Guarapiranga entre 1991 e 1992. Em seguida desenvolveu diversos trabalhos de gerenciamento desse programa na sua fase 1 (1993 a 1998), fase 2 (1998-2000), fase 3 (2000-2001) e avaliação de seu resultado, contratada pelo Governo do Estado de São Paulo, através da Secretaria de Recursos Hídricos, Saneamento e Obras. Desenvolveu projetos de urbanização de favelas do Programa Guarapiranga e Estudos de Concepção para Expansão do Sistema de Esgotos Sanitários e Reavaliação de Estudos das Bacias da Represa Billings - contratada pela Sabesp (1997-1998). Elaborou o Programa de Saneamento Ambiental dos Mananciais da Bacia Hidrográfica do Alto Tietê, contratada pela Secretaria de Energia, Recursos Hídricos e Saneamento (2004 - 2005), e a Avaliação da Infraestrutura Existente de Tratamento de Esgoto, Saneamento, Drenagem e Água Pluvial, para o Estudo de Melhoramento Ambiental da Bacia Hidrográfica da Represa Billings (Plano Diretor de Intervenções) contratada pela empresa japonesa NJS Consultants Co. Ltd. e financiada pela Japan International Cooperation Agency (Jica) (2005 - 2006). Fonte: http://www.cobrape.com.br/portfolio.php, acesso em 04/11/2011.

39 Informação verbal conforme entrevista de Patrícia Lorenz, concedida à autora em 26/07/2012.
} 
elaboração da minuta de LE-APRM Guarapiranga, que havia sido concluída em 2000, contribuindo para que esse modelo fosse replicado na Billings.

A demora na aprovação da minuta da LE-Guarapiranga, de 2000 a 2006, com o governo estadual "fora de cena" - o que expressava o desinteresse político na sua aprovação, interferiu na elaboração da LE-Billings que ocorria em paralelo, desestruturando e dificultando o trabalho que estava se construindo ${ }^{40}$. Mesmo enfraquecidos, os grupos de trabalho formados na Câmara Técnica de Planejamento e Gestão do Subcomitê Billings deram andamento as atividades técnicas relativas a elaboração da LE-Billings. A sociedade civil organizada também desempenhou papel ativo nos debates relativos à nova lei, e sua pauta central eram a regularização fundiária e instalação de infraestrutura.

A participação do governo estadual ganhou novo fôlego a partir de 2004, com a mudança de atuação do Secretário de Meio Ambiente, José Goldemberg (gestão de 2002 a 2006), que encaminhou a LE-Guarapiranga para aprovação.

Nesse período, outras iniciativas da sociedade civil incrementaram e impulsionaram o debate político e técnico sobre o destino da Bacia da Billings e sua legislação, produzindo conteúdos de forma participativa, em paralelo aos estudos técnicos contratados pelo Estado.

- Em 2002 houve o Seminário Billings 2002 (Instituto Socioambiental - ISA) que produziu um conjunto de recomendações gerais para a bacia, elaborado de forma participativa, e também o "Estudo sobre criação de Unidades de Conservação" (ISA/Fundação Florestal).

- Em 2005, foi feito o "Estudo sobre o Plano Integrado de Melhora Ambiental na Área de Mananciais da Represa Billings no Município de São Bernardo do Campo" (NJS/Yachiyo Engineering Co. Ltd./Jica) e também a "Indicação de áreas de intervenção e respectivas diretrizes e normas ambientais e urbanísticas de interesse regional na bacia hidrográfica Billings" (PRIME/CPLA/CPLEA).

- Em 2006, foi realizado o "Projeto: Avaliação da Implementação das propostas de ação e recomendações resultantes do Seminário Billings 2000", que resultou na produção de informações técnicas necessárias à elaboração da Lei Específica (ISA).

- Em 2008, foi lançada a publicação "Contribuições para a elaboração de leis específicas de mananciais: o exemplo da Billings" (ISA), que apresentou uma apreciação crítica sobre os pontos frágeis da minuta de Lei Específica, principalmente no que se refere às áreas de expansão urbana em áreas não ocupadas.

\footnotetext{
40 Conforme declaração de Márcia Nascimento, arquiteta que coordenou o grupo de trabalho por parte da SMA, corroborado por Patrícia Lorenz, que na época era representante da Prefeitura de Santo André no Subcomitê da Billings e coordenadora da Câmara Técnica de Planejamento e Gestão.
} 
Com o conjunto de informações produzidas, inclusive com a adaptação do modelo MQUAL para a Bacia da Billings, o modelo da LE-APRM Guarapiranga foi transposto para a LE-Billings, como já comentado.

Em 2009, após esse longo processo de discussões que ocorreu no âmbito do Subcomitê BillingsTamanduateí, foi promulgada a Lei no 13.579/2009, que Define a Área de Proteção e Recuperação dos Mananciais da Bacia Hidrográfica do Reservatório Billings - APRM-B, bem como regula a ocupação, preservação e recuperação desse manancial ${ }^{41}$.

Dentre os motivos que impulsionaram a aprovação da LE-APRM Billings está a aprovação da LEAPRM Guarapiranga ${ }^{42}$. Mas consideramos também relevante a concomitância do período de finalização dessa lei e o período de elaboração do Programa Mananciais da Bacia do Alto Tietê pelo governo estadual, cujo acordo de empréstimo foi firmado em 2008, ampliando a abrangência do financiamento do Banco Mundial para outros pontos desta Bacia, visando garantir o financiamento para obras de saneamento e urbanização, o que será melhor abordado no capítulo 8, a seguir. Também estavam em andamento o financiamento do PAC, do governo federal e da Jica, do governo japonês, para a Sabesp em São Bernardo. Nesse contexto, a aprovação da Lei Específica permitindo a regularização fundiária de interesse social, acompanhada da instalação de infraestruturas em assentamentos precários, seria estratégica para viabilizar tais projetos, numa escala ampliada de intervenções.

Considerando os diversos interesses envolvidos na aprovação da Lei Específica da APRM-Billings - particularmente dos municípios e da população residente na área protegida -, bem como as disputas pelo território da bacia e a concorrência pelo uso dos recursos hídricos para diferentes finalidades, brevemente apresentados nesse item, analisam-se a seguir os aspectos centrais dessa lei e sua implicação na ocupação atual da bacia da Billings.

\subsection{Lei Específica da APRM Billings: um instrumento de planejamento urbano e ambiental?}

A Lei Específica da APRM-Billings (LE-Billings) no 13.579 promulgada em de 13 de julho 2009, junto com o Decreto № 55.342 de 13 de janeiro de 2010, é o instrumento que atualmente estabelece a regulamentação de uso e ocupação do solo nessa bacia hidrográfica, com o objetivo central de promover sua recuperação e proteção para finalidade prioritária de

\footnotetext{
${ }^{41} \mathrm{O}$ trâmite de encaminhamento do projeto de lei à sua aprovação se deu na seguinte sequência: 1) Em 16 de setembro de 2008, Francisco Graziano Neto, Secretário do Meio Ambiente, encaminhou projeto de lei ao governador José Serra por meio do Ofício SMA/GAB 298/2.008 (Ref. Processo: SMA n? 15.397/2007). 2) Em 24 de setembro de 2008, por meio da Mensagem no 151/08, o Governador do Estado São Paulo José Serra encaminhou Projeto de Lei no 639, ao Presidente da Assembléia Legislativa do Estado, o Deputado Vaz de Lima. 3) Em 4 de junho de 2009, foram feitas emendas aglutinativas ao projeto de lei no 639 de 2008, compatibilizando o texto original às sugestões apresentadas no curso do processo legislativo. 4) A Lei no 13.579 foi aprovada em de 13/07/2009. Define a Área de Proteção e Recuperação dos Mananciais da Bacia Hidrográfica do Reservatório Billings - APRM-B, e dá providências correlatas. 5) O Decreto № 55.342, de 13 de janeiro de 2010 - Regulamenta dispositivos da Lei no 13.579/2009.

${ }^{42}$ Conforme avaliado por Márcia Nascimento, em entrevista concedida à autora em 25/10/2012.
} 
abastecimento metropolitano ${ }^{43}$, à semelhança da LE-APRM Guarapiranga. Por se tratar de uma lei específica, busca adequar-se às características da Bacia da Billings, que abrange seis municípios ${ }^{44}$ nos quais a ocupação urbana e rural apresentam características distintas, formando um grande mosaico de usos.

O discurso político e a justificativa técnica que dão suporte à Lei Específica amparam-se no esforço de torná-la mais adequada, adaptada ou mais "aderente" à realidade urbana existente na Bacia da Billings. Esses termos estão presentes em grande parte dos estudos técnicos que subsidiaram sua elaboração. Uma questão que logo se levanta é de que modo a lei se adéqua à realidade? Dois aspectos centrais expressam essa intenção da lei: a permissão da regularização fundiária acompanhada da instalação de infraestruturas nos assentamentos precários (desde que formulados os PRIS) e a correlação entre os diferentes tipos de uso do solo e a poluição gerada por cada um deles. Mas, para debatê-los, é preciso antes situar os principais conteúdos dessa lei.

A Lei Específica da Billings criou um conjunto de regulamentações relativas à gestão dessa APRM, formas de financiamento, licenciamento ${ }^{45}$, instrumentos de monitoramento da qualidade da água, instrumentos para compensação ambiental e instrumentos de planejamento territorial.

Em relação ao modelo de gestão, a Lei criou o Sistema de Planejamento e Gestão (vinculado ao Sistema Integrado de Gerenciamento de Recursos Hídricos - SIGRH), cujo órgão colegiado, de caráter consultivo e deliberativo, é o Comitê de Bacia Hidrográfica do Alto Tietê - CBH-AT (que poderá delegar suas atribuições ao Subcomitê Billings-Tamanduateí) e cujo órgão técnico é a Agência de Bacia Hidrográfica do Alto Tietê (com um escritório regional) ${ }^{46}$. Os órgãos e entidades da Administração Pública Estadual e Municipal são responsáveis pelo licenciamento, fiscalização e monitoramento ambiental e exercem atividades normativas, de planejamento, de gestão, de

\footnotetext{
${ }^{43}$ Atualmente, o principal uso do reservatório é o abastecimento público. Próximo à Barragem Anchieta, localiza-se uma estação de captação de água da Companhia de Saneamento Básico do Estado de São Paulo - Sabesp, responsável pela obtenção, na Estação de Tratamento de Água Rio Grande, de $4,7 \mathrm{~m}^{3} / \mathrm{s}$ de água para os municípios de Diadema, São Bernardo do Campo e parte de Santo André, para cerca de 1,6 milhões de habitantes. A primeira iniciativa para a ampliação do uso da Billings para o abastecimento público, utilizando outras áreas da Represa além do Braço do Rio Grande, foi a sua interligação com a Represa Guarapiranga, através do braço Taquacetuba, cuja operação de bombeamento, de até $4 \mathrm{~m} 3 / \mathrm{s}$, teve início em agosto de 2000. Nos próximos anos, a contribuição da Represa para o abastecimento deve aumentar, através da captação de água no braço do Rio Pequeno (PDPA Billings, 2011).

${ }^{44}$ Porcentagem do território municipal inserido na bacia: Diadema 23,68\%, Ribeirão Pires 64,32\%, Rio Grande da Serra 100\% (na totalidade), Santo André 54,82\%, São Bernardo do Campo 52,67\% e São Paulo 10,86\% (CAPOBIANCO; WHATELY; 2002, p.12).

${ }^{45}$ Que pode vir a ser realizado pelo município, desde que este faça parte do Sistema Nacional do Meio Ambiente, possuindo Diretoria/Secretaria, Conselho e Fundo Municipal de Meio Ambiente, além de terem firmado convênio com o órgão estadual licenciador que termina uma ação supletiva (Art. 23 da Constituição Federal, Lei Federal 140/11, Resolução Conama no 237/97).

${ }^{46}$ Conforme Artigo 10 das Disposições Transitórias da LE-Billings, até que seja criado o Escritório Regional da APRM-B, o órgão técnico do Sistema de Planejamento e Gestão da APRM-B é a Secretaria do Estado do Meio Ambiente, na forma a ser disciplinada por resolução do Titular da Pasta.
} 
uso e ocupação do solo, de controle e fiscalização de proteção dos recursos hídricos de interesse da APRM-B. O órgão estadual responsável pelo licenciamento é a Cetesb ${ }^{47}$.

Além dos objetivos já citados, estão:

- integrar os programas e políticas regionais e setoriais, especialmente aqueles referentes a habitação, uso do solo, transportes, saneamento ambiental, infraestrutura, educação ambiental, manejo de recursos naturais e geração de renda, necessários à preservação do meio ambiente;

- estabelecer diretrizes e parâmetros de interesse regional para a elaboração das leis municipais de uso, ocupação e parcelamento do solo, com vistas à proteção do manancial;

- incentivar a implantação de atividades compatíveis com a preservação, conservação, recuperação e proteção dos mananciais;

- propiciar a recuperação e melhoria das condições de moradia, implementando-se a infraestrutura de saneamento ambiental adequada e as medidas compensatórias para a regularização urbanística, ambiental, administrativa e fundiária destas áreas assegurando-se o acesso aos equipamentos urbanos e comunitários e aos serviços públicos essenciais; bem como garantir programas de redução com obras preventivas ou eliminação de áreas consideradas de risco;

- manter a integridade das Áreas de Preservação Permanente, dos remanescentes de Mata Atlântica e Unidades de Conservação, de forma a garantir a proteção, conservação, recuperação e preservação da vegetação e diversidade biológica natural;

- garantir a transparência das informações sobre os avanços obtidos com a implementação desta lei específica e suas metas.

Esses objetivos são coerentes quando se elege a Bacia da Billings para o abastecimento metropolitano público de água. Mas a avaliação crítica das leis precedentes, em relação à sua inadequação ante a dinâmica de produção e expansão do espaço metropolitano paulista, tipicamente segregadora, deve ser recuperada para uma análise da LE-Billings, ainda que o contexto seja diferente da década de 1970, e ponderações quanto aos avanços alcançados sejam necessários. Nessa perspectiva, a reflexão sobre possíveis impactos da LE nos municípios da bacia e em especial em São Bernardo (onde foi desenvolvido o estudo) deve, ao menos, considerar os conflitos de uso e de interesses que convivem nesse espaço e que representam limites ao alcance de tais objetivos.

Além da diversidade de usos e densidades de ocupação, a Bacia da Billings ainda apresenta grande extensão de área preservada (44\% da área total da bacia, conforme tabela 12, a seguir),

\footnotetext{
47 A Lei estadual no 13.542, de 8/05/2009, Alterou a denominação da CETESB - Companhia de Tecnologia de Saneamento Ambiental para Companhia Ambiental do Estado de São Paulo, e atribuiu a ela o licenciamento de atividades em área de proteção aos mananciais.
} 
relevante para a manutenção da vegetação e produção de água. Todavia, a disputa por esse território se trava em diversos níveis e faz com que a área de proteção aos mananciais não perca o caráter potencial de fronteira de expansão, comprometendo sua finalidade prioritária. Isso pode ser verificado a partir de diferentes projetos e obras ${ }^{48}$, que se somam ao conflito inicial da utilização do recurso hídrico para geração de energia.

Em relação à demanda habitacional, observa-se que o crescimento populacional e construtivo tem ocorrido com mais expressividade em áreas próximas ou internamente aos assentamentos existentes, aumentando a densidade dessas áreas consolidadas na precariedade (WHATELY, 2009, p.56). Diante desse quadro, os planos municipais de habitação - a exemplo de São Bernardo do Campo - já indicam a necessidade de se repensar o padrão de ocupação no próprio manancial, pois projetos de urbanização e saneamento têm gerado uma porcentagem de remoção da população que varia de 30 a $40 \%{ }^{49}$ dependendo da situação do assentamento e do projeto, ou seja, a demanda por áreas de reassentamento é bastante significativa.

Por outro lado, há que se questionar o argumento da ausência de terras fora das áreas protegidas e nos bairros consolidados. A política habitacional ainda se pauta pela obtenção de terras a preços acessíveis, que viabilizem os empreendimentos, ainda disponíveis na periferia geográfica da cidade, cuja fronteira se distancia cada vez mais das áreas centrais. Mas tanto os municípios como o Estado, apoiados em argumentos financeiros, não se contrapõem à valorização imobiliária em curso, em bairros situados fora de áreas protegidas, para viabilizar a aquisição de terrenos ou edifícios para a provisão de HIS em bairros centrais. E o argumento da ausência de terrenos acessíveis pelo poder público, por causa do preço da terra, mantém essa dificuldade, sem que se implementem outro instrumentos de controle fundiário. Essa concorrência é muito desigual.

Assim, a destinação de áreas para a construção de HIS dentro das áreas de mananciais tem se mostrado estratégica para garantir o reassentamento decorrente de intervenções de urbanização em áreas consideradas de urbanização complexa e que passam por desadensamento (remoção de moradores).

Mas a pressão por área urbana não se limita ao problema habitacional, ainda que esse seja eleito como o grande vilão da degradação. Os municípios têm interesse em incentivar atividades econômicas lucrativas (tanto por parte da municipalidade como dos proprietários de terras locais e de agentes empreendedores). Os municípios que ainda apresentam maiores áreas protegidas e que não recebem compensações financeiras por isso, enxergam na preservação a restrição ao seu desenvolvimento econômico. E os que apresentam áreas mais ocupadas, tendem a incentivar ainda mais as atividades econômicas. Além disso, o governo do Estado promove obras rodoviárias de grande impacto, sem implementar as devidas compensações

\footnotetext{
${ }^{48}$ Além dos projetos de urbanização de assentamentos precários, há projetos de grande porte tais como o Rodoanel Viário Metropolitano, já construído, e projetos em elaboração, como o Monotrilho e o Hidroanel metropolitano.

${ }^{49}$ Conforme o Plano Local de Habitação de Interesse Social de São Bernardo do Campo, (2012, p.77), a porcentagem de remoção de $40 \%$ foi aferida pela Prefeitura a partir das obras de urbanização complexa realizadas, ou seja, intervenções em assentamentos consolidados com alto grau de precariedade e ausência de infraestrutura.
} 
(como parques e plantios), a exemplo do Rodoanel, cuja consequência também é a atração de atividades de logística (galpões, armazéns) associados ao transporte de cargas $^{50}$. O controle desse território passa, portanto, por diferentes projetos dentro do próprio governo estadual e municipal.

Nesse sentido, podemos dizer que as normas lidam com uma situação de tensão, que se estabelece em meio à constante pressão da ocupação urbana sobre as áreas mais preservadas, internamente ao município e na escala metropolitana. Esta tensão também se explicita a partir do duplo objetivo da lei, ou seja, recuperar e proteger o manancial. E seu processo de elaboração, ainda que não de modo explícito, evidencia a dimensão de disputa sobre esse território.

A recuperação ambiental, por sua vez, está associada ao saneamento e regularização dos assentamentos precários, o que garantiria reduzir o aporte de poluição afluente à represa. Já a proteção é pautada por mecanismos de obtenção de recursos, a cobrança pelo uso da água e os recursos provenientes de compensações financeiras, de forma a incentivar os municípios a manterem suas áreas preservadas, mas esses instrumentos não são autoaplicáveis a partir da própria $L E$, é um tema usualmente postergado e em debate, ainda que tenha havido algum avanço nesta direção. Apesar de não detalhar, a lei incorpora o pagamento por serviços ambientais como um dos instrumentos de incentivo a preservação. Com isso, o desequilíbrio entre ações de recuperação - cujos instrumentos são de aplicação mais direta - e as relativas à proteção, é evidente.

Considerando a dimensão da tensão e da disputa, a abordagem de alguns aspectos da legislação tem como interesse salientar de que forma suas premissas e parâmetros urbanísticos influem e direcionam as intervenções na bacia, particularmente na relação que se estabelece entre os projetos de urbanização de assentamentos precários e o sistema de infraestrutura de saneamento metropolitano. Nessa perspectiva cabe discutir em maior detalhe dois instrumentos centrais da LE-Billings: o Modelo de Correlação entre o Uso do Solo e a Qualidade da Água MQUAL e Mapa das áreas de intervenção e os respectivos parâmetros urbanísticos, enfocando os parâmetros de regularização de interesse social.

\subsubsection{O Modelo de Correlação entre o Uso do Solo e a Qualidade da Água - MQUAL}

O Modelo de Correlação entre o Uso do Solo e a Qualidade da Água - MQUAL é a ferramenta de planejamento e gestão que foi desenvolvida ainda na primeira etapa do Programa Guarapiranga $^{51}$ e que posteriormente fundamentou as leis específicas da Guarapiranga e da Billings. Diferentemente da LPM no 1.172/1976 que estabelecia o controle do uso e ocupação

\footnotetext{
50 O Plano Diretor do município, por sua vez, já previu essa atividade, demarcando zonas especiais de interesse empresarial.

${ }^{51}$ A primeira versão da modelagem matemática foi feita para a bacia do Guarapiranga em 1997, e ao longo dos anos passou por aprimoramentos e novas versões, incorporando novos elementos e índices a serem considerados na avaliação da qualidade da água em meio urbano e rural, até a última versão de 2006 (SÃO PAULO, 2011).
} 
do solo por meio da densidade populacional, esta define uma ferramenta de controle de poluição que relaciona as categorias de uso do solo da bacia com a carga de fósforo gerada por cada uma delas, ou seja, que chega ao reservatório.

Como ilustram as tabelas a seguir, áreas urbanas consideradas de padrão inferior, ou seja, assentamentos precários sem infraestrutura, compõem o uso que mais gera mais carga de fósforo, seguido de usos industriais, áreas urbanas de padrão superior (com infraestrutura) e atividades agrícolas.

Tabela 11 - Coeficiente de exportação de tempo seco do MQUAL 2.0.

\begin{tabular}{lc}
\hline Fonte & $\begin{array}{c}\text { Fósforo total }(\mathbf{p}) \\
\mathbf{k g} / \mathbf{k m}^{2} \cdot \text {.dia }\end{array}$ \\
\hline Capoeira/Campo & 0,001 \\
Reflorestamento & 0,002 \\
Mata/Capoeirão & 0,002 \\
Chácaras & 0,005 \\
Atividade Agrícola & 0,066 \\
Áreas urbanas - Padrão superior & 0,136 \\
Áreas de uso industrial e comercial & 0,193 \\
Áreas urbanas - Padrão inferior & 0,272 \\
\hline
\end{tabular}

Fonte: Secretaria de Estado de Meio Ambiente. Plano de Desenvolvimento e Proteção Ambiental da Billings, 2011, p.100

Tabela 12 - Uso do solo na Bacia da Billings.

\begin{tabular}{|c|c|c|c|c|}
\hline \multicolumn{2}{|c|}{ Categorias de uso do solo } & \multicolumn{3}{|c|}{ Área ocupada } \\
\hline & & $\begin{array}{c}\text { Área } \\
\text { ocupada } \\
\text { em km² }\end{array}$ & $\begin{array}{c}\text { \% em relação } \\
\text { à área total } \\
\text { ocupada }\end{array}$ & $\begin{array}{c}\text { \% em relação } \\
\text { à área total } \\
\text { da bacia }\end{array}$ \\
\hline \multirow[t]{5}{*}{ Áreas urbanizadas } & Área urbana de alta densidade & 42,89 & 9,02 & 7,36 \\
\hline & Área urbana de baixa densidade & 24,63 & 5,18 & 4,23 \\
\hline & Área de expansão urbana & 16,56 & 3,48 & 2,84 \\
\hline & $\begin{array}{l}\text { Áreas industriais e corredores } \\
\text { comerciais }\end{array}$ & 3,08 & 0,65 & 0,53 \\
\hline & Total & 87,16 & 18,33 & 14,96 \\
\hline \multirow{6}{*}{$\begin{array}{l}\text { Áreas antropizadas } \\
\text { não urbanas ou } \\
\text { com cobertura } \\
\text { vegetal } \\
\text { rasteira/dispersa }\end{array}$} & Área de ocupação dispersa & 32,63 & 6,86 & 5,60 \\
\hline & Agricultura & 9,05 & 1,90 & 1,55 \\
\hline & Reflorestamento & 13,88 & 2,92 & 2,38 \\
\hline & Mineração & 1,55 & 0,33 & 0,27 \\
\hline & Campo & 73,24 & 15,40 & 12,57 \\
\hline & Total & 130,35 & 27,41 & 22,37 \\
\hline \multirow{4}{*}{$\begin{array}{l}\text { Áreas com } \\
\text { cobertura vegetal } \\
\text { mais conservada }\end{array}$} & Vegetação de várzea & 12,67 & 2,66 & 2,17 \\
\hline & Capoeira & 27,69 & 5,82 & 4,75 \\
\hline & Mata & 217,60 & 45,77 & 37,34 \\
\hline & Total & 257,96 & 54,25 & 44,26 \\
\hline
\end{tabular}

Fonte: Secretaria de Estado de Meio Ambiente. Plano de Desenvolvimento e Proteção Ambiental da Billings, 2011, p.41. 
O estudo de uso e ocupação do solo da Bacia da Billings em 2006, somado ao estudo de cargas de fósforo geradas por cada tipo de ocupação e nos corpos d'água ${ }^{52}$ resultou em uma carga meta para o reservatório Billings de $281 \mathrm{~kg}$ de fósforo por dia. Segundo os estudos técnicos da SMA, essa é a referência que garante o uso do reservatório para abastecimento público. Não entraremos em detalhe sobre o cálculo que resultou nessa meta, mas faremos algumas ponderações sobre como esse modelo altamente maleável - como qualquer modelo matemático, que muda conforme as variáveis adotadas - e ainda em fase de aprimoramento ${ }^{53}$ é utilizado de forma rígida na LE-Billings, o que coloca alguns problemas sobre a forma como será aplicado.

Devido à sua extensão e diversidade, a Bacia da Billings foi subdividida em compartimentos ambientais para os quais foram estabelecidas metas da qualidade de água - que se baseiam na redução de carga de fósforo gerada em cada um deles. Esta meta deverá ser atingida até o ano de 2015, sendo que o Plano de Desenvolvimento e Proteção Ambiental - PDPA deverá estabelecer metas intermediárias, a serem monitoradas a cada quatro anos (pelo Sistema de Monitoramento e Avaliação Ambiental a ser estabelecido em regulamento e detalhado no PDPA).

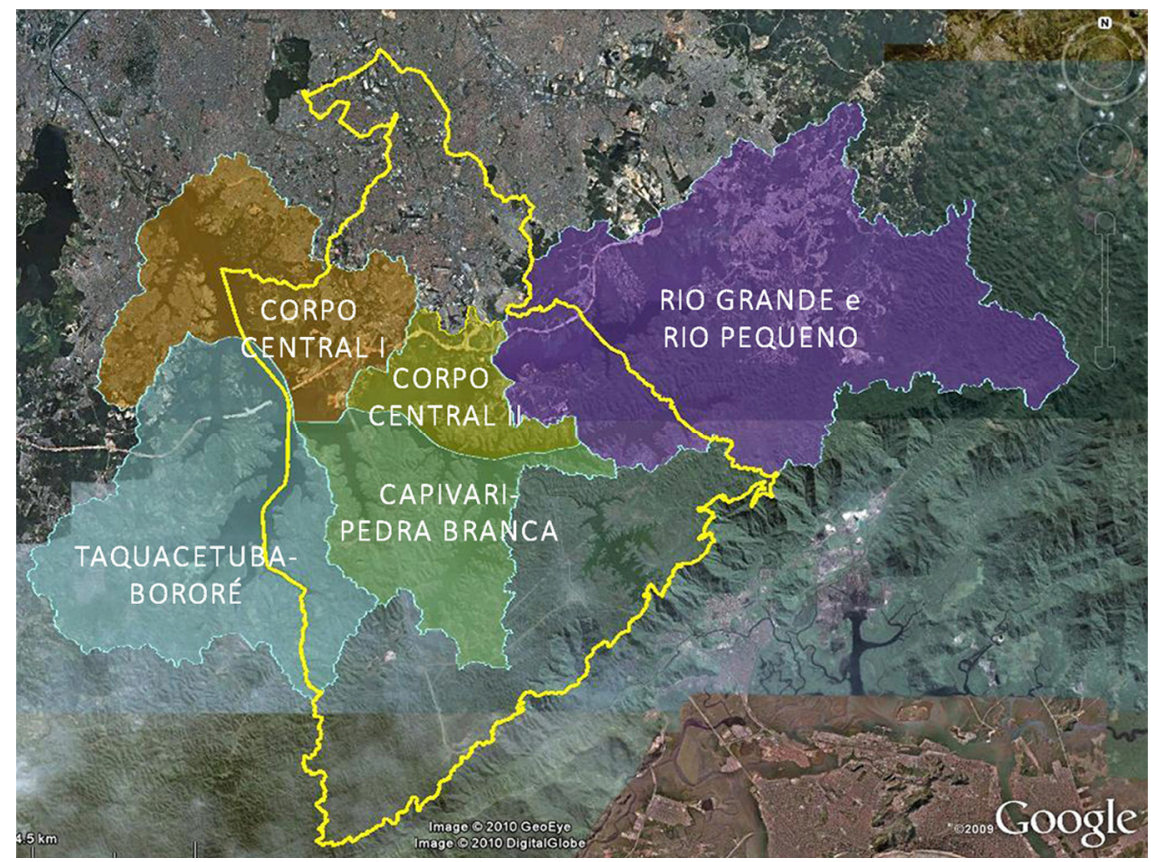

Figura $\quad 63$

Compartimentos Ambientais.

Fonte: Secretaria de Planejamento de São Bernardo do Campo, 2011.

Adicionalmente, a carga máxima de fósforo também é definida para cada município, ou seja, municípios com ocupação mais densa e extensa apresentam metas maiores de redução de poluição do que aqueles que apresentam áreas mais protegidas. O monitoramento deve ser feito no braço receptor e atualmente é feito pela Cetesb e Sabesp em pontos do reservatório.

\footnotetext{
52 O MQUAL é constituído por três módulos, cada um deles representando os fenômenos de geração e abatimento das cargas poluidoras nos três ambientes considerados: a superfície do terreno, onde estão as fontes de cargas poluidoras; os rios principais e seus afluentes e, por fim, o reservatório. E são consideradas tanto as cargas de poluição difusa como pontuais (SÃO PAULO, 2011, p.98).

53 O PDPA da Billings indica recomendações para aprimoramento desse modelo.
} 


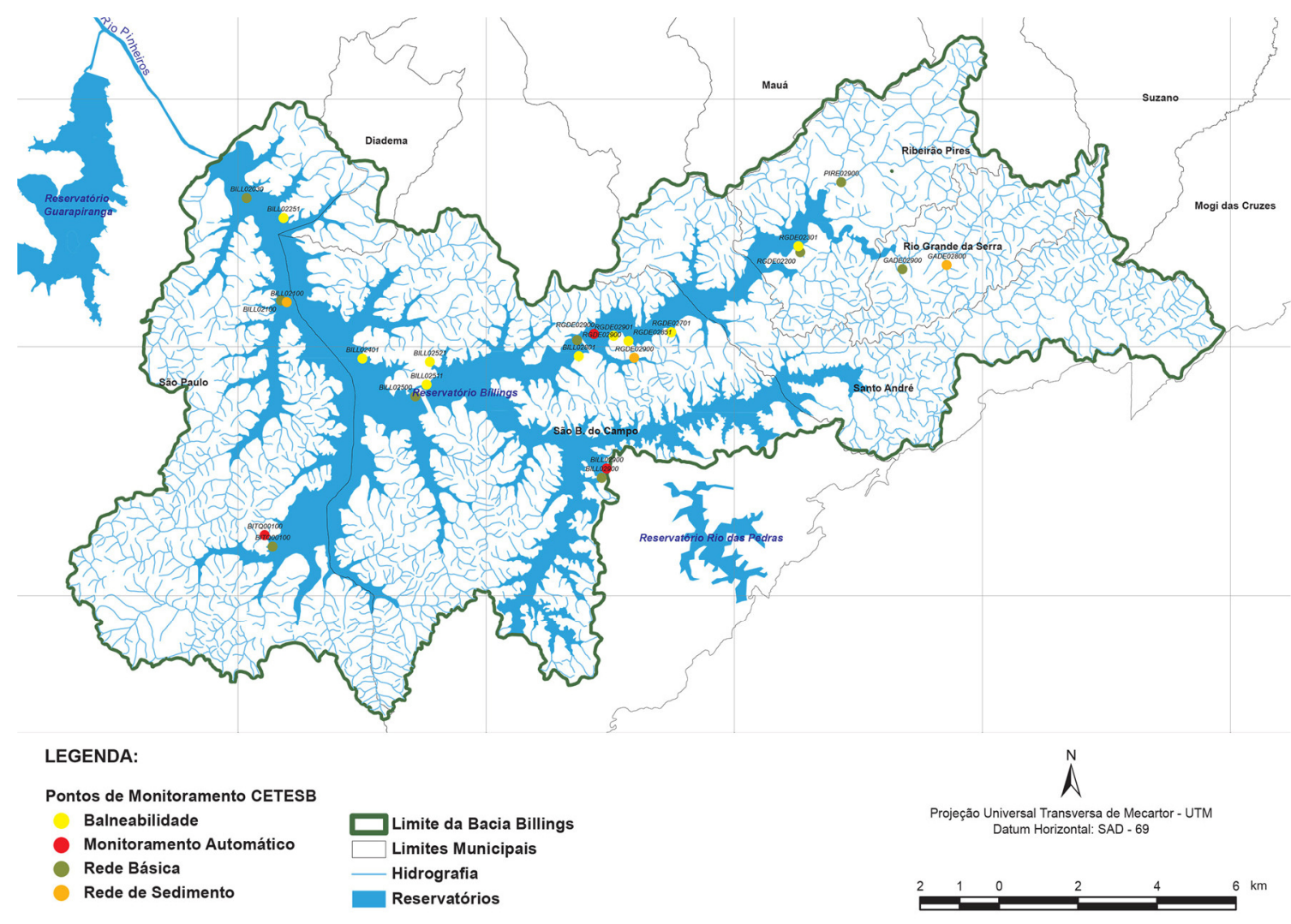

Mapa 25 - Pontos de monitoramento da Cetesb.

Fonte: São Paulo (Estado); SMA/CPLA; Cobrape. Plano de Desenvolvimento e Proteção Ambiental da APRM-Billings 2011.

No entanto, a sobreposição desses dois recortes territoriais - o compartimento ambiental e o município - gera dificuldades para aferição de carga meta por município, já que sua delimitação espacial não é compatível com o dos compartimentos ambientais e a situação da execução de obras de saneamento em cada município apresenta estágio também distinto. A situação mais difícil nesse sentido está colocada para São Bernardo do Campo, que apresenta porções de seu território em cada compartimento ambiental. O PDPA da Billings sugere que novos pontos de monitoramento sejam acrescentados e salienta a importância de debate técnico para aperfeiçoamento do instrumento, mas não equaciona essa questão.

Publicado após a LE-Billings, o PDPA da Billings (2011) explicita alguns limites desse modelo, a partir dos cenários elaborados para a Bacia. No primeiro cenário, que considerava a situação atual da ocupação em 2006 sem melhorias de saneamento, a carga de fósforo gerada era de $1.205 \mathrm{~kg} / \mathrm{dia}$, evidentemente muito superior à carga meta definida em lei de $281 \mathrm{~kg} / \mathrm{dia}$. Nos cenários tendenciais para os anos de 2011 e 2015, as condições de infraestrutura presentes em 2006 foram mantidas, assim como a proporção da população urbana e em favela. No cenário futuro, que considera a previsão de investimentos existentes sendo completamente executados até 2015 , chega-se a uma carga de $383 \mathrm{~kg} / \mathrm{dia}$, também superior ao limite da lei (SÃO PAULO, 2011, p.104). Portanto, o próprio PDPA conclui que os investimentos previstos são insuficientes para garantir o alcance da carga meta, ainda que ocorra uma melhora significativa na qualidade de água da Billings, ou que os municípios consigam atingir as metas intermediárias. Assim, o plano chama a atenção para a necessidade de investimentos adicionais, para que se atinja a 
carga meta da lei (Ibidem, p.114). Portanto, mal a lei foi aprovada, já necessita de revisão das cargas metas.

Tabela 13 - Cargas de Fósforo Total Geradas por região hidrográfica, município e compartimento ambiental no cenário atual (ano de referência 2006), em comparação com a carga meta da LE-Billings.

\begin{tabular}{|c|c|c|c|c|c|c|}
\hline \multirow[b]{2}{*}{ MUNICÍPIO } & \multirow{2}{*}{$\begin{array}{l}2006 \\
\text { Atual }\end{array}$} & \multicolumn{2}{|c|}{2011} & \multicolumn{2}{|c|}{2015} & \multirow{2}{*}{$\begin{array}{l}\text { LE-Billings } \\
P \text { total } \\
\text { (kg/dia) }\end{array}$} \\
\hline & & Tendencial & $\begin{array}{c}\text { Com } \\
\text { Investimentos }\end{array}$ & Tendencial & $\begin{array}{c}\text { Com } \\
\text { Investimentos }\end{array}$ & \\
\hline São Paulo & 690 & 758 & 345 & 790 & 120 & 110 \\
\hline Diadema & 105 & 121 & 50 & 137 & 44 & 14 \\
\hline São Bernardo do Campo & 228 & 143 & 174 & 254 & 93 & 60 \\
\hline Santo André & 30 & 33 & 25 & 36 & 25 & 9 \\
\hline Ribeirão Pires & 104 & 113 & 84 & 119 & 64 & 57 \\
\hline Rio Grande da Serra & 48 & 53 & 47 & 56 & 37 & 31 \\
\hline \multicolumn{7}{|l|}{ Compartimento Ambiental } \\
\hline Corpo Central I & 891 & 978 & 476 & 1.030 & 186 & 135 \\
\hline Corpo Central II & 31 & 34 & 31 & 35 & 34 & 11 \\
\hline Taquacetuba/Bororé & 85 & 93 & 44 & 97 & 24 & 27 \\
\hline Rio Grande/Rio Pequeno & 192 & 210 & 167 & 224 & 133 & 103 \\
\hline Capivari/Pedra Branca & 6 & 7 & 6 & 7 & 6 & 5 \\
\hline Total & 1.205 & 1.321 & 725 & 1.392 & 383 & 281 \\
\hline
\end{tabular}

Fonte: Extraído do Relatório Final "Elaboração do Plano de Desenvolvimento e Proteção Ambiental da Bacia Hidrográfica do Reservatório Billings", SMA/CPLEA/Cobrape, agosto de 2011, p.105. Complementado pela autora.

Apesar dessa previsão já anunciar problemas futuros, há posicionamentos favoráveis à definição de uma carga meta na lei, para obrigar o poder público a implantar infraestruturas de saneamento, independentemente das mudanças de gestão ${ }^{54}$, apesar de não haver uma sanção ${ }^{55}$ definida na lei, para o governo municipal ou estadual, caso a carga meta não seja atendida. A Sabesp tem maior parte nessa responsabilidade, pois atua em quatro dos seis municípios inseridos na Bacia da Billings: São Paulo, São Bernardo do Campo, Ribeirão Pires e Rio Grande da Serra. Os municípios de Diadema e Santo Andre são atendidos, respectivamente, pela Companhia de Saneamento de Diadema (SANED) e pelo Serviço Municipal de Saneamento Ambiental de Santo André (SEMASA). As duas empresas municipais adquirem água da Sabesp e encarregam-se da sua distribuição ${ }^{56}$.

Pode-se dizer que o horizonte de redução de poluição até 2015 é compatível com os prazos estabelecidos nos planos de investimentos de ampliação das redes coletoras da Sabesp, considerando os investimentos previstos, os financiamentos internacionais firmados (Programa Mananciais e Projeto Billings) e o Plano Diretor de Esgotos. Mas há uma grande aposta na

\footnotetext{
${ }^{54}$ Conforme informação verbal de Patrícia Lorenz, em entrevista concedida à autora em 26/07/2012.

${ }^{55}$ A Lei Específica da Billings remete às sanções previstas nos artigos 35 a 44 da Lei Estadual no 9.866/97, que variam conforme a gravidade da infração, de advertência, à embargo da obra ou atividade irregular, à aplicação de multas e perda ou suspensão de financiamentos em estabelecimentos estaduais de crédito.

${ }^{56}$ A Sabesp é responsável pela obtenção de 4,7m3/s de água na Estação de Tratamento de Água Rio Grande, para abastecer os municípios de Diadema, São Bernardo do Campo e parte de Santo André, atendendo cerca de 1,6 milhão de habitantes (SÃO PAULO, 2011).
} 
realização completa dos grandes projetos de saneamento, como a instalação de coletores de esgoto, sem considerar os problemas já conhecidos quanto à execução, a necessidade de desapropriações, os atrasos e problemas não previstos nas obras, que resultam no não cumprimento de prazos previamente estipulados. Soma-se a isso a questão do não tratamento integral dos esgotos na RMSP, ou seja, mesmo que o controle da carga de poluição afluente à represa seja perfeitamente realizado por um município, o tratamento do esgoto continua sendo central e indispensável, ainda mais porque se trata de um sistema único, por exemplo, para todo o $A B C D$ (os esgotos são coletados e levados para ETE do $A B C$ ).

Considerando essas ponderações, ainda que o MQUAL possa se constituir como mais um importante instrumento de planejamento e de tomada de decisão do poder público - municipal e estadual - na Bacia da Billings ${ }^{57}$, sua utilização como premissa da LE específica apresenta problemas e deixa questões em aberto sobre sua efetividade, pois os parâmetros de qualidade da água, do tratamento de esgotos e de padrões de ocupação dependem de muitas variáveis, que são dinâmicas. Além disso, a modelagem matemática pode ser constantemente aperfeiçoada e nesse sentido seria mais adequada a sua utilização como ferramenta de monitoramento do que instrumento definidor de parâmetros urbanísticos. Contudo, melhores avaliações serão possíveis quando o modelo passar a ser utilizado sistematicamente pelas prefeituras, pois a forma de implementá-lo ainda está em estudo na SMA ${ }^{58}$.

\subsubsection{O mapa das áreas de intervenção}

Outro aspecto fundamental da LE-Billings a ser debatido é o mapa que delimita as áreas de intervenção e os respectivos parâmetros urbanísticos que constituem instrumentos de aplicação direta no território da Bacia. Por isso a pertinência de abordá-los, visando problematizar de que forma a LE-Billings orienta, no espaço, a recuperação e proteção desse manancial. Isso implica na leitura do mapa como um todo, sem deixar de lado pontos importantes identificados no processo de sua elaboração, do qual participaram governo do estado, municípios e sociedade civil.

Considerando que a tensão entre recuperação e proteção pode ser evidenciada também por esse mapa, nosso enfoque prioritário refere-se aos parâmetros urbanísticos e ambientais relativos à recuperação ambiental, ou seja, aqueles que incidem sobre as áreas urbanas ocupadas, particularmente os assentamentos irregulares e precários.

Cabe observar que apesar da recuperação ambiental ser um objetivo que aparece em diversos artigos da lei, sua conceituação não é explicitada, podendo variar da recuperação vegetal à

\footnotetext{
${ }^{57}$ Como defende Márcia Nascimento, que participou da montagem de grupo de trabalho da SMA para auxiliar na sua implementação junto aos municípios. Declaração oral em entrevista concedida à autora em 25/10/2012.

58 De acordo com informação verbal de Márcia Nascimento, após a promulgação do Decreto Regulamentador da LEBillings em 2010, foi montado na SMA um Grupo de Monitoramento da Qualidade da Água da Guarapiranga e da Billings, para estruturar e elaborar um termo de referência para viabilizar o programa de monitoramento, junto com a Secretaria de Saneamento e Recursos Hídricos e com verba do Banco Mundial. Até o fechamento da pesquisa não foi possível aferir se esse Grupo está em andamento.
} 
recuperação urbana. Uma conceituação mais precisa é expressa no artigo 31, que define as Áreas de Recuperação Ambiental - ARA como "ocorrências localizadas de usos ou ocupações que estejam comprometendo a quantidade e a qualidade das águas, exigindo intervenções urgentes de caráter corretivo", ou seja, são os assentamentos precários, que dependem de investimentos em saneamento, recomposição vegetal e de melhorias habitacionais para que se minimize o impacto gerado sobre a Bacia. Assim, a noção de recuperação está plenamente articulada ao saneamento. Nesse sentido, a infraestrutura passa a ser fundamental na recuperação ambiental.

Do ponto de vista da produção técnica do mapa, identifica-se um esforço pelo reconhecimento da ocupação real da bacia. Os estudos realizados em 2006, embasaram a delimitação das áreas de intervenção, resultaram do cruzamento de uma série de levantamentos, tais como: o uso do solo em 2006 (analisado a partir de foto de satélite na escala 1:50.000), as tendências de crescimento populacional, os vetores de indução de ocupação, os assentamentos irregulares, os remanescentes florestais, as legislações municipais e a Carta de Aptidão Física ao Assentamento Urbano, editada pela EMPLASA e IPT.

A avaliação das áreas com restrições ambientais à ocupação baseou-se na Carta de Aptidão Física ao Assentamento Urbano, que é um importante instrumento de planejamento, pois indica as áreas com diferentes graus de aptidão à ocupação, segundo as características topográficas e geotécnicas, bem como áreas de inundação e de risco. E também considerou a avaliação da cobertura vegetal na bacia, identificando áreas onde porções de vegetação foram mais ou menos alteradas por atividades humanas. Nota-se que, ao contrário do que se poderia supor, a conclusão desse estudo foi que havia na bacia da Billings uma quantidade muito maior de áreas aptas a ocupação do que áreas inaptas, quando considerada a situação topográfica e áreas inundáveis. Mas quando consideradas as áreas com cobertura vegetal e atividade agrícola (a ser incentivava como uso compatível), as áreas disponíveis para a ocupação urbana diminuíam significativamente $^{59}$ (SÃO PAULO, 2011, p.91).

Em relação à construção política do mapa, esses estudos técnicos realizados por consultorias contratadas pela SMA eram debatidos no âmbito do grupo de trabalho da Câmara Técnica de Planejamento e Gestão do Subcomitê Billings, no qual os municípios e sociedade civil participavam. A participação dos municípios era variável, o que refletiu em diferentes graus de compatibilização entre os Planos Diretores Municipais e o mapa da LE ${ }^{60}$. Além da compatibilização entre as duas legislações, a participação de representantes dos municípios -

\footnotetext{
59 Tomando como exemplo São Bernardo do Campo, em 2006, cuja área inserida em APM era de 15.230,2 ha, teria como área disponível à ocupação urbana 2.170,5 ha. Nesse município a área desocupada que estaria apta à ocupação urbana totaliza $9.535,2$ ha e as áreas com vegetação, agricultura, mineração e faixa de domínio impróprias à urbanização totalizam 7.051,2 ha. A área inapta à ocupação era de 3.654,5 ha (SMA, 2011, p.92).

60 Os Planos Diretores municipais estavam sendo revisados no mesmo período em que a LE-Billings estava em elaboração, mas foram concluídos antes que a LE fosse aprovada, em 2006 (prazo estabelecido pela lei federal Estatuto da Cidade). Isso gerou uma série de incompatibilidades entre essas duas leis. A análise da compatibilização entre os Planos Diretores dos municípios inseridos na Bacia da Billings e a LE consta do PDPA-Billings (2011), mas sua importância é relativa, dado que os municípios seriam obrigados pela LE a revisar seus planos diretores municipais posteriormente.
} 
que conheciam o território local em maior detalhe - garantiria que demarcações incorretas no mapa da lei, feito numa escala ampliada, fossem corrigidas.

Contudo, o mapa da LE foi aprovado com algumas imprecisões em relação ao uso do solo, por exemplo, demarcando áreas que são ocupadas como áreas de conservação ambiental, ou viceversa $^{61}$. Após a promulgação da $L E$, mesmo que haja incompatibilidades entre esta e o território municipal, prepondera a legislação estadual, o que tem gerado conflitos, em alguns casos restringindo excessivamente a atribuição do município em legislar sobre o uso e ocupação do solo em seu território.

Esse tema tem sido debatido pelas prefeituras, que têm a atribuição de legislar sobre o uso e ocupação do solo municipal, com a SMA. As prefeituras questionam se o uso do solo municipal deva ser idêntico ao mapa estadual, ou seja, ponderam se o município não pode ser mais restritivo ou então mais flexível em relação à Lei Específica, desde que comprovando o atendimento de parâmetros urbanos e ambientais e de qualidade de água ${ }^{62}$, ou seja, a carga meta estabelecida pelo MQUAL. Questões como essa só serão resolvidas mediante um processo de negociação entre prefeituras e governo do estado, conforme surgirem os conflitos de aplicação da Lei Específica, que já se anunciam.

O mapa das áreas de intervenção que resultou desse processo abrange diferentes situações de ocupação da bacia hidrográfica: propõe a regularização de ocupações consolidadas e irregulares (existentes até 2006); estabelece parâmetros para novas ocupações e áreas a serem protegidas (Áreas de Preservação Permanente, dos remanescentes de Mata Atlântica e Unidades de Conservação).

Enquanto que os compartimentos ambientais figuram como recorte territorial para o monitoramento da qualidade da água, as áreas de intervenção são as "áreas programa" sobre as quais são definidas as diretrizes e normas ambientais e urbanísticas (art. $4^{\circ}$, II). A lei definiu áreas de intervenção a partir das três categorias de área de intervenção anteriormente estipuladas pela Lei no 9866/97: Restrição à Ocupação (ARO), Ocupação Dirigida (AOD) e Recuperação Ambiental (ARA). A LE-APRM Billings considera os três tipos de áreas de intervenção e cria subdivisões para as áreas de Ocupação Dirigida (o quadro 2 e o mapa 26 a seguir apresentam as definições de cada área e subárea de intervenção). As áreas de recuperação ambiental (ARA) serão indicadas pelos municípios, devem corresponder às Zonas Especiais de Interesse Social (ZEIS) e podem, após recuperadas, serem reenquadradas como ARO ou AOD.

\footnotetext{
${ }^{61}$ Isso ocorreu no município de São Bernardo do Campo. Segundo as entrevistadas: Sônia Lima (diretora da SHAMA) e Márcia Nascimento (SMA), esses conflitos ocorreram em grande parte devido à falta de representação institucional da prefeitura no Subcomitê, no momento de elaboração da LE. Havia a presença de técnicos e da diretora da SHAMA, que acreditavam que a participação era importante, mas esse trabalho não recebia amparo das secretarias interessadas no tema. Após a aprovação da LE, as Secretarias de Planejamento e Gestão Ambiental iniciaram um trabalho minucioso de identificar incompatibilidades entre a ocupação real e as áreas de intervenção definidas na LE, mas isso está em debate, pois uma mudança do mapa implica numa alteração da Lei Específica e o governo estadual apresenta resistência quanto às possíveis mudanças, no sentido de flexibilizar ainda mais a ocupação na bacia.

62 Informação verbal, conforme entrevista de Patrícia Lorenz (Diretora da Secretaria de Gestão Ambiental PMSBC) concedida à autora em 26/07/2012.
} 
Quadro 2 - Síntese das áreas de intervenção da Lei no 13.579/09:

\begin{tabular}{|c|c|c|}
\hline $\begin{array}{lr}\text { Área } & \text { de } \\
\text { Restrição } & \text { à } \\
\text { Ocupação } & \\
\text { (ARO) } & \end{array}$ & $\begin{array}{l}\text { área de interesse para a proteção dos } \\
\text { mananciais e para a preservação, } \\
\text { conservação e recuperação dos recursos } \\
\text { naturais, definida pela legislação como } \\
\text { área de preservação permanente e como } \\
\text { unidade de conservação de uso integral, } \\
\text { e em outros dispositivos da legislação } \\
\text { estadual e municipal. }\end{array}$ & $\begin{array}{l}\text { §10 - As áreas de que trata este artigo devem ser, } \\
\text { prioritariamente, destinadas à produção de água, } \\
\text { mediante a realização de investimentos e a aplicação } \\
\text { de instrumentos econômicos e de compensação } \\
\text { previstos nesta lei. } \S 20 \text { - As AROs são indicadas para } \\
\text { o exercício do direito de preempção pelos } \\
\text { Municípios, de acordo com a legislação pertinente. }\end{array}$ \\
\hline \multirow[t]{5}{*}{$\begin{array}{l}\text { Área de } \\
\text { Ocupação } \\
\text { Dirigida (AOD) }\end{array}$} & \multirow[t]{5}{*}{$\begin{array}{l}\text { área de interesse para o desenvolvimento } \\
\text { de usos urbanos e rurais desde que } \\
\text { atendidos requisitos que garantam } \\
\text { condições ambientais compatíveis com a } \\
\text { produção de água para abastecimento } \\
\text { público. }\end{array}$} & $\begin{array}{l}\text { Subárea de Ocupação Especial - SOE: prioritária para } \\
\text { implantação de HIS e de equipamentos urbanos e } \\
\text { sociais. } \\
\text { Gabarito máximo para HIS no PRIS: } 20 \mathrm{~m} \text { em todos os } \\
\text { compartimentos ambientais. }\end{array}$ \\
\hline & & $\begin{array}{l}\text { Subárea de Ocupação Urbana Consolidada - SUC: } \\
\text { área com ocupação urbana irreversível e servida } \\
\text { parcialmente por infraestrutura, inclusive de } \\
\text { saneamento ambiental e serviços urbanos. } \\
\text { Gabarito máximo para HIS no PRIS: } 20 \text { m em todos os } \\
\text { compartimentos ambientais. }\end{array}$ \\
\hline & & $\begin{array}{l}\text { Subárea de Ocupação Urbana Controlada - SUCt: } \\
\text { área já ocupada e em processo de adensamento e } \\
\text { consolidação urbana e com ordenamento } \\
\text { praticamente definido. } \\
\text { Gabarito máximo para HIS no PRIS: } 20 \mathrm{~m} \text { em todos os } \\
\text { compartimentos ambientais. }\end{array}$ \\
\hline & & $\begin{array}{l}\text { Subárea de Ocupação de Baixa Densidade -SBD: área } \\
\text { não urbana destinada a usos com baixa densidade de } \\
\text { ocupação, econômicos compatíveis com a proteção } \\
\text { dos mananciais. } \\
\text { Gabarito máximo para HIS no PRIS: } 15 \mathrm{~m} \text { (corpo } \\
\text { central I) e } 9 \mathrm{~m} \text { nos demais compartimentos. }\end{array}$ \\
\hline & & $\begin{array}{l}\text { Subárea de Conservação Ambiental - SCA: área } \\
\text { provida de cobertura vegetal de interesse à } \\
\text { preservação da biodiversidade, de relevante beleza } \\
\text { cênica ou outros atributos de importância ambiental. } \\
\text { Gabarito máximo para HIS no PRIS: } 15 \mathrm{~m} \text { (corpo } \\
\text { central I) e 9m nos demais compartimentos. }\end{array}$ \\
\hline \multirow[t]{2}{*}{$\begin{array}{l}\text { Área de } \\
\text { Recuperação } \\
\text { Ambiental } \\
\text { (ARA) }\end{array}$} & \multirow[t]{2}{*}{$\begin{array}{l}\text { área que apresenta uso e ocupação que } \\
\text { comprometem a quantidade e qualidade } \\
\text { dos mananciais e exige ações de caráter } \\
\text { corretivo, e que, uma vez recuperada, } \\
\text { deverá ser classificada em uma das duas } \\
\text { categorias anteriores (AOD ou ARO). }\end{array}$} & $\begin{array}{l}\text { Área de Recuperação Ambiental } 1 \text { - ARA 1: são } \\
\text { assentamentos habitacionais de interesse social pré- } \\
\text { existentes, desprovidos de infraestrutura de } \\
\text { saneamento ambiental, onde o Poder Público deverá } \\
\text { promover programas de recuperação urbana e } \\
\text { ambiental. }\end{array}$ \\
\hline & & $\begin{array}{l}\text { Área de Recuperação Ambiental } 2 \text { - } \begin{array}{r}\text { ARA 2: são } \\
\text { ocorrências degradacionais }\end{array} \text { previamente } \\
\text { identificadas pelo Poder Público, que exigirá dos seus } \\
\text { responsáveis ações de recuperação imediata do } \\
\text { dano ambiental. }\end{array}$ \\
\hline $\begin{array}{l}\text { Área de } \\
\text { Estruturação } \\
\text { Ambiental do } \\
\text { Rodoanel } \\
\text { (AER) }\end{array}$ & $\begin{array}{l}\text { área delimitada como Área de Influência } \\
\text { Direta do Rodoanel Mário Covas } \\
\text { conforme delimitado no mapeamento } \\
\text { das Áreas de Intervenção e } \\
\text { Compartimentos Ambientais da APRM-B, } \\
\text { parte integrante desta lei. }\end{array}$ & \\
\hline
\end{tabular}

Fonte: Elaborado pela autora a partir da Lei Específica APRM Billings no 13.579/2009 e do Decreto que a regulamenta no $55.342 / 2010$. 


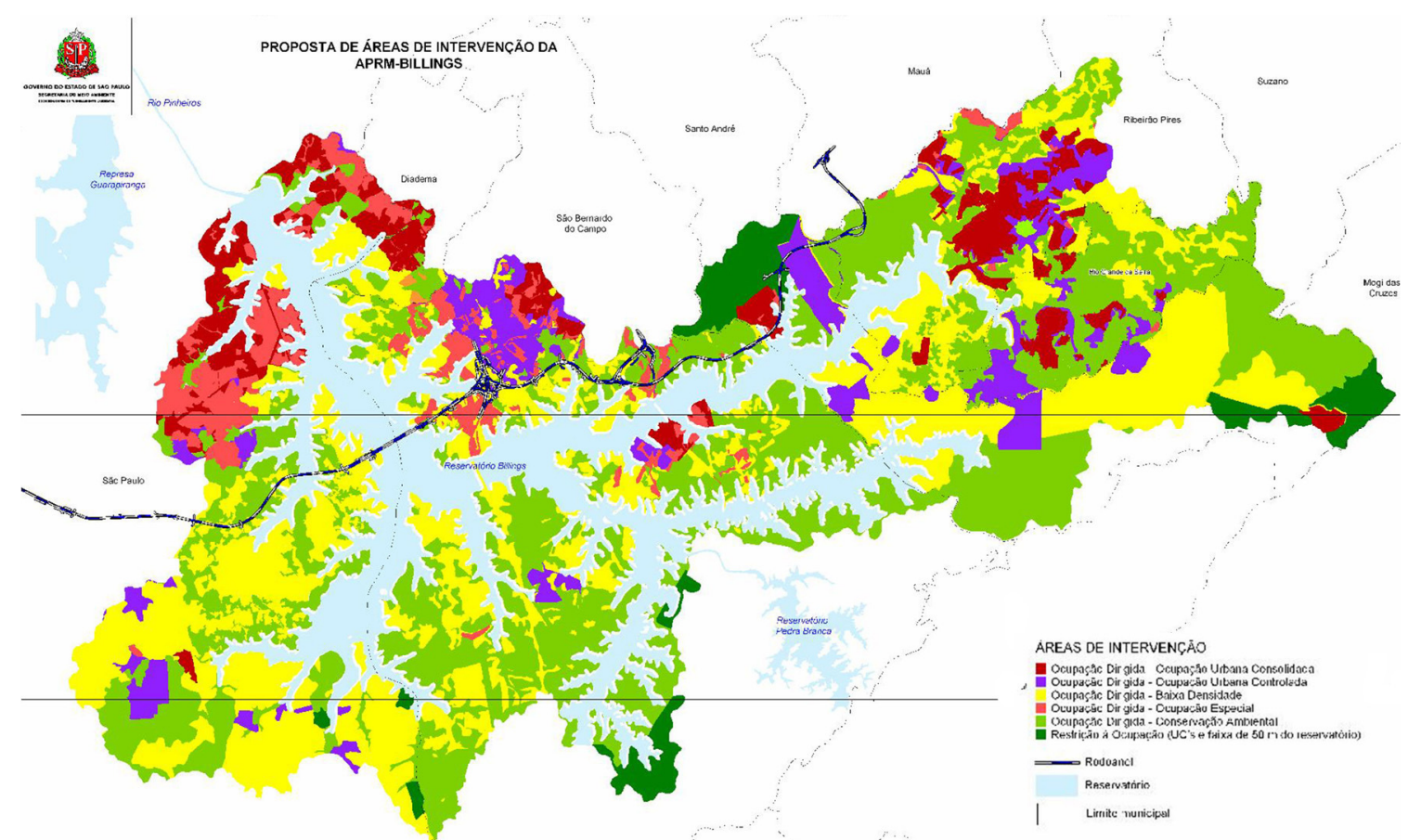

Mapa 26 - Áreas de intervenção da APRM-B (anexo I da Lei no 13.579/09)

Fonte: Diário Oficial do Estado de São Paulo, volume 119, número 128, 14 de julho 2009, p.7.

Ainda durante o debate do projeto de lei, quando a minuta foi divulgada, o Instituto Socioambiental publicou uma análise cuja crítica central chamou atenção justamente sobre a quantidade de áreas não densamente ocupadas existentes na bacia que haviam sido demarcadas, permitindo a ocupação urbana de maior densidade, numa extensa área da bacia; além de áreas que tinham ocupação de baixa densidade e que passaram para alta e média densidades. Além disso, o estudo também apontava que a lei não previa nenhuma área marcada como de Restrição à Ocupação, além das APPs existentes, ou seja, o governo estadual não se comprometia em criar novos parques de conservação ou investir na preservação. Assim, possibilitava um crescimento populacional expressivo a partir da delimitação proposta (WHATELY et alli., 2008). A lei aprovada, no entanto, não alterou essa demarcação.

Essa crítica se mantém válida para o mapa aprovado, que considera a bacia quase que integralmente como Área de Ocupação Dirigida ${ }^{63}$ e, apesar dela apresentar subdivisões segundo a situação da ocupação, uma grande extensão é demarcada como área de ocupação de baixa densidade (legenda em amarelo no mapa), cujos parâmetros urbanísticos definem: lote mínimo de $500 \mathrm{~m}^{2}$ a $1.000 \mathrm{~m}^{2}$, taxa de permeabilidade mínima (de 40 a 70\%) e índice de área (de 20 a $35 \%)$, conforme o compartimento ambiental. Portanto, ainda que a LE-Billings seja menos restritiva do que a LPM no 1.172/76, a diretriz de ocupação de novas áreas reproduz a noção desta, ou seja, de que a proteção ambiental é possível se controlada a ocupação de propriedades particulares, onde seriam desempenhados usos compatíveis com a produção de

\footnotetext{
63 Conforme conceituação da lei estadual no 9.866/97 as Áreas de Ocupação Dirigida: são as de interesse para a consolidação ou implantação de usos rurais e urbanos, desde que atendidos os requisitos que garantam a manutenção das condições ambientais necessárias a produção de água em quantidade e qualidade para o abastecimento das populações atuais e futuras.
} 
água. Mas para que isso se concretize, invertendo a lógica da rentabilidade máxima do solo para fins urbanos, uma série de ações de políticas públicas e investimentos são necessários, como comentado anteriormente.

Há uma relação entre os compartimentos ambientais e as áreas de intervenção no que diz respeito aos parâmetros de uso e ocupação do solo. As restrições aumentam conforme a área é mais preservada. Se a lei busca compensar com parâmetros mais restritivos a delimitação de uma grande Subárea de Ocupação de Baixa Densidade, incide no mesmo "erro" da legislação anterior ( $n$ o 1.172/1976) ao estabelecer lote mínimo com grande área e maior índice de permeabilidade, nas regiões mais sensíveis (ver tabela 21 no final do capítulo). Trata-se de um ponto polêmico na lei, porque a dinâmica de produção de loteamentos mostra que a subdivisão de grandes lotes é uma prática corrente e de difícil controle por parte das prefeituras.

No entanto, cabe ressaltar que a lei permite que os municípios alterem os parâmetros urbanísticos, desde que salvaguardadas as exigências ambientais. Ou seja, há uma abertura para se repensar o padrão de ocupação dessas áreas, que demandariam novas relações entre área edificada e permeável, e padrões de infraestrutura. Mas essa formulação abstrata é uma brecha da lei ainda não explorada e frequentemente limitada por concepções mais rígidas do atendimento da legislação ambiental. Há que se considerar também que os municípios, por sua vez, não podem ter uma legislação menos restritiva do que a lei estadual.

Além dos parâmetros urbanísticos, a LE-Billings também define um parâmetro ambiental que não havia sido adotado anteriormente, que é a taxa de permeabilidade.

A infraestrutura sanitária (implantação de sistema de coleta, tratamento ou exportação de esgotos) passou a ser uma exigência para a instalação, ampliação e regularização de edificações, empreendimentos ou atividades em toda a bacia (artigo 40). E são admitidas alternativas como sistema autônomo de tratamento de esgotos, quando a ligação com a rede pública não é possível:

$\S 1$ - Nas Subáreas de Ocupação Urbana Consolidada - SUC, nas Subáreas de Ocupação Urbana Controlada - SUCt e nas Subáreas Ocupação Especial - SOE a instalação ou regularização de edificações, empreendimentos ou atividades ficam condicionadas à efetiva ligação à rede pública de esgotamento sanitário ou, se for demonstrada a inviabilidade técnica, deverá ser adotado sistema autônomo de tratamento de esgotos, coletivo ou individual, com nível de eficiência demonstrado em projeto a ser aprovado pelo órgão competente, em conformidade com a legislação vigente.

§ 2 - Nas Subáreas de Baixa Densidade- SBD e Conservação Ambiental - SCA deverão ser adotados sistemas de tratamento autônomo, individual ou coletivo, com nível de eficiência aprovado pelo órgão competente, em conformidade com a legislação vigente.

Dessa forma, nas áreas da bacia onde a ocupação é rarefeita, com núcleos de ocupação isolada da mancha urbana, a lei não prevê a instalação de rede pública, mas sim sistemas localizados de tratamento de esgotos - e assemelha-se à diretriz da LPM nesse aspecto. 
Quanto à regularização urbanística, fundiária e ambiental, a lei contém três instrumentos principais. Um deles é a compensação que permite a alteração de índices e parâmetros urbanísticos estabelecidos na LE ou nas leis municipais (após sua compatibilização com a LE), para fins de licenciamento e regularização de empreendimentos, mantidos o valor da Carga Meta Referencial por compartimento, ou por município, e as demais condições necessárias à produção de água (art. 4익). Além disso, a lei elenca uma série de instrumentos de compensação, que variam desde a criação de RPPN (Reserva Particular de Patrimônio Natural) e doação de terrenos para preservação, até compensações financeiras. Porém, em ARA I (objeto de PRIS) não podem ser feitas compensações desse tipo.

O segundo é o PRIS - Programa de Recuperação de Interesse Social em Áreas de Recuperação Ambiental 1 - ARA $1^{64}$. O PRIS ${ }^{65}$ poderá ter sua elaboração e implantação sob responsabilidade dos órgãos e entidades do poder público das três esferas de governo, ou mediante responsabilidade compartilhada com as comunidades residentes no local organizadas em associação de moradores ou outras associações civis, bem como com o responsável pelo parcelamento e/ou proprietário da área. Nas áreas objeto de plano de urbanização permitem-se novas construções de habitações de interesse social, quando estas representam melhor adequação com a situação física e ambiental local.

O terceiro é o PRAM - Projeto de Recuperação Ambiental em Mananciais em Áreas de Recuperação Ambiental 2 - ARA 2 que deverão ser elaborados, apresentados e executados pelos responsáveis pela degradação, previamente identificada pelo órgão ambiental competente.

Esse conjunto de instrumentos da Lei Específica que viabilizam a regularização fundiária e a instalação de infraestrutura em assentamentos precários de fato constituiu um avanço em relação à legislação anterior, que adiou por praticamente duas décadas a definição de como o poder público interviria nessas situações, uma questão que afetava particularmente os municípios. Ao mesmo tempo, respondeu a uma reivindicação popular legítima por regularização - apesar das dificuldades de licenciamento dos PRIS, tratada adiante (capítulo 9). A LE-Billings tornou oficial a prática existente desde o programa Guarapiranga, assim a urbanização e regularização de assentamentos precários se confirmaram como tônica predominante da recuperação ambiental.

Contudo, ao pautar a recuperação ambiental desse modo, estabelece um tratamento desequilibrado em relação a outros usos também nocivos para a produção de água, como os industriais, a mineração e outros que implicam em desmatamentos de grandes áreas, sobre os quais não definiu novas formas de controle e compensação ambiental. E de certa forma desvia o

\footnotetext{
${ }^{64}$ As ARA 1, são definidas como ocorrências de Assentamentos Habitacionais de Interesse Social - preexistentes ao ano de 2006, desprovidos total ou parcialmente de infraestrutura de saneamento ambiental, onde o Poder Público deverá promover programas de recuperação urbana e ambiental por meio de PRIS.

65 Após a promulgação da LE-Billings, em julho de 2010, a Cetesb - órgão licenciador - publicou um Manual para a Elaboração do PRIS, no qual estabelece que para o PRIS, as áreas devem ser previamente identificadas pelo poder público municipal, como Zonas Especiais de interesse Social (ZEIS) nos termos previstos no art. 2o da Lei 10.257/2001 e na alínea b, inciso VII, art. 47, da Lei Federal n 11.977/2009. Essa definição, entretanto, não consta da Lei Específica, nem mesmo do Decreto que a regulamenta.
} 
foco do problema existente em relação ao sistema de saneamento como um todo. Com isso a lei reitera a noção que a degradação é decorrente da ocupação irregular de baixa renda.

Essa relação é explícita quanto ao sistema de tratamento de esgotos, que será retomado em maior detalhe no capítulo 9, a partir das experiências dos PRIS em São Bernardo do Campo. A lei não interfere no planejamento da expansão dessas redes, nem tampouco propõe uma articulação da solução habitacional com a sua extensão. E apesar de a LE preconizar a integração entre as políticas setoriais, isso não se verifica na prática, na medida em que o Sistema Integrado de Planejamento e gestão não foi instituído. Além disso, apesar da LE estabelecer cargas metas poluentes máximas, não há sanções para o poder público estadual ou municipal, caso tais metas não sejam atendidas.

A LE reforça, assim, a manutenção da setorialização das intervenções de escala metropolitana na bacia, garantindo que cada uma delas conviva, ainda que em concorrência com a finalidade prioritária do abastecimento de água. Apesar dessa tarefa não poder ser resolvida exclusivamente por meio da lei, ela colabora para direcionar nesse sentido a prática das intervenções na bacia. 


\section{CAPÍTUL0 8}

\section{Do Programa Guarapiranga ao Programa Mananciais}

Desde o Programa Guarapiranga (1992) se ampliaram os financiamentos nacionais e internacionais, bem como a abrangência territorial dos programas voltados às áreas de proteção aos mananciais. Esse capítulo busca compor, com a análise da legislação específica abordada anteriormente, o quadro de ações do poder público estadual e municipal na condução dessa política pública.

O Programa Guarapiranga, que obteve financiamento do Banco Mundial, se constituiu como modelo para o desenho de política pública voltada às áreas de proteção aos mananciais, considerado um caso de sucesso a ser ampliado - o que notoriamente aconteceu. O município de São Paulo representa um importante sujeito nesse processo, pois protagonizou o programa e concentrou grande parte dos investimentos de urbanização. Atualmente, está em curso o Programa Mananciais do Alto Tietê, no qual se observa concretamente a replicação das premissas e projetos do Programa Guarapiranga, dentre elas, o fato de que a precariedade dos assentamentos é a base para a realização de obras de urbanização de e de saneamento, e portanto da recuperação ambiental.

Ao mesmo tempo, observa-se que ao longo de 21 anos de existência do Programa Mananciais (nome que genericamente se refere ao conjunto das intervenções nessas áreas), as diversas ações complementares às obras de urbanização inicialmente propostas pelo Programa Guarapiranga foram sendo reduzidas, fazendo com que o objetivo de saneamento da bacia prevaleça sobre programas sociais. Por outro lado, os resultados destas obras de urbanização sobre a qualidade ambiental da bacia hidrográfica e da água não têm apresentado avanços substantivos, o que evidencia problemas relativos ao sistema de saneamento como um todo. É nesse sentido que serão problematizadas adiante tanto a noção de saneamento como a de recuperação ambiental.

A reflexão sobre esse modelo vigente é construída a partir da análise de documentos governamentais sobre as diversas fases e desenhos do Programa Mananciais - discurso, conteúdo e localização dos projetos propostos - em diálogo com pesquisas anteriores (UEMURA, 2000; ANCONA, 2002; FILARDO,2004) que analisaram em profundidade o Programa Guarapiranga. 


\subsection{Programa de Saneamento Ambiental da Bacia do Guarapiranga - Programa Guarapiranga}

Como já tratado no capítulo 7, a gestão da prefeita Luiza Erundina (1989-1992) representou uma mudança de prioridades em relação à política habitacional de interesse social no município de São Paulo como um todo e particularmente nas áreas de mananciais da zona Sul. No início dos anos 1990, o Plano de Preservação e Manejo da Área do Município de São Paulo e a experiência da fiscalização integrada do SOS Mananciais foram importantes referências para estruturar uma ação do poder público nessas áreas. Também a piora da qualidade da água da Represa Guarapiranga foi mais um motivo que impulsionou essas ações.

Nesse contexto, o Programa de Saneamento Ambiental da Bacia do Guarapiranga ${ }^{66}$ - Programa Guarapiranga, passou a ser elaborado em parceria com a Sabesp e coordenado pela Secretaria Estadual de Energia e Saneamento ${ }^{67}$. A proposta foi encaminhada ao Banco Mundial em $1991 \mathrm{e}$ foi aprovada em dezembro de 1992. Os objetivos principais eram a recuperação sanitária e ambiental do manancial, a implantação de um sistema de gestão integrada da bacia e o controle da qualidade da água da Represa e de seus afluentes.

O acordo de empréstimo entre o Governo do Estado e o Banco Mundial foi efetivado em 1993, bem como os convênios e contratos de repasse entre o Governo e os órgãos executores: Unidade de Gerenciamento do Projeto (UGP), Companhia de Saneamento Básico do Estado de São Paulo (Sabesp); Secretaria de Estado do Meio Ambiente (SMA); Companhia de Desenvolvimento Habitacional e Urbano (CDHU) e Prefeitura Municipal de São Paulo (PMSP).

Como observou Filardo (2004), enquanto agente financiador o Banco Mundial desempenhou um papel ativo na implementação do Programa, pois os valores financeiros determinaram sua estrutura, ritmos e prazos, bem como a definição dos instrumentos técnicos empregados em sua concepção, implementação e avaliação, interferindo inclusive na conceituação empregada em sua formulação. Até mesmo o jargão empregado nos relatórios é o dos economistas prestigiados em Washington (Ibidem, p.251-252).

Em relação ao financiamento, os demais agentes executores tais como a Prefeitura de São Paulo, o Governo do Estado de São Paulo, a Sabesp e a Eletropaulo, também aportaram recursos, conforme tabela a seguir.

\footnotetext{
${ }^{66}$ O Programa Guarapiranga foi criado pelo Decreto Estadual no 33.266 de 15/05/91.

67 Por meio do Decreto no 34.682/92, foi nomeado um grupo técnico para a elaboração do Estudo de Impacto Ambiental, que deu origem em 1992 ao RIMA - Relatório de Impacto sobre o Meio Ambiente, contratado pela Secretaria de Energia e Saneamento, para subsidiar o licenciamento do Programa Guarapiranga.
} 
Tabela 14 - Recursos do Programa Guarapiranga, valores iniciais entre 1992-1997.

\begin{tabular}{lc}
\hline FONTE DO RECURSO & $\begin{array}{c}\text { VALORES EM MILHÕES } \\
\text { (DÓLARES) }\end{array}$ \\
\hline Banco Mundial - BIRD & US\$ 119,00 \\
Governo do Estado de São Paulo & US\$ 68,00 \\
Prefeitura de São Paulo & US\$ 28,00 \\
Sabesp & US\$ 40,00 \\
Eletropaulo & US\$ 7,00 \\
\hline Total & US\$ 262,00 \\
\hline
\end{tabular}

Fonte: UGP, Relatório Final Ex Post do Programa Guarapiranga, 2001.

Além desses recursos, o Governo do Estado de São Paulo e a Prefeitura de São Paulo deveriam aportar, respectivamente, US\$13,8 milhões e US\$ 4,4 milhões para desapropriação de áreas. Os recursos destinados à Eletropaulo seriam transferidos para a Prefeitura de São Paulo. Posteriormente os investimentos previstos para o programa foram ampliados, para $\mathrm{R} \$ 363$ milhões até dezembro de 1999 (WHATELY et alli., 2009).

Em 1993, com a mudança de gestão municipal, a estrutura institucional para o programa de urbanização de favelas montada na Secretaria Municipal de Habitação - SEHAB/PMSP foi desfeita e o SOS Mananciais foi assumido pela estrutura do Governo do Estado, por meio da CEPM - Comissão Especial de Proteção aos Mananciais, que tinha a mesma composição, mas sem os recursos aportados pela PMSP (UEMURA, 2000, p.63).

Para o gerenciamento do Programa Guarapiranga foi criada uma estrutura descentralizada e intergovernamental vinculada à Secretaria de Recursos Hídricos, Saneamento e Obras chamada Unidade de Gerenciamento do Programa (UGP). O Conselho Consultivo (tripartite) ${ }^{68}$ da Bacia seria responsável por todas as deliberações enquanto que a UGP daria o suporte técnico e gerencial para integrar todos os agentes envolvidos. Contudo, o Conselho não teve reconhecimento político, durou apenas três anos, e seu papel ficou restrito à prestação de contas e ao caráter consultivo. Ele foi posteriormente substituído pelo Subcomitê CotiaGuarapiranga (Ibidem, p.77).

O Programa foi organizado em cinco Subprogramas: 1) Serviços de água e esgoto, 2) Coleta e disposição final de lixo, 3) Recuperação urbana, 4) Proteção ambiental, 5) Gestão; cuja execução ficou a cargo da Sabesp, SMA, CDHU e PMSP. Os quatro primeiros implicavam em intervenções físicas, em grande parte referentes às urbanizações de favelas realizadas pela PMSP e pela CDHU e às obras de saneamento realizadas pela Sabesp.

O Subprograma 1 - Serviços de água e esgoto, de responsabilidade da Sabesp, abarcavam, além da execução de obras para melhoria da infraestrutura e complementação do sistema de coleta e exportação dos esgotos para fora da bacia, a realização de estudos e aperfeiçoamento no

\footnotetext{
${ }^{68}$ Esse Conselho era formado por 14 membros do governo estadual, 14 membros da sociedade civil e 14 membros das prefeituras de São Paulo, Itapecerica da Serra, Embu e Embu-Guaçu.
} 
sistema de monitoramento da qualidade da água e a redução das cargas difusas afluentes ao reservatório.

O Subprograma 3 - Recuperação urbana, a cargo da CHDU e da PMSP incluía a urbanização e a adequação de infraestrutura nas favelas e loteamentos irregulares ou clandestinos. Nos primeiros contratos de obras de urbanização - lotes I, II e III (de 1992 a 1996), a intervenção era focada no núcleo de favela e eram priorizadas aquelas localizadas junto a afluentes ou tributários diretos da Guarapiranga. Mas a partir do quarto lote de obras, a forma de contratação foi alterada e as favelas e loteamentos de toda a bacia foram distribuídos em 13 lotes com valores de contrato de $R \$ 7$ a $R \$ 10$ milhões (referência de 1995). Com isso cada empreiteira vencedora da licitação executaria obras em uma ou mais favelas, que totalizassem esse valor. Todavia, os recursos eram insuficientes para atender a todas as demandas da urbanização. Além disso, não houve um critério prioritário, como de urbanizar as favelas nas sub-bacias mais poluentes (UEMURA, 2000, p.100). Essa forma de contratação é a atualmente praticada.

Por outro lado, a partir do quarto lote de obras uma mudança também ocorreu com a ampliação do escopo dos projetos de urbanização que passaram a desenvolver, além das soluções de instalação de infraestrutura, o redesenho do sistema viário, a implantação de áreas verdes, equipamentos comunitários e de lazer, o tratamento de cursos d'água e canalizações abertas, que visavam qualificar novos espaços públicos. Ou seja, buscava-se melhorar a condição urbana a partir de soluções articuladas de infraestrutura, espaço público e melhoria habitacional, que são indissociáveis em ocupações precárias. Esse conjunto de intervenções de fato gerava um novo padrão de urbanização de assentamentos precários tornando-se uma referência para a política de intervenção nessas áreas69, que antes frequentemente se restringiam à instalação de redes de água e esgotos (como pontuado no capítulo 3).

Apesar desse avanço, que até hoje é a face internacionalmente conhecida do programa, a execução das obras apresentaram diversos problemas, pois as empreiteiras as realizaram de forma pulverizada, e sem corresponder a um critério de seleção de sub-bacias mais poluentes. Ou seja, as intervenções não responderam aos objetivos ambientais porque não alcançaram a redução da carga poluente. Também não houve controle gerencial e acompanhamento sistemático das obras, inclusive em relação aos recursos empregados (Ibidem, p.107).

Portanto, do ponto de vista da minimização de geração de cargas poluidoras na represa, Uemura (2000, p.109) comparou a previsão de atendimento habitacional com o que foi efetivamente realizado até janeiro de 2000 e aferiu que grande parte das favelas continuava sem obras de infraestrutura e, portanto, não estavam ligadas à rede coletora, lançando os esgotos

\footnotetext{
${ }^{69}$ Além das já citadas, diversas pesquisas acadêmicas se debruçaram sobre o tema avaliação da qualidade urbana e ambiental dos projetos do Programa Guarapiranga, sob diferentes pontos de vista. Sobre avaliação de projeto e execução de obras ver BUENO (2002) e VALETTA (2006), e especificamente sobre infraestrutura e custos ver ANCONA e STETSON (2002) e CARVALHO et. al (2002). Para uma avaliação qualitativa abordando o ponto de vista da população ver ANCONA e BALTRUSIS (2006).
} 
diretamente nos corpos d'água formadores da Represa. De $1994^{70}$ a 2000, as intervenções atingiram 67 núcleos, dos 168 núcleos de favelas e 54 dos 135 loteamentos previstos inicialmente. Foram atendidas 22.599 famílias, da meta de 60.139, significando 37,6\% do total de famílias previstas pelo programa.

Do ponto de vista das obras de saneamento, conforme afirma Filardo (2004, p.271), embora o Programa tenha superado as metas físicas inicialmente previstas, principalmente nas atividades referentes à ampliação dos sistemas de esgotamento sanitário, o grau de cobertura pelos serviços de saneamento ficou em $61 \%$ do total de domicílios em 2000, muito aquém do inicialmente programado (89\%). Assim, a contribuição do Programa para a redução das cargas afluentes ao Reservatório, via aumento da cobertura por rede de esgotos e coleta de lixo, é diminuída pela persistência de uma quantidade significativa de domicílios não atendidos.

Além do número insatisfatório de atendimento de domicílios, as obras dos coletores-tronco a cargo da Sabesp também passaram por problemas, não seguiram o planejamento, ou seja, atrasaram e em muitos trechos ficaram interrompidas. Esse é mais um motivo que explica porque não houve alteração nos índices de exportação e tratamento de esgotos.

Complementarmente a essas avaliações, destaca-se ainda que as urbanizações não envolveram um plano para a regularização fundiária dos assentamentos.

O Programa Guarapiranga tinha a previsão de durar cinco anos, encerrando em 1997. Mas nos anos seguintes foi sendo sucessivamente prorrogado até 2000. Nos dois últimos anos, os recursos disponíveis para finalizar as obras e atividades dos Subprogramas eram reduzidos e insuficientes para alcançar as metas inicialmente estabelecidas. Esse foi o quadro encontrado quando houve a mudança de gestão da Prefeitura em 2001.

Segundo Uemura (2000), somente o Subprograma 4 - Recuperação ambiental ${ }^{11}$ a cargo da SMA e os Subprogramas 2 - Coleta e disposição final de lixo e 5 - Gestão, a cargo da UGP ${ }^{72}$, haviam sido concluídos.

\subsection{A ampliação do Programa Guarapiranga para a bacia da Billings, a partir de 2000}

Mesmo antes do término do Programa Guarapiranga, desde 1999, a Secretaria Estadual de Recursos Hídricos e a Prefeitura de São Paulo trabalhavam na elaboração de um novo pedido de financiamento para completar as obras do Programa Guarapiranga e estendê-las para a Billings e outras sub-bacias da Bacia do Alto Tietê, o chamado Projeto de Saneamento Ambiental dos

\footnotetext{
${ }^{70}$ As obras contratadas em 1992 se iniciaram em 1994 (UEMURA, 2002, p.99).

${ }^{71}$ O Sub-programa 4 - Proteção ambiental tinha como componentes: repovoamento vegetal nas margens da represa, áreas públicas e várzeas; arborização urbana; implantação de quatro parques; além de estudos sobre a Bacia para subsidiar instrumentos de fiscalização, monitoramento da qualidade da água, proteção ambiental, e promoção de atividades econômicas compatíveis com a preservação do manancial (UEMURA, 2002, p. 115).

72 O Sub-programa 5 - Gestão da Bacia tinha como componentes: ações de educação ambiental e sanitária; capacitação de equipes técnicas e agentes envolvidos e de ONG's; fiscalização; elaboração do PDPA e MQUAL; criação de um sistema de monitoramento (físico e da qualidade da água) (UEMURA, 2002, p. 124).
} 
Mananciais Alto Tietê. No entanto, os recursos só foram liberados em 2006. Esse programa será tratado no próximo item. O que buscamos por ora abordar é como os programas públicos se estenderam para a Bacia da Billings, ainda a exemplo do que aconteceu no município de São Paulo, para em seguida retomar o caso de São Bernardo do Campo, quando obtido o financiamento para a bacia do Alto Tietê.

No município de São Paulo, a gestão Marta Suplicy (2001-2004) deu continuidade ao programa com recursos próprios e previu no orçamento municipal verba para a reurbanização de favelas em algumas das áreas que já compunham o plano inicial. Os recursos do orçamento gastos entre 2004 e 2005 são da ordem de R\$ 35 milhões/ano, um pouco menos do que foi orçado, 50 milhões. E, ao contrário do que afirmam os anúncios oficiais sobre o programa posteriores a essa gestão, o mesmo não ficou parado entre 2000 e 2004. A Sabesp também mantém o investimento nesse período (WHATELY et alli., 2009, p.113).

Os assentamentos precários na Billings passam a ser considerados objetos de intervenção e o programa é denominado Programa Mananciais. Não houve mudança nos projetos de urbanização, mesmo porque, muitos deles precisavam somente ser concluídos. A novidade da gestão de Marta Suplicy foi a construção de Centros Educacionais Unificados - CEUs em área de mananciais, um equipamento de grande porte que visava suprir diversas demandas por educação, cultura, esporte e lazer num único lugar de referência.

O Programa Mananciais teve continuidade na gestão Serra/Kassab (2004-2008) e na gestão seguinte de Gilberto Kassab (2009-2012). A partir de 2005, a Prefeitura de São Paulo passa a denominar as ações na Guarapiranga e Billings como programa "Saneamento, Proteção Ambiental e Recuperação da Qualidade das águas em áreas degradadas de manancial hídrico", ainda conhecido genericamente como Programa Mananciais, gerido pela Superintendência de Habitação Popular da Secretaria Municipal de Habitação - SEHAB. A SEHAB manteve dentro de sua estrutura uma equipe destacada do Programa de Urbanização de Favelas para o Programa Mananciais, aproveitando a experiência acumulada no tema de grande parte dos técnicos, tanto nas ações do programa propriamente dito como representando a Prefeitura nos órgãos colegiados do Sistema Estadual de Recursos Hídricos.

No município de São Paulo, as intervenções organizam-se em fases e lotes de obras, desde o Programa Guarapiranga. Conforme informações da SEHAB/PMSP pode-se considerar a 1a Fase do Programa Mananciais o período entre 2005-2008 e a 2a Fase entre 2008-2012. No momento, o programa encontra-se em sua 3ạ fase, iniciada em 2012 (antes das eleições municipais).

O Programa Mananciais Fase 1 abrangeu a complementação de urbanização de assentamentos precários de lotes de obras que não haviam sido concluídos desde o Programa Guarapiranga e incluiu nove áreas novas, onde obras foram executadas entre 2005 e $2008^{73}$. Outras áreas, que

\footnotetext{
${ }^{73}$ Essa informação foi extraída de tabela com o balanço das obras da Fase 1, cedidas à autora pela SEHAB/PMSP, em 2008.
} 
por motivos diversos ficaram com obras paralisadas ou precisavam de obras complementares, entraram no planejamento da Fase 2 do programa.

Em 2008, foram eleitas 81 áreas de intervenção para a Fase 2 e os critérios utilizados para escolha, segundo a SEHAB/PMSP foram: a presença de riscos geotécnicos e de áreas do Plano Emergencial (especialmente as da Bacia Billings); as áreas com ações civis públicas; as ações judiciais em áreas de risco e aquelas áreas da Carta Consulta do Banco Mundial ${ }^{74}$. Segundo a matéria "Programa Mananciais: Promove uma revolução nas áreas das bacias Billings e Guarapiranga" divulgada no site da Prefeitura de São Paulo:

As 81 áreas compreendem Capela do Socorro, M'Boi Mirim, Cidade Ademar e Parelheiros, na Zona Sul. 68 são da Bacia do Guarapiranga e 13 da Billings. Somadas, elas compõem oito lotes, que somam 1.461 hectares e atingem 60.042 domicílios, dos quais 513 hectares (24.550 domicílios) são da Bacia do Guarapiranga e 948 hectares (35.492 domicílios) da Billlings.

Para a execução desse conjunto de obras está prevista a remoção e o reassentamento de 5.300 famílias, das quais 4.438 são da Billings e 2.483 da Guarapiranga. Dentre essas áreas, três receberão Parques Lineares, com a remoção, em duas delas, de assentamentos irregulares. Em Parque Europa (M'Boi Mirim), por exemplo, serão construídos dois conjuntos habitacionais, com 900 apartamentos. Em Mata Virgem (Cidade Ademar), outro exemplo, serão construídos 462 apartamentos. Nesta acepção de preservação, como se vê, preservar e proteger os mananciais da região metropolitana significa, essencialmente, implantar saneamento básico, infraestrutura urbana e construir moradias. Ou seja, controlar e ordenar a ocupação das áreas e promover a qualidade de vida da população de baixa renda (PMSP, 2008).

Para a urbanização das 81 áreas, houve uma composição de recursos. Desse total, 45 áreas receberam recursos do governo federal por meio do PAC Mananciais (também chamado de Programa Guarapiranga e Billings pelo governo estadual) $)^{75}$, além das contrapartidas da PMSP e do governo estadual (CDHU e Sabesp). Tratavam-se de áreas onde já haviam sido desenvolvidos projetos básicos e em condições de licitação, com horizonte de implantação compatível com o PAC (até 2010) ${ }^{76}$.

Segundo a Secretaria de Saneamento e Energia - SSE, o montante de R\$ 869,3 milhões de investimento se distribui da seguinte forma: $\mathrm{R} \$ 250$ milhões são do Orçamento Geral da União; R\$ 130,6 milhões do Governo do Estado de São Paulo, por meio da Companhia de Desenvolvimento Habitacional e Urbano do Estado de São Paulo (CDHU); R\$ 446,5 milhões da Prefeitura de São Paulo - PMSP e R\$ 42,2 milhões da Sabesp. As ordens de serviços são dadas pela Prefeitura, órgão responsável pela execução das obras.

\footnotetext{
74 Fonte: http://www.prefeitura.sp.gov.br/cidade/secretarias/habitacao/noticias/?p=3758, matéria de 30/01/2008, acesso em 11/11/11.

${ }^{75}$ Guarapiranga e Billings (Programa de Recuperação Ambiental de Mananciais, Urbanização de Favelas e Melhorias Urbanas - Guarapiranga e Billings), executado sob o Contrato de Repasse OGU no 0227.535-53/2007, firmado em 27/12/2007 com o Governo do Estado, por intermédio da Secretaria de Saneamento e Recursos Hídricos.

${ }^{76}$ Conforme apresentação pública do Programa Guarapiranga e Billings - o PAC Mananciais, feita por Amauri Pollachi , coordenador de planejamento da UGP, SSE, em 08 de abril de 2008.
} 
Tabela 15 - Recursos divulgados do PAC Mananciais, 2008.

\begin{tabular}{lcc}
\hline FONTE DO RECURSO & $\begin{array}{c}\text { VALORES EM MILHÕES } \\
\text { (REAIS) }\end{array}$ & $\begin{array}{c}\text { VALORES EM MILHÕES } \\
\text { (DÓLARES)* }\end{array}$ \\
\hline Orçamento Geral da União & $\mathrm{R} \$ 250,00$ & US\$ 153,37 \\
Governo do Estado de São Paulo/CDHU & $\mathrm{R} \$ 130,60$ & US\$ 80,12 \\
Prefeitura de São Paulo & $\mathrm{R} \$ 446,50$ & US\$ 273,92 \\
Sabesp & $\mathrm{R} \$ 42,20$ & US\$ 25,88 \\
\hline Total & $\mathrm{R} \$ 869,30$ & US\$ 533,31 \\
\hline
\end{tabular}

Fonte: Secretaria de Saneamento e Energia - SSE, 2008. *Cotação do dólar, em 04 de junho de 2008, R\$1,63.

Um balanço do andamento do Programa Mananciais Fase 2 para as 81 áreas de intervenção pôde ser feito a partir de dados da Prefeitura, constantes da "Agenda 2012 - Programa de Metas da Cidade de São Paulo"77, que apresentam a situação de cada área de intervenção (favelas e loteamentos) em maio de 2012, conforme sistematizado na tabela a seguir:

Tabela 16 - Balanço do andamento das obras da Fase 2, divulgadas em 2012.

\begin{tabular}{lccc}
\hline $\begin{array}{l}\text { Situação da obras em } \\
\text { maio/2012 }\end{array}$ & $\begin{array}{c}\text { Quantidade de } \\
\text { áreas de } \\
\text { intervenção }\end{array}$ & $\begin{array}{c}\text { Número de } \\
\text { Famílias } \\
\text { (maio 2012) }\end{array}$ & \% / Total \\
\hline Licitação & 1 & 44 & $0,1 \%$ \\
Contratação & 36 & 9.490 & $12,3 \%$ \\
$25 \%$ realizado & 8 & 2.946 & $3,8 \%$ \\
$50 \%$ realizado & 2 & 2.112 & $2,7 \%$ \\
$75 \%$ realizado & 9 & 28.474 & $36,8 \%$ \\
$100 \%$ realizado & 25 & 34.261 & $44,3 \%$ \\
\hline Total & 81 & 77.327 & $100 \%$ \\
\hline
\end{tabular}

Fonte: Elaborado pela autora a partir de dados da SEHAB/PMSP referentes a maio de 2012, disponíveis em http://agenda2012.com.br/cidade-sustentavel/metas/54/Urbanizacao-de-favelas-e-loteamentos-em-areas-demananciais-60000-familias/, acesso em 12/02/2013.

Quando divulgou esses dados, a SEHAB/PMSP considerou que sua meta de atendimento de 60 mil famílias havia sido cumprida, ou seja, considerou as áreas em que as obras haviam sido concluídas (100\%), somadas às que estavam próximas da conclusão (75\%), totalizando 62.735 famílias. No entanto, algumas considerações são importantes, no sentido de melhor expressar os resultados da Fase 2 do Programa Mananciais no Município de São Paulo, pois consideramos que o número de famílias atendidas é um critério muito restrito de avaliação de seus resultados, diante da problemática urbana e ambiental envolvida.

\footnotetext{
${ }^{77}$ Essas informações foram acessadas no sitio http://agenda2012.com.br/cidade-sustentavel/metas/54/Urbanizacaode-favelas-e-loteamentos-em-areas-de-mananciais-60000-familias/, acesso em 12/02/2013.
} 


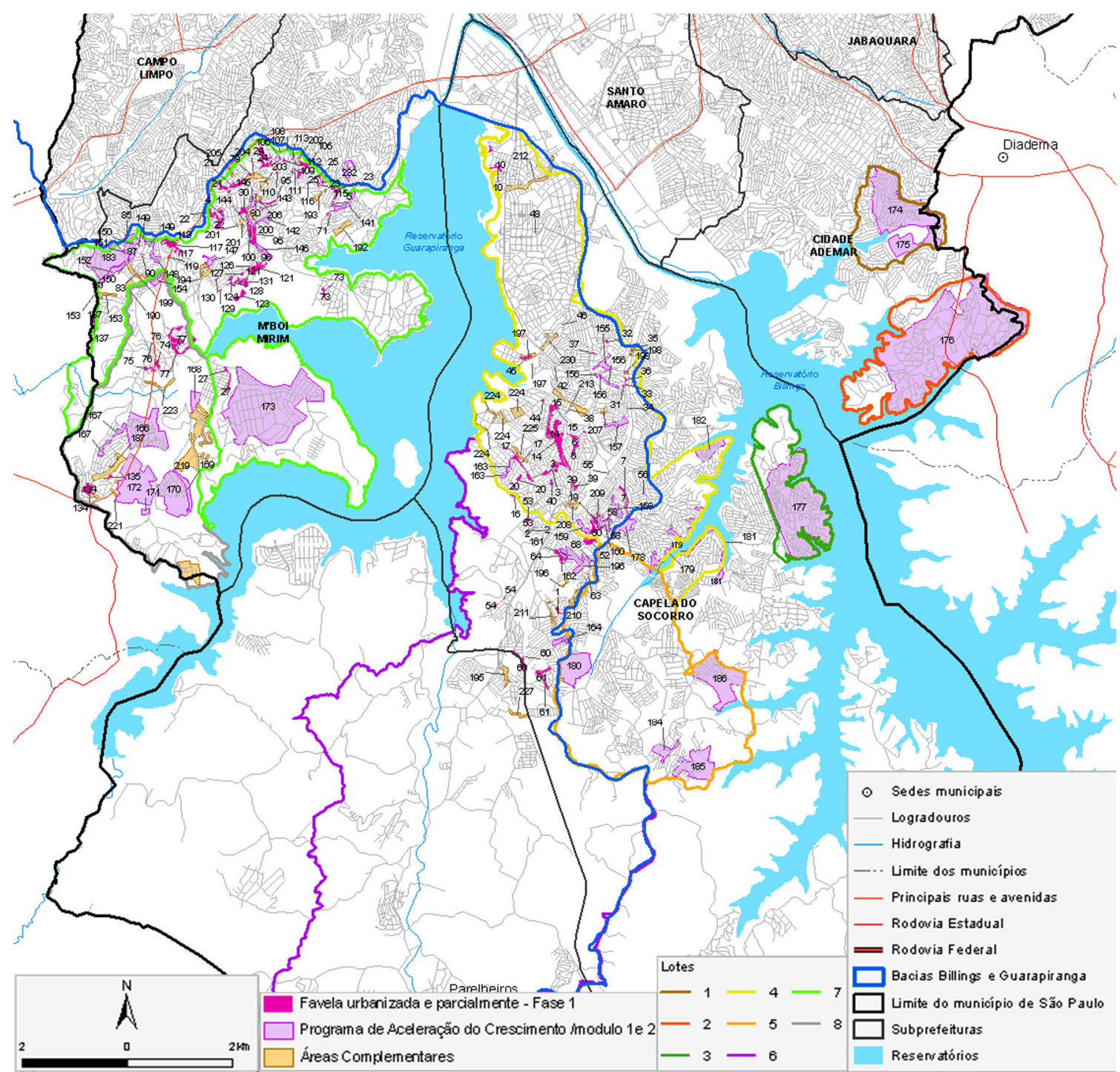

Mapa 27 - Programa Mananciais Fase 2 e obras do PAC no município de São Paulo.

Fonte: WHATELY et alli. 2008, p.253.

Primeiramente, o número total de famílias atendidas merece ponderação, já que de uma fase para outra há continuidade de intervenções de urbanização. Então, se a base de referência são as obras concluídas (ou quase concluídas) ainda na Fase 2, não houve atendimento da meta proposta por essa fase (nas 81 áreas há 77.327 família no total). Ainda, das áreas que a SEHAB considerou estar em $75 \%$ do andamento da obra, quatro delas terão continuidade na Fase 3 (ver a tabela comparativa no final do capítulo), que somadas totalizam 14.940 famílias. Então, excluindo-se essas obras, que serão continuadas, e considerando o número total de áreas previstas para a Fase 2, tem-se que 62\% das famílias (ou 47.795 famílias) da Fase 2 foram atendidas, ou seja, tiveram obras concluídas, e não a totalidade da meta (que é a soma do que se conseguiu concluir), como a Prefeitura divulgou. Se considerarmos as áreas onde as obras foram somente iniciadas, ou que estão em fase de contratação na Fase 2 e que serão realizadas na Fase 3, essa porcentagem de atendimento é ainda menor.

Ainda assim, verifica-se que o número de obras e de atendimento de famílias têm crescido. Para exemplificar a dimensão de cada programa, estima-se que o número de famílias atendidas no 
Programa Guarapiranga (1994-2000) com urbanização de favelas foi de 22.088 famílias. O Programa Mananciais Fase 1 (2005-2008) atendeu aproximadamente 38 mil famílias. E, na Fase 2, a previsão de atendimento era de 77.327 famílias, tendo sido atendidas (até maio 2012) aproximadamente 47.406 famílias. Dessas 77.327, o PAC Mananciais (2008-2010) beneficiaria 44.940 famílias, ou seja, 58\%. Por fim, a previsão de atendimento da Fase 3 é de aproximadamente 46.445 famílias.

Mesmo que todos esses investimentos de monta se concluam no tempo previsto não atenderão por completo o déficit habitacional estimado para áreas de proteção aos mananciais do município de São Paulo que, segundo os dados do Plano Municipal de Habitação (PMH 20092024), totalizava 166.779 domicílios em $2009^{78}$, sendo 150.973 domicílios déficit por inadequação $^{79}$ e 15.805 domicílios o déficit por substituição, ou seja, de provisão de novas unidades habitacionais ${ }^{80}$. O total do déficit por substituição, que não inclui o crescimento demográfico, divide-se em 9.958 domicílios em favelas e 5.847 domicílios em loteamentos precários (SÃO PAULO, 2010a, p. 33 e 35).

Além disso, após o anúncio da Fase 3 do Programa, uma comparação entre as áreas objeto de intervenção da Fase 2 e da Fase 3 apresenta sobreposições, justamente porque grande parte das áreas da Fase 2 encontrava-se, em 2012, em fase de contratação de obras. A comparação entre essas duas listas de atendimento ${ }^{81}$ nos permitiu concluir que das 61 áreas a serem atendidas na Fase 3, 39 também estavam previstas para serem atendidas na Fase 2 e 22 são áreas novas (ver tabela 22 no final do capítulo) não contempladas anteriormente. Há ainda 7 áreas que são remanescentes da Fase 1 do programa.

Muitos fatores podem explicar essa sobreposição como, por exemplo, a necessidade de se ajustar o projeto inicial às mudanças ocorridas no assentamento quando do início da obra, como o aumento de densidade construtiva e populacional; a necessidade de se complementar recursos para urbanizações complexas - pois muitas vezes problemas são descobertos quando a obra começa - implicando em aditivos de contrato; a organização e divisão de projetos extensos

\footnotetext{
78 O déficit por inadequação em área de proteção aos mananciais representa 18,74\% do déficit total por inadequação do município de São Paulo, que totalizava 889.808 domicílios em 2009. Nesse ano foram contabilizados na APM: 54.886 domicílios em favelas, 100.031 domicílios em loteamentos, 11.193 domicílios em núcleos de favela urbanizados e 669 domicílios em conjuntos habitacionais, totalizando 166.779 domicílios em situação de inadequação habitacional (PMSP/SEHAB, 2010, p. 30).

${ }^{79}$ A inadequação habitacional abrange todas aquelas necessidades de adequação da moradia existente - de natureza fundiária (irregularidade ou ausência da posse), urbanística (redes de infraestrutura insuficientes ou impróprias, existência de área de risco, carência de áreas verdes, equipamentos sociais) ou da edificação (seja por falta de condições de segurança, salubridade, conforto, seja por não contar com espaço interno suficiente para cada função). $\mathrm{Na}$ inadequação habitacional as moradias não precisam ser substituídas por uma nova moradia (PMSP/SEHAB, 2010, p. 29).

80 O déficit total por substituição no Município de São Paulo é de 133 mil moradias (sem considerar incremento demográfico e coabitação familiar, o que eleva o déficit para 266 mil domicílios) (Ibidem, p.35)

${ }^{81}$ Para fazer essa comparação, utilizamos a planilha sobre o Programa Mananciais Fase 2, fornecida pela SEHAB/PMSP à autora em 2008, e cruzamos com a lista de áreas da Fase 3 divulgada por meio da reportagem de lançamento do programa, que pode ser consultada em http://www.habisp.inf.br/pagina/b59h20_mais-de-46445-familias-que-vivemna-regiao-das-represas-billlings-e-guarapiranga-serao-beneficiadas, acesso em 28/08/2012.
} 
em etapas ${ }^{82}$ para que se viabilizem; ou ainda outros exemplos que seria possível citar a partir das especificidades da urbanização de favelas.

A tabela 22 explicita essa situação e, apesar das justificativas técnicas e financeiras possíveis, chama a atenção o fato de que 63\% das áreas da Fase 3 são continuidades da Fase 2 e que no início da Fase 2, grande parte dos projetos já estavam prontos para licitação. A partir dessas constatações e à luz da experiência do Programa Guarapiranga, é possível dizer que a pulverização de obras (organizadas em lotes, como mostra o mapa 27 do Programa Fase 2) e sua incompletude geram um grande impacto negativo na população local e em termos urbanos e ambientais, mas não afeta o ganho que isso representa para as empreiteiras envolvidas, que recebem seus pagamentos conforme as etapas de obras são concluídas. Os assentamentos precários nos mananciais representam assim um imenso canteiro de obras em potencial para essas empresas. E nesse ponto, o caso do município de São Paulo, por sua abrangência e dimensão, é bastante elucidativo.

Observa-se também que o Programa Mananciais recebeu significativa ampliação de investimentos. Considerando os recursos de todos os agentes executores, o PAC Mananciais (valor total de $U \$ 533,31$ milhões) ${ }^{83}$ recebe um financiamento maior se comparado ao que foi o do Programa Guarapiranga (valor final gasto até 2000 de U\$ 335,99) (UEMURA, 2000, p.136), para ser empenhado num menor tempo. A terceira fase, que tem sido anunciada como a última e conclusiva, tem orçamento de cerca de $\mathrm{R} \$ 2,8$ bilhões e contará com recursos da Prefeitura de São Paulo, do governo do estado e do governo federal ${ }^{84}$.

Segundo Ricardo Araújo, coordenador do Projeto Mananciais pela SSE em 2008, um dos fatores importantes a considerar no quadro de ampliação dos investimentos é a mudança do contexto econômico, de 2000 (quando começaram a estudar a continuidade e ampliação do programa) a 2008. Se em 2000 as dificuldades fiscais limitavam a capacidade de investimento estatal, a partir de 2003 ocorreu o crescimento do PIB e maiores condições de "saúde fiscal" (ARAÚJO, 2008, p.207). Mas destaca-se também a decisão do governo federal de ampliar os investimentos em urbanização de favelas e loteamentos e em saneamento.

Se de fato a situação econômica no contexto nacional mudou, ela vem acompanhada do reforço de antigas lógicas desenvolvimentistas que, aplicadas tanto à habitação de interesse social (como o atual programa federal Minha Casa Minha Vida) como nas urbanizações de assentamentos precários, apostam na solução quantitativa, e os projetos tendem a significar grandes intervenções. Isso não implica que urbanizações de grande porte, que requalificam o assentamento como um todo, não sejam necessárias, mesmo porque, é inegável que a

\footnotetext{
${ }^{82}$ Sabe-se que alguns projetos maiores também se dividem em fases, como é o caso do Cantinho do Céu, Jardim dos Lagos, Gaivotas, que já passou por implantação de parque na orla da represa e terá continuidade em outros trechos.

${ }^{83}$ Conforme Secretaria de Saneamento e Energia, 2008.

${ }^{84}$ Conforme matéria publicada em O Estado de São Paulo, "Recuperação de represas de São Paulo terá $R \$$ 2,8 bilhões", em 12/03/2012, disponível em http://www.estadao.com.br/noticias/cidades,recuperacao-de-represas-desp-tera-r-28-bilhoes,847509,0.htm.
} 
complexidade das intervenções tem aumentado, pois a precariedade também aumentou, as favelas estão mais densas e acumulam problemas de toda ordem. Mas nem sempre assentamentos de alta complexidade e vulnerabilidade passam por intervenções consideradas integradas e integrais. Sendo assim, apesar de se identificar uma postura do poder público em defender intervenções de grande porte, apostando na quantidade, o que se verifica na prática são projetos pontuais, que não se relacionam entre si, e que, quando apresentam qualidade urbanística e arquitetônica - o que não é uma constante - ganham a cena publicitária e concursos internacionais, sem que sejam avaliados os ganhos de conjunto - o que no caso das áreas de proteção aos mananciais é ainda mais fundamental.

\subsection{Programa de Saneamento Ambiental dos Mananciais do Alto Tietê}

A tentativa de conseguir novo acordo de empréstimo do Banco Mundial mobilizou o governo estadual logo após o encerramento do financiamento do Programa Guarapiranga, em 2000, aproveitando a experiência acumulada até então. O trabalho de preparação foi coordenado pela SSE - Secretaria de Saneamento e Energia do Estado de São Paulo, através de uma UGP Unidade de Gerenciamento do Programa. Foi proposto que o Programa passasse a abranger cinco sub-bacias da Bacia do Alto Tietê: Guarapiranga, Billings, Alto Tietê-Cabeceiras, JuqueriCantareira e Alto e Baixo Cotia, sendo por isso denominado de Programa de Saneamento Ambiental dos Mananciais do Alto Tietê (Programa Mananciais-AT).

Esse novo projeto teve de ser formatado segundo as orientações do Banco Mundial. Pelas suas características, o Programa Mananciais-AT recebeu a classificação de Categoria Ambiental "A", o que implicou a obrigatoriedade de incluir políticas de salvaguarda para: Avaliação Ambiental; Habitats Naturais; Recursos Físico-Culturais; Reassentamentos Involuntários; Segurança de Barragens.

Os objetivos centrais do projeto refletem a continuidade da proposta do Programa Guarapiranga, qual seja, de "contribuir para a proteção dos mananciais metropolitanos, propiciando, além disso, o ordenamento territorial e a melhoria da qualidade de vida da população". Particularmente nas bacias da Guarapiranga e Billings, que são mais adensadas e apresentam maiores impactos decorrentes da ocupação "o Programa prevê a execução integrada de ações variadas, de expansão e melhoria da infraestrutura pública, de preservação ambiental e de natureza social, além de estudos técnicos relacionados à qualidade da água e à gestão das sub-bacias" (SÃO PAULO, 2009, p.5).

Em 2001, o Programa Mananciais-AT foi discutido no âmbito do Subcomitê BillingsTamanduateí, aproveitando a fase de avaliação do Programa Guarapiranga e foi aprimorado a partir de propostas desse colegiado ${ }^{85}$ (Ibidem, p.6). A preparação do Programa levou à redação

\footnotetext{
${ }^{85}$ Em 2001, as discussões levaram ao estabelecimento de um acordo do Governo do Estado de São Paulo com o Policy and Human Resources Development Fund - PHRD, do Japão (Fundo de Políticas e Desenvolvimento de Recursos Humanos), intermediado pelo Banco Mundial, para doação de recursos destinados à preparação do Projeto Mananciais.
} 
de uma Carta Consulta, aprovada em maio de 2006, pela COFIEX - Comissão de Financiamento Externo, da Secretaria de Assuntos Internacionais do Governo Federal.

Segundo o documento consultado (SSE, 2009), o orçamento a ser executado em seis anos, totalizava U\$ 235 milhões dos quais US\$ 130 milhões financiados pelo Banco Mundial/BIRD, incluindo acordos de empréstimo das Prefeituras de Guarulhos e de São Bernardo do Campo conforme tabelas a seguir que mostram os recursos por agente tomador:

Tabela 17 - Valor do Programa por órgão executor/tomador empréstimo.

\begin{tabular}{l|cc|cc|cc}
\hline \multirow{2}{*}{ COMPONENTE } & \multicolumn{2}{|c|}{ TOTAL } & \multicolumn{2}{c|}{ FINANCIAMENTO } & \multicolumn{2}{c}{ CONTRAPARTIDA } \\
& (US\$ milhão) & (\%) & (US\$ milhão) & (\%) & (US\$ milhão) & (\%) \\
\hline Estado & 60,50 & $25,7 \%$ & 4,00 & $6,6 \%$ & 56,50 & $53,9 \%$ \\
SSE & 19,77 & $8,4 \%$ & 3,00 & $15,2 \%$ & 16,77 & $16,0 \%$ \\
SMA & 10,13 & $4,3 \%$ & 1,00 & $9,9 \%$ & 9,13 & $8,7 \%$ \\
CDHU & 30,60 & $13,0 \%$ & - & $0,0 \%$ & 30,60 & $29,2 \%$ \\
Sabesp & 125,00 & $53,2 \%$ & 100,00 & $80,0 \%$ & 25,00 & $23,9 \%$ \\
PMSBC & 37,67 & $16,0 \%$ & 18,96 & $50,3 \%$ & 18,71 & $17,8 \%$ \\
PMG & 10,67 & $4,5 \%$ & 6,06 & $56,7 \%$ & 4,61 & $4,4 \%$ \\
\hline Sub-total & 233,84 & $100 \%$ & 129,02 & $55,0 \%$ & 104,82 & $100,0 \%$ \\
Recursos Não Alocados & 1,16 & $0,5 \%$ & 0,98 & $84,5 \%$ & 0,18 & $0,2 \%$ \\
Total & 235,00 & $100 \%$ & 130,00 & $55 \%$ & 105,00 & $100 \%$ \\
\hline
\end{tabular}

Fonte: Secretaria de Saneamento e Energia, 2009, p. 65. Nota: Taxa de câmbio adotada: U\$ $1.00=R \$ 2.50$.

A Sabesp assinou seu Acordo de Empréstimo em 27/09/2009, efetivado em 24/03/2010, no valor de US\$ 125 milhões, sendo US\$ 100 milhões financiados. O Acordo com o Governo do Estado, com valor total de US\$ 60,5 milhões, dos quais US\$ 4 milhões financiados, foi assinado em 27/09/2010, com efetividade declarada em 21/12/2010. Os executores são a Secretaria de Saneamento e Recursos Hídricos, a Secretaria do Meio Ambiente e a CDHU.

Por meio destes acordos, em todos os mananciais da RMSP serão desenvolvidas ações de: (i) estruturação e recuperação urbana; (ii) preservação e recuperação ambiental; (iii) saneamento ambiental e (iv) instrumentos de gestão.

Tabela 18 - Valor do Programa por componente.

\begin{tabular}{|c|c|c|c|c|}
\hline \multirow{2}{*}{ COMPONENTE } & \multicolumn{4}{|c|}{ VALOR (US\$ milhão) } \\
\hline & \multicolumn{2}{|c|}{ TOTAL } & BIRD & $\mathrm{CP}$ \\
\hline Instrumentos de Sustentação e Gestão & 32,18 & $13,7 \%$ & 13,85 & 18,33 \\
\hline Estruturação e Recuperação Urbana & 54,30 & $23,1 \%$ & 11,50 & 42,80 \\
\hline Proteção e Recuperação Ambiental & 23,16 & $9,9 \%$ & 13,67 & 9,49 \\
\hline Saneamento Ambiental & 122,38 & $52,1 \%$ & 89,49 & 32,89 \\
\hline Front-end fee & 0,32 & $0,1 \%$ & 0,32 & - \\
\hline Sub-total & 232,34 & $98,9 \%$ & 128,83 & 103,51 \\
\hline Recursos Não Alocados & 2,66 & $1,1 \%$ & 1,17 & 1,49 \\
\hline Total & 235,00 & $100 \%$ & 130,00 & 105,00 \\
\hline
\end{tabular}

Fonte: Secretaria de Saneamento e Energia, 2009, p. 64. Nota: Taxa de câmbio adotada: U\$ $1.00=R \$ 2.50$ 
Tabela 19 - Valor do Programa por Sub-bacias de intervenção:

\begin{tabular}{l|cc|c|c}
\hline \multirow{2}{*}{ COMPONENTE } & \multicolumn{3}{|c}{ VALOR (US\$ milhão) } \\
\cline { 2 - 5 } & \multicolumn{2}{|c}{ TOTAL } & BIRD & CP \\
\hline Guarapiranga & 42,70 & $18,2 \%$ & 27,48 & 15,22 \\
Billings & 96,00 & $40,9 \%$ & 46,11 & 49,89 \\
Alto Tietê-Cabeceiras & 7,93 & $3,4 \%$ & 6,60 & 1,33 \\
Juqueri-Cantareira & 27,36 & $11,6 \%$ & 21,42 & 5,94 \\
Cotia & 8,80 & $3,7 \%$ & 3,50 & 5,30 \\
Geral (Comum a Todas as Bacias) & 34,93 & $14,9 \%$ & 15,17 & 19,76 \\
Front-end fee & 14,62 & $6,2 \%$ & 8,55 & 6,07 \\
\hline Sub-total & 232,34 & $98,9 \%$ & 128,83 & 103,51 \\
Recursos Não Alocados & 2,66 & $1,1 \%$ & 1,17 & 1,49 \\
Total & 235,00 & $100 \%$ & 130,00 & 105,00 \\
\hline
\end{tabular}

Fonte: Secretaria de Saneamento e Energia, 2009, p. 64. Nota: Taxa de câmbio adotada: U\$ $1.00=R \$ 2.50$

Além desse montante de financiamento do Banco Mundial, há o aporte de recursos do Governo Federal (da OGU), por meio do PAC Mananciais, totalizando um orçamento de 1,3 bilhão de reais.

O desenho institucional ${ }^{86}$ deste programa dá continuidade àquele estruturado pelo Programa Guarapiranga. Ele é coordenado pela SSE - Secretaria de Saneamento e Energia do Estado de São Paulo, através de uma UGP - Unidade de Gerenciamento do Programa, com a participação de Unidades Executoras Locais e um Conselho de Coordenadores do Programa Mananciais (que se reporta ao Secretário de Saneamento e Energia). Além dos órgãos estaduais, Secretaria de Meio Ambiente, da Companhia de Desenvolvimento Habitacional e Urbano do Estado de São Paulo (CDHU) e a Companhia de Saneamento de São Paulo (Sabesp), inicialmente o programa envolvia as prefeituras de São Bernardo do Campo, Santo André e Diadema. No entanto, devido à demora na obtenção de recursos do financiamento externo, as prefeituras de Diadema e Santo Andre saíram do Programa ${ }^{87}$, permanecendo apenas São Bernardo do Campo e Guarulhos ${ }^{88}$.

As ações previstas foram desenvolvidas em conjunto com os tomadores, sendo que a SSE verificava a compatibilidade tanto com as exigências do BIRD, quanto da prioridade dos projetos propostos em relação à recuperação dos mananciais. Os quadros 4 e 5, ao final deste capítulo,

\footnotetext{
${ }^{86}$ O Decreto $n^{\circ} 52.663$ de 24 de janeiro de 2008 dispõe sobre a estrutura organizacional voltada à implantação do Programa de Saneamento Ambiental dos Mananciais do Alto Tietê - Programa Mananciais e dá providências correlatas.

${ }^{87}$ Informação verbal, conforme Paulo Massoca, secretário adjunto da Secretaria de Habitação de São Bernardo do Campo em entrevista concedida à autora em 07/11/2011.

${ }^{88}$ Ao longo do processo de discussão, outros municípios da bacia da Billings como Ribeirão Pires e Rio Grande da Serra reivindicaram participação, apesar da baixa capacidade financeira para obter empréstimos internacionais. A SSE incluiu atividades pontuais nesses municípios, como a remediação de lixões, conforme quadro 5.
} 
apresentam os conteúdos resumidos de cada agente executor por tipo de atividade do programa $^{89}$.

Além do desenho institucional, o Programa Mananciais-AT manteve as linhas programáticas do Programa Guarapiranga, bem como o escopo geral das ações previstas. Nesse sentido há dois aspectos a pontuar. Apesar das avaliações críticas formuladas tanto pela academia quanto por demais instituições militantes pela proteção dos mananciais sobre os projetos e obras de urbanização, não se verifica a proposição de mudanças em relação a isso no atual programa além das exigências que aumentaram com a Lei Específica. Outro ponto se refere ao modelo de saneamento adotado pela Sabesp, particularmente o sistema de esgotos, cujo ritmo de construção está defasado em relação ao aumento de moradias, sem que se busquem alternativas, ainda que temporárias, para minimizar o aporte de poluentes na represa.

Assim, a análise dos conteúdos do programa nos permite dizer que não há propostas para mudar ou avançar no questionamento dos modelos utilizados pela Sabesp para a implantação das redes de saneamento, com o sistema separador completo e exportação dos esgotos coletados para fora da bacia, o que gera grande necessidade de remoção de famílias para sua construção e alto custo na execução de obras percorrendo longas distâncias.

Nesse ponto, os estudos que consideram outras formas de saneamento não são ao menos discutidos, já que questionam o sistema centralizado de investimentos em grandes obras de coletores-tronco e estações de tratamento. Dentre eles, há um questionamento por parte de técnicos da área de saneamento, que pesquisam o sistema unitário ${ }^{90}$ como sendo mais adequado às ocupações de alta densidade populacional e construtiva, padrão presente nos assentamentos precários urbanos das cidades brasileiras (YAZAKI, 2008, p.281-310).

O Programa Mananciais-AT teve sua abrangência territorial ampliada, mas manteve os projetos propostos segundo os componentes de gestão, recuperação ambiental, saneamento, recuperação urbana, ou seja, o escopo de atividades organiza-se de forma semelhante ao Programa Guarapiranga. A partir das informações sobre financiamento e projetos propostos, fica claro que as obras de urbanização e de saneamento continuam prioritárias e concentram maior aporte de recursos, com a diferença que o projeto de parques ganha relevância nessa versão.

Com isso, há um reforço de ações setoriais, que podem ocorrer de modo independente, contrariando o argumento de integração intersetorial proposto no próprio documento que embasa o projeto e que seria uma premissa para uma intervenção mais abrangente nas bacias hidrográficas. Fazendo uma comparação com o Projeto Billings, no qual as ações elencadas eram orientadas por objetivos relativos à recuperação e à proteção, o Programa Mananciais-AT acabou sendo diluído em linhas setoriais, dificultando a ação integrada (CARMO; TAGNIN, 2001, p.437).

\footnotetext{
${ }^{89}$ Este relatório e seus anexos estão disponíveis no site http://www.saneamento.sp.gov.br/cariboost_files/ relatorio_ambiental_revjun09.pdf. Acesso em 15/06/2011.

90 No sistema unitário as águas provenientes do sistema de drenagem e da coleta de esgotos é um só, e essas águas são tratadas conjuntamente.
} 
Se, por um lado, a continuidade da política pública é algo importante, por outro, fica claro que o Programa Mananciais-AT é pautado pelos financiamentos do BIRD e por prazos eleitorais para conclusão de obras.

Mas além dele, outros programas têm sido desenvolvidos nessas áreas, tais como: Programa Guarapiranga e Billings ou PAC Mananciais, abordado anteriormente; Pró-Billings - Programa Integrado de Melhoria Ambiental na Área de Mananciais da Represa Billings no município de São Bernardo do Campo, a cargo da Sabesp e financiado pelo governo do Japão ${ }^{91}$; Programa Córrego Limpo $^{92}$; Projeto Orla Guarapiranga ${ }^{93}$. Diante de todos esses investimentos, por que a qualidade da água continua sendo um problema? O que faz dessas intervenções melhorias pontuais?

O que chama a atenção é o fato de que não há uma estrutura institucional, como preconizado na Lei Específica, que articule e acompanhe o andamento desses projetos e seus impactos no conjunto das bacias e nos reservatórios. Esse papel também não tem sido desempenhado pelos Subcomitês de Bacias ${ }^{94}$ nos últimos anos. O conhecimento sobre cada projeto acaba ficando restrito aos responsáveis pela execução de suas respectivas partes. Até mesmo o monitoramento da qualidade da água, verificando melhorias ou pioras decorrentes das intervenções, fica comprometido, pois há não só uma fragmentação das próprias obras de urbanização e saneamento, como desses diferentes programas entre si. Além disso, grande parte das informações fica circunscrita à Sabesp, que desenvolve grande parte das intervenções, e à cada município participante, quando se tem acesso a elas. O acompanhamento social desse processo fica invialibilizado. O único dado disponibilizado facilmente ao público em geral são os de balneabilidade, mas não aqueles referentes à qualidade da água para consumo.

\footnotetext{
${ }^{91}$ Pró-Billings - Programa Integrado de Melhoria Ambiental na Área de Mananciais da Represa Billings no município de São Bernardo do Campo é um projeto financiado pela JICA - Japan International Cooperation Agency para a Sabesp, que prevê a expansão do sistema de esgotamento sanitário no município de São Bernardo do Campo (atendendo as áreas mais ocupadas da bacia da represa Billings). Seu orçamento é de US\$123 milhões e a principal obra planejada é a do coletor tronco do Ribeirão dos Couros, que permitirá o transporte dos esgotos coletados até a Estação de Tratamento do ABC. A população a ser beneficiada alcança 250 mil habitantes e o prazo previsto para a execução das obras é de cinco anos (até 2018).

92 O Programa Córrego Limpo é uma parceria da Prefeitura de São Paulo e Sabesp, que tem por objetivo corrigir deficiências de sistemas já existentes de esgotamento sanitário, ampliando as vazões transportadas até as estações de tratamento e gerando maiores benefícios ambientais. Uma vez que as deficiências são mais agudas em áreas marcadas pela urbanização precária (arruamento inadequado, ocupação de fundos de vale por favelas e outras moradias, problemas de drenagem), a ação da Sabesp com frequência deve ser apoiada por intervenções da Prefeitura, como remoção de imóveis situados nas faixas ribeirinhas ou reurbanização de favelas nas proximidades dos fundos de vale para permitir a implantação de coletores-tronco, e a implantação de parques lineares para a preservação dos fundos de vale. Contempla um total de 100 córregos com população estimada em 3,8 milhões de habitantes e orçamento estimativo de R\$ 440 milhões, dos quais R\$ 310 milhões deverão ser aportados pela Sabesp e R\$ 130 milhões pela Prefeitura de São Paulo (SÃO PAULO, 2009).

93 O Projeto Orla Guarapiranga, desenvolvido pela Prefeitura de São Paulo, objetiva a recuperação da região da orla do Guarapiranga para as atividades de esporte, turismo e lazer, por meio de investimentos na implantação de novos parques e equipamentos para uso da população. Os parques deverão ocupar, principalmente, áreas cedidas pela Empresa Metropolitana de Águas e Energia - EMAE (empresa do Governo do Estado), a quem pertence o patrimônio da barragem, da represa e de suas margens. Prevê-se um total de cinco parques, com área total de 1 milhão de m2, sendo um deles o Nove de Julho, que faz parte do Programa Mananciais. Os parques serão interligados por uma via pública, uma pista de caminhada e uma ciclovia (SÃO PAULO, 2009).

${ }^{94}$ Conforme aferido em diversas entrevistas realizadas.
} 
Há que se considerar também a presença de uma série de outras intervenções que são incompatíveis com a finalidade prioritária de abastecimento de água, como o já citado Rodoanel - sendo que nem mesmo as compensações ambientais foram concluídas; ou projetos como o Ferroanel, o Monotrilho e o Hidroanel, cujas análises de impacto são realizadas não como um critério de decisão de implementação ou suspensão do projeto, mas como argumento para compensar danos ambientais e justificar sua implantação.

Nesse contexto, a participação e o controle social não entram como elementos a serem considerados no Programa Mananciais-AT, tampouco nos demais, que se baseiam na utilização de instrumentos formais (audiências públicas) ou canais institucionalizados (Subcomitê) de participação, de forma que o caráter consultivo prevalece sobre a possibilidade de interferir em decisões e deliberações, ainda que haja movimento social como importante contraponto.

Isso mostra que a intervenção em mananciais entrou na pauta da política pública, completando 20 anos, e seu desenho e prática reforçam um modo de intervir sobre o espaço urbano que expressa um descolamento de seus objetivos centrais: proteção e recuperação dos mananciais, integração de políticas e participação social.

Assim, se formalmente a bacia hidrográfica é uma unidade de planejamento e gestão, conforme as leis vigentes, ela não é reconhecida politicamente em termos de planejamento de ações concretas e democráticas que transformarão esse território, ainda mais diante de uma desmobilização do próprio sistema de gestão de recursos hídricos. O reconhecimento da bacia como unidade sofre de problemas semelhantes ao da gestão metropolitana, que continua centralizada no governo estadual. 


\section{CAPÍTUL0 9}

\section{Os Programas de Recuperação de Interesse Social em São Bernardo: reflexões sobre a prática recente}

Nos capítulos 7 e 8 precedentes discutiu-se dois elementos que pautam a atual política de mananciais, quais sejam, a legislação pertinente e os programas de financiamento que constituem o Programa Mananciais. No presente capítulo enfocamos os Programas de Recuperação de Interesse Social - PRIS, no intuito de ilustrar exemplos de como esse instrumento da LE-Billings tem sido traduzido em projetos de intervenção.

Para isso, tomam-se duas experiências iniciais de PRIS no município de São Bernardo, que são bastante distintas entre si: o PAC Alvarenga e o PRIS Capelinha e Cocaia. O objetivo não é compará-las, mas explicitar as interfaces entre solução habitacional, de infraestrutura e de recuperação de áreas de preservação permanente presentes em cada projeto.

Além de explicitar de que forma a Lei Específica e os programas se espacializam por meio dos PRIS, este capítulo tem como objetivo pontuar mais um momento em que a implementação de infraestrutura, agora produzida a partir da ação do poder público, alcança as áreas de proteção aos mananciais, através de uma análise empírica.

Nesse sentido, confrontam-se as soluções dos PRIS com o planejamento de expansão das redes pela Sabesp, no município de São Bernardo do Campo, buscando articular, numa leitura urbana e ambiental, essas duas escalas de provisão de infraestrutura: a escala do assentamento precário e aquela do sistema de saneamento. Desse modo, as ambiguidades relativas à noção de recuperação ambiental, já formuladas em relação à Lei Específica e aos programas, são corroboradas pelas experiências práticas dos PRIS. 


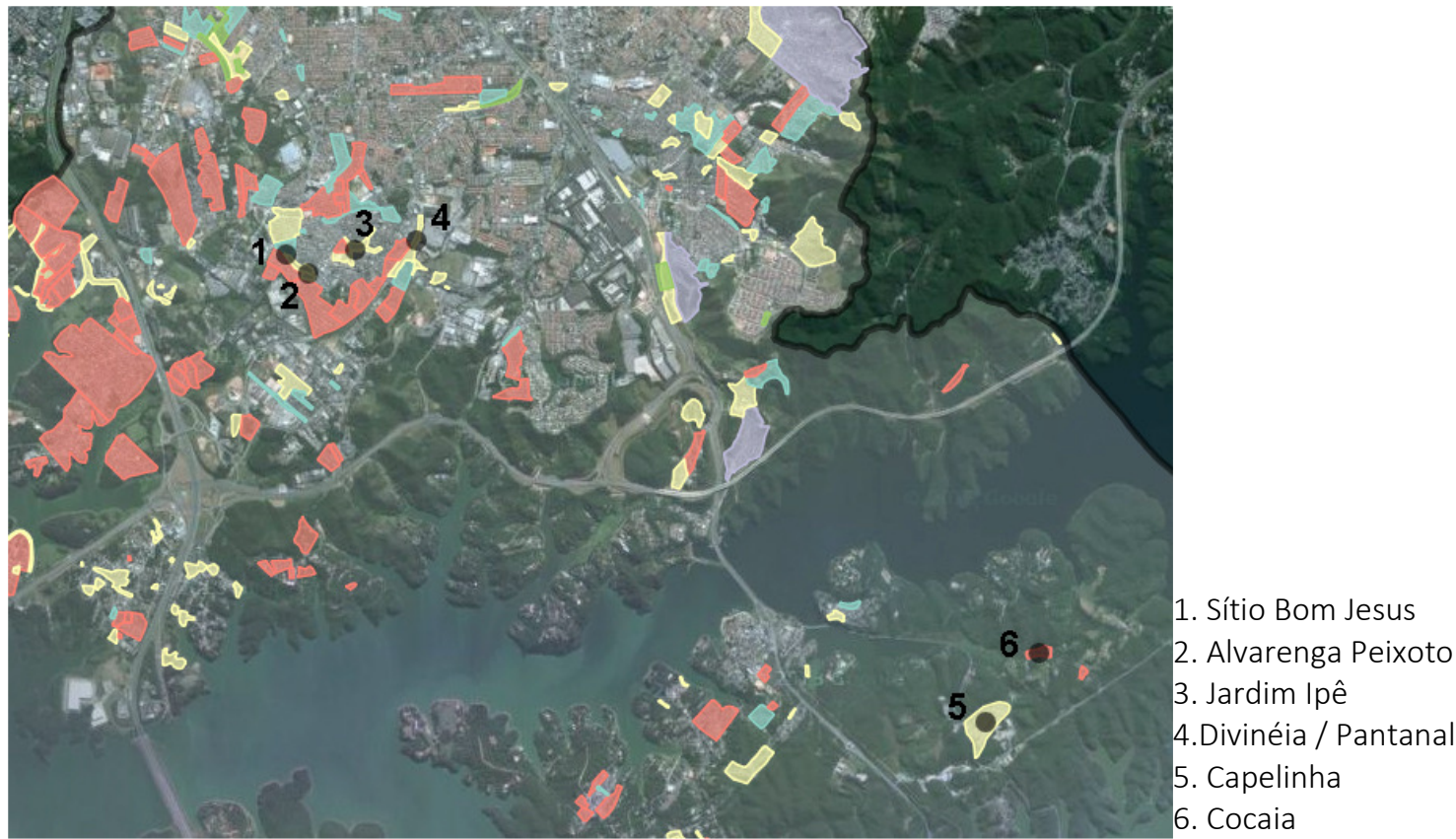

Figura 64 - Programas de Recuperação: PAC Alvarenga e Capelinha/Cocaia.

Fonte: Sistema de Informação de Habitação de Interesse Social de São Bernardo do Campo, 2013.

\subsection{Os PRIS: infraestrutura e regularização}

A urbanização de assentamentos precários foi incorporada à Lei Específica da Billings no 13.579/2009 por meio do Programa de Recuperação de Interesse Social - PRIS. Conforme a definição expressa no decreto no 55.342/2010 que regulamenta essa lei, o PRIS é um "conjunto de medidas e intervenções de caráter corretivo das situações degradacionais existentes e de recuperação ambiental e urbanística, previamente identificado pelo Poder Público competente, com o objetivo de melhoria das condições de saneamento ambiental e regularização fundiária dos locais enquadrados na categoria de Área de Recuperação Ambiental 1 - ARA 1".

Para que um PRIS possa ser implementado, o poder público responsável e proponente do programa deve primeiramente encaminhar justificativa de enquadramento do assentamento como PRIS, junto ao órgão técnico, que atualmente é a Cetesb. O parecer deve conter um diagnóstico físico, socioeconômico e ambiental da área de intervenção ${ }^{95}$, que o justifique enquanto tal.

Em seguida à obtenção do enquadramento, para a etapa de licenciamento do PRIS, o órgão ou entidade pública responsável por sua promoção deve apresentar um Plano de Urbanização, contendo o projeto completo de infraestruturas de saneamento ambiental, terraplenagem e pavimentação, paisagismo, trabalho social, circulação de transporte coletivo, proposta e

\footnotetext{
95 O parecer para enquadramento como PRIS deve conter: I - caracterização da ocupação e condição socioeconômica da população; II - risco ambiental e sanitário em relação ao manancial; III - condição e viabilidade de implantação de sistemas de saneamento ambiental; IV - cronograma físico da intervenção com respectivo orçamento estimativo; V indicação dos agentes executores do PRIS.
} 
estratégia de recuperação ambiental das áreas livres ou que serão desocupadas pela intervenção, proposta e estratégia de plano de regularização fundiária, e projeto de habitação de interesse social que privilegiem a melhor relação de ganho ambiental entre a área construída e o gabarito, e a maior taxa de permeabilidade e revegetação possíveis, devendo ser objeto de regulamentação.

Assim, a exigência da elaboração de um plano tem como intenção promover intervenções integradas, que venham abranger transformações estruturais nas ocupações e evitem ações pontuais que muitas vezes não se sustentam com o passar do tempo e com o aumento da densidade populacional, demandando reinvestimentos nas mesmas áreas. Ao mesmo tempo, essas intervenções requerem investimentos de grande porte.

No PRIS não há exigência de cumprimento de parâmetros urbanísticos básicos constantes da Lei Específica, mas devem ser atendidos a taxa de permeabilidade e o índice de área vegetada. 0 poder público deve aferir o abatimento de cargas poluidoras geradas pela intervenção, simulada com a ferramenta Modelo de Correlação entre o Uso do Solo e a Qualidade da Água - MQUAL, após as obras ${ }^{96}$. Cabe observar que a aplicação do MQUAL não está presente para novos usos a serem instalados na bacia, tornando a lei mais exigente em áreas de interesse social. Nesse sentido, nas áreas objeto de PRIS, por exemplo, é admitido o lote de $125 \mathrm{~m}^{2}$ para a regularização fundiária (o lote mínimo para novas ocupações é de $250 \mathrm{~m}^{2}$ ) e novas unidades habitacionais devem ter área mínima de $42 \mathrm{~m}^{2}$, sendo fixados gabaritos máximos para os edifícios de habitação de interesse social, que variam conforme a subárea onde estão inseridos (ver quadro 2 do capítulo 7).

É importante destacar que, em Área de Recuperação Ambiental 1 (ARA-1), a regularização fundiária poderá ser efetivada após confirmada a execução das obras e ações urbanísticas e ambientais, e será finalizada após comprovação de dois anos da manutenção das obras de saneamento ambiental. Segundo Márcia Nascimento, buscou-se com isso um maior comprometimento da população na manutenção das obras. Nas suas palavras, "ter um vínculo e um compromisso da população, do viés social com a questão ambiental, porque senão ia se caracterizar como mais uma anistia" ${ }^{\prime 7}$, haja visto que não há a obrigatoriedade de cumprimento de diversos parâmetros urbanísticos.

Da forma como o PRIS está definido na LE-Billings, ele viabiliza a regularização fundiária e a intervenção de saneamento ambiental nos assentamentos precários, a partir de projetos de intervenção, e propõe recuperar um passivo social e ambiental que há muitos anos ficou restringido pela Lei de Proteção aos Mananciais, a não ser em situações de exceção, conforme a Lei no 9866/1997, avaliada anteriormente. Contudo, os procedimentos para que o PRIS fosse licenciado não estavam definidos na LE-Billings. E, apesar do aparente consenso sobre a

\footnotetext{
${ }^{96}$ Conforme artigo 14, parágrafo 3ㅇ, do decreto no 55.342/2010.

${ }^{97}$ Informação verbal, conforme entrevista de Márcia Nascimento concedida à autora em 25/10/2012. Márcia Nascimento é arquiteta e urbanista, atuou como representante da SMA nos Subcomitê Billings-Tamanduateí e coordenou o grupo de trabalho da Lei Específica da Billings bem como do decreto regulamentador.
} 
importância de implementá-los, no momento em que as prefeituras passam a demandar o processo de licenciamento na Cetesb, e as definições da LE e do decreto passam a ser operacionalizadas e melhor detalhadas, surgem alguns conflitos de interpretação dessas, com consequências importantes para o andamento dos projetos de urbanização.

Em junho de 2011, a Cetesb lançou um "Manual para elaboração de PRIS", com procedimentos para orientar as prefeituras. Muitos desses procedimentos foram contestados por elas, pois consideraram o processo de licenciamento de alto custo financeiro, lento, e com aspectos

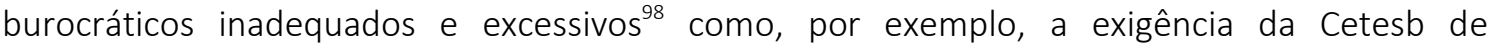
apresentação por parte da prefeitura do domínio da gleba a ser regularizada em seu nome, sendo que, em grande parte dos casos, trata-se de áreas cuja origem da irregularidade está justamente no fato de elas serem de propriedade particular.

Outro aspecto não equacionado pela lei decorria do fato dela tratar de forma homogênea diferentes situações de consolidação da ocupação. Ou seja, as exigências de elaboração do PRIS não consideraram que os assentamentos irregulares na Bacia da Billings apresentam diferentes graus de precariedade, consolidação e necessidades, e que nem todos dependem de grandes intervenções e obras para serem regularizados, particularmente em áreas de ocupação mais antiga, anterior a 1975, e que receberam instalação completa ou parcial de infraestrutura da Prefeitura ao longo dos anos. Nesse sentido, os municípios defendiam um procedimento diferenciado para assentamentos que seriam objeto somente de regularização fundiária.

Mais um ponto bastante problemático era tratar as áreas destinadas ao reassentamento habitacional em APM com os mesmos parâmetros utilizados para novas ocupações (mais restritivos) e não com aqueles flexibilizados para os PRIS, dificultando assim o melhor aproveitamento do terreno para provisão de habitação de interesse social.

Por isso, as prefeituras organizaram outro documento com propostas de alteração ao Manual, encaminhado à Cetesb pelo Consórcio do $A B C^{99}$, em agosto de 2011. Esse debate resultou na criação de um grupo de trabalho ${ }^{100}$ para acertar procedimentos específicos para os casos de PRIS, e tem gerado resultados positivos nesse sentido ${ }^{101}$ pois questões importantes para sua viabilização, como as citadas acima, foram revistas e alteradas.

Não abordaremos em detalhe todos os pontos que estão em debate, mesmo porque trata-se de um trabalho que se faz conforme os processos de licenciamento ${ }^{102}$ se esclarecem e os consensos

\footnotetext{
98 Informação verbal, conforme entrevista de Tássia Regino, Secretária de Habitação de São Bernardo do Campo, na gestão 2008-2012 e atual, concedida à autora em 16/01/2012.

99 O documento foi elaborado pelos Técnicos das Prefeituras da área de Habitação, Planejamento Urbano e Meio Ambiente e do Consórcio Intermunicipal Grande ABC (CONSÓRCIO..., 2011).

${ }^{100}$ Criado pela Resolução SMA 07/2012 para disciplinar o licenciamento ambiental na APRM-B.

${ }^{101}$ Conforme avalia Patrícia Lorenz, diretora da Secretaria de Gestão Ambiental de São Bernardo do Campo na gestão 2008-2012 em entrevista concedida à autora em 26/07/2012.

102 As decisões desse grupo de trabalho serão transformadas em resoluções SMA/CETESB. Até o momento de conclusão dessa tese, a minuta de resolução SM/CETESB definia que o PRIS deve passar por três estágios do licenciamento ambiental: a emissão de licença prévia, licença de instalação e licença de operação.
} 
alcançados pelo próprio grupo avançam, numa negociação constante. E uma avaliação mais precisa requereria aprofundar uma reflexão sobre o propósito do licenciamento ambiental ser aplicado ao caso de PRIS, o que foge ao escopo dessa tese.

De qualquer forma, nota-se que há um rigor excessivo quanto às exigências da Cetesb - que até então não trabalhava com questões relacionadas à habitação de interesse social, mas com empreendimentos e indústrias poluentes - a serem cumpridas pelos municípios e que, até o presente momento, há uma resistência em incorporar a experiência acumulada em projetos habitacionais, de urbanização e de regularização, no sentido de simplificar procedimentos e torná-los mais viáveis, até do ponto de vista de seu monitoramento.

O processo de licenciamento, da forma como tem se apresentado, indica uma busca pelo controle das intervenções por parte da Cetesb, pois ainda que as ARAs-1, objeto de PRIS, correspondam às áreas de ZEIS no Plano Diretor, ou seja, já são identificadas como áreas prioritárias para a intervenção do poder público municipal no sentido de uma regularização urbanística e fundiária, só são consideradas PRIS, passíveis de regularização em APM, após a autorização da Cetesb. Portanto, antes de um assentamento ser enquadrado como PRIS, valem para sua regularização os parâmetros definidos pelo Plano Diretor, indicados pela zona onde está inserido, que, nesse caso, são mais restritivos e incompatíveis com o padrão de ocupação precário. O que ocorre é que há uma interferência da legislação estadual ambiental no controle do uso e ocupação do solo urbano que é atribuição municipal, daí decorrem alguns conflitos de interpretação e uso da lei específica.

Com isso o Governo do Estado, por meio da Cetesb, mantém a postura do controle excessivo e regulatório, considerada capaz de garantir a qualidade ambiental das intervenções, o que nem sempre acontece.

A busca por um padrão urbano e ambiental possível, em urbanizações de assentamentos precários, coloca em questão a legislação ambiental porque se, de um lado, o seu não cumprimento, ou o cumprimento parcial de uma determinada restrição ambiental, pode impedir grandes remoções de moradias, por outro, a completa flexibilização das exigências ambientais pode inviabilizar e melhoria da qualidade ambiental da intervenção.

Esses impasses estão frequentemente presentes em projetos de urbanização de assentamentos precários, e seu equacionamento depende em grande medida das soluções projetuais, bem como das formas de compensação ambiental possíveis. Também dependem da adesão da população às mudanças para que se mantenham ao longo do tempo, ou seja, não se resolvem estritamente do ponto de vista técnico. Por outro lado, a qualidade das intervenções municipais pode ser questionada, e nem sempre é garantida, pois os projetos são heterogêneos e a qualidade de sua execução também é variável.

Sendo assim, pode-se afirmar que, apesar da LE-Billings avançar nas possibilidades de regularização de interesse social, não avançou nos termos da aplicação da legislação ambiental e na sua interface com o padrão precário consolidado, reiterando assim os conflitos já colocados, ao invés da busca por soluções, e até mesmo, em alguns casos, atravancando a própria 
regularização. Esse debate decorre das experiências concretas dos projetos de intervenção, como se verá adiante.

A disputa por caminhos e interpretações da legislação também explicita uma tensão entre municípios, que visam ampliar a ocupação e a regularização de interesse social em seus territórios, e os órgãos que zelam pela proteção ambiental no viés da aplicação, muitas vezes irrealista, da legislação ambiental.

Mas para a superação desses impasses é preciso que se criem formas de reconhecer primeiramente os ganhos sociais seguidos de melhorais ambientais dessas intervenções e em seu conjunto. E o desafio de implementar PRIS como forma de atuação articulada entre os governos estadual e municipal, a fim de atender ao mesmo tempo a demanda social e a recuperação ambiental, colocando em primeiro lugar o interesse público, ainda não superou essa oposição de posições.

Considerando esse quadro, abordam-se a seguir exemplos de PRIS no Município de São Bernardo do Campo visando evidenciar, a partir de casos concretos, como a legislação específica e a legislação ambiental têm sido traduzidas em projetos de urbanização, e como as redes de infraestrutura alcançam esses assentamentos.

\subsection{O PRIS do PAC Alvarenga}

O projeto chamado PAC Alvarenga, atualmente em execução, começou em 2005, com recursos do PAT PROSANEAR ${ }^{103}$, cujo objetivo principal era o saneamento dos núcleos de favelas: Jardim Ipê, Sítio Bom Jesus, Alvarenga Peixoto e Divinéia-Pantanal I e II, todos inseridos na área de proteção aos mananciais. Diante do alto grau de precariedade e densidade populacional desses núcleos, situados em sua maioria em beiras de córregos, a intervenção de saneamento demandava a articulação com a solução habitacional e de urbanização, com a criação de parques e áreas livres.

Por preceder a promulgação da LE-Billings, a concepção inicial do projeto não foi orientada pelas exigências do PRIS. Antes mesmo de ser desenvolvido como projeto de urbanização para pleitear recursos do PAT PROSANEAR, essa área foi uma das primeiras em que a Prefeitura buscou consultoria externa para avançar em soluções de urbanização em área de proteção aos mananciais $^{104}$.

\footnotetext{
103 O Projeto de Assistência Técnica ao Programa de Saneamento para Populações em Áreas de Baixa Renda (PAT PROSANEAR) é um programa do governo federal e CAIXA Econômica Federal decorrente de contrato de empréstimo entre União e BIRD, que visa prestar apoio técnico e financeiro a estados, municípios e prestadores de serviços de saneamento para elaboração de Planos de Desenvolvimento Local e Planos de Saneamento Integrado, desde que assegurados, pelos beneficiários, recursos para realização das obras. Fonte: http://www1.caixa.gov.br/gov/ gov_social/estadual/programas_desenvolvimento_urbano/saneamento_ambiental/pat/index.asp, acesso em 12 de fevereiro de 2013.

${ }^{104}$ Conforme informação verbal da promotora pública Rosangela Staurenghi, a Professora Laura Bueno elaborou um estudo de concepção para a região, com o objetivo de auxiliar a prefeitura na definição de projetos nessas áreas.
} 
Após a elaboração de projeto pelo Consórcio Habitat, o processo de licenciamento teve início em 2007. A Prefeitura de São Bernardo do Campo defendia que sua análise não deveria ser feita para cada núcleo em separado, mas considerar o conjunto da intervenção, porque grande parte das compensações ambientais concentrava-se em uma das áreas, no Jardim Ipê, cuja remoção quase total das moradias daria lugar a um parque municipal, com a recuperação de córregos e nascentes. Porém, em 2008, o licenciamento foi dividido em quatro partes, segundo cada intervenção. Até 2009, o projeto não havia sido executado e com a promulgação de LE-Billings foi adaptado tanto para atendê-la como para receber financiamento do PAC, o que viabilizou o início das obras em março de 2010. Com isso o projeto inicial foi atualizado e revisado, transformando-se numa "urbanização integrada"105, também adequando-se para cumprir as exigências do PRIS. Contudo, cada intervenção seguiu sendo analisada em separado pela Cetesb resultando em estágios diferentes de aprovação, o que comprometeu a análise de ganhos ambientais sobre o todo, e também o andamento das obras.

\subsubsection{Sobre o projeto PAC Alvarenga}

As quatro favelas objeto de intervenção se formaram a partir da ocupação de áreas públicas municipais por famílias de baixa renda, e correspondem ao padrão conhecido de ocupação de beira de córrego e de áreas de declividade acima de 30\%, frequentemente destinadas como área pública pelos loteadores porque eram as que "sobravam" do processo de parcelamento do solo. A favela Jardim Ipê (ocupação iniciada em 1972) ocupou área pública do loteamento Jardim Ipê, e as favelas Sítio Bom Jesus (1985) e Alvarenga Peixoto (1988) ocuparam áreas públicas do loteamento Jardim do Lago. Os núcleos Divinéia e Pantanal I e II (1989) ocuparam área de utilidade pública municipal para fins de abertura de ligação viária da Via Anchieta com a Rodovia dos Imigrantes. Por serem núcleos de favelas inseridos em loteamentos antigos (alguns anteriores a LPM), estão numa porção bastante consolidada da área de proteção aos mananciais (ver foto aérea).

\footnotetext{
105 Segundo a SEHAB de São Bernardo do Campo, a urbanização integrada é composta por ações de naturezas diversas, quais sejam: Ações de Natureza Físico-Urbanísticas (Obras): Urbanismo, Paisagismo, Áreas de Lazer; Obras habitacionais; Implantação de Infraestrutura; Equipamentos: CRAS, Mais Cultura, Centro Comercial, Creche. Ações de Recuperação Ambiental, Reparação e Mitigação: Liberação de APPs e Recuperação de Nascentes; Saneamento ambiental da área, integrado com coletor tronco da SABESP; Ampliação de áreas verdes, permeabilidade, arborização, etc. Ações de Natureza Jurídico-fundiárias: Regularização das áreas para a intervenção; Atividades relacionadas à aprovação e licenciamento da intervenção; Titulação aos Beneficiários Finais. Ações do Trabalho Social de Participação e Inclusão Social: Apoio à Organização Comunitária e Mobilização da População; Trabalho Social de Suporte às Obras e Remanejamentos; Educação Sanitária e Ambiental; Geração de Emprego e Renda e Ações de Inclusão Social; Avaliação e Acompanhamento Pós-Ocupação. Esse conceito da urbanização é uma exigência do PAC Urbanização, para que se obtenha financiamento.
} 


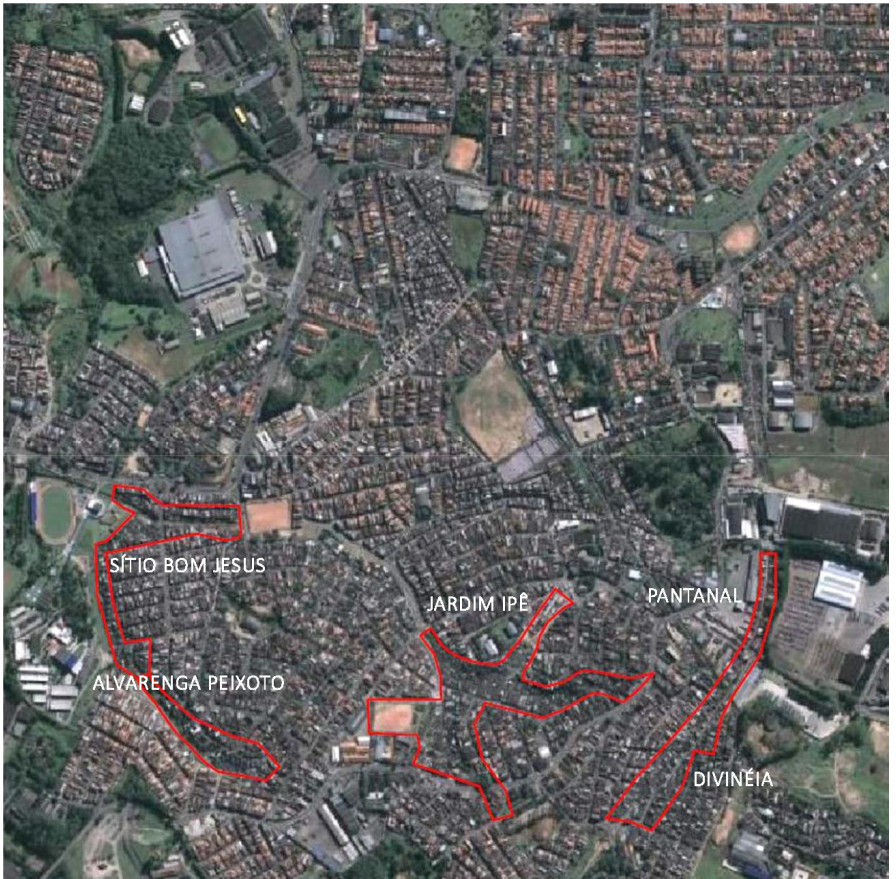

Figura 65 - Foto aérea com os perímetros de intervenção do PAC Alvarenga.

Fonte: Secretaria de Habitação de São Bernardo do Campo, 2010. Imagem cedida pela PMSBC, 2011.

Segundo os memoriais de projeto consultados ${ }^{106}$, durante os anos 1980, esses núcleos passaram por intervenções de urbanização e instalação de infraestrutura parciais, que por sua vez não atenderam ao conjunto, em alguns casos aumentando a precariedade. Com o passar dos anos, as favelas se adensaram, não restando áreas verdes ou livres. O uso era predominantemente residencial, com a presença de pequeno comércio e serviço de bairro em algumas áreas.

O projeto implementado a partir de 2010 foi desenvolvido buscando remover as famílias em situação de risco (deslizamento e inundação), e em áreas destinadas a passagem das redes de infraestrutura. Do total de 2514 unidades cadastradas, 610 unidades foram consolidadas, ou seja, receberam infraestrutura e regularização, 878 famílias foram reassentadas em novas unidades habitacionais na própria área e 1026 famílias foram reassentadas no conjunto Habitacional Três Marias, no bairro Cooperativa.
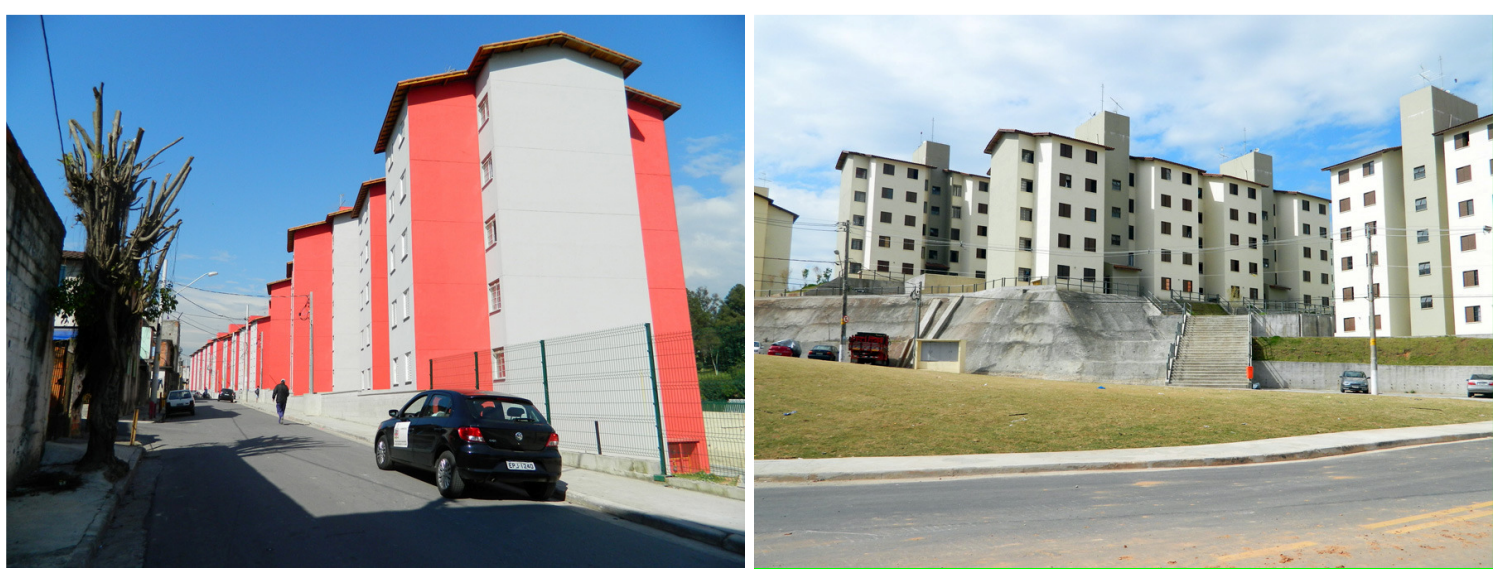

Figuras 66 e 67 - Reassentamento habitacional e Conjunto Habitacional Três Marias, respectivamente. Fotos da autora, 2012.

\footnotetext{
106 Estes memoriais constam do Projeto de urbanização integrada e remanejamento de moradias em área de proteção ambiental da região do Grande Alvarenga - PAC Alvarenga (SÃO BERNARDO, 2009).
} 
Tabela 20 - Famílias atendidas por tipo de solução.

\begin{tabular}{|c|c|c|c|c|c|c|c|c|}
\hline \multirow[b]{2}{*}{ ÁREA } & \multirow{2}{*}{$\begin{array}{l}\text { Imóveis } \\
\text { cadas- } \\
\text { trados }\end{array}$} & \multirow{2}{*}{$\begin{array}{l}\text { Imóveis } \\
\text { conso- } \\
\text { lidados }\end{array}$} & \multirow{2}{*}{$\begin{array}{c}\text { Total } \\
\text { de Uhs } \\
\text { Removidas }\end{array}$} & \multirow{2}{*}{$\begin{array}{c}\text { Reassen- } \\
\text { tamento } \\
\text { no cj. } 3 \\
\text { Marias }\end{array}$} & \multicolumn{4}{|c|}{$\begin{array}{l}\text { Soluções de reassentamento } \\
\text { habitacional nos } 4 \text { núcleos }\end{array}$} \\
\hline & & & & & $\begin{array}{l}\text { Uhs } \\
\text { produzidas } \\
\text { no núcleo }\end{array}$ & $\begin{array}{l}\text { Imóveis } \\
\text { consoli- } \\
\text { dados }\end{array}$ & $\begin{array}{c}\text { Imóveis } \\
\text { beneficiados } \\
\text { apenas c/ } \\
\text { infraest. }\end{array}$ & $\begin{array}{l}\text { Total } \\
\text { na área }\end{array}$ \\
\hline Sítio Bom Jesus & 749 & 226 & 523 & 179 & 344 & 226 & - & 570 \\
\hline $\begin{array}{l}\text { Divineia } \\
\text { Pantanal I e II }\end{array}$ & 757 & 214 & 543 & 139 & 404 & 214 & - & 618 \\
\hline $\begin{array}{l}\text { Alvarenga } \\
\text { Peixoto }\end{array}$ & 259 & 100 & 159 & 29 & 130 & 100 & - & 230 \\
\hline Jardim Ipê & 749 & 70 & 679 & 679 & 0 & 70 & 648 & 718 \\
\hline
\end{tabular}

Fonte: Secretaria de Habitação da Prefeitura de São Bernardo do Campo, 2011.

Importante destacar que a solução de reassentamento remanejou as famílias para conjuntos habitacionais construídos fora da área de proteção aos mananciais ${ }^{107}$. Segundo entrevistas realizadas na SEHAB e visitas de campo, apesar do projeto abranger uma grande área e envolver muitas famílias, as remoções e os reassentamentos não criaram grandes conflitos, e os moradores tiveram papel ativo no processo de organização das famílias.

Essa solução, contudo, tem poucas possibilidades de se repetir no município, segundo avaliação de Tássia Regino ${ }^{108}$, tendo em vista a grande quantidade de assentamentos precários existentes em APM (83 loteamentos irregulares e 68 favelas), e a taxa de remoção que chega a 40\% do total de famílias segundo dados do Plano Local de Habitação de Interesse Social - PLHIS (SÃO BERNARDO, 2011). Ou seja, a possibilidade de reassentar famílias em áreas fora de APM é bastante restrita em SBC. Segundo Tássia Regino, os reassentamentos resultantes de PRIS terão de ser equacionados na própria área de manancial, o que coloca em questão o padrão da ocupação.

Quanto à edificação habitacional e às soluções de saneamento ambiental, o projeto apresenta soluções convencionais. A primeira fase do projeto, no Sítio Bom Jesus, contempla o saneamento ambiental, a produção de unidades habitacionais no local, parque linear e consolidação de moradias existentes. A segunda fase, Divinéia Pantanal I e II, tem os mesmos componentes. Na terceira fase, no Jardim Ipê, 679 moradias removidas e reassentadas no conjunto habitacional darão lugar a um grande parque linear. E na quarta etapa, Alvarenga Peixoto, há mais consolidação de unidades e menos áreas transformadas em áreas de lazer.

\footnotetext{
${ }^{107}$ O processo de licenciamento de projetos teve início em 2007, portanto anteriormente à Lei Específica, quando não era permitido construir dentro de APM. Sendo assim, a área de reassentamento foi feita fora da área de proteção aos mananciais, num conjunto habitacional construído para essa finalidade, chamado Três Marias.

${ }^{108}$ Conforme informação verbal de Tássia Regino, Secretária de Habitação de São Bernardo do Campo na gestão 2008-2012 e atual, em entrevista concedida à autora em 16 de janeiro de 2012.
} 

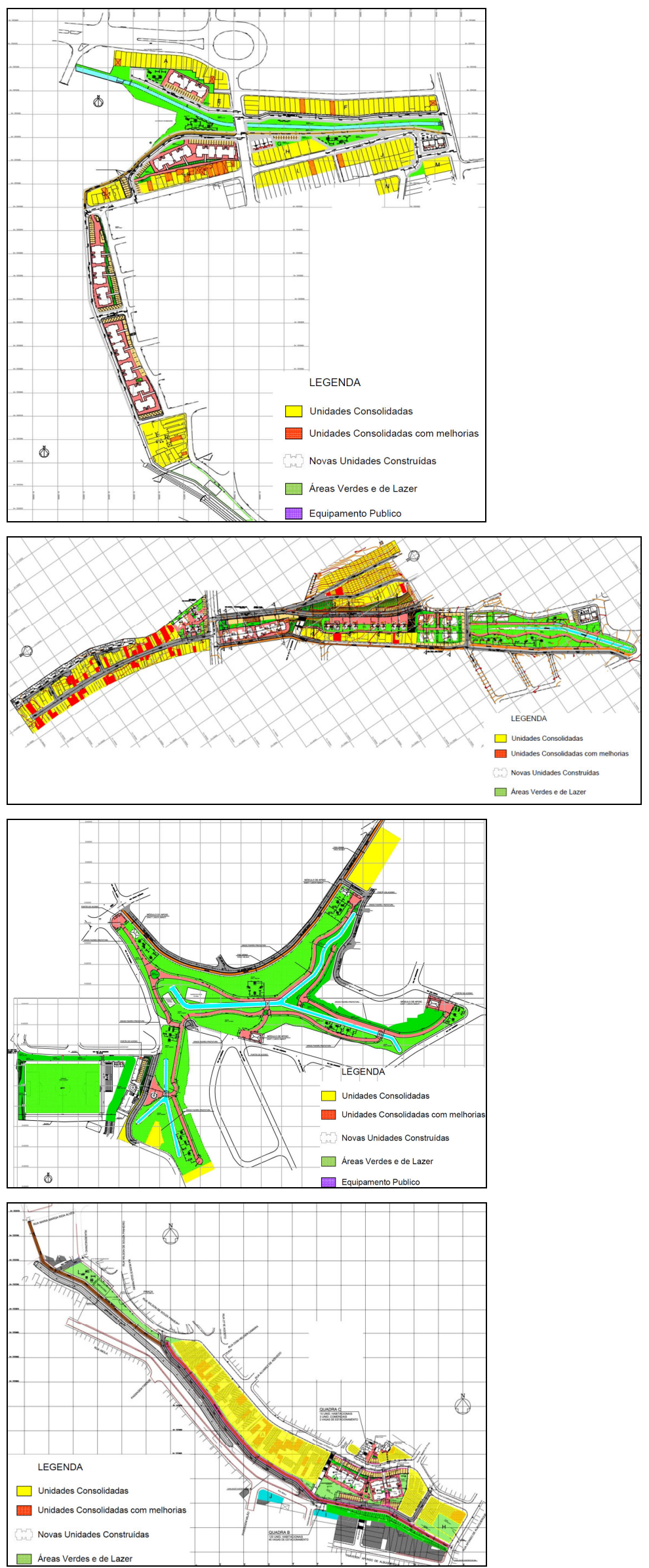

Figura 68 - Projetos por área de intervenção, Sítio Bom Jesus.

Figura 69 - Projetos por área de intervenção, Divinéia / Pantanal
Figura 70 - Projetos por área de intervenção, Jardim Ipê
Figura 71 - Projetos por área de intervenção, Alvarenga Peixoto.

Fonte: Secretaria de Habitação de São Bernardo do Campo, 2010. 
A solução para a recuperação das margens de córrego nesse projeto, além da construção de parque linear como área de lazer e de equipamentos públicos, apresenta proposta interessante de oferecer unidades comerciais para moradores que já realizavam essa atividade econômica. $\mathrm{O}$ uso misto associado a projetos de urbanização e habitação é discutido há muitos anos, mas dificilmente é implementado.

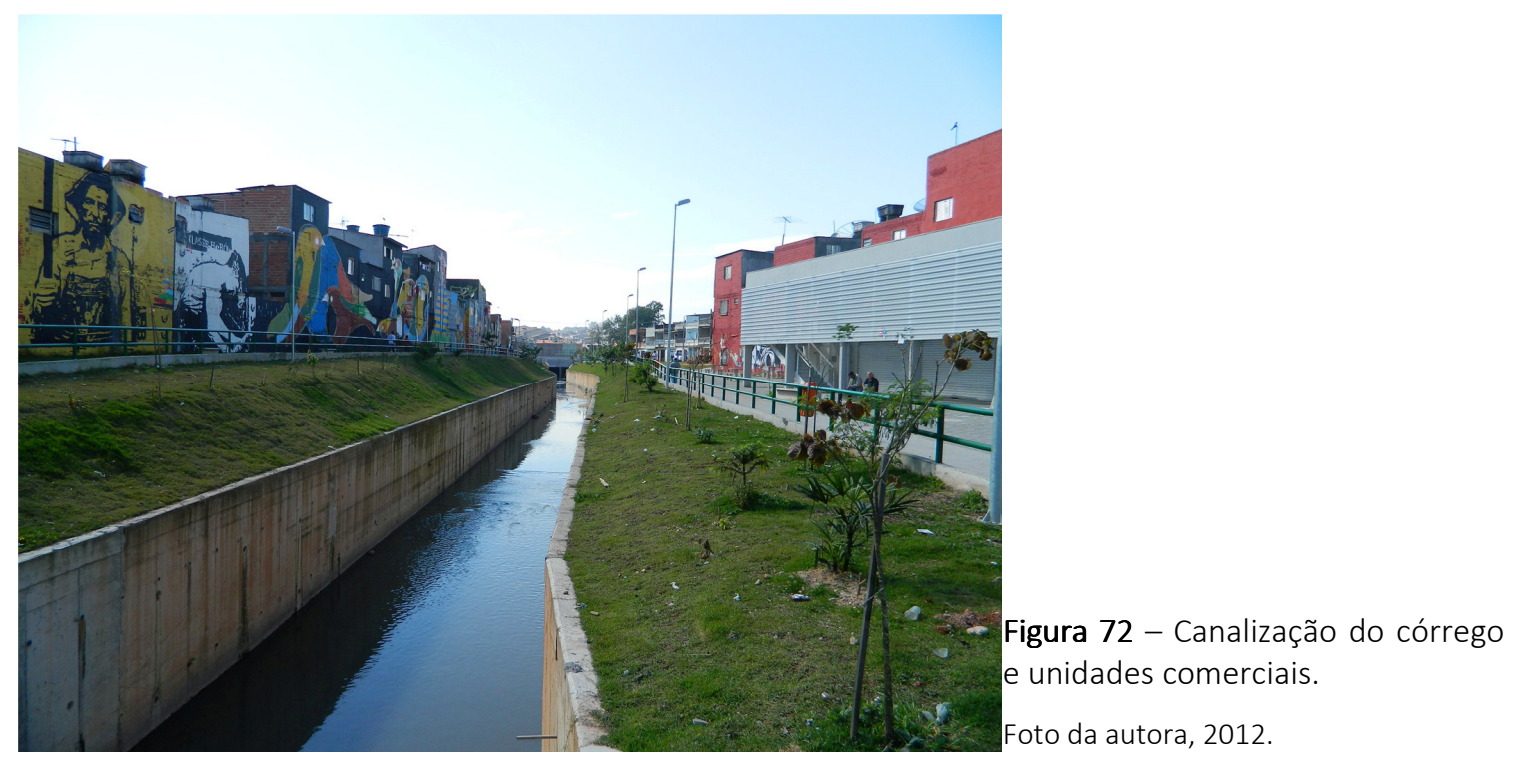

A localização das favelas em área urbanizada circundada por redes públicas fez com que a concepção do projeto de rede de abastecimento de água e coletora de esgotos se ligasse as redes existentes. A rede de abastecimento de água para os núcleos seguiu as diretrizes da SABESP de partir de interligações a serem feitas nas redes primárias existentes na região. Nos casos de reassentamento interno aos núcleos Alvarenga Peixoto, Sítio Bom Jesus, Divinéia e Pantanal, a solução habitacional adotada é de edificações verticais com 5 a 8 pavimentos, com 4 unidades habitacionais por andar. Para cada edifício foi previsto sistema de abastecimento de água do tipo convencional, constituído de um reservatório semi-enterrado e outro elevado, atendido através de bombeamento sob responsabilidade do condomínio. A rede da SABESP abastece o reservatório semi-enterrado (Memorial de Projeto - Rede de Abastecimento de Água, PMSBC, 2009).

Em relação à rede de esgotos, há o encaminhamento para dois coletores tronco previstos pela Sabesp para atender a região. No Sítio Bom Jesus havia rede coletora, mas ela não atendia a porção central e as margens do córrego. Assim, os esgotos coletados na área do núcleo e à montante dele foram projetados para serem lançados no Coletor-Tronco Alvarengas, que passa na margem direita do Córrego de mesmo nome. Esse coletor tronco e as estações de bombeamento serão construídos com recursos da Sabesp. Eles recalcam os esgotos para fora da Área de Proteção dos Mananciais, para o Coletor-Tronco Couros, de onde seguem para tratamento na Estação de Tratamento de Esgotos ABC. A rede do Sítio Bom Jesus também recebe os esgotos do núcleo Alvarenga Peixoto, que não era servido por redes coletoras. 
A ocupação do Jardim Ipê desenvolvia-se ao longo de três cursos d'água principais, contendo várias edificações em palafitas que foram totalmente removidas das margens dos córregos, dando lugar a um Parque Municipal e a equipamentos públicos. A rede coletora foi projetada sob a pista da ciclovia, localizada entre os córregos e as edificações existentes nas ruas adjacentes ao núcleo, para interceptar os lançamentos de esgotos lançados nos córregos, provenientes destas edificações bem como de áreas à montante. Previu-se também o prolongamento da rede coletora para o encaminhamento dos esgotos até o coletor tronco Alvarengas.

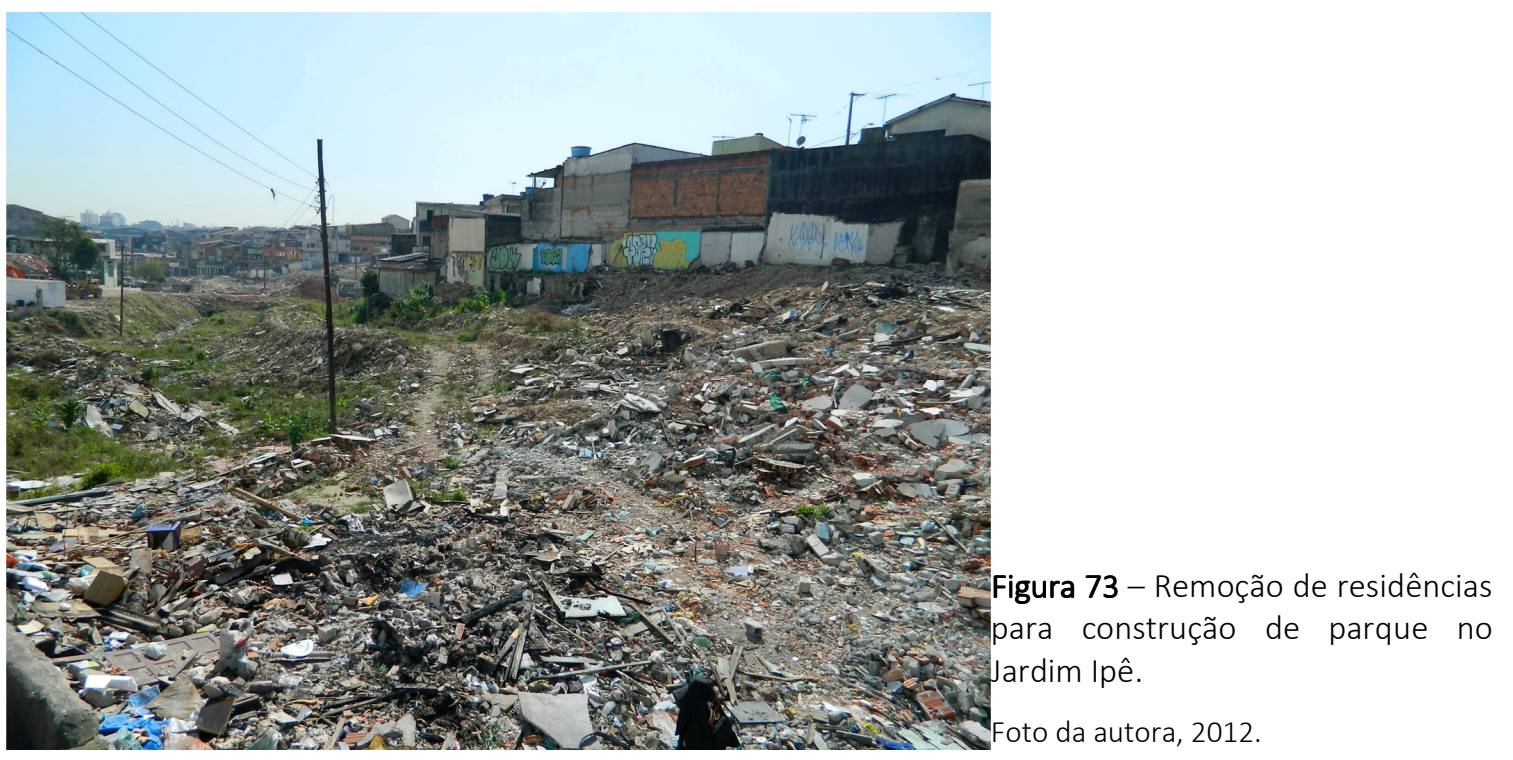

Nos núcleos Divinéia e Pantanal os esgotos coletados serão lançados na rede existente na Rua Principal, onde tem início o Coletor-Tronco Lavras. Este coletor tronco e as estações de bombeamento serão construídos com recursos da Sabesp. Eles também recalcam os esgotos para fora da Área de Proteção dos Mananciais, para o Coletor-Tronco Couros, de onde seguem para tratamento na Estação de Tratamento de Esgotos ABC. 


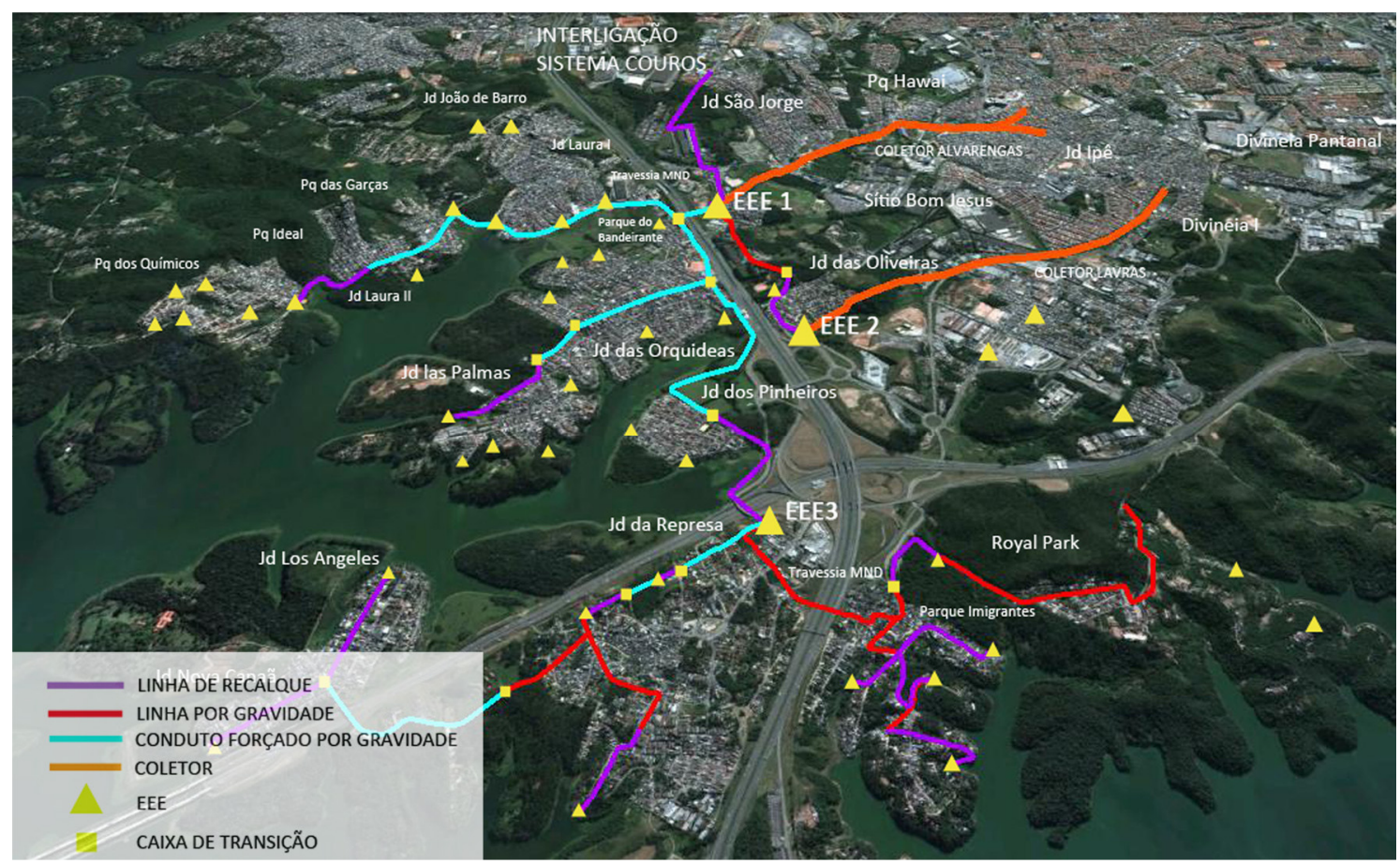

Figura 74 - Sistema de esgotamento sanitário - Sabesp, Projeto Pró-Billings, 2012.

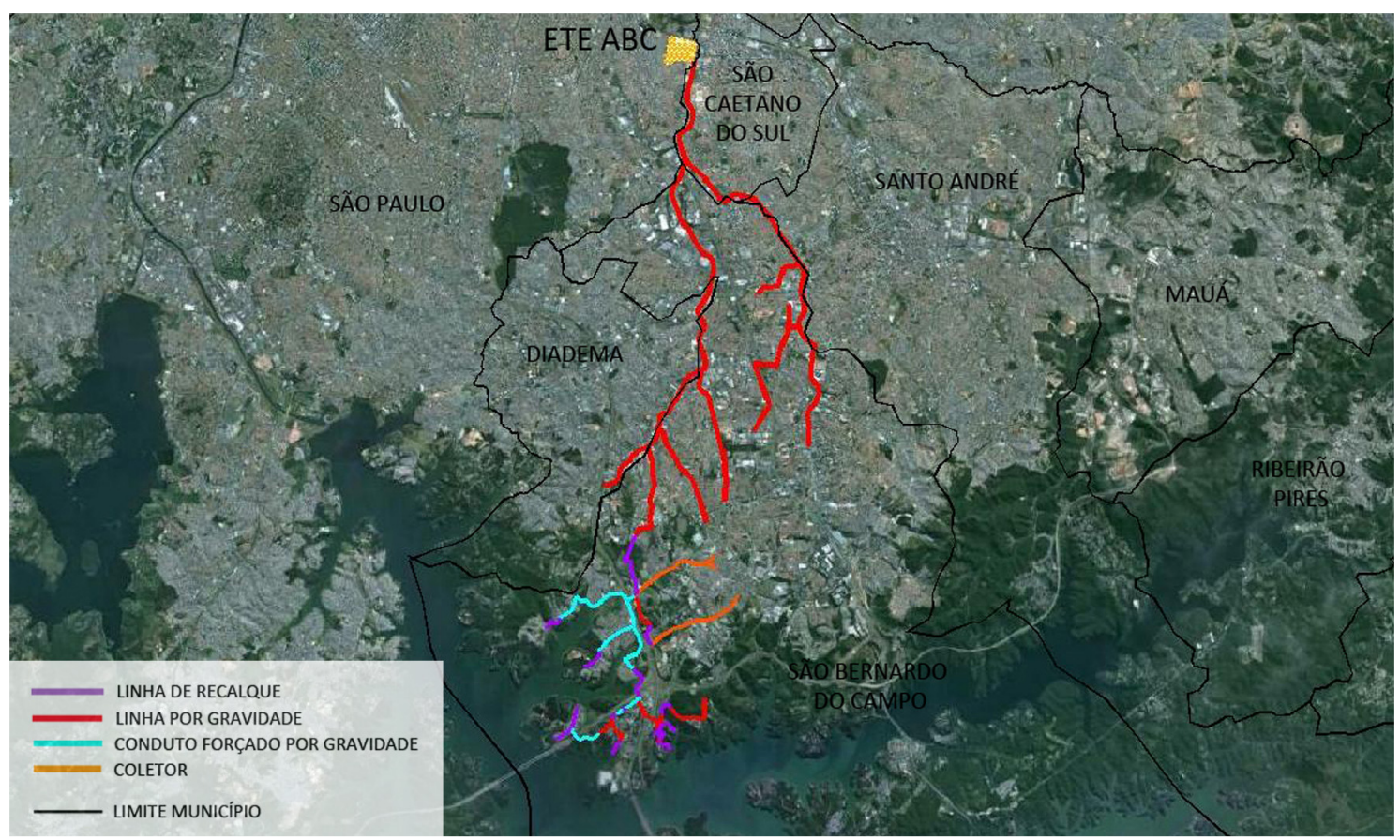

Figura 75 - Sistema de esgotamento sanitário e encaminhamento para a ETE ABC.

Fonte das Figuras 74 e 75: Sabesp, 10/08/2012. Apresentação do Projeto Executivo do Sistema de Esgotamento na bacia da Billings - Alvarengas, Lavras e Áreas A-F. Mapa reelaborado pela autora e desenhado por Paula de Oliveira.

A avaliação das intervenções após-obras ainda é um tema bastante incipiente, especialmente em São Bernardo do Campo onde o PAC Alvarenga é a único PRIS em andamento. Com o objetivo de aferir melhorias e comprovar os ganhos ambientais das intervenções junto à Cetesb, a SEHAB de São Bernardo do Campo utiliza alguns indicadores que ilustram, de forma simples, os resultados alcançados, conforme tabelas a seguir. Do ponto de vista quantitativo, os ganhos são evidentes, particularmente no que se refere ao aumento da área permeável, o que por sua vez 
dependerá de manutenção e cuidado com a vegetação a ser plantada no parque linear. Além disso, a exportação do esgoto para fora da bacia é um dado positivo e representa um ganho de qualidade significativo no local. Mas em termos de redução de impacto de poluentes na bacia há que se considerar que ainda nem todo o esgoto coletado é tratado, e por isso não se pode considerar o problema $100 \%$ resolvido. Observa-se que, até o momento, não foram feitas análises de qualidade da água, outro componente que pode ser agregado aos quadros de ganhos ambientais.

Quadro 3 - Ganhos ambientais do projeto PAC Alvarenga, Sítio Bom Jesus.

\begin{tabular}{|c|c|c|c|c|}
\hline & \multicolumn{2}{|l|}{ ANTES DA OBRA - 2012} & \multicolumn{2}{|l|}{ DEPOIS DA OBRA } \\
\hline & $\begin{array}{l}\% \text { de coleta e tratamento de } \\
\text { esgoto }\end{array}$ & $30 \%$ & $\begin{array}{l}\% \text { de coleta e tratamento de } \\
\text { esgoto }\end{array}$ & $100 \%$ \\
\hline & $\begin{array}{l}\text { \% famílias com ligação de água } \\
\text { oficial }\end{array}$ & $60 \%$ & $\begin{array}{l}\text { \% famílias com ligação de água } \\
\text { oficial }\end{array}$ & $100 \%$ \\
\hline SÍTIO BOM JESUS & $\%$ coleta de lixo & $60 \%$ & $\%$ coleta de lixo & $100 \%$ \\
\hline \multirow{5}{*}{$\begin{array}{l}\text { 1a ETAPA } \\
\text { INTERVENÇÃO }\end{array}$} & \% área permeável & $\begin{array}{c}7 \% \\
\left(2.801,29 \mathrm{~m}^{2}\right)\end{array}$ & \% área permeável & $\begin{array}{c}24 \% \\
\left(10.053,25 \mathrm{~m}^{2}\right)\end{array}$ \\
\hline & $\begin{array}{l}\text { Faixa APP de } 30 \text { metros. Área } \\
\text { permeável dentro da faixa de } \\
\text { preservação permanente }\end{array}$ & $\begin{array}{c}14 \% \\
\left(2.471,35 \mathrm{~m}^{2}\right)\end{array}$ & $\begin{array}{l}\text { Faixa APP de } 30 \text { metros. Área } \\
\text { permeável dentro da faixa de } \\
\text { preservação permanente }\end{array}$ & $\begin{array}{c}47 \% \\
\left(8.353,53 \mathrm{~m}^{2}\right)\end{array}$ \\
\hline & $\begin{array}{l}\text { Número de famílias em risco } \\
\text { geotécnico, incluindo inundação }\end{array}$ & 229 & Número de famílias removidas & 523 \\
\hline & $\begin{array}{l}\% \text { de coleta e tratamento de } \\
\text { esgoto }\end{array}$ & $25 \%$ & $\begin{array}{l}\% \text { de coleta e tratamento de } \\
\text { esgoto }\end{array}$ & $100 \%$ \\
\hline & $\begin{array}{l}\text { \% famílias com ligação de água } \\
\text { oficial }\end{array}$ & $40 \%$ & $\begin{array}{l}\text { \% famílias com ligação de água } \\
\text { oficial }\end{array}$ & $100 \%$ \\
\hline \multirow{6}{*}{$\begin{array}{l}\text { DIVINÉIA } \\
\text { PANTANAL I e II } \\
\text { 2a ETAPA } \\
\text { INTERVENÇÃO }\end{array}$} & $\%$ coleta de lixo & $50 \%$ & $\%$ coleta de lixo & $100 \%$ \\
\hline & \% área permeável & $\begin{array}{c}5 \% \\
\left(2.193,66 \mathrm{~m}^{2}\right)\end{array}$ & \% área permeável & $\begin{array}{c}28 \% \\
\left(12.391,25 \mathrm{~m}^{2}\right)\end{array}$ \\
\hline & $\begin{array}{l}\text { Área permeável dentro da faixa } \\
\text { de preservação permanente ( } 30 \\
\text { metros nas margens de córregos) }\end{array}$ & $\begin{array}{c}8 \% \\
\left(730,95 \mathrm{~m}^{2}\right)\end{array}$ & $\begin{array}{l}\text { Área permeável dentro da faixa } \\
\text { de preservação permanente ( } 30 \\
\text { metros nas margens de córregos) }\end{array}$ & $\begin{array}{c}84 \% \\
\left(7.473,36 \mathrm{~m}^{2}\right)\end{array}$ \\
\hline & $\begin{array}{l}\text { Número de famílias em risco } \\
\text { geotécnico, incluindo inundação }\end{array}$ & 180 & Número de famílias removidas & 543 \\
\hline & $\begin{array}{l}\% \text { de coleta e tratamento de } \\
\text { esgoto }\end{array}$ & $10 \%$ & $\begin{array}{l}\% \text { de coleta e tratamento de } \\
\text { esgoto }\end{array}$ & $100 \%$ \\
\hline & $\begin{array}{l}\text { \% famílias com ligação de água } \\
\text { oficial }\end{array}$ & $20 \%$ & $\begin{array}{l}\text { \% famílias com ligação de água } \\
\text { oficial }\end{array}$ & $100 \%$ \\
\hline \multirow{4}{*}{$\begin{array}{l}\text { JARDIM } \\
\text { IPÊ } \\
\text { 3a ETAPA } \\
\text { INTERVENÇÃO }\end{array}$} & $\%$ coleta de lixo & $35 \%$ & $\%$ coleta de lixo & $100 \%$ \\
\hline & \% área permeável & $\begin{array}{c}11 \% \\
\left(5.808,38 \mathrm{~m}^{2}\right)\end{array}$ & \% área permeável & $\begin{array}{c}74 \% \\
\left(36.435,70 \mathrm{~m}^{2}\right)\end{array}$ \\
\hline & $\begin{array}{l}\text { Faixa APP de } 30 \text { e } 50 \text { metros. } \\
\text { Área permeável dentro da faixa } \\
\text { de preservação permanente }\end{array}$ & $\begin{array}{c}14 \% \\
\left(5.237,80 \mathrm{~m}^{2}\right)\end{array}$ & $\begin{array}{l}\text { Faixa APP de } 30 \text { e } 50 \text { metros. } \\
\text { Área permeável dentro da faixa } \\
\text { de preservação permanente }\end{array}$ & $\begin{array}{c}91 \% \\
\left(32.729,13 \mathrm{~m}^{2}\right)\end{array}$ \\
\hline & $\begin{array}{l}\text { Número de famílias em risco } \\
\text { geotécnico, incluindo inundação }\end{array}$ & 492 & Número de famílias removidas & 679 \\
\hline $\begin{array}{l}\text { ALVARENGA } \\
\text { PEIXOTO }\end{array}$ & $\begin{array}{l}\% \text { de coleta e tratamento de } \\
\text { esgoto }\end{array}$ & $10 \%$ & $\begin{array}{l}\% \text { de coleta e tratamento de } \\
\text { esgoto }\end{array}$ & $100 \%$ \\
\hline 4a ETAPA & $\begin{array}{l}\text { \% famílias com ligação de água } \\
\text { oficial }\end{array}$ & $25 \%$ & $\begin{array}{l}\text { \% famílias com ligação de água } \\
\text { oficial }\end{array}$ & $100 \%$ \\
\hline
\end{tabular}




\begin{tabular}{|c|c|c|c|c|}
\hline \multirow[t]{4}{*}{ INTERVENÇÃO } & $\%$ coleta de lixo & $50 \%$ & $\%$ coleta de lixo & $100 \%$ \\
\hline & \% área permeável & $\begin{array}{c}29 \% \\
\left(5.479,22 \mathrm{~m}^{2}\right)\end{array}$ & \% área permeável & $\begin{array}{c}39 \% \\
\left(7.394,39 \mathrm{~m}^{2}\right)\end{array}$ \\
\hline & $\begin{array}{l}\text { Faixa APP de } 30 \text { e } 50 \text { metros. } \\
\text { Área permeável dentro da faixa } \\
\text { de preservação permanente }\end{array}$ & $\begin{array}{c}39 \% \\
\left(5.523,80 \mathrm{~m}^{2}\right)\end{array}$ & $\begin{array}{l}\text { Faixa APP de } 30 \text { e } 50 \text { metros. } \\
\text { Área permeável dentro da faixa } \\
\text { de preservação permanente }\end{array}$ & $\begin{array}{c}51 \% \\
\left(7.219,74 \mathrm{~m}^{2}\right)\end{array}$ \\
\hline & $\begin{array}{l}\text { Número de famílias em risco } \\
\text { geotécnico, incluindo inundação }\end{array}$ & 36 & Número de famílias removidas & 159 \\
\hline
\end{tabular}

Fonte: Prefeitura de São Bernardo do Campo/Secretaria de Habitação, 2012.

A busca por indicadores de avaliação, como os expressos nesses quadros, indica a necessidade de se criar formas e referências de quantificar e qualificar ganhos ambientais e urbanos. A legislação é taxativa nas suas definições: faixas de proteção, taxas de permeabilidade, etc. Contudo, a transposição para o padrão dos assentamentos precários exige formas de compensação, que por sua vez ficarão mais claras e factíveis se referências quantitativas e qualitativas forem elaboradas, sem que se prendam às normas fixas da legislação ambiental, mas que garantam a recomposição de funções ambientais o quanto for possível. Isso depende, por sua vez, de um conhecimento ambiental do sítio objeto da intervenção que muitas vezes faz parte dos extensos diagnósticos de projeto, mas que são pouco incorporados nas soluções adotadas.

Uma análise qualitativa, que não acompanha esses quadros, incluiria uma avaliação dos moradores e usuários dos espaços públicos construídos, bem como das áreas verdes e demais equipamentos, identificando formas de apropriação, problemas, e possíveis soluções futuras, ou seja, poderiam fornecer novos elementos para apreciação do resultado espacial e ambiental da intervenção.

Esses aspectos, das formas de avaliação e monitoramento das intervenções, caros aos arquitetos e urbanistas e engenheiros, dentre outros profissionais, indicam quão incipiente é a influência das dos resultados na qualidade ambiental nos projetos de urbanização.

\subsection{O PRIS Capelinha e Cocaia}

Os assentamentos Capelinha e Cocaia se diferenciam em diversos aspectos dos núcleos do PAC Alvarenga pois são loteamentos de baixa renda situados numa área mais isolada da mancha urbanizada do município de São Bernardo do Campo, na região do Riacho Grande, bairro Varginha. A origem do projeto também é distinta, porque surgiu da demanda organizada pela população local e aprovada no Orçamento Participativo.

O projeto para o PRIS Capelinha/Cocaia foi desenvolvido pela assessoria técnica Peabiru. O pedido de enquadramento foi encaminhado à CETESB em dezembro de 2010. Até o momento de conclusão dessa pesquisa, a Cetesb ainda não havia emitido comunique-se à prefeitura dando prosseguimento ao processo. 
A prefeitura do Município de São Bernardo do Campo teve selecionada sua proposta pelo Programa de Aceleração do Crescimento - Fase 2 (PAC 2 ), estando com as condições de viabilização financeira assegurada. Mas o início das obras está impedido por conta do andamento do licenciamento ambiental.

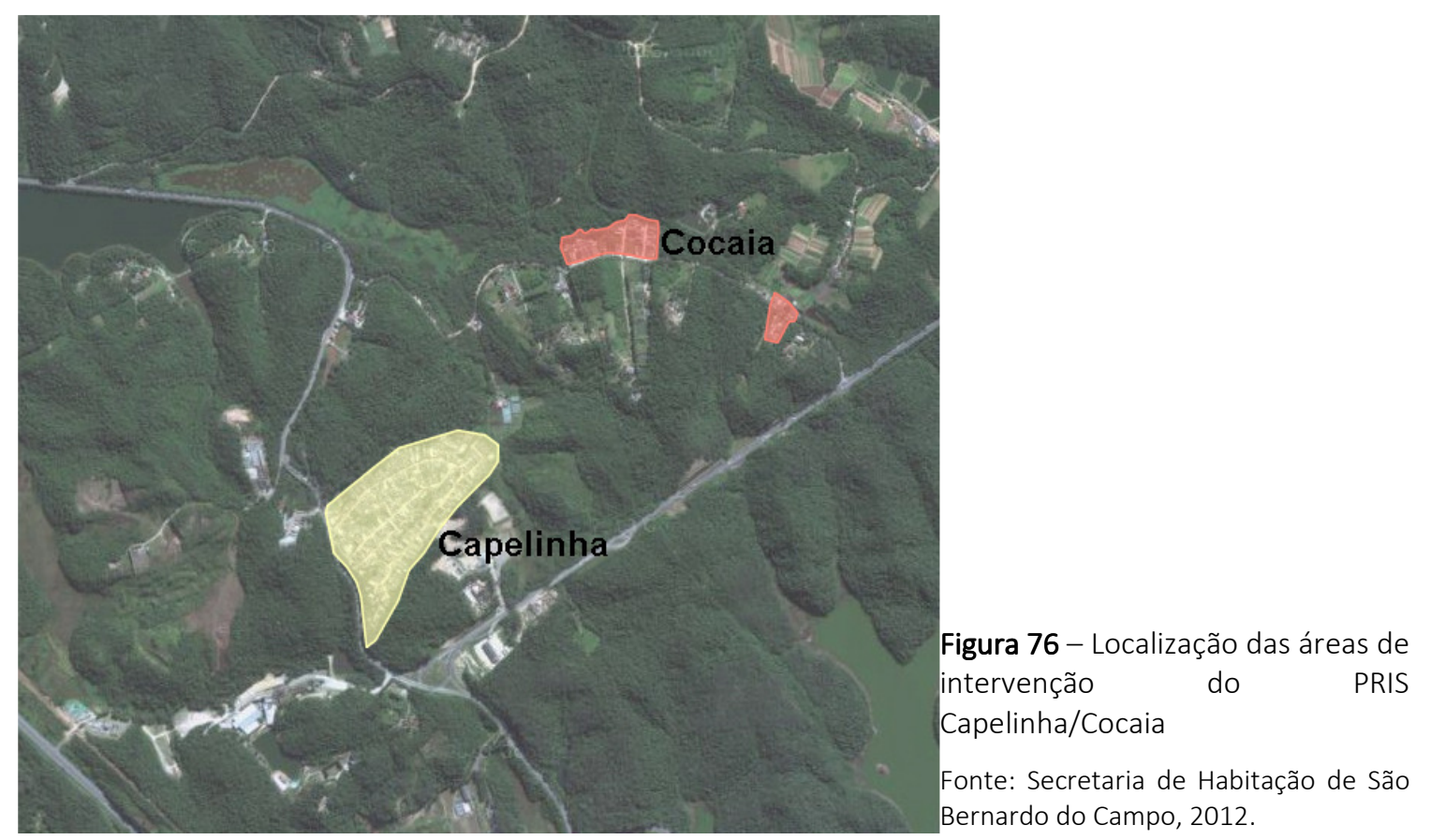

\subsubsection{Sobre o projeto Capelinha e Cocaia}

Segundo diagnóstico realizado para o PRIS, a ocupação do núcleo Capelinha teve início em 1990. Em 1995, diante da ação de reintegração de posse movida pela proprietária da gleba, os moradores organizaram-se em associação para se defender da ação, o que resultou na negociação da compra do terreno. Com isso, a associação de moradores logrou legitimar a posse de $45 \%$ da área ocupada e tem trabalhado para concluir a aquisição do restante da área (SÃO BERNARDO, 2010c).

Ainda, segundo o diagnóstico, em 2009 havia no assentamento Capelinha 786 imóveis, de uso predominantemente residencial. Dentre os imóveis residenciais, em 611 foram realizadas entrevistas (91,3\% do total) a partir dos quais foram computados 2.101 moradores, com a média de 3,4 por domicilio. Estima-se que o total de moradores é de 3.144 pessoas, aproximadamente 925 famílias. As residências são de baixo padrão e as que apresentam situação de risco representam minoria da área (17,0\%). Dentre elas, 8,5\% estão sob risco de inundação, 6,4\% sob risco de deslizamento e $1,8 \%$ com risco de solapamento.

Além dos riscos ambientais, há o risco sanitário, consequência das condições precárias de infraestrutura. O abastecimento de água é feito por meio de caminhão pipa ou por poços artesianos no interior das próprias unidades habitacionais (SÃO BERNARDO, 2010c, p. 37). Não há rede pública de coleta e tratamento de esgoto e, por isso, os moradores construíram redes 
alternativas, como valas abertas ou cobertas que despejam o esgoto nos córregos, ou fossas negras ou sépticas. A única rede instalada é a de energia elétrica da Eletropaulo, que colocou medidores em quase todas as casas.

O loteamento Cocaia tem histórico semelhante aos demais loteamentos irregulares de São Bernardo do Campo. Em 1991, a Associação Pró-Habitar iniciou a venda de lotes para as famílias associadas à Associação de Moradores da Estrada da Cocaia, por meio de Instrumento Particular de Compromisso de Compra e Venda, sem registro. Após a venda, a associação interrompeu suas atividades (SÃO BERNARDO, 2010c).

O mesmo diagnóstico identificou 72 imóveis na área do Cocaia, de uso predominantemente residencial. Nos domicílios entrevistados foram computados 212 moradores, perfazendo uma média de 3,6 moradores por domicílio. As residências em situação de risco são minoria da área, sendo que somente $6,8 \%$ apresentam risco de deslizamento ou solapamento. O perfil socioeconômico também é de baixa renda, concentrando-se a renda domiciliar na faixa de zero até três salários mínimos.

Nesse assentamento o abastecimento de água por meio de poço é condição de $96,6 \%$ dos domicílios e, ainda assim, 3,4\% destes não têm qualquer tipo de abastecimento. Não há rede de esgoto, e as soluções encontradas pelos moradores são semelhantes às do assentamento Capelinha. A energia elétrica regularizada é situação de 96,6\% dos domicílios.

Conforme o Memorial de Projeto da Assessoria Técnica Peabiru, buscou-se integrar o espaço construído às áreas de preservação ambiental em seu entorno, adotando-se como diretrizes principais: prover o núcleo de infraestrutura; garantir habitação de qualidade a todos; e melhorar as condições ambientais da área.

Para a implementação de infraestrutura e para o reassentamento de moradias removidas de área de risco e de preservação permanente, foi necessário integrar os lotes desocupados do loteamento Cocaia, aumentando as possibilidades de qualificação urbana e ambiental do Capelinha, ao mesmo tempo em que se melhora a condição de infraestrutura pública do Cocaia.

O Capelinha é um loteamento irregular formado por 120 lotes de dimensão típica de área de manancial, ou seja, $125 \mathrm{~m}^{2}$. A proposta de implantação de novas unidades habitacionais se compatibiliza à forma de ocupação pré-existente, removendo situações de risco e maior precariedade e "costurando" unidades novas de reassentamento com o padrão de ocupação consolidado. Com isso, visa-se minimizar a quantidade de remoções, criando espaços coletivos e de lazer entre os edifícios, que por sua vez fazem a transição entre espaços coletivos e privados. Assim, a qualidade do projeto habitacional se destaca, pois não reproduz as tipologias de edifícios de interesse social, frequentemente utilizados indistintamente nos projetos de intervenção.

O projeto contempla 246 unidades novas e cerca de 300 remoções, do total de 826 domicílios, correspondendo a aproximadamente $36 \%$ do total, uma porcentagem que tem se repetido em outros projetos em São Bernardo. No Cocaia, o projeto prevê a construção de 52 unidades, 
sendo oito relocações no próprio núcleo, em lotes individuais, e 44 para receber moradores do Capelinha.

No que se refere à recuperação de áreas de preservação permanente (APP), tema tratado na entrevista com o arquiteto da equipe ${ }^{109}$, foi possível recuperar uma das margens do córrego, e uma nascente que está próxima da estrada que dá acesso ao loteamento. A aplicação do Código Florestal nesse caso, uma área de proteção delimitada por um raio de 50 metros da nascente, implicaria em uma maior quantidade de remoções, e no redesenho de acesso ao loteamento. Outro curso d'água que supostamente existiria no local, pois estava indicado na carta da Emplasa, não foi identificado por laudo técnico. Por isso, a justificativa de descaracterização de APP foi aceita nesse caso.

O processo participativo com a população também identificou demandas quanto às áreas livres e de lazer. Além da área de campo de futebol, foi reservada uma área institucional para a construção de uma creche.

A situação de implantação desses assentamentos, seu traçado irregular e a alta densidade da ocupação implicam obras complexas de infraestrutura urbana, de consolidação geotécnica e de drenagem urbana (SÃO BERNARDO, 2010c). A solução de micro-drenagem urbana adotada é convencional.

O projeto e a obra da rede de água no Capelinha e no Cocaia é de responsabilidade da SABESP ${ }^{110}$ e inclui: captação em poço existente próximo ao Capelinha, tratamento da água numa estação compacta (ETA), reservação, bombeamento através de booster ${ }^{111}$, adução até a área os assentamentos e distribuição. O sistema foi concluído em $2012^{112}$.

O sistema de coleta de esgoto nos dois assentamentos será composto pela rede coletora dos esgotos das moradias e sistema de afastamento. Para o sistema de afastamento, a Sabesp ${ }^{113}$ prevê a implantação de uma pequena EEE (estação elevatória de esgotos) no ponto mais baixo da área do Capelinha e uma linha de recalque até a localização do poço na Estrada do Cocaia, de onde os afluentes seguirão até a ETE - Riacho Grande ${ }^{114}$. No Cocaia, uma linha de recalque será ligada à linha de recalque do Capelinha, seguindo para a mesma estação de tratamento de esgotos. Com isso, a redução de carga poluente no manancial será obtida por meio do

\footnotetext{
${ }^{109}$ Arquiteto e Urbanista André Drummond, entrevista concedida à autora em 12/09/2011.

${ }^{110}$ Em ação movida pelo Ministério Público na qual a Sabesp figurava como réu, esta já estava condenada a resolver o abastecimento de água no Capelinha.

${ }^{111}$ O booster é um equipamento utilizado pela Sabesp para o controle de pressão das redes de água, cuja tecnologia regula automaticamente sua velocidade de funcionamento nos períodos de menor e maior consumo, a partir de um programa em que são estabelecidos comandos para cada situação, reduzindo a incidência de vazamentos.

112 Conforme boletim informativo "Sabesp no seu bairro", edição no 18 de 2012. Disponível no site: http://site.sabesp.com.br/uploads/file/seu_bairro/Jornal_Capelinha_baixa.pdf, acesso em 13 de fevereiro de 2013.

${ }^{113}$ Segundo a Sabesp, os recursos para a rede coletora e estação elevatória estão previstos na terceira fase do Projeto Tietê.

${ }^{114}$ A ETE Riacho Grande foi construída em 1969.
} 
afastamento dos esgotos sanitários, que serão tratados numa ETE localizada próxima aos assentamentos, ou seja, dentro da bacia hidrográfica.

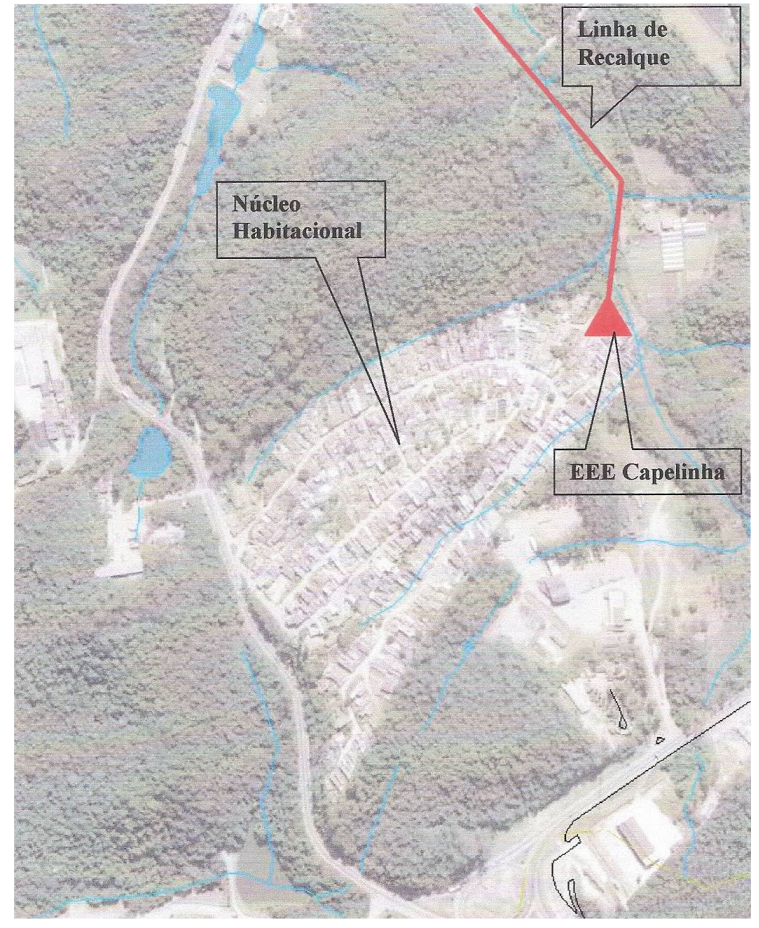

Figura 77 - Diretriz de abastecimento de água da Sabesp

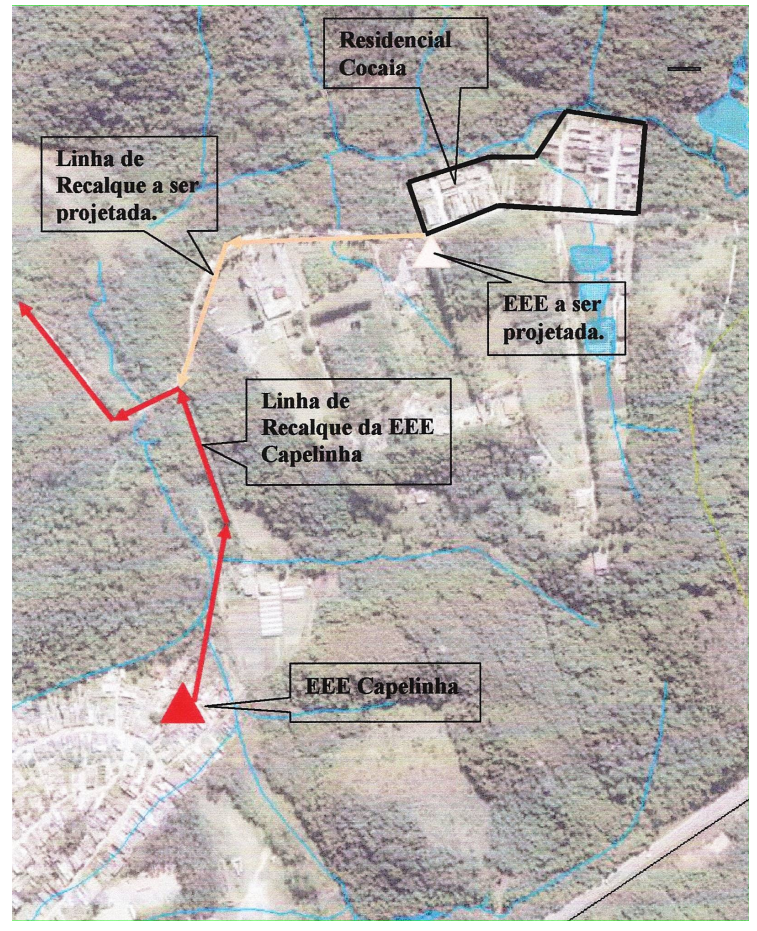

Figura 78 - Diretriz de esgotamento sanitário da Sabesp.

Fonte: Secretaria de Habitação de São Bernardo do Campo; Peabiru Trabalhos Comunitários. Relatório de justificativa de enquadramento para obtenção de parecer favorável, conforme dispõe o artigo 78 da lei no 13.579/2009 - APRM Billings, 2010.

Note-se que, no Plano Diretor de Esgotos da Região Metropolitana de São Paulo (PDE-2010), a Sabesp apresenta como diretriz geral desativar estações isoladas de tratamento de esgotos, conectando-as às estações principais. A ETE Riacho Grande faz parte desse planejamento, com sua reversão para ETE ABC, conforme cenário traçado pelo PDE, para os anos de 2018, 2023 ou 2030 (SABESP, 2010, p.126).

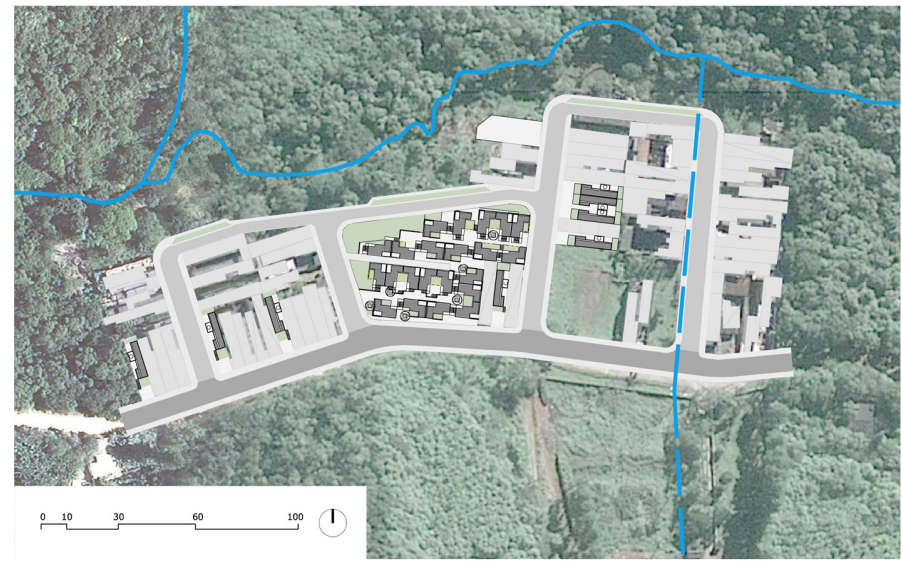

Figura 79 - Implantação do Projeto de Intervenção Cocaia. 


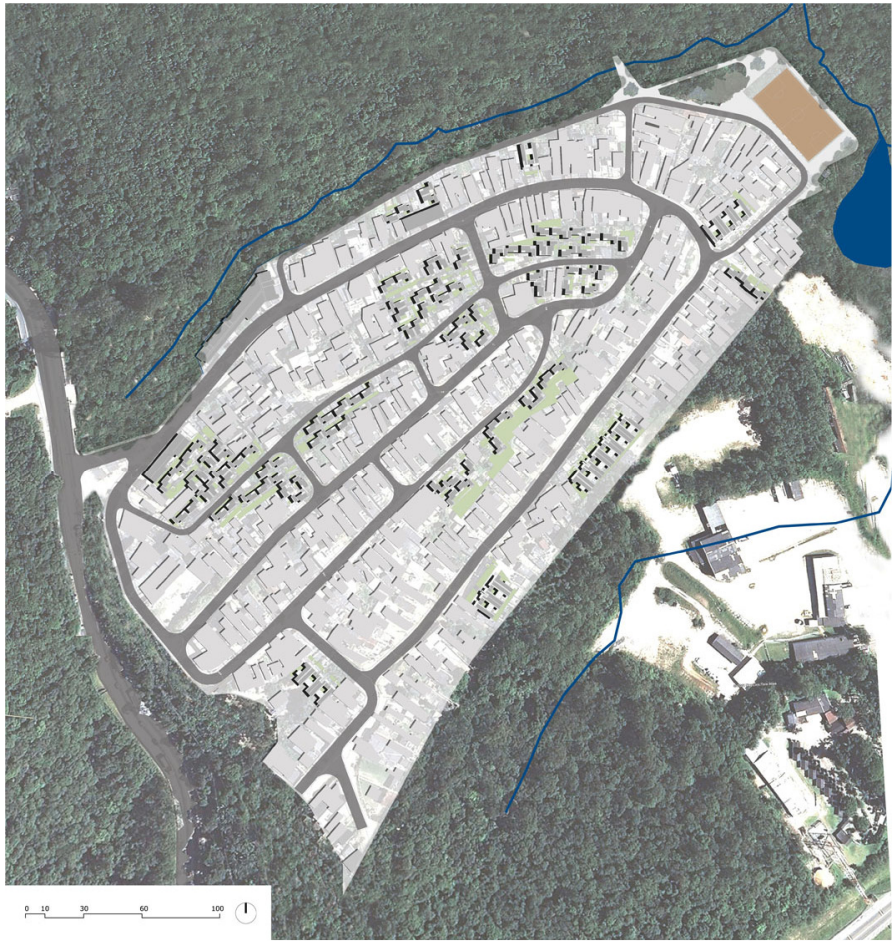

Figura 80 - Implantação do Projeto de Intervenção Capelinha.

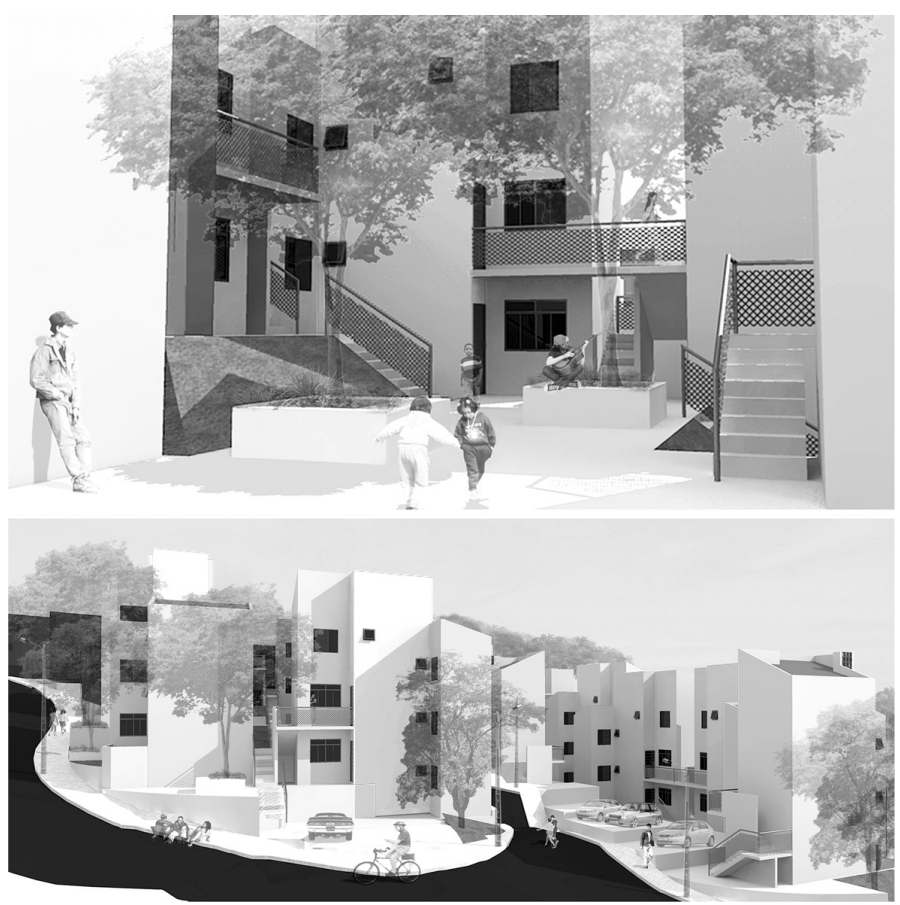

Figura 81 - Unidades habitacionais propostas.

Fonte: Cedido à autora por Peabiru, autora do projeto.

\subsection{Considerações sobre os PRIS}

Os dois PRIS apresentados, quais sejam, o PAC Alvarenga e o Capelinha/Cocaia - os primeiros a serem elaborados em São Bernardo do Campo - explicitam, a partir de suas diferenças, algumas questões relevantes no que tange às soluções de saneamento, habitação, e no tratamento de áreas de preservação permanente, comentadas a seguir. Essas soluções remetem à reflexão da qualidade das intervenções na escala dos assentamentos, visando promover recuperação 
ambiental e regularização fundiária, e podem alimentar reflexões futuras sobre mudanças no atual padrão de ocupação de APMs. Mas, além das soluções de projeto, que podem variar muito de um caso para o outro, a execução dos PRIS evidencia contradições sobre a concepção de recuperação ambiental que somente a leitura da LE-Billings não permite facilmente identificar. É na relação entre as escalas dos PRIS e sua interface com os sistemas metropolitanos de saneamento, particularmente o sistema de tratamento de esgotos, que a perspectiva de análise se constitui nesse item.

Uma primeira observação a reforçar é que a noção de recuperação ambiental de assentamentos precários é bastante imprecisa e ampla. E, apesar dos diversos projetos de urbanização realizados em área de proteção aos mananciais no município de São Paulo, e dos primeiros PRIS em São Bernardo do Campo, há pouco debate e sistematização de conhecimento sobre padrões diversificados de qualidade espacial e ambiental que possam servir como referência para as intervenções. As principais referências para os projetos continuam sendo, apesar dos conflitos de aplicação em contextos de ocupação precária e irregular, as leis ambientais.

Considerando as diretrizes para a realização de PRIS que constam na LE-Billings e os exemplos apresentados, pode-se dizer que a recuperação ambiental tem se baseado em dois componentes principais. Um deles é a recuperação de áreas de preservação permanente como margens de córregos, nascentes e áreas de alta declividade, o que implica frequentemente remoção de moradias em situação de risco. Complementarmente, e por se tratar de área de proteção aos mananciais, o aumento de área permeável é um objetivo inerente à recuperação ambiental, resultando em áreas de lazer, parques, parques lineares etc. O segundo componente é o saneamento ambiental ${ }^{115}$, particularmente a coleta e o tratamento de esgotos.

Em relação à recuperação das áreas de preservação permanente, há que se considerar a possibilidade de atendimento da legislação federal, em especial o Código Florestal. De fato, após a promulgação do Estatuto da Cidade, a legislação ambiental tem sido paulatinamente flexibilizada em casos em que a recuperação de APP é impossível, dado que está totalmente descaracterizada pela ocupação urbana, e em casos em que o seu cumprimento inviabiliza a regularização de interesse social. São exemplos de normas nesse sentido a Resolução CONAMA 369/096 ${ }^{116}$, e a Lei Federal n $11977 / 09^{117}$ que dispõe sobre o Programa Minha Casa, Minha Vida e sobre a regularização fundiária de assentamentos localizados em áreas urbanas.

\footnotetext{
${ }^{115}$ A infraestrutura de saneamento ambiental contempla além das redes de abastecimento de água e coleta e tratamento de esgotos, a rede de drenagem e a coleta de resíduos sólidos. Mas, no momento, nosso enfoque prioritário são as redes de água e esgoto.

116 Dispõe sobre os casos excepcionais, de utilidade pública, interesse social ou baixo impacto ambiental, que possibilitam a intervenção ou supressão de vegetação em Área de Preservação Permanente (APP). Na definição de interesse social, estabelece como um dos casos "a regularização fundiária sustentável de área urbana" em áreas urbanas demarcadas como ZEIS no Plano Diretor, e de baixa renda.

117 “O Município poderá, por decisão motivada, admitir a regularização fundiária de interesse social em Áreas de Preservação Permanente, ocupadas até 31 de dezembro de 2007 e inseridas em área urbana consolidada, desde que estudo técnico comprove que esta intervenção implica a melhoria das condições ambientais em relação à situação de ocupação irregular anterior" (Lei Federal no 11977/09, artigo 54 § 1ㅇ). O estudo técnico deverá ser composto no mínimo por: I - caracterização da situação ambiental da área a ser regularizada; II - especificação dos sistemas de
} 
Contudo, em áreas de mananciais, o licenciamento ambiental tende a ser mais rigoroso, e em alguns casos essa sobreposição de regulamentações gera conflitos de entendimento da lei e contraditoriamente chega a entravar projetos de urbanização com fins de regularização de interesse social. Por isso, o debate mais amplo e para além do meio técnico sobre a questão do padrão aceitável de urbanização de interesse social é um tema importante, e pode explicitar conflitos que normalmente ficam ocultados pelo debate meramente normativo, sem correspondência com formas possíveis e diversificadas de ocupação urbana.

Ao mesmo tempo, vê-se que os projetos têm buscado incorporar, nas soluções de desenho urbano, algumas "demandas ambientais" das áreas de proteção aos mananciais como a ampliação de áreas permeáveis, a recomposição de margens de córregos e da vegetação - o que nem sempre significa cumprir a legislação ambiental (Código Florestal) à risca, mas sim propondo compensações, como é o caso do Parque no Jardim Ipê, ou a proteção de ao menos uma das margens do córrego e a recuperação de nascente no Capelinha. Assim, se por um lado as exigências ambientais são difíceis de serem cumpridas à risca em áreas ocupadas irregularmente, por outro, muitas vezes elas garantem uma qualidade ambiental aos projetos, que não está presente em projetos para áreas situadas fora de APMs, uma vez que são mais adensadas em termos construtivos ${ }^{118}$.

Ao mesmo tempo, a flexibilização generalizada das normas ambientais tem como possível consequência a piora de qualidade da proposta de recuperação ambiental, tornando o equilíbrio entre regularização e recuperação algo difícil de ser alcançado, e variável caso a caso. E nesse sentido, é preciso reconhecer que falta maior conhecimento do meio natural, e das consequências da transformação desse meio natural no contexto urbano, para que se possa intervir e regulamentar de modo menos homogêneo e restritivo, as funções ambientais de margens de córregos, rios, nascentes, várzeas etc.

A preocupação quanto a um sistema de espaços livres, dependendo da densidade e complexidade do padrão do assentamento consolidado, pode gerar novas possibilidades para a "reurbanização" e para a recuperação ambiental. Para isso, a conotação estritamente técnica da infraestrutura urbana precisa entrar na discussão dos projetos como algo a ser conhecido e apropriado coletivamente. O mesmo desafio se coloca na busca de articulação entre os espaços de moradia, os espaços livres, e as infraestruturas. O projeto do núcleo Capelinha aponta possibilidades nesse sentido. O que os projetos brevemente analisados indicam é que soluções integradas, que são mais propositivas em termos de desenho urbano, sugerem formas de apropriação de espaços que vão além da solução estrita do saneamento ambiental, dando novas

\footnotetext{
saneamento básico; III - proposição de intervenções para o controle de riscos geotécnicos e de inundações; IV recuperação de áreas degradadas e daquelas não passíveis de regularização; $V$ - comprovação da melhoria das condições de sustentabilidade urbano-ambiental, considerados o uso adequado dos recursos hídricos e a proteção das unidades de conservação, quando for o caso; VI - comprovação da melhoria da habitabilidade dos moradores propiciada pela regularização proposta; e VII - garantia de acesso público às praias e aos corpos d'água, quando for o caso.

118 Informação verbal, conforme entrevista com Karla Sanches, arquiteta responsável pelas obras da SEHAB/PMSBC, em 8/11/2012.
} 
qualidades urbanas e ambientais associadas a novos usos do espaço "natural" nos assentamentos.

Em relação à coleta e tratamento de esgotos, como já comentado anteriormente, a Sabesp investe num sistema centralizado em grandes estações. Nas áreas de proteção aos mananciais de São Bernardo do Campo, a expansão da rede coletora de esgotos começou a ser projetada em 2007, quando da elaboração do projeto JICA, citado anteriormente, e foi desenvolvida pela Sabesp constituindo o atual Projeto Billings, cuja previsão de execução é até 2015, conforme plano e cronograma de execução divulgados. Seguindo a lógica de expansão da rede coletora principal, esta se inicia com a construção do coletor Ribeirão dos Couros e se prolonga até a APM, última fase do projeto.

Essa previsão é uma referência que está sendo seguida sem questionamentos - apesar do passivo acumulado em relação ao não tratamento de esgotos - e pressupõe a execução da rede coletora de forma que os esgotos realmente alcancem as estações de tratamento no prazo previsto. Assim, a previsão de extensão da rede de esgotos pelo Projeto Billings colabora, inclusive, para amparar os argumentos da prefeitura para a realização de PRIS. Mas é importante ressaltar que caso a rede coletora de esgotos não se complete nesse prazo, os esgotos continuarão sendo lançados diretamente nos corpos d'água, como já constataram Uemura (2000) e Filardo (2004) em relação às obras do Programa Guarapiranga (tratadas no capítulo anterior).

O que se observa a partir dos PRIS em andamento é que, apesar do argumento utilizado pela Sabesp de que o planejamento da execução da rede principal (Programa Pró Billings) está ajustado ao cronograma de obras da Secretaria de Habitação ${ }^{119}$, o que de fato acontece é que as obras de urbanização se ajustam às diretrizes da Sabesp, conforme os projetos de urbanização se realizam, se preparando para a chegada futura dessas redes. Essa compatibilização no desenvolvimento do projeto é necessária, mesmo porque a construção de coletores-tronco frequentemente implica remoção de moradias construídas em fundos de vale. Mas, se por um lado as urbanizações "puxam as redes", e adaptações são feitas entre projetos municipais e aqueles da Sabesp, numa composição fragmentada de melhorias, por outro lado, essas urbanizações (ou essas adaptações) não alteram a concepção e a temporalidade das soluções de saneamento, particularmente do sistema de esgotos, cujo planejamento de execução da rede coletora principal segue de forma independente.

Este é um dos pontos importantes da crítica, ou seja, a defasagem entre a construção de redes locais e de redes coletoras, que representa um grande impacto do ponto de vista da qualidade da água e do ambiente urbano, não é considerada como um elemento de planejamento: não há soluções intermediárias ou remediadoras, o que de certa forma torna o abastecimento de água "refém" das grandes obras de saneamento.

\footnotetext{
119 Informação verbal, conforme Claudionor Gabas, Sabesp Regional sul SBC, entrevista concedida à autora em 10/08/2012.
} 
Em relação aos sistemas de drenagem superficial, mais um componente da infraestrutura que interfere de modo significativo no encaminhamento das águas num assentamento, as soluções comumente adotadas são as convencionais, combinadas à pavimentação com asfaltamento das ruas. Alternativas de drenagem compensatória, que são calculadas a partir de diferentes premissas de projeto e visam segurar as águas nos locais de precipitação, por meio de sistemas de infiltração no solo, não são aventadas como alternativas, exceto em raras exceções, à exemplo do projeto Parque Andreense, em Santo André (citado no capítulo 6). Há pesquisas sobre drenagem compensatória em várias universidades brasileiras, mas ainda pouca aplicação prática desse tipo de solução ${ }^{120}$.

Portanto, o padrão de infraestrutura pública atual é algo tomado como dado, ainda que haja produção de conhecimento e outras experiências que apontem alternativas ao modelo centralizado em grandes estações de tratamento de esgotos e de abastecimento de água. 0 padrão adotado não é alterado mesmo considerando a diversidade de ocupações presentes na área de proteção aos mananciais e segue sendo reproduzido sem questionamentos, reforçando o modelo Sabesp (no caso do sistema de esgoto) e o padrão construtivo e tecnológico das empresas construtoras, correspondendo assim a uma racionalidade econômica que prepondera sobre o interesse público e coletivo pelo acesso à água em quantidade e qualidade.

Outro aspecto relativo às urbanizações de interesse social é o modo como se dá sua distribuição espacial em função da priorização da intervenção habitacional em determinados locais. Essa priorização depende dos recursos disponíveis, da capacidade de resposta do poder público às pressões políticas da população, bem como das prioridades políticas estabelecidas pelo próprio governo; além das dificuldades de licenciamento, comentadas no item anterior.

Assim, a falta de planejamento prévio que articule ações de saneamento, intervenção habitacional e de urbanização faz com que não seja possível ao menos aferir o impacto sobre a água da represa causado por esse descompasso entre as obras nos assentamentos e o tempo em que ficam sem ligação à rede principal. Portanto, as intervenções se baseiam no fato de que, mais cedo ou mais tarde, o esgoto será exportado e tratado, sem que se avalie o custo e o impacto de problemas já conhecidos. As ligações domiciliares, contudo, entrarão no computo da universalização de atendimento da Sabesp, e os moradores pagarão nas suas contas de água pelo serviço de coleta de esgotos sem a garantia de seu completo tratamento.

Além disso, a visualização do resultado do conjunto das intervenções sobre o território fica comprometida, tanto em termos de paisagem construída como em termos de qualidade ambiental. Nesse sentido, considerando o modo como são executados, os PRIS reforçam a ação fragmentada no território e contraditoriamente a eles é atribuída grande parte da

\footnotetext{
${ }^{120}$ Desde 2011, a autora passou a integrar equipe do projeto Manejo de Águas Pluviais em Meio Urbano, referente à chamada pública 07-2009 MCT/Finep/Cnpq/Ação Transversal Saneamento Ambiental e Habitação, que envolve 14 equipes de universidades brasileiras. A FAUUSP está desenvolvendo o Subprojeto 2: Técnicas Compensatórias, sob coordenação de Maria Lucia Refinetti Martins. O objetivo é estudar soluções não convencionais de drenagem urbana articuladas à configuração física de assentamentos precários e em situações de risco físico, visando elaborar recomendações para a sua regularização urbanística e ambiental.
} 
responsabilidade pela recuperação ambiental da Billings, sem que o devido peso da responsabilidade pela degradação seja atribuído sobre a ineficácia do tratamento de esgotos e das demais infraestruturas, como a drenagem. Apesar dos impactos desse descompasso não se limitarem às áreas de mananciais, eles não são avaliados tomando em consideração as especificidades dessa área onde o que está em jogo é a água para abastecimento metropolitano.

Isso não significa que a exportação integral dos esgotos seja suficiente para garantir a qualidade da água, que depende em grande medida de processos de depuração natural, promovidos pela permeabilidade do solo e presença de vegetação na bacia hidrográfica, mas esta se tornou indispensável, principalmente em áreas de ocupação mais densa.

Em se tratando da escala dos assentamentos, os PRIS do PAC Alvarenga e Capelinha/Cocaia, que resolvem a questão habitacional de forma diferenciada - o primeiro com grande parte do reassentamento fora de APM e o segundo na própria área, até por conta da quantidade de habitações necessárias em cada caso -, reforçam a necessidade de se repensar o padrão de habitação em áreas de mananciais, dados os limites para a aquisição de terras e para a construção de edifícios destinados a HIS, e do difícil "enfrentamento" do mercado imobiliário pelo poder público, na briga por localização de HIS, como comentado anteriormente.

O mercado imobiliário residencial tem crescido da região do $A B C D$ nos últimos anos. Em São Bernardo do Campo, foco desse estudo, além da área urbana consolidada não ter muitos terrenos disponíveis, os terrenos industriais cujas plantas foram desativadas têm se transformado em empreendimentos habitacionais de médio e alto padrão, ocupando "vazios" remanescentes da área urbana consolidada do município (SIGOLO, 2010).

O Plano Municipal de Habitação de Interesse Social de SBC (PLHIS 2010-2025) estimou como déficit quantitativo (novas unidades a construir) 38.017 unidades habitacionais, que somado ao déficit qualitativo (situações irregulares e inadequações a corrigir) de 69.624 unidades totaliza o déficit habitacional em 107.641 unidades. Dessa demanda, uma parte do atendimento será feito na própria área, e outra parte compõe a necessidade de novas terras. Considerando a quantidade de área total necessária ${ }^{121}$, o Plano Diretor triplicou a demarcação de áreas de ZEIS ${ }^{122}$, que no total representa $70 \%$ do atendimento do déficit no município. Portanto, observase que grande parte do atendimento do déficit será equacionado na área de proteção de mananciais pois nela se concentram as ZEIS 1 (ocupações precárias existentes) e aproximadamente metade das ZEIS 2 (áreas para provisão).

\footnotetext{
${ }^{121}$ Segundo cálculo do PLHIS, que estabelece diferentes frações ideais de terreno conforme a região do município, quanto maior a fragilidade ambiental, maior a fração de terreno estimada: nos bairros centrais é de $70 \mathrm{~m}^{2}$, no manancial é de 90 m2 e na área de maior declividade e proteção ambiental é de 200 m² (SÃO BERNARDO, 2012).

${ }^{122}$ Que passou de $628.300 \mathrm{~m}^{2}$ para 2.188,042 $\mathrm{m}^{2}$.
} 


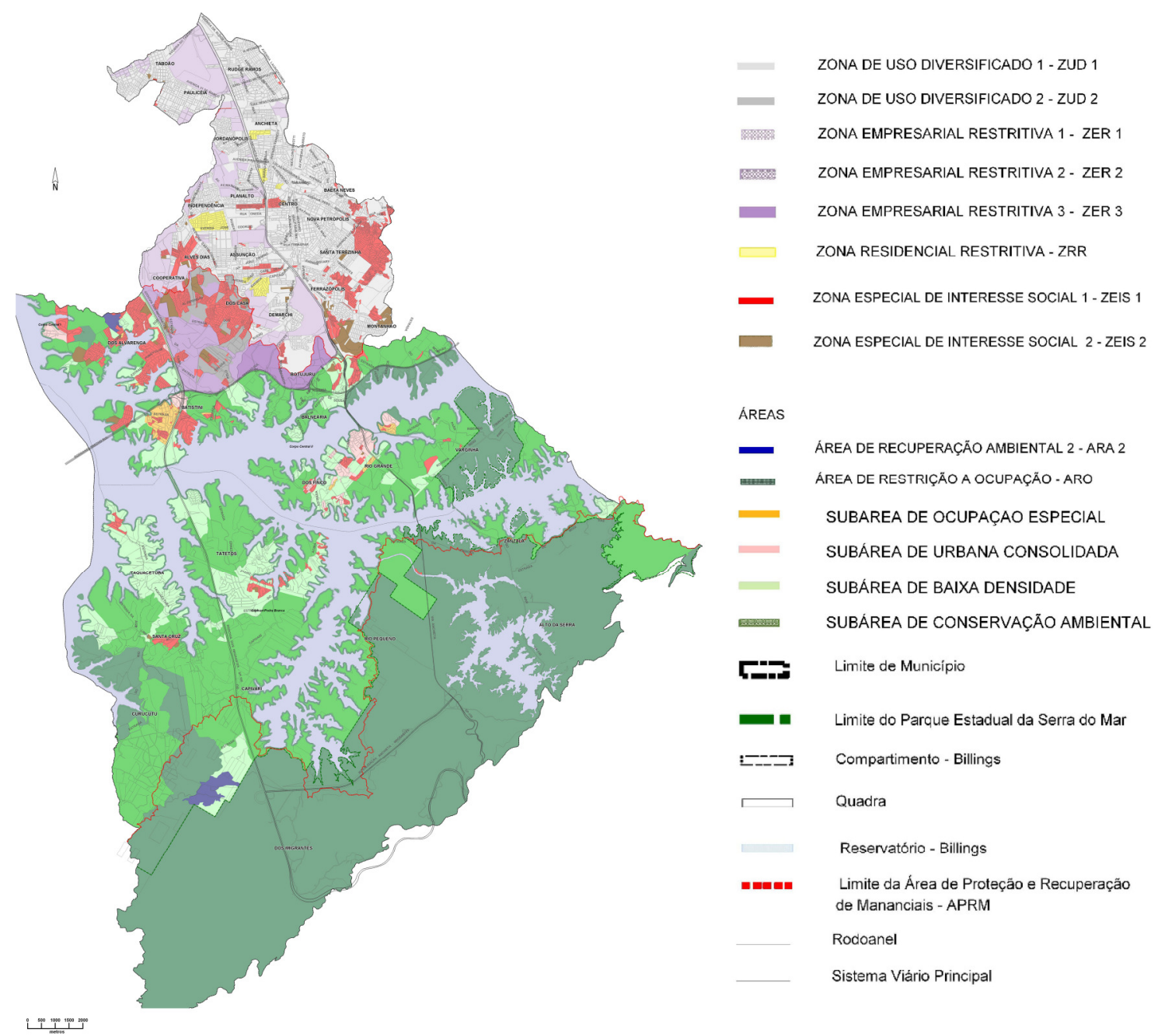

Mapa 28 - Plano Diretor - Zoneamento de São Bernardo do Campo - Zonas especiais de Interesse Social (ZEIS). Anexo ao PL 70/2012 que altera a lei municipal no 6.184/2011.

Fonte: Secretaria de Planejamento de São Bernardo do Campo. Mapa alterado pela lei no 6.238/2012. Disponível em http://www.saobernardo.sp.gov.br/dados2/PlanoDiretor/2013/Mapa2_alterado_623812.jpg. Acesso em: 22/04/2013.

Segundo dados da Secretaria de Habitação de São Bernardo, até junho de 2012 foram construídos sete conjuntos habitacionais e urbanizadas 04 áreas, situados fora da área de proteção aos mananciais. Em área de proteção aos mananciais foram realizadas obras nas quatro áreas do PAC Alvarenga e licitado o projeto Capelinha/Cocaia (obras não iniciadas) (ver tabela 23 ao final do capítulo). Conforme as demandas do Orçamento Participativo de 2012, mais treze projetos serão realizados nos próximos anos, dos quais oito situam-se em área de proteção aos mananciais, e contemplam 20 áreas de intervenção (ver tabela 24 ao final do capítulo).

Portanto, considerando que a área de proteção aos mananciais em São Bernardo do Campo continuará sendo local de assentamento da população de baixa renda, o que está em questão é de que forma esses projetos articularão adequação social, urbana e ambiental na bacia em seu conjunto, sem que a reprodução de assentamentos precários avance sobre a área não ocupada, que é essencial tanto para manter o manancial como produtor de água potável, mas é ainda mais essencial do ponto de vista da justiça ambiental - no sentido de reverter o quadro de 
expansão periférica sobre essas áreas protegidas. Bons projetos de urbanização também não podem ser motores de expulsão de população pobre por causa da valorização que promovem, uma contradição própria da cidade capitalista, cujo contraponto possível é a ação política. Nesse sentido o PRIS é instrumento insuficiente para a recuperação da área de proteção aos mananciais, na medida em que não se articula a um plano maior para a área da bacia.

Por fim cabe destacar que a precariedade, a pobreza e a instabilidade da posse são condições iniciais e fundamentais para que o poder público intervenha e promova a recuperação ambiental. Ou seja, a recuperação ambiental das áreas de proteção aos mananciais tem um lado contraditório e um componente ideológico pois está totalmente associada a uma imagem de transformação dos territórios onde vivem os pobres, sem incidir com a mesma força ideológica para o conjunto da sociedade e da metrópole, reforçando o estigma da degradação da água causada pela ocupação de baixa renda, e não por um processo estrutural de reprodução de desigualdades sociais, e portanto ao mesmo tempo ambientais. 


\section{Tabelas e quadros:}

Tabela 21 - Parâmetros urbanísticos APRM - Billings conforme Lei no 13.579/2009.

\begin{tabular}{|c|c|c|c|c|c|c|}
\hline \multirow[b]{2}{*}{$\begin{array}{l}\text { ÁREAS DE } \\
\text { INTERVENÇÃO }\end{array}$} & \multirow[b]{2}{*}{ ÍNDICES URBANÍSTICOS } & \multicolumn{5}{|c|}{ COMPARTIMENTOS AMBIENTAIS } \\
\hline & & $\begin{array}{l}\text { Corpo } \\
\text { Central I }\end{array}$ & $\begin{array}{c}\text { Corpo } \\
\text { Central II }\end{array}$ & $\begin{array}{l}\text { Taqua- } \\
\text { cetuba } \\
\text { Bororé }\end{array}$ & $\begin{array}{c}\text { Rio } \\
\text { Grande Rio } \\
\text { Pequeno }\end{array}$ & $\begin{array}{c}\text { Capivari } \\
\text { Pedra } \\
\text { Branca }\end{array}$ \\
\hline \multirow{4}{*}{$\begin{array}{l}\text { AOD } \\
\text { Ocupação } \\
\text { Especial }\end{array}$} & Lote mínimo (m2) & & & 250 & & \\
\hline & Coef. de aproveitamento & & & 2,5 & & \\
\hline & Taxa de permeabilidade (\%) & & & 15 & & \\
\hline & Índice de área vegetada (\%) & & & 8 & & \\
\hline \multirow{4}{*}{$\begin{array}{l}\text { AOD } \\
\text { Ocupação } \\
\text { Urbana } \\
\text { Consolidada }\end{array}$} & Lote mínimo (m2) & 250 & 250 & 250 & 250 & - \\
\hline & Coef. de aproveitamento & 2,5 & 1 & 1 & 2 & - \\
\hline & Taxa de permeabilidade (\%) & 15 & 15 & 15 & 15 & - \\
\hline & Índice de área vegetada (\%) & 8 & 8 & 8 & 8 & - \\
\hline \multirow{4}{*}{$\begin{array}{l}\text { AOD } \\
\text { Ocupação } \\
\text { Urbana } \\
\text { Controlada }\end{array}$} & Lote mínimo (m2) & 250 & 250 & 250 & 250 & 500 \\
\hline & Coef. de aproveitamento & 2 & 1 & 1 & 1 & 0,8 \\
\hline & Taxa de permeabilidade (\%) & 20 & 20 & 20 & 20 & 40 \\
\hline & Índice de área vegetada (\%) & 10 & 10 & 10 & 10 & 20 \\
\hline \multirow{4}{*}{$\begin{array}{l}\text { AOD } \\
\text { Ocupação } \\
\text { de Baixa } \\
\text { Densidade }\end{array}$} & Lote mínimo (m2) & 500 & 500 & 1.000 & 3.000 & 5.000 \\
\hline & Coef. de aproveitamento & 0,5 & 0,5 & 0,2 & 0,5 & 0,2 \\
\hline & Taxa de permeabilidade (\%) & 40 & 40 & 50 & 70 & 70 \\
\hline & Índice de área vegetada (\%) & 20 & 20 & 25 & 35 & 35 \\
\hline \multirow{4}{*}{$\begin{array}{l}\text { AOD } \\
\text { Conservação } \\
\text { Ambiental }\end{array}$} & Lote mínimo (m2) & 5.000 & 5.000 & 7.500 & 7.500 & 10.000 \\
\hline & Coef. de aproeitamento & 0,2 & 0,2 & 0,1 & 0,1 & 0,1 \\
\hline & Taxa de permeabilidade (\%) & 90 & 90 & 90 & 90 & 90 \\
\hline & Índice de área vegetada (\%) & 45 & 45 & 45 & 45 & 45 \\
\hline
\end{tabular}

Fonte: Lei Específica da APRM - Billings no 13.579/2009. 
Tabela 22 - Programa Mananciais Fase 2 e 3 no município de São Paulo.

\begin{tabular}{|c|c|c|c|c|c|c|c|c|c|c|c|c|}
\hline \multirow{2}{*}{\multicolumn{9}{|c|}{\begin{tabular}{|c|} 
PROGRAMA MANANCIAIS - FASE 2 \\
Áreas de Intervenção - Favelas e Loteamentos \\
- Plano Emergencial e Licenciamento
\end{tabular}}} & \multirow{3}{*}{\multicolumn{3}{|c|}{$\begin{array}{l}\text { Situação da área em } \\
\text { relação ao início da } \\
\text { intervenção }\end{array}$}} & \\
\hline & & & & & & & & & & & & \\
\hline & & & & & ínea Inte & egrant & & & & & & \\
\hline 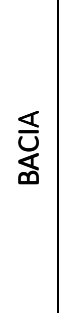 & 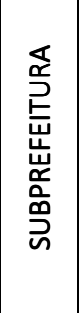 & $\begin{array}{l}\text { FAVELA / LOTEAMENTO } \\
\text { FASE } 2\end{array}$ & 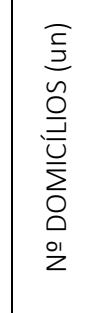 & 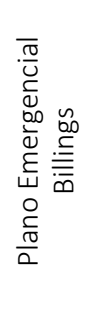 & 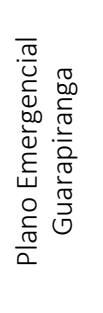 & 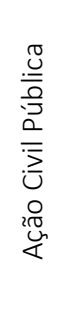 & 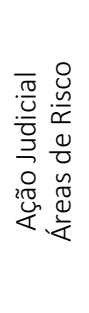 & 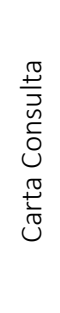 & 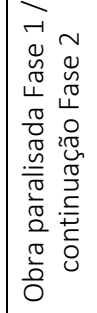 & 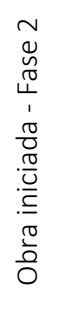 & 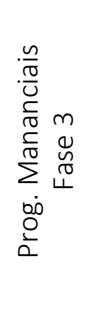 & 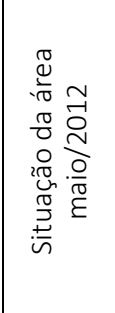 \\
\hline & & Cidade Júlia & 4.140 & $\mathrm{x}$ & & & & $x$ & & - & & $75 \%$ \\
\hline & 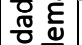 & Nova Pantanal & 1.725 & $x$ & & & & $\mathrm{x}$ & & • & & $100 \%$ \\
\hline & & Jardim Eldorado / Mata V irgem & 2.365 & $\mathrm{x}$ & & & & $\mathrm{x}$ & & - & - & $75 \%$ \\
\hline & & Cantinho do Céu / Gaivota & 9.789 & $x$ & & $\mathrm{x}$ & $x$ & $x$ & & - & • & $100 \%$ \\
\hline & & Alto da Alegria & 429 & $\mathrm{x}$ & & & $\mathrm{x}$ & $\mathrm{x}$ & & & - & $25 \%$ \\
\hline 兄 & & Nova Grajaú II * & 1.635 & & & $\mathrm{x}$ & & $\mathrm{x}$ & & & • & $50 \%$ \\
\hline$\geqq$ & & Chácara do Conde II & 521 & $\mathrm{x}$ & & & & $\mathrm{x}$ & & - & & $100 \%$ \\
\hline & & Cocaia I* & 648 & & & & & $x$ & & & & $75 \%$ \\
\hline & & Jd. Toca & 450 & $\mathrm{x}$ & & & & $\mathrm{x}$ & & - & & $100 \%$ \\
\hline & & Nova Varginha & 741 & $\mathrm{x}$ & & $\mathrm{x}$ & $\mathrm{x}$ & & & & & contrat. \\
\hline & & Jd. Novo Marilda & 2.700 & $x$ & & $\mathrm{x}$ & $\mathrm{x}$ & & & - & & $75 \%$ \\
\hline & & Jd. Noronha & 4.349 & $x$ & & $x$ & $x$ & & & $\bullet$ & & $75 \%$ \\
\hline & & Condomínio Vargem Grande & 6.000 & $\mathrm{x}$ & & & & & & & & $75 \%$ \\
\hline & & Vinte & 478 & & & & & $\mathrm{x}$ & & - & & $100 \%$ \\
\hline & & Dezenove & 531 & & & & & $\mathrm{x}$ & & - & & $100 \%$ \\
\hline & & Vila Rubi & 476 & & & & $\mathrm{x}$ & $\mathrm{x}$ & & - & & $100 \%$ \\
\hline & $\stackrel{2}{2}$ & Pq. São José I e II & 2.700 & & & & $x$ & $x$ & $\bullet$ & $\bullet$ & $\bullet$ & $25 \%$ \\
\hline & $\breve{~}$ & Jd. Manacás & 228 & & & & $\mathrm{x}$ & $\mathrm{x}$ & • & - & - & |contrat. \\
\hline & 8 & Pq. São José VII, Três Cânticos e Entorno & 198 & & & & & $\mathrm{x}$ & & & - & $25 \%$ \\
\hline & $\frac{\pi}{d}$ & Jd. Icaraí II E III & 482 & & & & $\mathrm{x}$ & $x$ & & $\bullet$ & & $100 \%$ \\
\hline & $\mathbb{0}_{0}^{\frac{2}{0}}$ & Jd. Icaraí I & 241 & & & & & $x$ & & $\bullet$ & & $100 \%$ \\
\hline & & Jd. Pouso Alegre & 368 & & & & & $x$ & & $\bullet$ & & contrat. \\
\hline$\sum_{5}^{2}$ & & Jardim Icaraí IV & 74 & & & & & & & • & & $100 \%$ \\
\hline$\frac{c}{a}$ & & Alcindo Ferreira I / Jardim Cruzeiro & 63 & & & & & & & • & - & contrat. \\
\hline 产 & & Jardim Satélite I e II / Maria A A II & 77 & & & $\mathrm{x}$ & & & & $\bullet$ & $\bullet$ & contrat. \\
\hline ऽ & & Ipojuca Lins de Araújo & 189 & & & & & & & & - & |contrat. \\
\hline & & Parque São José VI & 358 & & & & & & & & - & contrat. \\
\hline & & Jardim Itatiaia & 44 & & & & $\mathrm{x}$ & & & - & & |licitação \\
\hline & & Jardim São Bernardo II & 168 & & & & & & & $\bullet$ & & $100 \%$ \\
\hline & & Vila Santa Francisca Cabrini IV & 312 & & & & & & & $\bullet$ & & $100 \%$ \\
\hline & & Jardim dos Lagos & 1.000 & & & & & & & & & contrat. \\
\hline & & Ribeirão das Pedras & 1.000 & & & & & & & - & & $100 \%$ \\
\hline & & Jardim Represa & 200 & & & & & & & $\bullet$ & & contrat. \\
\hline & & Jardim Real & 200 & & & & & & & • & & contrat. \\
\hline
\end{tabular}




\begin{tabular}{|c|c|c|c|c|c|c|c|}
\hline & Parque América & 63 & & & $\bullet$ & & $100 \%$ \\
\hline & CEU Cidade Dutra & 80 & & & $\bullet$ & $\bullet$ & contrat. \\
\hline \multirow{3}{*}{ 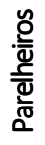 } & Santa Fé & 218 & & $\mathrm{x}$ & $\bullet$ & & $100 \%$ \\
\hline & Parque Maria Fernanda I e II & 295 & & & $\bullet$ & $\bullet$ & contrat. \\
\hline & Jardim Iporã / Casa Grande & 200 & & & $\bullet$ & & $100 \%$ \\
\hline \multirow{42}{*}{ 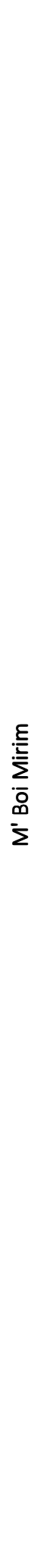 } & Jd. Arnaldo & 542 & & $\mathrm{x}$ & $\bullet$ & & contrat. \\
\hline & Jd. Herculano & 177 & & $\mathrm{x}$ & $\bullet$ & & $25 \%$ \\
\hline & |Kagohara II & 35 & & $\mathrm{X}$ & • & & contrat. \\
\hline & Kagohara III & 353 & & $\mathrm{X}$ & $\bullet$ & & contrat. \\
\hline & Jd. Planalto & 208 & & $x$ & $\bullet$ & & contrat. \\
\hline & Alto da Riviera B & 195 & & $\mathrm{x}$ & $\bullet$ & & $75 \%$ \\
\hline & Fujihara II & 215 & & $\mathrm{x}$ & - & & contrat. \\
\hline & Pq. Novo Santo Amaro I e II & 214 & & $x$ & $\bullet$ & $\bullet$ & contrat. \\
\hline & Pq. Novo Santo Amaro III & 183 & & $\mathrm{X}$ & $\bullet$ & $\bullet$ & contrat. \\
\hline & Pq. Novo Santo Amaro V / Luz Soriano & 389 & & $\mathrm{X}$ & $\bullet$ & & $75 \%$ \\
\hline & Pq. Novo Santo Amaro VI & 18 & & $\mathrm{x}$ & • & & contrat. \\
\hline & Pq. Novo Santo Amaro VII & 255 & & $\mathrm{x}$ & $\bullet$ & & $100 \%$ \\
\hline & Jararaú II & 129 & & $x$ & $\bullet$ & $\bullet$ & $25 \%$ \\
\hline & Jd. Solange & 180 & & $x$ & $\bullet$ & $\bullet$ & $25 \%$ \\
\hline & Pq. das Cerejeiras & 728 & $x$ & $x$ & $\bullet$ & & $100 \%$ \\
\hline & Jd. Capela / Santa Bárbara & 477 & & $x$ & $\bullet$ & $\bullet$ & $50 \%$ \\
\hline & Araguari (Muriçoca) & 140 & & $x$ & $\bullet$ & & contrat. \\
\hline & Angelo Tarsini & 326 & & $x$ & $\bullet$ & $\bullet$ & $75 \%$ \\
\hline & Cavalo Branco & 1.000 & $x$ & $x$ & $\bullet$ & $\bullet$ & $100 \%$ \\
\hline & Cardeal Rossi & 100 & & $x$ & $\bullet$ & & $100 \%$ \\
\hline & Arizona & 2.400 & $x$ & $x$ & $\bullet$ & & $100 \%$ \\
\hline & Cidade Ipava / Vila Jaci & 2.486 & $x$ & $\mathrm{X}$ & $\bullet$ & & $100 \%$ \\
\hline & Boulevard da Paz & 1.209 & & $x$ & $\bullet$ & $\bullet$ & $25 \%$ \\
\hline & Enlevo & 317 & & & $\bullet$ & $\bullet$ & contrat. \\
\hline & Jardim Horizonte Azul / Sapato Branco & 452 & $x$ & & $\bullet$ & $\bullet$ & contrat. \\
\hline & Jardim Calú & 373 & & & $\bullet$ & $\bullet$ & contrat. \\
\hline & Costa do Valado & 339 & & & $\bullet$ & $\bullet$ & contrat. \\
\hline & São Lourenço & 127 & $x$ & & $\bullet$ & $\bullet$ & contrat. \\
\hline & Parque São Francisco & 110 & & & $\bullet$ & $\bullet$ & contrat. \\
\hline & Jardim São Joaquim & 23 & & & $\bullet$ & & $100 \%$ \\
\hline & Jardim Fujihara I, III e Jardim Nakamura II & 114 & & & $\bullet$ & $\bullet$ & contrat. \\
\hline & Renato Locchi & 259 & & & $\bullet$ & $\bullet$ & contrat. \\
\hline & Minuetos & 304 & & & $\bullet$ & & contrat. \\
\hline & Neumas / Kagohara IV & 105 & & & $\bullet$ & & contrat. \\
\hline & Santa Margarida V & 45 & & & $\bullet$ & $\bullet$ & contrat. \\
\hline & Nagib I e II & 94 & & & $\bullet$ & & contrat. \\
\hline & Jardim Angela II & 237 & & & $\bullet$ & $\bullet$ & $25 \%$ \\
\hline & Vila Santa Zélia & 154 & & & $\bullet$ & $\bullet$ & contrat. \\
\hline & Vila Bom Jardim I & 89 & & & $\bullet$ & & contrat. \\
\hline & Chácara Flórida/ Bandeirantes & 1.000 & & & $\bullet$ & $\bullet$ & contrat. \\
\hline & Chácara Sonho Azul & 200 & $x$ & & $\bullet$ & $\bullet$ & $100 \%$ \\
\hline & Parque do Lago (Xamborés I e II) & 300 & & & $\bullet$ & $\bullet$ & $100 \%$ \\
\hline
\end{tabular}

Fonte: Secretaria de Habitação do Município PMSP, 2008. Atualizado pela autora a partir de dados da imprensa e internet. 
Quadro 4 - Ações previstas pelo Programa Mananciais Alto Tietê, segundo agente executor do Governo do Estado de São Paulo.

\begin{tabular}{|c|c|c|c|c|}
\hline \multirow[t]{2}{*}{ PROGRAMAS } & \multicolumn{4}{|c|}{ GOVERNO DO ESTADO DE SÃO PAULO } \\
\hline & SSE & $\mathrm{CDHU}$ & SMA & SABESP \\
\hline $\begin{array}{l}\text { Instrumentos de } \\
\text { Sustentação, } \\
\text { Acompanhamento, } \\
\text { Controle, e } \\
\text { Viabilização } \\
\text { do Programa } \\
\text { (Gestão) }\end{array}$ & $\begin{array}{l}\text { Apoio Técnico à operação, integração e atualização dos } \\
\text { instrumentos de gestão (GIS e PDPA); Centro de } \\
\text { Integração da Cidadania - Grajaú; Desenvolvimento de } \\
\text { instrumentos técnicos para apoio aos Municípios; Apoio } \\
\text { Técnico-Operacional pós-obra e acompanhamento } \\
\text { social pós-ocupação; Operação do Sistema de Gestão e } \\
\text { Rede de Informações de Apoio à Gestão e divulgação; } \\
\text { Promoção de Seminários Internacionais; Auditoria } \\
\text { Ambiental Independente; Programa de } \\
\text { Desenvolvimento de Atividades Econômicas } \\
\text { Compatíveis, Geraçãa de Empregos e Gerenciamento de } \\
\text { Receitas para Proteção Ambiental; Apoio a Projetos de } \\
\text { Entidades Civis; Gerenciamento das intervenções do } \\
\text { Programa Mananciais do Alto Tietê }\end{array}$ & & $\begin{array}{l}\text { Capacitação de Agentes Ambientais; Oficinas de } \\
\text { Capacitação para Leis Especificas; Ações diversas de } \\
\text { Educação Ambiental; Implementação de Sistema de } \\
\text { Fiscalização Ambiental nas Bacias do Guarapiranga e } \\
\text { Billings, articulado ao Sistema de Fiscalização Integrada } \\
\text { dos Mananciais da Bacia do Alto Tietê; Adequação das } \\
\text { instalações físicas, visando a implementação de um } \\
\text { Sistema de Fiscalização; Concepção, desenvolvimento e } \\
\text { implementação de Programa de Monitoramento do Uso } \\
\text { e Ocupação do Solo; Monitoramento da Qualidade } \\
\text { Ambiental }\end{array}$ & $\begin{array}{l}\text { - Desenvolvimento de Instrumentos Técnicos para } \\
\text { Gestão; } \\
\text { - Modelos Hidrodinâmicos dos reservatórios } \\
\text { Guarapiranga, Rio Grande, Taiaçupeba, Jundiaí, Biritiba, } \\
\text { Paiva Castro, Atibainha; } \\
\text { - Sistema de Suporte à Decisão e Controle para } \\
\text { Operação Integrada dos Mananciais do Sistema Adutor } \\
\text { Metropolitano; } \\
\text { - Educação Ambiental e Monitoramento (incluído pós- } \\
\text { obra) }\end{array}$ \\
\hline $\begin{array}{l}\text { Ações de } \\
\text { Estruturação } \\
\text { e Recuperação } \\
\text { Urbana }\end{array}$ & $\begin{array}{l}\text { - Implantação de Áreas de Uso Comunitário; } \\
\text { - Projeto e Obras de recuperação de áreas degradadas } \\
\text { (subbacias Guarapiranga e Billings) }\end{array}$ & $\begin{array}{l}\text { Construção de } \\
\text { moradias para o } \\
\text { reassentamento das } \\
\text { famílias a serem } \\
\text { removidas de SP e SBC }\end{array}$ & & \\
\hline $\begin{array}{l}\text { Ações de } \\
\text { Preservação } \\
\text { e Recuperação } \\
\text { Ambiental }(*)\end{array}$ & $\begin{array}{l}\text { Projeto e Obras de implantação do Parque Nove de } \\
\text { Julho, abrangendo 26,9 hectares na sub-bacia do } \\
\text { Guarapiranga. }\end{array}$ & & $\begin{array}{l}\text { Estudos, Projetos e obras para Implantação de Parques } \\
\text { ao longo da Represa Billings, em São Paulo, Ribeirão } \\
\text { Pires e Rio Grande da Serra; Projeto e obras de } \\
\text { recomposição vegetal das matas ciliares e margens da } \\
\text { Billings; Projeto e obras de recuperação de áreas } \\
\text { degradadas e revitalização urbana em São Paulo; Plano } \\
\text { de Controle do Transporte de Cargas Perigosas (inclui a } \\
\text { bacia do Guarapiranga) }\end{array}$ & \begin{tabular}{|l|} 
Estações de Remoção de Carga Poluidora; Wetland \\
Parelheiros; Retenção de detritos na captação do \\
Guarapiranga; Planos de Manejo (Capivari, Rio Claro, \\
Morro Grande); Remoção de Macrófitas; Dessasso- \\
reamento de reservatórios (Paiva Castro e Isolina); \\
Infraestrutura para aplicação de algicidas; Implantação \\
de Parques (Paiva Castro, Atibainha, Cachoeirinha e \\
Isolina); Melhorias ESI - Elevatória Santa Inês
\end{tabular} \\
\hline $\begin{array}{l}\text { Ações de } \\
\text { Saneamento } \\
\text { Ambiental }\end{array}$ & $\begin{array}{l}\text { Projetos e Obras de remediação de lixões e implantação } \\
\text { de aterro sanitário em Embu Guaçu; avaliação de } \\
\text { disposição clandestina de resíduos sólidos em Ribeirão } \\
\text { Pires e Rio Grande da Serra; Compra de equipamentos } \\
\text { para amparo ao sistema de coleta de resíduos em área } \\
\text { pública de Rio Grande da Serra }\end{array}$ & & & $\begin{array}{l}\text { Melhoria dos Processos de Tratamento de Água } \\
\text { (automação da ETA ABV, ETA Rio Grande, ETA Rio Claro, } \\
\text { ETA Guaraú, ETAs Alto e Baixo Cotia, e adequação dos } \\
\text { processos, filtração etc.); Implantação de sistemas de } \\
\text { remoção de lodo das ETAs; Sistemas de Recuperação de } \\
\text { Águas de Lavagem; Implantação de sistemas de } \\
\text { abastecimento de água (PAT PROSANEAR e Grajaú); } \\
\text { Execução e/ou ampliação de Estações EEE; Extensão da } \\
\text { rede coletora de esgotos; Ampliação da ETE Mairiporã; } \\
\text { Aperfeiçoamento Tecnológico; Otimização e Melhorias } \\
\text { Operacionais (Controle); Eliminação de } \\
\text { Extravasamentos. }\end{array}$ \\
\hline
\end{tabular}

Fonte: Secretaria de Saneamento e Energia. Relatório de Avaliação Ambiental dos Componentes do Programa Mananciais, 2009. 
Quadro 5 - Ações previstas pelo Programa Mananciais Alto Tietê, segundo agente executor - municípios.

\begin{tabular}{|c|c|c|c|}
\hline \multirow{2}{*}{ PROGRAMAS } & \multicolumn{3}{|c|}{ PREFEITURAS MUNICIPAIS } \\
\hline & \begin{tabular}{|l} 
SÃO BERNARDO DO CAMPO \\
\end{tabular} & GUARULHOS & SÃO PAULO * \\
\hline $\begin{array}{l}\text { Instrumentos de } \\
\text { Sustentação, } \\
\text { Acompanhamento, } \\
\text { Controle, e Viabilização } \\
\text { do Programa (Gestão) }\end{array}$ & \begin{tabular}{|l|} 
Educação Ambiental \\
Monitoramento e Fiscalização \\
Planejamento Integrado \\
Controle dos Processos Erosivos e de Produção de \\
Sedimentos \\
Programa de Desenvolvimento de Atividades Econômicas \\
Compatíveis, \\
Geração de Empregos e Gerenciamento de Receitas para \\
Proteção Ambiental \\
Controle da Disposição Clandestina de Resíduos Sólidos \\
\end{tabular} & $\begin{array}{l}\text { Estudo para ampliação do Programa de Educação Ambiental e } \\
\text { aquisição de materiais e equipamentos para o Programa de } \\
\text { Educação Ambiental; } \\
\text { Estudo para criação, regulamentação e implementação de } \\
\text { fiscalização municipal na Bacia do Cabuçu, para o manancial } \\
\text { subterrâneo e para a sub-bacia do Tanque Grande; } \\
\text { Estudo para desenvolvimento e implantação do SIG; } \\
\text { Aquisição de equipamentos e softwares para o SIG e } \\
\text { treinamento; Aquisição de equipamentos para o laboratório } \\
\text { central. }\end{array}$ & \\
\hline $\begin{array}{l}\text { Ações de Estruturação } \\
\text { e Recuperação Urbana }\end{array}$ & \begin{tabular}{|l|} 
Elaboração de Levantamentos e Programas para \\
Adequação do Uso Habitacional/Reassentamentos \\
Urbanização de Favelas \\
Relocação de Áreas de 1a Categoria e Recuperação das \\
Áreas Desocupadas na Relocação de Áreas de 1ạ \\
Categoria \\
Regularização e Readequação Urbana e Ambiental de \\
Loteamentos \\
Acompanhamento Sócio Ambiental das Intervenções \\
Urbanas e Habitacionais \\
\end{tabular} & $\begin{array}{l}\text { Estudo para criação e regulamentação de APA municipal (Sub- } \\
\text { bacia Tanque Grande); Projetos e obras de parque municipal } \\
\text { (Sub-bacia Tanque Grande); } \\
\text { Projeto e obras de centro de educação ambiental (Sub-bacia } \\
\text { Tanque Grande); Estudo para criação e regulamentação de APA } \\
\text { municipal (Subbacia Lagoa Azul/Lavras); Projeto e obras de } \\
\text { parque municipal (Sub-bacia Lagoa Azul/Lavras); Estudo para } \\
\text { ampliação da Exploração do Manancial Subterrâneo }\end{array}$ & $\begin{array}{l}\text { Urbanização em aproximadamente } 15 \text { favelas (6.220 famílias) } \\
\text { Construção de unidades habitacionais para favelas } \\
\text { urbanizadas } \\
\text { Fornecer auxílio social às famílias reassentadas Aproximadamente } \\
1.000 \text { famílias reassentadas }\end{array}$ \\
\hline $\begin{array}{l}\text { Ações de Preservação } \\
\text { e Recuperação } \\
\text { Ambiental }(*)\end{array}$ & $\begin{array}{l}\text { Arborização Urbana } \\
\text { Urbanização de Áreas Públicas Livres - Criação de Praças } \\
\text { e Equipamentos de Lazer, Implantação de Parques e } \\
\text { Unidades de Conservação } \\
\text { Repovoamento Vegetal } \\
\text { Recuperação de Áreas Degradadas (Intervenções de } \\
\text { Baixo Custo em Encostas, Taludes e Áreas de Produção } \\
\text { de Sedimentos - Bacia Rio Grande } \\
\text { e Taquacetuba) } \\
\text { Controle do Transporte de Cargas Perigosas } \\
\end{array}$ & & \\
\hline $\begin{array}{l}\text { Ações de Saneamento } \\
\text { Ambiental }\end{array}$ & $\begin{array}{l}\text { Remediação do Lixão do Alvarenga } \\
\text { Aquisição de Equipamentos para Coleta de Resíduos } \\
\text { Sólidos } \\
\text { Implantação de Centros de Ecologia e Cidadania } \\
\text { Plano de Gerenciamento Integrado de Resíduos Sólidos }\end{array}$ & \begin{tabular}{|l|} 
Projeto e obras das reformas gerais na ETA Tanque Grande; \\
Projeto e obras do sistema de abastecimento de água Ururuquara \\
e Lagoa Azul/Lavras; \\
Estudos de viabilidade técnico-econômico-ambiental Sub-bacia \\
Engordador e Borracha; Elaboração e implantação de Programa \\
de Controle e Redução de Perdas;. Projeto e obras do sistema de \\
esgotamento sanitário Lagoa Azul / Lavras
\end{tabular} & \\
\hline
\end{tabular}

*O município de São Paulo não é tomador do empréstimo, participa como executor.

Fonte: Secretaria de Saneamento e Energia. Relatório de Avaliação Ambiental dos Componentes do Programa Mananciais, 2009. 
Tabela 23 - Projetos do PAC 1 e PAC 2 em São Bernardo do Campo

\begin{tabular}{|c|c|c|c|c|c|c|c|c|c|c|}
\hline $\begin{array}{l}\text { EMPREENDIMENTOS HABITACIONAIS } \\
\text { NA REGIÃO }\end{array}$ & $\begin{array}{l}\text { EM } \\
\text { APM }\end{array}$ & $\begin{array}{l}\text { TOTAL } \\
\text { UHS }\end{array}$ & $\begin{array}{l}\text { UHS } \\
\text { CONS. }\end{array}$ & $\begin{array}{l}\text { UHS } \\
\text { NOVAS }\end{array}$ & $\begin{array}{l}\text { SÓ REG. } \\
\text { FUND. }\end{array}$ & $\begin{array}{c}\text { UHS } \\
\text { ENTREGUES } \\
\text { ATÉ JUN/2012 }\end{array}$ & ESTÁGIO ATUAL & $\begin{array}{l}\text { INVESTIMENTO } \\
\text { TOTAL }\end{array}$ & REPASSE & CONTRA PARTIDA \\
\hline \multicolumn{11}{|l|}{ Recursos próprios: } \\
\hline Cj. Hab. Vila Esperança - 1’a. Etapa & & 80 & - & 80 & - & 80 & Concluído & $S / 1$ & $S / 1$ & $S / I$ \\
\hline \multicolumn{11}{|l|}{ PAC 1: } \\
\hline Cj. Hab. Três Marias & & 1.236 & - & 1.236 & - & 964 & Em obras & $\mathrm{R} \$ \mathbf{8 1 . 7 9 2 . 8 0 0}$ & $\mathrm{R} \$ 57.000 .000$ & $R \$ 24.792 .800$ \\
\hline $\begin{array}{l}\text { Urbanização Integrada da Região do } \\
\text { Alvarenga-PAC Alvarenga }\end{array}$ & $x$ & 1.488 & 610 & 878 & - & 212 & Em obras & $\mathrm{R} \$ 68.202 .702$ & $\mathrm{R} \$ 36.000 .000$ & $\mathrm{R} \$ 32.202 .702$ \\
\hline Cj. Hab. Silvina / Oleoduto - 2a . Etapa & & 532 & - & 532 & - & 300 & Em obras & $\mathrm{R} \$ \mathbf{5 3 . 5 0 8 . 7 5 5}$ & $\mathrm{R} \$ 19.816 .160$ & $\mathrm{R} \$ 33.692 .595$ \\
\hline Cj. Hab. Jd. Esmeralda - 2a . Etapa & & 564 & - & 564 & - & 480 & Concluído & $\mathrm{R} \$ \mathbf{5 3 . 8 6 0 . 2 6 0}$ & $\mathrm{R} \$ 21.954 .400$ & $\mathrm{R} \$ 31.905 .860$ \\
\hline Cj. Hab. Jardim Silvina/ Naval & & 540 & - & 540 & - & 360 & Em obras & $\mathrm{R} \$ \mathbf{4 3 . 7 0 8 . 2 6 8}$ & $\mathrm{R} \$ 16.272 .644$ & $\mathrm{R} \$ 27.435 .624$ \\
\hline Cj. Hab. Vila Esperança - 2ạ. Etapa & & 366 & - & 366 & - & 148 & Em obras & $\mathrm{R} \$ \mathbf{2 3 . 6 7 0 . 2 1 2}$ & $\mathrm{R} \$ 11.127 .000$ & $\mathrm{R} \$ 12.543 .212$ \\
\hline $\begin{array}{l}\text { Urbanização do Parque São Bernardo, } \\
\text { Alto da Bela Vista e Novo Parque }\end{array}$ & & 3.123 & 2.345 & 778 & 582 & - & Em obras & $\mathrm{R} \$ 93.872 .609$ & $\mathrm{R} \$ 62.418 .687$ & $\mathrm{R} \$ 31.453 .922$ \\
\hline Cj. Hab. Pai-Herói & & 22 & - & 22 & - & - & Concluído & $\mathrm{R} \$ \mathbf{1 . 5 7 6 . 7 8 2}$ & $\mathrm{R} \$ 419.994$ & $\mathrm{R} \$ 1.156 .788$ \\
\hline Cj. Hab. Jd. Lavínia - 2a Etapa & & 184 & - & 184 & - & - & Em obras & $\mathrm{R} \$ 16.267 .370$ & $\mathrm{R} \$ 6.921 .600$ & $\mathrm{R} \$ 9.345 .770$ \\
\hline Urbanização Integrada do Jardim Colina & & 156 & 56 & 100 & - & - & Em obras & $\mathrm{R} \$ \mathbf{8 . 0 8 6 . 9 9 2}$ & $\mathrm{R} \$ 5.581 .811$ & $\mathrm{R} \$ 2.505 .181$ \\
\hline Total PAC 1: Produção + Urbanização & & 8.291 & 3.011 & 5.280 & 582 & 2.544 & & $\mathrm{R} \$ 444.546 .750$ & $\mathrm{R} \$ 237.512 .296$ & $\mathrm{R} \$ 207.034 .454$ \\
\hline \multicolumn{11}{|l|}{ PAC 2: } \\
\hline Capelinha/ Cocaia & $x$ & 935 & 620 & 315 & - & - & $\begin{array}{l}\text { Contrato de repasse com } \\
\text { CAIXA assinado. Preparação } \\
\text { da licitação de obra }\end{array}$ & $\mathrm{R} \$ 44.223 .200$ & $\mathrm{R} \$ 32.376 .745$ & $\mathrm{R} \$ 11.846 .454$ \\
\hline Silvina Audi & & 3.333 & 2.344 & 989 & - & - & $\begin{array}{l}\text { Contrato de repasse com } \\
\text { CAIXA assinado. Preparação } \\
\text { da licitação de obra }\end{array}$ & $\mathrm{R} \$ 156.867 .685$ & $\mathrm{R} \$ 111.803 .000$ & $\mathrm{R} \$ 45.064 .685$ \\
\hline Saracantan/ Colina & & 2.973 & 2.513 & 460 & - & - & $\begin{array}{l}\text { Contrato de repasse com } \\
\text { CAIXA assinado. Preparação } \\
\text { da licitação de obra }\end{array}$ & $\mathrm{R} \$ 39.604 .271$ & $\mathrm{R} \$ 37.624 .058$ & $\mathrm{R} \$ 1.980 .216$ \\
\hline Total PAC 2: Produção + Urbanização & & 7.241 & 5.477 & 1.764 & - & - & & $\mathrm{R} \$ 240.695 .156$ & $\mathrm{R} \$ 181.803 .803$ & $\mathrm{R} \$ 58.891 .355$ \\
\hline Sub-total Contratados & & 15.532 & 8.488 & 7.044 & 582 & 2.544 & & & & \\
\hline TOTAL RECURSOS PAC 1 + PAC 2 & & & & & & & & $\mathrm{R} \$ 685.241 .906$ & $\mathrm{R} \$ 419.316 .098$ & $\mathrm{R} \$ 265.925 .809$ \\
\hline
\end{tabular}

Fonte: Secretaria de Habitação de São Bernardo do Campo, atualizado a partir do http://sihisb.saobernardo.sp.gov.br/sihisb/index2.jsp, acesso em 04/04/2013 
Tabela 24 - Demandas eleitas no OP 2012 para a SEHAB e incorporadas pelo CMO - Conselho Municipal de Orçamento.

№ REG. DEMANDA ELEITA

Obras de Urbanização Integrada dos Bairros

1 S Areião, Sabesp, Monte Sião Vila dos Estudantes condicionada a captação de recursos externos

Obras de Urbanização Integrada do Batistini, Rua

2 P das Flores e Vila do Bosque - condicionada a captação de recursos externos

Obras de Urbanização Integrada do Parque

3 P Imigrantes e Jardim Represa, condicionada a captação de recursos externos.
Custo Médio

Número de Unidades da Intervenção Habitacionais

3202 cadastros

3303 atendidos

UH consol.: 2211

UH prod.: 1092

1996 cadastros

2065 atendidos

UH consol.: 1407

UH prod.: 658

1885 cadastros

1936 atendidos

UH consol.: 1376

UH prod.: 560

Atendida
Custo Total

ESTIMADO

$R \$ 44.825,87 \quad R \$ 148.059 .850,32$

$\mathrm{R} \$ 43.961,29 \operatorname{R} \$ 90.780 .069,38$

$\mathrm{R} \$ 41.837,66 \quad \mathrm{R} \$ 80.997 .716,00$

Sub-total Obras; 3 (09 Áreas) 7304

Plano Estratégico Global para a região dos bairros

Jd. Nova America (91 UHs), Pq. Ideal (204 UHs), Jd.

$4 \mathrm{M}$ Novo Horizonte I (237 UHs), Novo Horizonte II (317 UHs), Pq. dos Químicos (395 UHs) e Jd. Cruzeiro do Sul (108 UHs)

Sub-total PGE: 01 (06 Áreas) (*)

1350

$R \$ 880,00$

$\mathrm{R} \$ 1.188 .000,00$

R\$ 319.837.635,70

304

$\mathrm{R} \$ 1.188 .000,00$

5 R Projeto Executivo de Urbanização para o Grotão

1.350

$\$ 243.100,00$

6 M Projeto Executivo de Urbanização do Jd. Serro Azul Sub-total Projetos com Estudo de Viabilidade (02 Áreas)

221

$R \$ 1.100,00$

$R \$ 423.500,00$

385

$R \$ 1.100,00$

$\mathrm{R} \$ 666.600,00$

7 Q Projeto Executivo de Urbanização para a Biquinha

459

1944

$R \$ 1.600,00$

$\mathrm{R} \$ 734.400,00$

8 Projeto Executivo de Urbanização para o Montanhão

1944

$R \$ 1.600,00 \quad R \$ 3.110 .400,00$

$9 H$ Projeto Executivo de Urbanização do Jd. Limpão e Regina (916 UHs Jd. Limpão; 383 UHs Jd. Regina) Projeto Executivo de Urbanização Integrada para o

$10 \mathrm{~T}$ Bairro Tatetos conforme as diretrizes do Plano de Manejo da região do pós-balsa Projeto Executivo de Urbanização Integrada para o

$11 \mathrm{~T}$ Assentamento Rio Acima II / Capivari conforme as diretrizes do Plano de Manejo da região pós-balsa. Projeto Executivo de Urbanização Integrada para o

$12 \mathrm{~T}$ Bairro Santa Cruz conforme as diretrizes do Plano de Manejo da região do pós-balsa

13 H Projeto Executivo de Urbanização dos Núcleo Jesus de Nazareth 930 UHhs e Novo Horizonte UHs 413 Sub-total projetos: 07 (09 Áreas) - famílias (*) 1299

$R \$ 1.600,00 \quad R \$ 2.078 .400,00$

526

$R \$ 1.600,00 \quad R \$ 841.600,00$

526

51

$R \$ 1.600,00$

$\mathrm{R} \$ 81.600,00$

1023

$R \$ 1.600,00 \quad R \$ 1.636 .800,00$

1343

$R \$ 1.600,00$

$\mathrm{R} \$ 2.148 .800,00$

TOTAL 13 Demandas - 24 Áreas

6.645

$-$

$\mathrm{R} \$ 10.632 .000,00$

$15.905 \quad$ - $\quad \mathrm{R} \$ 332.324 .235,70$

* Unidades mapeadas acrescidas de $10 \%$

** Unidades cadastradas mais famílias da área removidas por risco, hoje no Programa Renda Abrigo.

*** Projeto em fase de concepção. O valor final será apresentado quando da conclusão do Projeto.

Critérios utilizados para orçamento de Obras

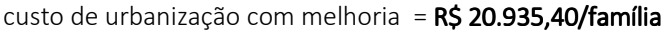

custo de produção de unidades habitacionais = R\$ 93.197,51/família

remoções: adotado o número de remoções do estágio atual do Estudo de Concepção

reassentamentos: foram acrescidos $10 \%$ ao número de reassentamentos. Essa reserva técnica foi acrescentada no total de reassentamento fora da área

o número de famílias atendidas é a somatória do número de cadastros (unidades urbanizadas + reassentamentos somados, os 10\% de reserva técnica)

Fonte: Secretaria de Habitação de São Bernardo do Campo, 2012. Informação cedida à autora 
CONSIDERAÇÕES FINAIS 



\section{CONSIDERAÇÕES FINAIS}

Logo, trataria-se, ao horizonte, ao limite dos possíveis, de produzir o espaço da espécie humana, como obra coletiva (genérica) desta espécie, a exemplo do que nomeava e nomeia ainda "a arte" e que não tem mais sentido à escala do "objeto" isolado, para e pelo individual (LEFEBVRE, 2006 p.135).

Este trabalho se propôs a uma reflexão crítica sobre a ocupação dos mananciais ao sul da Região Metropolitana de São Paulo, considerando o conceito de socionatureza da cidade (HARVEY, 1996; SWYNGEDOW, 2001) e de produção do espaço (LEFEBVRE, 2006), que indissociam o processo social do processo de transformação da natureza. Assim, a noção de urbanização da natureza (SWYNGEDOW; HEYNEN, 2003) contribuiu para elucidar a perspectiva adotada pela pesquisa. Procuramos explicitar que os conflitos presentes nas áreas de mananciais, que têm como centro a apropriação da água, foram materialmente e discursivamente construídos no processo de urbanização metropolitano, no contexto do capitalismo periférico.

Analisamos um quadro de agentes públicos e privados, políticas, regulamentações, posicionamentos e as práticas espaciais, portanto ambientais, por eles engendradas, conformando um panorama de elementos articulados que contribuem, para além da situação particular tratada, para o debate da "questão ambiental urbana". Para isso, a pesquisa privilegiou o processo de formação de loteamentos precários, que se expandiram, a partir do final dos anos 1980, na bacia da represa Billings em São Bernardo do Campo - uma área de manancial protegida por lei, verificando como as infraestruturas públicas alcançam essas áreas, em diferentes momentos, até sua consolidação, assumindo, nos dias de hoje, o papel de sua recuperação ambiental. A partir daí, desdobraram-se outras escalas de abordagem do problema.

Diante da extensão dos assentamentos precários consolidados, do histórico das intervenções governamentais e dos investimentos que se acumulam nas áreas de mananciais, o ponto de partida da pesquisa, que resultou na presente tese, foi o questionamento da implementação de infraestruturas, tal como ocorre, como condição de recuperação ambiental das áreas de proteção aos mananciais, particularmente a extensão de redes de abastecimento de água e de coleta e tratamento de esgotos, que interferem diretamente na qualidade da água (além da drenagem superficial, aspecto igualmente importante, mas sobre o qual a pesquisa não se ateve) e na vida dos moradores dos assentamentos precários.

A articulação entre infraestrutura urbana e recuperação ambiental é uma proposição presente nas atuais leis e programas de intervenção incidentes nessas áreas e se constituiu como resposta do Estado à grande extensão das ocupações precárias e irregulares sobre as áreas de mananciais, que se intensificaram a partir dos anos 1980 e 1990; respondendo também às reivindicações legítimas por regularização e infraestrutura dos moradores. Com isso, estaria se 
logrando conciliar a ocupação urbana - um uso incompatível com a produção de água, com a manutenção e a conservação desse manancial?

Ao contrário dessa perspectiva de recuperação ambiental, a precedente Lei Estadual de Proteção aos Mananciais, ainda na década de 1970, regulou o uso e ocupação do solo nas bacias protegidas, buscando restringir a expansão dessas redes como forma de desincentivar o aumento da ocupação. Como se sabe, a ocupação ocorreu inversamente ao padrão urbano elitista preconizado por essa lei, que por sua vez não foi acompanhada de uma política que a sustentasse. Tampouco foram promovidos ações e usos vinculados à proteção de fontes de água por parte do poder público. Essa atribuição foi transferida aos proprietários particulares, que preferiram lucrar com a venda irregular das propriedades. Como consequência de uma política habitacional insuficiente e de um processo de urbanização desigual, as áreas de mananciais se tornaram, e continuam sendo, uma alternativa de acesso à terra em condição precária e irregular para a população pobre dos municípios no sul da metrópole.

Assim, formou-se um consenso de que a degradação dos mananciais resultava, em grande medida, das ocupações precárias e irregulares, além do esgoto proveniente dos rios Pinheiros e Tietê enquanto foram bombeados para a Billings. A lei continuou a ser debatida nas décadas seguintes até sua revisão (Lei no 9866/1997) e completa substituição em 2009 - a Lei Específica da APRM-Billings, na qual a infraestrutura está vinculada a realização de Programas de Recuperação Ambiental de Interesse Social - PRIS e à regularização fundiária, e a novas ocupações.

Esse sentido da recuperação ambiental, equivalendo-a, de modo genérico, à urbanização de favelas e loteamentos, foi inaugurado pelo Programa Guarapiranga, a partir de 1992. A implementação de infraestruturas assumiu não só um caráter social, na medida em que, a princípio, qualificaria espaços de moradia da população de baixa renda, como ambiental, pois impediria que os esgotos comprometessem ainda mais os corpos d'água e a própria represa. De fato houve uma extensão das redes, reproduzindo o padrão atual de infraestruturas públicas, sem que os locais de intervenção se conectassem às redes centrais, aumentando a poluição afluente à represa. Até hoje não se sabe ao certo o quanto dessa situação foi remediada com a complementação de redes, e ainda são insuficientes as avaliações sobre os resultados ambientais das urbanizações.

Mas, mesmo que se ampliassem totalmente as infraestruturas, o problema da degradação da água e do território dos mananciais estaria resolvido? Do ponto de vista da produção de água pura em qualidade e quantidade, a resposta é negativa, já que dependeria da conservação de fontes de água e da vegetação, ou seja, de outros tipos de programas voltados ao uso associado à proteção ${ }^{1}$. E do ponto de vista das infraestruturas, a questão é mais complexa e extrapola os

\footnotetext{
${ }^{1}$ Sobre a degradação das águas dos mananciais metropolitanos e a importância da proteção de bacias hidrográficas ver Tundisi (2008). Dentre outras medidas, o autor defende a conservação de florestas ripárias e áreas alagadas da RMSP como forma de reduzir as cargas não pontuais de poluição e os custos do tratamento da água bruta (Ibidem, p.94).
} 
limites da bacia hidrográfica, já que os sistemas são metropolitanos. A maior parte do abastecimento de água da RMSP já depende da transposição de outras bacias hidrográficas, ainda que o Sistema Billings seja a principal fonte de água do ABC paulista e de parte de São Paulo. Ou seja, a perspectiva de solução da escassez de água é, novamente, a transposição de outras bacias hidrográficas. E os problemas relativos à poluição dos corpos d'água, somados à falta de tratamento integral dos esgotos em escala metropolitana têm se constituído em entraves a serem superados há várias décadas. O sistema da rede de coleta e tratamento de esgotos, implementado desde o Sanegran na década de 1970, instituiu o desenho de grandes estações de tratamento, centralizadas, que demandam extensas obras e investimentos vultosos, para que os esgotos as alcancem. Os impactos se fazem presentes em grande parte dos corpos d’água, inclusive na represa Billings, mantendo praticamente inalterado o ciclo da poluição.

O predomínio de uma visão técnica do saneamento, pautada em obras de engenharia, combinada aos interesses econômicos do setor de obras públicas, fez com que esse modelo se impusesse como solução, havendo pouca abertura para que alternativas de tecnologias existentes pudessem ser aplicadas aos diferentes padrões de ocupação urbana, como é o caso de diversos assentamentos em APM afastados da mancha urbana consolidada, por exemplo. O modo como as redes são concebidas e construídas nas áreas de proteção aos mananciais não foge à regra do restante da metrópole, ou seja, corresponde ao planejamento geral das redes de água e esgotos, nesse caso, sob responsabilidade da Sabesp. Esse padrão de saneamento, bem como seu tempo de execução, são dados raramente questionados. Ou seja, são poucos os momentos em que se pensou diferentemente o padrão de infraestrutura, de acordo com diferentes situações urbanas. Ainda, seus impactos negativos não são contabilizados, nem do ponto de vista ambiental, tampouco do social. E do ponto de vista da população, a extensão das redes é uma reivindicação constante, o que garante demanda para sua expansão no território.

Apesar de a bacia da Billings desempenhar o papel vital de manancial e reservatório de água para uma parte da RMSP, verifica-se a manutenção de conflitos no uso desse recurso para outras finalidades, que nem sempre são compatíveis com sua função principal. Coloca-se assim em questão o peso atribuído à importância da produção de água desse manancial ante outros interesses econômicos e políticos em disputa por esse território, que enfrenta diversos impasses dentre os quais, além dos já citados, destacam-se: o tratamento da água para consumo exige investimentos altos e a qualidade da água fica cada vez mais comprometida.

Desse modo, atribuir a recuperação ambiental dos mananciais à urbanização dos assentamentos precários, mesmo que isso seja fundamental, parece servir a um reducionismo dos problemas envolvidos nessa área, à manutenção da produção centralizada das redes de infraestrutura e à desresponsabilização do Estado diante da questão, na medida em que a resposta fica a cargo do mercado, no caso a Sabesp, como uma solução economicamente viável. Revela-se então um paradoxo da recuperação ambiental economicista, fragmentadora e homogeneizadora da infraestrutura e do espaço.

Essa problematização encontrou maior complexidade, nuances e profundidade, quando a pesquisa empírica, junto a seis loteamentos precários situados à beira da represa Billings, em 
São Bernardo do Campo, explicitou uma situação concreta: a autoprovisão de infraestruturas denotava a demora da chegada das redes públicas nessas áreas. O histórico da formação dos loteamentos revelou de que modo se dá a implementação fragmentada dessas redes, compondo um quadro de agentes privados e públicos, com suas respectivas práticas, nas quais também interferem a interpretação de um emaranhado de leis e concepções sobre a proteção ambiental e sobre o próprio ambiente urbano, em transformação ao longo do tempo. Nesse sentido, foi preciso recompor o histórico da chegada de infraestruturas aos loteamentos, objetos-problema da pesquisa, enquanto questão social e política.

Além disso, o entendimento dos problemas ambientais extrapola o espaço da moradia, ainda que o acesso à terra seja seu fundamento. A pesquisa buscou então articular as múltiplas escalas relativas à produção das redes de infraestrutura, no espaço e nas políticas setoriais, que "conectam" o local ao metropolitano, sendo que os projetos do governo estadual para a captação de água em outras bacias já alcançam a escala macrometropolitana, passando pelas relações políticas e técnicas que conformaram, historicamente, o atual padrão de infraestruturas, bem como o modo como estas são distribuídas no espaço.

Considerando esse conjunto de questões, os conflitos presentes nas áreas de proteção aos mananciais (APM) não podem ser compreendidos sem que se considere o desenvolvimento das políticas setoriais de saneamento e habitação, suas articulações e descompassos, bem como as políticas, programas e leis que conformam as atuais intervenções nessas áreas. Esse conjunto de questões tem reflexo, então, sobre o sentido da recuperação ambiental que é colocado em prática pelo conjunto de ações governamentais.

Esse panorama levou à hipótese de que a realização da política de recuperação e proteção dos mananciais reitera a reprodução de um modelo de saneamento e de intervenção habitacional (promovida pelo Estado), construídas historicamente, que tendem a ampliar a degradação do ambiente urbano e sua fragmentação restringindo, assim, as possibilidades de apropriação do espaço, do ambiente (e da água) no sentido de seu uso e não via sua mercantilização.

Nesse sentido, o argumento ambiental que ampara a intervenção em assentamentos precários e que, ao mesmo tempo, representaria, segundo o discurso oficial a recuperação do manancial, opera na prática, paradoxalmente, a função de encobrir contradições e conflitos, que desviam o foco da compreensão do problema de forma mais integral e interdisciplinar e garantem a reprodução de cada interesse, de acordo com suas especificidades setoriais, nesse espaço. Nesse sentido destacamos duas questões centrais.

A primeira questão refere-se aos próprios loteamentos precários e às intervenções habitacionais, ou seja, a recuperação só é possível porque o poder público tem a premissa de intervir em áreas de interesse social, o que se faz cada vez mais imprescindível. Entretanto, a quantidade de remoções necessária para que a urbanização aconteça com padrões mínimos de qualidade gera um deslocamento significativo de pessoas, que vão para outros conjuntos habitacionais ou para uma situação mais instável de aluguel, pago pela prefeitura durante um tempo determinado. Soma-se a isso a demanda habitacional crescente, o que implica repensar 
os padrões de densidade e ocupação dentro dos mananciais, particularmente nas áreas mais consolidadas. Mas isso não exclui a necessidade de se enfrentar a assimétrica disputa por terra urbana e localização fora das áreas protegidas, que tem sido vencida pelo setor imobiliário e pouco combatida pelo poder público.

Quando programas habitacionais são realizados, ainda que pautados por uma política habitacional, os projetos são elaborados conforme um perímetro de intervenção determinado. Os critérios de priorização de áreas a beneficiar são estabelecidos em grande medida pelos financiamentos, sem que haja flexibilidade para a integração prévia de projetos, o que raramente é logrado pelo poder público (municipal ou estadual), promotor da intervenção. Contudo não são pequenos os desafios que, pontualmente, os assentamentos precários apresentam para os projetos de urbanização, que têm se tornado cada vez mais complexos. Mas o que se evidencia, no caso dos mananciais, é que a urgência do atendimento habitacional, combinada à falta de um planejamento territorial voltado às especificidades dessa área produtora de água, faz com que a fragmentação dessas intervenções se mantenha, como um obstáculo a um sentido mais amplo de recuperação ambiental que se paute por enfrentar desigualdades socioambientais, por meio de um planejamento socioambiental.

A segunda questão, que se relaciona com a primeira, é que a urgência do atendimento habitacional, que converge tensão social e ganho político sem que haja um planejamento integrado da bacia, distancia o debate público desse território, do impacto e da forma de produção de infraestruturas orientadas por planos que abrangem macroescalas, deixando sem visibilidade os problemas socioambientais causados por sua execução em parcelas. A tese buscou demonstrar que as infraestruturas relativas à água explicitam claramente esse aspecto. $\mathrm{E}$ no caso da bacia da Billings congrega-se, ainda, o conflito entre a utilização da água para abastecimento e a produção da hidroeletricidade, sendo que a qualidade da água fica ainda mais comprometida pela falta de tratamento de esgotos, problemas que extrapolam os limites geográficos da bacia hidrográfica.

A premissa que subjaz a essa crítica é que o território dos mananciais, desde que se pretenda sua manutenção enquanto tal, demandaria intervenções diferenciadas, planejadas em conjunto (em termos territoriais e sociais), sem que necessariamente reproduzam o padrão de infraestruturas e de produção habitacional instituídas. Essa crítica problematiza a atual tecnologia empregada nessas redes, no sentido de que da forma como estão dadas acabam por inviabilizar a convivência com outras soluções, que por sua vez podem ser descentralizadas, demandar novas formas de gestão e talvez sejam menos interessantes do ponto de vista econômico da Sabesp, que detém o monopólio do setor.

Além disso, ainda é possível dizer que a falta de planejamento do território, segundo as características do manancial, viabiliza a realização de projetos e a promoção de usos impactantes pelo próprio poder público, seja municipal ou estadual, como a construção de rodovias, galpões de logística, gasodutos, incineradores de resíduos sólidos (em projeto em São Bernardo do Campo) etc. Dessa forma, pode-se afirmar que a prioridade da água como bem público, não interfere nas decisões governamentais no sentido de equacionar conflitos de uso 
do recurso e do território da bacia, "jogando para frente" ou para outras bacias e territórios, os problemas ambientais de uma questão estratégica não resolvida. Do ponto de vista econômico, até mesmo a recuperação das águas poluídas tem-se desenhado como um possível negócio.

A crítica da falta de integração das políticas setoriais é pertinente, mas uma visão ampla da fragmentação em diversos níveis favorece justamente a realização setorial no sentido de que cada interesse econômico se beneficia dessa fragmentação e da setorialização. E reitera simultaneamente a reprodução de desigualdades socioambientais. Pouco se aprofunda a pesquisa sobre à quem serve essa falta de articulação.

Para demonstrar a questão levantada pela tese, a parte I se dedica a remontar historicamente a constituição dos "modelos" (ou seja, concepções e práticas) das políticas de saneamento e habitação em tela, partindo de uma abordagem histórica da apropriação da água no processo de urbanização de São Paulo e arredores, particularmente quando a construção de infraestruturas, no final do século XIX, se constituiu como um dos elementos de suporte da expansão urbana, promovendo as condições de um espaço reprodutível, virtualmente homogêneo, condição de sua troca e mercantilização (MAUTNER; OSEKI, 1993, p.14). Buscou-se destacar que, desde quando os chafarizes deixaram de ser o principal modo de abastecimento de água e se iniciou a adução do manancial Cantareira, criaram-se descompassos entre: a velocidade de reprodução de edifícios e o acompanhamento das redes; a distribuição desigual dessas redes na área ocupada, privilegiando as áreas altas ocupadas pelas elites, e uma diferença de produção entre as próprias redes, ou seja, a rede de água se expandiu antes e mais rapidamente do que a rede de esgotos, gerando a poluição dos corpos d'água e inviabilizando seu uso para diferentes fins. Tais descompassos são ampliados em termos de escala e complexidade, durante o processo de formação da metrópole.

Do final do século XIX até as primeiras décadas do século XX, as intervenções de infraestrutura associavam saneamento e saúde, servindo ao combate de epidemias e dando suporte ao crescimento urbano. Essa visão também deu margem às ações higienistas, apoiadas por regulamentação e executadas pela política sanitária, que intervinha violentamente sobre áreas insalubres, como os cortiços, onde não por acaso moravam os mais pobres, o que assumia também um sentido moralizante e discriminatório.

Já no século XX, mudanças significativas no contexto urbano decorrem do avanço da industrialização. O aumento da demanda por serviços urbanos e por energia elétrica foi resolvido pelo capital estrangeiro e monopolístico da Companhia Light. Para isso, foram construídas as represas Guarapiranga e Billings (resultado do Projeto Serra) controlando a vazão dos rios, e que posteriormente passaram a ser aproveitadas para o abastecimento público de água. Assim se configurou parte do atual sistema de abastecimento da bacia do Alto Tietê e instituiu-se então um conflito, até hoje presente, pela dificuldade de uso múltiplo da água para geração de energia e abastecimento público, devido principalmente à falta de tratamento de esgotos. A preocupação com a proteção do manancial Guarapiranga, em relação à ocupação de sua bacia, já se fazia presente. 
Tanto no plano institucional quanto no plano técnico, saneamento e saúde se distanciaram e se especializaram. A noção de saneamento básico é construída e pautada pela engenharia de obras de água e esgoto, e por uma visão empresarial do serviço público. A busca por mananciais para superar a crescente demanda por água acompanhou os problemas de extensão física da rede e, até meados dos anos 1940, apesar de tentativas anteriores para se elaborar planos de conjunto, as soluções foram reativas às situações emergenciais, às crises de abastecimento, às estiagens e ao crescimento da ocupação. A questão da falta de tratamento de esgotos, por sua vez, manteve-se como um problema sem solução. Assim, o saneamento se caracterizou pela realização de obras financiadas pelo governo federal ou estadual e pautadas por planos sucessivos, nem sempre integralmente implementados.

Ao mesmo tempo, a extensão horizontal da mancha urbana se acelerou a partir de 1950, sem generalizar qualidade de vida, e a política pública habitacional insuficiente transferiu aos trabalhadores de baixa remuneração o problema da moradia, adquirida pelo acesso irregular à terra não urbanizada, pela autoconstrução e sobretrabalho, demandando também a extensão de infraestruturas.

De forma resumida, reafirma-se a noção já conhecida de que até a criação do BNH, durante o governo sob a ditadura militar, políticas de desenvolvimento urbano não faziam parte da agenda estatal enquanto política social, pois o Estado se ocupava do desenvolvimento econômico e industrial. Com o BNH, habitação e saneamento passam a ser pautados pelo governo federal. $\mathrm{O}$ financiamento habitacional teve como resultado construção de grandes conjuntos habitacionais monofuncionais sem, contudo, atender as camadas mais baixas de renda. Além disso, a partir de 1972, foram priorizados os investimentos em infraestrutura, beneficiando grandes construtoras de obras públicas. O Planasa instituiu a política centralizada de concessão dos serviços pelas companhias mistas estatais, condicionando o acesso aos recursos pelos municípios à sua adesão ao sistema.

Nesse contexto, a Sabesp é criada em 1973 incorporando o patrimônio de diversas companhias do estado. A partir dos anos 1970, os planos de abastecimento de água e de tratamento de esgoto começam a ser elaborados tendo como base territorial a região metropolitana. Nesse momento, o sistema de adução de água já contava com mananciais localizados fora da bacia do Alto Tietê, com a transposição da bacia do Piracicaba para a bacia do Alto Tietê, formando o Sistema Cantareira. Na RMSP, a concepção do Sistema Adutor Metropolitano (SAM) se baseou num esquema de áreas de influência dos mananciais regionalizados. A rede metropolitana de água passa a ser ampliada com a implantação de equipamentos de aumento da pressão de água na rede e, em seguida, com equipamentos para o controle de perdas. A expansão da ocupação urbana em direção aos mananciais provocou a promulgação da Lei Estadual de Proteção aos Mananciais, em 1975. Em relação ao tratamento de esgotos, o Projeto Sanegran (de 1976) implementa o desenho de grandes estações de tratamento de esgotos, com importante impacto sobre a qualidade dos corpos d'água em geral, afetando a represa Billings, como citado anteriormente. Esse Plano foi revisado e dentre as medidas adotadas estava o aumento do número de estações de tratamento. 
Nos anos 1980, com a crise econômica e financeira do Estado em seus vários níveis e com o término do BNH, as políticas de habitação e saneamento caem num "vazio" institucional. Após a redemocratização, as lutas da sociedade civil organizada, nesses dois campos, impulsionam o desenho de políticas públicas voltadas ao interesse público e social. Contudo, os direitos garantidos pela Constituição Federal de 1988 e reivindicados pela sociedade civil organizada colidiram com a reorganização neoliberal do Estado, que passa a tomar forma a partir dos anos 1990.

Na habitação, os movimentos organizados de luta por moradia reivindicam terra e habitação, prefeituras progressistas buscaram diversificar o atendimento habitacional. A produção de habitação praticamente não contava, nesse momento, com aporte relevante de recursos federais, ficando a cargo de estados e municípios. É justamente nesse período que a ocupação precária e irregular dos mananciais cresce significativamente.

No saneamento, vários embates foram travados por entidades representativas para conter projetos governamentais que visavam organizar o setor à luz das orientações dos organismos internacionais de financiamento, que já vislumbravam o interesse da iniciativa privada por alguns setores controlados por empresas estatais. A partir de 2003, a orientação se alterna no sentido do resgate e do fortalecimento da gestão pública e da retomada dos investimentos que visam a universalização, com eficácia na aplicação dos recursos e com qualidade na prestação dos serviços.

Apesar dos avanços obtidos com a política nacional, a racionalidade econômica e financeirizada de empresas com capital acionário aberto e interesse privado, capturou e orientou a produção de infraestrutura de saneamento, como é o caso da Sabesp. O discurso da universalização é compatível com a lógica financeira de expansão do setor, mas não explicita a responsabilidade da empresa em relação à desigualdade na qualidade do atendimento, os passivos ambientais acumulados e a sua falta de abertura para avançar em soluções que sejam mais adequadas à realidade social dos assentamentos precários, com novas tecnologias e diversificação de atividades, o que coloca em questão sua lógica de investimentos concentrados em grandes obras.

Apesar do desenvolvimento institucional do setor dos recursos hídricos, observa-se que ainda há um caminho a avançar no sentido de sua democratização. A falta de debate público sobre o equacionamento do problema de escassez de água da bacia do Alto Tietê, cujos estudos apontam para a necessidade de transposição de outras bacias, explicitam que ainda há uma "blindagem" técnica que garante a tomada de decisão sobre grandes intervenções.

Uma das questões que surgem nesse contexto, refere-se à importância que os mananciais existentes assumem diante dessa política que parece frequentemente protelar o enfrentamento dos conflitos presentes nas bacias urbanizadas, mesmo que essas não resolvam plenamente o problema do abastecimento de água, que já extrapola a escala da metrópole e está sendo pensada na atual macrometrópole. 
Essa discussão seria socialmente mais justa se o uso prioritário da bacia da Billings se definisse e se garantisse, pois o histórico mostra que apesar de sua importância para o abastecimento de água da RMSP, ele não se afirma na prática, implicando em usos diferenciados, diante dos grandes interesses econômicos em disputa e que são incompatíveis com a conservação desse território como manancial. É nesse sentido que a desarticulação de políticas setoriais governamentais reitera a realização de usos econômicos hegemônicos, incompatíveis com a proteção, independentemente das restrições ambientais.

Considerando a constituição histórica do espaço das redes de infraestrutura e os condicionantes do descompasso de sua distribuição nos espaços ocupados por diferentes faixas de renda, engendrando um ambiente precário em escala metropolitana, na Parte II, o tema das infraestruturas é tratado no contexto particular da ocupação dos mananciais, a partir da experiência de moradores de um conjunto de seis loteamentos à beira da Billings em São Bernardo do Campo. Focalizaram-se as múltiplas dimensões das relações sociais com o meio físico e o ambiente urbano, resultante da apropriação ilegal da terra, os agentes envolvidos nesse processo, bem como as mudanças de concepção e de ação política do poder público municipal sobre o conflito entre ocupação urbana versus proteção ambiental, presentes nesse território. Destacamos dessa segunda parte, duas perspectivas principais, que se imbricam: de um lado a do poder público municipal e de outro a dos moradores e proprietários do baixo Alvarenga.

No município de São Bernardo do Campo, a expansão dos loteamentos irregulares (e favelas) ocorreu expressivamente a partir dos anos 1980 e durante a década de 1990, período em que não houve uma política pública habitacional estruturada no município e a reivindicação por moradia era pressionada por movimentos organizados. Entretanto, muitos loteamentos irregulares resultaram da combinação da demanda social por moradia e do interesse econômico de proprietários e intermediários em transformá-la em negócio.

Conforme a análise que a CPI dos loteamentos irregulares explicitou, no início dos anos 1990, o posicionamento do poder público ante a questão da proteção dos mananciais foi bastante ambíguo e contraditório. Houve um momento em que o interesse político de promover assentamentos populares caracterizou gestões municipais "ocupacionistas", desconsiderando por completo as restrições ambientais, sem que se proporcionasse um local de moradia adequado à população pobre. Em seguida, os loteamentos irregulares foram tratados do ponto de vista jurídico, encaminhando o conflito ao judiciário, por meio da proposição de ações civis públicas por parte da Prefeitura ou do Ministério Público. Mesmo julgadas, as decisões que estipulavam demolições não foram cumpridas. Ao mesmo tempo, o poder público respondia às demandas de infraestrutura da população, atendendo situações de extrema precariedade, o que se combinava também ao ganho político.

A CPI também explicitou as divergências de posicionamento de outros sujeitos em relação à questão dos mananciais, polarizadas entre posturas conservacionistas, de um lado, e de defesa da permanência da população, de outro. $O$ argumentou do loteamento irregular em área de 
proteção ambiental serviu de justificativa para a prisão de alguns envolvidos, no entanto, sem implicar proposições mais amplas que revertessem o processo de ocupação irregular.

Foi nesse contexto que os loteamentos do baixo Alvarenga foram construídos. A partir do histórico de seu processo de formação e consolidação, foi possível evidenciar, num primeiro momento, as transformações no ambiente que decorrem da ocupação irregular, da autoconstrução da moradia e da autoprovisão de infraestrutura e, em seguida, de que modo as infraestruturas públicas foram reivindicadas e obtidas, ao longo do tempo, envolvendo uma trama de agentes públicos e privados, regulamentações e concepções sobre a recuperação ambiental. Nesse sentido, esse conjunto de loteamentos representa e reflete as diferentes fases do tratamento dos loteamentos irregulares em São Bernardo do Campo.

Nos anos seguintes à CPI, a via judicial e a repressão policial não se confirmaram como caminho possível para se reverter o processo de ocupação irregular. No final dos anos 1990, uma conjunção de fatores confluiu para que a ação municipal sobre o conflito se transformasse. A perspectiva de elaboração de Termos de Ajustamento de Conduta, amparados pelo Plano Emergencial (da Lei no 9866/1997), possibilitou intervir na recuperação ambiental dos loteamentos por meio do Programa Bairro Ecológico, visando futura regularização. Já com a mudança de gestão municipal, em 2009, e a promulgação de Lei Específica da Billings, esse tratamento não teve continuidade e foram priorizados a execução da Política Habitacional Municipal e o Orçamento Participativo (OP), como meio de dialogar com as demandas da população.

Os moradores dos loteamentos do baixo Alvarenga reivindicaram o TAC e o Bairro Ecológico, sem consegui-los. Também participaram do OP, cuja resposta foi, primeiro, a realização de uma obra questionável (criticada no capítulo 6), até que lograram ser incluídos nas demandas de projeto. Assim, pode-se dizer que apesar de buscarem se enquadrar, estiveram à margem desses processos, com momentos de embate e desmobilização frente ao poder público municipal, mas com uma postura de resistência constante. De modo mais ou menos organizado, logrando conquistas parciais, participaram dessas diferentes etapas do desenvolvimento do conflito.

Nesse percurso de pesquisa, a dialética entre espaço da moradia e espaço das infraestruturas elucidou a dialética entre o público e o privado na produção do ambiente urbano, bem como a importância da fragmentação do espaço como categoria para a interpretação da urbanização da natureza. A fragmentação do espaço, segundo Lefebvre (2006), decorre de sua determinação econômica, a troca. Nessa pesquisa, a fragmentação está presente em todas as escalas socioespaciais que foram tratadas, na casa e no espaço coletivo, no cotidiano, no projeto e no plano, no loteamento e na metrópole.

Nesse sentido, desde a construção inicial dos loteamentos, uma primeira fragmentação é a do lote, a terra dividida em parcelas. No contexto da ocupação irregular, o argumento ambiental aparece inicialmente como interdição ao estabelecimento do morador. Mas apesar dele, houve consentimento do poder público em relação à ocupação. Isso fez com que a ausência das 
infraestruturas públicas surgisse como problema e fosse resolvida, na medida do possível, pelo próprio morador, numa espécie de "presença às avessas" do próprio Estado. As soluções provisórias de infraestrutura também aparecem aos pedaços, como fragmentos e não como rede ou sistema.

Houve uma funcionalidade nessa aparente "ausência" do Estado ao transferir para o morador os ônus de construção do espaço público, que deveriam ter sido arcados, anteriormente, pelo empreendedor, no caso o loteador ilegal e, posteriormente, pelo poder público - quando as áreas públicas resultantes de um loteamento são doadas à municipalidade. Nesse sentido, as infraestruturas assim construídas também expressam uma forma de espoliação urbana, agravada por um contexto de maior fragilidade ambiental e precariedade, e revelam o caráter privado desse processo de urbanização.

Simultaneamente, outras leituras sobre a autoprovisão de infraestruturas foram possíveis, no sentido de que, enquanto natureza segunda, teriam como possibilidade promover apropriações mediadas pelo uso do espaço. A autoprovisão de infraestruturas representa, ainda que contraditoriamente e de forma residual, uma forma de adaptação ao padrão de ocupação irregular, que não segue exigências urbanísticas e normativas de ocupação do solo. Nesse sentido, apesar da autoprovisão de infraestruturas não ser aqui entendida como solução de urbanização, ela coloca em questão o próprio padrão de construção de infraestruturas públicas e as possibilidades de sua adaptação ao desenho urbano precário (ou irregular).

Além disso, entrevistas com os moradores mais antigos, que participaram da construção dos loteamentos, evidenciaram um grande conhecimento ambiental sobre o terreno, que geralmente não se verifica em áreas de ocupação mais recente e já transformadas, onde essa "memória" sobre a situação do ambiente anterior é esquecida. O reconhecimento desses aspectos indicaria possibilidades de intervenção no espaço que considerassem a infraestrutura para além da solução técnica da engenharia, ou seja, articulada ao desenho urbano e ambiental de forma mais ampla.

Essa mudança de postura ante o espaço e as redes técnicas de infraestrutura foi aventada em alguns momentos como possibilidade de qualificar os assentamentos e visando minimizar o impacto sobre cursos e fontes de água, como foi experimentado nas intervenções do programa Bairro Ecológico (capítulo 6), decorrente de uma mudança de postura do poder público e do MP na condução dos processos.

Por outro lado, nos loteamentos do baixo Alvarenga, a condição de interdição ao acesso às redes públicas, por se tratar de área de proteção ambiental, serviu ao clientelismo e à troca de favores, que se estabeleceram no momento da negociação das melhorias: particularmente a solução do abastecimento de água, além do cascalhamento, ou pavimentação de ruas, e a instalação de redes elétricas e de telefonia. Esse processo implica a fragmentação espacial, tanto do ponto de vista físico e territorial, pois as "melhorias" não são pensadas para o conjunto, ao contrário, favorecem alguns pontos dos loteamentos; quanto do ponto de vista político e social, já que as demandas são respondidas de forma desigual, diante da pressão exercida pelas 
diferentes associações de moradores, quando não corresponderam a trocas de favores, especialmente com vereadores locais. Durante os anos 1990, portanto, a chegada de algumas infraestruturas ocorreu de forma negociada, reivindicada pelos moradores, sem seguir os trâmites formais estabelecidos pela legislação ambiental em vigor (a LPM de 1976), sendo resolvidas seja por ordem do prefeito, seja por negociação direta com empresas concessionárias de serviços. A consolidação dos loteamentos realizou-se assim de modo bastante gradual, num embate permanente tanto interno aos bairros, ou seja, na construção instável da organização coletiva dos moradores; quanto externo, no diálogo dos moradores com o poder público.

A reivindicação por "melhorias" também aconteceu no plano jurídico, devido às Ações Civis Públicas, cujas sentenças determinavam o desfazimento dos loteamentos, para a reconstituição do estágio original da vegetação, e por isso interditavam a realização de obras e construções. Já no final dos anos 1990, a perspectiva de realização de Termos de Ajustamento de Conduta e a premissa do Plano Emergencial abriram um espaço para que alternativas de regularização fossem elaboradas. Como já comentado, os loteamentos do baixo Alvarenga não foram contemplados pelas obras do programa Bairro Ecológico. Mas a possibilidade do TAC foi abraçada tanto pelos moradores que participavam das associações, como pela ONG local Holos21, que militava pela recuperação socioambiental desses assentamentos.

No bojo do projeto desenvolvido pela Holos21 junto às associações, a observação participante e a construção das cartografias comunitárias se constituíram num momento privilegiado da pesquisa, ao tornar possível o debate coletivo, não institucionalizado, sobre os problemas e as potencialidades de transformação daquele ambiente, a partir do ponto de vista dos moradores, como um aporte à discussão técnica, assumindo um significado político enquanto ferramenta de reivindicação. Dentre as diversas discussões que emergiram das cartografias, destacamos as que convergem para as questões aqui levantadas.

Nas cartografias comunitárias o debate sobre as infraestruturas sempre esteve presente assim como a expectativa de que elas sejam solucionadas pelo poder público, de forma convencional, já que de fato representam algo que está fora do alcance dos moradores, como a implantação da rede de esgotos, de drenagem, pavimentação etc. A sua não realização ao longo do tempo, submete os moradores a situações precárias e de risco durante décadas, implicando cada vez mais em iniciativas de autoprovisão sobre o espaço coletivo, quando possíveis. As tentativas dos moradores de suprir funções públicas no contexto de precariedade e vulnerabilidade socioeconômica têm portanto um limite de alcance. Por outro lado, a discussão inicial sobre as infraestruturas extrapolou para o ambiente urbano um conjunto de reivindicações sobre serviços e equipamentos.

As ambiguidades em relação aos efeitos da legislação ambiental explicitaram algumas contradições entre a defesa da propriedade privada e as possibilidades de uma abordagem socioambiental do conjunto. Para os moradores, a vivência dos conflitos decorrentes de sua situação irregular, proporcionou um aprendizado sobre questões e regulamentações ambientais que os diferencia de outros núcleos urbanos. Por um lado, essa "consciência" é utilizada como resistência e proteção do espaço da moradia. Daí a defesa da preservação de áreas de 
compensação ambiental (como no caso do Parque Ideal), de áreas de preservação permanente e nascentes, e a participação em atividades de plantio de mudas, promovidas em parceria com instituições municipais. Entretanto, quando a legislação ambiental afeta a propriedade individual e a necessidade de remoção de moradias se coloca - como no caso da discussão sobre os lotes em APPs durante a elaboração das cartografias - a defesa ambiental deixa de ser prioritária e passa a ser entendida como problema e não como solução.

Ao mesmo tempo, observou-se também que a defesa, pelos moradores, da qualidade ambiental não se restringiu à estratégia de defesa da propriedade individual. Ou seja, há um reconhecimento das possibilidades de qualificar o espaço coletivo por meio de ações de recuperação ambiental, que foram em parte expressas nas cartografias comunitárias, tais como os projetos concebidos para praças e para os demais espaços coletivos associados à manutenção de vegetação e cursos d'água. Assim como demonstradas por iniciativas autônomas, como a tentativa de transformar um terreno particular por onde passa um córrego, contíguo aos loteamentos, num espaço de lazer, com pista de caminhada ao longo de suas margens, o que implicaria sua recuperação. Para isso, os moradores tentam negociar a área com o proprietário, que tem dívidas de impostos, por intermédio da promotora pública e da prefeitura, o que evidencia se tratar de uma situação que só será resolvida com a junção de esforços.

Por fim, a Parte II desta tese problematiza a condução das políticas territoriais que estão em curso nas áreas de proteção aos mananciais, mostrando que os atuais instrumentos de participação e planejamento territorial, como é o caso do Orçamento Participativo, têm pouca relação com as especificidades do território da bacia e com a diversidade de ocupações. Sendo assim, o atual desenho de gestão da política urbana colabora para que se mantenha a ação setorial, com a fragmentação de planos e projetos, distante da integração das ações que é requerida para o enfrentamento da questão ambiental.

Nesse sentido, o que chamamos aqui de precariedade urbana e ambiental não se restringe aos aspectos físicos e ambientais das ocupações, mas é a expressão da tensão e da relação imbricada e contraditória entre o público e o privado, que engendra a própria construção do espaço urbano precário.

A terceira parte desta tese abordou a ação prática do Estado no manejo dos conflitos existentes nas áreas de proteção aos mananciais (APM), a partir das leis, programas e projetos de intervenção que constituem o quadro de conflitos tratados. Buscou-se evidenciar de que forma a ocupação irregular e a implementação de infraestrutura foi tratada na concepção desses três elementos, que juntos, conformam a atual política das áreas de mananciais. Para isso, a análise privilegiou o histórico de constituição e transformação dessa política, enfatizando a atual Lei Específica da Billings, e o instrumento que possibilita a recuperação ambiental e a regularização fundiária, o Programa de Recuperação de Interesse Social - PRIS.

A revisão da Lei Estadual de Proteção aos Mananciais (no 898/1975 e no 1.172/1976) durante os anos 1990, foi impulsionada tanto pela consolidação de ocupações precárias e de baixa renda nas áreas de proteção aos mananciais, como pela piora da qualidade da água das represas, ao 
que se contrapunha o movimento ambientalista. A Lei Estadual no 9866/1997 alterou o sistema de gestão dos mananciais e buscou ser mais compatível com a realidade existente, ao indicar diferentes áreas de intervenção conforme o uso do solo, definindo a necessidade da elaboração de leis específicas por bacias. Também abriu a premissa da realização de obras em assentamentos com maior precariedade, por meio do Plano Emergencial. O Programa Guarapiranga, que foi desenvolvido para a Recuperação da bacia do Guarapiranga, desde 1992 já avançava em alternativas para viabilizar a intervenção nessas áreas. Assim, o discurso político e a justificativa técnica que dão suporte à Lei Específica da Guarapiranga, promulgada em 2006, e da Billings, em 2009, amparam-se no esforço de torná-las mais adequadas, adaptadas ou mais "aderentes" à realidade urbana existente nas respectivas bacias hidrográficas.

A importância do Programa Guarapiranga não se deve somente ao fato de que foi a primeira intervenção estruturada do poder público municipal e estadual para lidar com a condição de precariedade dos assentamentos. Como argumentado nos capítulos 7 e 8, esse programa instituiu um modelo de intervenção e também pautou em grande medida o desenho das leis específicas, que foram subsidiadas pelos estudos técnicos inicialmente realizados durante sua vigência.

Em relação aos programas de intervenção, a experiência do Programa Guarapiranga, financiada pelo Banco Mundial, se expandiu para a bacia da Billings, e também para a bacia do Alto Tietê. Além da ampliação da abrangência territorial, houve significativo aumento do aporte de recursos, particularmente com a adição dos recursos do PAC, do governo federal.

Em termos de escopo das intervenções, há uma divisão de responsabilidades entre os órgãos públicos envolvidos, como secretarias municipais de habitação, CDHU, Secretaria Estadual de Meio Ambiente, Secretaria de Saneamento e Energia e Sabesp. O Programa Mananciais se apresenta como uma soma dos projetos sob atribuição de cada executor, que recebe parte do financiamento, e é gerenciado por uma unidade de gestão do projeto (UGP), atualmente a cargo da SSE. Não há um conselho ou outra forma de acompanhamento social do programa, como chegou a ser experimentado no Programa Guarapiranga, o que ficaria a cargo do subcomitê de bacia. Esse desenho, portanto, reitera o modo setorial de atuar de cada agente envolvido.

A renovação de financiamentos com o Banco Mundial e, mais recentemente, os recursos do governo federal, desde 2008, têm garantido a continuidade do programa ao longo do tempo. Já não existem mais tantas restrições de financiamento ou legais para que essas obras aconteçam. Assim, a urbanização de assentamentos precários tornou-se um imenso campo de trabalho e de realização de obras, compondo de forma significativa o circuito econômico. Contudo, também tem se mantido a realização de projetos de urbanização que se apresentam qualitativamente bastante desiguais entre si, beneficiando algumas áreas em detrimento de outras, sem critérios ambientais e/ou sociais explicitados num plano de conjunto. Assim, não há avaliação dos impactos sociais e ambientais das urbanizações sobre os assentamentos, sobre a bacia e sobre a água da represa, que não tem, por sua vez, apresentado melhoras significativas. 
Em relação à Lei Específica da Billings, se por um lado ela representa um avanço ao permitir a regularização de interesse social e responde à reivindicação dos moradores dessas áreas, por outro lado, ela não avança nos demais conflitos de uso que estão postos no território da bacia. Ao contrário, ela os incorpora, nem sempre explicitamente.

Como tratado no capítulo 7, apesar da recuperação ambiental ser um objetivo da lei, sua conceituação não é explicitada, podendo variar da recuperação vegetal à recuperação urbana. Uma conceituação mais precisa é expressa no artigo 31, que define as Áreas de Recuperação Ambiental - ARA como "ocorrências localizadas de usos ou ocupações que estejam comprometendo a quantidade e a qualidade das águas, exigindo intervenções urgentes de caráter corretivo", ou seja, são os assentamentos precários, que dependem de investimentos em saneamento, recomposição vegetal e de melhorias habitacionais para que se minimize o impacto gerado sobre a bacia. Assim, a noção de recuperação está plenamente articulada ao saneamento. Nesse sentido, a infraestrutura passa a ser fundamental na recuperação ambiental.

Tomando como exemplo o Modelo de Correlação entre Uso do Solo e Qualidade da Água MQUAL, que embasa a lei específica, a definição da redução do aporte de poluição afluente à represa, com estabelecimento da carga-meta de fósforo, até 2015, aposta na realização integral dos grandes projetos de saneamento a cargo da Sabesp, tais como a instalação de coletores de esgoto. Contudo esse prazo desconsidera os problemas já conhecidos quanto à execução, tais como a necessidade de desapropriações, os atrasos e problemas não previstos nas obras, que resultam no não cumprimento dos cronogramas previamente estipulados. Enquanto isso, a poluição dos corpos d'água se mantém, sem que se criem medidas preventivas, localizadas, mesmo que temporárias, até que a rede se complete. Soma-se a isso a questão do não tratamento integral dos esgotos na RMSP, ou seja, mesmo que o controle da carga de poluição afluente à represa seja perfeitamente realizado por um município, o tratamento do esgoto continua sendo central e indispensável, ainda mais porque se trata de um sistema único, por exemplo, para todo o $A B C D$, onde os esgotos são coletados e levados para ETE do $A B C$.

Contraditoriamente, o próprio Plano de Desenvolvimento de Proteção Ambiental da Billings avalia que, de acordo com as cargas-meta poluentes estipuladas em lei, os investimentos previstos em infraestrutura serão insuficientes para garantir o alcance dessas metas (SÃO PAULO, 2011). Ou seja, o controle da poluição dos corpos d'água é algo que não recebe a devida atenção, o que não impede que a expansão das redes, tal como são produzidas, aconteça.

A defasagem entre a construção de redes locais e redes coletoras, que representa um grande impacto do ponto de vista da qualidade da água e do ambiente urbano, não é considerada um elemento de planejamento, não há soluções intermediárias ou remediadoras e de certa forma o abastecimento de água fica "refém" das grandes obras de saneamento.

Outro importante instrumento da Lei Específica é o mapa das áreas de intervenção, que corrobora a crítica de que a recuperação ambiental, do modo como está sendo realizada, não tem logrado seu próprio objetivo. Apesar desse mapa ser resultado de um extenso estudo de reconhecimento da ocupação real da bacia, na análise das áreas de intervenção fica claro que as 
áreas não densamente ocupadas existentes na bacia foram demarcadas de forma a permitir a ocupação urbana de maior densidade numa grande extensão; além das áreas que apresentavam ocupação de baixa densidade e que passaram para alta e média densidades. Além disso, o governo estadual não se comprometeu a criar parques de conservação ou investir na preservação, para além dos parques de compensação oriundos da obra do Rodoanel, que provocou um desmatamento significativo. A questão que se recoloca, a partir desse mapa, é a necessidade de se avançar em qualificar propostas de uso e ocupação do solo na bacia.

A Lei Específica da Billings reforça assim, a manutenção da setorização das intervenções de habitação, saneamento transportes etc, garantindo que cada uma delas conviva, ainda que em concorrência com a finalidade prioritária do abastecimento de água. Apesar dessa tarefa não poder ser resolvida exclusivamente por meio da lei, ela colabora para direcionar nesse sentido a prática das intervenções na bacia.

O capítulo 9 discutiu a recuperação ambiental tal como ela está sendo realizada na prática, explicitando os desafios que diferentes ocupações, localizadas em porções distintas da bacia, representam em termos de intervenção de urbanização.

Cabe destacar que a precariedade, a pobreza e a instabilidade da posse são condições iniciais e fundamentais para que o poder público intervenha e promova a recuperação ambiental. Ou seja, a recuperação ambiental das áreas de proteção aos mananciais tem um lado contraditório e um componente ideológico, pois está totalmente associada a uma imagem de transformação dos territórios onde vivem os pobres, sem incidir com a mesma força ideológica em outros usos do território que também "degradam" as águas, reforçando o estigma da degradação da água causada pela ocupação de baixa renda, e não por um processo estrutural de reprodução de desigualdades sociais, portanto, ao mesmo tempo, ambientais. Essa crítica não se manifesta contra as urbanizações, é justamente o seu sentido que está em questão.

Esses argumentos recuperados, que vão do cotidiano ao planejamento estatal, sintetizam um conjunto de situações analisadas ao longo da tese e expressam o sentido controverso da recuperação ambiental que tem sido "produzida", nos termos de Lefebvre (2006). O seu sentido social e ambiental, enquanto apropriação coletiva, ou nas palavras de Jorge Oseki, como autogestão de paisagens, fica inviabilizado. Mas ainda, segundo Lefebvre, mesmo que a natureza seja destruída e distanciada, ela se mantém como fundamento da ação humana sobre o espaço. Também persistem, "sobrevivem" no cotidiano, resíduos, momentos que escapam à lógica da mercadoria. A transformação do espaço, simultânea à transformação social, dependeria de uma ação transgressora, insurgente e política. O direito à diferença, ao espaço da diferença, abre e estimula o pensamento e a prática nessa direção. A autogestão de paisagens e a luta por justiça ambiental são projetos possíveis, ainda que imersos num manancial de contradições e paradoxos que implicam produção do espaço urbano e as especificidades do contexto brasileiro. 


\section{REFERÊNCIAS BIBLIOGRÁFICAS}

ABICALIL, Marcos Thadeu. Investimentos em saneamento durante a transição. In: BAUMANN, R. (org.). Brasil - uma década em transição. São Paulo: Campus/Cepal, 2000.

ACSELRAD, Henri. Discursos da sustentabilidade urbana. Revista Brasileira de Estudos Urbanos e Regionais, Rio de Janeiro: ANPUR, ano I, no1, p.79-90, maio 1999. ISSN 1517-4115

. (Org.). A Duração das Cidades - sustentabilidade e risco nas políticas urbanas. 1. Ed. Rio de Janeiro: DP\&A, v. 1, 237p, 2001.

(Org.). Conflitos Ambientais no Brasil. Rio de Janeiro: Relume Dumará/Fundação Heinrich Boll, 2004.

(Org). Cartografias sociais e território. Rio de Janeiro: Universidade Federal do Rio de Janeiro, Instituto de Pesquisa e Planejamento Urbano e Regional, 2008.

Ambientalização das lutas sociais - o caso do movimento por justiça ambiental. Revista Estudos Avançados, São Paulo, n. 24, p.103-119, 2010. ISSN 0103-4014

AGÊNCIA DE COOPERAÇÃO INTERNACIONAL DO JAPÃO - JICA; PREFEITURA DE SÃO BERNARDO DO CAMPO. Relatório Final - Estudo sobre o Plano Integrado de melhoria ambiental na área de mananciais da represa Billings no município de São Bernardo do Campo. São Bernardo do Campo, 2007.

AGÊNCIA NACIONAL DE ÁGUAS (Brasil) - ANA. Atlas Brasil: abastecimento urbano de água: resultados por estado. Agência Nacional de Águas; Engecorps/Cobrape, Brasília, v. 2, 2010.

ANCONA, Ana Lucia. Direito ambiental, direito de quem? Políticas públicas do meio ambiente na metrópole paulista. 2002. Tese (doutorado em arquitetura e urbanismo) - FAU, USP, São Paulo: 2002.

. ; STETSON Laren. Avaliação do Programa Gurapiranga: custos e componentes de Infraestrutura. Trabalho apresentado no seminário de avaliação de projetos IPT, São Paulo, p.51-68, 2002. Disponível em http://habitare.infohab.org.br/pdf/publicacoes/arquivos/45.pdf. Acesso em 03/11/2003.

ANDRADE, Carlos Roberto Monteiro de. A peste e o plano: o urbanismo sanitarista do Engo Saturnino de Brito. 1992. Dissertação (mestrado em arquitetura e urbanismo) - FAU, USP, 1992.

ARAÚJO, Ricardo. Projeto Mananciais: o que muda em relação ao Programa Guarapiranga? In: WHATELY et. al (orgs.). Mananciais: uma nova realidade? São Paulo: Instituto Socioambiental, 2008. p. 201232.

ARRETCHE, Marta. Intervenção do Estado e setor privado: o modelo brasileiro de política habitacional. Espaço \& Debates - Revista de Estudos Regionais e Urbanos, São Paulo: NERU, ano X, no 31, p. 2136, 1990.

AZEVEDO NETTO, José M. de. Abastecimento de água de São Paulo: subsídios para a História (1a parte). Revista DAE, São Paulo: [s.n.], no106, p.24-27, 1976.

Cronologia do abastecimento de água (até 1970). Revista DAE, São Paulo: [s.n.], v. 44, no 137, p. 106-111, jun. 1984.

BAITZ, Ricardo. A propriedade e a sustentabilidade em áreas de mananciais: problema econômico, ambiental ou social? Trabalho apresentado no $1^{\circ}$ Simpósio de Pós-Graduação em Geografia do Estado de São Paulo, Rio Claro, 2008. Disponível em http://www.rc.unesp.br/igce/simpgeo/322331ricardo.pdf. Acesso em 08/08/2011.

BALTRUSIS, Nelson; ANCONA, Ana Lucia. Recuperação ambiental e saúde pública: o Programa Guarapiranga. Saúde e Sociedade, São Paulo: FSP, v. 15 no 1, p. 9-21, 2006. 
BARRAQUE, Bernard. A gestão da água em alguns países europeus. Espaço \& Debates - Revista de Estudos Regionais e Urbanos, São Paulo: NERU, ano XII, no 35, p. 35-45, 1992.

BARRETO, Maria Luiza G. de O.; SÓCRATES, Jodete Rios; TANAKA, Marta Soban. Loteamentos em São Bernardo do Campo. Relatório de pesquisa, Faculdade de Arquitetura e Urbanismo USP 115p. São Paulo: FAU-USP, 1976.

BENTON, Ted. Marxism and Natural Limits. New Left Review, Londres: [s.n.] no178, p.51-86, nov./ dez. 1989.

BERÉ, Cláudia Maria. Legislação Urbanística: A Norma e o fato das áreas de proteção aos mananciais da região metropolitana de São Paulo. 2005. Dissertação (mestrado em arquitetura e urbanismo) FAU, USP, São Paulo: 2005.

BICHIR, Renata Mirandola; MARQUES, Eduardo Cesar. Investimentos públicos, infra-estrutura urbana e produção da periferia em São Paulo. Espaço \& Debates - Revista de Estudos Regionais e Urbanos, São Paulo: NERU, ano XVII, no 42, p. 9-30, 2002. Disponível em http://www.centrodametropole. org.br/pdf/marques bichir esp deb.pdf. Acesso em 05/10/2009.

BÓGUS, Lucia; RAPOSO, Isabel; PASTERNAK, Suzana (orgs). Da irregularidade fundiária à regularização: análise comparativa Portugal/Brasil. São Paulo: EDUC, 2010.

BOLAFFI, Gabriel. A casa das ilusões perdidas: aspectos socio-econômicos do Plano Nacional de Habitação. Cadernos Cebrap no 27, 1977.

BONDUKI, Nabil; ROLNIK, Raquel. Periferia da Grande São Paulo? Reprodução do espaço como expediente de reprodução da força de trabalho. In: MARICATO, Ermínia (org.). A produção capitalista da casa (e da cidade) no Brasil industrial. São Paulo: Alfa-Omega, 1982. p. 117-154.

BONDUKI, Nabil. Origens da habitação social no Brasil: arquitetura moderna, Lei do Inquilinato e difusão da casa própria. São Paulo: Estação Liberdade, 5ạ ed., 2011.

BRASIL. MINISTÉRIO DAS CIDADES. Cadernos MCidades Saneamento Ambiental. vol.5. Brasília, 2004.

BRITO, S. Obras completas de Saturnino de Brito. Volumes II e III. Rio de Janeiro: Imprensa Nacional, 1943.

BRITTO, Ana Lucia. Redes de infraestrutura na cidade: uma revisão dos conceitos e concepções de saneamento. Trabalho apresentado no IX Seminário de História da Cidade e do Urbanismo, São Paulo, 2006. Disponível em http://www.anpur.org.br/revista/rbeur/index.php/shcu/article/view/ 1122/1097. Acesso em 14/11/2012.

BUENO, Laura M. M. O saneamento da urbanização de São Paulo. 1994. Dissertação (mestrado em arquitetura e urbanismo) - FAU, USP, São Paulo: 1994.

Projeto e favela: metodologia para projetos de urbanização. 2000. Tese (doutorado em arquitetura e urbanismo) - FAU, USP, São Paulo: 2000.

Parâmetros para a avaliação de vida urbana e qualidade habitacional em favelas urbanizadas. Em: ABIKO, Alex K.; ORNSTEIN, Sheila W. (orgs.). Inserção Urbana e Avaliação PósOcupação (APO) da Habitação de Interesse Social. São Paulo, Coleção HABITARE, v.1, p.318-349, 2002.

O Tratamento especial de fundos de vale em projetos de urbanização de assentamentos precários como estratégia de recuperação das águas urbanas. Artigo para o Seminário Nacional sobre regeneração ambiental das Cidades Águas Urbanas. Rio de Janeiro, 5 a 8 dezembro de 2005.

BURKETT, Paul. Marx and Nature: a red and green perspective. New York: St. Martin's, 1999.

CABANES, Robert. et. al. Saídas de emergência: ganhar/perder a vida na periferia de São Paulo. São Paulo: Boitempo, 2011.

CANO, Wilson. Questão regional e urbanização no desenvolvimento econômico brasileiro pós-1930. In: Anais do Encontro Nacional de Estudos Populacionais VI, 1988. Olinda: ABEP, 1988. 4v. p. 67-99, v.2.

Urbanização: sua crise e revisão de seu planejamento. Revista de Economia Política, v. 9, no 1, p.62-82, jan./mar. 1989. 
CAPOBIANCO, João Paulo Ribeiro; WHATELY, Marussia. Billings 2000: Ameaças e perspectivas para o maior reservatório de água da RMSP. Relatório do Diagnóstico Socioambiental Participativo da Bacia da Billings no período 1989-99. São Paulo: Instituto Socioambiental, 2002.

CARMO, Roberto Luiz do; TAGNIN, Renato. Uso múltiplo da água e múltiplos conflitos em contextos urbanos: o caso do reservatório Billings. In: HOGAN, D.J.; CUNHA, J.M.P da; BAENINGER, R.; CARMO, R. L. (orgs.). Migração e Ambiente nas Aglomerações Urbanas. Campinas: NEPO/PRONEX, 2001. p. 421-441.

CARVALHO, Celso Santos; MORETTI, Ricardo de Souza; ROCHA, Renata Faria. Procedimentos para tomada de decisão em programas de urbanização de favelas. Em: ABIKO, Alex K.; ORNSTEIN, Sheila W. (orgs.). Inserção Urbana e Avaliação Pós-Ocupação (APO) da Habitação de Interesse Social. São Paulo, Coleção HABITARE, v.1, p.294-317, 2002.

CARVALHO, Cristina Toledo de. Antiga Freguesia de São Bernardo: antecedentes, criação e paróquia. Raízes, São Paulo, p.32-39, 2005.

CARVAlHO, Maria do Carmo A. A.; TEIXEIRA, Ana Claudia C.; ANTONINI, Luciana; MAGALHÃES, Inês. Orçamento Participativo nos municípios paulistas: gestão 1997-2000. Caderno Pólis n5, 32p. São Paulo: Pólis, 2002.

CARVAlHO, Maria do Carmo A. A. e FELGUEIRAS, Débora. Orçamento Participativo no ABC. Mauá, Ribeirão Pires e Santo André. Publicações Pólis, n³4 80p. São Paulo: Pólis, 2000.

COING, Henri. Serviços urbanos: velho ou novo tema? Espaço \& Debates - Revista de Estudos Regionais e Urbanos, São Paulo: NERU, ano VIII, no 23, p. 86-95, 1988.

COMISSÃO PARLAMENTAR DE INQUÉRITO - CPI; Câmara dos Deputados de São Bernardo do Campo. Relatório Final. Encaminhado ao Ministério Público do Estado de São Paulo, Procuradoria Geral de Justiça. v. 1 - v. 11, 1991.

COMITÊ DA BACIA HIDROGRÁFICA DO ALTO TIETÊ; FUNDAÇÃO DE APOIO À UNIVERSIDADE DE SÃO PAULO - FUSP. Documenta no1 - Drenagem e Controle de Inundações. São Paulo, 1998. Disponível em ftp://ftp.sp.gov.br/ ftpdarc/ftpcomiteat/Dowload/ docum 01.doc. Acesso em: 04/06/2012.

Documenta no7. Rodoanel e Mananciais. São Paulo, 2002. Disponível em http://www.comiteat.sp.gov.br/Dowload/Documenta\%207.pdf. Acesso em: 04/06/2012.

. Plano de Bacia do Alto Tietê. São Paulo, v. 1 a v. 4, dezembro de 2009.

CONSÓRCIO INTERMUNICIPAL DO ABC; Fundação para o Desenvolvimento da UNESP - FUNDUNESP. Elaboração de diretrizes para a proposta de Lei Específica da APRM Billings-Tamanduateí e PDPARelatório Final. São Paulo, 2001.

CONSÓRCIO INTERMUNICIPAL DO ABC. Propostas do Consórcio Intermunicipal Grande ABC para Enquadramento e Licenciamento no Programa de Recuperação de Interesse Social - PRIS na APRM - Billings. Santo André, agosto de 2011.

COSTA, Heloísa Soares de Moura. Desenvolvimento Urbano Sustentável: Uma contradição em termos? Revista Brasileira de Estudos Urbanos e Regionais, Rio de Janeiro: ANPUR, no 2, nov. 1999. ISSN 1517-4115

DAMIANI, Amelia Luisa. Espaço e Geografia: Observações de Método - Elementos da obra de Henri Lefebvre e a Geografia; - Ensaio sobre Geografia Urbana a partir da Metrópole de São Paulo. 2008. Tese (Livre-docência em Geografia) - FFLCH, USP, São Paulo: 2008.

DAVIS, Mike. Ecologia do Medo: Los Angeles e a fabricação de um desastre. Tradução de Aluizio Pestana da Costa. Rio de Janeiro: Record, 2001.

DE PAULA, Eurípedes Simões. A segunda fundação de São Paulo (da pequena cidade à metrópole de hoje). Revista de História. São Paulo, no 17, p.167-179, 1954. E Relatório apresentado por João Theodoro Xavier à Assembléia Legislativa em 5 de fevereiro de 1873 publicada por Eurípedes Simões de Paula como complemento ao seu artigo. Revista de História, São Paulo, no 17, p.233242, 1954. 
DEAN, Warren. A ferro e fogo: a história e a devastação da Mata Atlântica brasileira. Tradução de Cid Knipel Moreira. São Paulo: Companhia das Letras, 1996.

DELÉAGE, Jean Paul. Historia de la Ecología. Una ciencia Del hombre y la naturaleza. Barcelona: Icaria, 1993.

FARAH, Marta Ferreiro Santos. Processo de Trabalho na Construção Habitacional: Tradição e mudança. São Paulo: Annablume, 1996.

FARIA, Antonio Augusto da Costa. Abastecimento de água na cidade de São Paulo (1554-1960). Revista do Arquivo Municipal, São Paulo: Departamento do Patrimônio Histórico, v. 203, p. 37-56, 2004.

FARIA, Simone Alves de; FARIA Ricardo Coelho de. Cenários e Perspectivas para o setor de saneamento e sua interface com os recursos hídricos. Engenharia Sanitária e Ambiental, Rio de Janeiro: ABES, v. 9 - no 3, p. 202-210, jul./set. 2004. ISSN 1413-4152. Disponível em http://www.abesdn.org.br/publicacoes/engenharia/resaonline/v9n3/ p202a210.pdf. Acesso em: 19/02/2013.

FAUSTO, Boris. História concisa do Brasil. 2.ed. São Paulo: Edusp, 2011.

FERREIRA, J. S. W. O mito da cidade global: o papel da ideologia na produção do espaço urbano. 1. ed. Petrolpolis - RJ: Vozes, 2007. v. 1. 247p.

(org) Construir casas ou produzir cidade? Desafios para um novo Brasil urbano. Parâmetros de qualidade para a implementação de projetos habitacionais e urbanos., São Paulo: LABHAB/FUPAM, 2012. Disponível em: http://www.usp.br/fau/depprojeto/labhab/biblioteca/textos/ferreira 2012 produzirhab cidades.pdf.

FERRO, Sérgio. A Casa popular. São Paulo: GFAU, 1972.

O canteiro e o desenho. São Paulo: Vicente Wissenbach, 2005.

ARANTES, Pedro (orgs.). Arquitetura e Trabalho Livre. São Paulo: Cosac Naify, 2006.

FILARDO, Ângelo. Externalidade e gestão dos valores do ambiente: considerações teóricas e uma aplicação ao caso do Programa Guarapiranga (1991-2000). 2004. Tese (doutorado em arquitetura e urbanismo) - FAU, USP, São Paulo: 2004.

FIX, Mariana de A. B. Parceiros da exclusão: duas histórias da construção de uma "nova cidade" em São Paulo: Faria Lima e Água Espraiada. São Paulo: Boitempo, 2000.

São Paulo Cidade Global: Fundamentos financeiros de uma miragem. São Paulo: Boitempo, 2007. 192p.

Financeirização e transformações recentes no circuito imobiliário no Brasil.2011. Tese (doutorado em desenvolvimento econômico) - IE, UNICAMP, Campinas: 2011.

FOLADORI, Guillermo. O metabolismo com a natureza. Crítica Marxista, São Paulo: Boitempo, n.12, p.105107, 2001.

FOLIN, Marino. La ciudad del capital y otros escritos. Barcelona: Gustavo Gili, 1976.

FOSTER, John Bellamy. A Ecologia de Marx: materialismo e natureza. Rio de Janeiro: Civilização Brasileira, 2005

FREITAS, J.C. Sugestões para Elaboração do Termo ou Compromisso de Ajustamento. São Paulo: 2002. Disponível em http://www.mp.sp.gov.br. Acesso em: julho de 2003.

FUKS, M. Conflitos Ambientais no Rio de Janeiro: ação e debate nas arenas públicas. Rio de Janeiro: UFRJ, 2001.

FUNDAÇÃO AGÊNCIA DA BACIA HIDROGRÁFICA DO ALTO TIETÊ - FABHAT; VALLENGE CONSULTORIA. Relatório de Situação dos Recursos Hídricos da Bacia do Alto Tietê. São Paulo, 2010.

GEERTZ, Clifford. A interpretação das culturas. Rio de Janeiro: LTC, 1989.

GORZ, André. Técnica, técnicos e luta de classes. In: (org.). Crítica da Divisão do Trabalho. São Paulo: Martins Fontes, 2001. p. 211-248. 
GOTTDIENER, Mark. A Produção do Espaço Urbano. 2.ed. São Paulo: Edusp, 1997.

GROSTEIN, Marta Dora. Cidade clandestina os ritos e os mitos; o papel da "irregularidade" na estruturação do espaço urbano no município de São Paulo, 1900-1987. 1987. Tese (doutorado em arquitetura e urbanismo), FAU, USP, São Paulo: 1987.

GRUPO DE COORDENAÇÃO DO SANEGRAN. Sabesp inicia a operação da primeira unidade de tratamentos de esgotos do Programa Sanegran. Revista DAE, São Paulo: [s.n.], no 129, p.45-49, 1982.

HARRIBEY, Jean Marie. Marxismo Ecológico ou Ecologia Política Marxista. In: BIDET, J. ; KOUVÉLAKIS, E. (orgs.). Dictionnaire Marx contemporain. Paris : PUF/Actuel Marx Confrontation, 2001. p.183-200. Tradução de Jorge Hajime Oseki e Inês Oseki (versão preliminar).

HARVEY, David. O trabalho, o capital e o conflito de classes em torno do ambiente construído nas sociedades capitalistas avançadas. Tradução de Flavio Villaça. Revista Espaço \& Debates - Temas Urbanos e Regionais, São Paulo: Cortez, no 6, p. 6-35, 1982.

. Justice, Nature and the Geography of Difference. Oxford: Blackwell, 1996.

O Novo Imperialismo. São Paulo: Loyola, 2005.

O Neoliberalismo: história e implicações. São Paulo: Loyola, 2008.

HÉLLER, L. (Coord). Panorama do saneamento ambiental no Brasil - Elementos conceituais para o saneamento básico. v. 1. Brasília: MCidades/Secretaria Nacional de Saneamento Ambiental, 2011. Disponível em http://www.cidades.gov.br/images/stories/ArquivosSNSA/PlanSaB/PANORAMA Vol 1.pdf. Acesso em: 22/06/2012.

Crescimento econômico e saneamento básico: impactos, oportunidades e desafios para o Brasil. Artigo produzido para o Ministério das Cidades, Ministério do Meio Ambiente e ONUHabitat. Diálogos da Rio+20, Rio de janeiro, junho 2012 (mimeo).

ITIKAWA, Valdete Kanagusko. Mananciais e Urbanização. Recuperação Ambiental na sub-bacia Billings: os Bairros Ecológicos em São Bernardo do Campo, São Paulo (1997 a 2007). Dissertação (mestrado em arquitetura e urbanismo) - Universidade Presbiteriana Mackenzie, São Paulo: 2008.

JACOBS, Jane. Morte e vida de grandes cidades. São Paulo: Martins Fontes, 2000.

JARAMILLO, Samuel. Crise dos meios de consumo coletivo urbano e capitalismo periférico. Espaço \& Debates - Revista de Estudos Regionais e Urbanos, São Paulo: NERU, ano VI, v. 2, no 18, p. 19-39, 1986.

JORGE, Janes. Tietê, o rio que a cidade perdeu: o Tietê em São Paulo 1890-1940. São Paulo: Alameda, 2006.

INSTITUTO BRASILEIRO DE GEOGRAFIA E ESTATÍSTICA. Censo Demográfico de 1940, disponível em http://biblioteca.ibge.gov.br/visualizacao/periodicos/65/cd 1940 v2 br.pdf. Acesso em junho de 2011.

Censo Demográfico de 1950, disponível em http://biblioteca.ibge.gov.br/visualizacao/ periodicos/67/cd 1950 v1 br.pdf. Acesso em junho de 2011.

KFOURI, Antonio Carlos. Habitar o ABCD paulista ou que políticas habitacionais foram adotadas pelas administrações municipais do ABCD no período de 1989 a 1992. Serviço Social \& Sociedade, São Paulo: Cortez, ano XIII, no 40, p.27-41, dez. 1992.

KOWARICK, L. A espoliação urbana. São Paulo: Paz e Terra, 1979.

LAGO, Antonio; PÁDUA, José Augusto. O que é ecologia. São Paulo: Brasiliense, 1984.

LANGENBUCH, Juergen Richard. A estruturação da Grande São Paulo estudo de geografia urbana. Rio de Janeiro: Instituto Brasileiro de Geografia, Departamento de Documentação e Divulgação Geográfica e Cartográfica, 1971.

LEFEBVRE, Henri. El materialismo dialéctico. Buenos Aires: La Pleyade, 1971.

De lo rural a lo urbano. Barcelona: Península, 1971. 
La Production de l' Espace. Paris: Anthropos, 1974.

O direito à cidade. São Paulo: Moraes, 1981.

A revolução urbana. Belo Horizonte: UFMG, 1999.

- A Produção do Espaço. Trad. Grupo "As (im)possibilidades do urbano na metrópole contemporânea" de La production de l'espace. 4a ed. Paris: Éditions Anthropos, 2000. (mimeo), 2006.

LEMOS, Carlos; SAMPAIO, Maria Ruth Amaral de. Habitação Popular Paulistana. Relatório de Pesquisa. São Paulo. FAUUSP, 1977.

LENOBLE, Robert. História da idéia de Natureza. Lisboa: 70, 1990.

LIPIETZ, Alain. A Ecologia Política e o Futuro do Marxismo. Ambiente e Sociedade, Campinas, v. 5, no2; v. 6, no1, p. 9-22, ago./dez. 2002; jan./jul. 2003. Disponível em http://www.scielo.br/pdf/asoc/v5n2/ a02v5n2.pdf. Acesso em 28/08/2008.

MAGNANI, José Guilherme Cantor. De perto e de dentro: notas para uma etnografia urbana. Revista Brasileira de Ciências Sociais, São Paulo, v. 17, no 49, p. 11-29, jun. 2002. Disponível em http://www.anpocs.org.br/portal/content/view/55/54/. Acesso em: 09/2007.

MARCONDES, Maria José de A. Cidade e Natureza: proteção dos mananciais e exclusão social. São Paulo: Studio Nobel, 1999.

MARTINS, José de Souza. O Cativeiro da terra. São Paulo: LECH, 1981.

As temporalidades da História na dialética de Lefebvre. In: (Org.). Henri Lefebvre e o retorno à dialética. São Paulo: Hucitec, 1996. p. 13-23.

A aparição do demônio na fábrica - Origens do Eu dividido no subúrbio operário. São Paulo: Ed. 34, 2008.

MARICATO, E. A proletarização do espaço sob a grande indústria - o caso de São Bernardo do Campo na Região Metropolitana de São Paulo. 1977. Dissertação (mestrado em arquitetura e urbanismo) FAU, USP, São Paulo: 1977.

(org.). A produção capitalista da casa (e da cidade) no Brasil industrial. São Paulo: AlfaOmega, 1982.

Política habitacional no regime militar: do milagre brasileiro à crise econômica. Rio de Janeiro: Vozes, 1987.

Metrópole na periferia do capitalismo: ilegalidade, desigualdade e violência. São Paulo: Hucitec, 1995.

Brasil Cidades: alternativas para a crise urbana. Petrópolis: Vozes, 2001.

. ; MARTINS, Maria Lucia Refinetti. Moradia social e meio ambiente. Sinopses, São Paulo, no 35, p. 54-69, jun. 2001.

O Impasse da política urbana no Brasil. Petrópolis: Vozes, 2011.

MARTINS, Maria Lucia Refinetti. Direito Urbanístico e Reparação de Dano: entre o modelo e o real. MINISTÉRIO PÚBLICO DO ESTADO DE SÃO PAULO. Temas de Direito Urbanístico 3, São Paulo: Ministério Público/Imprensa Oficial, p. 65-83, 2001.

Reparação de Danos e Ajustamento de Conduta em Matéria Urbanística. Relatório Intermediário da pesquisa, fase II. São Paulo. Programa de Políticas Públicas da FAPESP. nov. 2003.

Moradia e Mananciais - tensão e diálogo na Metrópole. São Paulo: FAU-USP/FAPESP, 2006.

(coord.). O acesso ao solo e à habitação social em cidades de regiões metropolitanas da América Latina e da Europa. São Paulo: URB-AL/PMSP/MR/IMPSOL/Regione Toscana, 2007.

MARX, Murillo. Cidade no Brasil terra de quem? São Paulo: Nobel/Edusp, 1991.

MARX, Karl. O Capital Livro I capítulo VI (inédito). São Paulo: Ciências Humanas, 1978. 
O Capital: crítica da economia política - tomos I, II e IIII. São Paulo: Nova Cultural, 1988.

Manuscritos econômico-filosóficos. São Paulo: Boitempo, 2004.

MAUTNER, Yvonne. A periferia como fronteira da expansão do capital. In: DEAK, Csaba; SHIFFER, Sueli (orgs.). O processo de urbanização no Brasil. São Paulo: Fupam/Edusp, 1999. p. 245-259.

The periphery as a frontier for the expansion of capital. 1991. Tese (doutorado em arquitetura e urbanismo) - Bartlet School Of Architecture Planning, 1991.

MEICHES, José. Plano de Tratamento de esgotos de São Paulo - resumo apresentado pela Comissão Especial de Tratamento de Esgotos. Revista DAE, São Paulo: [s.n.], no 25, p. 104-109, 1954.

$\mathrm{MENCIO}$, Mariana. A presença do tema "assentamentos populares irregulares em área de mananciais" no Judiciário, nas Promotorias de Justiça de Habitação e Urbanismo, nos Registros de Imóveis e Órgãos Licenciadores. Relatório de Pesquisa apresentado à Fapesp-Políticas Públicas, FAU-USP, 2003.

MONTENEGRO, Lara. A presença do capital privado no setor de água e esgotos no Brasil. Trabalho de Graduação Individual (graduação em geografia) - FFLCH, USP, São Paulo: 2006.

MOREIRA, Antonio Claudio M. L. Política Pública de Proteção aos Mananciais. 1990. Dissertação (mestrado em arquitetura e urbanismo) - FAU, USP, São Paulo: 1990.

MOREIRA, Renata. Distribuição de água na RMSP: tecnologias da universalização e produção do espaço. 2008. Dissertação (mestrado em arquitetura e urbanismo) - FAU, USP, São Paulo: 2008.

MOTTA, Antenor. O abastecimento de água em São Paulo. Boletim da Repartição de Águas e Esgotos, [São Paulo], n², p. 203, 1937.

. A taxa da água em São Paulo. Boletim da Repartição de Água e Esgoto, [São Paulo], o 4, p.62-65, 1938.

MUNFORD, Lewis. A cidade na história, suas origens, transformações e perspectivas. São Paulo: Martins Fontes, 1991.

NETTO, J. P. Jesus. Dados sumários sobre os esgotos da cidade de São Paulo e Estação experimental de esgotos do Ipiranga. Boletim da Repartição de Águas e Esgotos, [São Paulo], n¹7, p. 100-115, 1946.

NOGARA. Mônica de Azevedo da Costa. Conflitos Socioambientais na Justiça: Da formulação das normas à ação do Poder Judiciário no conflito entre os direitos à habitação e ao meio ambiente em assentamentos irregulares, um estudo de jurisprudência do Tribunal de Justiça de São Paulo (1985 a 2006). 2008. Dissertação (mestrado em arquitetura e urbanismo) - FAU, USP, São Paulo: 2008.

OLIVEIRA, Francisco de. Acumulação monopolista, Estado e urbanização: a nova qualidade do conflito de classes. In: MOISÉS, José Álvaro et al. Contradições urbanas e movimentos sociais. Rio de Janeiro: Paz e Terra, 1977. p.65-76.

Os direitos do antivalor: a economia política da hegemonia imperfeita. Petrópolis: Vozes, 1998.

Crítica à razão dualista: o ornitorrinco. São Paulo: Boitempo, 2003.

OLIVEIRA, Walter Engracia de. Novo sistema de abastecimento de água para os municípios de Santo André, São Bernardo do Campo e São Caetano do Sul. Revista do Departamento de Águas e Esgotos, Secretaria de Viação e Obras Públicas do Estado de São Paulo. São Paulo, ano 19, no 32, p. 41-75, dez.1958.

OSEKI, Jorge Hajime. Pensar e viver a construção da cidade. Canteiros e desenhos de Pavimentação, Drenagem de Águas Pluviais e Rede de Esgotos em São Paulo. 1992. Tese (doutorado em arquitetura e urbanismo) - FAU, USP, São Paulo: 1992.

O único e o homogêneo na produção do espaço. In: MARTINS, José de Souza (org.). Henri Lefebvre e o retorno da dialética. São Paulo: Hucitec, 1996. p. 109-119.

A Fluvialidade no Rio Pinheiros: um projeto de estudo. Pós - Revista do Programa de Pós Graduação em Arquitetura e Urbanismo da FAUUSP. São Paulo, no 8, p. 168-177, dez. 2000. 
; MAUTNER, Yvonne. O espaço das redes de serviços urbanos - o esgoto em São Paulo. Sinopses, São Paulo: FAU-USP, no 20, p.13-20, 1993.

; PELLEGRINO, Paulo Renato M. Paisagem, Sociedade e Ambiente. In: Curso de Gestão Ambiental, São Paulo: Manole, 2004. p. 486-516.

PARANHOS, Haroldo. Saneamento do Lago de Santo Amaro. Boletim da Repartição de Águas e Esgotos, [São Paulo], no 2, p.177-193, 1937.

PASTERNAK, Suzana. Evolução espacial dos loteamentos irregulares em São Paulo. In: BÓGUS, Lucia; RAPOSO, Isabel; PASTERNAK, Suzana (orgs). Da irregularidade fundiária à regularização: análise comparativa Portugal/Brasil. São Paulo: EDUC, 2010. p. 385-419.

PEDROSO, José Samuel de O. Medidas de proteção das águas do reservatório do Guarapiranga. Revista do DAE, São Paulo: [s.n.], no 36, p.53-56, 1960.

PINHATA, Viviane Baddini. Habitação Popular em São Bernardo do Campo. 1987. Trabalho Final de Graduação (graduação em arquitetura e urbanismo) - FAU, USP, São Paulo, 1987.

POLLI, Simone Aparecida. Moradia e Meio Ambiente, os conflitos pela apropriação do território nas áreas de mananciais em São Paulo. 2010. Tese (doutorado em planejamento urbano e regional) IPPUR, UFRJ, Rio de Janeiro: 2010.

PONTUAL, Pedro. O processo educativo no Orçamento Participativo: aprendizado dos atores da Sociedade Civil e do Estado. 2000. Tese (doutorado em educação, história política e sociedade) - PUC, São Paulo: 2000.

PORTO, Monica Ferreira do Amaral; SILVA, Ricardo Toledo. Gestão urbana e gestão das águas: caminhos da integração. Revista Estudos Avançados, São Paulo, v. 17, no47, p. 129-145, jan./abr. 2003. ISSN 0103-4014

PRADO JUNIOR, Caio. História econômica do Brasil. São Paulo: Brasiliense, 1959.

O fator geográfico na formação e no desenvolvimento da cidade de São Paulo. Revista do Arquivo Municipal, São Paulo: Departamento do Patrimônio Histórico, vol. 202, 2004.

PRETECEILLE, Edmond. Políticas Urbanas, equipamentos e serviços coletivos: elementos para um balanço das pesquisas. Tradução de Regina Pacheco. Espaço \& Debates - Revista de Estudos Regionais e Urbanos, São Paulo: NERU, ano VI, v. 2, no 18, p. 5-18, 1986.

PROGRESSO DE SÃO BERNARDO DO CAMPO S.A. - PROSBC. Projeto CURA - Plano Plurianual. São Bernardo do Campo, 1975.

QUEIROZ, Victor Oscar de S. Abastecimento de água na cidade de São Paulo. Revista DAE, São Paulo: [s.n.], no 52, p.29-37, 1964.

REIS FILHO, Nestor Goulart. Aspectos da história da engenharia civil em São Paulo 1860-1960. São Paulo: Kosmos, 1989.

REZENDE, Sonaly Cristina; HELLER, Léo. O saneamento no Brasil: políticas e interfaces. Belo Horizonte: UFMG/Escola de Engenharia, 2002.

RODRIGUES, Roberta Menezes. Governos Municipais e Política urbana no Brasil (Belém) e na Argentina (Rosário) - limites da contingência, ou horizontes da possibilidade. Tese (doutorado em Programa de Integração da América Latina) - PROLAM, USP, 2008.

ROSSETO, Rossella. Fundo municipal de Habitação. São Paulo: Instituto Pólis, PUC - SP, 2003.

ROYER, Luciana de Oliveira. Financeirização da Política Habitacional: limites e perspectivas. 2009. Tese (doutorado em arquitetura e urbanismo) - FAU, USP, São Paulo: 2009.

SABESP. Plano Diretor de Esgotos da Região Metropolitana de São Paulo PDE 2010. Relatório Síntese. São Paulo, 2010.

SANT'ANNA, Denize Bernuzzi de. Vida e morte dos chafarizes na cidade de São Paulo. Revista do Arquivo Municipal. São Paulo: Departamento do Patrimônio Histórico, v. 203, p.81-90, 2004. 
SANTO ANDRÉ (Prefeitura); SEMASA - Serviço Municipal de Saneamento Ambiental de Santo André. O abastecimento de água em Santo André: aspectos históricos e quadro atual. Santo André: PMSA/Semasa, 2008.

Agência Canadense para o Desenvolvimento Internacional. Moradia Social em áreas de mananciais. São Paulo: Annablume, 2004a. 84 p.

; Agência Canadense para o Desenvolvimento Internacional. Áreas ambientalmente sensíveis e regularização fundiária. São Paulo: Annablume, 2004b.

SANTORO, Paula. Planejar a expansão urbana: dilemas e perspectivas. 2012. Tese (doutorado em arquitetura e urbanismo) - FAU, USP, São Paulo: 2012.

SANTOS, Fábio Alexandre dos. Domando águas: salubridade e ocupação do espaço na cidade de São Paulo, 1875-1930. São Paulo: Alameda, 2011.

SCHMIDT, Alfred. Pour un matérialisme écologique. Tradução Jorge Hajime Oseki. Paris: PUF, 1971 (mimeo).

. El concepto de naturaleza en Marx. México: Siglo XXI, 1976.

SEABRA, Odette Carvalho de Lima. Os meandros dos rios nos meandros do poder: Tietê e Pinheiros valorização dos rios e das várzeas na cidade de São Paulo. 1987. Tese (doutorado em geografia) FFLCH, USP, São Paulo: 1987.

Energia elétrica e modernização social: implicações do sistema hidrelétrico de São Paulo na bacia do Alto Tietê. Artigo apresentado no Simpósio Internacional Globalización, innovación y construcción de redes técnicas urbanas em América y Europa, 1890-1930 Brazilian Traction, Barcelona Traction y otros conglomerados financeiros y técnicos. Universidade de Barcelona, 2326 de janeiro de 2012.

SÃO BERNARDO DO CAMPO (Prefeitura). Secretaria de Habitação. Sumário de Dados 2010 (ano base 2009). São Bernardo do Campo: PMSBC, 2010.

- ; FUNEP. Mapeamento, caracterização e hierarquização dos assentamentos precários e irregulares de São Bernardo do Campo. Relatório Final. São Bernardo do Campo, 2010a.

; SECRETARIA DE HABITAÇÃO. Diagnóstico Habitacional do Plano Municipal de Habitação do Município de São Bernardo do Campo. São Bernardo do Campo, $2010 b$ (mimeo).

Plano Local de Habitação de Interesse Social 2010-2025. Produto Final consolidado. São Bernardo do Campo, maio de 2012.

. ; Peabiru Trabalhos Comunitários. Relatório de justificativa de enquadramento para obtenção de parecer favorável, conforme dispõe o artigo 78 da lei no 13.579/2009 - APRM Billings (Capelinha e Cocaia). São Bernardo do Campo, 2010.

Projeto de Urbanização Integrada e Remanejamento de moradias e áreas de proteção ambiental da região do Grande Alvarenga - PAC-Alvarenga. São Bernardo do Campo, 2009.

SÃO PAULO (Estado). Secretaria de Estado do Meio Ambiente. A água no olhar da história. São Paulo: SMA, 1999.

; TAGNIN, Renato (coord). Programa de Recuperação Ambiental da Bacia da Billings - Síntese. São Paulo, 2002. (disponibilizado ao grupo de e-mails Sub-Comitê da Billings em 2002).

; PRIME ENGENHARIA. Calibração de Sistema Relacional de Correlação de Manejo do Território e da Qualidade Ambiental para o reservatório Billings. Relatório Parcial RT-4. São Paulo, 2003.

; COBRAPE. Elaboração do Plano de Desenvolvimento e Proteção Ambiental da Bacia Hidrográfica do Reservatório Billings. Relatório Final. São Paulo, 2011.

SÃO PAULO (Estado). Secretaria de Saneamento e Energia - SSE /BANCO MUNDIAL - BIRD. Projeto Mananciais: Marco conceitual da política de reassentamento. São Paulo, 2007a.

Relatório de Avaliação dos Impactos Sociais do Projeto Mananciais, São Paulo, 2007b. 
. ; COBRAPE; JNS; CNEC. Revisão do Relatório de Análise Econômica e Análise de Recuperação de Custos. São Paulo, 2007c.

Relatório de Avaliação Ambiental dos componentes do Programa Mananciais. Versão revisada. São Paulo, jul. 2009.

SÃO PAULO (Prefeitura). Secretaria de Habitação. Plano municipal de Habitação - PMH São Paulo 20092024. Setembro de 2010a. http://www.habisp.inf.br/theke/documentos/pmh/pmh versao setembro 2010/files/pmh 2009-2024.pdf. Acesso em 12 de março de 2012.

SAVELLI, Mário. Histórico do Aproveitamento das Águas da região Paulistana. Revista do DAE, São Paulo: [s.n.], no 53, p. 84, 1964.

SHIMBO, L. Z. Habitação social de mercado: a confluência entre Estado, empresas construtoras e capital financeiro. 1. Ed. Belo Horizonte: C/Arte, 2012. 224p.

SIGOLO, Letícia. O Mercado habitacional em São Bernardo do Campo: uma leitura a partir do comportamento do mercado do ABCD. In: SÃO BERNARDO DO CAMPO (Prefeitura). Secretaria de Habitação. Diagnóstico Habitacional - Produto 2.2 (mimeo), novembro de 2010.

SILVA, Helena Maria Menna Barreto. Terra e moradia: qual o papel para o município? 1997. Tese (Doutorado em arquitetura e urbanismo) - FAU, USP, São Paulo, 1997.

SILVA, Ricardo Toledo. Habitação, Infra-estrutura e regulação pública: limites da privatização. 1991. Tese (doutorado em arquitetura e urbanismo) - FAU, USP, São Paulo, 1991.

; NUCCl, Nelson Luiz Rodrigues; COSTA, João Jorge da. Recursos hídricos, saneamento e gestão metropolitana: novos desafios. Revista Engenharia, São Paulo: Engenho Editora Técnica, no 609, p.102-110, 2012.

SMITH, Neil. Desenvolvimento desigual: natureza, capital e a produção do espaço. Tradução de Eduardo de Almeida Navarro. Rio de Janeiro: Bertrand Brasil, 1998.

SÓCRATES, Jodete Rios; GROSTEIN, Marta Dora; TANAKA, Marta Maria Soban. A cidade invade as águas: qual a questão dos mananciais? Sinopses, São Paulo: FAU-USP, Edição Especial, 1985.

SOUZA, Edgard Egidio de. História da Light: primeiros 50 anos. São Paulo: Eletropaulo, 1982.

SPIRN, A. O Jardim de Granito. São Paulo: Edusp, 1995.

SYDENSTRICKER-NETO, John. Mapeamentos Participativos: Pressupostos, Valores, Instrumentos, Perspectivas. Revista Brasileira de Estudos Urbanos e Regionais, Rio de Janeiro: ANPUR, v.10, no 2, p.73-96, nov. 2008.

SWYNGEDOUW, Erik. A cidade como um híbrido: natureza, sociedade e urbanização-cyborg. In: ACSELRAD, H. (org.). A duração das cidades: sustentabilidade e risco nas políticas urbanas, Rio de Janeiro: CREA-RJ/DP\&A, 2001. p.83-104

; HEYNEN, Nikolas C. Urban Political Ecology, Justice and the Politics of Scale. Antipode - A Radical Journal of Geography. Oxford: Blackwell, v. 35, no 5, Special Issue, p. 898-918, nov. 2003. ISSN 0066-4812

TAGNIN, Renato. O tratamento da expansão urbana na proteção aos mananciais - o caso da Região Metropolitana de São Paulo. 2000. Dissertação (mestrado em engenharia civil e urbana) - Escola Politécnica, USP, São Paulo: 2000.

Quais características os mananciais devem ter para produzir água. In: WHATELY et al. Mananciais: uma nova realidade? São Paulo: Instituto Socioambiental, 2008. p. 55-66.

TAVARES, Maria da Conceição. (Des)ajuste global e modernização conservadora. Rio de Janeiro: Paz e Terra, 1993.

THOMPSON, Oswaldo B. Dados sobre o abastecimento de água em São Paulo. Boletim da Repartição de Águas e Esgotos, [São Paulo], no 9, 1940, p. 32-45. 
TOLEDO, Benedito Lima de. São Paulo: três cidades em um século. São Paulo: Cosac Naify; Duas Cidades, 2007.

TORRES, Haroldo da G. Fronteira Paulistana. Trabalho apresentado no XIV Encontro Nacional de Estudos Populacionais, ABEP. Caxambu, 2003. Disponível em http://www.abep.nepo.unicamp.br/ site eventos abep/PDF/ABEP2004 64.pdf. Acesso em: 05/12/2012.

TRAVASSOS, L. Revelando Rios: novos paradigmas para intervenção em fundos de vale urbanos na cidade de São Paulo. 2010. Tese (doutorado em ciência ambiental) - Programa de Pós-Graduação em Ciência Ambiental, USP, São Paulo: 2010.

TUNDISI, José Galizia. Desafios atuais e futuros para garantir a qualidade da água dos mananciais de município e da Região Metropolitana de São Paulo. In: WHATELY et. al (orgs.). Mananciais: uma nova realidade? São Paulo: Instituto Socioambiental, 2008. p. 83-97.

. Água no século XIX: enfrentando a escassez. São Paulo: RIMA/IIE, 2003.

UEMURA, Margareth Matiko. Programa de Saneamento Ambiental da Bacia do Guarapiranga. Alternativa para a proteção dos mananciais? 2000. Dissertação (mestrado em arquitetura e urbanismo) - FAU, PUC, Campinas: 2000.

VAINER, C. Pátria, empresa e mercadoria. Notas sobre a estratégia discursiva do Planejamento Estratégico Urbano. ARANTES, O; VAINER, C.B.; MARICATO, E. (orgs.). A cidade do pensamento único: desmanchando consensos. Petrópolis: Vozes, 2000. p. 75-103.

Os liberais também fazem planejamento urbano? Glosas ao Plano Estratégico do Rio de Janeiro. In: ARANTES, O; VAINER, C.B.; MARICATO, E. (orgs.). A cidade do pensamento único: desmanchando consensos. Petrópolis: Vozes, 2000. p. 105-119.

VALADARES, Licia do Prado (org.). Habitação em questão. Rio de Janeiro: Zahar, 1981.

VALETTA, Maria Regina. Assentamentos urbanos construídos espontaneamente e a questão ambiental: plano de reordenamento físico da bacia do Guarapiranga, Programa Guarapiranga, São Paulo. Pós - Revista do Programa de Pós Graduação em Arquitetura e Urbanismo da FAUUSP, São Paulo, no 19, 2006.

VIANA, Mônica A. Proteção ambiental e Desenvolvimento: uma reflexão sobre a Bacia Hidrográfica Billings. 2003. Dissertação (mestrado em arquitetura e urbanismo) - FAU, USP, São Paulo: 2003.

VICTORINO, Valério Igor. Monopólio, conflito e participação na gestão dos recursos hídricos. Ambiente \& Sociedade. v. 6, no 2, p. 47-62jul./dez. 2003. ISSN 1414-753X

Uma Visão Histórica dos Recursos Hídricos na Cidade de São Paulo. Revista Brasileira de Recursos Hídricos, São Paulo: v. 7, no 1, p. 51-68, jan./mar. 2002.

VILLAÇA, F.J.M. A implantação Urbana de São Bernardo do Campo. Revista Engenharia Municipal, $n^{\circ} 26$, ano X, São Paulo, p. $21-47,1966$.

. Efeitos do espaço sobre o social na metrópole brasileira. In: Anais VII Encontro Nacional da ANPUR, 1997. Recife, 1997.

. Reflexões sobre as cidades brasileiras. São Paulo: Studio Nobel, 2012.

O espaço intra-urbano no Brasil. São Paulo : Studio Nobel, 1998.

. Uma contribuição para a história do planejamento urbano no Brasil. In: DEAK, C. ; SCHIFFER, S. R. (orgs.). O processo de urbanização no Brasil. São Paulo: Edusp, 1999. p. 169 -243.

WHATELY, Marussia (org.) et al. Mananciais: uma nova realidade? São Paulo: Instituto Socioambiental, 2008.

; SANTORO, Paula; TAGNIN, Renato Arnaldo. Contribuições para a elaboração de leis específicas de mananciais: o exemplo da Billings. São Paulo: Instituto Socioambiental, 2008.

; SANTORO, Paula Freire; FERRARA, Luciana Nicolau. Mananciais: diagnóstico e políticas habitacionais. São Paulo: Instituto Socioambiental, 2009. 
; CUNHA, Pilar. Cantareira 2006 - Um olhar sobre o maior manancial de água da Região Metropolitana de São Paulo. São Paulo: Instituto Socioambiental, 2007.

WHITAKER, Plínio Penteado. Relatório da Repartição de Águas e Esgotos de São Paulo referente ao ano de 1942. Boletim de Repartição de Águas e Esgotos, [São Paulo], n 16, jan. a dez. de 1943.

Abastecimento de água da cidade de São Paulo: sua solução. Boletim da Repartição de Águas e Esgotos, [São Paulo], no 17, p. 3-41, 1946.

WINES, James. L'Architecture Verte. Colônia, Amelanha: Taschen, 1992.

YAZAKI, Luis Fernando O. L. Ações de saneamento ambiental para recuperação e proteção de mananciais. In: WHATELY et. al (orgs.). Mananciais: uma nova realidade? São Paulo: Instituto Socioambiental, 2008. p.281-310.

ZALUAR, Alba. A máquina e a revolta: as organizações populares e o significado da pobreza. São Paulo: Brasiliense, 2002.

\section{Leis e Resoluções Federais, Estaduais e Municipais:}

BRASIL. Lei Federal no 4.771, de 15 de setembro de 1965. Institui o novo Código Florestal. Brasília, 1965.

Lei Federal $n^{\circ}$ 6.766, de 19 de dezembro de 1979. Dispõe sobre o Parcelamento do Solo Urbano e dá outras Providências. Brasília, 1979.

Resolução Conama no 369, de 28 de março de 2006. Dispõe sobre os casos excepcionais, de utilidade pública, interesse social ou baixo impacto ambiental, que possibilitam a intervenção ou supressão de vegetação em Área de Preservação Permanente-APP. Brasília, 2006.

Lei no 11.977, de 7 de julho de 2009. Dispõe sobre o Programa Minha Casa, Minha Vida e sobre regularização fundiária de assentamentos localizados em áreas urbanas. Brasília, 2009.

Lei Federal no 12.651, de 25 de maio de 2012.Dispõe sobre a proteção da vegetação nativa; altera as Leis nos 6.938, de 31 de agosto de 1981, 9.393, de 19 de dezembro de 1996, e 11.428, de 22 de dezembro de 2006; revoga as Leis nos 4.771, de 15 de setembro de 1965, e 7.754, de 14 de abril de 1989, e a Medida Provisória no 2.166-67, de 24 de agosto de 2001; e dá outras providências. Brasília, 2012.

SÃO PAULO (Estado). Lei Estadual de Proteção aos Mananciais no 898/75. São Paulo, Assembleia Legislativa, 10/11/1975. (Já alterada pela Lei Estadual no 3.746/83).

Lei Estadual no 1.172/76. Delimita as áreas de proteção relativas aos mananciais, cursos e reservatórios de água, a que se refere o artigo 20 da Lei Estadual no 898, 18 de dezembro de 1975, estabelece normas de restrição do uso do solo em tais áreas e dá providências correlatas. São Paulo, Assembleia Legislativa, 17/11/76.

Lei Estadual de Proteção aos Mananciais no 9866/97 - Uma nova política de Mananciais: Diretrizes e Normas para a Proteção e Recuperação das Bacias Hidrográficas dos Mananciais de interesse Regional do Estado de São Paulo. São Paulo, Assembleia Legislativa, 28/11/1997.

Plano Emergencial - regulamentado pelo Decreto Estadual no 43.022/98. Regulamenta dispositivos relativos ao Plano Emergencial de Recuperação dos Mananciais da Região Metropolitana da Grande São Paulo, de que trata a Lei no 9.866, de 28 de novembro de 1997, que dispõe sobre diretrizes e normas para a proteção e a recuperação dos mananciais de interesse regional do Estado de São Paulo e dá providências correlatas (classificou as diferentes sub-bacias de mananciais segundo o nível de criticidade de degradação ambiental em função da ocupação urbana, sendo esse o principal critério para autorização das obras emergenciais). São Paulo, 07/04/1998. 
Lei Estadual no 12.233. Define a Área de Proteção e Recuperação dos Mananciais da Bacia Hidrográfica do Guarapiranga, e dá outras providências correlatas. São Paulo, Assembleia Legislativa, 16/01/2006.

Projeto de lei que define a Área de Proteção e Recuperação dos Mananciais Billings - APRM-B no 639/08

Lei Estadual no 13.579. Define a Área de Proteção e Recuperação dos Mananciais da Bacia Hidrográfica do Reservatório Billings - APRM-B, e dá outras providências correlatas. São Paulo, Assembleia Legislativa, 13/07/2009.

SÃO BERNARDO DO CAMPO. Lei Municipal de Parcelamento do Solo do Município de São Bernardo do Campo no 5398/05. (Altera a Lei Municipal no 4.446, de 12 de agosto de 1996, a Lei Municipal no 4.803, de 4 de novembro de 1999). São Bernardo do Campo, Câmara Municila de SBC, $16 / 06 / 2005$.

Lei do Plano Diretor do Município de São Bernardo do Campo no 5593/06. São Bernardo do Campo, Câmara Municipal de SBC, 05/10/2006. 


\section{LISTAS}

\section{Lista de Figuras}

Figura 1 Largo da Memória e Chafariz dos Piques, 1862. Foto de Militão Augusto de Azevedo

Figura 2 Represa do Cassununga $n$

Figura 3 Reservatório de acumulação

Figura 4 Réplica do mapa da 2ạ Concessão do Projeto Serra como construído entre 1928-1944.

Figura 5 Barragem rio das Pedras, 1932.

Figura 6 Enchente de 1929 em São Paulo.

Figura $7 \quad$ Enchente de 1929 em São Paulo.

Figura 8 Rio Pinheiros, anos 1930.

Figura 9 Perímetro da área a sanear na bacia do Guarapiranga.

Figura 10 Planta das linhas adutoras do abastecimento do ABC.

Figura 11 Ilustração do esquema geral das instalações do sistema de abastecimento do ABC.

Figura 12 Esquema do curso do rio Tietê e zonas de poluição, 1946.

Figura 13 Estações de tratamento de esgotos DAE.

Figura 14 Esquemas dos coletores de esgotos.

Figura $15 \quad$ Foto aérea de 1957

Figura $16 \quad$ Foto aérea de 1973

Figura $17 \quad$ Foto aérea de 1993

Figura $18 \quad$ Foto aérea de 1998

Figura 19 Foto aérea de 2000

Figura $20 \quad$ Foto aérea de 2012

Figura 21 Delimitação da área dos loteamentos estudados. Fonte: Secretaria de Habitação de São Bernardo do Campo, 2012. Informação cedida à autora em 2012 
Figura 22 Levantamento planialtimétrico, Sítio Capuava

Figura $23 \quad$ Panfletos de venda - montagem

Figura 24 Planta do loteamento Jardim Novo Horizonte - Associação Comunitária Ouro Verde, sem escala. Proprietário: Associação Comunitária Ouro Verde.

Figura 25 Planta do loteamento Parque ideal - Associação de Amigos do Parque ideal.

Figura $26 \quad$ Planta do loteamento Jardim Nova América. Proprietário: Associação Comunitária Pró-Moradia Repartição do Espaço.

Figura 27 Planta do loteamento Parque dos Químicos - Associação Parque dos Químicos. Proprietário: Empregados das Indústrias Químicas do ABC

Figura 28 - 31 Moradias no baixo Alvarenga.

Figura $32 \quad$ Pequenos jardins

Figura 33 Caixas da Sabesp para o abastecimento de água

Figura $34 \quad$ Ausência de rede de esgoto

Figura 35 - $38 \quad$ Melhorias pontuais

Figura 39 - 40 Calçadas e circulação

Figura 41 - $44 \quad$ Escadarias e passagens

Figura 45 Área aterrada com ao longo do tempo. Na parte superior da imagem: muro de contenção construído pela PMSBC em 2011-2012

Figura 46 Manifesto das associações de construção comunitária.

Figura $47 \quad$ Manifesto dos ecologistas

Figura 48 Estação localizada de tratamento de esgoto no Jardim Pinheirinho

Figura 49 - 50 Loteamento Jardim Senhor do Bonfim - recuperação de córrego

Figura 51 -52 Circulação, escadas e acessos

Figura $\mathbf{5 3}$ - $\mathbf{5 5}$ Praças e espaços coletivos

Figura 56 - 59 Discussão das cartografias comunitárias

Figura 60 - 62 Obras de guias e sarjetas, no loteamento Parque dos Químicos e Nova América

Figura $63 \quad$ Compartimentos Ambientais da Billings

Figura 64 Programas de Recuperação: PAC Alvarenga e Capelinha/Cocaia

Figura 65 Foto aérea com os perímetros de intervenção do PAC Alvarenga 
Figura 66 - 67 Reassentamento habitacional e Conjunto Habitacional Três Marias, respectivamente.

Figura 68 Projetos por área de intervenção, Sítio Bom Jesus

Figura 69 Projetos por área de intervenção, Divinéia / Pantanal

Figura 70 Projetos por área de intervenção, Jardim Ipê

Figura 71 Projetos por área de intervenção, Alvarenga Peixoto

Figura 72 Canalização do córrego e unidades comerciais

Figura 73 Remoção de residências para construção de parque no Jardim Ipê.

Figura 74 Sistema de esgotamento sanitário - Sabesp, Projeto Pró-Billings, 2012

Figura 75 Sistema de esgotamento sanitário e encaminhamento para a ETE ABC

Figura 76 Localização das áreas de intervenção do PRIS Capelinha/Cocaia

Figura 77 Diretriz de abastecimento de água da Sabesp

Figura 78 Diretriz de esgotamento sanitário da Sabesp

Figura 79 Implantação do Projeto de Intervenção Cocaia

Figura $80 \quad$ Implantação do Projeto de Intervenção Capelinha

Figura $81 \quad$ Unidades habitacionais propostas.

\section{Lista de Mapas}

Mapa 1 Planta da Cidade de São Paulo em 1881. Repartição de Águas e Esgotos de São Paulo.

Mapa 2 Rede de água da cidade de São Paulo, 1929.

Mapa 3 Rede de esgotos da cidade de São Paulo, 1929.

Mapa $4 \quad$ Setores de abastecimento de 1942

Mapa $5 \quad$ Sistema adutor metropolitano

Mapa 6 Sistemas produtores na Região Metropolitana de São Paulo

Mapa $7 \quad$ ETEs existentes e sistema principal, 2010

Mapa 8 Reversão dos sistemas isolados.

Mapa 9 Situação atual do sistema de coleta de esgotos e encaminhamento para as

Mapa 10 Sistema Atual e Projeto Tietê 3a etapa. 


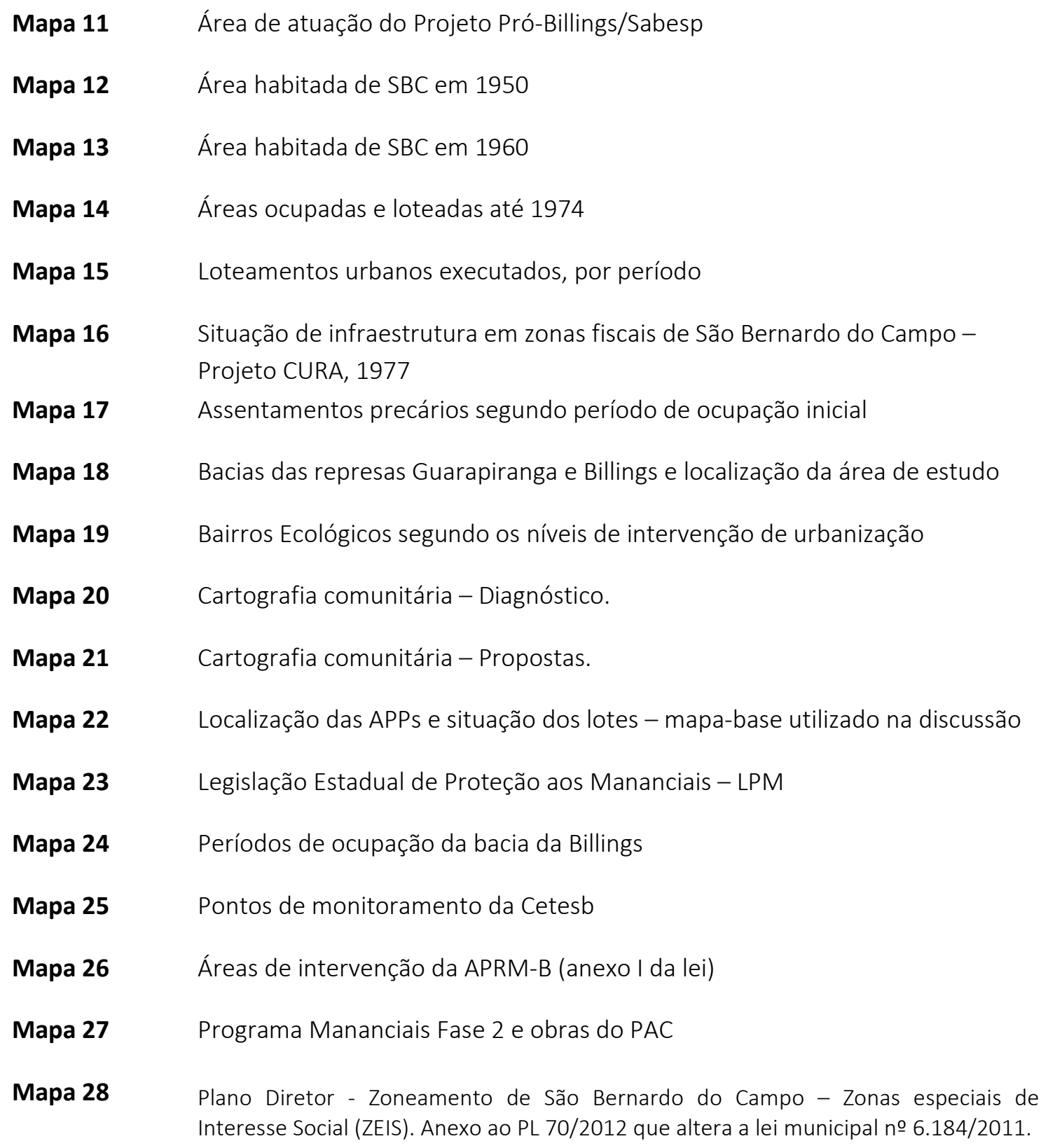

\section{Lista de Tabelas}

Tabela 1 Situação dos prédios existentes e abastecidos na cidade de São Paulo, 19291942

Tabela 2 Análise da Situação dos sistemas Produtores de água na bacia do Alto Tietê,

Tabela 32009 Produção Habitacional do município de São Bernardo do Campo, na década

Tabela $4 \quad$ População nas áreas de proteção aos mananciais por bairro, São Bernardo do Campo, 1980 a 2009

Tabela 5 Período inicial da ocupação por tipo do assentamento

Tabela 6 Assentamentos Precários e situação de infraestrutura em 2010, em APM. 
Tabela 7 Assentamentos Precários e situação de infraestrutura em 2010, fora de APM

Tabela 8 Índice de atendimento (percentual da população atendida) pela rede de esgoto e índice de tratamento de esgoto SABESP, São Bernardo do Campo, 2004 e 2009.

Tabela 9 Índice de atendimento (percentual da população atendida) pela rede de esgoto e índice de tratamento de esgoto SABESP, São Bernardo do Campo, 2004 e 2009.

Tabela 10 Perfil de renda segundo rendimento do responsável pelo domicílio, bairro dos Alvarengas, São Bernardo do Campo, 2000-2010

Tabela 11 Coeficiente de exportação de tempo seco do MQUAL 2.0

Tabela $12 \quad$ Uso do solo na Bacia da Billings

Tabela 13 Cargas de Fósforo Total Geradas por região hidrográfica, município e compartimento ambiental no cenário atual (ano de referência 2006), em comparação com a carga meta da LE-Billings

Tabela 14 Recursos do Programa Guarapiranga, valores iniciais entre 1992-1997

Tabela 15 Recursos divulgados do PAC Mananciais, 2008

Tabela 16 Balanço do andamento das obras da Fase 2, divulgadas em 2012

Tabela 17 Valor do Programa por órgão executor/tomador empréstimo

Tabela $18 \quad$ Valor do Programa por componente

Tabela 19 Valor do Programa por Sub-bacias de intervenção

Tabela 20 Famílias atendidas por tipo de solução.

Tabela $21 \quad$ Parâmetros urbanísticos APRM - Billings

Tabela 22 Programa Mananciais no Município de São Paulo

Tabela 23 Projetos do PAC 1 e PAC 2 em São Bernardo do Campo

Tabela 24 Demandas eleitas no OP 2012 para a SEHAB e incorporadas pelo CMO Conselho Municipal de Orçamento.

\section{Lista de Quadros}

Quadro $1 \quad$ Sistemas produtores de água na RMSP.

Quadro 2 Síntese das áreas de intervenção da Lei no 13.579/09

Quadro 3 Ganhos ambientais do projeto PAC Alvarenga, por área de intervenção

Quadro 4 Ações previstas pelo Programa Mananciais Alto Tietê, segundo agente executor do Governo do Estado de São Paulo. 
Quadro 5 Ações previstas pelo Programa Mananciais Alto Tietê, segundo agente executor - municípios.

\section{Lista de Siglas}

ABC - Municípios de Santo André, São Bernardo do Campo e São Caetano do Sul ABCD - Municípios de Santo André, São Bernardo do Campo, São Caetano do Sul e Diadema ACP - Ação Civil Pública

APM - Área de Proteção dos Mananciais APP - Área de Preservação Permanente APRM - Área de Proteção e Recuperação dos Mananciais AT - bacia hidrográfica do Alto Tietê BIRD - Banco Internacional de Reconstrução e Desenvolvimento - Banco Mundial BNH - Banco Nacional de Habitação CDHU - Companhia Estadual de Desenvolvimento Habitacional e Urbano CEPM - Comissão Especial de Proteção aos Mananciais Cetesb - Companhia Ambiental do Estado de São Paulo CONAMA - Conselho Nacional de Meio Ambiente CPLA - Coordenadoria de Planejamento Ambiental $\mathrm{CRH}$ - Conselho Estadual de Recursos Hídricos DUSM - Departamento de Uso do Solo Metropolitano EMAE - Empresa Metropolitana de Águas e Energia S.A.

Emplasa - Empresa Paulista de Planejamento Metropolitano S/A

FEHIDRO - Fundo Estadual de Recursos Hídricos

HIS - Habitação de Interesse Social

LE- Lei Específica de bacia hidrográfica

LPM - Lei Estadual de Proteção aos Mananciais no 898/75 e no 1172/76

MP - Ministério Público de São Paulo

MQUAL - Modelo de Correlação entre o Uso do Solo e a Qualidade da Água

$O A B$ - Ordem dos Advogados do Brasil

PAC - Programa de Aceleração do Crescimento

PD - Plano Diretor

PDPA - Plano de Desenvolvimento e Proteção Ambiental

PMDI - Plano Metropolitano de Desenvolvimento Integrado

PMSP - Prefeitura do Município de São Paulo

PMSBC - Prefeitura do Município de São Bernardo do Campo

PRIS - Programa de Recuperação de Interesse Social 
RMSP - Região Metropolitana de São Paulo

Sabesp - Companhia de Saneamento de São Paulo

Sanegran - Projeto de Saneamento para a Grande São Paulo

SEHAB-SBC - Secretaria Municipal de Habitação de São Bernardo do Campo

SHAMA - Secretaria Municipal de Habitação e Meio Ambiente de São Bernardo do Campo

SFH - Sistema Financeiro Habitacional

SIGRH - Sistema de Gerenciamento dos Recursos Hídricos

SMA - Secretaria Estadual de Meio Ambiente

SVMA - Secretaria Municipal do Verde e Meio Ambiente

TAC - Termo de Ajustamento de Conduta

UGP - Unidade Gestora do Programa

ZEIS - Zona Especial de Interesse Social 
Lista dos entrevistados

\begin{tabular}{|c|c|c|}
\hline entrevistados & data & local \\
\hline \multirow[t]{2}{*}{1 - coletiva com moradores } & & $\begin{array}{c}\text { Sede Associação de } \\
\text { Moradores Parque dos }\end{array}$ \\
\hline & 13-03-09 & Químicos \\
\hline \multirow[t]{2}{*}{2 - coletiva com moradores } & & $\begin{array}{l}\text { Sede Associação de } \\
\text { Moradores Parque dos }\end{array}$ \\
\hline & $16-03-09$ & Químicos \\
\hline \multirow[t]{2}{*}{3 - coletiva com moradores } & & $\begin{array}{l}\text { Sede Associação de } \\
\text { Moradores Parque dos }\end{array}$ \\
\hline & 20-03-09 & Químicos \\
\hline \multirow[t]{2}{*}{4 - coletiva com moradores } & & $\begin{array}{l}\text { Sede Associação de } \\
\text { Moradores Parque dos }\end{array}$ \\
\hline & 04-04-09 & Químicos \\
\hline $5-$ Filismino & & $\begin{array}{l}\text { Sede Associação de } \\
\text { Moradores Parque dos }\end{array}$ \\
\hline Morador do Parque Ideal & 04-04-09 & Químicos \\
\hline \multirow[t]{2}{*}{6 - coletiva com moradores } & & $\begin{array}{c}\text { Sede Associação de } \\
\text { Moradores Parque dos }\end{array}$ \\
\hline & 05-04-09 & Químicos \\
\hline \multicolumn{3}{|l|}{7 - Darci } \\
\hline Morador do Nova América & $27-06-10$ & Em sua casa, Nova América. \\
\hline \multicolumn{3}{|l|}{8 - Ricardo Couto } \\
\hline Arquiteto SEHAB SBC, gerente projeto PAC & & SEHAB/PMSBC. Visita à obra \\
\hline Alvarenga & $19-07-11$ & do PAC Alvarenga \\
\hline \multicolumn{3}{|l|}{9 - André Drummond } \\
\hline Arq. Peabiru Assessoria Técnica & $12-09-11$ & Peabiru assessoria \\
\hline \multicolumn{3}{|l|}{10 - Paulo Massoca } \\
\hline Secretário Adjunto SEHAB SBC & 07-11-11 & SEHAB/PMSBC \\
\hline \multicolumn{3}{|l|}{11 - Renato Tagnin } \\
\hline Arquiteto e Urbanista & 29-11-11 & FAU Maranhão \\
\hline \multicolumn{3}{|l|}{12 - Tássia Regino } \\
\hline Secretária de Habitação PMSBC & $16-01-12$ & SEHAB/PMSBC \\
\hline \multicolumn{3}{|l|}{13 - Sonia Lima } \\
\hline Ex-Diretora de Meio Ambiente PMSBC & 20-07-12 & Restaurante em São Paulo \\
\hline \multicolumn{3}{|l|}{14 - Américo Sampaio } \\
\hline Sabesp & 24-07-12 & Sabesp em São Paulo \\
\hline 15 - Patrícia Lorenz & & Secretaria de Gestão \\
\hline Diretora da Secretaria de Gestão Ambiental SBC & $26-07-12$ & Ambiental PMSBC \\
\hline 16 - Claudionor Gabas e Eng. Sueli & & Sabesp em São Bernardo do \\
\hline Sabesp Regional SBC & $10-08-12$ & Campo \\
\hline \multicolumn{3}{|l|}{17 - Neide } \\
\hline Moradora do Novo Horizonte & 23-08-12 & Em sua casa, Ouro Verde \\
\hline 18 - Rosangela Staurenghi & & Promotoria de Justiça em \\
\hline Promotora Pública em SBC & $30-08-12$ & São Bernardo do Campo \\
\hline \multicolumn{3}{|l|}{19 - Márcia Nascimento } \\
\hline Arquiteta e Urbanista /SMA & $25-10-12$ & FAU USP \\
\hline \multicolumn{3}{|l|}{20 - Karla Sanches } \\
\hline SEHAB São Bernardo & $08-11-12$ & SEHAB/PMSBC \\
\hline
\end{tabular}


